\title{
CONFERENCE PROCEEDINGS
}

14th Annual International Bata Conference for Ph.D. Students and Young Researchers

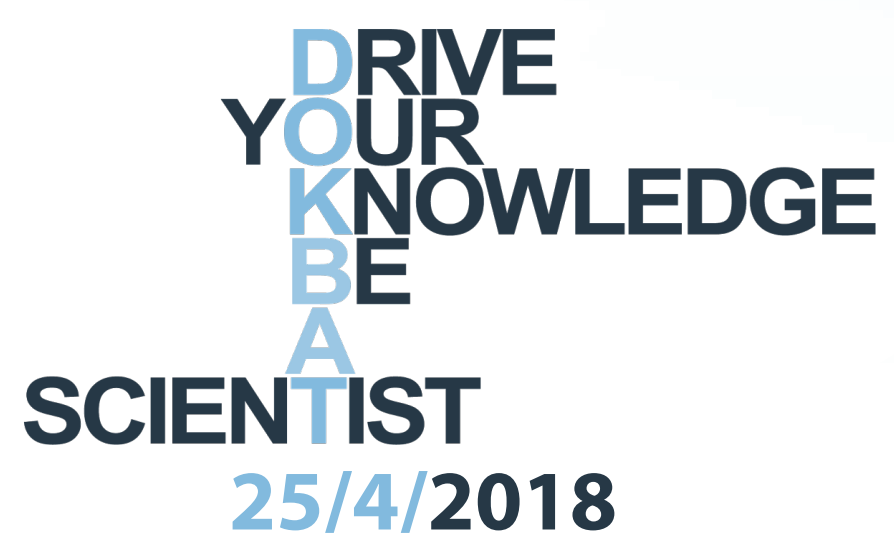

Tomas Bata University in Zlín Faculty of Management and Economics 
Conference Proceedings

DOKBAT

14th Annual International Bata Conference

for Ph.D. Students and Young Researchers

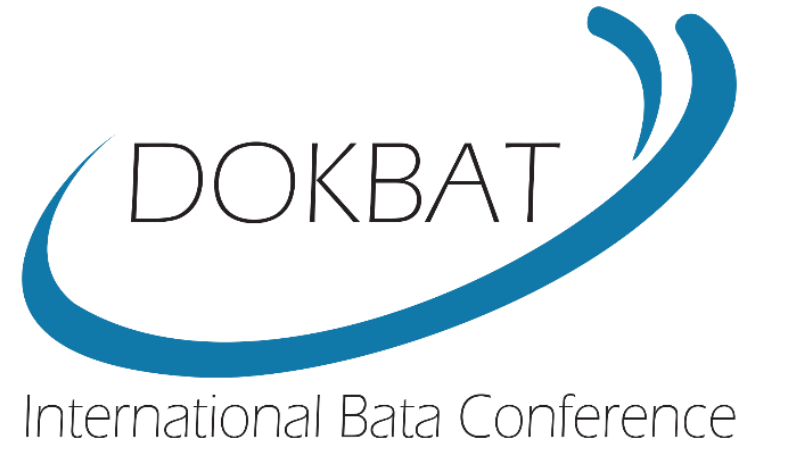

Tomas Bata University in Zlín

Faculty of Management and Economics

Mostní 5139 - Zlín, 76001

Czech Republic 
Copyright (C) 2018 by authors. All rights reserved. Digital publishing - www.dokbat.utb.cz. Published in 2018.

Edited by: Ing. et Ing. Monika Hýblová

ISBN: 978-80-7454-730-0

DOI: $10.7441 /$ dokbat.2018

The publication was released within the DOKBAT conference, supported by the IGA project No. SVK/FaME/2018/002.

Many thanks to the reviewers who helped ensure the quality of the papers.

No reproduction, copies or transmissions may be made without written permission from the individual authors. 


\section{HOW TO CITE:}

Surname, First Name. (2018). Title. In DOKBAT 2018 - 14th Annual International Bata Conference for Ph.D. Students and Young Researchers (Vol. 14). Zlín: Tomas Bata University in Zlín, Faculty of Management and Economics. Retrieved from http://dokbat.utb.cz/conference-proceedings/ ISBN: 978-80-7454-730-0 


\section{CONTENT}

BUILDING CUSTOMER RELATIONSHIP THROUGH THE SOCIAL NETWORKS IN THE FIELD OF E-COMMERCE IN CZECHIA - CONCEPTUAL FRAMEWORK OF RESEARCH

Ottó Bartók 6

ENTERPRISE PERFORMANCE ANALYSIS OF THE SLOVAK HEALTH SPA SECTOR BY APPLYING SELECTED MODERN FINANCIAL METHODS

Veronika Čabinová, Erika Onuferová, Dana Kisel’áková, Beáta Šofranková. 17

SECTORAL DIFFERENCES IN THE CREDIT ACCESS IMPEDIMENTS OF TURKISH SMEs30

Mehmet Civelek and İbrahim Dursun 30

ECONOMIC EVALUATION OF THE FREE MOVEMENT OF CIZIZENST IN THE EU

Meri Duduci. 44

THE DETERMINANTS OF EXPECTED INFLATION IN VIETNAM

Do Phuong Thao, Le Tuan Doanh, Do Thi Thanh Nhan 51

INSURANCE DISTRIBUTION IN THE FUTURE

Alexander Fichter 57

FINANCING POLICY OF CZECH AUTOMOTIVE COMPANIES

Florin Aliu, Gent Jusufi, Besnik Krasniqi, Hoang Khang Tran 62

THE LINKS BETWEEN MEANINGFULNESS OF WORK, WORK-ENGAGEMENT AND MENTAL WELL-BEING

Frank W. Hager .76

THE CONSUMER DECISION-MAKING PROCESS WHICH FORM DOMESTIC BRAND LOYALTY: A LITERATURE REVIEW

Fortesa Haziri, Miloslava Chovancová, Florin Aliu. 95

CHANGEOVER TIME REDUCTION THROUGH LEAN TOOL "SMED" - A CASE STUDY FROM FOOD SECTOR

Kateřina Gálová..... 103

THE ROLE OF THE PENSION SYSTEM IN THE MODERN WORLD

Raman Herasimau 116

CURRENT STATE OF SCIENTIFIC KNOWLEDGE IN THE FIELD OF CRM USE IN TOURISM

Monika Hýblová 127

RELATIONSHIP BETWEEN REPUTATION AND COMPETITIVENESS

Mária Kozáková 137 


\section{CZECH COMPANIES' ATTITUDES IN TRAINING MANAGEMENT}

Ladislav Kudláček, Ravindra Hewa Kuruppuge, Aleš Gregar. 148

THE EXISTING CORRELATION BETWEEN THE CPI OF OTC DRUGS AND OTHER GOODS AND SERVICES

Eva Loubalová.....

SOCIAL MEDIA: NEW CHANNEL OF INTERNAL COMMUNICATION FOR EMPLOYEE ENGAGEMENT?

Lien. H.L. Nguyen and Aleš Gregar.

ASSESSMENT OF EFFICIENCY IN GOVERNMENT SERVICES DELIVERY THROUGH E-PLATFORM IMPLEMENTATION? EVIDENCE FROM KENYA

Patrick Asango Okanga, Ho Thanh Tri, Nguyen Thi Bich Thuy 188

APPLICATION OF VALUE STREAM MAPPING IN ORDER TO RECOGNIZE OPPORTUNITIES TO IMPROVE PROCESSES AND INCREASE BUSINESS PROCESS PERFORMANCE: A CASE STUDY FROM MANUFACTURING COMPANY IN THE CZECH REPUBLIC

Pavel Ondra 199

HOW THE HOUSING POLICY CONTRIBUTES TO THE BRAND OF CITY DISTRICT

Petr Štěpánek 211

PHENOMENON BITCOIN: MONEY OF FUTURE OR JUNK COMMODITY?

Vojtěch Sadil

THE ROLE OF MANAGERS IN THE CONTEXT WITH THE IMPLEMENTATION OF LEAN SIX SIGMA IN SMALL AND MEDIUM-SIZED ENTERPRISES

Roland Stankalla and Felicita Chromjakova

WHY IT IS IMPORTANT TO USE SOCIAL MEDIA IN INTERNATIONAL MARKETING STRATEGIES

Mariana Tesařová 240

MODEL 5P FOR ECONOMIC ZONES IN VIETNAM

Tran Ngoc Son 253

TOURIST ATTITUDE ON LUXURY HOTELS

Nga Vo. 261

INVESTMENT-RELATED ISSUES IN VIETNAM: A CASE STUDY OF THE AUTOMOTIVE AND ELECTRONIC INDUSTRIES

Vu Hoang Duong and Do Le Nhu Quynh 276

LINKEDIN AND ITS IMPACT ON MARKETING STRATEGY IN BUSINESS

Nikola Vykydalová. 289 


\title{
BUILDING CUSTOMER RELATIONSHIP THROUGH THE SOCIAL NETWORKS IN THE FIELD OF E-COMMERCE IN CZECHIA - CONCEPTUAL FRAMEWORK OF RESEARCH
}

\author{
Ottó Bartók
}

\begin{abstract}
This article discusses the concept of building customer relationship through the social networks (SN) to maintain loyalty and increase customer satisfaction in e-commerce in the Czech Republic. SN are a phenomenon at the beginning of the 21 st century and it is a question of whether they can be used as a supportive tool in building relationships with customers. This research framework provides the basic theoretical knowledge necessary to create a conceptual framework of research. For this was used content analysis of literature. Includes individual research methods, both qualitative and quantitative. The qualitative part is supported by an interview and quantitative is supported by the Structural equation modelling (SEM). At the end of the article, the is suggested implications for theory and social practice are given.
\end{abstract}

Key words: CRM, social networks, e-commerce, Czechia

\section{INTRODUCTION}

In today's dynamically developing companies, companies face huge challenges such as high competition and the associated saturation of the market. There are also unpredictable changes in customer trends and requirements, both for companies themselves and for products. (Porter, 2008) This saturation of the market, as well as competition, puts the emphasis of companies on customer care. Maintaining customers is essential, not only for the key but also for existing ones. Social networks (SNs) have the potential to increase revenue and offer the opportunity as a new communication tool within Market 4.0. CRM, in turn, manages customer relationships. Combining these two tools can help increase customer loyalty and thus improve customer relationships as a result of these changes and improve the position of businesses in a market environment.

The research gap of this research concept is in the identifying the influence of the use of SNs on the satisfaction and loyalty of e-commerce customers in the Czech Republic in the selected segment and to propose recommendations for applications in business practice.

The Czech Republic has been selected due to unrealized research in this country and due to the continuous development of this area in the Czech Republic. This sector has grown more markedly in the Czech Republic since the millennium when the turnover of CZK 1 billion was exceeded. At present (2017), the turnover is CZK 115 billion, which is still only a fraction of the turnover in Germany, which is equivalent to ten times the Czech turnover in e-commerce for the same period. In addition, it is expected that this sector will continue to evolve. According to a published case study of the Association of Electronic Commerce (APEK), the electrical sector for 2017 is the most visited and most sought-after e-commerce sector. Therefore, this sector offers considerable potential for implying results. We can understand the electrical sector according to the APEK portal as a sector dealing with the sale of electrical appliances and electrical household appliances. 


\section{THEORETICAL FRAMEWORK}

\subsection{CRM}

It necessary to understood customer relationship management (CRM) in the reason the CRM including activities that serve to enhance customer satisfaction and maintain loyalty (Lee, 2013) According to Kaderják \& Simon (2009), there are many CRM definitions because the theoretical knowledge is constantly evolving, as well as practice. CRM is not just a software solution, but rather a strategy and long-term goals in building customer relationships. Bull (2003) and Levine (2000) summarized the theory of CRM, and in general, it can be said that the purpose of CRM is to obtain customer data. And their behaviour in such a way that these customers can be provided with products or services that are effective enough to build positive relationships.

Progress in IT provides marketing professionals with new ways to interact with customers. (Harrigan et al., 2011) It should not be forgotten that technology is a key tool of CRM that facilitates customer communication and customer data management. (Jayachandran et al., 2005) The trend in CRM according to Olbrich \& Holsing (2012) is the use of social media (SM) or SN to increase customer interaction. According to Harrigan, Soutar, Choudhury \&Lowe (2015), SM and SN are not used to replace the CRM software solution but only to makes easier customer relationships.

There is ongoing scientific research deal with SM and SN. The reason is that this is a relatively new trend that gives an unexplored possibility, as mentioned by Trainor (2014).

\section{$2.2 \quad$ E-commerce}

As well as the development of information technologies, the company is developing and gradually adopts new approaches. New approaches include e-commerce, which is spreading due to wider use of the internet. Laudon \& Traver (2015), define e-commerce as the purchase of goods or services using a digital transaction between the organization and the individual. In the area e-commerce combines business activities and communications over the Internet. At the same time (2017) there are 37,000 in the Czech Republic entities using e-commerce for their activities. These assets, more precisely, transactions, services and communications are conducted remotely to create or acquire business activity. The difference from the traditional business can be seen in the requirement to provide consumer information for successful completion of the purchase. Typically, this is an address, a phone number, and possibly a credit card information. (Chellappa \& Sin, 2005) According to Suchanek (2012), e-commerce has grown and became known to many people thanks to the new Web 2.0 approach. Dinev et al. (2006) note that the market environment is changing due to the more frequent use of ecommerce, eliminating the time and space barriers that once operated the exchange of goods or services between vendors and buyers. However, there still remains a problem with the need to transfer personal data.

\subsection{Social networks}

The earlier study by Kaplan and Heanlein (2010) defines SM as a set of Web 2.0 based Web applications that allow users to create (post posts) and exchange user-generated content (share posts). They also provide much data that needs to be collected, measured and evaluated, and then interpreted. According to Obar \& Wildman (2015), terminology in social media is still 
unclear, and some define SM as well as SN. For example, Boyd \& Ellison (2008) puts the concept of $\mathrm{SN}$ and defines it as a means of enabling online communication. He also mentions that this area has experienced development over the past years thanks to mobile phones. Obar \& Wildman (2015) add that SN are also part of many games like a Second Life. The team of Barker, Barker, Bormann, Roberts, \& Zahay (2017) for example dived SNs into the following groups: Facebook, LinkedIn, Google+, CafeMom.

\subsection{SEM components}

The credibility of information - Li \& Suh (2015) have said that the credibility of social information affects the attitude of the customer. Further research shows that the credibility and quality of information that companies share and share on SNs to some degree correlates with customer satisfaction (Freedman \& Jin, 2017). Also, the credibility of the information is linked to the company's reputation. The reputation concerns the opinions of stakeholders, especially customers. These are signs of credibility, affection and respect. (Lange, Lee \& Dai, 2011). According to Maamar, Costantino, Petrocchi and Martinelli (2015), the loyalty of the customer largely affects the reputation that companies have on SNs.

Usefulness and timeliness information - Users search for information that has utility value (Cheung et al., 2008). Users require quality information sources from their perspective (Moliner et al., 2007). Authors Arnaboldi, Conti, Passarella, \& Dunbar (2017) suggest that information quality is also reflected in the number of social network monitors. Customers who search for useful information also want access to the current information they can identify or self-identify. Self-confidence in consumers is the way consumers present themselves on SNs. When they share and share certain messages that present them. This allows them to create a clear picture of their person on SNs. (Malhotra et al., 2012) Kressmann et al. (2006) state that selfdetermination affects customer loyalty to a large or firm. Research by Zhang \& Bloemer (2008) states that self-determination reflects both the content and the value of the company.

Amount of information - Not only the usefulness, timeliness and credibility of information but the amount and frequency of information affect customer behaviour on SNs too. The frequency of information along with the relevance of the information is positively reflected in the relationship of the social network user to the company that disseminates these messages ( $\mathrm{Li}$ $\&$ Suh, 2015). The possibility of information influences not only the satisfaction but also the behaviour of social network users (McEwan, 2017).

Data security - We understand such security to prevent destructive forces causing them to be destroyed or altered or alienated by unauthorized users (Bertino, 2010). According to a study by Rathore, Sharma, Loia, Jeong \& Park (2017), social data security is often mentioned and is an important factor in deciding whether to use the social network. Further studies conducted in the online banking sector point to the relationship between data security and the user's willingness to use the technology. As a result, customer satisfaction is affected by this relationship. (Aboobucker \& Bao, 2018)

Easy use - It is one of the kinds of user-friendliness and has an impact on the positive thinking of the user (Zillmann, 2000). It is essential for applications and other services to be user-friendly and easy to use. The extent to which an application or service is easily "usable" is reflected in customer satisfaction. We must not forget that everyone perceives this factor differently, depending on their skills (Rahman, Sakip \& Nayan, 2016). Ease of use affects interactivity. So, 
to what extent is the environment intuitive and interactive to the user. McWilliam's research (2000) shows that interactivity is important for communicating with consumers in online communities. This means creating different content with the need for customer engagement. Interactivity also reflects customer satisfaction and makes it easier to identify with a company and thus to build loyalty to a brand or company (Kuo \& Feng, 2013).

Demographic characteristics of the customer - Customer characteristics are essential to understanding the relationship. These features include demographics and self-efficacy. Personal characteristics can be characterized by age, gender and education (Scott \& Bruce, 1994). These characteristics influence the perception and behaviour of the individual. (Jacobsson \& Associates, 2000) Self-efficacy can be defined as the ability or self-confidence in using the instrument or means to achieve our own goal. (Bandura, 1982) This name is not interpreted for Czech language and can be understood as a user's determination to use a particular technology or tool in a translated sense. Therefore, you can define the ability to use your computer as a computer self-efficacy.

Satisfaction - Kotler \& Keller (2009) defined customer satisfaction as feelings of joy or disappointment. According to Zamazalova (2008), customer satisfaction is perceived as a specific goal of his behaviour towards which he is directed. A study by Chen (2012) showed a positive correlation between customer satisfaction and loyalty to the company or brand. According to Nenadal (2017), satisfaction can be perceived in the levels. Research by Nisar \& Whitehead (2016) tells us that only a satisfied customer can become loyal.

Loyalty - Earlier studies suggest that customer loyalty can be defined in terms of loyalties of attitudinal and procedural in the relationship between the participant and another entity in the presence of alternative entities (Dick \& Bass, 1994; Melnyk et al., 2009; Oliver, 1999). In this work, customer loyalty will be defined as the loyal attitude and behaviour of the consumer towards a particular company providing services, products, despite competitors providing alternative services on the market. Loyalty is a positive attitude towards the brand and also and re-purchase (Oliver, 2010). Loyalty is closely related to customer satisfaction, but with image company too. Loyalty can be measured as customer retention, but also as a customer recommendation (Kandampully \& Suhartanto, 2000).

Company image - Keller (1993) the image of the company as perceived by the consumer organization in its memory. That will be a control transformation, because there is a relationship between satisfaction and company image (Brown et al., 2007). Only a company that is trustworthy and has a good image can get loyal and compliant customers (Park et al., 2009; Tokunaga, 2011). If the image of the company is not well known to customers, there is no relationship between SNs.

\section{PROPOSED CONCEPTUAL FRAMEWORK}

The areas of research are the specifics of building customer relationships through SN in the field of e-commerce in the electrical sector in the Czech Republic. A study by Chen (2012), Kumar et al. (2013), and last but not least, Suh \& Yi (2006), states that customer relationship building is focused on customer satisfaction and loyalty, with satisfaction and loyalty closely related. Hassan, Nawaz, Lashari \& Zafar (2015) state that the main contribution to building customer relationships lies in increasing customer satisfaction and consolidation. Building relationships with customers means activities aimed primarily at enhancing customer 
satisfaction and customer loyalty. Because customer satisfaction has several levels, satisfaction can be enhanced or increased. In contrast, customer loyalty means, and it is only possible to state whether the customer is loyal or not. Therefore, customer loyalty can only be maintained (Nenadal, 2017). SN are an integral part of our daily life, and through technological developments, they are more intrusive to our day-to-day activities. Just like e-commerce, SN are available via the internet. Because of some similarities, the relationship of SN and ecommerce could have a greater positive effect on the customer in using together. ( $\mathrm{Li} \& \mathrm{Ku}$, 2018)

The object of the research is external customers (business-to-consume) using the services of companies in the e-commerce sector in the Czech Republic.

The research problem can be defined as follows: What are the possibilities of using SNs in ecommerce in the Czech Republic to increase loyalty and customer satisfaction? The main goal of the research is to: Identify the influence of the use of SNs on customer satisfaction and loyalty in e-commerce in the Czech Republic in the selected segment and to propose recommendations for applications in business practice.

\section{SUGGESTED RESEARCH DESIGN AND METHOD}

The basic methods used in the creation of scientific work, as well as any work, include analysis. The analysis represents the decomposition of the whole into individual parts. The purpose and purpose of such an action are to identify and explore the links between the components and their reciprocal functioning. Molnár (2012) define analysis as an analysis of characteristics, relationships, facts moving from one to the other. In this research, the analysis is carried out using SEM. The advantage of SEM is that it allows not only to model phenomena but also to test them statistically. This method will be based on the conclusions of Raykov \& Marcoulides (2006), which provides the theoretical and practical knowledge necessary to understand and apply the SEM method. The SEM model can be formulated algebraically using a system of structural or simultaneous equations. The model is made up of variables that are latent, prominent, and residual. Last but not least, the structural parameters that characterize relations between variables. Mathematical and statistical methods will be used, these mathematical and statistical methods will be supported by the findings of Hindls, Hron, Seger, and Fischer (2007). The work will also use inductive and deductive scientific methods. Induction methods for representation of results and deduction method for literary research. Empirical methods will also be used and the most frequent empirical method is a questionnaire survey. The questionnaire survey will be used to examine the impact of SNs on the loyalty of e-commerce customers in the Czech Republic, reflecting their satisfaction. Collective methods will use already-considered data analysis and measurement methods. Measurements will be made using the above mentioned mathematical and statistical methods. The work will also use syntheses in the processing of knowledge from the literary research and the acquired data. Analogy methods will be used to draw conclusions and compare when comparing the conclusions with similar studies. Modelling will be used to create measurements and perceives customer loyalty through $\mathrm{SN}$ in the e-commerce area of the Czech Republic. Last but not least, the prediction methods will be used to describe the expected evolution of the selected phenomenon in the future. Other predicted statistical methods are described below. 


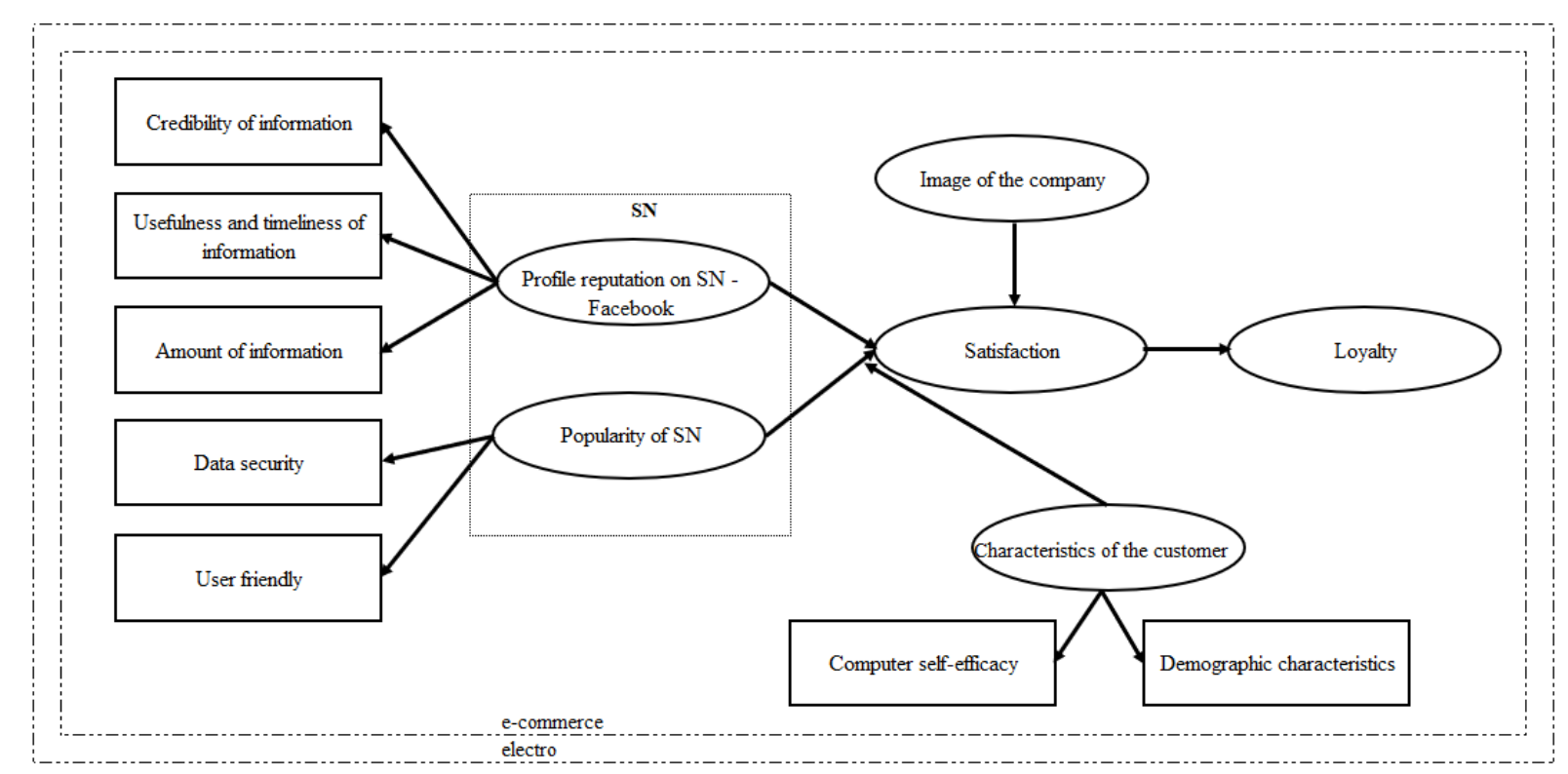

Figure 1 - SEM. Source: own

\subsection{Sample size}

Determining the sample size can be done based on the level of significance required by the accuracy of the estimate by Soukup \& Kočvarová (2016). Therefore, assuming a maximum $\alpha$ 0.05 error rate at the level of significance $\beta 0.95$ and the distribution of knowledge of the respondents $\Delta 10.50 \times \Delta 20.50$, the sample size is 601 of the respondents. This number can be considered as the minimum representative sample. When collecting data, emphasis will be placed on the proportional distribution of respondents from the basic files.

\subsection{Data collection}

\section{Survey}

The questionnaire survey that will be necessary to obtain the data will take place depending on the agreed terms and conditions with the addressed companies. The assumption is that they will be e-commerce customers with a uniform representation of women, age and age. Several portals offering these services (SurveyMonkey, Vyplnto.cz, Survio.cz, Google Forms, etc.) can be used for the electronic questionnaire. The link can also be disseminated using a common commercial message or using MailChimp. The questionnaire will consist of closed questions using the Likert scale, which serves to measure attitudes (Hayes, 1998). At 1 (totally disagree) to 5 (I totally agree). The form of the individual questions will depend on the direction of the research, the SEM model will provisionally contain 27 questions. The evaluation will be carried out using the following mathematical-static methods.

\section{Interview}

Interview with managers will take place using a semi-standardized interview. Enterprises will be contacted depending on the size of the business under investigation. The purpose of this qualitative research will be to identify the current state of social media in relation to customer relationship management. The evaluation will be carried out using a thematic analysis and open coding. The assumption is twelve managers with a uniform distribution depending on the size of the subject. 


\subsection{Data testing}

Data testing will be performed using the MS Excel spreadsheet, the IBM SPSS, R and Minitab 18 statistical software. For quantitative part will be used a double t-test, Cronbach alpha, factor analysis, RMSEA and CFI. for SEM. Qualitative part will be supported by thematic analysis.

\section{EXPECTED RESULTS}

The results of the work can be used to supplement the theoretical knowledge and to evaluate new ones. Literary research provides a comprehensive state of knowledge about social networking issues, satisfaction and customer loyalty. Learning outcomes and concepts of SN and defining individual factors can serve as teaching material for the subject of marketing and CRM for both full-time study and combined form of study. Another benefit can be seen in the development of customer relationship building methodology. Authentication of the customer relationship model will contribute to the illumination of the issue. Research can serve as a basis for training and other educational activities for companies. The benefits of work for social practice can be seen in the results of the dissertation and the new approaches it provides. The results of SEM can be serve to increase the competitiveness of Czech companies or increase loyalty and customer satisfaction. Another level may be to strengthen the innovation potential of companies. The research will also provide practical implications and inspiration to consider when implementing e-commerce SNs in the Czechia.

\section{DISCUSSION AND CONCLUSIONS}

The research gap of this research concept is in the identifying the influence of the use of SNs on the satisfaction and loyalty of e-commerce customers in the Czech Republic in the selected segment and to propose recommendations for applications in business practice. This research will help to understand the relationship between SN and CRM. The researches focused only on e-commerce and SN were not implemented yet. The research method is mainly focused on SEM, which is supported by an interview. The research area can serve as a basis for other research or for comparison with countries with a similar history as Czechia, namely Poland, Hungary, Slovakia. Understanding of relationship between SNs and building customer relationships will help to develop innovation and increase competitiveness on market.

\section{Acknowledgement}

The author would like to thank the Internal Grant Agency of FaME for providing financial support to carry out this research. Funding was extended through: TBU No. IGA/FaME/2018/002 - Using of Marketing 4.0 principles for customer relationship management in the Czech Republic. 


\section{References}

Aboobucker, I., \& Bao, Y. (2018). What obstruct customer acceptance of internet banking? Security and privacy, risk, trust and website usability and the role of moderators. The Journal of High Technology Management Research. doi:10.1016/j.hitech.2018.04.010

Arnaboldi, V., Conti, M., Passarella, A., \& Dunbar, R. I. (2017). Online Social Networks and information diffusion: The role of ego networks. Online Social Networks and Media, 1, 44-55. doi:10.1016/j.osnem.2017.04.001

Bandura, A. (1982). Self-efficacy mechanism in human agency. American Psychologist, 37(2), 122-147. doi:10.1037/0003-066x.37.2.122

Bertino, E. (2010). Access Control for Databases: Concepts and Systems. Foundations and Trends in Databases, 3(1-2), 1-148. doi:10.1561/1900000014

Brown, J., Broderick, A. J., \& Lee, N. (2007). Word of mouth communication within online communities: Conceptualizing the online social network. Journal of Interactive Marketing, 21(3), 2-20. doi:10.1002/dir.20082

Brunsson, N., Jacobsson, B. \& Associates. (2000).A world of standards. New York: Oxford University Press.

Bull, C. (2003). Strategic issues in customer relationship management (CRM) implementation. Business Process Management Journal, 9(5), 592-602. doi:10.1108/14637150310496703

Dick, A. S., \& Basu, K. (1994). Customer loyalty: Toward an integrated conceptual framework. Journal of the Academy of Marketing Science, 22(2), 99-113. doi:10.1177/0092070394222001

Dinev, T., Bellotto, M., Hart, P., Russo, V., Serra, I., \& Colautti, C. (2006). Privacy calculus model in e-commerce - a study of Italy and the United States. European Journal of Information Systems, 15(4), 389-402. doi:10.1057/palgrave.ejis.3000590

Freedman, S., \& Jin, G. Z. (2017). The information value of online social networks: Lessons from peer-to-peer lending. International Journal of Industrial Organization, 51, 185222. doi:10.1016/j.ijindorg.2016.09.002

Harrigan, P., Ramsey, E., Ibbotson, P. (2011) Critical factors underpinning the e-CRM activities of SMEs. J. Mark. Manage (12) 26

Harrigan, P., Soutar, G., Choudhury, M. M., \& Lowe, M. (2015). Modelling CRM in a social media age. Australasian Marketing Journal (AMJ), 23(1), 27-37. doi: 10.1016/j.ausmj.2014.11.001

Hassan, R. S., Nawaz, A., Lashari, M. N., \& Zafar, F. (2015). Effect of Customer Relationship Management on Customer Satisfaction. Procedia Economics and Finance, 23, 563-567. doi:10.1016/s2212-5671(15)00513-4

Hayes, N. (1998). Základy sociální psychologie. Praha: Portál

Hindls, R., Hronová, S., Seger, J., \& Fischer, J. (2007). Statistika pro ekonomy. Praha: Professional Publishing.

Holsing, C. \& Olbrich, R. (2012). Effect of User-generated Content on Website Stickiness the case of social shopping communities. International Conference on Electronic Commerce, 12, 301-308.

Chellappa, R. K., \& Sin, R. G. (2005). Personalization versus Privacy: An Empirical Examination of the Online Consumer's Dilemma. Information Technology and Management, 6(2-3), 181-202. doi:10.1007/s10799-005-5879-y

Chen, C., Chang, S., \& Liu, C. (2012). Understanding Knowledge-Sharing Motivation, Incentive Mechanisms, and Satisfaction in Virtual Communities. Social Behavior and Personality: An International Journal, 40(4), 639-647. doi:10.2224/sbp.2012.40.4.639 
Chen, S. (2012). The customer satisfaction-loyalty relation in an interactive e-service setting: The mediators. Journal of Retailing and Consumer Services, 19(2), 202-210. doi:10.1016/j.jretconser.2012.01.001

Cheung, C. M., Lee, M. K., \& Rabjohn, N. (2008). The impact of electronic word-of-mouth. Internet Research, 18(3), 229-247. doi:10.1108/10662240810883290

Jayachandran, S., Sharma, S., Kaufman, P., Raman ,P. (2005) The role of relational information processes and technology use in customer relationship management. J. Mark. (4) 69

Kaderják, G., \& Simon, A. (2009). Open source CRM systems. In 4th Aspects and Visions of Applied Economics and Informatics, 4(1)

Kandampully, J., \& Suhartanto, D. (2000). Customer loyalty in the hotel industry: The role of customer satisfaction and image. International Journal of Contemporary Hospitality Management, 12(6), 346-351

Kaplan, A. M., \& Haenlein, M. (2010). Users of the world, unite! The challenges and opportunities of Social Media. Business Horizons, 53(1), 59-68. doi: 10.1016/j.bushor.2009.09.003

Kim, M., Lee, C., \& Chung, N. (2013). Investigating the Role of Trust and Gender in Online Tourism Shopping in South Korea. Journal of Hospitality \& Tourism Research, 37(3), 377-401. doi:10.1177/1096348012436377

Kotler, P., \& Keller, K. L. (2009). Marketing management. Upper Saddle River, N.J: Pearson Prentice Hall.

Kressmann, F., Sirgy, M. J., Herrmann, A., Huber, F., Huber, S., \& Lee, D. (2006). Direct and indirect effects of self-image congruence on brand loyalty. Journal of Business Research, 59(9), 955-964. doi:10.1016/j.jbusres.2006.06.001

Kumar, V., Pozza, I. D., \& Ganesh, J. (2013). Revisiting the Satisfaction-Loyalty Relationship: Empirical Generalizations and Directions for Future Research. Journal of Retailing, 89(3), 246-262. doi:10.1016/j.jretai.2013.02.001

Kuo, Y., \& Feng, L. (2013). Relationships among community interaction characteristics, perceived benefits, community commitment, and oppositional brand loyalty in online brand communities. International Journal of Information Management, 33(6), 948-962. doi:10.1016/j.ijinfomgt.2013.08.005

Lange, D., Lee, P. M., \& Dai, Y. (2011). Organizational reputation: A review. Journal of Management, 37(1), 153-184. doi:10.1177/0149206310390963

Laudon, K. C., \& Traver, C. G. (2015). E-commerce: Business, technology, society. Boston: Pearson.d

Levine, S. (2000) The rise of CRM. America's Network, 104(6)

Li, C., \& Ku, Y. (2018). The power of a thumbs-up: Will e-commerce switch to social commerce? Information \& Management, 55(3), 340-357. doi:10.1016/j.im.2017.09.001

Li, R., \& Suh, A. (2015). Factors Influencing Information credibility on Social Media Platforms: Evidence from Facebook Pages. Procedia Computer Science, 72, 314-328. doi:10.1016/j.procs.2015.12.146

Maamar, Z., Costantino, G., Petrocchi, M., \& Martinelli, F. (2015). Business Reputation of Social Networks of Web Services. Procedia Computer Science, 56, 18-25. doi:10.1016/j.procs.2015.07.171

Malhotra, N. (2012). Conference Note. Metamorphosis: A Journal of Management Research, 11(1), 7-8. doi:10.1177/0972622520120103

McEwan, B. (2017). Navigating new media networks. Lanham, MD US: Lexington Books.

Mcwilliam, G. (2000). Building Stronger Brands Through Online Communities. SLOAN Management Review. 41. 
Melnyk, V., Van Osselaer, S. M. J., \& Bijmolt, T. H. A. (2009). Are women more loyal customers than men? gender differences in loyalty to firms and individual service providers. Journal of Marketing, 73(4), 82-96. doi:10.1509/jmkg.73.4.82

Moliner, M. A., Sánchez, J., Rodríguez, R. M., \& Callarisa, L. (2007). Perceived relationship quality and post-purchase perceived value. European Journal of Marketing, 41(11/12), 1392-1422. doi:10.1108/03090560710821233

Molnár, Z. (2012). Competitive intelligence, aneb, Jak získat konkurenční výhodu. V Praze: Oeconomica.

Nenadál, J. (2016). Systémy managementu kvality: Co, proč a jak měřit? Praha: Management Press.

Nisar, T. M., \& Whitehead, C. (2016). Brand interactions and social media: Enhancing user loyalty through social networking sites. Computers in Human Behavior, 62, 743-753. doi:10.1016/j.chb.2016.04.042

Obar, J. A., \& Wildman, S. (2015). Social media definition and the governance challenge: An introduction to the special issue. Telecommunications Policy, 39(9), 745-750. doi: 10.1016/j.telpol.2015.07.014

Oliver, R. L. (1999). Whence consumer loyalty? Journal of Marketing, 63(SUPPL.), 33-44. doi:10.2307/1252099

Oliver, R. L. (2010). Satisfaction: A behavioral perspective on the consumer. Armonk, NY: M.E. Sharpe.

Park, N., Kee, K. F., \& Valenzuela, S. (2009). Being Immersed in Social Networking Environment: Facebook Groups, Uses and Gratifications, and Social Outcomes. CyberPsychology \& Behavior, 12(6), 729-733. doi:10.1089/cpb.2009.0003

Porter, C. E., \& Donthu, N. (2008). Cultivating Trust and Harvesting Value in Virtual Communities. Management Science, 54(1), 113-128. doi:10.1287/mnsc.1070.0765

Rahman, N. A., Sakip, S. R., \& Nayan, N. M. (2016). Physical Qualities and Activities for a User-friendly Shopping Street in the Context of a Malaysian City. Procedia-Social and Behavioral Sciences, 222, 196-202. doi:10.1016/j.sbspro.2016.05.147

Rathore, S., Sharma, P. K., Loia, V., Jeong, Y., \& Park, J. H. (2017). Social network security: Issues, challenges, threats, and solutions. Information Sciences, 421, 43-69. doi:10.1016/j.ins.2017.08.063

Raykov, T., \& Marcoulides, G. A. (2006). A First Course in Structural Equation Modeling. Lawrence Erlbaum Associates, Inc: Mahwah, New Jersey

Scott, S. G., \& Bruce, R. A. (1994). Determinants Of Innovative Behavior: A Path Model Of Individual Innovation In The Workplace. Academy of Management Journal, 37(3), 580607. doi:10.2307/256701

Soukup, P., \& Kočvarová, I. (2016). Velikost a reprezentativita výběrového souboru v kvantitativně orientovaném pedagogickém výzkumu. Pedagogická Orientace, 26(3), 512. doi:10.5817/pedor2016-3-512

Suh, J., \& Youjae, Y. (2006). When Brand Attitudes Affect the Customer Satisfaction-Loyalty Relation: The Moderating Role of Product Involvement. Journal of Consumer Psychology, 16(2), 145-155. doi:10.1207/s15327663jcp1602_5

Suchánek, P. (2012). E - commerce: elektronické podnikání a koncepce elektronického obchodování. 1. vyd. Praha: Ekopress.

Tokunaga, R. S. (2011). Social networking site or social surveillance site? Understanding the use of interpersonal electronic surveillance in romantic relationships. Computers in Human Behavior, 27(2), 705-713. doi:10.1016/j.chb.2010.08.014

Trainor, K. J., Andzulis, J. (., Rapp, A., \& Agnihotri, R. (2014). Social media technology usage and customer relationship performance: A capabilities-based examination of social 
CRM. Journal of Business Research, 67(6), 1201-1208. doi: 10.1016/j.jbusres.2013.05.002

Zamazalová, M. (2008). Spokojenost zákazníka. Acta Oeconomica Pragensia, 16(4)

Zhang, J., \& Bloemer, J. M. (2008). The Impact of Value Congruence on Consumer-Service Brand Relationships. Journal of Service Research, 11(2), 161-178. doi:10.1177/1094670508322561

Zillmann, D. (2000). Mood management in the context of selective exposure theory. In M.E. Roloff (Ed.), Communication yearbook. Thousand Oaks, CA: Sage.

\section{Contact information}

Ottó Bartók

Tomas Bata University in Zlín

Faculty of Management and Economics

Mostní 5139, 76001 Zlín

bartok@fame.utb.cz

ORCID: 0000-0001-6340-676X

DOI ID: https://www.doi.org/10.7441/dokbat.2018.01 


\title{
ENTERPRISE PERFORMANCE ANALYSIS OF THE SLOVAK HEALTH SPA SECTOR BY APPL YING SELECTED MODERN FINANCIAL METHODS
}

\author{
Veronika Čabinová, Erika Onuferová, Dana Kisel'áková, Beáta Šofranková
}

\begin{abstract}
Nowadays, the analysis and management of enterprise performance is getting more and more attention than in the past due to the constantly changing global business environment bringing new, modern approaches to solve the issue in question. The main aim of this paper is to evaluate the financial performance of the health spa sector in Slovakia over the years $2012-2016$ with use of selected modern financial methods. Based on the results, relatively identical values were achieved within the application of both modern methods (EVA in $€$ and RONA in \%). When evaluating the performance of Slovak spa sector as a whole, the best results were achieved in year 2015 and, on the contrary, year 2012 was identified as the worst-performing one. In this regard, a positive continuous performance growth was recorded over the period of $2012-2015$, but this optimistic trend was influenced negatively by a sharp drop in net profit in the following year 2016. According to the results of EVA and RONA application, the best-performing enterprises within the analysed spa sector were Spa Bojnice, Spa Lúčky, Spa Dudince and Spa Stós. Contrary, the worst-performing enterprises over the years 2012 - 2016 were Spa Brusno, Spa Sliač, Horezza and Spa Číž. To conclude, some recommendations for improving the current financial performance of the selected group of spa enterprises in Slovakia were formulated.
\end{abstract}

Keywords: enterprise performance, modern methods of evaluation, health spa enterprises, EVA, RONA

\section{INTRODUCTION}

Spa tourism is getting more and more attention as people started to prefer healthy lifestyle, taking care of their mind, body and spirit. Due to rich abundance of healing resources on the relatively small territory, Slovakia is one of the major and the most interesting spa countries in Europe. In addition, spa tourism is one of the economy sectors with high growth potential and the main product line of tourism in Slovakia. For this reason, we focused especially on the evaluation of health spa sector in Slovakia and identification of the best and the worstperforming enterprises in the case of application of both modern financial methods.

\section{ENTERPRISE PERFORMANCE AND METHODS OF ITS MEASUREMENT}

Currently, when measuring and evaluating the enterprise performance is highly up-to-date, companies are forced to use always new methods, metrics and indicators. Reaching and maximization of profit as the major business goal has not been considered as a top business goal for a long time. Contrary, enterprise development activities should support the growth of enterprise performance within the financial as well as non-financial perspectives. As reported by author Śalaga (2016), there are many management styles supporting the above-mentioned enterprise development growth, but at first the performance should be quantified correctly, then compared in the individual time periods and finally increased with use of specific selected tools and methods. 


\subsection{Definition of the performance}

According to Wagner (2009), performance can be defined generally as a characteristic describing the process by which the observed subject realizes the activity on the basis of similarity to the recommended way of performing this activity. Suchánek (2013) likens this term to the production capacity of the enterprise in terms of achieving the performance as the on-going production process result. Souček (2010) acknowledges performance as the enterprise ability to produce a certain amount of goods and services over the given period, whereas an enterprise striving for the highest long-term performance should achieve the performance at least twice as high as the average value of the analysed industry.

Business performance and its growth is one of the main objectives of company's financial management. In this context, enterprises should constantly monitor, evaluate and increase their level of performance (Pavelková, Knápková, 2009). Durkáčová (2010) states that the organization is considered to be well-performing only if it achieves the performance objectives pre-defined in its strategy. According to Niznikova, Feranecova, Sabolova, Staskova (2015), the enterprise performance represents one of the crucial factors for responsible company governance, especially from the perspective of valuation in the current competitive environment. For this reason, all enterprises have to dispose of a set of financial and nonfinancial indicators that can characterize its performance as accurately as possible. As reported by Dluhošová (2007), the definition of business performance is generally understood as the ability of a company to utilize invested capital. In this context, Wagner (2011) adds that the development of economic environment also reflects the development of all performance measurement system components, including the most visible part of this process - performance measures and their methods.

\subsection{Traditional vs. modern performance measurement methods}

The most important criterion of measuring the performance of business entity is certainly the monitoring its financial performance. However, quantification of performance is not easy task as the shareholders, managers, employees, customers and other stakeholders often perceive it differently (Šulák, Vacík, 2005; Stýlo, 2008). In general, measuring and increasing the enterprise performance is represented as its ability to achieve objectives in an optimal way (Grell, Hyránek, 2012). There are many different classifications of the enterprise performance indicators in the literature. The following figure (Fig. 1) presents basic classification of the enterprise performance indicators.

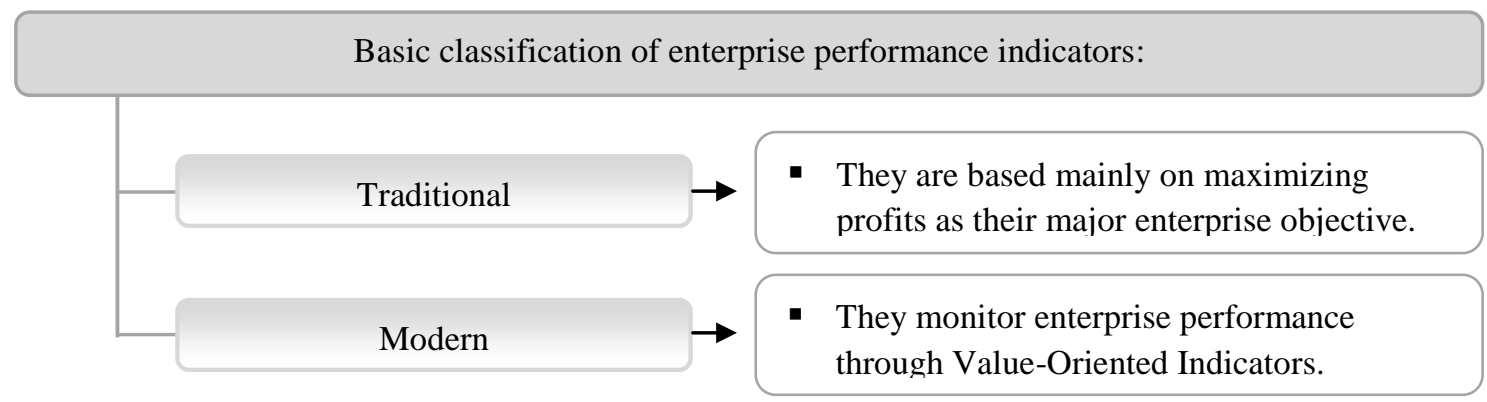

Figure 2 - Basic classification of the enterprise performance indicators. Source: own processing according to Kabát et al., 2013.

The traditional performance measurement indicators still represent the significant part of financial analysis. However, there have been many significant changes in the past, not only in the performance measurement approaches, but also in the methods and instruments applied for 
their evaluation (Šofranková, Kisel'áková, Horváthová, 2017). As stated by author Svobodová (2015), the traditional approaches indicate the level of company's management only from a managerial point of view, which do not take into account the risks accrued to owners by investing their funds. Závarská (2012) adds that despite of the popularity of new modern indicators, financial indicators remain irreplaceable as they truly reflect the past, give a retrospective view of the company's competitive position and can predict its short-term development. Kislingerová et al. (2011) summarized the following underlying weaknesses of the financial indicators that are used as the enterprise evaluation systems: they are confusing, unreliable and not transparent with the historical background; there is a possibility of its undesired modification by the management; they are not appropriate for predicting the future development and creation of the business strategy because they are linked to a short-term objectives and do not cover strategically significant sections.

In this regard, authors Šofranková, Kisel'áková, Horváthová (2017) emphasize that above mentioned traditional financial indicators have a low informative value in the analysis and evaluation of reporting the enterprise financial performance in terms of tactical and strategic management decisions. Contrary, approaches that quantify the key performance indicators are becoming more and more popular in order to analyse and improve the enterprise performance (Šofranková, Horváthová, Kisel'áková, 2016). Authors Zemánková, Kruntorádová, Boušková (2010) add that the financial analysis indicators do not take into account risks and income requirements of investors. It has been proved that the financial analysis indicators are insignificantly correlated with the development of companies' shareholder value, as they are based on accounting statements and do not take into account the economic point of view. According to Maříková and Mařík (2005), the above mentioned failings are covered by the selected modern performance indicators, which should have the closest possible link to the value of shares that can be demonstrated by statistical calculations; allow for using as much information and data provided by accounting as possible, including indicators based on the accounting data; overcome objections against accounting indicators affecting financial efficiency, it is necessary to include risk calculation and take into account the extent of the committed capital. In this regard, Pavelková and Knápková (2009) add that these new indicators should allow a clear identification of their links to the all management levels and they should also support company's value management.

The new financial management is based on the shareholder value management concept, which is focused on the modified financial indicators enabling the successful and better identification of activities that can increase the long-term value for shareholders as well as the overall company's value (Dluhošová, 2007). As reported by Kisel'áková, Horváthová, Šofranková (2016), actual trends of the performance evaluation are leading to useof the non-financial indicators. Attention is focused on creating the performance measurement indicators that include not only financial inputs but also non-financial inputs accepting the individual company sections and strategy.

At present, one of the most popular financial performance measurement indicators reflecting the value creation process are undoubtedly the Economic Value Added (EVA) and the Return on Net Assets (RONA). The following subchapters are devoted to their brief characteristic.

\subsection{Economic Value Added (EVA)}

Actually, the principle of EVA methodology is not new. In 1896, the concept of residual profit was the subject of Alfred Marshall's study (Pavelková, Knápková, 2009). The EVA indicator is based on the economic principle of the residual revenue, through which companies in order to create value added must ensure higher returns on capital than costs themselves (Hamilton, Rahman, Lee, 2009). Nowadays, there are several calculations for this indicator (equity, entity 
and APV method). In this paper, we applied the equity approach and the equation for calculating the EVA indicator is following (Neumaierová, Neumaier, 2002):

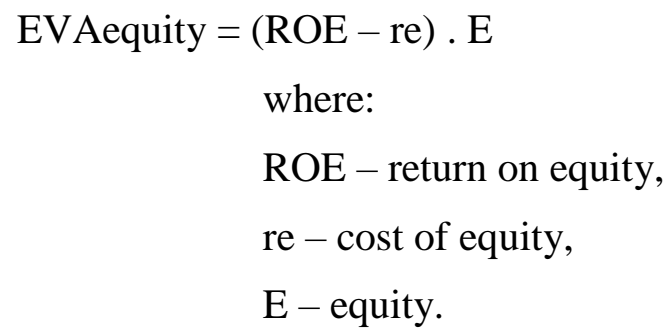

When calculating the EVA indicator, it is important to identify correctly the alternative rate of equity (re) value. From various ways of quantifying them, the Capital Asset Pricing Model (CAPM) should be emphasized. As reported by Damodaran (2004), the final cost of equity is quantified by the CAPM as follows:

$$
\begin{aligned}
\mathrm{re}=\mathrm{rf}+\beta . & \mathrm{ERP}+\mathrm{CRP} \\
& \text { where: } \\
& \mathrm{rf}-\text { risk free rate of return, } \\
& \beta-\text { beta coefficient, } \\
& \mathrm{ERP}-\text { equity risk premium, } \\
& \mathrm{CRP}-\text { country risk premium. }
\end{aligned}
$$

As stated by Nelson (2015), the achieved value of the EVA indicator should be positive. It means that the company actually produces economic profit and creates value for its owners even after paying salaries to employees, paying interest to demanders and shares to shareholders. Otherwise, the cost of the capital invested is higher than its returns and the wealth of shareholders is reducing.

\subsection{Return on Net Assets (RONA)}

Another value indicator measuring the percentage of the return on invested capital is the RONA indicator that provides information concerning the enterprise efficiency, the ability to generate revenue from available resources and managerial capabilities to manage enterprise costs (Hussey, 2014). According to Mulačová, Mulač et al. (2013), the RONA quantifies company's performance in \%, not in $€$ as the EVA. Generally, deviations between the RONA and WACC (Weighted average cost of capital) ratios are observed, whereas the desired relation is RONA > WACC. The RONA value is quantified on the basis of equation:

RONA $=$ NOPAT $/$ NA

where:

NOPAT - net operating profit after taxes,

$\mathrm{NA}$ - net assets.

The WACC represents the cost of the total invested long-term capital. The level of the WACC indicator depends according to Vochozka (2012) mainly on the way of using own resources equity and secondarily at resources. The construction of this indicator is following:

$\mathrm{WACC}=\mathrm{rd} .(1-\mathrm{d}) . \mathrm{D} / \mathrm{K}+\mathrm{re} . \mathrm{E} / \mathrm{K}$

where:

rd - cost on debt capital, $\quad \mathrm{K}-$ paid total capital, 


$$
\begin{array}{ll}
\mathrm{d} \text { - tax rate, } & \text { re - cost of equity, } \\
\mathrm{D} \text { - paid debt capital, } & \mathrm{E} \text { - paid equity. }
\end{array}
$$

\section{DATA AND METHODOLOGY}

In this paper, we addressed the financial performance evaluation of the health spa sector in Slovakia over the years 2012 - 2016 with use of selected modern financial methods (the EVA and the RONA). The other purpose of this paper was to identify the best and the worstperforming enterprises in the case of application of both modern methods.

The research sample consisted of the 28 Slovak health spa enterprises with the official permission from the Ministry of Health of the Slovak Republic to operate the natural health spas and spa medical institutions in Slovakia.

The financial statements of the analysed spa enterprises' sample were drawn from a publicly available internet portal managed by the company DataSpot, Ltd. The level of "rf" indicator was determined on the basis of the rate of return on risk-free assets (10-year government bonds), whereas the values were drawn from the official website of the National Bank of Slovakia (NBS, 2018). The height of "re" indicator was determined on the basis of CAPM and risk premium values were obtained from the official websites of prof. Damodaran (Damodaran, 2018). All data obtained were processed in Microsoft Excel.

\section{RESULTS AND DISCUSSION}

At first, based on the financial statement data over the period of $2012-2016$, we evaluated the performance of the health spa enterprises by applying the EVA indicator.

As the EVA reached the value of $€-446,483$ on average in 2012 , this year can be considered as the worst-performing one within the whole period analysed. The average value of the ROE ranged only around $0.33 \%$, whereas the "re" indicator recorded its highest level at all $\%)$. The net profit achieved by all spa enterprises was only $€ 25,635$ on average, which subsequently resulted in insufficient values of the profitability indicators and primarily caused the achievement of such a high negative values of the EVA. Overall, the most progressive positive trend in the EVA development was recorded in the following year 2013, when the average value added loss decreased by $€ 256,024$. This positive development was the result of significant decrease of the "re" indicator by $1.60 \%$ compared to 2012 and another reason was also an increase in ROE to an average value of $2.15 \%$. Despite these positive changes and significant net profit growth of $€ 148,152$ on average, analysed enterprises were not able to generate value added for shareholders. However, a positive change occurred in the following years and performance of enterprises started to get the appropriate development trend.

Re-decreasing the "re" indicator to the value of $2.27 \%$ and increasing the ROE by $0.24 \%$ on average in 2014 caused the improving financial performance development of the Slovak health spa sector in the following year 2015. Thus, it was considered as the best-performing year within the whole period analysed. In 2015, the EVA reached the highest (and the only positive) average value of $€ 29,171$. This positive development ensured that the desired relation "ROE $>$ re" was respected, so enterprises were able to generate added value for their shareholders. The most significant decline within the "re" components was recorded in the case of "rf" indicator that dropped by $1.19 \%$ compared to the previous period. A more pronounced average increase in total costs (by $12.98 \%$ ) than total revenues (by $7.03 \%$ ) was the main reason for the reduction of net profit in 2016, which subsequently influenced the creation of negative ROE. Despite the continuing decline in "re" indicator and an increase in enterprises' equity, the financial 
performance of the analysed medical spa sector was getting worse and the positive trend since 2012 has been significantly disrupted.

Over the years $2012-2016$, the average level of EVA was $€-185,487$. The relation "ROE $>$ re" was not respected in most of the analysed years, which is a sign of non-performing sector. The average financial performance development of the Slovak spa enterprises quantified on the basis of the EVA indicator is shown in the following figure (Fig. 2).

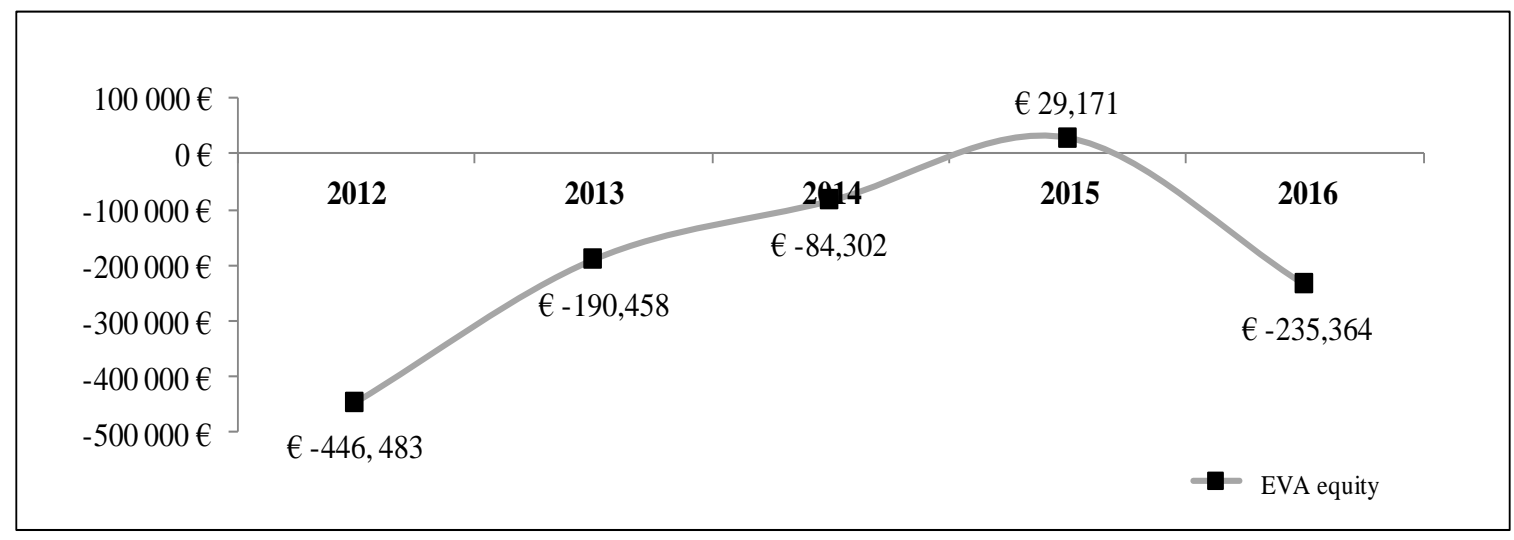

Figure 2 - The performance development of the health spa enterprises calculated on the EVA model application. Source: own processing based on the financial statements of analysed enterprises.

The positive EVA was reached at least in one year by 18 spa enterprises during the whole period analysed, 12 enterprises were able to generate value added for shareholders at least in two years, 9 enterprises at least in three years, 4 enterprises achieved the positive EVA at least in 4 years over the analysed period and only 1 enterprise was able to generate added value for shareholders in every single year ( $€ 87,568$ on average). However, if we have analysed more closely the development of the number of performing and non-performing enterprises evaluated by EVA model in individual years, there has been recorded a positive trend in terms of decreasing number of enterprises with negative EVA values (see Fig. 3).

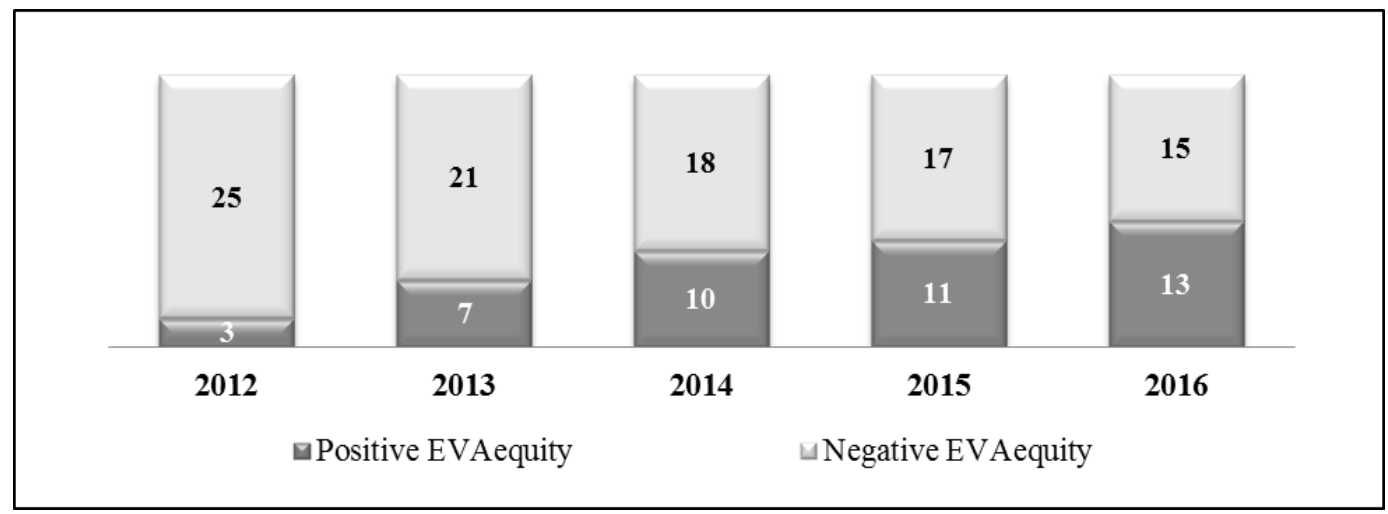

Figure 3 - Comparison of the number of performing and non-performing health spa enterprises based on the EVA model application. Source: own processing based on the financial statements of analysed enterprises.

Based on the results of EVA model application, we consider the best-performing enterprises Spa Bojnice, Spa Dudince and Spa Lúčky (EVA of these enterprises reached the average value of $€ 436,638$ over the analysed years). Contrary, the worst-performing enterprises were Spa Brusno, Spa Sliač and Horezza. In this case, the desired relation "ROE > re" was not respected in any of the years analysed. 
The following analysis is focused on financial performance evaluation of the health spa sector in Slovakia over the years $2012-2016$ by use of the RONA. Its essence is the same as the EVA with one simple difference: RONA is a relative ratio indicator that measures enterprise performance not in $€$, but in $\%$.

The most noticeable difference $(4.52 \%)$ between the RONA and WACC was recorded in the first analysed year 2012, when the RONA of enterprises operating in the Slovak health spa sector reached the average level of $1.13 \%$. The intense rise in the NOPAT by $106.61 \%$ as well as an increase in the NA value of $€ 314,597$ in the following year 2013 caused the RONA growth by an index of 1.9963 . Contrary, the WACC dropped by $1.37 \%$ mainly due to declining "re" value. This change caused a desired reduction in the difference between the RONA and WACC, even more than twice compared to the previous year. The positive development trend of both indicators continued in 2014 as well. The average NOPAT reached the value of $€$ 249,421 and the NA ranged around $€ 10,144,670$. For this reason, the RONA increased by $0.21 \%$ compared to previous year 2013 .

In 2015, the RONA re-increased and reached its maximum value of $2.55 \%$. This positive result was mainly influenced by the average NOPAT growth of $€ 15,121$. In the same year, the level of NA also increased by an index of 1.0236. However, due to more noticeable NOPAT increase by $3.61 \%$, enterprises operating in the Slovak medical spa sector achieved again higher profitability compared to previous years and the value of WACC continued in declining up to the level of $2.22 \%$. In 2015, the desired relation "RONA > WACC" was respected for the first time (and only in this year during the whole period analysed) and medical spa enterprises were able to create value added to owners. This positive development trend of all indicators was disrupted in the last analysed year 2016. The decline in net profit of the enterprises by $92.31 \%$ compared to previous year 2015 caused the decline in RONA by $2.35 \%$ only to the level of $0.19 \%$. This sharp drop in the NOPAT, despite the re-reduction of "re" indicator by an index of 0.8289 , did not ensure to maintain the desired relation "RONA > WACC" recorded in the previous year.

In this regard, much more important is to quantify the difference between the profitability measured by the RONA and the WACC indicator. Over the years $2012-2016$, the RONA ranged around $1.72 \%$ on average, whereas the WACC reached the level of $3.45 \%$. Therefore, the desired relation "RONA > WACC" was not respected in most of the analysed years. The average performance development of the Slovak spa sector quantified on the basis of the RONA and WACC comparison is presented in the following figure (Fig. 4).

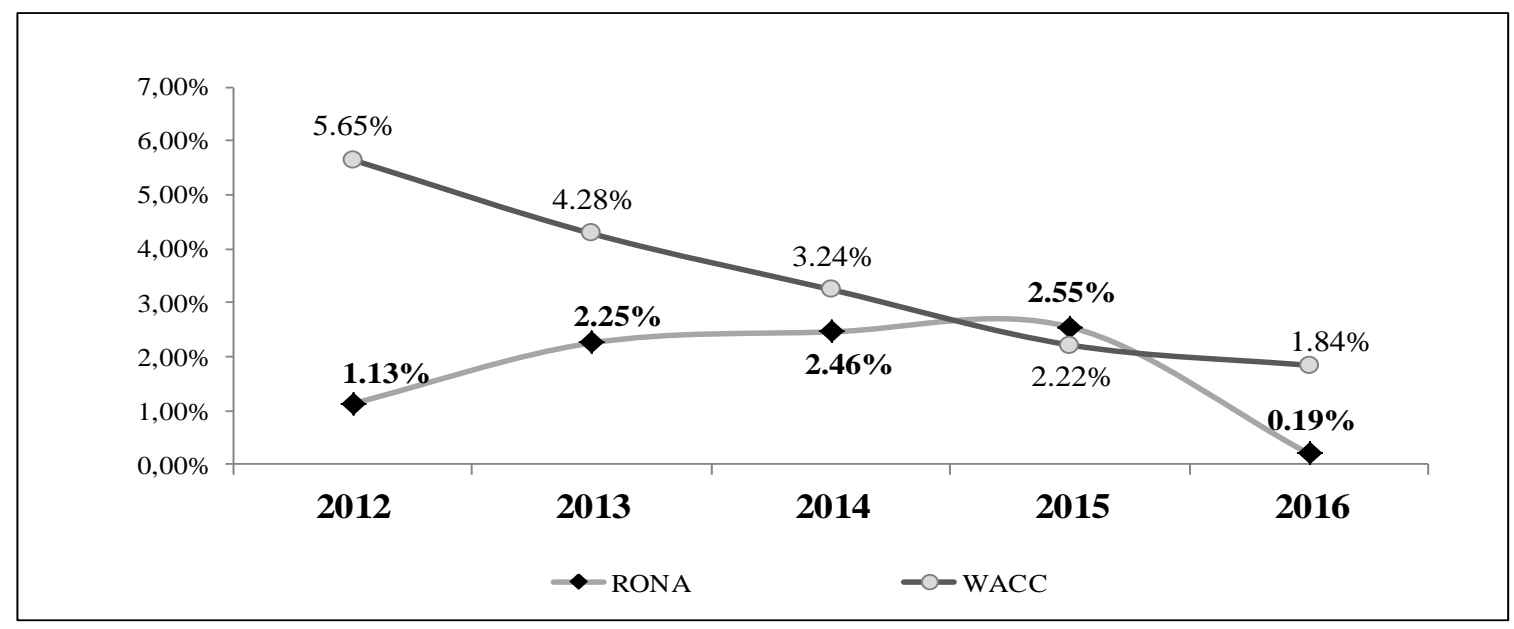

Figure 4 - The performance development of the health spa enterprises based on the RONA model application. Source: own processing based on the financial statements of analysed enterprises. 
It is worthy to note that during the whole period analysed the desired relation "RONA > WACC" was kept in the case of 16 spa enterprises (at least in one year), 12 enterprises were able to generate value for shareholders at least in two years, 7 enterprises at least in three years, in the case of 2 spa enterprises the RONA exceeded the WACC at least in 4 years and only 1 enterprise was able to maintain this desirable status in each analysed year. However, if we have concentrated on the number of performing and non-performing enterprises development evaluated on the basis of the RONA (see Fig. 5), the positive progress was also recorded in terms of increasing number of enterprises with the positive difference between the RONA and WACC values.

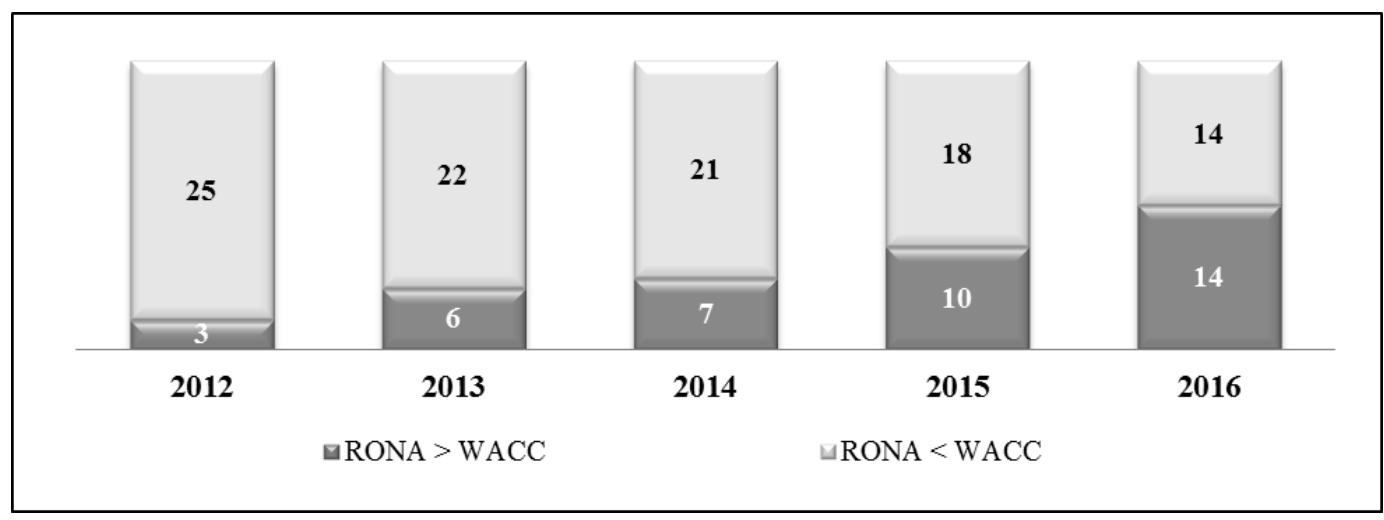

Figure 5 - Comparison of the number of performing and non-performing health spa enterprises based on the RONA model application. Source: own processing based on the financial statements of analysed enterprises.

In this regard, Spa Bojnice, Spa Lúčky and Spa Štós were identified as the best-performing medical spa enterprises by comparing the financial situation of enterprises based on the RONA and WACC values. On the contrary, the worst-performing enterprises over the years 2012 2016 were Spa Brusno, Spa Sliač and Spa Č́íž.

The following table (Tab. 1) presents the average resulting order of the Slovak medical spa enterprises that was compiled by the application of selected modern methods evaluating the financial performance during the analysed period of 2012-2016.

Table 1 The average resulting order of the spa enterprises compiled by the application of EVA and RONA model. Source: own processing based on the financial statements of analysed enterprises.

\begin{tabular}{|c|c|c|c|c|c|}
\hline Enterprise & EVA & RONA & Enterprise & EVA & RONA \\
\hline SE01 & 4. & 7. & SE15 & 20. & 26. \\
\hline SEO2 & 26. & 20. & SE16 & 24. & 11. \\
\hline SE03 & 1. & 3 & SE17 & 6. & 9. \\
\hline SE04 & 28. & 28. & SE18 & 15. & 12. \\
\hline SE05 & 2. & 8. & SE19 & 11. & 14. \\
\hline SE06 & 7. & 10. & SE20 & 12. & 2. \\
\hline SE07 & 3. & 5. & SE21 & 17. & 1. \\
\hline SE08 & 18. & 16. & SE22 & 22. & 22. \\
\hline SE09 & 13. & 15. & SE23 & 5. & 4. \\
\hline SE10 & 27. & 27. & SE24 & 8. & 13. \\
\hline SE11 & 9. & 6. & SE25 & 16. & 24. \\
\hline SE12 & 25. & 18. & SE26 & 10. & 19. \\
\hline SE13 & 23. & 21. & SE27 & 19. & 23. \\
\hline SE14 & 14. & 17. & SE28 & 21. & 25. \\
\hline
\end{tabular}

Based on the results, it is obvious that spa enterprises SE04 (Spa Brusno), SE10 (Spa Sliač), SE22 (Spa Dudince) reached the same position using the both modern performance evaluation 
methods - the EVA and the RONA. As we have already mentioned, the calculation of these methods is based on a bit different input data and indicators reflecting subsequently the different business performance assessment. Despite the fact that most enterprises did not reach identical performance position assessed by mentioned models, we have to emphasize the identical recognition of the best and worst-performing spa enterprise evaluated on the basis of the EVA and RONA model application.

Over the analysed period of 2012 - 2016, the worst-performing spa enterprise SE04 (Spa Brusno) was not able to generate added value for shareholders at all. In addition, the average EVA ranged around $€-2,177,293$ and the RONA did not exceed the value of WACC, which was higher by $24.06 \%$ on average. On the other hand, SE03 (Spa Bojnice) reached the highest average positive EVA ( $€ 958,469)$ and the RONA exceeded the value of WACC by $3.41 \%$ on average. Therefore, it was identified as the best-performing health spa enterprise within the selected sector. In this case, Spa Bojnice ranked 3rd in the case of RONA model application, however, this result was markedly influenced by distorted values causing the better position of SE21 (Spa Pieniny Resort) and SE20 (Spa Kováčová).

The issue of EVA calculating and its application in practice is the subject of many empirical studies. For example, Součková (2016) compared EVA and value added in industry sectors in the Czech Republic. The study results showed that the EVA equity is the most often applied method. The modified model of the financial planning based on the linking of the data to the EVA was built-up by Marková, Sedliačiková and Gurová (2016). Authors consider this model as the modern way of measuring enterprise performance and budgeting in the Slovak conditions. One of the possible methods of calculating the EVA indicator for Slovak companies in the conditions of valid accounting legislation in Slovakia were presented also in research study by Šalaga, Bartošová, Kicová (2015). Svobodová (2015) analysed the use of selected sophisticated modern financial performance indicators such as EVA, MVA and BSC in trading companies operating in the Czech Republic. The author also pointed to the inadequate use of these sophisticated tools that would help companies manage and monitor their performance more effectively. The RONA model application as a key tool for assessing the achieved level of enterprise performance was also the subject of many research papers (in different section and ways), mostly in foreign countries (Liu, An, Shen, 2015; Wang, Lin, 2012; Pei, 2012). The analysis of the correlation between the enterprise performance and the ownership structure were performed by the authors $\mathrm{Xu}$, Zhang, Tang (2007), who used the above-mentioned RONA indicator to assess the enterprise performance. Assessing the enterprise performance on the basis of the RONA indicator and monitoring the relationship between the degree of internationalization and the enterprise performance was the object of Ma's (2015) research study. Miecoanski, Palavecini (2017) also focused on assessing the profitability of enterprises by applying RONA indicator.

In accordance with the above mentioned empirical studies we also consider the EVA and the RONA as a key tools for assessing and managing the enterprise performance.

\section{CONCLUSION}

Natural health spas in the Slovak Republic are a significant phenomenon of the national economy development due to the rich representation of natural healing resources throughout the country. The main aim of this paper is to evaluate the financial performance of the health spa sector in Slovakia over the years 2012 - 2016 with use of selected modern financial methods (the EVA and the RONA). The other purpose was to identify the best and the worst-performing enterprises in the case of application of both modern methods. 
Based on the results, the positive EVA was reached at least in one year by 18 spa enterprises during the whole period analysed. However, the desired relation "ROE > re" was not respected in most of the analysed years, which is a sign of non-performing sector. Overall, the EVA reached the level of $€-185,487$ on average. Positive values of mentioned indicator were recorded only in year 2015, which is considered to be the best-performing one. However, the positive development of the EVA since 2012 was significantly disrupted in year 2016. This trend was mainly affected by the decline in net profit by $92.31 \%$, which despite of continuing decline in "re" indicator negatively influenced the creation of value added for shareholders.

The level of RONA ranged around $1.72 \%$ on average, whereas the WACC reached the average level of $3.45 \%$. For this reason, the desired relation "RONA > WACC" was not respected in most of the analysed years. Overall, only 16 spa enterprises were able to create value added for their shareholders and keep the mentioned relation at least in one year during the whole period analysed. A continuous increase in the RONA and a drop in the WACC since 2012 have led to a desirable approximation of these indicators and analysed spa sector was considered to be wellperforming in 2015. A sharp drop in the NOPAT in 2016, despite of re-reduction of "re" indicator by an index of 0.8289 , did not ensure to maintain the desired relation "RONA > WACC" and the positive performance development of the Slovak medical spa sector was significantly disrupted.

Based on the results, relatively identical values were achieved within the application of both modern methods (EVA in $€$ and RONA in \%). When evaluating the performance of Slovak spa sector as a whole, the best results were achieved in year 2015 and, on the contrary, year 2012 was identified as the worst-performing one. The financial performance trend of enterprises was also the same; a positive continuous performance growth was recorded over the period of 2012 - 2015, but this optimistic trend was influenced negatively by a sharp drop in net profit in the following year 2016. However, it is important to point out the declining number of enterprises reaching the negative EVA or enterprises complying the relation "RONA > WACC". According to the results of EVA and RONA model application, the best-performing enterprises within the analysed spa sector were Spa Bojnice, Spa Lúčky, Spa Dudince and Spa Štós. Contrary, the worst-performing enterprises over the years 2012 - 2016 were Spa Brusno, Spa Sliač, Horezza and Spa Č́íz.

The causes of declining performance in most Slovak spa enterprises can be found in several areas, not just in the financial one. However, the enterprises are able to influence their performance mainly by own business activity, therefore it is very important to focus on achieving a profit in a sufficient amount to improve the overall financial performance. One of the ways how to reach this goal can also be investment into tourist infrastructure, accommodation, catering, sport or cultural facilities.

Due to the selected methodology for calculating both modern financial methods, we also recommend applying other models and approaches to financial performance evaluation of the health spa sector in Slovakia. It will be the subject of our further research interest.

\section{Acknowledgements}

This paper is one of outputs of project VEGA 1/0791/16 "Modern approaches to improving enterprise performance and competitiveness using the innovative model - Enterprise Performance Model to streamline Management Decision-Making Processes. 


\section{References}

Damodaran, A. (2004a). Valuation the Big Picture. [online]. Available at: http://pages.stern.nyu.edu/ adamodar/

Damodaran, A. (2018b). [online]. Available at: http://pages.stern.nyu.edu/ adamodar/

Dluhošová, D. (2007). Nové přístupy k měření výkonnosti podniku. In: Ekonomická revue. s. 21-39, ISSN 1212-3951.

Durkáčová, M. (2010). Prístupy k hodnoteniu výkonnosti podniku a jeho procesov v kontexte ekonomického vývoja. In: 13th International Scientific Conference Trends and Innovative Approaches in Business Processes 2010.

Grell, M., Hyránek E. (2012). Maticové modely na meranie výkonnosti produkčných systémov. 1. vyd. Bratislava: Ekonóm. ISBN 978-80-225-3901-2.

Hamilton, J., Rahman, S., Lee, A. C. (2009). EVA: Does Size Matter? In: Review of Pacific Basin Financial Markets and Policies. Vol. 12, No. 2, p. 267-287. https://doi.org/10.1142/S0219091509001629

Hussey, R. (2014). MBA Accounting. New York: Palgrave Macmillan. ISBN 978-0-23030337-9. https://doi.org/10.1007/978-1-137-40435-0

Kabát, L. et al. (2013). Hodnotenie podniku a analýza jeho finančného zdravia. Bratislava: Iura Edition. ISBN 978-80-8078-608-3.

Kiseláková, D., Horváthová, J., Šofranková, B. (2016). Controlling rizík podnikania v modeloch ovplyvňujúcich výkonnost' a prognózovanie rizík v EÚ. Prešov: Prešovská univerzita v Prešove. ISBN 978-80-555-1561-8.

Kislingerová, E. et al. (2011). Nová ekonomika: Nové př́iležitosti? Praha: C. H. Beck. ISBN 978-80-7400-403-2.

Liu, L., An, N., Shen, Y. (2015). Research on the Relationship between Ex-financial Performance and IPO Under-pricing in China GEM. In: 4thInternationalConference on Social Sciences and Society. Vol. 72, p. 264-274. ISSN 2160-1070.

Ma, P. (2015). Empirical Analysis of the Relationship between Internationalization and Firm Performance. In: The 5thInternationalConference on Information, Communication and Education Application (ICEA 2015). Vol. 85, p. 224-229. ISSN 2160-1070.

Miecoanski, F., Palavecini, A. (2017). Profitability and Bussiness Sustainability of Banks that negotiating shares at Bm \& Fbovespa. In: Revista De Gestao Financas E Contabilidade. Vol. 7, No. 3, p. 76-85. ISSN 2238-5320.

Marková, V., Sedliačiková, M., Gurová, D. H. (2016). The Model of Financial Budgeting and Planning for Micro and Small Enterprises. In: Globalization and Its Socio-Economic Consequences, 16th International Scientific Conference Proceedings. p. 1305-1312

Maříková, P., Mařík, M. (2005). Moderní metody hodnocení výkonnosti a oceňování podniku. 2. vyd. Praha: EKOPRESS. ISBN 978-80-86119-61-0.

Mihaliková, E., Hrabovská, Z. (2012). Finančná analýza organizácie. Košice: UPJŠ v Košiciach. ISBN: 978-80-7097-939-6.

Mulačová, V., P. Mulač et al. (2013). Obchodní podnikáníve 21. století. Praha: Grada Publishing, a. s. ISBN 978-80-247-4780-4. 
Národná banka Slovenska. (2018). [online]. Dostupné z: https://www.nbs.sk/sk/statistickeudaje/financne-trhy/urokove-sadzby/dlhodobe-urokove-sadzby

Nelson, S. L. (2015). Quick Books 2015 All-in-One For Dummies. Hoboken, NJ: John Wiley \& Sons, Inc. ISBN 978-1-118-92017-6.

Neumaierová, I., Neumaier, I. (2002). Výkonnost a tržní hodnota firmy. Praha: Grada Publishing, a. s. ISBN 80-247-0125-1.

Nižniková, Z., Feranecová, A., Sabolová, M., Stašková, S. (2015). Enterprise Valuation by Using EVA Method in Slovakia. In: Era of Science Diplomacy: Implications for Economics, Business, Management and Related Disciplines, Bratislava, s. 654-660.

Pavelková, D., Knápková, A. (2009). Výkonnost podniku z pohledu finančního manažera. 2., aktualiz. a dopln. vyd. Praha: Linde. ISBN 978-80-86131-85-6.

Pei, H. (2012). Process Scan of Enterprise Performance Evaluation. In: Proceeding of the 2012 International Conference on Management Innovation and Public Policy (ICMIPP 2012). Vol. 1, No. 6, p. 1237-1241. ISBN 978-1-61896-012-2.

Souček, Z. (2010). Firma 21. století: (Předstihněme nejlepší!!!). Praha: Professional Publishing. 2. vyd. ISBN 978-80-7431-007-2.

Součková, M. (2016). Using Value Added in Sustainability Measurement. In: Innovation Management and Education Excellence Vision 2020: From Regional Development Sustainability to Global Economic Growth, 27thInternational Business Information Management Association Conference. s. 2727-2738.

Stýblo, J. (2008). Výkonnost' firiem. In: Moderní řízení, Roč. 43, č. 11, s. 25. ISSN 0026-8720.

Suchánek, P. a kol. (2013). Vliv kvality na výkonnost a konkurenceschopnost podniku. Brno: Masarykova univerzita. ISBN 978-80-210-6627-4. https://doi.org/10.5817/CZ.MUNI.M210-6627-2013

Svobodová, L. (2015). Moderní ukazatele finanční výkonnosti obchodní společnosti. In: Ekonomika a management : vědecký časopis Fakulty podnikohospodářské Vysoké školy ekonomické v Praze. Č. 2, s. 1-16. ISSN 1802-8934.

Šalaga, J., Bartošová, V., Kicová, E. (2015). Economic Value Added as a Measurement Tool of Financial Performance: Book Series: Procedia Economics and Finance. In: 4thWorldConference on Business, Economics and Management (WCBEM 2015). Roč. 26, s. 484-489.

Šalaga, J. (2016). Implementation of Economic Value Added in Conditions of Globalization. In: Globalization and Its Socio-Economic Consequences, 16thInternationalScientificConferenceProceedings. s. 1934-1939.

Šofranková, B., Kisel'áková, D., Horváthová, J. (2017). Actual questions of risk management in models affecting enterprise performance. In: Ekonomický časopis. Vol. 65, No. 7, p. 644-667. ISSN 0013-3035.

Šofranková, B., Horváthová, J., Kisel'áková, D. (2016). Key performance indicators of food companies and their analysis and aplication in enterprise performance model. In: Political sciences, law, finance, economics and tourism: 3rdInternationalmultidisciplinaryscientificconferenceSocialsciences\&arts SGEM 2016: Conference Proceedings, p. 387-394, Sofia: STEF92 Technology, ISBN 978-619-710574-2.

Šulák, M., Vacík, E. (2005). Měření výkonnosti firem. Praha: Eupress. ISBN 80-86754-33-2. 
Vochozka, M. (2012). Metody komplexního hodnocení podniku. Praha: Grada Publishing, a.s. ISBN 978-80-247-7462-6.

Wagner, J. (2009a). Měření výkonnosti: Jak měřit, vyhodnocovat a využívat informace o podnikové výkonnosti. Praha: Grada Publishing, a. s. ISBN 978-80-247-2924-4.

Wagner, J. (2011b). Měrení výkonnosti - vývojové tendence 2. poloviny 20. století. In: Politická ekonomie. Roč. 15, č. 6, s. 775-793. ISSN 0032-3233.

Wang, L., Lin, Q. (2012). Study of Infuencing Factors on Companies' Equity Financing Preferences - Case Study of theManufacturing Sector in Electronics Industry. In: Proceedings of China Private Economy Innovation International Forum 2012. p. 243247. ISBN 978-0-9845209-9-2.

$\mathrm{Xu}$, J., Zhang, B., Tang, Y. (2007). Comparative research on the ownership structure and corporate performance of state-ownedlisted enterprises and private listed enterprises. In: Proceedings of 2007 International Conference on Management Science \& Engineering. Vol. 1, No. 3. ISBN 978-7-5603-2278-0.

Závarská, Z. (2012). Manažment kapitálovej štruktúry pri financovaní rozvoja podniku ako nástroj zvyšovania finančnej výkonnosti. Prešov: PU v Prešove. ISBN 978-80-5550553-4.

Zemánková, L., Kruntorádová, M., Boušková, S. (2010). Použití ukazatele EVA v konkrétním podniku. In Trendy Ekonomiky a Managementu. Roč. 4, č. 7, s. 67-80, ISSN 18028527.

\section{Contact information}

Mgr. Veronika Čabinová

University of Presov in Presov, Faculty of Management

Konštantínova 16, 08001 Prešov

veronika.cabinova@smail.unipo.sk

ORCID: 0000-0003-4367-3590

Mgr. Erika Onuferová

University of Presov in Presov, Faculty of Management

Konštantínova 16,080 01 Prešov

erika.onuferova@smail.unipo.sk

ORCID: 0000-0001-8529-8843

doc. Ing. Dana Kisel'áková, PhD.

University of Presov in Presov, Faculty of Management

Konštantínova 16, 08001 Prešov

dana.kiselakova@unipo.sk

ORCID: 0000-0001-5662-5809

Ing. Beáta Šofranková, PhD.

University of Presov in Presov, Faculty of Management

Konštantínova 16, 08001 Prešov

beata.sofrankova@unipo.sk

ORCID: 0000-0001-9766-0467

DOI ID: https://www.doi.org/10.7441/dokbat.2018.02 


\title{
SECTORAL DIFFERENCES IN THE CREDIT ACCESS IMPEDIMENTS OF TURKISH SMES
}

\author{
Mehmet Civelek and Ibrahim Dursun
}

\begin{abstract}
Contributions of Small and Medium-sized enterprises (SMEs) that have been operating in various sectors to economies have increased over the years especially in job creation and growth. In an attempt to continue their activities in different conditions, SMEs need financing although they encounter some impediments. When it comes to the problems that firms perceive during their credit access, their feelings may differ because of being in different industries. In this context, the purpose of this research is to reveal if sectoral differences exist in perceptions of bank loan constraints for SMEs in manufacturing and service industries. Higher collateral requirements of banks, high expenses of loans and high number of procedures in credit application are the impediments that the research investigates. The sample of the study consists of 424 Turkish SMEs that are affiliated in Ankara Chamber of Commerce (ATO). Moreover, face to face surveys were performed to gain the responses from these businesses. By using ChiSquare and $\mathrm{Z}$ score statistics, and analyzing $\mathrm{p}$ values from these statistics, the study confirms that perceptions of SMEs that are in manufacturing and service sectors differ regarding to the selected credit access impediments. But contrary to the assumptions in the hypotheses that presume service firms are more likely to face with these impediments than manufacturing firms, the research finds that more SMEs in manufacturing sector perceive the chosen statements as obstacles in their credit application process than service firms do. Therefore, the research partially accepts the hypotheses. The study elucidates that manufacturing firms usually have high level of financial needs because of being exposed to higher amount of sunk costs and capital requirements to continue their activities and also make more export. These facts can make manufacturing firms risky from the banks' point of view. As a consequence of that, banks can take actions that cause tough loan conditions for SMEs in manufacturing industry and this can be the reason why more manufacturing firms in this study perceive the selected facts as obstacles than service firms do.
\end{abstract}

Keywords: Credit Obstacles, Bank Credit, SMEs, Manufacturing, Service, Turkey

\section{INTRODUCTION}

Nobody can ignore the contributions of Small and Medium-sized Enterprises on economic growth and workforce of countries. $98 \%$ of firms are SMEs that create $67 \%$ of work force and $58 \%$ of gross value added in European Union (EC, 2012). Moreover, SMEs consist of small, medium and microenterprises and 93.6\% of SMEs are microenterprises in Turkey (TSI, 2013). According to Turkish Official Gazette (2012), those firms differentiate regarding to their staff headcounts, turnovers and financial balance sheets. For example, the number of staff differs between 1 to 9 for microenterprises, 10 to 49 for small firms and 50 to 249 for medium-sized firms respectively. Furthermore, $75.8 \%$ of workforce, 55\% of GDP and $59.2 \%$ of export are provided by SMEs in this developing country (The Union of Chambers and Commodity Exchanges of Turkey, 2014). SMEs operate in different sectors such as manufacturing, service, 
construction, trade, mining, etc. According to Turkish Statistical Institute (2015), $12.6 \%$ of SMEs carry on their activities in manufacturing industry.

In order to produce and develop new products, expand their activities, such as R\&D and improve their economic growth SMEs need to be financed (Kira \& He, 2012). SMEs may not be competitive in an international market and may not enlarge its' businesses if they cannot get external finance (Osano \& Languitone, 2016) because SMEs usually do not have a high amount of internal funds. For this reason, the study mainly focuses on bank credit that is the major external source for most of SMEs in Europe (Badulescu A. \& Badulescu D., 2012) and Turkey (Uyar \& Guzelyurt 2015).

Yet, due to having information asymmetry between SMEs and banks in relation to those firms' credit default problem, enterprises face with several credit obstacles. Furthermore, characteristics of entrepreneurs and firms are also vital factors that may provide firms to get easier credit access. For instance, sizes and ages of firms and difficulties that they encounter in gaining bank loans have been analyzed by some researchers (Okura, 2009; Zarook, 2013). Some other studies also exist in the literature that compare sectors such as manufacturing and service industries regarding to their innovation and R\&D activities (Lejpras, 2009), international growth strategies (Kathuria et al., 2008), innovation and internationalization strategies (Forsman, 2011) and strategic abilities in their export performance (Raymond et al., 2014). But when it comes to the differences between SMEs in manufacturing and service industries and their perception on credit impediments, there are just a few studies in the literature.

In this regard, the purpose of the study is to examine whether some differences exist between the perceptions of bank loan constraints for SMEs in manufacturing and service sectors or not. In relation to bank credit obstacles, the study will consider some of the most common credit difficulties for SMEs in worldwide, namely, high costs of credits, high collateral requirements of banks and the existence of the high number of procedures in credit application. The contribution of the research is twofold. First, it emphasizes the credit impediments and then shed on lights on the sectoral differences in the credit access of SMEs. By focusing on the selected credit problems, this study can make the financial impediments more understandable for SMEs that operate in different sectors and this can be a key point in their growth and development. The data that study analyzes was obtained in 2011 when the financial system of Turkey was recovering from the global financial crunch. Hence finding differences between SMEs from different sectors in connection with bank loan issues can be a significant value addition to the SMEs financing literature especially after the financial crises. Also, governments and financial institutions can gain some advantages from the results of this study and they can apply some policies that may provide easier credit conditions or provide more financial support for these kinds of businesses.

The answers of the research question, the impediments of bank loans and the reasons for these issues will be explained in Section 1. Next, the way how the research question is examined will be described in Section 2. The results of the study and discussion that suggest some managerial implications will be clarified in Section 3. Lastly, section 4 ends with suggestions for further research and limitations of this study. 


\section{LITERATURE REVIEW}

SMEs not only provide benefits for the economic development of countries, but also improve entrepreneurial characteristics of firms' executives. For instance, by carrying their business owners of SMEs can gain some abilities, make strategic decisions in competitive markets on the spur of the moment (Rahman et al., 2016) and can promote their firms' entrepreneurial and innovative operations (Erdogan, 2015). In order to continue those operations and develop their entrepreneurship access to finance is a critical factor for entrepreneurs (Naude et al., 2008). But entrepreneurs are prone to gain credits from banks because they usually have lack of internal sources such as personnel assets, supports from their families and friends (Ogubazghi \& Muturi, 2014). Within this context, Yilmaz (2016) examines owners of 296 Turkish SMEs and finds that bank credit is the primary financing source for around $71 \%$ of those entrepreneurs.

However, compared with larger businesses, SMEs in emerging market economies such as Turkey have more constraints to gain bank loans (Erdogan, 2015). One of the reasons of this fact can be the crises that Turkey has faced through the last ten years. These crises have caused to SMEs to face with more obstacles comparing with the countries that have more stable markets (Karadag, 2015). By investigating small enterprises in USA and Mexico, Hayes et al. (2015) find similar results that compare to developing countries, small firms in developed countries face with lower difficulties when they need to access to finance.

Moreover, Makler et al. (2013) investigate SMEs in Brazilian market and outline the percentage of larger firms that gained funds from banks is higher in comparison with smaller businesses. The reason for this can be small firms' lack of transparency that creates difficulties for banks to assess small firms' capabilities and their credit ratings (Erdogan, 2015). So, information asymmetry problem comes into existence between those firms and banks and banks meet with some troubles to give correct credit decision. In order to cope with these issues, banks implement some regulations that hinder credit access of SMEs.

Corresponding to credit risk issues, in case of borrowers' bankruptcy and probability of default (Trenca \& Bolocan, 2010) and also borrowers' financial deterioration can create credit risks for banks due to causing financial losses for them (Nurgaliyeva, 2014). Moreover, SMEs have high amount of intangible assets (Zhang et al., 2014), lower level of return, a higher amount of transaction costs (Pandula, 2015) higher amount of debt, lack of assets to collateralize, lower level of cash flows (Belás et al., 2014). So, lending to SMEs becomes more riskier for banks in comparison with bigger firms and to minimize their financial losses and also to close the information gap between them and firms (Pandula, 2015) banks charge SMEs with higher prices (Cowling et al., 2012), look for more collateral requirements, (Ghimire \& Abo, 2013) and set cost for small firms with higher rates of interest and expenditures (Yildirim et al., 2013).

Considering the most common problems that SMEs encounter to gain bank loans, Pandula (2015) asserts that the lower level of collateral that is provided by firms, complex and too many procedures in credit application process and the high amount of loan costs are the main credit obstacles in Sri Lanka. Yilmaz (2016) also states that high numbers of procedures and requirements, collaterals and high level of loan rates are the main constraints for the majority of Turkish SMEs. Because of these reasons this study considers these three most common bank loan impediments for SMEs' credit access namely, too many procedures in loan applications, high level of collateral requirements and high costs of credits. 
According to Civelek et al. (2016) banks ask many procedures in an attempt to evaluate creditworthiness of SMEs. Those procedures enable banks to be informed about present and future performance of SMEs (Fatoki \& Asah, 2011) so information asymmetry and credit risk can be minimized. On the other hand, by investigating some SMEs in Greek market Daskalakis et al. (2013) submit that bureaucratic procedures are the most common impediments for these firms.

With respect to collateral issues, banks ask for collateral to reduce the impacts of information asymmetry, uncertainties and monitoring costs regarding to the credit risks of businesses (Yildirim et al, 2013). This is because collateral plays as an assuring role for banks against information asymmetry problem (Newman et al., 2010). By asking collateral banks can be informed of the capacity of repayment and financial information of firms (Wangmo, 2015). Fatoki and Asah (2011) express that collateral is a significant factor that plays a determining role to access to loans. By providing their personal assets or their firms' assets entrepreneurs can get loans from banks (Fatoki \& Asah, 2011). But higher amount of collaterals that are required by banks is negatively related with the credit application of SMEs (Abdesamet \& Wahab, 2014) and poses an obstacle for these firms to gain bank loans.

When examining the high costs of credit, legal fees, stamp tax and credit evaluation fee are the expenses that can increase credit costs for SMEs (Pandula, 2015). By collecting data from 241 Jordanian SMEs, Al-Hyari (2013) finds that high cost of financing is one of the most significant constraints for the development of these firms. In the wake of the financial crises, SMEs have encountered higher interest rates that have caused a rise in the costs of bank loans (Ključnikov et al., 2016). Furthermore, when lenders provide finance for SMEs in imperfect markets, they increase the cost of loans to cope with issues related with the uncertainness, riskiness and, information asymmetry (Cowling et al., 2012). This is because the information that is insufficient and opaque increases the cost of having accurate information for banks (Jenkins \& Hussain, 2014). Moreover, Magda (2014) implies that banks make credits more costly for SMEs because of monitoring these businesses and evaluation of SMEs' credit worthiness. Also, economy of scale creates more costs for SMEs compared to bigger firms because information and transaction costs rise when the size of enterprises decreases (Okura, 2009). In order to reimburse those extra costs, banks apply for some loan pricing policies that increase the cost of credits for SMEs.

Regarding to sectors of firms, the industry that businesses carry on their activities is an important factor for businesses to get loans (Domeher et al., 2017). For instance, by analyzing 557 Libyan SMEs Zarook et al. (2013) find the positive relationship between sector of firm and access to finance. Similarly, Kira and He (2012) investigate 163 Tanzanian SMEs and result that a positive and significant relationship exists between industries of firms and being funded by debt financing. The reason for this can be the difference functions of each sector. For instance, the services that are provided by enterprises in service sector are usually intangible, personal and perishable. A service can be called as intangible when there is not any standard process to do the business. Due to depending on customers' wants and requests a service may differ for each person thus it can be called as personalized. Moreover, a service can consist of abilities of human and their innovation skills so those factors make services perishable (Raymond et al., 2014). On top of that SMEs in service industry usually have intangible and perishable assets that cannot be stored. For this reason their assets cannot play an assuring role against their debts (Silva \& Carreira, 2010) and service firms may not collateralize those assets 
to banks in order to gain credit. For these reasons, to reduce their credit risks, banks can charge service firms with more costs and can apply for more procedures to give service firms a loan. Hence firms in service sector encounter more difficulties regarding to access to loans (Silva \& Carreira, 2010).

On the other hand, products of manufacturing industry have higher level of standardization compared to firms in service sectors (Lejpras, 2009). Manufacturing firms have value chains that enable them to trade, make transportation and make their products non-perishable. Those activities might be linked to their manufacturing processes. By having these opportunities, it can be easier for manufacturing firms to grow globally. Also, manufacturing firms have lots of tangible assets that can be used as collateral to face with reduced loan obstacles (Chakraborty \& Mallick, 2012). Furthermore, Donati (2016) finds that the average amount of cash flows is higher for businesses in manufacturing industry comparing to the enterprises in service industry.

By having tangible assets, higher cash flows, efficient standards in value chains and more chances to grow globally manufacturing firms can provide more collateral, encounter with less procedures and credit costs. For these reasons, the study assumes and hypothesizes that manufacturing firms are less likely to face with bank credit constraints in comparison with the businesses in service sector.

\section{DATA AND METHODOLOGY}

The data that the study analyzes is gained from a thousand Turkish SMEs by face to face survey in 2011. The survey is based on 23 questions that are not only related to demographic characteristics of firms and respondents (location, number of years that firms have been operating, size, industry of firms and job position of respondents etc.) but also related to firms' financial indicators ( firms' annual sales, total sales, the percentages of sales from import and export activities). Moreover, some other survey questions exist regarding to financial constraints that enterprises have encountered when funding from external sources. The firms that are investigated operate in various industries such as manufacturing, service, construction and agriculture and are members of Ankara Chamber of Commerce. Furthermore, companies' owners, executives, shareholders and accountants are the survey respondents of this study.

The sample is chosen to fit the purpose of the study. For this reason, the study focuses on firms that have gained bank loans and also operate in manufacturing and service sectors. Due to having higher numbers of respondents from those industries, the study compares both of them and tries to find differences between their perceptions of credit difficulties. Hence, 424 SMEs are selected to examine. The structure of the sample consists of 250 respondents (59\%) from service sector and 174 respondents $(41 \%)$ from manufacturing industry. Corresponding with the bank loan obstacles, the study choses three following problems, "Many procedures exist in credit application", "Banks ask for collateral that is higher than the requested credit by firms", "Costs of credits are expensive". Five points Likert Scale is employed to scale the responses from these questions (1-totally disagree, 2-disagree, 3-partially agree, 4-agree, 5-totally agree). The study excludes the response of "partially agree" from the tests because it is not an obvious choice that can be considered. Three hypotheses that are located below are set up in connection with the selected aim. 
H1: There is a significant difference between sectors of firms and the perception of the impediments that many procedures exist in the credit application. The study professes that SMEs in service sectors perceive the selected fact as a constraint more than manufacturing firms do.

H0: No statistically significant differences exist between the sectors and the perception of the obstacle that many procedures exist in the credit application.

H2: A statistically significant difference exists between sectors of the enterprises and the perception of the credit difficulty that banks ask for collateral that is higher than the requested credit by firms. The study posits that the businesses in service industry are more prone to perceive this statement as a loan obstacle compared with enterprises in manufacturing industry.

H0: No statistically significant differences exist between the sectors and the perception of the impediment that banks ask for more amount of collateral than the requested credit amount of firms.

H3: There is a statistically significant difference between sectors and the perception of the loan problem that costs of credits are expensive. The study presumes that manufacturing firms are less likely to perceive this case as a problem when applying to credit in comparison with service firms.

H0: No statistically significant differences exist between the sectors and their aspects of the credit constraint that the credit costs are expensive.

In order to find differences between the sectors and their perceptions of credit impediments, the study applies Chi-Square test and Person statistics at 5\% level of significance. Moreover, $\mathrm{P}$ values from $\mathrm{Z}$ score are employed to test whether the differences from individual responses are statistically significant or not. The study accepts the null hypotheses if $\mathrm{p}$ values from $\mathrm{Z}$ score are higher than $10 \%$ confidence level. In case of having p values less than $10 \%$, the study rejects the null hypotheses that assume the non-existence of statistically significant differences between the sectors and their perception of credit problems. Ms Excel and a software that exists at this website: http://www.socscistatistics.com/tests are employed to make calculations. Moreover, $\mathrm{Z}$ score is also performed by the same software that is in existence in the following website: http://www.socscistatistics.com/tests/ztest/Default2.aspx.

\section{RESULTS AND DISCUSSION}

In this section, the study briefly explains the results that are found by statistical analyses. Moreover, the study makes some comments regarding to these findings and support them by providing some empirical studies from literature. The results regarding to the obstacle namely, high numbers of procedures in credit application and its perception by SMEs in different sectors are reported by Table 1 .

Table 1 Evaluation of the perception of the selected loan impediments among firms in different sectors.

Source: Own processing. 


\begin{tabular}{|c|c|c|c|c|}
\hline $\begin{array}{l}\text { Many procedures } \\
\text { exist in } \\
\text { credit application. }\end{array}$ & Total & Manufacturing & Service & $\begin{array}{l}\text { Z-score/ } \\
\text { p-value }\end{array}$ \\
\hline $\begin{array}{l}\text { Completely agree } \\
\text { and agree }\end{array}$ & 303 & $\begin{array}{l}132 \\
(\mathbf{7 5 . 9 )}\end{array}$ & $\begin{array}{l}171 \\
(68.4)\end{array}$ & $\begin{array}{l}1.6737 \\
\mathbf{0 . 0 9 4 9 2} \\
\end{array}$ \\
\hline Partially agree & 62 & $\begin{array}{l}31 \\
(17.8)\end{array}$ & $\begin{array}{l}31 \\
(6.84)\end{array}$ & $\begin{array}{l}1.5526 \\
0.12114 \\
\end{array}$ \\
\hline $\begin{array}{l}\text { Completely disagree and } \\
\text { disagree }\end{array}$ & 59 & $\begin{array}{l}11 \\
(6.3)\end{array}$ & $\begin{array}{l}48 \\
(19.2)\end{array}$ & $\begin{array}{l}-3.7689 \\
0.00016\end{array}$ \\
\hline Total: & 424 & 174 & 250 & \\
\hline $\begin{array}{l}\text { chí - square/ } \\
\text { p-value }\end{array}$ & & $\begin{array}{l}15.0852 \\
\mathbf{0 . 0 0 0 5 3}\end{array}$ & & \\
\hline
\end{tabular}

Table 1 illustrates that the $\mathrm{P}$ value from Chi-square is significant at $5 \%$ significance level $\left(\chi^{2}\right.$ $(1, N=424)=15.08, p=.00<0.05)$. This result proves that a difference exists between manufacturing and service firms regarding to their perception of the stated bank credit obstacle. Moreover, the table demonstrates that around $76 \%$ of manufacturing firms agree with the fact that banks ask too many procedures in their credit application while this percentage is $68 \%$ for firms in service industry.

On the other hand, $\mathrm{P}$ value from $\mathrm{Z}$ score is also significant at $10 \%$ significance level $(\mathrm{z}=1.67$, $\mathrm{p}=.09<0.10$ ). So, $\mathrm{P}$ value from $\mathrm{Z}$ score confirms that the difference in the perception of the selected loan constraint between manufacturing and service firms is statistically significant. Although the study corroborates the statistically significant difference between various industries, $\mathrm{H} 1$ hypothesis can be partially accepted. This is because, the study assumes in the first hypothesis that respondents from service firms are more prone to sense credit procedures as a bank credit impediment comparing to respondents of manufacturing firms. But according to results from table 1, more SMEs in manufacturing industry agree and completely agree that they face with many procedures in their credit application.

Table 2 Evaluation of the perception of the stated credit constraint among SMEs in various industries.

Source: Own processing.

Banks ask for

collateral that is

higher than the requested credit by firms.

$$
\begin{array}{cc}
\text { Total } \quad \text { Manufacturing } \quad \text { Service } & \text { P value }
\end{array}
$$

Completely agree and agree
131

(75.29)
160

(64.00)
2.464

0.0139 


\begin{tabular}{lllll}
\hline Partially agree & 72 & $\begin{array}{l}25 \\
(14.37)\end{array}$ & $\begin{array}{l}47 \\
(18.80)\end{array}$ & $\begin{array}{l}-1.1957 \\
0.23014\end{array}$ \\
\hline $\begin{array}{llll}\text { Completely disagree and } \\
\text { disagree }\end{array}$ & 61 & $\begin{array}{l}18 \\
(10.34)\end{array}$ & $\begin{array}{l}43 \\
(17.20)\end{array}$ & $\begin{array}{l}-1.9785 \\
0.0477\end{array}$ \\
\hline Total: & & 174 & 250 & \\
\hline chí - square/ & 424 & & & \\
p-value & & 6.4425 & & \\
\hline
\end{tabular}

Table 2 depicts the results in relation with higher collateral requirements of banks and its perception by the respondents from distinct industries. According to table 2, $\mathrm{P}$ value from ChiSquare substantiate that the perception of the highlighted loan constraint for SMEs in manufacturing and service industries differ. The reason for this is $\mathrm{p}$ value from Chi-Square statistics is significant at $5 \%$ significance level $\left(\chi^{2}(1, N=424)=6.44, p=.03<0.05\right)$. High collateral requirements of banks are perceived as a credit obstacle by $76 \%$ of company owners, executives, shareholders and accountants in the investigated SMEs from the manufacturing sector. $64 \%$ of the respondents in service industry also approve that banks ask for collateral that is higher than their credit need. When examining $\mathrm{P}$ value from $\mathrm{Z}$ score, the result bears out that the difference between SMEs in both manufacturing and service industries in relation with their perception of higher amount of collateral is statistically significant $(\mathrm{z}=2.46, \mathrm{p}=.01<.05$ significant at 5\%). But comparing to manufacturing firms, service firms experience the collateral problems less than SMEs in manufacturing industry. So these results refute the assumption of the study in the second hypothesis that service firms tend to be more agreed with the fact that banks ask for more collateral than the requested credit by firms. Hence, the second hypothesis of the study can also be partially accepted.

Next, the study comes to the last analysis by considering manufacturing and service industries and their perception of the following fact as an impediment that "Costs of credits are expensive". By performing Chi-Square and $\mathrm{Z}$ tests, the study gains results and indicate them by table 3 . Table 3 shows the existence of statistically significant difference between the examined sectors in relation with the problem that firms face in bank credit access. By having significant $\mathrm{p}$ values from $\mathrm{Z}$ score and Chi-Square at $5 \%$ significant level, the statistically significant difference is confirmed by the study. $\left(\chi^{2}(1, N=424)=7.22, p=.03<0.05, \mathrm{z}=2,45, \mathrm{p}=.01<\right.$ $.05)$.

Table 3.Evaluation of the perception of the chosen credit obstacle between enterprises in manufacturing and service sectors. Source: Own processing.

\begin{tabular}{lllll}
$\begin{array}{l}\text { Costs of credits } \\
\text { are expensive. }\end{array}$ & Total & Manufacturing & Service & $\begin{array}{l}\text { Z-score/ } \\
\text { p-value }\end{array}$ \\
\hline $\begin{array}{l}\text { Completely agree } \\
\text { and agree }\end{array}$ & 320 & 142 & 178 & 2.4505 \\
\hline
\end{tabular}




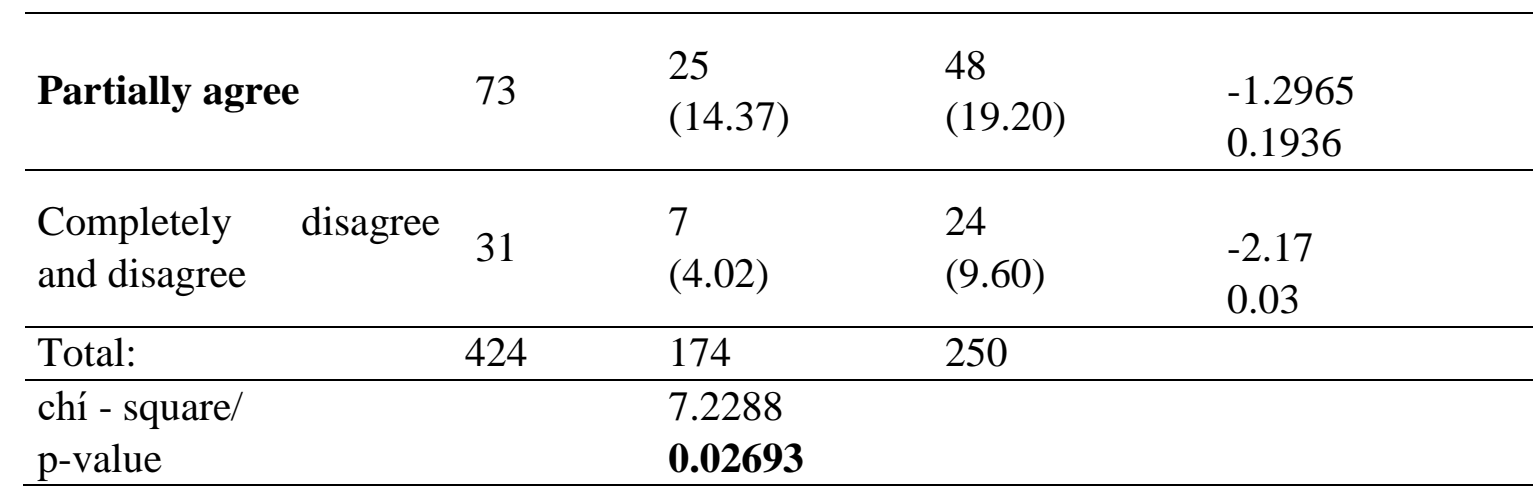

On the other side, SMEs in manufacturing sector have higher percentage of respondents $(81 \%)$ that agree with the fact that costs of credits are expensive comparing to the respondents from service firms $(71 \%)$. For this reason, the supposition of the study in the third hypothesis that service firms are more likely to perceive the high credit costs as a credit difficulty is not confirmed. Thus, the study partly accepts the third hypothesis.

In order to summarize the all results, the study briefly interprets that statistically significant differences exist between manufacturing and service industries regarding to bank credit obstacles. Contrary to the assumptions of the study, SMEs in service industry face with reduced credit impediments in comparison with manufacturing firms. One of the reasons that firms in service sector face with lower financial constraints might be having lower sunk costs comparing to SMEs in manufacturing industry. Another reason why manufacturing firms are more likely to encounter credit constraints can be the fact that manufacturing firms need more capital to operate in minimum scale in comparison with service firms (Silva \& Carreira, 2010) and establishing a manufacturing factory might be more expensive than setting up a business in service sector (Lejpras, 2009).

Moreover, by comparing SMEs in different sectors of US market, Chakraborty and Mallick (2012) posit that the credit gap for service industry is lower than the gap in manufacturing industry. Credit gap consists of borrowers that face with credit constraints and credit limitation, are discouraged because of the possibly of being rejected in their credit application, and also small firm that have lack of credits in their balance sheets (Chakraborty \& Mallick, 2012). This high level of credit gap for manufacturing firms can make banks' investments more risky and banks can ask for more collateral, charge them with higher costs or ask for more procedures. Banks are more prone to give credits for sectors that have a more amount of profits and lower level of risks (Dohcheva, 2009). In order to protect themselves against credit risks of manufacturing firms, banks in Turkey might have applied these implementations that create difficulties for SMEs to get credit.

Furthermore, Erdogan (2015) points out firms with higher level of export sales are more inclined to see the process of being funded as difficulty comparing with SMEs that have lower level of export sales. According to study of Kathuria et al. (2008) businesses in manufacturing sector are more prone to develop their international market while firms in service industry usually focus on internal market and aim to improve it. Hence, manufacturing firms are more likely to export comparing to service firms. But uncertainties related to their receivables from their international customers can make exporting SMEs riskier for banks so these SMEs can be faced with more impediments when they access to bank loans especially in the crises period 
(Ključnikov \& Popesko, 2017). This can be another reason why manufacturing firms in this study face with increased obstacles when they access to finance. The data of this study can also prove to this fact by having higher number of exporting companies in the manufacturing sector in comparison with the service firms.

In the study of Forsman (2011), it is validated that SMEs in the service sector has more abilities to improve their products and services in comparison with manufacturing firms. Service firms are more active to make innovation and make investments for research and development activities while manufacturing firms hire lower number of workers for their R\&D activities (Lejpras, 2009). In this research, the banks that SMEs gained credit from, could have considered these innovative activities of service firms when they made their credit decisions about these firms. So banks may have provided easier credit access for the firms in the service industry.

Because of having higher sunk costs, higher capital needs to work in minimum scale and making more exporting activities, manufacturing firms that the study investigates might have asked for more credit and might be seen more risky by the banks. For these reasons, banks might have taken precautions that create impediments for the manufacturing firms and make them to perceive the process of gaining access more difficult in comparison with SMEs in service industry. Moreover, the study suggests that Turkish government, Credit Guarantee Fund, Small and Medium Enterprises Development Organization (KOSGEB) and other financial institutions should support firms in manufacturing industry to provide them easier access conditions such as giving loan with low interest rate, making more credit aid, charging them with lower credit expenses. Having been operated in one of the biggest industries that makes exporting and contribute Turkish economy and workforce, SMEs in the manufacturing sector should be encouraged by those institutions in larger extend.

\section{CONCLUSION}

The purpose of the research is to explore sectoral differences in the perception of bank credit impediments for SMEs. In line with this objective, the study takes manufacturing and service industries in consideration and compares them. The study pays regard to credit expenses, collateral requirements and procedures in credit application corresponding with credit obstacles. In order to collect the data, the research applies face to face surveys that consist of 424 respondents from Turkish SMEs. The statistical data analyses are performed by means of Chi-Square and $\mathrm{Z}$ score. The results of the research vindicate that the perception of loan impediments is diluted for SMEs in the service sector by comparison with manufacturing SMEs.

On the other hand, some limitations exist in this research. For instance, the study is only limited to bank loans, the selected impediments, manufacturing and service industries, Turkish SMEs that have carried their businesses in a the capital city of Turkey and have accessed bank credit in the last three years. Moreover, the study had limited time in data collection so the perceptions of firms' executives were like snapshots. Because of having many problems related to bank credit constraints of SMEs in different markets, the study cannot provide a general solution for each firm. For these reasons, researchers can analyze more financial sources, more financial obstacles, more industries or more characteristics of SMEs, more countries and widen geographical areas in order to provide more detailed and more extensive study. 
Acknowledgement

The authors are thankful to the Internal Grant Agency of FaME TBU No. IGA/FaME/2017/010: "Financial Constraints on Economic Activities" for financial support to perform this research.

\section{References}

Abdesamed, K. H., \& Wahab, K. A. (2014). Financing of small and medium enterprises (SMEs): Determinants of bank loan application. African Journal of Business Management, 8 (17), 717-727. https://doi.org/10.5897/AJBM2013.7222

Al-Hyari, K. (2013). Identification of Barrier Factors and Potential Solutions to SMEs Development among Jordanian Manufacturing Sector. International Journal of Business and Management, 8 (24), 132-140. https://doi.org/10.5539/ijbm.v8n24p132

Badulescu A., \& Badulescu, D. (2012). SMEs Financing Needs and The Relationship Lending Perspective: Theoretical Considerations And Empirical Evidence. Metalurgia International, 1-6.

Belás, J., Bartoš, P., Habánik, J., \& Novák, P. (2014). Significant Attributes Of The Business Environment In Small And Medium-Sized Enterprises. Economics And Sociology, 7 (3), 22-39. https://doi.org/10.14254/2071-789X.2014/7-3/2

Chakraborty, A., \& Mallick, R. (2012). Credit gap in small businesses: Some new evidence. International Journal of Business, 17 (1), 1083-4346.

Civelek M., Ključnikov A., Dobrovič J., \& Hudáková, M. (2016). A model of measurement of the quality of business environment in SME segment. Journal of International Studies, 9 (2), 251-263. https://doi.org/10.14254/2071-8330.2016/9-2/6

Cowling, M., Liu, W., \& Ledger, A. (2012). Small business financing in the UK before and during the current financial crisis. International Small Business Journal, 30 (7), 778800. https://doi.org/10.1177/0266242611435516

Daskalakis, N., Jarvis, R., \& Schizas, E. (2013). Financing practices and preferences for micro and small firms. Journal of Small Business and Enterprise Development, 20 (1), 80-101. https://doi.org/10.1108/14626001311298420

Dohcheva, D. (2009). Credit Rationing In Agricultural Credit Markets In Bulgaria. Trakia Journal of Sciences, 7 (3), 57-62.

Domeher, D., Musah, G., \& Hassan, N. (2017). Inter-sectoral Differences in the SME Financing Gap: Evidence from Selected Sectors in Ghana. Journal Of African Business, 18 (2), 194-220. https://doi.org/10.1080/15228916.2017.1265056

Donati, C. (2016). Firm growth and liquidity constraints: Evidence from the Manufacturing and service sectors in Italy. Applied Economics, 48 (20), 1881-1892.

Erdogan, A. I. (2015). Which SMEs Perceive Access to Finance As An Obstacle To Their Operations?: Evidence From Turkey. Journal of Economic and Social Development, 2 (2), 13-19.

Eurpean Commission. (2012). Annual Report on Small and Medium-sized Enterprises in the EU: EU SMEs in 2012: At the crossroads. https://ec.europa.eu

Fatoki, O., \& Asah, F. (2011). The Impact of Firm and Entrepreneurial Characteristics on Access to Debt Finance by SMEs in King Williams' Town, South Africa. International 
Journal of Business and Management, $6 \quad$ (8), 170-179. https://doi.org/10.5539/ijbm.v6n8p170

Forsman H. (2011). Innovation capacity and innovation development in small enterprises: A comparison between the manufacturing and service sectors. Res Policy, 40, 739-750. https://doi.org/10.1016/j.respol.2011.02.003

Gama, A. P. M., \& Geraldes, H. S. A. (2012). Credit Risk Assessment and The Impact Of The New Basel Capital Accord On Small And Medium-Sized Enterprises An Empirical Analysis. Management Research Review, 35 (8), 727 - 749. https://doi.org/10.1108/01409171211247712

Ghimire, B., \& Abo, R. (2013). An empirical investigation of Ivorian SMEs access to bank finance: Constraining factors at demand-Level. Journal of Finance and Investment Analysis, 2 (4), 29-55.

Hayes, J. P., Chawla, S. K., \& Kathawala, Y. (2015). A comparative study of problems encountered in the development of small businesses in the U.S. and Mexico. Journal of Developing Areas, 49 (3), 395-406. https://doi.org/10.1353/jda.2015.0175

Jenkins, H. \& Hussain, M. (2014). An analysis of the macroeconomic conditions required for SME lending: The case of Turkey. Development Discussion Paper, 1-29.

Karadag, H. (2015). The Role and Challenges of Small and Medium-sized Enterprises (SMEs) in Emerging Economies: An Analysis from Turkey. Business and Management Studies, 1 (2), 179-188. https://doi.org/10.11114/bms.v1i2.1049

Kathuria, R., Joshi M. P., \& Dellande, S. (2008). International growth strategies of service and manufacturing firms: The case of banking and chemical industries. International Journal of Operations \& Production Management, $28 \quad$ (10), 968-990. https://doi.org/10.1108/01443570810903113

Kira, A. R., \& He, Z. (2012). The Impact of Firm Characteristics in Access of Financing by Small and Medium-sized Enterprises in Tanzania. International Journal of Business and Management, 7 (24), 108-119. https://doi.org/10.5539/ijbm.v7n24p108

Ključnikov, A., Belás, J., Kozubíková, L., \& Paseková, P. (2016). The Entreprenurial Perception of SME Business Environment Quality in the Czech Republic. Journal of Competitiveness, 8 (1), 66-78. https://doi.org/10.7441/joc.2016.01.05

Ključnikov, A., \& Popesko, B. (2017). Export and its Financing in The SME Segment: Case Study From Slovakia. Journal of Competitiveness, 9 (1), pp. 20-35. https://doi.org/10.7441/joc.2017.01.02

Lejpras, A. (2009). Determinants of Internationalization: Differences between Service and Manufacturing SMEs. DIW Berlin, Discussion Papers, 1-29. https://doi.org/10.2139/ssrn.1461395

Magda, F. M. (2014). Basel III Impact on Banking Sector and SMEs Financing. Studies and Scientific Researches, Economics Edition, 19, 112-120. https://doi.org/10.1515/gej2013-0024

Makler, H., Ness, W. L., \& Tschoegl, A. E. (2013). Inequalities in Firms' Access to Credit in Latin America. Global Economy Journal, 13 (3-4), 283-318. https://doi.org/10.1515/gej-2013-0024 
Naudé, W., Gries, T., Wood, E., \& Meintjies, A. (2008). Regional determinants of entrepreneurial start-ups in a developing country. Entrepreneurship and Regional Development, 20 (2), 111-124. https://doi.org/10.1080/08985620701631498

Newman, A., Gunessee, S., \& Hilton, B. (2010). Applicability of financial theories of capital structure to the Chinese cultural context: A study of privately owned SMEs. International Small Business Journal, 20 (10), 1-19.

Nurgaliyeva, A. (2014). Ways to Improve Credit Risk Management of The Banking System Of Kazakhstan: The Post-Crisis Approaches. Actual Problems Of Economics, 5 (155), 119.

Ogubazghi, S.K., \& Muturi, W. (2014). The effect of age and educational level of owner/managers on SMMEs' access to bank loan in Eritrea: Evidence from Asmara City. American Journal of Industrial and Business Management, 4, 632-643. https://doi.org/10.4236/ajibm.2014.411069

Okura, M. (2009). Firms Characteristics and Access to Bank Loans: SMEs in China. International Journal of Business and Management Science, 1 (2), 165-186.

Osano, H. M., \& Languitone H. (2016). Factors Influencing Access to Finance by SMEs in Mozambique: Case of SMEs in Maputo Central Business District. Journal of Innovation and Entrepreneurship, 5 (13), 1-16. https://doi.org/10.1186/s13731-016-0041-0

Pandula, G. (2015). Bank Finance for Small and Medium-Sized Enterprises in Sri Lanka: Issues and Policy Reforms. Studies in Business and Economics, 10 (2), 32-43.

Rahman, A., Civelek, M., \& Kozubíková, L. (2016). Proactiveness, Competitive Aggressiveness and Autonomy: A Comparative Study From The Czech Republic. Equilibrium, Quarterly Journal of Economics and Economic Policy, 11(3), 631-650. https://doi.org/10.12775/EQUIL.2016.028

Raymond, L., St-Pierre, J., Uwizeyemungu, S., \& Le Dinh, B. (2014). Internationalization capabilities of SMEs: A comparative study of the manufacturing and industrial service sectors. Journal of International Entrepreneurship, 12, 230-253. https://doi.org/10.1007/s10843-014-0123-7

Silva, F., \& Carreira, C. (2010). Financial constraints: Are there differences between manufacturing and services? Estudos Do Gemf, 16, 1-34.

The Union of Chambers and Commodity Exchanges of Turkey. (2014). http://kobi.org.tr/index.php/tanimi/stats, Accessed: 28.02.2018.

Trenca, I., \& Bolocan, M. (2010). Considerations Regarding Credit Portfolio Risk Management Of The Banking Institution. Finance - Challenges Of The Future, 9 (11), 84-90.

Turkish Official Gazette. (2012). Küçük ve Orta Büyüklükteki İşletmelerin Tanımı, Nitelikleri ve Sınıflandırılması Hakkında Yönetmelikte Değişiklik Yapılmasına Dair Yönetmelik. Available at: http://www.resmigazete.gov.tr/eskiler/2012/11/20121104-11.htm

Turkish Statistical Institute. (2013). http://www.turkstat.gov.tr/Start.do Accessed: 26.02.2018.

Turkish Statistical Institute. http://www.turkstat.gov.tr/PreHaberBultenleri.do?id=21540 Accessed: 05.03.2018.

Uyar, A., \& Guzelyurt, M. K. (2015). Impact Of Firm Characteristics On Capital Structure Choice Of Turkish SMEs. Managerial Finance, 41(3), 286-300. https://doi.org/10.1108/MF-01-2014-0016 
Wangmo, C. (2015). Small Medium Enterprise (SME) Bank Financing Constraints In Developing Countries: A Case Study of Bhutan. International Journal of Arts \& Sciences, 8 (5), 569-590.

Yildirim H. S., Akci, Y., \& Eksi I. H. (2013). The Effect of Firm Characteristics in Accessing Credit for SMEs. Journal of Financial Services Marketing, 18, 40-52. https://doi.org/10.1057/fsm.2012.28

Yilmaz, G. H. (2016). Küçük ve Orta Ölçekli İşletmelerin Kredi Sorunları Üzerine Muğla İlinde Yapılan Bir Araştırma. Journal Of Social Sciences And Humanities Researches, 17 (36), 67-82.

Zarook, T., Rahman, M. M., \& Khanam, R. (2013). The Impact of Demographic Factors on Accessing Finance in Libya's SMEs. International Journal of Business and Management, 8 (14), 55-65. https://doi.org/10.5539/ijbm.v8n14p55

Zhang, J., Chen, L., Liu, X., \& Ding, F. (2014). Measurement Of Credit Risk Of Small And Medium-Sized S\&T Enterprises In China. International Journal Of Business Administration, 5 (4), 21-31. https://doi.org/10.5430/ijba.v5n4p21

\section{Contact information}

Mehmet Civelek

Tomas Bata University in Zlin, Faculty of Management and Economics

Mostní 5139, 76001 Zlín, Czech Republic

civelek@fame.utb.cz

Prof. Dr. İbrahim Dursun

International University of Sarajevo, Faculty of Business and Administration

Hrasnička cesta 15, 71210, Ilidža, Sarajevo, Bosnia and Herzegovina

idursun@iud.edu.ba

ORCID: 0000-0002-1247-5308

DOI ID: https://www.doi.org/10.7441/dokbat.2018.03 


\title{
ECONOMIC EVALUATION OF THE FREE MOVEMENT OF CIZIZENST IN THE EU
}

\author{
Meri Duduci
}

\begin{abstract}
Economic evaluation of the free movement of citizens in the European Union is an analysis of how this movement has helped the economy of the EU member countries. It is very important to mention the analysis done through the years and the results that was gathered from it. Through the information gathered it is possible to notice how the movement changes between the countries. It can be pointed out which countries are most preferred due to the economic possibilities that they offer, and which ones are less preferred due to economic lacks and instability.

There were analyzed some economic variables and through the analysis, it was possible to notice how the variables change due to the free movement of citizens in the EU.

The advantages and disadvantages that this movement has offered to the native and hosting EU countries are a very significant economic analysis of how much this movement is affecting the general economy of the EU.
\end{abstract}

Keywords: European Union, Free Movement of Citizens, Labour, Economic Evaluation.

\section{INTRODUCTION}

One of the four pillars of where the European Union was built was the free movement of citizens. The free movement of citizens includes the freedom of working, visiting and living all the European citizens. The citizens will always have the same legal treatment in any of the member countries of the EU, except of some countries that did not fully accept the free movement of citizens.

There have been different changes in the intramovement flows during the years caused by several factors as the economic situations of different member countries. Citizens tend to move to where the living and working conditions are better and offer more opportunities.

According to the situation there are countries who support and fiercely defend the freedom of movement and working with the citizens and there are others who strongly stress on the fact that there are several economic problems caused by this movement.

In a time frame analysis, it is possible to notice that the countries are divided between two big groups. The first group includes the countries whose citizens are called movers. The second group is created by countries whose citizens are called stayers. It is important to acknowledge the fact that the movers have become so due to different causes, starting from the economic reasons to the social ones.

There are also several advantages and disadvantages that the European Union member countries are facing due to the free movement of citizens. The countries benefit when the working force is specialized and well known in their working position. As they are gaining a worker for whom they never invested in and is ready to contribute to the economic development of the country. There are also several other reasons that are listed as advantages of the free movement of citizens.

On the other hand, there are also different disadvantages that the hosting countries are facing due to citizens flows. To mention the fact that it might affect the working positions of their native citizens causing problems with the employment and unemployment rate of the country. Due to several economic disadvantages this might also lead to some social problems among the native citizens and movers. 


\section{MATERIALS AND METHODS}

There were used different methodological tools to conduct this manuscript. The resources used to write it have been mainly gathered from literature resources regarding the free movement of citizens in the EU, different statistical websites that have a similar aim, to analyze this situation of movement in the European Union countries.

The selective research was used to collect the information in a selective way, focusing mainly on the economic sector of the EU countries and the different theoretic analysis of the movers. The main focus was to gather the information focusing only on the specific sources that analyzed the free movement of citizens. The research was carefully focused only on the internal movement without involving external immigration.

Another methodology that was used in this paper is the factual research. Through this research it was possible to focus on finding specific dates through several years, which are important in the history of the freedom of movement in the European Union. As it is the date when the Maastricht Treaty was signed in 1992 that introduced the concept of creating the EU citizenship and demolishing the internal borders. Another important date that is important in this analysis is the year 2008 where the economic crises started and how it changed the internal movement in search of better economic conditions for the EU citizens. During the years of crisis, it happened a high rate of movement as some of the countries were more affected than others. Having the possibility to an EU citizenship, they opted to move to countries such as the Czech Republic, Germany, France and other countries where the economy was more stable. The countries from where the citizens moved the most were Italy, Spain, Greece and Portugal.

In the entire manuscript, it was used the Qualitative methodology describing the reasons why some citizens decide to become "Movers", such as economic instability, political instability and not sufficient possibilities to have a successful profession life.

On the other hand also the Quantitative methodology enriched this paper through the specific data regarding the number of citizens moving into the countries of the Union. It is important to mention that countries who have the highest number of movements are Romania with a $13 \%$ and Italy with a $10 \%$ of the whole population. Also, it is important to mention that according to the data gathered from Eurostat there are 10.5 million of EU citizens that have opted to work and live in another country of the EU.

It is also used the deductive analysis that through all the data and information gathered, after studying them it was possible to reach a conclusion. So from general information gathered from books and other resources, the next step was to process and to carefully analyze them to finalize to a conclusion. By gathering some data from the free movement, it was possible to see that in years of crises the movement is higher. Also, the movement of younger people is higher due to the fact that they want to experience different lifestyles and to gain foreign experience. The movement of younger people is higher in the countries with an economic stability less than the others.

The vertical analysis was used in this paper as well, an analysis that is expanded in time and does not do the analysis of a certain specific time. The free movement of citizens in the EU is one of the main pillars of the Union, so to focus on a specific moment was not possible. Not only was not possible to focus on a specific time moment, but also is not possible to focus on a specific place, this is done by using the Horizontal analysis, which is an analysis expanded in place, by not focusing on just a specific place. In this paper were considered and gathered information from the European Union as a whole, with the 28 countries part of it. So it was focused on 28 countries. 


\section{DISCUSSION}

There were several data gathered regarding the free movement of citizens in the European Union. The aim of this paper is to be up to date with the information collected, this is the reason why the data have been selected near to the present year 2010 up to 2017. In this way it is possible to analyse the present situation.

\subsection{EU citizens living in another country}

Due to the fact that it is very important to analyze the situation of free movement between countries of the EU during the economic crisis. As it is one of the main reasons that has caused the citizens to move.

Table 2 EU Native Citizens living in another Member State (Departure Country, 2017). Source: WorldBank

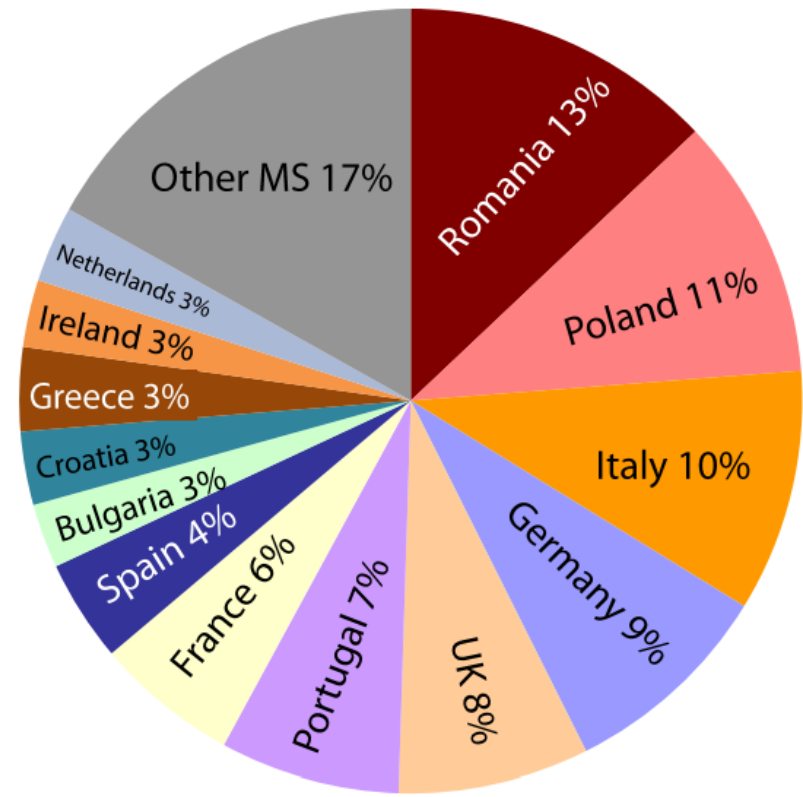

It is easily understandable that the countries are divided in two groups. Those countries who have a lower percentage of native citizens, living in another country. The second group is created by the countries who have a high percentage of citizens living in another EU country. It is quite noticeable that countries like Italy, that was deeply affected by the economic crisis, has still a high percentage of citizen living outside of the country.As seen on the figure 1 with a $10 \%$ and this is caused due to political instability and economic recession.

It can be seen a lower percentage of movement of Greece and Spain, even if they were deeply affected by the crise. The answer to this is that the high rate of movement was mainly part of the years after crise and it has reached a stability now. With the big debts that the economy got from the European Union this has made possible the stability of these states. On the other hand countries such as Germany and Czech Republic that are not part of the graph specifically, but collected all together, have the lowest movement percentage. 


\subsection{Employed, Unemployed and Inactive citizens}

Figure2 Employed, unemployed and inactive EU citizens living in the host member states (in millions 2015). Source:Eurostat

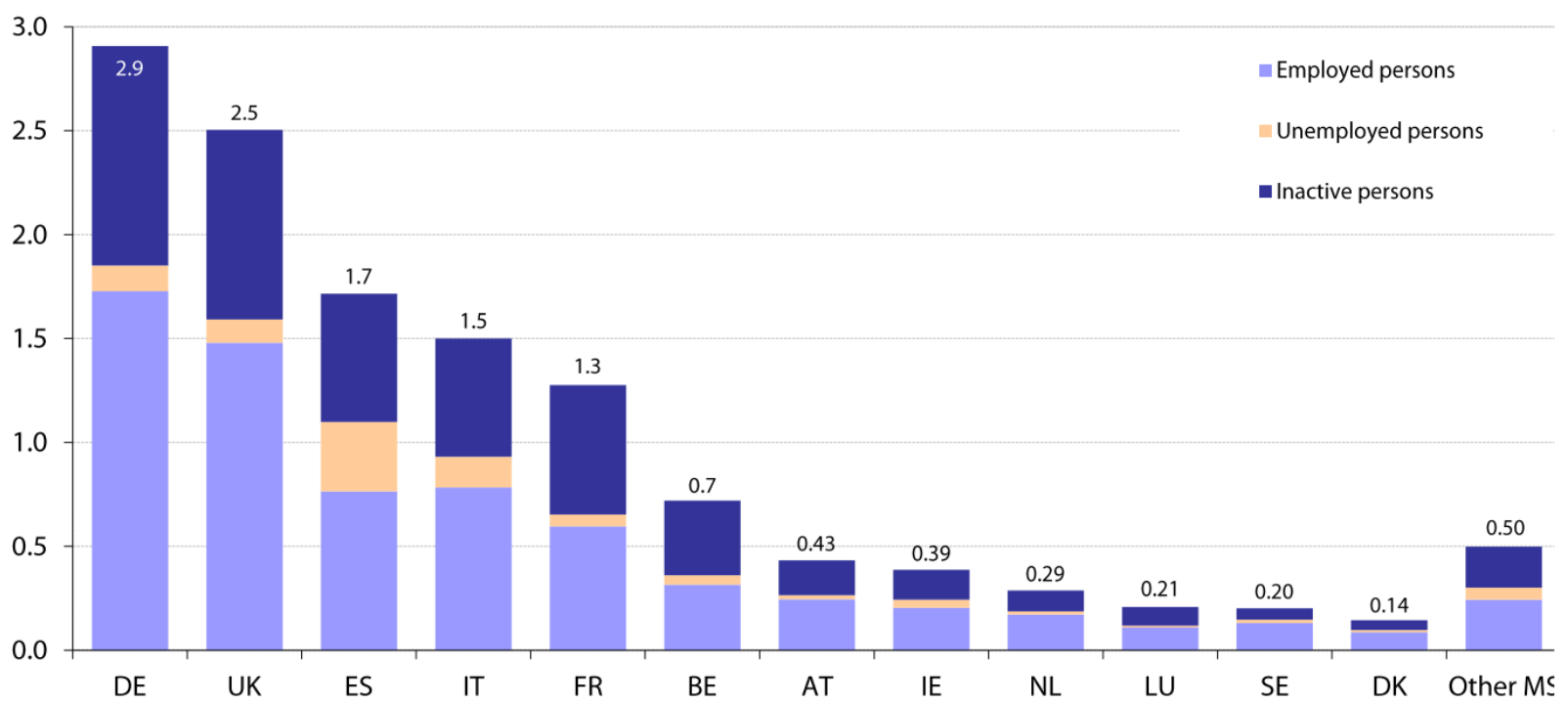

In the Figure 2 is shown the rate of employment, unemployment and inactive EU citizens. It is being study the year 2015. It is interesting to analyze Germany with the highest employment and unemployment persons. Due to the fact that specialized forces and also unspecialized forces seek ermany as a residence country. The advantage of the countries that have a higher amount of employed people is that in most cases graduated student are in search for a better place with higher living standard and higher professional opportunities. Also universities of Germany and UK too, are highly rated from the students of other countries. This is also very positive for the economy of a country due to the fact that they are collecting the future specialized workforce.

On the other hand, movers who are not specialized causes a decrease in the economy as they tend to lower the salaries and working standards.

\subsection{Price Index for household}

Figure3 Price index for household final consumption expenditure (EU28=100, 2015) Source:Eurostat

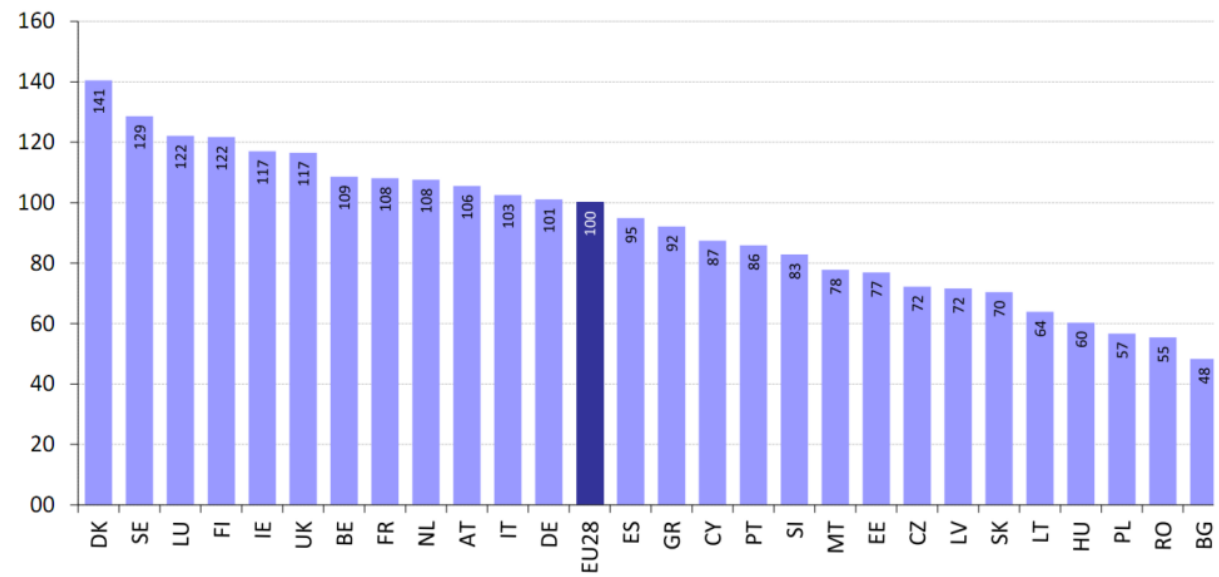

This is one of the main indexes that shows the changes that the economy has faced due to the free movement of citizens in the EU. It is visible in here a difference that the Nordic counries have faced the highest rate of price index household. 
Table 3 Composition of intra-EU mobility by different types, EU-28 citizens in the EU-28, 2015. Source: Eurostat

\begin{tabular}{|c|c|}
\hline Type of mobility & Extent \\
\hline $\begin{array}{l}\text { 'Long-term' EU-28 movers of working age ( } 20-64 \text { years) living in } \\
\text { EU-28* (Eurostat figures) }\end{array}$ & 11.3 million \\
\hline (as share of the total working-age population in the EU-28 $8^{42}$ ) & $(3.7 \%)$ \\
\hline EU-28 movers of working age living in EU-28*(EU-LFS figures) & 10.5 million $^{43}$ \\
\hline ...of which active EU-28 movers (employed or looking for work)** & 8.5 million $^{44}$ \\
\hline (as share of the total labour force in the EU-28) & $(3.6 \%)$ \\
\hline Cross-border workers (20-64 years)** & 1.3 million \\
\hline (as share of the total employed in the EU-28) & $(0.6 \%)$ \\
\hline $\begin{array}{l}\text { Number of postings }{ }^{45} \text { (of employed and self-employed), (no. of PDs } \\
\text { A1)*** }\end{array}$ & 2 million \\
\hline Annual return mobility (20-64 years) $(2014) * * * *$ & 630,763 \\
\hline (as share of 'long-term' EU-28 movers of working age) & $(6 \%)$ \\
\hline $\begin{array}{l}\text { (as share of EU-28 nationals emigrating from their country of origin in } \\
2014)^{* * * * *}\end{array}$ & $(59 \%)$ \\
\hline Retired EU-28 movers (all ages) & 1.4 million \\
\hline
\end{tabular}

\subsection{Economic advantages and disadvantages}

As mentioned before, there are several economic advantages because of the free movement of citizens of the hosting countries.

It is possible to gather the best specialized work force as those are the main who are seeking for better opportunities. According to this fact, there will be more taxes paid into the host countries that significates more revenues for the economic part.

Also the fact of having not qualified work force can be seen as an advantage as there are several jobs that native workers of developed countries are not willing to do. These positions can be fulfilled by the new comers.

On the other hand, there are several disadvantages for the countries who are facing the free movement of countries. Less tax income for the countries that are left and this leads directly to less income for some countries.

It is called "Brain Drain" that these countries are facing with their qualified and specialist workforce leaving. This is a very negative side for some countries as they are loosing incomes generated by these workforce and a slower economic growth and development.

\section{CONCLUSIONS}

Through this paper research it is possible to reach to the conclusions of the big importance that the free movement of citizens has in the economy of the European Union.

The European Union is one of a kind union in the world that gives possibilities to the citizens to not only find more opportunities but seek for better standards and higher professional possibilities. 
There are several advantages and also disadvantages for the welcoming countries and also for the home countries that after studying can be possible to notice that both combined have brought the European Union to be one of the powerful leaders in the world.

For sure there exist some limitations regarding this research due to the fact that there is a percentage of people who move to several countries continuously, as a plan of gaining experience so to go back to their country and contribute.

In future research activities this research will be continuing with a questionnaire where EU citizens will have the possibility to express their thoughts regarding movement and at what level they find it beneficial.

\section{References}

Fella S. Ruzza C. Anti-Racist Movements in the EU: Between Europeanisation and National Trajectories, Palgrave Macmillan 2012 ISBN 9780230290907

Guild E. Peers S. Tomkin J. The EU Citizenship Directive: A Commentary, OUP

Oxford 2014, ISBN 01987052392014 https://doi.org/10.1007/978-94-6265-162-3

Hazelhorst M. Free Movement of Civil Judgments in the European Union and the Right to a Fair Trial, T.M.C. Asser Press, 2017, ISBN 9789462651623

Rechi E. Mobile Europe: The Theory and Practice of Free Movement in the EU, Palgrave Macmillan UK, 2015 ISBN 1137316020 https://doi.org/10.4337/9781849802314

Recchi E. Favell A. Pioneers of European Integration: Citizenship and Mobility in the EU, Edward Elgar Publishing 2009, ISBN 9781849802314

Thym D. Questioning EU Citizenship: Judges and the Limits of Free Movement and Solidarity in the EU, Bloomsbury Publishing, 2017, ISBN 9781509914661

Shuibhne N. The Coherence of EU Free Movement Law: Constitutional Responsibility

and the Court of Justice, OUP Oxford 2013, ISBN 9780191511066 https://doi.org/10.1093/acprof:oso/9780199592951.001.0001

European parliament, Facts Sheets on the European Union, 2016 [online] Accessible at http://www.europarl.europa.eu/atyourservice/en/displayFtu.html?ftuId=FTU_2.1.3.ht $\mathrm{ml}$

European commission. Free Movement - EU nationals, 2017 [online] - Accessible at http://ec.europa.eu/social/main.jsp?catId=457\&langId=en

European commission, Movement and Residence, 2016 [online] - Accessible at http://ec.europa.eu/justice/citizen/move-live/index_en.htm

European commission, Movement and Residence, 2016 [online] - Accessible at http://ec.europa.eu/justice/citizen/move-live/index_en.htm

Eurostat, Annual Report on Intra-EU Labour Mobility 2017 [online] -Accessible at file:///C:/Users/User/Downloads/KE-BQ-17-002-EN-N\%20(1).pdf

Fondation robert schuman, The Free Movement of People in the European Union: principle, stakes and challenges, 2014 [online] - Accessible at http://www.robertschuman.eu/en/european-issues/0312-the-free-movement-of-peoplein-the-european-unionprinciple-stakes-and-challenges 


\section{Contact information}

MSc. Meri Duduci

Tomas Bata Univerzity, Faculty of management and econom। Mostní 5139, Zlín

$+42077808788$

meriduduci@gmail.com

ORCID: 0000-0001-8668-2484

DOI ID: https://www.doi.org/10.7441/dokbat.2018.04 


\title{
THE DETERMINANTS OF EXPECTED INFLATION IN VIETNAM
}

\author{
Do Phuong Thao, Le Tuan Doanh, Do Thi Thanh Nhan
}

\begin{abstract}
The article focuses on the factors which can affect the expected inflation rate in Vietnam. The paper review the theories and related studies to find out the six main factors impact the expected inflation in Vietnam: historical inflation, volume gap, effective exchange rate, interest rate, oil prices and the price of rice. The model (VAR model) is built to find out whether six factors influence the expected inflation.
\end{abstract}

Keywords: expected inflation, inflation, interest rates, macroeconomic policies.

\section{INTRODUCTION}

As reported by the World Bank (2013), inflation is a very serious problem of Vietnam's economy, controlling the inflation is the top priority task in comparison with other macroeconomic targets. In the crisis period, the solutions of the government in order to control inflation are less effective and cause some consequences on the economic development. In general, when the inflation rises in Vietnam, the given solutions mostly focus on monetary tightening without considerations of other important factors. As the tight monetary policy is a short-term solution and there is not fully to solve in the long term; this made inflation become more and more serious in Vietnam. Therefore, the study find outs the factors has the influence on the inflation in order to make the overall solution. Patra and Partha Ray (2010) demonstrate that among the factors affecting inflation such as historical inflation is an important one. There have been many domestic and foreign researches about inflation (Camen, 2006; Nguyen and Nguyen, 2010). However, these authors have not considered the determinants of inflation by using the quantitative methods.

There are many studies from developed economies in the UK, U.S, Germany, Brazil, India which investigate the importance of expected inflation in predicting and controlling inflation (Patra and Ray, 2010),. But there are not any studies in Vietnam about this issue. In addition, the finding will be very helpful in implementing the macroeconomic policies. Therefore, the main objective of this paper is to identify the determinants that impact the expected inflation in the Vietnamese context.

\section{LITERATURE REVIEWS}

In the current studies, the theories are normally applied: the theory of wages, consumption and unemployment rate by Keynes (1936). Meanwhile, research by Friedman (1968) not only introduced two types of Philips curve but also opens up a macroeconomic aspect of "prospect theory," that is the people's expectations of future economic events that may affect economic outcomes. Along with Friedman, Phelps (1967) has modified and adjusted Philip curve and taken expected inflation into consideration. Initially, the expectation is assumed to be oriented to the past (backward - looking), the objects make economic expectations when observed equilibrium inflation in the past. Woodford (2003) and many other researchers have made assumptions about the future expectations (forward-looking). This theory states that people can predict future inflation based on many different variables from the historical information available and the credibility of central banks. New Keynesians sought to combine the two assumptions: expectations towards the past and the future while proposing Hybrid New Keynesian Philips Curve model. Clarida (1999) developed a structural model using quarterly data to analyze a rate of companies using past behavior to set prices. Also, Clarida said that the 
public, including those who are forward-looking and those who are backward-looking and the coefficients from which the authors test the dominant behavior. As a result, the forward-looking behavior dominates the backward-looking through empirical evidence. In this study, the authors also examined the cross-correlation between three factors: inflation, output gaps and labor income (a representative for the marginal cost). The estimation results show that unit labor costs dominates the output gaps when estimated by the new Philips curve. Output gap led to inflation rather than vice versa. Besides, they also showed that unit labor costs have a strong correlation with inflation. Ranyard (2008) have outlined mechanisms and factors leading to the formation of expected inflation, suggesting that inflation is formed under the influence of perceptions and attitudes about inflation from economics of the professional, the Government's policy announcements, the Central Bank speeches, the amplification of social media and word of mouth. Also, the perception of inflation impacted directly from the fluctuations of prices and income. The factors above not only impact the future expectations but these factors also affected by expectations in the past that is stored in the current period. Windram (2007) suggested that the impact of social factors - economic and cognitive impact of cognitive expectations, certain latency (latency of it) when the economy has signaled to fall, it may take for changes in inflation. The speed may vary depending on: the length of the shock, the response of the central bank policy and how to create expected inflation. Thus, from this idea, the central bank should react and implement drastic measures, effective immediately when the shocks occur to stabilize market sentiment to keep long-term expected inflation stable. There is such a drag on the inflation target will be more easily and quickly. Cerisola research and Gelos (2005) focused on testing the factors affecting expected inflation in Brazil, based on a survey of the private sector and market survey data of the Bank of Brazil. The study used regression models to test the 6 factors affecting expected inflation in Brazil include: Lagging inflation, inflation target; real effective exchange rate gap; real wage gap, interest rate; primary surplus. In addition, the study results also indicated that the level of impact of these factors on expected inflation change over time. This research has pointed out the difficulties in controlling inflation and anchor inflationary expectations when it comes to the impact of administering prices. These items are included management of some public services, such as price using gas prices, electricity prices, the price of public transport services, ... The regulation of commodity prices may be due to the private companies or are set directly by the government. Research by Patra and Ray (2010) aims to build quantitative models to calculate expected inflation and testing factors affecting expected inflation in India.The author uses the ARIMA model to calculate the expected inflation in India and used VAR models to test the 6 factors affecting expected inflation in India: past inflation, output gap, spending government consumption, real effective exchange rate, real interest rates, prices of basic commodities, the price of fuel. From these studies, the authors apply this model to study the existing practices in Vietnam, namely model using autoregressive moving average - ARIMA to simulate sequence number expected inflation from past inflation data, based on the factors affecting expected inflation are: past inflation, output gaps, real effective exchange rate, real interest rates, oil price and rice price. These factors have been used and tested in the study of Cerisola and Gelos (2005) and Patra and Ray (2010), eliminating government spending by a negligible impact on expected inflation. Besides, the authors used a model vector autoregression - VAR to test the factors affecting expected inflation. In this analysis, the impulse response functions and variance decomposition results in expected inflation would help clarify the timing and extent of the impact of these factors on expected inflation. 


\section{METHODOLOGY}

\subsection{Research Model}

This article uses two main research models: ARIMA model to determine the sequence of expected inflation in Vietnam and VAR model to test factors affecting expected inflation in Vietnam between 2000 - 2010. ARIMA model is a univariate model using time series data; the model considered the historical values of the variable $\mathrm{Y} \neg \mathrm{t}$ to clarify some of the relationships between the values $\mathrm{Y} \neg \mathrm{t}$, Estimated value of $\mathrm{Y} \neg \mathrm{t}$ in the future. This model does not need changes or a relationship complicated structure, so it is pretty simple, but there are also certain disadvantages such as: (i) not supported by the theoretical basis or a relationship basic system; (ii) ARIMA model cannot generate a result in long-term quality. However, ARIMA has been proven to generate short-term inflation forecasted reliable and showed better performance compared with other quantitative models, and it has been used in many research articles as in previous studies of Patra and Partha Ray (2010).

In this paper, the model vector autoregression - VAR is selected to conduct the factors affecting expected inflation in Vietnam. The application of VAR model of Sims (2009) has the following advantages : (i) Sims said that if relationships exist between the variables and the variables which must be considered for the same role, so it is unreality to have a complete variable which does not affect the other variables, taking into account all the variables are endogenous variables and do not need to identify endogenous and exogenous variables; (ii) the method of Sims shows ability to decompose unexpected changes in macroeconomic variables from the expected volatility was aimed at analyzing the impact of policy under sudden shocks, no are contemplated; (iii) the method of Sims also helps economists estimating the degree and response time of a particular economy to various shocks through each impulse response functions and variance decomposition. This is called "shock view" in VAR. This view points out that unless the structure changes suddenly, the value of the endogenous variables can be expected. Therefore, VAR observations focused sudden changes in $Y(t)$ caused by the shock. Because of these advantages that this research has used VAR model to test factors affecting expected inflation in Vietnam as many previous studies did before. Among the factors affecting expected inflation in Vietnam, article 6 selected and tested the main factors affecting expected inflation in Vietnam, these factors have been used in the research of Patra and Partha Ray (2010). Besides, during the commissioning of the Vietnam sequence data, the results document that the sequence data are taken into account in the original stop, the ideal conditions to use VAR models. In addition, expected inflation sequences generated from ARIMA model is also consistent with the actual string inflation in Vietnam.

\subsection{Research Data}

The data in the article are collected and calculated from reputable sources such as the World Bank, IFS (Organization International Financial Statistics of the IMF), GSO VN (GSO), the report of the State Bank of Vietnam.

- Historical inflation (\%) (Source: General Statistics Office of Vietnam): Inflation in the past to assess the persistence or inertia of the price changes as well as looking to the historical behavior of the people of Vietnam (backward-looking). In this study, inflation is calculated quarterly based on collected CPI; CPI quarterly data series is calculated from the monthly CPI data series by the General Statistics Office of Vietnam announced.

- Output gap (\%) (Source: IMF, ADB): Output gap is defined as the difference between actual output and potential output, output gaps show the pressure aggregate demand. Data sequence data using quarterly real GDP in Vietnam after adjusting to seasonal factors and using Hodrick 
- Prescott filter (HP)to create potential GDP chain (potential GDP). Output gap in all variables will be measured by: Output gap = (real GDP - potential GDP $) /$ potential GDP.

- The real interest rate (\%) (source: IMF): The real interest rate represents the impact of monetary policy; the real interest rate is calculated as follows: real interest rate $=$ nominal interest rate - inflation data interest in the study was calculated on a quarterly basis. Quarterly nominal interest rate is calculated by the average nominal interest rate of 3 -month interest rate futures.

- Real effective exchange rate (source: Datastream): To represent the marginal cost, get the data changes the effective rate (REER). REER variable is the degree of variation of the real value of the domestic currency compared to the base year, while the share price target for a year $(t)$, this index is calculated based on a base year (base), nominal exchange rate, CPI, the proportion of commercial trading partners. The date is quarterly.

- The price of oil: the history of quarterly data from the website of the Vietnamese government.

- The price of rice: is from the website of statistic department of the Vietnamese government with quarterly data.

$e_{\text {base: }}^{i}$ The VND and currency in this country basis

$e_{t}^{i}$ : The VND and currency country i year $\mathrm{t}$

$\boldsymbol{C P I} \boldsymbol{I}_{t}^{i}$ : Price index of trading partner i year $\mathrm{t}$.

$\boldsymbol{C P I} \boldsymbol{I}_{t}^{V N}$ : Price Index in Vietnam in $\mathrm{t}$.

$\boldsymbol{W}_{t}^{i}$ : : Proportion of commercial trading partner in $\mathrm{t} \mathrm{i}$.

- Oil prices (source: www.eia.gov)

- Rice prices (source: IFS)

\section{CONCLUSION}

The expected results show that the model can be used autoregressive moving average - ARIMA to simulate sequences strings expected inflation from historical inflation. Based on the analysis results VAR model, the impulse response model and the results of variance decomposition of expected inflation, the results can indicate which is the most powerful factor in expected inflation. Then inflation and oil prices may be factors which influence expected inflation. The real effective exchange rate may affect expected inflation, the remaining elements include the real interest rate and the price of rice. Furthermore, the factors as the historical inflation, output gaps, real effective exchange rate, real interest rates and oil price shocks may impact the expected inflation. Additionally, the expected inflation is quite sensitive to the news of the price of petrol prices - oil. This plays an important role in regulating macroeconomic government, in which the government should consider adjusting the price of basic commodities (oil prices) carefully and have an appropriate route to avoid causing shocks to the market and make changes in expected inflation. Furthermore, an increase in interest rates may cause unwanted effects on expected inflation. This is because the interest rate mechanism operating in Vietnam has not been uniform, corporate credit structure, the proportion of high and variable interest rates are very important for economic subjects, especially to increase costs for businesses, impact the target of economic growth. So the government should be cautious when using this tool in macroeconomic governance. The study results also imply that the control of expected inflation plays a significant role in the formulation of macroeconomic governance. All factors can be 
employed to test their influence on the expected inflation rate to become the references for the government.

Ackowledgment

The authors would like to thank the Internal Grant Agency of FaME for providing financial support to carry out this research. Funding was extended through: TBU No. IGA/FaME/2017/004 - The Relationship between Concentration Ownership and Financial Reporting Quality.

\section{References:}

Camen, U., 2006. Monetary policy in Viet Nam: the case of a transition country. BIS Papers, $31,1-12$.

Cerisola, M. and G. GELOS, 2005. What Drives Expected inflation in Brazil? An Empirical Analysis. IMF Working Paper, WP/05/109, 22-33.

Clarida, R. J. and Mark G., 1999. The science of monetary policy: A new Keynesian perspective. NBER Working Paper, 7147, 12-33.

Fridman, M., 1968. The Role of Monetary Policy. The American Economic Review,58 (1), 1 17

Le T. S., Q. Truong and Nguyen T. P., 2011. The theoretical basis for expected inflation - Initial survey and anchor expectations solution long term in Vietnam. Public participation at Award "Talented young scientists Vietnam ", 1, 24-37.

Nguyen, T. T. H. and Nguyen, D. T., 2011. The origins of inflation in Vietnam 2000-2010: from the discovery of new evidence. Center for Economic Research and Policy VEPR, $N C$ - 22, University of Economics - Hanoi National University, 1, 23-40.

Patra, M.D. and P. Ray, 2010. Expected inflation and Monetary Policy in India: An Empirical Explorations. IMF Working Papers, WP/10/84, 13-35.

Pfajfar, and D. Zakeji, 2009. Experiment Evidence on Inflation Expectation Formation. Center for Economic Research Discussion Paper, 1, 20-37.

Phelps, E.S., 1967. Phillips Curves, Expectations of Inflation and Optimal Unemployment over Time. Economica: New Series, 34 (13, 254 - 281.

Ranyard, R., Misser, B. and Barbara, 2008. Perceptions and Expectations of Price Changes and Inflation: A Review and Conceptual Framework. Journal of Economic Psychology, 29 (2008), 378-400. https://doi.org/10.1016/j.joep.2008.07.002

Sims, C.A, 2009. Expected inflation, Uncertainty and Monetary Policy. BIS Working Papers, 275, 1-12.

Windram, R., 2007. Public Attitudes to Inflation and Interest rate. Bank of England Quarterly Bulletin ,47(2), 208 - 217. 


\section{Contact information}

Do thi thanh nhan.

Email: dothithanhnhan@tdt.edu.vn

Tomas Bata university in Zlin, Fame

ORCID: 0000-0002-2505-1715

ORCID: 0000-0001-7808-8231

DOI ID: https://www.doi.org/10.7441/dokbat.2018.05 


\title{
INSURANCE DISTRIBUTION IN THE FUTURE
}

\author{
Alexander Fichter
}

\begin{abstract}
The article investigates the changes in the insurance distribution that have happened over the past years, and the changes that tend to come in the future. The article shows the consequences of the changes for insurance market and explores the future development of it. The research is a result of a six months review of the insurance industry's sales and channels of distribution, looks at the root cause of emerging problems in insurance distribution cost structures, around face-to-face sales. Despite a majority of insurers are aware of the changes in the industry, many insurers still have to adapt to coming challenges. The author evaluates the peer-reviewed articles of leading scientists in this field of study and examines the impact these challenges may have on future profitability of insurance business.
\end{abstract}

Keywords: insurance distribution, insurance market, customer expectations, technological progress, digital distribution, sale models, future sales.

\section{INSURANCE DISTRIBUTION IN THE FUTURE}

Nowadays, insurance distribution has been facing the biggest changes over the past decades, and these are triggered by numerous factors with the profound consequences, such as:

- changes in customer expectations due to experiences from other areas of life;

- technological progress offers new opportunities, but also increases the requirements for

the process efficiency of insurers;

- new digital competitors who are stepping up the fight for the access to customers;

- demographic changes: "the world is getting older and more urban";

- increasing regulation, requiring more transparency and process security;

- omnipresent pressure of the costs that will result in a drastic reduction in the volume of commission and comprehensive reduction in sales overhead costs.

Together, these factors unfold an explosive effect that has to be defused by reorganizing the sale models. All models rely on offering tailor-made "customer journeys", the various contact points of a potential customer with the insurance at different points in the sales process, and offer digitally supported, frictionless and cost-efficient processes" (Sommer 2017). The main purpose of the article is to investigate insurance distribution in the future and to identify how insurance market will change in the nearest future. In the research, I used a method of peerreviewed evaluation to investigate the topic.

\section{LITERATURE REVIEW}

Mayers indicated six main changes in insurance distribution such as customer expectations, technologies, new digital competitors, regulations, demography and cost pressure (2017). Nowadays, customers expect to have twenty-four hours interactive options to deal with the insurers as they are used to in other areas of the life. Insurers do not benefit enough from modern technologies that could help to satisfy customers' needs. Increasing regulation and greater importance of consumer protection require complex, transparent and comprehensible consultation and sales processes as well as the necessary qualification of sales staff. Traditional business models suffer due to increased process requirements and high costs. The increasing demands will increasingly lead to the channel share shifts. The demographic developments cause an aging society, which is reflected in the customer and intermediary structures. The 
reduced cost-bearing capacity of the products due to the low interest rates, the regulatory requirements and the decreasing commission income require a higher cost management in sales than is often the case today (Meyer 2017).

Olins indicates (1995) that future-oriented design of the sales mix must not only focus on profitability and efficiency. Sales will only be successful in the future, if it fully aligns with customer needs. Customers expect they will be able to transfer the positive experiences from other digitally oriented industries to their interactions with insurance companies. Customers choose many different ways to access insurers using the most convenient or effective channel for them. For example, insurance agents inform half of the customers about the insurance online that is more convenient way for both. Despite that, the share of online accounts is still not more than twenty percent of all accounts on the market (Harrington 1997). Online accounts help to make the process of insurance easier and quicker than in manual mode. The changes in the customer journey force insurers to develop sophisticated and integrated solutions to interact the customers. The Customer Journey describes the various contact points of a potential customer with the insurance at different points in the sale process. When designing the future sales structure, the offer of individual customer journeys must therefore be in the foreground (Ettner 20017). In the research, Ettner indicates that a tailor-made customer journey is possible because of the three key-elements of the sale models of the future such as the networking of sale channels and services, the consistent optimization of process and the corresponding technological support of the sales process.

Gunter (2001) claims the importance to enter into effective partnerships in the design of the service offering. Furthermore, while planning the model of insurance, the question must be clarified as how the future sale success will be defined. However, insurers must determine which key figures can be used to measure and manage the performance of the sale organizations. Karten (2017) also indicates that the costs of sale for many insurance products are another challenge for insurance companies in the future. Companies, which can optimize the cost, are able to survive in a very high competitive market. Expanded direct sales, where the communication with the customer either online or via call center runs and is combined with systematic advice, for example by video telephony. Ecosystem experts specializing in offering insurance as an integral part of existing or emerging ecosystems (such as smart home systems) (Beenken 2010). This requires building and deepening cross-industry partnerships with other companies. Specialists for third-party, broker and partnership sales, who sells insurance integrated into the (online) offer of other business systems without direct customer contact. Digitized exclusivity distribution focused on personal sales, utilizing all the technical possibilities to increase efficiency and providing a strong integration of online and offline. Fully integrated multi-channel distribution geared directly to the needs of the hybrid customer, a smooth customer journey, and complete channel integration (Beenken 2010). The research, a result of a six months review of the insurance industry's sales and channels of distribution, looked at the root cause of emerging problems in insurance distribution cost structures, around face-to-face sales and examined the likely impact these challenges may have on future profitability.

\section{METHODS}

In the research, I investigated what changes are about to happen on the insurance market in the future, and how these changes will affect the market. I used peer-reviewed evaluation as a scientific method in the study of the issue of the changes on the insurance market in the future. I used the researches of leading economists that work at the topic.

For example, the research of Karten (2017) shows that the industry as a whole became competitive, cutting operating costs by $50 \%$ across the past decade. However, distribution costs 
will move up to $38 \%$ of total operating costs, an increase of $29 \%$ in 20 years. Daniels (1997) also claimed that insurance companies will change the way of service and will focus on online customer relationship that can make the process of cooperation easier and more convenient. Insurers want to improve the mobility of the business, and companies will develop new models of business. Potential clients will be able to buy insurance while shopping for other things, for examples, from a car dealer or at the supermarket (Shwarcz 2010).

However, Harrington (2007) indicated that insurance market experienced short-term increases of the price because of catastrophe losses. The effects of catastrophe losses cause revision of price policies by a majority of insurance companies, and the cost of raising capital will be significant because of the information about the past claim costs. Without regulations on the catastrophe insurance rate changes, insurers may reduce voluntary coverage supply.

\subsection{Results}

According to the peer-reviewed method of investigation, I have come to conclusion that most insurers are aware of the changes that are necessary, and effective change is often hampered by a variety of hurdles, such as the complexity of the distribution model, inadequate IT expertise, and legitimate fear of losing business. Especially against the background of these hurdles, the necessary process of change takes time. Therefore, insurers must start to work out a new strategic direction and initiate the necessary transformation process. Otherwise, they run the risk of missing out on the current strategic window of change" (Kim, 2017). Absent regulations on catastrophe losses policies lead to the revision of the price policies, and it discourages insurers to voluntary supply insurance coverages. Moreover, the market will focus on online cooperation with clients in order to be available twenty-four hours, and insurers expect the increase a share of the distributional costs in the total costs (Shwarcz 2010).

\subsection{Discussion}

The research stated that the evidence conflicted with other data examining the changes in the insurance distribution, and this statement is supported by discussion. The analyzes and discussions with sales partners as well as sales managers and executives show that the quality of inventory management varies greatly between the individual sales partners and that there is often a considerable need for optimization. This means, on the one hand, that traditional distribution channels do not sufficiently exploit the existing potential. On the other hand, new high-tech companies are using such gaps in inventory management to specifically lure customers and stocks. Digitally consolidate the "insurance folder" of the customer and also offer analysis and optimization functions, in effect so the digital replacement of today's insurance broker want to effect.There are other offers on the market, in addition to a complete transparency on commission figures and the repayment of commissions, depending on the Interpretation of the commission tax prohibition, or to provide for the donation of parts of the commission.

Central process specifications and controls, data mining and data analytics as well as digital information provision for distribution partners for targeted inventory processing should be the focus here. If we think about inventory management consistently, we also have to ask ourselves whether the current system can simply be "only" optimized - or whether new types of allocation and distribution mechanisms are more effective: for example, the agreement of rules that stipulate that there are insufficient In extreme cases, it would also be conceivable that all stocks are assigned centrally and all distributors process the stocks according to defined rules and a processing fee for the respective sales or support activity. 


\section{CONCLUSION}

Consequently, sale models of insurance companies are complex, interlocking systems, and, it is important to look at all elements of the sale models and at the changes that are necessary to reorient the strategy (Dixon 2011). In order to avoid overburdening the organization, it is important to organize the design and change each element of the system step-by-step. The biggest challenges in building a new sale model lay in the networking of the individual elements, the control of interactions and a meaningful sequential implementation (Hilker, 2017).

Insurance companies have already made significant changes in recent years. However, due to the further increase in pressure for change, a fundamental redesign of the current sales models is to be expected. The basis of the transformation process should be an individually determined strategic objective and the corresponding implementation path. Both have to be shared by the sales management and the entire board, as soon as there is clarity about the strategy, the necessary operational changes can be aligned with it and defined with the necessary depth of detail. I recommend a multi-stage process that systematizes this process, specifically avoids the hurdles described above and ensures sustainable results.

\section{References}

American Banker. (1997). Electronic Insurance Distribution Could Aid Sales: Kiosks Enable Consumers to Analyze Product Offerings. American Banker, 162(109).

Beenken, Matthias. (2010) Vertriebsmanagement: Fach- und Führungskompetenz für die Assekuranz. Munich, Germany: Proximus.

Daniels, Mark. (1999). Insurance and the Future of Financial Services. Canadian Speeches, 13(1).

Dixon, Mathew, and Adamson, Brent (2011). The Challenger Sale: Kunden herausfordern und erfolgreich überzeugen. Munich, Germany: Redline Verlag.

Ettner, Susan. (2017). Adverse selection and the purchase of Medigap insurance by the Elderly. Journal of Health Economics, 16(5).

Gunter, Bernd, and Helm, Sabrina (2001). Kundenwert: Grundlagen - Innovative Konzepte Praktische Umsetzungen. Wiesbaden, Germany: Betriebswirtschaftlicher. /https://doi.org/10.1007/978-3-322-94626-3

Harrington, Scott. (1997). Insurance Derivatives, Tax Policy, and the Future of the Insurance Industry. Journal of Risk and Insurance, 64(4). https://doi.org/10.2307/253894

Hilker, Claudia. (2017). Social-Media-Marketing am Beispiel der Versicherungsbranche. Dissertation.

Karten, Walter. (2017). Einführung: Grundlagen der Versicherungsmärkte. Wiesbaden, Germany: Springer Gabler.

Kim, K. (2016). An International Analysis of Life Insurance Demand. The Journal of Risk and Insurance.

Meyers, D. (2017). Guaranty funds and risk-taking evidence from the insurance industry. Journal of Financial Economics.

Olins, Wolf. (1995). The New Guide to Identity: How to Create and Sustain Change Through Managing. Aldershot, England: Gower Publishing.

Shawarcz, Daniel. (2010). Insurance Demand Anomalies and Regulation. The Journal of Consumer Affairs, 44(3). https://doi.org/10.1111/j.1745-6606.2010.01184.x

Sommer, D. (2017). The Impact of Firm Risk on Property-Liability Insurance Prices.

The Journal of Risk and Insurance. 


\section{Contact Address}

Alexander Fichter

Department of Management, Comenius University in Bratislava the Republic of Slovenia, 820

05 Bratislava 25, Odbojarov 10

Email: fichter@alexander-fichter.de

Phone number: 016090813697

ORCID: 0000-0001-5439-3557

DOI ID: https://www.doi.org/10.7441/dokbat.2018.06 


\title{
FINANCING POLICY OF CZECH AUTOMOTIVE COMPANIES
}

\author{
Florin Aliu, Gent Jusufi, Besnik Krasniqi, Hoang Khang Tran
}

\begin{abstract}
Constructing accurate capital structure is crucial element in guarding the company from unexpected financial and non-financial shocks. Still there is not scientific consensus among economist that would show which is the optimal capital structure for the company. The aim of the study is to investigate factors affecting capital structure of the company's operating as automotive suppliers in Czech Republic. Existing theories on capital structure has been tested to identify which one of them represents current state of the financing policy on the Czech automotive industry. The study performed panel data analysis of the companies operating in automotive industry. Results of our study show that long term debt (LTD) and profitability (P) are considered to be crucial determinants that influence the capital structure of the Czech automotive suppliers.
\end{abstract}

Keywords: capital structure, financing policy, automotive industry, theories on capital structure

\section{INTRODUCTION}

Optimal capital structure is linked with the managerial ability to outperform competitors. However, financing policy of the economic entity is constrained by current state of the company and influenced from firm specific characteristics and macroeconomic environment. Highly indebted companies tend to be more exposed toward bankruptcy when economic crisis are in place. High debt levels discourage stockholders to show interest within the company (Booth et al., 2001). In addition, Myer (2001) considers that it is impossible to expect results which would show optimal capital structure for the economic entities. Baum et al. (2009) shows that macroeconomic risk, limits firms to decrease short term financial leverage. However, continues increase in the price level (inflation) has negative relationship with debt to equity ratio (Hatzinikolaou et al. 2002). Bhamra et al. (2010) confirm that uncertainties coming from macroeconomic variables influence financing polices of the companies. The way companies finance their activities is constrained from the country economic development and structure of the financial system. USA and England are more focused on stock markets to finance operating activities of the companies. In contrast, in the European union countries banking industry holds the major share within the financial pie (EUCB. 2017). Caglayan and Rashid (2014) on their study found out that risk coming from macroeconomic conditions negatively affect short term debt of the UK manufacturing companies. Inefficient stock and bond markets do not create incentives for investors to raise capital from financial instruments. Banks are major creditors within the Czech financial system (CNB, 2017). However, within the Prague Stock Market operate only 14 public companies (PSE, 2017). Moreover, Czech automotive companies are not listed in the PSE. Standing under these limitations financing policies are mainly influenced from the bank loans. Automotive industry stands as the crucial engine of the Czech economy. Based on the results of Albertina database (database for Czech and Slovak companies), 92\% of 
borrowings are short term. In addition, this reflects that Czech automotive companies are in a need for short term liquid instruments.

The term capital structure associates with combination of financial securities that company use during operative activities (long term debt, short term debt, common stocks, preferred stocks). Company's leverage is distinguished in two types of financial items, such as: financial leverage and operating leverage. In addition, operational leverage allies with fixed operating costs while the financial leverage with fixed debt costs. Capital structure has important impact on cost of capital (WACC) as a core component in influencing intrinsic value of the firm. Moreover, higher cost of capital which causes higher risk level within the company, results on a lower value of the firm and vice versa. Finding the arrangement among debt and equity that would lower cost of capital is a fundamental objective of the managers. The pioneering work of Modigliani and Miller (1958), shed light on the optimal structure with limitations within their propositions. Their work intends that under efficient markets, companies shouldn't be concerned with their capital structure, since any mixture of debt or equity is as good as another. In this study, we investigate relationship between capital structure and firm specific characteristics in Czech automotive industry. Standing on the previous studies, structure of the companies is influenced from financial items, such as: company size, tangibility, growth potentials and debt structure. Studies can confirm only historical facts on the way capital structure is arranged on the companies. In contrast, manager's decisions on arranging passive side of the balance sheet is influenced from their working experience, instinct and vision for the upcoming events. Our work differentiates itself from the previous studies, since it is the first attempt measuring factors influencing capital structure in the Czech automotive industry. Moreover, the work tends to shed light on the capital structure on the Czech auto-suppliers. In addition, findings of our work will explain the long term financial actions of the Czech automotive managers.

The papers structure is as follows. Section two captures the literature review; Section three gives explanation on determinant factors affecting capital structure; Section four presents model specification and data. While in the fifth section represents results obtained from the study while in the sixth section stands conclusion.

\section{LITERATURE REVIEW}

One of the essential aims of the managers is to arrange the long run mix within equity and debt (capital structure). Managers tend to maximize firm value through lowering financial and operational costs. Moreover, organizing an optimal capital structure minimize cost of capital (WACC) and increase market price of the company. The initial work on capital structure theories is linked with Modigliani and Miller (1958) named as MM theory. Their work showed that eliminating income taxation, bankruptcy costs and other market imperfections, firm value is not dependent on the debt to equity ratio. In a line with MM theory, additional theories have been developed on capital structure determinants such as trade-off theory, pecking order theory, agency theory and cash flow theory.

The trade-off theory and pecking order theory provide explanation on the combinations between debt and equity that the firm use to finance its activities. The trade-off theory shows benefits 
and costs associated with financing activities with debt. Each firm must construct its own objectives on capital structure, since it will maximize firm value (Acaravci, 2007). Welch (2004) confirm that approximately $60 \%$ of the movements in the firm's leverage are due to firm's financial problems and not because of the leverage objectives. However, the studies conducted by (Ozkan 2001; Flamnery and Rangan 2006; Faulkender et al. 2012) show that firms rapidly adjust their capital structure toward their objectives. In contrast, Huang and Ritter (2009) claim that previous studies that measure speed of leverage adjustment toward firms targets are biased. Additional element that constrain speed of capital adjustments is linked with costs and benefits of changing capital structure (Elsas and Florysiak, 2010; Dang et al. 2012). Capital structure determines the compounding arrangement of debt and equity that the company keeps in the balance sheets. Moreover, financing most of the firm's activities with debt, exposes the company to huge bankruptcy risk when hard times are in place. While financing all activities with equity is impossible, since issuing common stocks is very costly for the company. None of the three theories can give a clear picture on the optimal capital structure, since they are all based on certain assumptions and limitations (Myers, 2001). The majority of research on capital structure has been conducted for developed countries with less focus on developing countries (Booth et al, 2001; Eldomiaty, 2008; Mohammed. K et al, 2015). Beside numerous studies on developed countries, still there is not a clear portrait if factors affecting capital structure on developed countries converge with developing countries. In addition, Zingales (1995) found that factors affecting capital structure in U.S. experience the same pattern with G7 countries. In addition, the study by Zingales (1995) proves existence of the certain level of economic unification within G7 countries and USA. Each theory works out under its own assumptions and limitations (Myers, 2001). Results obtained from different scholars on capital structure determinants are mixed, while Fama and French (2002) consider that two theories of capital structure (trade-off theory and pecking order theory) give representative determinants on the company leverage. Since interest expenses are tax deductible, they stimulate firms to orient their financing recourses toward more debt intensive capital structure. But in addition there are also other forms how to reduce tax burdens such as depreciation of tangible and intangible assets. According to the pecking order theory there is negative relationship between non-debt tax shields and leverage (Zabri, 2012). The study conducted by Bauer (2004) for Czech listed companies confirm that leverage of the firm is positively related with the size while negatively related with the profitability and non-debt tax shield. Moreover, Bauer (2004) has extended his work on capital structure through including companies that operate in Visegrad countries. However, his work confirms that leverage is positively correlated with the size while negatively linked with tangibility, profitability and tax shields.

Capital structure is affected also by the company size. Big companies have more long term debt in their balance sheets than short term debt because of shareholder-lenders conflict. Indebted companies tend to be more efficient, since they are opposed toward bankruptcy. In contrast, some scholars studied debt issue on the macroeconomic outlook not simply on the enterprise viewpoint. Relationships within economic growth and leverage ratio of the country are diverse. When the company is going bankrupt, problem is isolated within the enterprise stakeholders. Although when countries are highly indebted and facing solvency issued, in that case problem might cross national borders. The recent Greek economic crisis of 2010 proved that debt might 
not cause problems when the country owns healthy economic framework. Since automotive manufacturers and automotive suppliers target diverse set of costumers. In addition, our work tends to identify difference in the capital structure within subindustries.

\section{DETERMINANTS OF CAPITAL STRUCTURE}

In this section we give a brief descriptions of the indicators impacting capital structure. These indicators are classified as growth opportunities, size, profitability and tangibility.

\section{Dependent Variable}

Independent and dependent variables were selected from the previous studies done on the capital structure. Dependent variable stands as leverage ratio (LTD) which is a measure ratio of total debts to total assets. Leverage ratio as dependent variable is confirmed by studies conducted by Huang and Song (2002), Antonion et al., (2002), Chen (2004) and Buferna et al. (2005). The study confirms portion of total assets that are financed from total liabilities. Using debt within the capital structure raise bankruptcy risk but also in the same time oppose company toward more investment opportunities.

\section{Growth Opportunities}

According to Fama and French (2000) firms with higher growth potential use more equity for their investment projects. The trade-off theory shows that exist negative trade-off between leverage and investment opportunities. In the same route with trade-off theory, pecking order theory and agency problem theory proclaim that negative relationship exist between capital structure and firm growth opportunities. Moreover, negative relationship between leverage and growth opportunities has been confirmed by (De Miguel and Pindado, 2001; Bevan and Danbold, 2001; Chen and Jiang, 2001). In a contrast, studies realized by Fatouh et al, (2002) confirm positive relationship between leverage and growth.

\section{Size}

Statistical results within size and leverage for different countries tend to be mixed. Trade-off theory considers that exists positive relationship within firm size (TA) and leverage. In addition, positive trade-off between firm size and leverage is confirmed through studies conducted by (Tomak, 2013; Banerjee et al, 2000; Bevan and Danbolt, 2001). It is considered that larger firms are less opposed to bankruptcy issues, since they can be more diversified than small firms. While the work done by (Chen, 2003; Yolanda and Soakerno, 2012) prove negative relationship between capital structure and size. Some scholars use natural logarithm of net sales to identify size of the company, while the others natural logarithm of assets. In our work, we have used natural logarithm of assets, since statistically both items are acceptable.

\section{Profitability}

In terms of profitability indicators there is a dispersion within existing theories on the impact that they imply on capital structure. The trade-off theory confirms that exists positive relationship between capital structure and profitability $(\mathrm{P})$ of the company. Since more profitable companies try to shield on taxes by getting more leverage. The pecking order theory 
proclaims that the relationship is negative between profitability and capital structure, since more profitable firms have less needs for debt financing (they utilize internal financial recourses). However, cash flow theory considers that more profitable companies are more indebted, since leverage self-control managers to pay more cash than investing in unprofitable projects.

\section{Tangibility}

Empirical studies realized confirm that there is a positive relationship between tangible assets and leverage (Bevan and Danbolt, 2001; Wahab et al, 2012). The trade-off theory considers that there is positive relation within debt and tangible assets (FTA). Moreover, companies that contain huge collateral level, carry more debt on their financial statements. Higher level of tangible assets within the company lower insecurity of creditors. Positive relationship is expected among tangibility and leverage. In contrast, studies realized by Booth et al. (2001), and Huang and Song (2002) show negative relationship within tangibility and leverage. Even though, tangibility item in their work is calculated by dividing tangible assets by total assets.

\section{MODEL SPECIFICATION AND PANEL DATA ANALYSIS}

The study sample is focused on the companies operating in the Czech automotive industry from 1998 until 2014. Sample size contain all companies that operate as auto suppliers in the Czech Republic. Statistical tests are conducted on the automotive suppliers. Data concerning the annual financial statements were collected from Albertina database. Thus the following model is used to assess the relationship of capital structure and its determinants:

$$
L R_{i t}=\alpha_{1}+\beta_{1} \log T A_{i t}+\beta_{2} F T A_{i t}+\beta_{3} P_{i t}+\beta_{4} L T D_{i t}+u_{i t}
$$

The method used is Fixed effects model, which result from the assumption that individual specific effects $\alpha_{i}$ in the main model are correlated with explanatory variables $x_{i}$.

$$
y_{i t}=\alpha_{i}+x^{\prime}{ }_{i t} \beta+u_{i t}
$$

construction the clustering of the individual-specific effects $\alpha_{i}$ with explanatory variables (time invariant):

$$
\bar{y}_{i}=\alpha_{i}+\bar{x}_{i}^{\prime} \beta+\bar{u}_{i}
$$

In the model we include $\alpha_{i}$ as an intercept, counting on different intercept per single individual while all individuals have the same slope parameters. As fixed effect estimator no longer considers time variant from eq. 2 , we subtract eq. 2 and eq1. and re-obtain the model:

$$
\left(y_{i t}-\bar{y}_{i}\right)=\left(x_{i t}-\bar{x}_{i}\right)^{\prime} \beta+\left(u_{i t}-\bar{u}_{i}\right)
$$

the number of observation are $N T$, subtraction led the specific-individual effect $\alpha_{i}$ (timeinvariant i.e. $\alpha_{i}-\alpha_{i}=0$ ) to cancel out. 


\section{EMPIRICAL RESULTS}

\section{$5.1 \quad 5.1$ Descriptive statistics}

Summarization and description of the variables used in this study is shown in Table 1, which presents the arithmetic mean and standard deviation of the predefined capital structure (leverage ratio) and its determinants respectively used in the model. An impression of average difference among scores and the mean in the period 1998-2014.

Table 4 Leverage and its determinants statistics summary (1998-2014)

\begin{tabular}{llll}
\hline Dependent variable & OBS & Mean & Std.Dev \\
\hline LR & 685 & 0.199 & 0.232 \\
& & & \\
\hline Independent Variable & OBS & Mean & Std.Dev \\
\hline TA $(\log )$ & 685 & 5.954 & 0.615 \\
FTA & 685 & 0.491 & 0.171 \\
P & 685 & 0.059 & 0.094 \\
LTD & 685 & 0.095 & 0.166
\end{tabular}

The average capital structure ratio defined as LR is estimated approximately $20 \%$ for 85 observed companies within 8 years on average ${ }^{1}$ that gives a brief explanation that Czech automotive suppliers are financing its growth with debt. The average ratio indicates that companies' capital structure contains $20 \%$ of debt. Similarly, we observe form estimation the summary of statistics, companies' Total assets (natural logarithm) is averaged 6\%, Tangentability as a ratio of tangible assets over total assets averaged to nearly $50 \%$, with midlow rate on profitability (ratio of net profit/total assets) generation averaged $6 \%$.

On the following table 2 we display the correlation coefficients among variables:

Table 2. Correlation among all variables used in the model.

\begin{tabular}{l|lllll}
\hline \multicolumn{1}{l}{ Variable } & LR & TA $(\log )$ & FTA & $\mathrm{p}$ & LTD \\
\hline LR & 1.000 & & & & \\
TA(log) & -0.256 & 1.000 & & & \\
FTA & 0.270 & 0.115 & 1.000 & & \\
P & -0.100 & -0.019 & -0.289 & 1.000 & 1.000 \\
LTD & 0.871 & -0.144 & 0.266 & -0.142 &
\end{tabular}

\footnotetext{
${ }^{1}$ We use unbalanced data set for 85 companies within 1998 to 2014.
} 
Results obtained from the correlation estimation, capital structure (LR) and long term debt (LTD) have a significant positive relationship (coefficient 0.87 ). This might lead to or raise a suspect for a multicollinearity problem. A concrete check is done with variance inflation factor (VIF) to detect the multicollinearity - which is not present in our model, see table 3 below.

Other variables, see table 2, suggest that there is either positive or negative relationship among capital structure (LR) and its determinants, and coefficients do no not indicate any possible multicollinearity, yet check is performed using VIF.

Table 3. variance inflation factor

\begin{tabular}{l|ll}
\hline \multicolumn{1}{l}{ Variable } & \multicolumn{1}{l}{ VIF } & 1/VIF \\
\hline TA(log) & 1.05 & 0.844 \\
FTA & 1.18 & 0.894 \\
P & 1.10 & 0.911 \\
LTD & 1.05 & 0.954
\end{tabular}

\subsection{HAUSMAN Specification Test}

To determined which method is more appropriate to estimate and analyze our panel data, Hausman Specification test is performed ${ }^{2}$. Test results estimated suggests that are in favor of alternate hypothesis, thus we reject the null hypothesis, claiming that fixed effects is more appropriate for this case, and therefore estimation of model is done by using fixed effects method (complete results, Appendix 3).

Table 4. Results of Hausman Specification Test

\begin{tabular}{lll}
\hline & Fixed Effects & Random Effects \\
\hline TA(log) & -0.0066313 & -0.0296179 \\
FTA & 0.047336 & 0.0748176 \\
P & 0.1070068 & 0.1148079 \\
LTD & 1.209896 & 1.191124 \\
\hline Chi Square & & \\
statistic & 10.98 & \\
P-Value & 0.0268 &
\end{tabular}

\footnotetext{
${ }^{2} \mathrm{H}_{0}$ : assumes random effects model is appropriate

$\mathrm{H}_{\mathrm{a}}$ : assumes fixed effects model is appropriate
} 


\subsection{Panel Regression Estimated Results}

Estimated results show a relationship among capital structure and its determinants as analyzed by panel regression for Czech automotive suppliers. The method used by fixed-effects model and its results are shown in table 5 (complete results are shown in Appendix 1).

Table 5. Results on capital structure of Czech Automotive suppliers

\begin{tabular}{lllll}
\hline LR & Coefficients & t value & $\mathrm{p}$ value & \\
\hline TA $(\log )$ & -0.0066313 & -0.43 & 0.666 & - \\
FTA & 0.047336 & 1.36 & 0.174 & - \\
P & 0.1070068 & 2.17 & 0.031 & $* * *$ \\
LTD & 1.209896 & 32.62 & 0 & $* * *$ \\
Constant & 0.0940754 & 0.98 & 0.327 & -
\end{tabular}

Based on the results obtained, an indication is that long term debt (LTD) a ratio calculated by long-term debt and total assets has a major effect on capital structure (LR). The analysis show that LTD have a significant positive association with LR. Similarly, results show that profitability $(\mathrm{P})$ is also positively associated to LR, which is inline and backed by the Trade-off theory. While tangentability (FTA) and total assets (TA - natural logarithm used in the model) results with no relationship to LR, both variables represent company's size and are linked to capital structure. Hence, our estimation results add evidence to support profitability and long term debt as key determinants that play important role on company's capital structure.

\section{CONCLUSION}

Automotive industry in the Czech Republic stands as important economic framework that generates employment, exports and economic growth. The last financial crises of 2008 proved that automotive industry is highly sensitive toward business cycles. The form automotive industry finance its activities influence its financial position and bankruptcy issues. Capital structure represents compounding structure on the passive side of the balance sheet. Since, lending activities within the Czech financial system are dominated from banks, this gives clear picture that most of the economic entities in the Czech Republic inject their activities from bank loans. Moreover, Czech automotive companies are not listed within Prague Stock Market (PSE) which reflects that capital structure items are book value. Standard theories on capital structure confirm that does not exist clear guidelines which should be the capital structure of the company. Moreover, the way companies arrange their capital structure stands on the managerial talent, size of the company, objectives, taxing system of the country and shareholders interest.

Economic history has shown that companies find their appropriate way to finance their operations through diverse channels and sources. Bank loans and retained earnings generated from the company performance are the main passages for the Czech companies to raise money. Our work confirms that long term debt (LTD) and profitability $(\mathrm{P})$ are considered to be crucial 
determinants that influence the capital structure of the Czech automotive suppliers. In addition, this stands in line with the trade-off theory and successfully explains the determinants of capital structure for Czech automotive suppliers. Nevertheless, the focus of our study tend to clarify the general attitude of capital structure determinants of the overall the automotive suppliers in Czech Republic rather than specific company. Testing the company specific and the performance of company's capital structure determinants is a subject of other promising studies.

Study does not consider macro variables as a determinant factors of capital structure which is considered as a limitation of the study. Future research might identify to what extent macro indicators influence capital structure of the companies operating in the automotive industry in the Czech Republic.

\section{References:}

Antoniou, A., Guney, Y., \& Paudyal, K. (2002). The determinants of corporate capital structure: Evidence from European countries. University of Durham, Department of Economics and Finance. https://doi.org/10.2139/ssrn.302833

Banerjee, S., Almas, H., Clas, W. (2000), The Dynamics of Capital Structure, SE/EFI Working Paper Series in Economics and Finance, 333, 1-20.

Bauer, P. (2004). Capital structure of listed companies in visegrad countries. Prague economic papers, 2, 159-175. https://doi.org/10.18267/j.pep.237

Baum, C. F., Stephan, A., \& Talavera, O. (2009). The effects of uncertainty on the leverage of nonfinancial firms. Economic Inquiry, 47(2), 216-225. https://doi.org/10.1111/j.14657295.2007.00116.x

Bhamra, H. S., Kuehn, L. A., \& Strebulaev, I. A. (2010). The aggregate dynamics of capital structure and macroeconomic risk. The Review of Financial Studies, 23(12), 4187-4241. https://doi.org/10.1093/rfs/hhq075

Booth, L, V, Aivazian, A, Demirguc-Kunt and M, Vojislav 2001, 'Capital structures in Developing countries', Journal of Finance, vol. 56, no. 1, pp. 87-130 https://doi.org/10.1111/0022-1082.00320

Buferna, F. M., Bangassa, K., \& Hodgkinson, L. (2005). Determinants of capital structure: evidence from Libya (Vol. 8). University of Liverpool.

Caglayan, M., \& Rashid, A. (2010). The response of firms' leverage to uncertainty: Evidence from UK public versus non-public firms.

Chen, J. J. (2004). Determinants of capital structure of Chinese-listed companies. Journal of Business research, 57(12), 1341-1351. https://doi.org/10.1016/S0148-2963(03)000705

Chen, J.J. (2003), Determinants of Capital Structure of Chinese-Listed Companies, Journal of Business Research, 57, 1341-1351. https://doi.org/10.1016/S0148-2963(03)00070-5 
Chen, L.H., Jiang, G.J. (2001), Determinants of Dutch Capital Structure Choice, The European Economic Association Annual Congress, Berlin, 1-25.

Czech National Bank (CNB). Annual Reports (2000-2017). https://www.cnb.cz/en/about_cnb/performance/annual_reports/index.html

Dang, V. A., Kim, M., \& Shin, Y. (2012). Asymmetric capital structure adjustments: New evidence from dynamic panel threshold models. Journal of Empirical Finance, 19(4), 465-482. https://doi.org/10.1016/j.jempfin.2012.04.004

Eldomiaty, T. I. (2008). Determinants of corporate capital structure: evidence from an emerging economy. International Journal of Commerce and Management, 17(1/2), 25-43

Elsas, R., \& Florysiak, D. (2015). Dynamic capital structure adjustment and the impact of fractional dependent variables. Journal of Financial and Quantitative Analysis, 50(5), 1105-1133. https://doi.org/10.1017/S0022109015000496

European Central Bank (EUCB). Annual report (2017). https://www.ecb.europa.eu/pub/annual/html/index.en.html

Evidence from Libya", University of Liverpool, Working Paper, pp: 2-7.

Fama, E.F. and French, K.R. (2002), “Testing trade-off and pecking order predictions about dividends and debt", Review of Financial Studies, Vol. 15, pp. 1-33

Fama, E.F., French, K.R. (2000), Testing Tradeoff and Pecking Order Predictions about Dividends and Debt, The Center for Research in Security Papers, University of Chicago, Working Paper No.506. https://doi.org/10.1093/rfs/15.1.1

Fattouh, B., Harris, L., Scaramozzino, P. (2002), Capital Structure in South Korea: A Quantile Regression Approach, Royal Economic Society Annual Conference, 70, 1-34

Faulkender, M., Flannery, M. J., Hankins, K. W., \& Smith, J. M. (2012). Cash flows and leverage adjustments. Journal of Financial Economics, 103(3), 632-646. https://doi.org/10.1016/j.jfineco.2011.10.013

Flannery, M. J., \& Rangan, K. P. (2006). Partial adjustment toward target capital structures. Journal of financial economics, 79(3), 469-506. https://doi.org/10.1016/j.jfineco.2005.03.004

Hatzinikolaou, D., Katsimbris, G. M., \& Noulas, A. G. (2002). Inflation uncertainty and capital structure: Evidence from a pooled sample of the Dow-Jones industrial firms. International Review of Economics \& Finance, 11(1), 45-55. https://doi.org/10.1016/S1059-0560(01)00085-5

Huang, R., \& Ritter, J. R. (2009). Testing theories of capital structure and estimating the speed of adjustment. Journal of Financial and Quantitative analysis, 44(2), 237-271. https://doi.org/10.1017/S0022109009090152

Huang, S. and Song, F. (2002) The Determinants of Capital Structure: Evidence from China,

Jordan, Arabic Journal of Administrative Sciences, 8: 273-289. https://doi.org/10.2139/ssrn.320088 
Kakilli Acaravci, S. (2007), The Existence of Inter-Industry Convergence in Financial Ratios: Evidence from Turkey, Investment Management and Financial Innovations, 4(2), 71-76

Modigliani, F. and M, Miller 1963, 'Corporate income taxes and the cost of capital: A correction', American Economic Review, vol. 53, pp. 443-53

Mohammed, K., Abdullahi, S. F., \& Yonas Mekonnen Wetere, H. (2015). Financing Policy of Ethiopian Manufacturing Firms. Global Journal of Management And Business Research, 15(5).

Myers, S.C. (2001), “Capital structure”, Journal of Economics Perspectives, Vol. 15, pp. 81102. https://doi.org/10.1257/jep.15.2.81

Ozkan, A. (2001). Determinants of capital structure and adjustment to long run target: evidence from UK company panel data. Journal of Business Finance \& Accounting, 28(1-2), 175-198. https://doi.org/10.1111/1468-5957.00370

Prague Stock Market (PSE). Listed companies. https://www.pse.cz/en/indices/description-ofindices/px-index/

Tomak, S. (2013), The Impact of Overconfidence on Capital Structure in Turkey, International Journal of Economics and Financial Issues, 3(2), 512-518.

Welch, I. (2004). Capital structure and stock returns. Journal of political economy, 112(1), 106131.Working paper, The University of Hong Kong, pp: 2-7 .

Yolanda, K., Soekarno, S. (2012), Capital Structure Determinants of Indonesian Plantation Firms: Empirical Study on Indonesian Stock Exchange, 2nd International Conference on Business, Economics, Management and Behavioral Sciences

Zabri, S.M. (2012), The Determinants of Capital Structure among SMES in Malaysia, Proceedings International Conference of Technology Management, Business and Entrepreneurship.

\section{Contact information}

Florin Aliu

Tomas Bata University in Zlin

Mostní 5139, 76001 Zlin

Email: aliu@fame.utb.cz

ORCID: 0000-0002-4782-8820

Gent Jusufi

Czech University of Life Science

PEF CZU v Praze, Kamycka 129, 16521 Praha 6-Suchdol

Email : gent@pef.czu.cz

ORCID : 0000-0001-7673-0569

Besnik Krasniq

Faculty of Economics, University of Prishtina 
Agim Ramadani, 10000 Prishtine

Email: b.krasniqi@staffs.ac.uk

Hoang Khang Tran

Tomas Bata University in Zlin

Mostní 5139, 76001 Zlin

Email: tran.h.khang0906@gmail.com

DOI ID: https://www.doi.org/10.7441/dokbat.2018.07 


\section{APPENDIX}

Appendix 1.

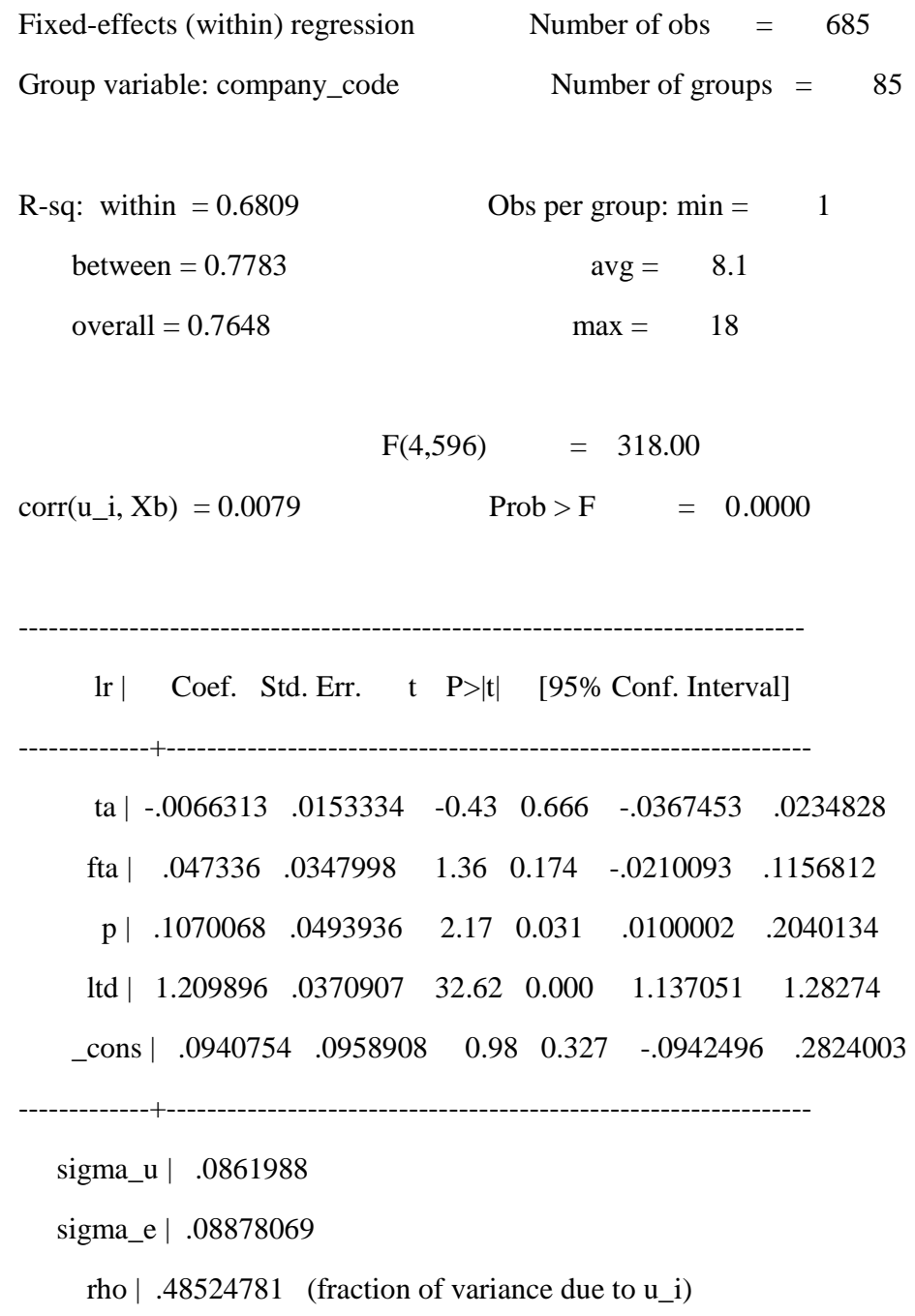

F test that all $u_{-} \mathrm{i}=0: \quad \mathrm{F}(84,596)=5.15 \quad$ Prob $>\mathrm{F}=0.0000$

Appendix 2.

Random-effects GLS regression

Group variable: company_code

R-sq: within $=0.6792$

between $=0.7992$

overall $=0.7762$
Number of obs $=\quad 685$
Number of groups $=\quad 85$

Obs per group: $\min =\quad 1$

$\operatorname{avg}=\quad 8.1$

$\max =18$ 
Wald chi2(4) $=1615.43$

corr $\left(\mathrm{u} \_\mathrm{i}, \mathrm{X}\right)=0$ (assumed) $\quad$ Prob $>$ chi2 $=0.0000$

lr $\mid \quad$ Coef. Std. Err. $\quad \mathrm{z} \quad \mathrm{P}>|\mathrm{z}| \quad$ [95\% Conf. Interval]

$\begin{array}{rrrrrrr}\mathrm{ta} \mid & -.0296179 & .0101492 & -2.92 & 0.004 & -.04951 & -.0097258 \\ \mathrm{fta} \mid & .0748176 & .0302111 & 2.48 & 0.013 & .0156049 & .1340303 \\ \mathrm{p} \mid & .1148079 & .046219 & 2.48 & 0.013 & .0242203 & .2053956 \\ \mathrm{ltd} \mid & 1.191124 & .0322609 & 36.92 & 0.000 & 1.127894 & 1.254355 \\ \text { cons } & .216523 & .0629327 & 3.44 & 0.001 & .0931771 & .3398689\end{array}$

sigma_u | .06967124

sigma_e | 08878069

rho .38112804 (fraction of variance due to $u_{-} i$ )

Appendix 3.

Hausman Specification test (Fixed-Effects method vs Random-Effects method)

--- Coefficients ----

| (b) (B) (b-B) $\operatorname{sqrt}\left(\operatorname{diag}\left(\mathrm{V}_{-} \mathrm{b}-\mathrm{V} \_\mathrm{B}\right)\right)$

| fixed_auto random_auto Difference S.E.

$\begin{array}{rrrrr}\mathrm{ta} \mid & -.0066313 & -.0296179 & .0229866 & .0114938 \\ \mathrm{fta} \mid & .047336 & .0748176 & -.0274816 & .0172719 \\ \mathrm{p} \mid & .1070068 & .1148079 & -.0078011 & .017422 \\ \mathrm{ltd} \mid & 1.209896 & 1.191124 & .0187714 & .0183017\end{array}$

$\mathrm{b}=$ consistent under Ho and $\mathrm{Ha}$; obtained from xtreg

$\mathrm{B}=$ inconsistent under Ha, efficient under Ho; obtained from xtreg

Test: Ho: difference in coefficients not systematic

$$
\begin{gathered}
\operatorname{chi} 2(4)=(b-B)^{\prime}\left[\left(V_{-} b-V_{-} B\right)^{\wedge}(-1)\right](b-B) \\
=\quad 10.98 \\
\text { Prob }>\text { chi2 }=0.0268
\end{gathered}
$$




\title{
THE LINKS BETWEEN MEANINGFULNESS OF WORK, WORK- ENGAGEMENT AND MENTAL WELL-BEING
}

\author{
Frank W. Hager
}

\begin{abstract}
The objective of this study is to identify and synthesize what is known about links between (job-) meaningfulness, work-engagement and psychological well-being of employees. Therefore the respective understandings of a meaningful work and of healthy work has to be elaborated, to develop the underlying interpretations of subjectivity, in order to propose a perspective for empirical investigations of health-oriented working conditions. It is argued that a proactive thematization of meaningful work (e. $\mathrm{g}$ the individual attributions of meaningful work as well as the practices of making work meaningful) is closely related to workengagement and well-being. A holistic view of these constructs enables a comprehensive understanding of meaningful work and creates further starting points for future research work in Organizational Development (OD) or Human-Resources (HR) Management. The study was carried out as a review of general and relevant science literature as well as scientific publications researched in common journal-databases. The results show, that meaningfulness can be seen as a core, which interconnects different constructs. Therefore, meaningfulness is closely linked to work-engagement. The more meaningfulness employees perceive in their daily work, the more motivated they are performing on a higher level. Meaningfulness is also linked to the Sense of Coherence (SoC), a coping capacity of employees to deal with everyday life stressors. SoC refers to an individual's generalized perception of environmental stimuli. Thus, if an employee has a high level of sense of coherence he/she experiences work more meaningful and tends to have good coping strategies handling stressors. Meaningfulness has also a connection to wellbeing. By losing the meaningfulness at work, typical symptoms of burnout can be observed. It is argued, that creating meaningfulness at work is essential for positive work outcomes and healthy employees.
\end{abstract}

Keywords: meaningfulness, work-engagement, sense of coherence, well-being, mental health, JEL-Classification: M140, M540, Z130

\section{INTRODUCTION}

The current German Gallup Engagement Index 2016 published alarming figures: According to this, $70 \%$ of the surveyed employees have a low emotional bond, another $15 \%$ have no emotional bond to their organization. $57 \%$ of those employees with no emotional bond stated, that they would leave the company within one year, which can be equated with a mental resignation by cutting of their ties with the job. These numbers are also reflected in the sick leave. Employees with low emotional bond were absent an average of 6.8 days, employees with no emotional bond an average of 10.3 days, because they felt sick or not well. The economic damage due to mental resignation or lack of emotional bond is estimated between 80.3 and 105.1 billion euros annually. Compared to recent years, only marginal differences in the study results are apparent (Gallup 2016). Wehner and Güntert (2010) report in a study, that more than $50 \%$ of the interviewed employees and two thirds of the top executives who has been surveyed, were motivated to accept pay cuts and give up their present status for more demanding and meaningful jobs. These results reflect the testimony of the former German Chancellor Willy Brandt. In his view, for most people, work is more than just a source of income - it has a deeper meaning and guarantees a successful life process (Brand, 1983:9). 
Thus, it is only understandable, that this disturbing development raises the question of how employees see their work as meaningful, what meaningful work consist of and how work can be designed to make it meaningful, to eliminate psychosomatic complaints. While Aaron Antonovsky demonstrated the significance of a "Sense and Meaningfulness" for well-being and mental health as part of his theory of the Sense Of Coherence (Antonovsky, 1979) in the context of the concept of Salutogenesis, there are no previous works discussing the links between the different understandings of meaningfulness, work-engagement and mental health issues.

The analysis of different research offers the chance to show blind spots and thus to contribute to a sharpening of these linkages. For this purpose, three linkages are to be considered in more detail, which are of particular relevance for HR-management, organizational development and for work and organizational psychology: [1] By analyzing the linkage between meaningfulness and work-engagement, decisive factors and predictors, which are crucial in the workplace, are worked out. In the context of this paper, meaningfulness is strongly related to the "will to perform" and intrinsic motivation. [2] Another important link discussed, is the relationship between Antonovsky's Sense Of Coherence and employee health. Antonovsky's theory describes coherence as a particular "emotional quality" (Ducki, 2000:70), which can be considered as an indicator for mental health. Antonovsky (1979:8) is speaking of the "way of looking at the world", a general attitude towards the world and life, which is characterized by a high degree of reflexivity regarding one's own feelings and needs. Although the Sense Of Coherence is a relatively broad and generally accepted construct, connections with the organizational working context are shown along this discourse, researched from the work results of recent years. [3] Finally, the description of the relationship between work engagement and mental health is intended to address organizational and personal factors, which are responsible for employee motivation. Work-engagement in general, but also in this paper, is characterized by energy, involvement and professional efficacy.

\section{METHODOLOGY AND LIMITAITONS}

This paper aims to provide clarity by identifying, analyzing and discussing the main linkages between meaningfulness of work, work-engagement and psychological well-being, found in general and relevant science literature as well as scientific publications in common databases. Papers and research materials published in the databases of Taylor \& Francis, SAGE Publications, Jstor, Wiley, NCBI, PsycNET, APA, Elsevier and Emerald made part of the basis of the scientific analysis. In addition, an internet search on google-scholar was undertaken to identify relevant studies and literature. In this way, also German articles in scientific journals were found. In some cases, it was necessary to contact researchers on researchgate.net to get full access to papers. Of the 118 identified scientific papers, 65 were screened as relevant to the review and had been included in the work. 22 works were reviews but most of the evidence identified or included within the reviews was of medium or low quality. Various German and English terms from the categories "work-engagement" (e.g. intrinsic motivation, commitment, work enthusiasm), "well-being" (e.g. employee health, mental health, sense of coherence) and "meaningfulness" (e.g. comprehensibility, self-fulfillment, affiliation) were combined and searched for. In addition, a manual search of references found in the articles was made. In addition, anthologies and scientific books were reviewed. Such a choice was determined by the degree of their availability in the University of Augsburg and the University Of Applied Sciences, Augsburg, Germany, which is the author's place of writing during his doctoral thesis.

Since meaningfulness and work-engagement are very comprehensive terms, they are analyzed more precisely at the beginning of this work, in order to be able to identify the linkages to 
mental health. This work is limited by the assumption, that mental health is determined largely by the Sense of Coherence, the core theory of the Salutogenesis concept after Antonovsky (1979), which, in terms of a global emotional state, is developing as the overall result of many consistent process experiences characterized by the achievement of goals, which were part of higher-level motivational contexts. Other neighboring theories, like "resilience" or "hardiness" are not considered in detail. This paper is part of the author's doctoral thesis, which is intended to answer the question, how mobile telework can affect the mental health of teleworkers. Mobile Teleworkers are isolated physically from their organization and this work-form is therefore characterized by the lack of social contacts with colleagues and executives. The major contribution of the planned study is to examine the role of telecommuting on teleworkers psychological well-being and how neighboring constructs as work-engagement, meaningfulness of work, social support, social isolation, identity and sense of coherence (as an indicator for well-being) can mediate or moderate these processes.

\section{THEORETICAL BACKGROUND}

The explanations in this section are intended to provide a basic understanding of meaningfulness, work-engagement, and Sense of Coherence, which is a prerequisite for further discussion.

\subsection{Meaningfulness at Work}

The research for this work has revealed, that employees' inability to understand their work as significant is often a cause of mental disorder. In order to get a more accurate picture of exactly what the desire for meaningful work refers to, the following section will deal with the concept of meaningfulness in more detail.

In the understanding of May, Gilson \& Harter (2004) experiencing purpose and meaningfulness is an important determinant of work-engagement. Hurrelmann and Albrecht (2014: 227) emphasize that work must have a clearly recognizable social benefit, promoting self-fulfillment, personal development and as well as allowing to reconcile work and family life in order to be experienced as meaningful. In this context it is surprising, that the heterogeneity of the different understandings of meaningful work and the associated fact, that the desire to reconcile work and family life also falls into the category of meaningfulness, is mentioned in the same breath as the desire for social responsibility of the employer, organizational identification and commitment (Hardening, 2015). According to Faltermaier et al. (2002:27), work is not just a way to experience recognition, fulfilment and social interaction, but also an important part of personality development. In their daily work, people change their motives, abilities and behaviors. Höge \& Schnell see work as an individual experience of meaningfulness, goalorientation and coherence in terms of personality and attitudes to life (Höge \& Schnell, 2012:91). This comes close to Rudow's statement, which makes clear, that work has a strong impact on people's self-esteem, identity and health (Rudow, 2003:34).

Pratt and Ashforth (2003) define meaning as an individual interpretation of what work signifies in an individual's life (in the sense of a higher calling something to do, or an oppression). This opinion is also shared by Wrzesniewski et al. (2003). The perception of the meaningfulness of work is determined by employees themselves, although they are also significantly influenced by the environment or the social context. Schnell (2004:54) expresses this circumstance with the following words: "We know what we mean, but we cannot explain it and hardly describe it. Meaningfulness is felt, received, experienced. And yet it is also mentally mediated". According to Frankl (1962), people are actively looking for this feeling. They are seeking the meaning and purpose of life, in order to enrich and fulfill their sense of self. Frankl describes professions as 
part of lifes. Lips-Wiersma \& Morris (2009) explain meaningfulness in a similar way, as "the subjective experience of the existential significance or purpose of life."

Meaningful work is often designated as a comprehensive term, which can refer to the importance of work for life, as well as the perceived benefits of working for oneself and others (Rosso et al., 2010, Steger et al., 2012). This "subject-oriented" perspective, which is not primarily based on the technical and organizational conditions of work in society, but follows the action perspective of the employees, and thereby includes the entire life context of the workers, is also taken up by Voß \& Pongratz (1997). Hence, work is seen as a fundamental element that can give meaning to life. The more meaningfulness people experience, the happier they are with their daily work. How work have to be designed to be perceived as stimulating and empowering by employees had been discussed especially in the 1970s, at the time of the humanization of the world of work. It should be noted, however, that the „Human Relations Approach" was developed at a time when the mechanization of production increased corporate capital intensity, high skills of employees were required and trained workers in North America tended to be scarce. Staff has become more valuable, and consequently, people should be more committed to the organization. The prevailing viewpoint of Taylorism, of treating the laborers only as part of a "machine", was no longer appropriate (Staehle \& Sydow, 1991:634-636, Kieser, 1995:101-135, Vahs 2009:29-30). Ulich (2011:561) understands the quality of work as a decent, personality-promoting and health-promoting design of working conditions. Meaningfulness of work can therefore be understood as a dimension of work quality, which refers to conditions enabling the experience of significance, as well as to the direct perception of meaningfulness of one's own activity or tasks (Hardening, 2015).

According to Isaksen (2000), the feeling of belonging to the organization and tasks, engagement in social relationships in the workplace, consideration of work in a broader context and a sense of responsibility and pride contribute significantly to meaningfulness at work. Schnell, Höge \& Pollet (2013) showed in their study, that not only characteristics of employees, but also the lived values of the company are crucial for the experience of meaningfulness. In addition, features of the work task, the fit of person and work contribute to the experience of meaningfulness. These findings are reflected in the Job Characteristics Model by Hackman \& Oldham (1975, 1976, 1980). Meaningfulness of work is therefore an important "reference dimension" becoming relevant in two different forms. Firstly, the meaningfulness of the task (task significance) is understood as a job feature in addition to the variety and holism of requirements. Secondly, meaningfulness is defined as an experiential state resulting from the mentioned job characteristics. The desire for the experience of the existential significance or purpose of life (LipsWiersma \& Morris, 2009) already described, associated with meaningfulness, can be explained by the need for self-actualization (Maslow 1943, 1954:22, 1971:269). According to Maslow, self-actualization can be compared to a mystical summit experience: The employee transcends his own limits, becoming one with humanity and the cosmos. In Maslow's view, the individual has reached in this way the very core of existence at all. This self-actualization is based on personal growth through the fulfillment of a life's mission, which may lie in the unfolding of one's own creativity and just and worthwhile causes. In this context, Koltko-Rivera (2006) speaks of self-transcendence. In his view, the experience of meaningfulness ascends, if employees perceive an authentic link between their daily work and a broader transcendent lifepurpose beyond the self.

Surprisingly, in the last few decades, the question of qualitative claims (and thus also of meaningfulness) of work has hardly been raised and has been pushed into the background by the thematization of employment conditions (Sauer, 2011). 


\subsection{Work-Engagement}

According to Nerdinger (2000), work-engagement refers to occupational activities that promote the organization's objective. These activities are outside the primary work instructions and are carried out on employees own initiative. This includes helping colleagues, protecting the organization from vandalism, making suggestions for improvement, acquiring knowledge in own initiative (which is conducive to an improvement in work performance), taking responsibility which has not been formally credited and representing the organization outwardly in a positive way. The basic prerequisite for work-engagement is intrinsic motivation. Enthusiasm is often described as an intrinsic-motivational disposition (Moé, 2015; Kunter, 2011). Work-engagement is "the individual's involvement and satisfaction (as well as enthusiasm) for work." (Harter et al., 2002). It is characterized by energy, involvement and professional efficacy (Schaufeli, 2013). The absence of these positive, engagement-promoting aspects can adversely affect the mental health of employees and thus decrease work engagement - when "[...] energy turns into exhaustion, involvement turns into cynicism, and efficacy turns into ineffectiveness" (Maslach, 1997:24).

Work-engagement presupposes that every person has to identify with his/her work and performance. This is also the statement of Kahn (1990:694): „In engagement, people employ and express themselves physically, cognitively, and emotionally during role performances." Macey et al. (2009:7) describe work-engagement on an emotional level as energy or absorption, which leads to a behavior beyond one's role - directed toward organizational goals. Schaufeli et al. (2002) define engagement as a ,[...] positive, fulfilling, work-related state of mind that is characterized by vigor, dedication, and absorption“. The dimension vigor ,„[...] is characterized by high levels of energy, the willingness to invest effort in the own work, and persistence even in the face of difficulties. Dedication refers to being strongly involved in the own work, and experiencing a sense of significance, enthusiasm, inspiration, pride and challenge. Absorption is characterized by being fully concentrated and happily engrossed in one's work, whereby time passes quickly and one has difficulties with detaching oneself from work. "Losing the sense of time and a state of uninhibited, full involvement is also associated with the flow-experience (Csíkszentmihályi, 1975).

This approach is based on the fact, that the motivation potential of an action does not arise from the result or the success of an activity, but from the incentive of the work itself and thus an intense pleasure is associated. Concentration strength on acting, self-forgetfulness, steering attention carrying out the tasks and losing the sense of time are characteristics of flow. In the definition of Csíkszentmihályi $(1975: 9,38-43,71)$, the flow-experience is described as an autotelic experience or a state of uninhibited, full involvement in the process of an activity. Schaufeli \& Bakker (2010), however, differentiate flow from absorption. They refer flow to special, short-term, high-level experiences, while absorption is a profound, persistent state of mind. Work-engagement can be divided into various dimensions. These include inter alia: helpfulness, conscientiousness, politeness, straightforwardness, respectively sporting spirit (expressed by the fact that small deficiencies and shortcomings are tolerated), self-initiative and bourgeois virtue, regarding regular, courageous and constructive participation in the company life.

\subsection{Sense of Coherence - Indicator for Well-Being and Health}

Antonovsky defines the Sense of Coherence $(\mathrm{SoC})$ as a general basic attitude of the individual towards the world and one's own life. However, he also describes the fact, that health condition is additionally influenced by external factors. Nevertheless, people's well-being also differs, living under the same external conditions. According to Antonovsky, this depends on the 
individual, the cognitive, as well as the affective-motivational basic attitude. In other words, it depends on how well the individual can use his or her resources and to use it for health maintenance. This is defined by Antonovsky as a global life orientation and referred to as Sense Of Coherence. It means, that the stronger the feeling of Sense Of Coherence is perceived, the healthier an individual is, or the faster this person is able to recover from disease (Antonovsky 1979:123; Antonovsky, 1987a:30; Meckel-Haupt, 2001:7).

The Sense Of Coherence is composed of three components. The feeling of perceiving the world as organized (Sense Of Comprehensibility), but also the conviction to find a solution (Sense Of Manageability) for each problem and to consider it as meaningful to invest energy for certain tasks (Sense Of Meaningfulness) (Antonovsky, 1991; Bengel et al., 2001:37-38; Lindström \& Eriksson, 2006; Eriksson \& Lindström, 2006).

Sense Of Comprehensibility represents the most important component in Antonovsky's conceptual formation. It describes the ability of a person to perceive his environment, everyday situation and information as ordered, explainable, realistic - combining it into a consistent image. "It refers to the extent to which one perceives the stimuli that confront one, deriving from the internal and external environments, as making cognitive sense, as information that is ordered, consistent, structured, and clear, rather than noise-chaotic, disordered, random, accidental, inexplicable." (Antonovsky, 1987a:16). Sense Of Comprehensibility is a cognitive component. It is thereby only be possible to make sense from the stimuli and information, the inner and outer environment, which appear to be chaotic at first sight. „Death, war, and failure can occur, but such a person can make sense of them" (Antonovsky, 1987a:17). Therefore, situations or conditions interpreted as meaningful will not lead into distress and can even be a challenge (Meckel-Haupt, 2001:9). Comprehensibility, however, is also an active process, which serves flexible interpretations acting as a guide in the concern with the reality. Comprehensibility represents what Antonovsky postulates for the Sense Of Coherence but also in general: „A strong sense of coherence includes a solid capacity to judge reality“ (Antonovsky, 1979:127).

Antonovsky describes Sense of Manageability as the conviction of individuals that tasks, recognized as significant and meaningful are solvable. It includes the basic trustfulness and the realistic assessment of accessible resources, in order to cope with the emerging problems and requirements. Through participation, or the opportunity to shape the workday actively, employees have a high degree of manageability and cannot easily be pushed into a victim role (Antonovsky, 1987a:18; Bengel et al., 2001:29). According to Antonovsky, it is not just about control and the use of own resources, but also direct access to resources controlled by legitimate others, such as confidants (Antonovsky, 1979:127). For this reason, this attribute is closely related to concrete coping strategies. The stress avoided or repelled in this way, is the positive result of a developed ability facing difficult situations in a better way (Meckel-Haupt, 2001:10; Bauer et al., 2015:21).

The third component, the Sense of Meaningfulness, includes the skills and conviction, or the confidence to solve tasks. It can be interpreted as motivation and willingness to tackle difficulties, or to see a meaning in it. An important aspect of Sense Of Meaningfulness is its emotional aspect. Individuals with a strong ability to consider life as meaningful also see many situations in their everyday life as important and significant. They therefore have the ability to interpret critical circumstances not as stress but as a challenge (Idan et al., 2013). A Sense of Meaningfulness is described in the words of Antonovsky (1987a) as "[...] the extent to which one feels that life makes sense emotionally, that at least some of the problems and demands posed by living are worth investing energy in, are worthy of commitment and engagement, are challenges that are welcome rather than burdens that one would much rather do without" (Antonovsky, 1987a:18). 


\subsection{Generalized Resistance Resources (GRR)}

In Antonovsky's stress management process, Generalized Resistance Resources (GRR) describe individuals ability to cope with the given social and biological strains and pressures so as to contribute to their own benefit and to promote their own development (Höfer, 2000:82). GRR must be available to the individual in order to meet the requirements of the real world of life (Reinshagen, 2008). GRRs can therefore support the effective stress management of the organism, whereby strain can be avoided or better be managed, so that strain is not experienced as stress, but the stressors are given a sense (Hurrelmann, 2000:52-60). "What is common to all GRRs, I proposed, was that they facilitated making sense out of the countless stressors with which we are constantly bombarded" (Antonovsky, 1989:52). In the understanding Antonovsky these resources are effective in situations of all kind (Bengel et al., 2001:34). Antonovsky attaches particular importance to the management of stress, especially to the social and cultural environment. "Ready answers provided by one's culture and its social structure are probably the most powerful GRR at all" (Antonovsky, 1979:119). This is exactly the point, GRR provides people with information that help them to cope with stress. According to his view, the functional commonality of the GRR lies in the ability of the individual to build up a robust life concept, which enables a cognitive, emotional and practical stress management. The GRRs therefore specify the framework, the existence or non-existence of which determine the non-existence of individual coping competencies. This is how Antonovsky sees the GRR - ,as defined, which build up a strong Sense of Coherence (SoC) crucial to one's ability to manage tension well“" (Anonovsky, 1987a:30, Meckel-Haupt, 2001:7).

\section{LINKS BETWEEN SOC, MEANINGFULNESS \& HEALTH}

The following chapter describes the relationships between the constructs meaningfulness, work-engagement, and Sense of Coherence.

\subsection{Meaningfulness of Work and its Link to Work-Engagement}

Kahn (1990) defines personal engagement with the presence of physical, cognitive and emotional commitment and considers meaningfulness as a condition for work-engagement. Kahn's studies indicate that, in general, three factors influence the experience of meaningfulness - (1) Task characteristics: Clarity of the task and autonomy, (2) Role characteristics: Harmony between self-image and role, (3) Work interactions: Significant interpersonal interactions. Kahn (1990) also refers to connections between "core job characteristics" from the Job Characteristics Model (JCM) of Hackman and Oldham (1980) and work engagement. In addition, findings suggest that these core features of work of the JCM (autonomy, skill variety, task identity, task significance and feedback), not only correlate with work-engagement but also with meaningfulness. He also concluded that people in work situations unconsciously deal with three questions that determine whether they are personally involved or more distant. The questions are: "How meaningful is it for me to bring myself into this performance?", "How safe is it to do so?" and "How available am I to do so?" If people perceive their role as psychologically significant or meaningful, they do not expect negative consequences (psychological safety) and feel that they have the necessary resources for work tasks (availability). Finally, they will engage in their work role (Kahn, 1990). May et al. (2004) were able to demonstrate Kahn's studies empirically, and confirmed, among others, that meaningfulness is significantly related to engagement. In the opinion of Holbeche \& Springett (2003) the perception of meaningfulness in the working context clearly relates to their engagement and ultimately to their performance. They even go a step further and argue, that employees are actively looking for meaningfulness in their daily work. In their view, high levels of engagement can be seen only in workplaces, with a shared sense of destiny and purpose, that connects people at an 
emotional level, which raises their personal aspirations. Meaningfulness at work can be seen in this way as one of the antecedents of work engagement. This position is also supported by Geldenhuys et al. (2014). For them, meaningfulness is a predictor for work engagement, while meaningfulness and engagement predicts organizational commitment. Milliman et al. (2003) investigated workplace spirituality and employee work attitudes. They revealed, that an employee who experiences his/her job as meaningful, is likely to be a desirable employee. These workers are willing to do extra work, spend more time on their work, and do it more diligently. Spirituality has three dimensions in the context of this study: (1) meaningful work on an individual level, (2) sense of community on a group level, and being in (3) alignment with organizational values and mission on an organization level.

From this point of view, spirituality at work and work attitudes are part of meaningfulness (Milliman et al. 2003). The study of Hoole \& Bonnema (2015) established a relationship between meaningfulness and work-engagement at different age groups. The research has shown, that in particular older employees are valuable to their business as they have a strong work-commitment and thus contribute to the company's success. Also Kordbacheh et al. (2014) studied different age groups of employees and established a relationship between employeeengagement, motivation, meaningfulness, and intrinsic motivation. The results has shown that especially younger people - compared to older employees, who are engaged despite considering their work meaningful or not - are less intrinsically motivated. Höge \& Schnell (2012) describe the positive affective-motivational states of experience as a prerequisite for work-engagement. This was also confirmed in the study by May et al. (2004), who followed up with Kahn's (1990) conceptualization of work-engagement. Positive correlations between psychological meaningfulness, psychological safety and availability with work engagement were confirmed. Experience of meaningfulness at work showed the strongest relationship to work-engagement. In addition, there is further research confirming the strong relationship between workengagement and meaningfulness of work (Chen et al., 2011, Olivier \& Rothmann, 2007).

It can thus be stated, that employees who experience meaningfulness at work, invest more time, diligence and energy in their job. In other words: These employees are more motivated. From a reverse perspective, it can be argued that engaged employees might consider their work as meaningful due to the time and effort they spend on it. The constructs of meaningfulness at work and work-engagement thus have a direct relationship - the more an employee is engaged, the more he or she is dedicated, vigorous and absorbed.

\subsection{Sense of Coherence and its Link to (mental) Well-Being}

Currently several studies are existing, that relate the three dimensions of SoC to employeemotivation and mental health (Pallant \& Lae, 2002; Gana, 2001, Erikson \& Lindström, 2006; Kivimäki et al., 2002; Buddeberg-Fischer et al., 2001). Direct, moderator - and mediator-effects has been observed.

Antonovsky assumed, that work in adulthood plays an important role for the SoC (Antonovsky, 1996; Nilsson et al., 2010; Hakanen et al., 2007). He described a balanced workload (neither over- nor under-challenging), as well as control as important factors for manageability. He mentioned participation, decision-making and social assessment (power, reward, prestige) as important influencing factors for meaningfulness. Finally, Antonovsky argued, that comprehensibility of work depends on its consistency, holistic tasks, roles, workplace security, and social relationship quality (Antonovsky, 1987b).

In this context, Albertsen et al. (2001) reported in a large cross-sectional study of more than 2,000 Danish employees, between the ages of 18 and 69 with a variety of occupational backgrounds, that individuals with higher SoC levels experience far less stress symptoms. They 
were also able to confirm a mediating effect in in relation to work environment and stress symptoms. Lu et al. (2016) found similar results in a study focusing the modern service industry in Shanghai. Van der Colff \& Rothman (2009) report that SoC is not only closely related to mental exhaustion, but also to the work results and engagement shown by employees at work. Employees with a high SoC are able to perceive their environment in a positive sense and show a higher work-engagement due to better coping strategies. The study was supplemented by Muller and Rothman (2009). They carried out a content analysis, whose quantitative evaluation of over 600 employees showed, that the perception of support and the feeling of restriction in a familiar work environment, is decisively dependent on the extent of the employee's SoC. In the field of forestry, a 10-year longitudinal study by Kalimo et al. (2003), with 174 participating employees showed, that $\mathrm{SoC}$ can have a protective effect regarding to the burnout syndrome. The studies by Feldt (1997) and Söderfeldt et al. (2000) show similar results. The stronger the SoC, the less psychosomatic symptoms and emotional exhaustion occur among individuals, consequently people are better protected against adverse effects of unfavorable working conditions. Kinman (2008) reported in a study with academic staff about poor physical and mental health, which was related to a low SoC. To a small extent, an interaction effect of SoC, as a personal resource, could also be demonstrated, regarding to the connection between working conditions and health. A one-year longitudinal study by Feldt et al. (2000) confirmed that a good organizational climate, job security and a good relationship with management are strongly related to a high SoC, which in turn could be strongly related to the well-being of employees. Just as Albertsen et al. (2001), Hogh and Mikkelsen (2005) proclaimed, that SoC describes the relationship between work environment and stress. Feldt et al. (2004) found that employees with a high SoC also have better opportunities to change their personal workability towards the positive. Höge and Büssing (2004) examined various mechanisms of action of SoC more precisely. In their study, which took place in the working contexts of hospital workers, they found that SoC affects perception, self-selection and stress-creating mechanisms at work. In a similar work environment, Khamisa et al. (2016) and Vinoth \& Hansi (2016) adehere to the statement, that empolyees with a higher SoC have been found to have better mental health, fewer incidences of burnout, a greater level of job satisfaction, and a greater sense of accomplishments concerning regular working activities. The studies confirmed also the moderating role of SoC between coping strategies and occupational stress.

\subsection{Work-Engagement and its Impact on Well-Being and SoC}

In today's working world, employees are required to show their own initiative, demonstrating that they are joyful to perform their tasks in a motivated manner. Bakker et al. (2011) refer to a psychological interconnectedness with work activities, which includes an individual commitment to the team and the organization, as well as the provision of personal resources, in the form of full abilities, into the work process.

Satisfaction of basic psychological needs is considered by Ryan \& Deci (2000) as a central aspect of subjective well-being and mental health. According to Emmons (1986), the achievement of personal goals is associated with increased subjective well-being. Not all personal goals serve equally to satisfy basic psychological needs. Personal goals influence mental health in a positive sense only if they are based on an intrinsic motivation. According to Sheldon et al. (2004), these goals must also be pursued autonomously and outside the control of other individuals. In addition, goals must harmonize with the needs (of a person) which are characterized by their implicit motives. According to Baumann \& Quirin (2006), the long-term pursuit and the monitoring of non-congruent goals, i. e. goals, which are not in the interest of an individual and not part of its own desires, lead to a need-frustration, accompanied by permanent stress and psychosomatic symptoms. Mental health is largely based on the ability to cope with critical life events and to self-control stress. Individuals who are able to master stress 
and negative affect in an adequate way, have a higher subjective well-being and a better mental health, than those who cannot regulate their stress level and mood, without external support (Hobfoll, 1989; Lazarus \& Folkman, 1984). Closely intertwined with the ability to cope with stress is Antonovsky's concept of Sense Of Coherence. Maslach et al. (2001) describe engagement as the opposite of burnout and note that burnout involves the ,erosion of engagement with the job". Maslach et al. (2001) name six factors that can lead to burnout or, in the positive sense, to engagement. In their opinion, job engagement is associated with: (1) A sustainable workload, (2) feelings of choice and control, (3) appropriate recognition and reward, (4) a supportive work community, (5) fairness, justice and meaningfulness, (6) as well as valued work. Just like burnout, engagement acts as a mediator between individual work-life factors. The connections of work-engagement and Sense of Coherence, as a holistic concept, are shown by Van der Colff \& Rothman (2009). They illustrated, that stress at the workplace, due to lack of organizational support and due to high workload contributed essentially to emotional exhaustion and depersonalization. Furthermore, the results show a moderate correlation between emotional exhaustion and work-engagement, while depersonalization was associated with personal performance and work-engagement. The results clearly show that people with a strong SoC are better able to cope with work-related stress because of lack of organizational support and high workload. SoC was the only variable in this study that showed a link to personal performance. Feldt (1997) and Naudé \& Rothmann (2006) found that there is a negative relationship between burnout constructs (emotional exhaustion and cynicism) and SoC. Van den Broeck et al. (2008) argue that health-promoting work-tasks should be designed, that exhaustion, which is a core component of burnout, is avoided, and that vigor, a core component of work-engagement, is supported.

\section{CONCLUSION AND CONCEPTUAL MODEL}

Roosevelt's assertion on a speech on September 7, 1903, still sounds true today - meaningful work can greatly enrich human life: "Far and away the best prize that life has to offer is the chance to work hard at work worth doing." (Pine, 2012:39). This is also the explanation of this paper. The research suggests that people experience their professional lives much more positively as they make progress in a work that they find significant or meaningful. What matters is not what we do - but whether we recognize a deeper meaning in our work. If the words of Viktor E. Frankl are to be believed, that the search of life's meaning appertains to the nature of man, today's leaders must take on their role as ,giver of meanings“, if they want to maintain the performance of their employees and their well-being. If employees find meaningfulness, and as long as they can see significance in their work-tasks, they are ready for maximum achievements and personal sacrifices. Meaningfulness can be seen as the origin from which the mentioned power rises that stimulates people, if motivation is depleted whilst the goal has not yet been reached. Like Frankl, Aaron Antonovsky also emphasizes that people want to understand their lives and shape their own values. To accomplish this, it is all about identifying complex relationships. People want to fathom their existence and life, and they are ready to make all reasonable efforts. 


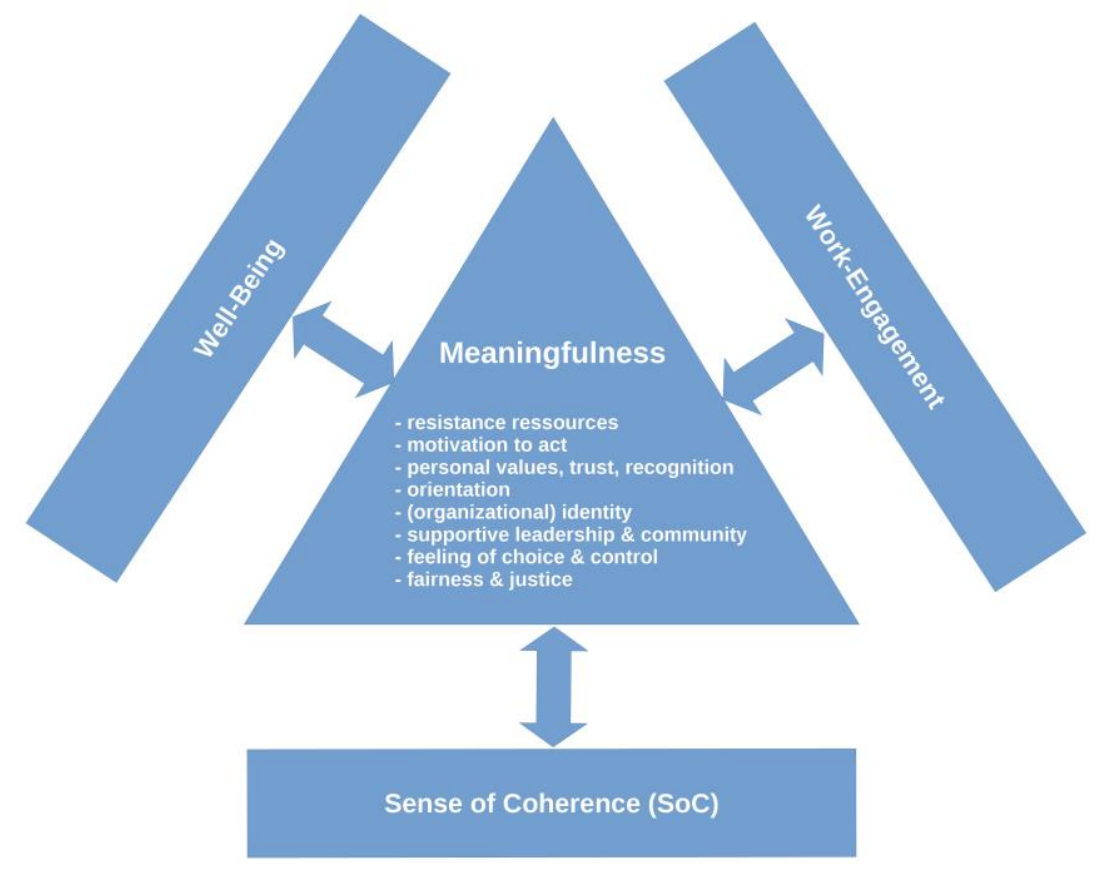

Figure 1: The Triangle of Meaningfulness. Source: Own work

The previous discussion raises the question, how the relationship between well-being, Sense of Coherence and work-engagement of field sales members can be conceptualized. The model in Figure 1, in the shape of a triangle structure, contains this three constructs discussed before, attempting to link these against the background of meaningfulness at work. It is a reduced to the essentials, graphical, clear representation of the complex interrelationships and could serve as a conceptual model or a general guidance. However, it is expressive enough to adequately implement further recommendations in the framework of organizational development. In summary, from the model can be deducted:

\section{Meaningfulness and motivation:}

Employees want to know what the company stands for and why their work is important to the company. They want to investigate out what their personal contribution to the organizational success looks like, where the organization is supposed to develop, and, basically, what the company is fighting for. Answering the question of meaningfulness is important for the orientation and identification which employees seek in their working lives. By answering the question of meaningfulness, there are also operating guidelines for everyday business. Above all, meaningfulness is the implementation of common values as an orientation benchmark for actions. These values are guidelines that have to be found in the mission statement and management principles. Supervisors should give a clear vision what their company or their team wants to achieve, and how and by which rules the objective shall be reached. Only in this way employees can be given the necessary orientation.

Meaningfulness cannot be prescribed. Meaningfulness can be found, discovered and felt only by the individual in a specific situation or task. The answer to the question of meaningfulness is different for each employee and may change over time. The authentic and comprehensible communicated meaningfulness of work not only creates a personal identity, but also motivates employees to act purposefully. The awareness, that this effective action contributes to the company's achievements, provides a stable and lasting motivation (work-engagement). It is therefore the primary task of all leaders illustrate employees' significant contribution to the company's success (vgl. Malik, 2003). 


\section{Meaningfulness and Well-Being:}

Self-fulfillment respectively loss of meaningfulness during the daily work is manifested in certain emotions and cognitions. At the appearance of self-fulfillment, joy and satisfaction can be felt, which can increase to the flow experience. By losing the meaningfulness at work, typical symptoms of burnout can be observed. Accompanying feelings are boredomness, apathy, inner dissatisfaction and irritability. The joy, the passion, the burning for the task can no longer been felt by the employee. Earlier incentive systems such as power, money or status have lost their effect. Mentally, questions of meaningfulness arise. Cynicism and sarcasm are often observed at affected workers. Loss of meaningfulness leads to changes in behavior: postponing or unenthusiastic completion of work tasks or motivational blocks can be consequences. Losing meaningfulness at work can produce a creeping discomfort over years, can reduce motivation and take the pleasure in life. This crisis regarding the deep meaning of work is associated with problems in the professional identity. In the case of losing the meaningfulness of work, not only identity problems occur in the currently practiced profession, but rather the questioning of the entire self-concept occurs. This creeping process of inner erosion leads into a life crisis (Rudow 2006:139).

\section{Meaningfulness and SoC:}

Leadership should be understood as providing resistance resources for employees. According to Antonovsky, GRR are important in order to offer enhanced protection and resistance against stressors or to represent the sources of a positive development. In his opinion, they significantly influence the maintenance or improvement of health, life satisfaction and quality of life. Sense of Coherence, the enduring global orientation that expresses itself in the expectation that life's things will develop in a rational way, can be greatly supported by the provision of GRR. Worthwhile emphasizing are the works of Bauer \& Jenny (2007), Vogt et al. (2013) and Bauer et al. (2015). The so-called Work-SoC clarifies additional variance of work-related demands and proves to be a stronger predictor than the global SoC. The construct can also be interpreted as a meta-resource that reduces the pathogenic effects of stressors in the workplace and providing an integrative explanation of why personal and external resistance resources in the workplace reduce work-related strains.

Executives play a decisive role in helping to organize such experiences, which employees consider as significant and meaningful within supportive leadership. It will only succeed if they are capable to "invite," "encourage" and "inspire" their staff. Leadership becomes a matter of attitude and trust in that way and recognition of life motives can be crucial in developing the necessary empathy.

\section{References}

Albertsen, K., Nielsen, M. L. \& Borg, G, V. 2001. The Danish psychosocial work environment and symptoms of stress: The main, mediating and moderating role of Sense Of Coherence. Work \& Stress, Taylor \& Francis, Milton Park, 15, pp. 241-253. DOI: $10.1080 / 02678370110066562$

Antonovsky, A. 1979. Health, Stress and Coping. Jossey-Bass, San Francisco.

Antonovsky, A. 1987a. Unraveling the mystery of health. How people manage stress and stay well. Jossey Bass, San Francisco.

Antonovsky, A. 1987b. Health promoting factors at work: the sense of coherence. In: Cooper, C. L.; Kalimo, R. \& El-Batawi M. (Eds.), Psychosocial factors at work and their relation to health, World Health Organization, Geneve, pp. 153-167. 
Antonovsky A. 1989: Die salutogenetische Perspektive: Zu einer neuen Sicht von Ge-sundheit und Krankheit. Meducs, 2, pp. 51-57.

Antonovsky, A. 1991. The structural sources of salutogenic strengths. In: Cooper, C. L, Payne, R., (Eds.), Personality and stress: Individual differences in the stress process. Wiley, New Jersey, pp. 67-104.

Antonovsky, A. 1996. The sense of coherence - An historical and future perspective. Journal of Medical Sciences, Peshewar, 32(3-4), pp. 170-178.

Bakker, A. B.; Albrecht, S. L.; Leiter, M. P. 2011. Key questions regarding work engagement. European Journal of Work and Organizational Psychology. Routledge, London, 20, pp. 4-28. DOI: 10.1080/1359432X.2010.485352

Bauer, G. \& Jenny, G. F. 2007. Development, implementation and dissemination of occupational health management (OHM): Putting salutogenesis into pratice. Occupational Health Psychology, Washington, 2, pp. 219-250.

Bauer, G.; Vogt, K.; Inauen, A. \& Jenny, G. J. 2015. Work-SOC - Entwick-lung einer Skala zur Erfassung des arbeitsbezogenen Kohärenzgefühls. Zeitschrift für Gesundheitspsychologie, Hogrefe, Göttingen, 23(1), pp. 20-30.

Baumann, N. \& Quirin, M. 2006. Motivation und Gesundheit - Bedürfnis-frustration als Vermittler zwischen Selbststeuerungsdefiziten und psychosomatischen Symptomen. Zeitschrift für Gesundheitspsychologie. Hofgrefe, Göttingen, 14(2), pp. 46-53.

Bengel, J.; Strittmatter, R. \& Willmann, H. 2001. Was erhält Menschen gesund? Antonovskys Modell der Salutogenese - Diskussionsstand und Stellenwert. Forschung und Praxis der Gesundheitsförderung, Köln.

Brandt, W. 1983. Foreword. In: Marie Jahoda: Wieviel Arbeit braucht der Mensch. BeltzPVU, Weinheim.

Buddeberg-Fischer, B.; Klaghofer, R.; Schnyder, U. 2001. Sense of Coherence in adolescents. Sozial- und Präventivmedizin, Birkhäuser, Basel, 46(6), pp. 404-410.

CHen, Z.; Zhang, X. \& Vogel, D. 2011. Exploring the underlying processes between conflict and knowledge sharing: a work-engagement perspective. Journal of Applied Social Psychology, Wiley, New Jersey, 41, pp. 1005-1033. DOI: 10.1111/ j.15591816.2011.00745.x

Csíkszentmihályi, M. 1975. Beyond Boredom and Anxiety. The Experience of Play in Work and Games, Jossey-Bass, San Francisco.

Ducki, A. 2000. Diagnose gesundheitsförderlicher Arbeit. Eine Gesamtstrategie zur betrieblichen Gesundheitsanalyse. (Mensch - Technik - Organisation). vdf Hochschulverlag AG, ETH Zürich.

Emmons, R. A. 1986. Personal strivings: An approach to personality and subjective well-being. Journal of Personality and Social Psychology, APA, Washington, 51, pp. 1058-1068. DOI: $10.1037 / 0022-3514.51 .5 .1058$

Erikson, M. \&. Lindström, B. 2006. Antonovsky's sense of coherence scale and the relation with health: A systematic review. Journal of Epidemiology and Community Health, BMJ, London, 60(5), pp. 376-381. DOI: 10. 1136/jech.2005.041 616

Faltermeier, T.; Mayring, P.; Saup, W. \& Stremel, P. 2002. Entwick-lungspsychologie des Erwachsenenalters. Kohlhammer, Stuttgart. 
Feldt, T. 1997. The role of sense of coherence in well-being at work: Analyses of main and moderator effects. Work and Stress, Taylor \& Francis, Milton Park, 11, pp. 134-147. DOI: $10.1080 / 02678379708256830$

Feldt, T.; Kinnunen, U.; Mauno, S. 2000. A mediational model of sense of coherence in the work context: A one-year follow-up study. Journal of Organizational Behavior, Wiley, New Jersey, 21, pp. 461-476. DOI: 10.1002/(SICI) 1099-1379(200 006)21:4\%3C461::AID-JOB11\%3E3.0.CO;2-T

Feldt, T.; Kivimäki, M.; Rantala, A. \& Tolyanen, A. 2004. Sense of coherence and work characteristics: A cross-lagged structural equation model among managers. Journal of Occupational and Organizational Psychology, Wiley, New Jersey, 77, pp. 323-342. DOI: $10.1348 / 0963179041752655$

Frankl, V. E. 1962. The will to meaning. Foundations and applications of logotherapy. Penguin, New York.

Gallup 2016. Engagement Index 2016. URL: http://www.gallup.de/183104/enga gementindex-deutschland.aspx. Retrieved on 30. Oct. 2017

Gana, K. 2001. Is Sense of coherence a mediator between adversity and psycho-logical wellbeing in adults? Stress \& Health: Wiley, New Jersey, 17, pp. 77-83. DOI: $10.1002 /$ smi.882

Geldenhuys, M.; Łaba, K. \& Venter, C. M. 2014. Meaningful work, work engagement and organizational commitment. SA Journal of Industrial Psychology, SAJIP, Johannesburg, 40(1), pp. 1-10. DOI: 10.4102/sajip.v40i1.1098

Hackman, J. R., \& Oldham, G. R. 1975. Development of the Job Diagnostic Survey. Journal of applied Psychology, APA, Washington, pp. 159-170. 10.1037/h007 6546

Hackman, J. R., \& Oldham, G. R. 1976. Motivation through the design of work: Test of a theory. Organizational Behavior and Human Performance, Elsevier, Amsterdam, 16, pp. 250-279. DOI: 10.1016/0030-5073(76)90016-7

Hackman, J. R., \& Oldham, G. R. 1980. Work redesign. Prentice Hall, Upper Saddle River.

Hakanen, J.; Feldt, T. \& Leskinen, E. 2007. Change and stability of sense of coherence in adulthood: Longitudinal evidence from the Healthy Child Study. Journal of Research in Personality, Elsevier, Amsterdam, 41, pp. 602-617. DOI: 10.1016/j.jrp. 2006.07.001

Hardening, F. 2015. Meaningful work: Sinnvolle Arbeit zwischen Subjektivität, Arbeitsgestaltung und gesellschaftlichem Nutzen. Österreichische Zeitschrift für Soziologie, Springer Fachmedien, Wiesbaden, 40, pp. 391-410.

Harter, J. K.; Schmidt, F. L. \& Hayes, T. L. 2002. Business-unit-level relationship between employee satisfaction, employee engagement, and business outcomes: A meta-analysis. Journal of Applied Psychology, APA, Washington, 87(2), pp. 268-279. DOI: 10.1037/0021-9010.87.2.268

Hobfoll, S. 1989. Conservation of resources: A new attempt at conceptualizing stress. American Psychologist, APA, Washington, 44, pp. 513-524. DOI: 10.1037/00 03-066X.44.3.513

Hogh, A. \& Mikkelsen, E. G. 2005. Is sense of coherence a mediator or moderator of relationships between violence at work and stress reactions? Scandinavian Journal of Psychology, Linköping, 46, pp. 429-437. DOI: 10.1111/j.14 67-9450.2005.00474.x

Holbeche, L. \& Springett, N. 2003. In search of meaning in the workplace. Roffey Park Institute Ltd., Horsham, Roffey Park. 
Hoole, C. \& Bonnema, J. 2015. Work engagement and meaningful work across generational cohorts. SA Journal of Human Resource Management, Cape Town, 13(1). DOI: 10.4102/sajhrm.v13i1.681

Höge, T. \& Büssing, A. 2004. The impact of sense of coherence and negative affectivity on the work stressor - strain relationship. Journal of Occupational Health Psychology, APA, New York, 9(3), pp. 195-205. 10.1037/1076-8998.9.3.195

Höge, T. \& Schnell, T. 2012. Kein Arbeitsengagement ohne Sinnerfüllung. Eine Studie zum Zusammenhang von Work Engagement, Sinnerfüllung und Tätigkeits-merkmalen. Wirtschaftspsychologie, 1/2012, pp. 91-99.

Höfer, R. 2000. Jugend, Gesundheit und Identität. Studien zum Kohärenzgefühl. Leske \& Budrich, Opladen.

Hurrelmann, K. 2000. Gesundheitssoziologie. Eine Einführung in sozialwis-senschaftliche Theorien von Krankheitsprävention und Gesundheitsförderung. Juventa, München.

Hurrelmann, K. \& Albrecht, E. 2014. Die heimlichen Revolutionäre - Wie die Generation Y unsere Welt verändert. Beltz, Weinheim.

Idan, O.; Braun-Lewensohn, O. \& Sagy, S. 2013. Qualitative, Sense of Coherence-Based Assessment of Working Conditions in a Psychiatric In-Patient Unit to Guide Salutogenic Interventions. In: Bauer, G. F. \& Jenny, G. J. (Eds.): Salutogenic organizations and change the concepts behind organizational health intervention research. Springer, Wiesbaden, pp. 55-74.

Isaksen, J. 2000. Constructing Meaning despite the Drudgery of Repetitive Work. Journal of Humanistic Psychology, Sage Publications, Thousand Oaks, 40, pp. 84-107. DOI: $10.1177 / 0022167800403008$

Kahn, W. A. 1990. Psychological conditions of personal engagement and disenga-gement at work. Academy of Management Journal, Briarcliff Manor, 33, pp. 692-724. DOI: $10.2307 / 256287$

Kalimo, R.; Pahkin, K.; Mutanen, P. \& Toppinen-Tanner, S. 2003. Stay-ing well or burning out at work: Work characteristics and personal resources as long-term predictors. Work \& Stress, Taylor \& Francis, Milton Park, 17(2), pp. 109-122. DOI: 10.1080/0267837031000149919

Khamisa, N.; Oldenburg, B. \& Peltzer, K. 2016. Work related stress, burnout, job satisfaction and general health of nurses. International Journal of Environmental Research and Public Health, MDPI, Basel, 12(1), pp. 652-666. DOI: 10.3390/ijerph120100652

Kieser, A. 1995. Organisationstheorien, Kohlhammer, Stuttgart.

Kinman, G. 2008. Work stressors, health and sense of coherence in UK academic employees. Educational Psychology, APA, Washington, 28, pp. 823-835. DOI: 10.10 80/01443410802366298

Kivimäki, M.; Elovainio, M.; Vahtera, J.; Nurmi, J.-E.; Feldt, T.; Kelti-Kangas Järvinen, L. \& Pennti, J. 2002. Sense of coherence as a mediator between hostility and health: Sevenyear prospective study on female employees. Journal of Psychosomatic Research, Elsevier, Amsterdam, 52(4), pp. 239-247. DOI: 10.1016/S0022-3999(01)00305-1

Koltko-Rivera, M. E. 2006. Rediscovering the later version of Maslow's Hierarchy of Needs: Self-Transcendence and opportunities for theory, research, and unification. Review of 
General Psychology, APA, Washington, 10, pp. 302-317. DOI: 10.1037/10892680.10.4.302

Kordbacheh, N.; Shultz, K. S. \& Olson, D. A. 2014. Engaging mid and late career employees: The relationship between age and employee engagement, intrinsic motivation, and meaningfulness. Journal of Organizational Psychology, West Palm Beach, 14(1), pp. 1125 .

Kunter, M. 2011. Motivation als Teil der professionellen Kompetenz - Forschungsbefunde zum Enthusiasmus von Lehrkräften. In: Kunter, M.; Baumert, J.; Blum, W.; Klusmann, U.; Krauss, S.; Neubrand, M. (Eds.): Professionelle Kompetenz von Lehrkräften. Ergebnisse des Forschungsprogramms COACTIV. Waxmann, Münster, pp. 259-275.

Lindström, B. \&. Erikson, M. 2006. Contextualizing Salutogenesis and Antonovsky in Public Health Development. Health Promotion International, Oxford Academic, Oxford, 21(3), pp. 238-244. DOI: 10.1093/heapro/dal016

Lazarus, R. \& Folkman, S. 1984. Stress, Appraisal, and Coping. Springer, New York.

Lips-Wiersma, M. \& Morris, L. 2009. Discriminating Between "Meaningful Work" and the "Management of Meaning". Journal of Business Ethics, Springer International Publishing AG, Basel, 88(3), pp. 491-511. DOI: 10.1007/s10551-009-0118-9

Lu, X..; Dai, J. M.; Wu, N.; Shu, C.; Gao, J. L. \& Fu, H. 2016. Association between sense of coherence and occupational stress of workers in modern service industry in Shanghai. Chinese journal of industrial hygiene and occupational diseases, China, 34(10), pp. 731736. DOI: 10.3760/cma.j.issn.1001-9391.2016.10.003

Macey, W. H.; Schneider, B.; Barbera, K. \& Young, S. A. 2009. Employee engagement: Tools for analysis, practice, and competitive advantage. Blackwell, London.

Malik, F. 2003. Strategie des Managements komplexer Systeme. Haupt, Bern.

Maslach, C.; Schaufeli, W. B. \& Leiter, M. P. 2001. Job burnout. Annual Review of Psychology. Annual Reviews, Palo Alto, 52, pp. 397-422. DOI: 10.1146/ annurev.psych.52.1.397

Maslach, C. \& Leiter M. P. 1997. The truth about burnout. Jossey-Bass, San Francisco.

Maslow, A. H. 1943. A Theory of Human Motivation. Psychological Review, APA, Washington, 50(4), pp. 370-396. DOI: 10.1037/h0054346

Maslow, A. H. 1954. Motivation and Personality. Harper, New York.

Maslow, A. H.; Geiger, H. \& Maslow, B. G. 1971. The Farther Reaches of Human Nature. Viking Press, New York.

May, D. R.; Gilson, R. L. \& Harter, L. M. 2004. The psychological conditions of meaningfulness, safety and availability and the engagement of the human spirit at work. Journal of Occupational and Organizational Psychology, Wiley-Blackwell, Oxford, 77, pp. 11-37. DOI: $10.1348 / 096317904322915892$

Meckel-Haupt, A. 2001. Ein Beitrag zur Validierung des deutschsprachigen SOC-Fragebogens von Aaron Antonovsky. Medizinische Fakultät der Heinrich-Heine-Universität Düsseldorf.

Milliman, J.; Czaplewski, A. J., \& Ferguson, J. 2003. Workplace spirituality and employee work attitudes: An exploratory empirical assessment. Journal of Organizational Change Management, Bingley, 16, pp. 426-447. DOI: 10.1108/09534 810310484172 
Moé, A. 2015. Does displayed enthusiasm favour recall, intrinsic motivation and time estimation? Cognition and Emotion, 30(7), Taylor \& Francis, London, pp. 1361-1369. DOI: 10.1080/02699931.2015.1061480

Muller, Y. \& Rothmann, S. 2009. Sense of coherence and employees' perceptions of helping and restraining factors in an organisation. South African Journal of Industrial Psychology, SAJIP, Johannesburg, 35(1), pp. 89-98. DOI: 10.2478/s115 36-013-0222-1

Nausé, J. L. P. \& Rothmann, S. 2006. Work-related well-being of emergency workers in South Africa. South African Journal of Psychology. University of Kwa Zulu-Natal, Durban, 36, pp. 63-81. DOI: 10.1177/008124630603600105

Nerdinger, F. W. 2000. Extra-Rollenverhalten. Gruppendynamik und Organisationsberatung, VS Verlag für Sozialwissenschaften, Wiesbaden, 31, pp. 155-167.

Nilsson, K. W.; Leppert, J.; Simonsson, B \& Starrin, B. 2010. Sense of coherence and psychological well-being: improvement with age. Journal of Epidemiology and Community Health, BMJ, London, 64, pp. 347-352. DOI: 10.1136/ jech.2008.081174

Olivier, A. \& Rothmann, S. 2007. Antecedents of work engagement in a multinational oil company. Journal of Industrial Psychology, SAJIP, Johannesburg, 33, pp. 49-56. DOI: 10.4102/sajip.v33i3.396

Pallant, J. F. \& Lae, L. 2002. Sense of Coherence, well-being, coping and personality factors: Further evaluation of the sense of coherence scale. Personality and individual differences, Elsevier, Amsterdam. 33(1): pp. 39-48. DOI: 10.1016/S0191-8869(01)00134-9

Pine, J. 2012. Wit and Wisdom of the American Presidents: A Book of Quotations. Dover Publications, Mineola.

Pratt, M. G. \& Ashforth B. E. 2003. Fostering meaningfulness in working and at work, in Cameron, K. S.; Dutton, J. E. \& Quinn, R. E. (Eds.), Positive Organi-zational Scholarship: Foundations of a New Discipline, Berrett-Koehler Publishers, San Francisco, pp. 309327.

Reinshagen, R. 2008. Antonovsky - Theorie und Praxis der Salutogenese. In: Pflege und Gesellschaft, Juventa, München, 13(2), pp. 142-158.

Rosso, B. D.; Dekas, K. H. \& Wrzesniewski, A. 2010. On the meaning of work: A theoretical integration and review. Research in Organizational Behavior, Elsevier, Amsterdam, 30, pp. 91-127. DOI: 10.1016/j.riob.2010.09.001

Rudow, B. 2003. Arbeits- und Gesundheitsschutz im Lehrerberuf. Gefährdungs-beurteilung und Schutzmaßnahmen. In: Sicher durch den Schulalltag (1-12). Berlin, Stuttgart, Raabe.

Rudow, B. 2006. Das gesunde Unternehmen - Gesundheitsmanagement, Arbeits-schutz, Personalpflege. Oldenbourg, München.

Ryan, R. M. \& Deci, E. L. 2000. Self-determination theory and the facilitation of intrinsic motivation, social development, and well-being. American Psychologist, Washington, 55, pp. 68-78. DOI: 10.1037/0003-066X.55.1.68

Sauer, D. 2011. Von der „Humanisierung der Arbeit“ zur „Guten Arbeit“. Aus Politik und Zeitgeschichte, Bundeszentrale für politische Bildung, Bonn, 15, pp. 18-24.

Schaufeli, W. B.; Salanova, M.; Gonzàles-Romà, V.; Bakker, A. B. 2002. The Measurement of Engagement and Burnout: A Two Sample Confirmatory Factor Analytic Approach. Journal of Happiness Studies, International Publishing AG, Basel, 3(1), pp. 71-92. DOI: 10.1023/A:1015630930326 
Schaufeli, W. B.; Bakker, A. B. 2010. The conceptualization and measurement of work engagement. In: A. B. Bakker and M. P. Leiter (Eds.), Work engagement: A handbook of essential theory and research, Psychology Press, New York, pp. 10-24.

Schaufeli, W. B. 2013. What is engagement? In: Truss, C.; Alfes, K.; Delbridge, R.; Shantz, A. \& Soane, E. (Eds.), Employee Engagement in Theory and Practice Routledge, London, pp. 15-35.

Schnell, T. 2004. Implizite Religiosität - Zur Psychologie des Lebenssinns. Pabst Science Publishers, Lengerich.

Schnell, T., Hoege, T. \& Pollet, E. 2013. Predicting Meaning in Work: Theory, Data, Implications. The Journal of Positive Psychology, Routledge, New York. DOI: $10.1080 / 17439760.2013 .830763$

Sheldon, K. M.; Ryan, R. M.; Deci, E. L. \& Kasser, T. 2004. The independent effects of goal contents and motives on well-being: It's both what you pursue and why you pursue it. Personality and Social Psychology Bulletin, SAGE Publications, Los Angeles, 30, pp. 475-486. DOI: 10.1177/0146167203261883

Staehle, W. H. \& Sydow, J. 1991. Managementforschung 1. De Gruyter, Berlin.

Steger, M. F., Dik, B. J. \& Duffy, R. D. 2012. Measuring meaningful work: The work and meaning inventory. Journal of Career Assessment, Sage Publications, Thousand Oaks, 20, pp. 322-337. DOI: $10.1177 / 1069072711436160$

Söderfeldt, M.; Söderfeldt, B; Ohlson, C. G.; Theorell, T. \& Jones, I. 2000. The impact of sense of Coherence and high demand/low-control job environment on self-reported health, burnout a psychophysiological stress indicators. Work \& Stress, Taylor \& Francis, Milton Park, 14(1), pp. 1-15. DOI: 10.1080/026783 700417195

Ulich, E. 2011. Arbeitspsychologie. Schäffer-Poeschel, Stuttgart.

Vahs, D. 2009. Organisation: Ein Lehr- und Managementbuch. Schäffer Poeschel, Stuttgart.

Van Der Colff, J. J., \& Rothmann, S. 2009. Occupational stress, sense of coherence, coping, burnout and work engagement of registered nurses in South Africa. South African Journal of Industrial Psychology, SAJIP, Johannesburg, 35(1), pp. 1-10. DOI: 10.4102/sajip.v35i1.423

Vinoth, K. M.; Hansi, H. 2016. Moderating role of Sense Of Coherence in the relationship between coping strategies and occupational stress among intensive care unit nurses. International Journal of research in organizational behavior and human ressource management, Asian Research Consortium, New Delhi, 4(3), pp. 15-26.

Vogt, K.; Jenny, G. J.; Bauer, G. F. 2013. Comprehensibility, manageability and meaningfulness at work: Construct validity of a scale measuring work-related sense of coherence. South African Journal of Industrial Psychology, SAJIP, Johannesburg, 39(1), pp. 1-8. DOI: 10.4102/sajip.v39i1.1111

Voß G. G. \& Pongratz H. J. 1997. Subjekt und Struktur - die Münchener subjektorientierte Soziologie. Zur Einführung. In: Voß G. G. \& Pongratz H. J. (Eds.) Subjektorientierte Soziologie. VS Verlag für Sozialwissenschaften, Wiesbaden, pp. 7-29.

Wehner, T. \& Güntert, S. T. 2010. Beruf und Berufung. Gehirn und Geist, Spektrum der Wissenschaft, Heidelberg, 7-8, pp. 24-27. 
Wrzesniewski, A.; Dutton, J. E., \& Debebe, G. 2003. Interpersonal sense-making and the meaning of work. Research in Organizational Behavior, Elsevier, Amsterdam, 25, pp. 93135. DOI: $10.1016 / \mathrm{S} 0191-3085(03) 25003-6$

\section{Contact information}

Frank Hager, Dipl.-Wirt.-Ing. (FH), MBA, M.A.

University Of Latvia - Faculty of Economics and Management,

Raina bulvāris 19, Centra rajons, Rīga,

LV-1586, Latvia.

Home-Adress:

Geltendorfer Str. 15,

D-86316 Friedberg

Cell: +49 (0)170 2849556

E-mail: info@mitarbeiterdiagnostik.de

ORCID-ID: 0000-0002-7268-7564

DOI ID: https://www.doi.org/10.7441/dokbat.2018.08 


\title{
THE CONSUMER DECISION-MAKING PROCESS WHICH FORM DOMESTIC BRAND LOYALTY: A LITERATURE REVIEW
}

\author{
Fortesa Haziri, Miloslava Chovancová, Florin Aliu
}

\begin{abstract}
This paper presents a literature review regarding consumer decision-making process and its impact on creating domestic brand loyalty. The paper focuses on investigating previous studies on the topic. The articles are collected from Scopus and Web of Science, analysed by using decision-making process and domestic brand loyalty concepts. As filtering criteria for articles were used relevance, methodology, analysis details, results and implications for future research. The results provide an overview of the context regarding decision-making process and each phase impact. Furthermore, the impact of this process in brand loyalty explored by previous scholar has been analysed for the purpose of this paper.
\end{abstract}

Keywords: brand loyalty, domestic brand, decision-making process, purchase decision, developed countries, developing countries.

\section{INTRODUCTION}

Companies are founded to fulfil the costumers' needs. Moreover, buying products are considered challenging action within the decision making process. However, the process is followed by costumers during the time they purchase outputs of the domestic companies. Customers are opposed to the information asymmetry concerning the intrinsic value of the product and its usage. Consequently, they tend to eliminate information asymmetry via conducting extra research regarding product attributes. The decision-making process is not time constrained when consumers face lack of information concerning the quality of the product (Bansal and Voyer, 2000). According to Bansal and Voyer (2000), the relationship between consumer knowledge about the product and suggestions they obtain from friends and relatives is strong. Consumer loyalty is considered key element for the economic entities in achieving stable and long-lasting profit (TaghiPourian and Bakhsh, 2015). Consumers that constantly buy products from the same brand and are willing to spread their satisfaction are qualified as loyal consumers (TaghiPourian and Bakhsh, 2015). In addition, consumers are considered loyal when they constantly purchase and expose their satisfaction level for the same brand.

The decision-making process is influenced mostly by the way information are received. Evaluating obtained information has the identical level of the importance as the process of collecting information. According to Solomon et al. (2006) products and brand, features are mainly appraised before the final decision is made. Moreover, costumes on occasions are leaded by their emotions and do not analyse the consequences of buying behaviour (Becker, 2016). When numerous choices are presented takes time in the context of gathering information and classifying them. Correspondingly, costumers will be able to decide which product to buy. In contrast, Solomon et al. (2006) refer to the time consumer will spend when they purchase products while deeply analysing information will have negative tradeoff on time spent for the other activities. The traditional methods of decision-making process applied were facing changes due to increase in the internet usage (Darley, Blankson and Luethge, 2010). Previously, searching for information and places to buy product has been limited. Nowadays, due to technological evolution information availability, consumers are exposed to a diverse set of options. Due to super-crowded shops, the internet can facilitate purchasing process by allowing consumers to buy products whenever they find it convenient (Huang et al., 2017). Standing on the work done by Huang et al. (2017) concerning overcrowded places confirms that consumers 
feel attached to the brand and the need of being part of the group. Moreover, the study also implies that the need of belonging is fulfilled only in the case when the brand is mentioned. Purchasing online deliver signals to consumers on the trust and risk that they must undertake. Kim et al., (2008a) state that consumers decide based on reputation, privacy and security protection provided by suppliers. In contrast, the work differentiates itself from the previous scholars since it is the first attempt to measure brand loyalty factors in Kosovo. Since Kosovo is an emerging economy, a lot of structural changes occurred. The economic system went from the centrally managed economy to the market-oriented economy. However, during the transition enterprises experienced enormous managerial modifications. Enterprises were based on the output objectives during the socialist era, while currently operate under the market forces. The business environment and consumer behaviour have gone through constant changes, this is expressed in Kosovo as well. Enterprises face various obstacles to generate loyal consumers to their brands. Most of Kosovans are employed in education, construction, trade and less on manufacturing companies. Based on Kosovo Agency of Statistics report (2017) the employed average is $42.8 \%$. The other report regarding the structure of the companies in Kosovo, $47.7 \%$ of companies have trade as their main activity (Berisha et al., 2017). Eventually, trade has the highest traffic regarding profit, and most of Kosovans work in these companies. Furthermore, the average salary in privat sector is 371 EUR and in public sector is $525 \mathrm{EUR}$.

This paper is organized as follows. The second section describes the brief theoretical framework of the decision-making process. Methodology and data collection stands in the third section. The fourth section contains discussion and findings while the conclusion is in the last section.

\section{LITERATURE REVIEW}

The initial phase of the decision-making process is identifying the need which must be fulfilled. Motivated by the need consumers try to find the suitable channels regarding information obtainability. The next step is evaluating all alternatives, followed by purchasing decision and post-purchasing evaluation. In contrast, for online purchase costumer, the decision-making process is unstructured (Häubl and Trifts, 2000). Häubl and Trifts suggest that consumers first scan the information obtained, but not analyse them in depth. The following step is to evaluate the alternatives, compare, and make the purchase decision.

Solomon et al. (2006) confirm that decisions done by costumers are influenced by information availability. Information regarding the product attributes may not be sufficient to decide when purchasing the product. Word of mouth as a source of information has a higher impact on consumer buying decision. However, the brain finds it easier to save them and access later than the information provided in the printed version (Grewal et al., 2003). Furthermore, similarities between brands have a positive impact on considering the suggestion to buy the product (Grewal et al., 2003). The study done by Tarpey and Peter (1975) explain the core concept of consumer decision-making process. According to their study, consumers decide to maximize the net valence, based on their attractiveness or awareness of the decision. According to Kohli et al. (2004) online purchasing channels consume more time than the traditional instruments due to information asymmetry. Generally, the filters which are available when searching for information facilitates data collection (Häubl and Trifts, 2000).

Evaluating alternatives is not the same for every customer. The image of origin country matters a lot during this stage of the process. Globalization has generated problems in the country of origin for products. In developed countries, consumers choose domestic products (Essoussi and Merunka, 2007). The opposite is for developing countries, they choose products from western countries (Essoussi and Merunka, 2007). Another link with products and country of origin is the perception of quality. Products from the industrialized country are rated as higher quality 
than unindustrialized countries (Essoussi and Merunka, 2007). Frequently, filters presented by the online supplier help during the online purchasers (Häubl and Trifts, 2000). Filters such as recommendation agent and search engine present the most frequently searched information by the customer.

The purchase decision is affected by several factors where brand awareness is considered as the key element. Chi et al. (2009) in their study on the cellular phones, besides brand awareness, they found that perceived quality and brand loyalty are additional components. Adding factors which firmly affect the purchase intention are brand identity and brand recall. All those components will lead consumers to buy well-known brands. When purchasing online, the feedback given by previous costumers is considered as the factor with the highest impact (Kohli et al., 2004). The study continues to mention other influencing factors such as privacy, security and buying believe. Namely, for the online buyer, the decision they take is very complex but precise. Kim et al. (2008b) in their research about trust-based consumer decision-making in electronic commerce highlight the relation between trusted brand and purchasing intention.

In the post-purchase evaluation phase, consumers decide if they will buy the same product permanently. The utility they will have from the product they bought is expected to be shown in this phase. Bigné et al. (2005) emphasize a positive relation between intention to return and willingness to recommend. Moreover, the study confirms that the quality of services is important elements of the satisfaction level. The importance of quality regarding services provided by companies are also emphasized done by Kuo et al. (2009). The scholars confirm the strong relationship between quality of services and perceived value, customer satisfaction, and post-purchase intention. Moreover, word of mouth is equally important as for offline and online purchasers. Satisfaction level, advertisement and fashionability of product are equivalent elements for online purchasing (Dellarocas and Narayan, 2006).

Consumer decision making is highly linked with individuals' experience. Good experience tends to shorten the process while bad experience tends to change the whole process or use other strategy followed before the process (Hoyer, 1984). Grewal et al. (2003) confirm the word of mouth as the cheapest way of communication, credible and trustworthy. Continuesly, Aaker and Keller (1990) offer strong evidence which links brand awareness with brand loyalty. Huang et al. (2004) argue that online purchasers that stand for brand name and brand status that is positioned as the least risky element within the decision-making process. Bloemer and Kasper (1995) state the possibility of consumer satisfaction translated into consumer loyalty is considered as the positive effect on brand evaluation. Additionally, not on every purchase consumer follow the same decision-making program. Depending on the current situation, consumers adjust to the decision-making process. Rundle-Thiele and Bennett (2001) study imply the importance of diving brand loyalty based on product category. The reasoning is that the division will help companies to create an adequate marketing strategy. For e-brand loyalty, psychological factors are the determinant factor for consumers to be brand loyal and brand committed (De Vries and Carlson, 2014). Psychological factor influences as well the positive word of mouth and increase the changes for purchase in future. Regarding multicultural brands, consumers tend to show a higher level of brand loyalty for brands which reflect individual culture (Palumbo and Herbig, 2000). Furthermore, powerful culture member tends to present a higher brand loyalty attitude.

Wang et al., (2004) considers that consumers in developed countries consider imported goods of lower quality and they would prefer domestic goods. Moreover, consumers prefer domestic brand in cases when the information provided about the foreign brand are not sufficient (Lu Wang and Xiong Chen, 2004). The study conducted on Chinese economy by Wang et al. (2000), is considered as the opposite situation regarding domestic and foreign brands. Moreover, the study confirms that consumers consider the brands from developed country as 
higher quality. Identical results have been reached also in countries such as Nigeria (Agbonifoh and Elimimian, 1999), Romania and Turkey (Ger, Belk and Lascu, 1993), India (Brand Local et al., 2000) and China (Li et al., 1998; Sklair, 1994).

\section{METHODOLOGY}

The sample size is focused on the Kosovo economic environment. Moreover the study sample considers seven major cities in the Kosovo republic. Primary data are considered to answer the research questions. Questionnaires will be utilized to gather qualitative data. The sample size is calculated based on the following formula ):

$n=\frac{N * X}{X+N-1}$

where,

$X-\frac{\mathrm{Z} \alpha / 2^{2} * \mathrm{p} *(1-\mathrm{p})}{\mathrm{MOE}^{2}}$

Sample targets employees in private and public sector. The age of respondent varies, within fifteen to sixty-four years old. Regarding gender, the majority will be male since the percentage of employed male is higher than female. Part of the sample is respondents living in rural and urban areas. In the following figure will be explained the plan for gathering data process:

To analyse the collected data structural equation modelling will be used. The reasoning is that the mentioned model is commonly used for behavioural studies (Schumacker and Lomax, 2010). Also, the model will allow describing the relation between variables.

\section{RESULTS}

Scholars have different opinions concerning the valid model that creates brand loyalty. Since Kosovo is a young transitional economy, application of the brand loyalty model might generate interesting results for scholars. Moreover, will be analysed the loyalty of consumers for the domestic brand and the impact on the decision-making process of employed citizens. The study is for offline and online buying. The relation between each decision-making stage and brand loyalty factor will be analysed as well. Following the literature review, the first phase of decision making, identifying the need which should be fulfilled is not relevant when analysing brand loyalty. Gathering information, evaluation alternatives, purchase decision and postpurchase evaluation are able to provide evidence for brand loyalty. The expected results will be given explanation for the impact of the decision-making process on consumer loyalty for domestic products. The research will be based on primary data. To analyse the collected data structural equation modelling will be employed. The reasoning is that the mentioned model is commonly used for behavioural studies (Schumacker and Lomax, 2010). Also, the model will allow describing the relationship between variables.

Brand loyalty level will be analysed based on the following criteria: product quality, brand name and promotion. Based on literature review, these are the factors which influence mostly on creating loyal consumer for a brand. Furthermore, the mention factors of brand loyalty will be evaluated for their impact on every phase of the decision-making process. Search for information is expected to provide a solution of brand influence and information channel usage. In this phase, the promotional mix will be taken into consideration as well. Evaluate alternatives is expected to answer related to selective filters applied regarding the brand name, product quality or promotion impact. Purchase decision, regarding brand awareness, is explored, but not that much about brand loyalty. As the critical phase of decision making, the post-purchase 
evaluation will provide an explanation of impacted factors which allows consumers to express their satisfaction level and buy the same brand over and over again. Additionally, analysing each factor separately, they will be analysed together as well.

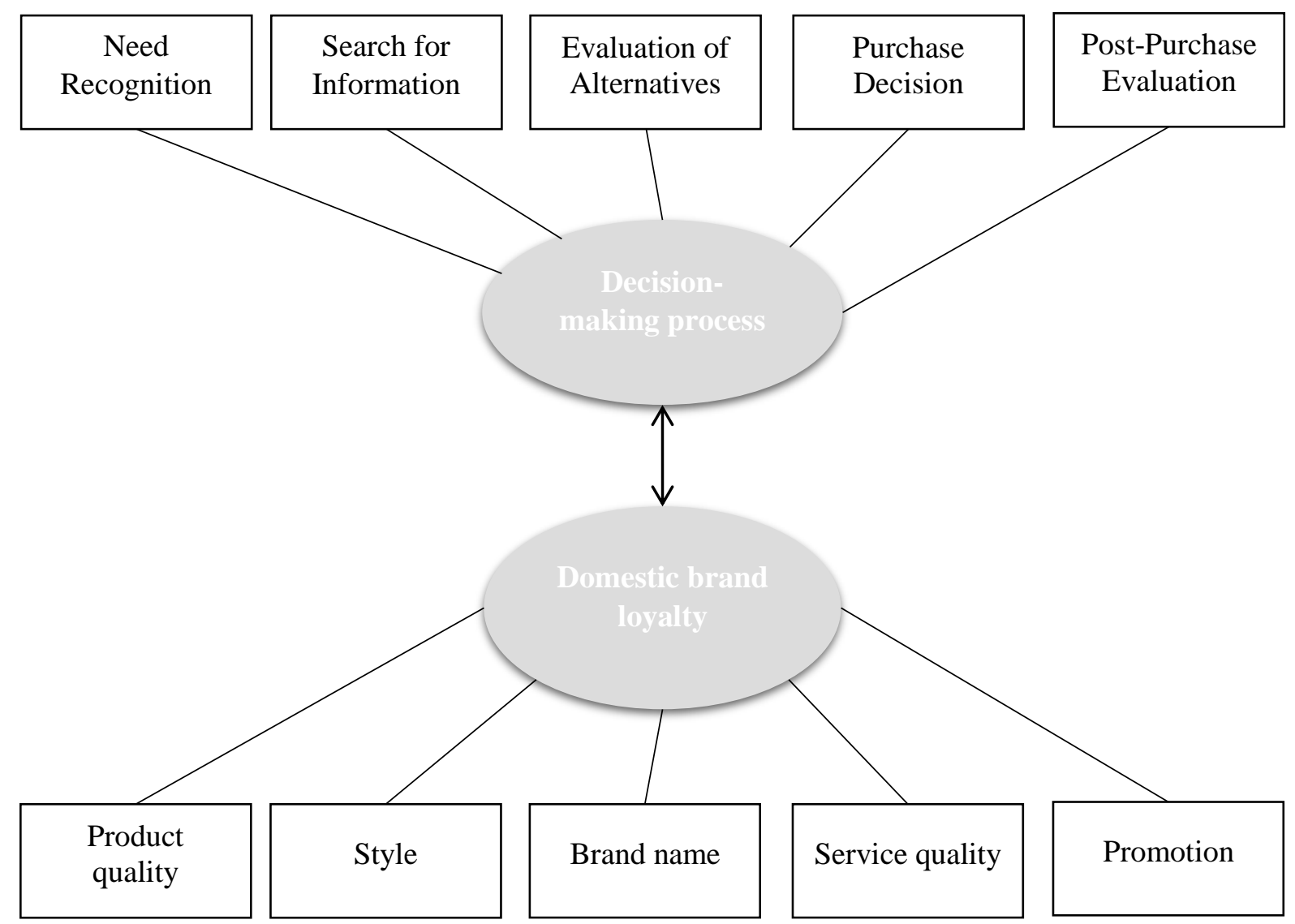

Figure 3. The conceptual framework, Source: Designed by the authors

\section{CONCLUSIONS AND IMPLICATIONS}

Tracking consumer behavioural changes during online and offline purchase has motivated numerous scholar to work in the field of brand loyalty. This paper has outlined issues for interested shareholders regarding the decision-making process and domestic brand loyalty concept. The study tends to provide a better understanding of the impact of each stage of the decision-making process on strategy development for building domestic brand loyalty. Ideally, all consumers would follow the same path of the decision-making process. However, due to different factors, this is not possible. Consumers purchase decision is affected by emotions, information availability, supplement, time, technology evolution, risk, and numerous other factors aimed to identify within an empirical research. In consumable markets, behavioural measures are suitable for forecasting the brand loyalty level. Due to behavioural changes, consumers' ability to adjust to divergent situations and decide under different circumstances impacts purchase process and brand loyalty. Measuring the attitudinal loyalty could predict the consumer behavioural brand loyalty, leading to the marketing strategy building. This is important because the behavioural change affects the market generally. 
Future research is required, which empirically evaluates the decision-making process and its impact on creating loyal consumers for domestic brands. The research can be done by different groups. Differences are likely to exist due to dissimilarities in purchasing. In addition, the drivers of brand loyalty in the different market types need to be empirically studied.

Acknowledgement

The authors are very grateful for the support provided by the Internal Grant Agency of Tomas Bata University in Zlin IGA/FaME/2018/2020.

\section{References}

Aaker, D. A. and Lane Keller, K. (1990) 'Consumer Evaluations of Brand Extensions', Journal of Marketing, 54(1), p. 27.

Agbonifoh, B. A. and Elimimian, J. U. (1999) "Attitudes of Developing Counties Towards "Country-of-Origin" Products in an Era of Multiple Brands', Journal of International Consumer Marketing. Taylor \& Francis Group , 11(4), pp. 97-116. doi: 10.1300/J046v11n04_06.

Bansal, H. S. and Voyer, P. A. (2000) 'Word-of-Mouth Processes Within a Services Purchase Decision Context', Journal of Service Research, 3, pp. 166-177.

Becker, J. (2016) The more of less : finding the life you want under everything you own. Colorado: Waterbrook Press.

Berisha, I. et al. (2017) Rezultatet e Anketës Strukturore të Ndërmarrjeve 2016. Prishtinë.

Bigné, E. et al. (2005) 'Relationships among residents' image, evaluation of the stay and postpurchase behaviour', Journal of Vacation Marketing, 11(4), pp. 291-302. doi: $10.1177 / 1356766705056626$.

Bloemer, J. M. and Kasper, H. D. P. (1995) 'The complex relationship between consumer satisfaction and brand loyalty', Journal of Economic Psychology. North-Holland, 16(2), pp. 311-329. doi: 10.1016/0167-4870(95)00007-B.

Brand Local, R. et al. (2000) 'Effects of Brand Local and Nonlocal Origin on Consumer Attitudes in Developing Countries', Journal of Consumer Psychology, 9(2), pp. 83-95.

Chi, H. K., Yeh, H. R. and Yang, Y. T. (2009) 'The Impact of Brand Awareness on Consumer Purchase Intention: The Mediating Effect of Perceived Quality and Brand Loyalty', The Journal of International Management Studies, 4(1), pp. 135-144.

Darley, W. K., Blankson, C. and Luethge, D. J. (2010) 'Toward an integrated framework for online consumer behavior and decision making process: A review', Psychology and Marketing. Wiley Subscription Services, Inc., A Wiley Company, 27(2), pp. 94-116. doi: 10.1002/mar.20322.

Dellarocas, C. and Narayan, R. (2006) 'A Statistical Measure of a Population's Propensity to Engage in Post-Purchase Online Word-of-Mouth', Statistical Science, 21(2), pp. 277285. doi: 10.1214/088342306000000169.

Essoussi, L. H. and Merunka, D. (2007) 'Consumers' product evaluations in emerging markets Does country of design, country of manufacture, or brand image matter?', International Marketing Review, 24(4), pp. 409-426. doi: 10.1108/02651330710760991. 
Ger, G., Belk, R. W. and Lascu, D.-N. (1993) 'The Development of Consumer Desire in Marketizing and Developing Economies: the Cases of Romania and Turkey', ACR North American Advances, NA-20, pp. 102-107.

Grewal, R., Cline, T. W. and Davies, A. (2003) 'Early-Entrant Advantage, Word-of-Mouth Communication, Brand Similarity, and the Consumer Decision-Making Process', Journal of Consumer Psychology, 13(3), pp. 187-197. doi: 10.1207/S15327663JCP1303_01.

Hajrizi, B., Demaj, B. and Thaçi, B. (2017) Anketa e Fuqisë Punëtore TM3 - 2017, Agjencia e Statistikave të Kosovës. Prishtinë.

Häubl, G. and Trifts, V. (2000) 'Consumer Decision Making in Online Shopping Environments: The Effects of Interactive Decision Aids', Marketing Science. INFORMS, 19(1), pp. 4-21. doi: 10.1287/mksc.19.1.4.15178.

Hoyer, W. D. (1984) 'An Examination of Consumer Decision Making for a Common Repeat Purchase Product', Journal of Consumer Research. Oxford University Press, 11(3), p. 822. doi: $10.1086 / 209017$.

Huang, W., Schrank, H. and Dubinsky, A. J. (2004) 'Effect of brand name on consumers' risk perceptions of online shopping', Journal of Consumer Behaviour. John Wiley \& Sons, Ltd., 4(1), pp. 40-50. doi: 10.1002/cb.156.

Huang, X. I. et al. (2017) 'The Influence of Social Crowding on Brand Attachment', Journal of Consumer Research. Oxford University Press, 44(5), pp. 1068-1084. doi: 10.1093/jcr/ucx087.

Kim, D. J., Ferrin, D. L. and Rao, H. R. (2008a) 'A trust-based consumer decision-making model in electronic commerce: The role of trust, perceived risk, and their antecedents', Decision Support Systems. North-Holland, 44(2), pp. 544-564. doi: 10.1016/J.DSS.2007.07.001.

Kim, D. J., Ferrin, D. L. and Rao, H. R. (2008b) 'A trust-based consumer decision-making model in electronic commerce: The role of trust, perceived risk, and their antecedents', Decision Support Systems. North-Holland, 44(2), pp. 544-564. doi: 10.1016/J.DSS.2007.07.001.

Kohli, R., Devaraj, S. and Mahmood, M. A. (2004) 'Understanding Determinants of Online Consumer Satisfaction: A Decision Process Perspective', Journal of Management Information Systems. Routledge, 21(1), pp. 115-136. doi: 10.1080/07421222.2004.11045796.

Kuo, Y.-F., Wu, C.-M. and Deng, W.-J. (2009) 'The relationships among service quality, perceived value, customer satisfaction, and post-purchase intention in mobile valueadded services', Computers in Human Behavior. Pergamon, 25(4), pp. 887-896. doi: 10.1016/J.CHB.2009.03.003.

Li, Z. G., Fu, S. and Murray, L. W. (1998) 'Country and Product Images', Journal of International Consumer Marketing. Taylor \& Francis Group, 10(1-2), pp. 115-139. doi: 10.1300/J046v10n01_07.

Lu Wang, C. and Xiong Chen, Z. (2004) 'Consumer ethnocentrism and willingness to buy domestic products in a developing country setting: testing moderating effects', Journal of Consumer Marketing. Emerald Group Publishing Limited, 21(6), pp. 391-400. doi: 10.1108/07363760410558663. 
Palumbo, F. and Herbig, P. (2000) 'The multicultural context of brand loyalty', European Journal of Innovation Management, 3(3), pp. 116-125. doi: $10.1108 / 14601060010334876$.

Peter, P. J. and Tarpey, L. X. (1975) 'A Comparative Analysis of Three Consumer Decision Strategies', Source Journal of Consumer Research, 2(1), pp. 29-37.

Population Proportion - Sample Size - Select Statistical Consultants (2018) Select Statistical Services. Available at: https://select-statistics.co.uk/calculators/sample-size-calculatorpopulation-proportion/ (Accessed: 23 February 2018).

Rundle-Thiele, S. and Bennett, R. (2001) 'A brand for all seasons? A discussion of brand loyalty approaches and their applicability for different markets', Journal of Product \& Brand Management. MCB UP Ltd, 10(1), pp. 25-37. doi: 10.1108/10610420110382803.

Schumacker, R. E. and Lomax, R. G. (2010) A Beginner's Guide to Structural Equation Modeling. 3rd edn. New Yor: Taylor and Francis Group, LLC.

Sklair, L. (1994) 'The culture-ideology of consumerism in urban China: Some findings from a survey in Shanghai', Research in Consumer Behavior, 7, pp. 259-292.

Solomon, M. et al. (2006) Consumer Behaviour A European Perspective. Third. Harlow: Edinburgh Gate.

TaghiPourian, M. J. and Bakhsh, M. M. (2015) 'Loyalty: From Single-Stage Loyalty to FourStage Loyalty', International Journal of New Technology and Research (IJNTR), 1(6), pp. 48-51.

De Vries, N. J. and Carlson, J. (2014) 'Examining the drivers and brand performance implications of customer engagement with brands in the social media environment', Journal of Brand Management. Palgrave Macmillan UK, 21(6), pp. 495-515. doi: 10.1057/bm.2014.18.

Wang, C.-L. et al. (2000) 'The Influence of Hedonic Values on Consumer Behaviors: An Empirical Investigation in China'. Haworth Press, Inc, 14(9), pp. 169-186.

Wang, C., Siu, N. Y. M. and Hui, A. S. Y. (2004) 'Consumer decision-making styles on domestic and imported brand clothing', European Journal of Marketing. Emerald Group Publishing Limited, 38(1/2), pp. 239-252. doi: 10.1108/03090560410511212.

\section{Contact information}

Fortesa Haziri, Ph.D. candidate

Tomas Bata University, Faculty of Management and Economics

Address: T. G. Masaryka 3050, 76001 Zlin, Czech Republic

Telephone number: +383 44486 273, +420 774220261

E-mail: fortesa.haziri@gmail.com, haziri@utb.cz

ORCID: 0000-0002-0804-3801

DOI ID: https://www.doi.org/10.7441/dokbat.2018.09 


\title{
CHANGEOVER TIME REDUCTION THROUGH LEAN TOOL "SMED" - A CASE STUDY FROM FOOD SECTOR
}

\author{
Kateřina Gálová
}

\begin{abstract}
With the expansion of the product portfolio, businesses are faced with the problem of rising costs and downtime associated with changeovers. The classic approach to this issue is based on a system of large production batches, which will minimize the number of changeovers, thus eliminating the costs associated with them. However, customer requirements often do not allow them to produce in large batches, which also entail relatively high storage costs. Therefore, it is necessary to focus attention on their efficient operation when reducing production batches and simultaneously increasing the frequency of changeovers. One way of actively influencing the cost and downtime that occurs during the changeovers is the Single Minute Exchange of Die method. The presented article approximates a case study that deals with the implementation of this method in a specific food industry company. The results obtained show that saving only thirty minutes of the average length of one of the most frequent changeover can save up to CZK 130,000 per year.
\end{abstract}

Keywords: Industrial engineering, lean, SMED, changeover time, setup, food production

\section{INTRODUCTION}

A challenging business environment is a relatively big challenge for many companies. Changes in recent decades have forced businesses to find ways to reduce costs, shorten production and delivery times, and yet increase performance. The company must be competitive and meet changing customer requirements, otherwise its market position is unusable. Flexibility is one of the key elements in this dynamic environment that allows businesses to survive. (Krugman, 1994; Chase et al., 2001; BlackBurn, 1991)

According to Sahin (2000), there are four basic systems to help the company maintain its competitive edge and market position: specialized factories, lean factories, mass customization and flexible production. Any activities in this context that do not add value to the customer and are therefore unnecessary need to be eliminated. One of the options here is industrial engineering (IE) with its tools, which allows to achieve the basic factors contributing to competitiveness: namely continual improvement; simple, reliable and flexible devices; employee involvement; reducing machine settings and changeover times. (Anand \& Kodali, 2009; Sahin, 2000).

The trend in lot size reduction and mass customization brings one great waste area - the total times of changeovers. Set up the machine from one type of product to another can be time consuming, especially if the machine needs to be perfectly cleaned or the setting up are done very often. The IE method, which deals with the reduction of the time required for changeovers, is the SMED method. This article deals with the possibility of using SMED methods in specific conditions of the food industry. In this sector of the national economy, there is a specific requirement for perfect cleanliness of the plant from the production of one type of food to another. In the selected company dozens of products are produced in different variants, which in a limited space and a limited number of machines represents a huge amount of castings per 
day. In the form of a case study, it introduces the introduction of this method and its possible benefits.

\section{LITERATURE REVIEW}

The performance of the business and its ability to sustain its position on the market is a key feature today (Yoo \& Seo, 2017). Businesses are therefore looking to find ways to get any competitive advantage. These include, for example, increasing productivity, focusing on shop floor improvements, increasing customer value (Smith, 2003). One of the possible tools to achieve this is IE, or lean.

The lean concept was designed to eliminate all kinds of waste, thereby increasing customer value (Shah \& Ward, 2003) and includes various tools that, among other things, help identify the direction of improvement (Holweg, 2006).

Lean is a concept originally from Toyota, which is aimed at eliminating any waste. In this context, waste is characterized as any redundant operation or cost-inducing activity that does not generate any added value to the customer. Several studies have shown that lean is a very powerful tool for increasing performance in terms of quality, stock minimization, productivity gains, or cost reductions (Fullerton and Wempe, 2009; Cua et al., 2001).

The reasons for implementing the lean concept are many. It can be, for example, efforts to improve quality at low cost (Liker \& Wu, 2000) or to increase productivity while eliminating waste (Worley \& Doolen, 2006; Bhamu et al., 2012). Stone (2012) summarized the basic knowledge of the literature as follows:

- the Lean concept has gradually evolved to be applicable everywhere in the organization (not only in production) and is also universally applicable in all sectors (also outside of industry)

- modern lean literature is already paying a lot of attention to the development of human resources

- the successful transformation of the enterprise towards the lean is conditioned by strategic support throughout the enterprise

The number of tools actively used by the lean concept is relatively large. The professional literature is largely inconsistent in their uniform classification. E.g. Shah and Ward (2003) divided the methods into four basic categories, namely: JIT, TPM, TQM and human resource management. Compared to that Moyano-Fuentes and Sacristan-Diaz (2012) defined their four basic categories from a completely different perspective: shop floor, value chain, work organization and geographical context.

According to Melton (2005) basic lean tools and techniques include:

- Kanban

- $5 \mathrm{~s}$

- Visual control

- Poka-yoke

- SMED

Focusing on reduction of setup time is one of the key activities of lean thinking. The total setup time has traditionally been solved in enterprises by the effort of large lot sizes and thus minimizing the number of setups required. (Holweg, 2006) However, this contradicts the 
philosophy of the lean, which focuses primarily on eliminating all waste (an activity that does not add value to the customer). And the customer currently requires flexible fulfilment of his often-unique requirements. This bring out the need for product customization and production in small doses, which contradicts the efforts of companies to minimize casting time by using large lot sizes. (Ezeiruaku, ResearchGate, 2004; McIntosh et al, 2000) Companies therefore need to be able to produce a large variety of products in small quantities and therefore have the necessary competencies quick changeover activities. To compete, companies need to look for ways to shorten setup time and eliminate waste and non-value-added activities. In addition, they must be able to transfer the idle time to the normal production time. (Park et al., 2001)

SMED was developed by Shingo is characterized as a scientific approach for substantially reduction of setup times and it can be used in any industry and any machine (Shingo, 1985; Ani $\&$ Shafei, 2012). This method was originally developed through the study of a die change process. In general, the SMED method deals; with the simplification and standardization of shuffle operations, which also entails a reduced need for professionally trained staff. (Shingo, 1985; Ulutas, 2011)

Changeover time is the time that is required to prepare a machine for the batch of different products. Specifically, the total changeover time is time from the end of production of the last good piece to the end of the production of the first good piece of the new batch. This means that the activities in the cast are, for example, setup, warm up, trial run, adjustment, first-piece inspection. (Ezeiruaku, ResearchGate, 2004)

In the Single Minutes Exchange of Die there are four stages, including the preliminary stage, involved to make some setup reductions (Shingo, 1985):

- Preliminary stages.

- Stage 1: Separate internal and external setup.

- Stage 2: Convert internal to external setup.

- Stage 3: Streamlining all aspect of setup.

The most critical phase is phase one, in which it is necessary to divide all the activities that are performed during the casting into internal and external. Internal activities cannot be performed during the machine activity, while external activities can be performer during the machine activity. The primary task of the SMED method is then to transfer as many internal activities as possible to the internal workforce that can be handled by the machine during the machine's time. (Shingo, 1985; Moxham \& Greatbanks, 2001) Only activities that cannot be performed (typically for safety) during operation of the machine, such as picking tools or parts, should be performed during the machine stop. (Sivasankar et. al, 2011)

However, the SMED method is not implemented in isolation from other lean tools. According to Pellergrini et al (2012) are some of another lean tools typically implemented at the same time as SMED, e.g. Kaizen and PDCA for continuous improvement, standardization to maintain the established changes or 5S for clean, orderly and safe workplace. Similarly, it has been demonstrated (Trovinger et.al, 2005) that the SMED method of the sophisticated computer methods should not be separated because their maximum effect can be achieved by their mutual use.

The SMED method deals with a relatively large number of expert articles. Their main outcomes are summarized in Dave \& Sohani (2012):

- To maximize the true potential of the SMED method, it is necessary to implement continuous training an awareness program from top to bottom management. 
- The SMED method is suitable for any type of industry

- In order to increase the benefits of introducing the SMED method, it is also appropriate to introduce $5 \mathrm{~S}$ and various forms of visual control.

- The SMED method (as well as other lean management tools) should not be implemented in isolation, but at the same time with other tools.

\section{METHODOLOGY}

The main objective of this case study is to find out how much savings can be achieved by reducing the average time of the changeovers without significant financial investment in new machinery and equipment in the conditions of the selected manufacturing enterprise.

The selected enterprise is one of the main players in the food industry in the Czech Republic. It is part of a multinational company that focuses on a wide range of products - such as sweets, spices and soups, coffee, cereals, baby food, canned food, fruit juices, mineral water, and the non-food sector - feed for dogs and cats. The plant itself, in which the case study was processed, focuses on the production of chocolate and chocolate confectionery.

The study was prepared on the basis of a real project that took place in a selected company with the participation of an author who was part of the project as a project team member and project coach. The project consisted of basic project management structures, i.e. a project team was formed at the beginning, a project sheet was created, a project objective and its potential benefits were set. The main goal of the project was to reduce the time of the chosen changeover on the given line and thus increase its capacity by at least 15 tons per year and to achieve an average shuffle time of 220 minutes from the original 244 minutes.

For the purpose of the study, it was necessary to obtain detailed information about the activities within the entire changeover. This data was collected directly at the shop floor during the changeovers. To record the individual activities and their duration, stopwatch time study was used and the data were recorded in the pre-prepared checklist. Concurrently, a video was made for later detailed analysis.

On the basis of the analyses conducted, the project team designed and implemented changes to improve the current state (and to achieve the project goal).

\section{CASE STUDY}

\subsection{Specific project assignment}

Before the start of the project, a project team consisted of a team leader (head of IE), a sponsor (production manager), process owner (production master), coach (IE department employee), 4 team members, 1 operator, 1 mechanic.

For the project only one line was selected in the production plant (see next chapter). The first step was to collect data. In order to select a specific changeover, Paret's several-step analysis was carried out. For Pareto analysis data from the company's internal information system was used over the last 12 months. In the first step, the largest contributor to the total loss in the production area (planned vs. unplanned stoppages, loss of speed, etc) was found, in the second step a specific centre was selected, then the specific line of the given centre was selected, then the type of stoppages and finally the specific changeover was outlined, which was further analysed. 
When selecting a project (SMED method and specific product type), a historical analysis of all recorded stoppages at the factory was performed. The first step (Figure 1) was the analysis of the individual stoppages types (planned stoppages, unplanned stoppages, loss of speed, waste and rework). It is clear from the chart that the most important were planned stoppages with total time 10184 hours.

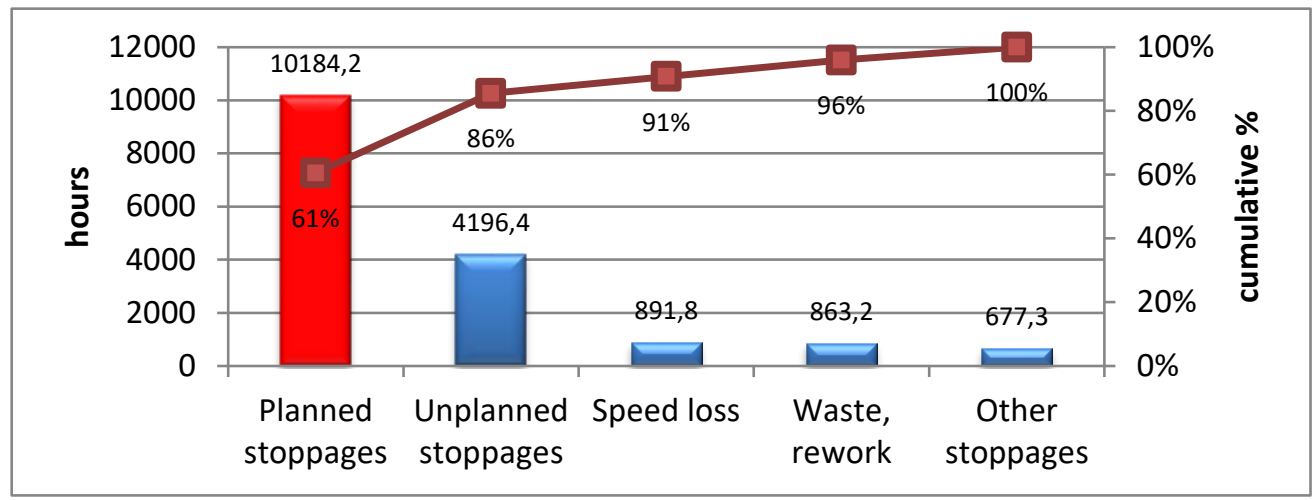

Figure 4 Analysis of plant stoppages. Source: own

In the next step (Figure 2), planned stoppages were analysed considering the location where these stoppages were reported. From this point of view, the most planned stoppages were recorded at the dessert centre, where, at the time of the preparation of the project, the improvement projects were already in progress. Therefore, the second centre - the tables - was selected for further analysis.

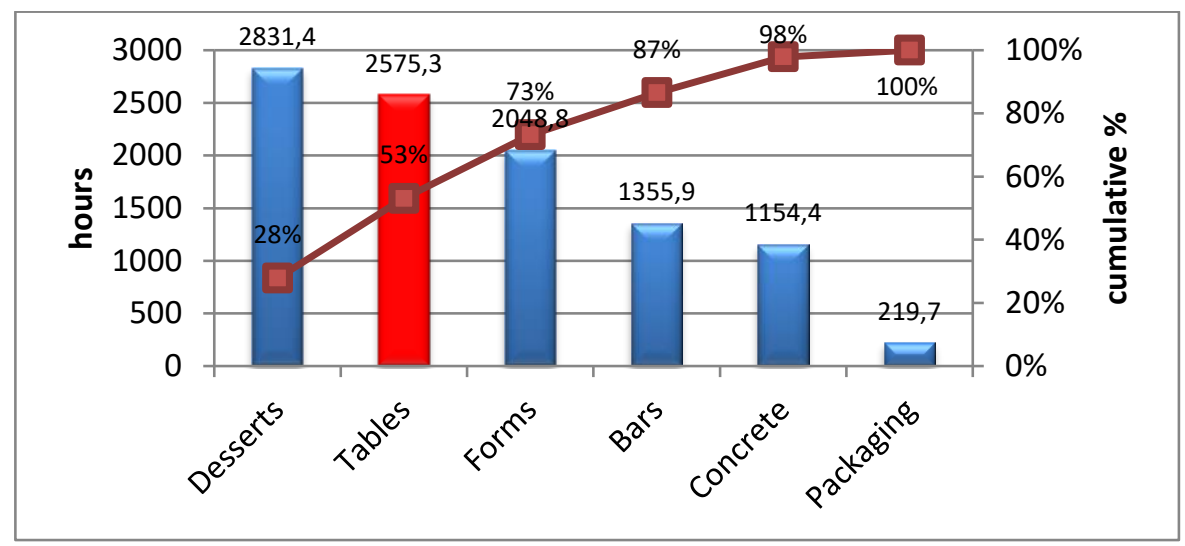

Figure 5 Planned stoppages. Source: own

At the tables centre, data is collected from five lines. By analysing the planned stoppages on these lines (Figure 3) it was found that D1 line has the largest share of these stoppages.

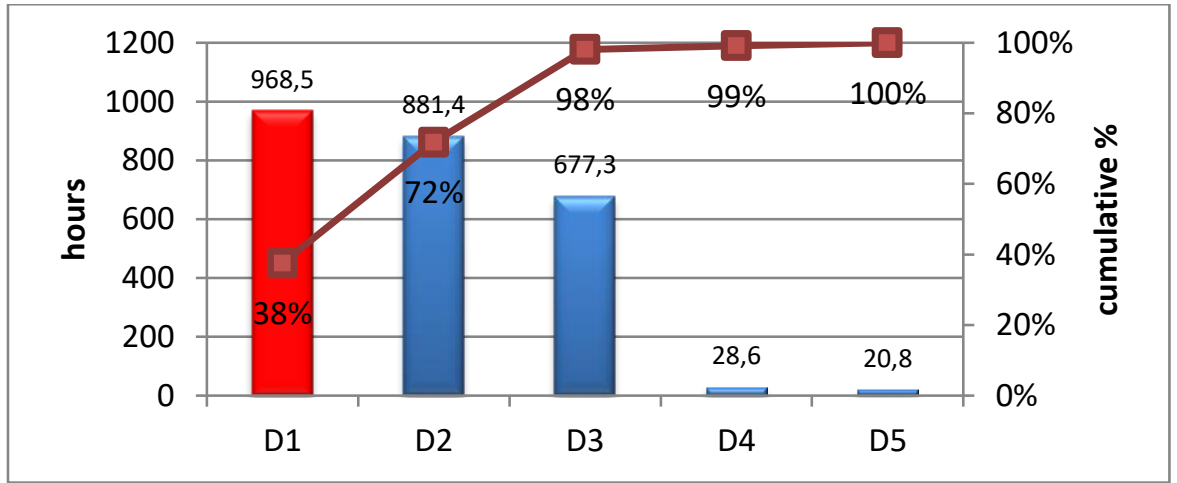

Figure 6 Planned stoppages - Tables. Source: own 
Various types of planned stoppages are reported on the D1 line (Figure 4). The most significant share of these stoppages is occupied by changeovers (76\% of all planned D1 sites). For this reason, the SMED method was selected.

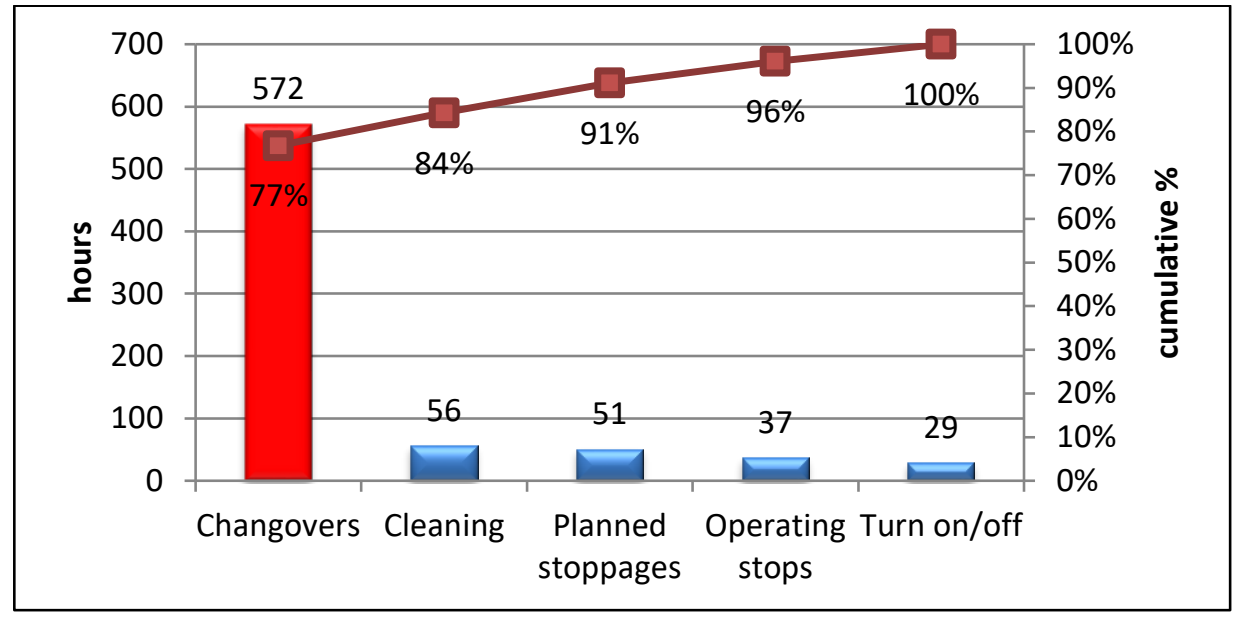

Figure 7 Types of planned stoppages on the D1 line. Source: own

It was also necessary to select a specific type of changeover. There are fourteen types of changeovers on the selected line, the total time and frequency of them is shown in the following chart (Figure 5). Of these types of changeovers, the fourth longest changeover was the most frequent (which would take 185 minutes), but the longest and second most frequent type of changeover (240 minutes) was eventually chosen by project team for the next step.

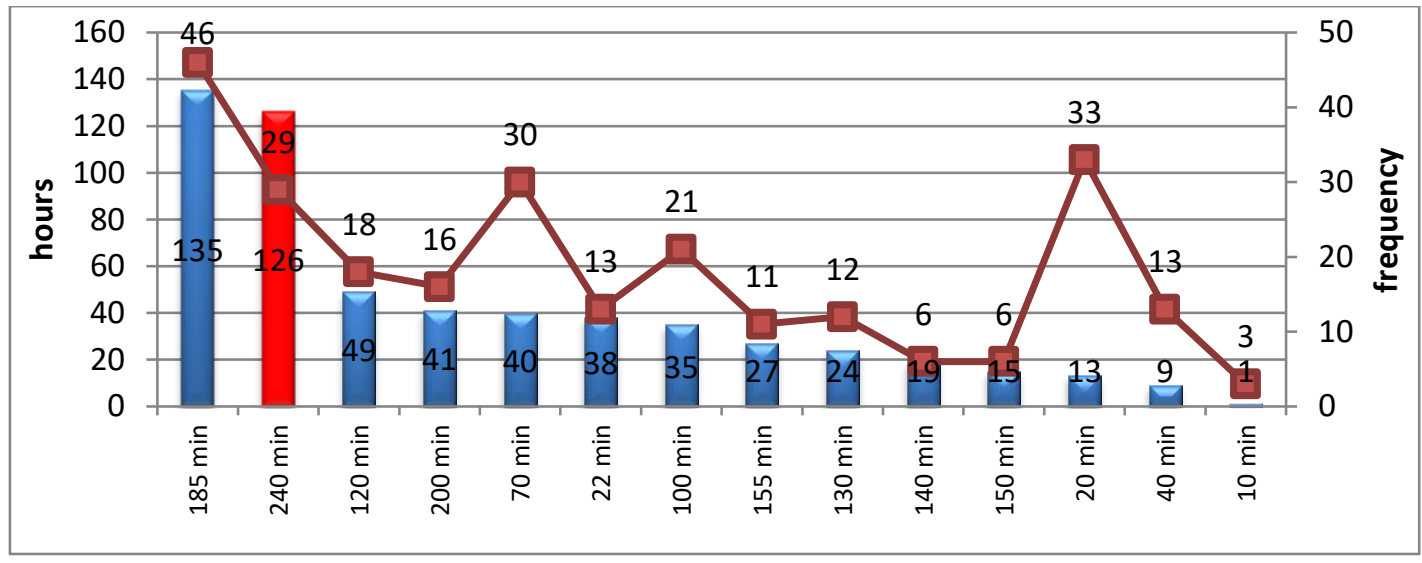

Figure 8 Changeovers on D1 line. Source: own

\subsection{Specific project assignment}

Problem: The selected line has the second largest loss in scheduled times, with up to 1500 machine hours per year lost. It is also necessary to optimize the entire changeover process.

Benefit of the project: The goal of the project is to reduce the changeover time and thus increase the capacity of the line by up to $15 \mathrm{t}$ while maintaining the price of the product, which can save up to CZK 92,000.

Expected output of the project: Reduction of the changeover time, correct timing of cleaning, maximum use of staff during cleaning, standard updating, standardization of cleaning time.

The project benefits from the company's main priorities, which are safety, cost, quality, innovation. It is expected to increase the safety of the job during the changeover, shortening the 
planned downtime and thereby reduce costs, reduce the risk of foreign objects entering the product during the changeover, increase the flexibility of the production.

Specification of the project objective: The next step was to analyse the total times of the selected kind of changeover in the last seasons, and to calculate the average time of this changeover. The times of the individual changeovers were variable, ranging from 195 minutes to 375 minutes. The project team decided on the main goal of the project, which was to reduce the time of the selected sort by $10 \%$ of the average changeover time, from 244 minutes to 220 minutes.

At the beginning of the project was a simplified financial analysis prepared and a quantification of the expected savings have been described. At a frequency of 58 changeovers per year and with a given number of operators and wage rates, the annual savings would be 91 thousand. CZK. At the same time, the time savings (23.4 hours) would allow the line capacity to increase by 15 tons.

The following table (Table 1) shows the basic data needed to calculate the total cost of a given type of changeover: changeover time (CT) for original changeover (OC) and expected status after changes (EC), calculated costs for both before and after project changes and expected savings.

Table 5 Expected project savings. Source: own

\begin{tabular}{|c|c|c|c|c|c|c|c|}
\hline & $\begin{array}{l}\mathrm{CT} \\
{[\text { minute }} \\
\mathrm{s}]\end{array}$ & $\begin{array}{l}\text { Frequen } \\
\text { cy }\end{array}$ & $\begin{array}{l}\text { Numbe } \\
\mathrm{r} \quad \text { of } \\
\text { operato } \\
\text { rs }\end{array}$ & $\begin{array}{l}\text { Rate } \\
{[\mathrm{CZK} / \mathrm{hou}} \\
\text { r] }\end{array}$ & $\begin{array}{l}\text { Number of } \\
\text { mechanica } \\
\text { ls }\end{array}$ & $\begin{array}{l}\text { Rate } \\
{[\mathrm{CZK} / \mathrm{hou}} \\
\mathrm{r}]\end{array}$ & Costs \\
\hline \multirow{2}{*}{$\mathrm{OC}$} & \multirow{2}{*}{244} & \multirow{2}{*}{58} & 14 & 227 & 2 & 394 & \multirow{2}{*}{$\begin{array}{l}934 \\
041\end{array}$} \\
\hline & & & \multicolumn{2}{|l|}{3172} & \multicolumn{2}{|l|}{788} & \\
\hline $\mathrm{EC}$ & 220 & 58 & \multicolumn{4}{|l|}{3960} & $\begin{array}{l}842 \\
169\end{array}$ \\
\hline $\begin{array}{l}\text { Expected } \\
\text { saving }\end{array}$ & 24 & 58 & \multicolumn{4}{|l|}{3960} & $\begin{array}{l}91 \\
873\end{array}$ \\
\hline
\end{tabular}

Analysis of the selected changeover

The following activities and times were identified during the recording of the individual activities of the selected changeover (based on the wishes of the company, only groups of activities that group shorter activities and individual movements of operators). The total changeover time was 3:36:59.

Table 6 Changeover activities. Source: own 


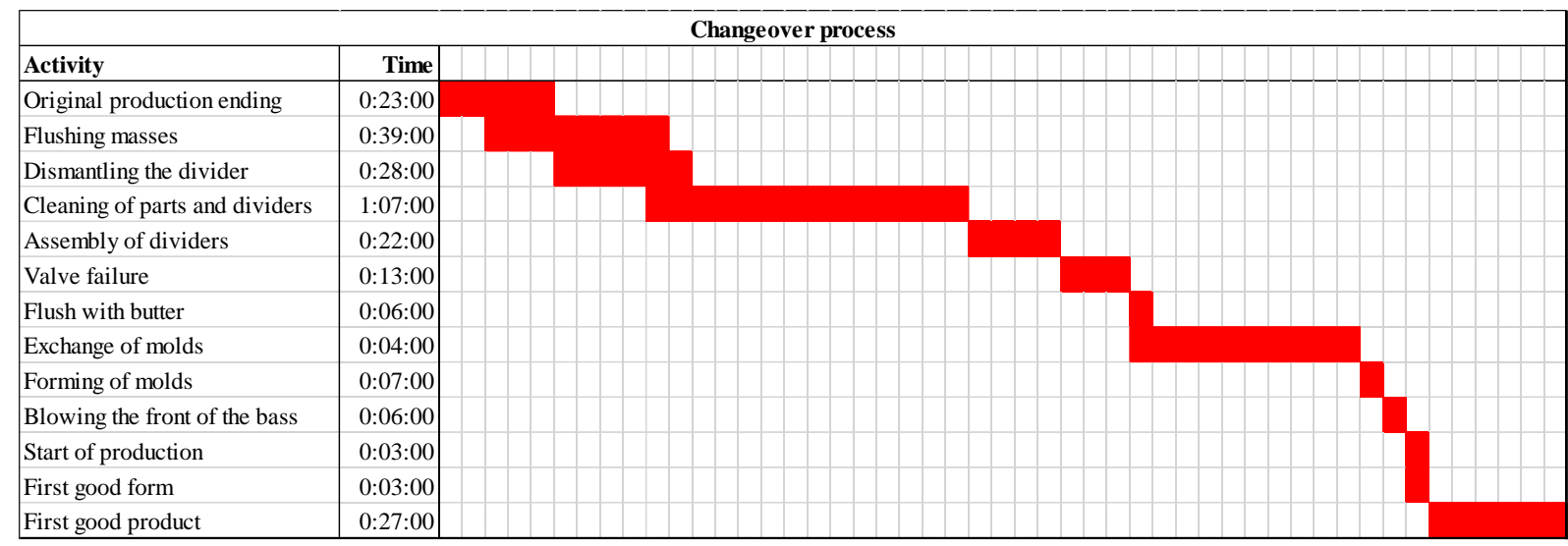

The distribution of internal and external activities is shown in the following Chart (Figure 6). Internal activities occupied $83 \%$ of the total time.

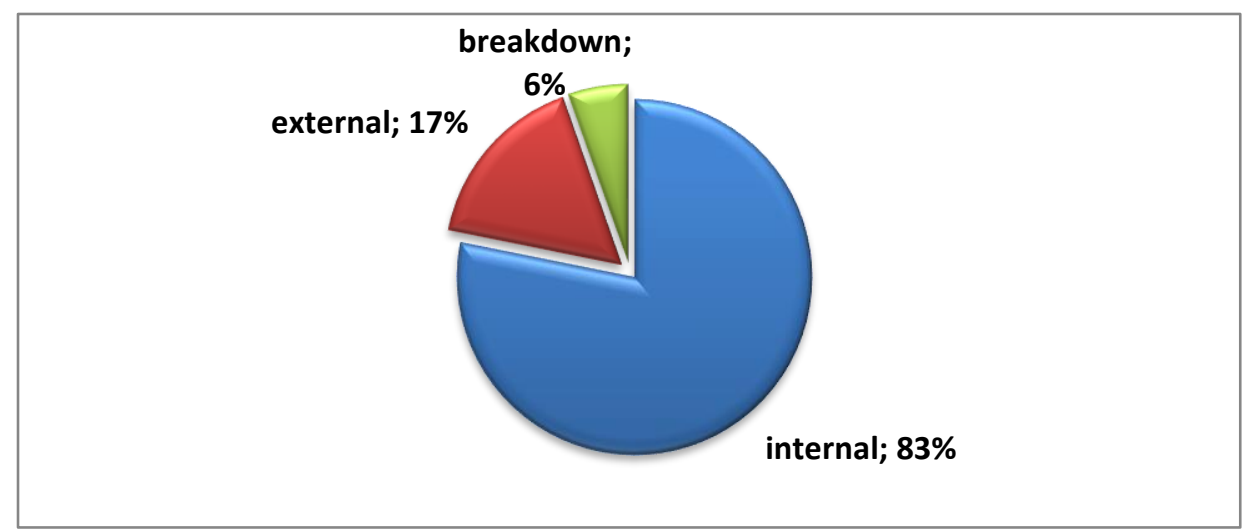

Figure 9 Internal vs external activities. Source: own

Suggestions for improvement

During several brainstormings, the project team came up with ideas on how to shorten the time of the selected changeover. Supporting the preparation of remedial measures was the ECRS internal methodology based on the basic steps of improvement and IE - elimination, combination, reduction, simplification. Proposals that were selected for implementation by the point method are listed in the following table (Table 3).

Table 7 Proposals to improve the current state

\begin{tabular}{|l|l|l|}
\hline What & Activity & Specific activities \\
\hline 1 - simplified & $\begin{array}{l}\text { valve opening - start of } \\
\text { flushing }\end{array}$ & Flushing time for approx. 8 min \\
\hline 2 - reduction & dismounting the divider & accelerate screw making - frequency, length \\
\hline $3-$ simplified & $\begin{array}{l}\text { removing parts of the } \\
\text { dishwasher }\end{array}$ & original cart for plates \\
\hline $4-$ reduction & $\begin{array}{l}\text { flushing mass into the } \\
\text { trolley }\end{array}$ & trolley for whitewash +1 trolley \\
\hline
\end{tabular}




\begin{tabular}{|c|c|c|}
\hline 5 - reduction & cleaning the dividers & $\begin{array}{l}\text { scraping the divider before washing - do not } \\
\text { take the pistons separately }\end{array}$ \\
\hline 6 - simplified & drying parts & chamber for component drying \\
\hline 7 - simplified & $\begin{array}{l}\text { cleaning of mixers- } \\
\text { pipes }\end{array}$ & better tool on the dishwasher \\
\hline 8 - simplified & $\begin{array}{l}\text { scraping the sheet under } \\
\text { the divider }\end{array}$ & $\begin{array}{l}\text { a larger sheet under a divider - taking out from } \\
\text { the other side }\end{array}$ \\
\hline 9 - elimination & piston lubrication & $\begin{array}{l}\text { define what work the mechanic performs and } \\
\text { what operator and try to use lecithin against } \\
\text { seizure }\end{array}$ \\
\hline $\begin{array}{l}10- \\
\text { elimination }\end{array}$ & start-up fault & to prevent breakdowns \\
\hline 11 - simplified & exchange of molds & control of trucks in line - camera \\
\hline \multirow[b]{2}{*}{12 - reduction } & \multirow[b]{2}{*}{ mold heating } & mold heating - automatic switching off \\
\hline & & $\begin{array}{l}\text { mold heating - other type - smaller / OSH / } \\
\text { energy }\end{array}$ \\
\hline
\end{tabular}

Based on the project team's suggestions, an action plan for each activity was defined, which defined the problem and action to resolve the problem, the specific date by which the action is to be met and the person responsible for the action. Of the twelve original actions, four were cancelled (due to technological difficulty or the need for a major financial investment). All other proposals have been implemented.

Of course, standardization of new procedures was a matter of course. New SOPs (standard operating procedure), new APIs, and line breakers have been created to monitor adherence to the changeover time. Part of the project included training all operators for a new SOP and filling out new indicators.

Actual impacts of the project

After implementing all suggestions for improvement and training all of operators, the times of the selected changeover were re-recorded. The average throw time dropped from 244 minutes to 194 minutes (Figure 7) and the target was met. The new changeover time was even lower than the project goal, but in the long run, the time was 210 minutes. This time is kept without any major problems. 


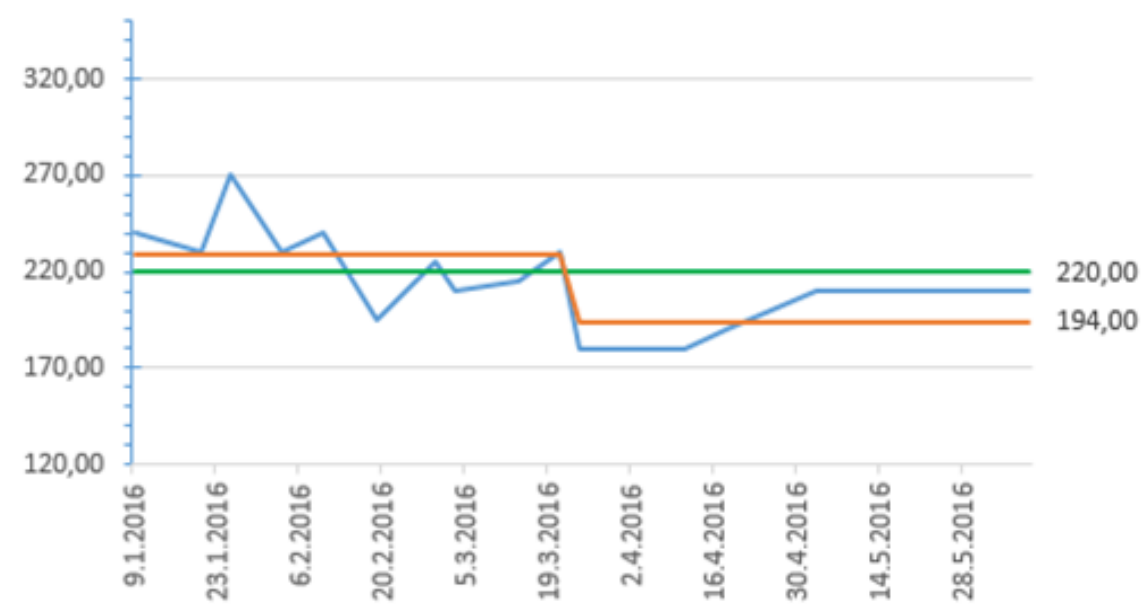

Figure 10 The impact of our project on changeover time

From a financial point of view, the project was also more successful than it was commissioned. Total savings amounted to 130 thousand CZK. Savings in the form of released production were 21 tons / year.

Table 8 Financial impact of the project

\begin{tabular}{|c|c|c|c|c|c|c|c|}
\hline & $\begin{array}{l}\text { CT } \\
{[\text { minute }} \\
\text { s] }\end{array}$ & $\begin{array}{l}\text { Frequen } \\
\text { cy }\end{array}$ & $\begin{array}{l}\text { Numbe } \\
\mathrm{r} \quad \text { of } \\
\text { operato } \\
\text { rs }\end{array}$ & $\begin{array}{l}\text { Rate } \\
{[\mathrm{CZK} / \mathrm{hou}} \\
\text { r] }\end{array}$ & $\begin{array}{l}\text { Number of } \\
\text { mechanica } \\
\text { ls }\end{array}$ & $\begin{array}{l}\text { Rate } \\
{[\mathrm{CZK} / \mathrm{hou}} \\
\text { r] }\end{array}$ & Costs \\
\hline \multirow{2}{*}{$\mathrm{OC}$} & \multirow{2}{*}{244} & \multirow{2}{*}{58} & 14 & 227 & 2 & 394 & \multirow{2}{*}{$\begin{array}{l}934 \\
041\end{array}$} \\
\hline & & & \multicolumn{2}{|l|}{3172} & \multicolumn{2}{|l|}{788} & \\
\hline $\mathrm{EC}$ & 210 & 58 & \multicolumn{4}{|l|}{3960} & $\begin{array}{l}803 \\
888\end{array}$ \\
\hline $\begin{array}{l}\text { Expected } \\
\text { saving }\end{array}$ & 34 & 58 & \multicolumn{4}{|l|}{3960} & $\begin{array}{l}130 \\
153\end{array}$ \\
\hline
\end{tabular}

In addition to visible or measurable impacts (financial savings, capacity savings, documentation, etc.), the project had other impacts. One of these other impacts was a relatively large expansion of the competencies matrix of the concerned workers. Team members have increased their competencies both in SMED methods and in other aspects. Another big plus of the project was the involvement of operators. Documentation related to the standardization of new activities was created directly by operators who had the opportunity to comment on the proposals and, if necessary, to revise them after approval by the team.

The SMED project has created room for further improvement. Already during the project, proposals were made to further shorten the changeover time by involving operators from other parts of the line or other changes in the activities performed. The successful completion of the project also has, due to the large number of changeovers on all parts of the line, a great potential for expansion to other sections. 


\section{CONCLUSION}

Industrial engineering and LEAN concepts are one of the basic building blocks that can increase the production performance of a business and thus also have a positive impact on competitiveness. Literary research has identified the basic assumptions of relations between methods and tools of industrial engineering and the competitiveness of the enterprise.

The SMED method was applied to a selected line in a case study case. The goal of the project was to reduce the average casting time by $10 \%$, i.e. from 244 minutes to 220 minutes. Based on the analysis of available data from previous months, a specific changeover was selected. This changeover, according to available data, represents one of the largest contributors to the total stop time reported from the entire company. Plates fall into planned stoppages, accounting for $61 \%$ of all stoppages of the company. Changeovers on a particular selected line then account for a total of $77 \%$ of all planned stoppages on this line.

After selecting a specific line and a changeover, a detailed analysis of this changeover was performed. It was found that $83 \%$ of all the activities performed during the changeover are external. Based on the analysis of the activities and the progress of the work during the changeover, the project team defined several amendments that should lead to a reduction in the total time of the changeover.

All selected suggestions were implemented directly on the shop floor. Of course, standardization of corrective actions and thorough training of all operators was a matter of course. After a few months, the target was met. The average changeover time was reduced to 194 minutes after the standardization of all proposed measures, which represents a decrease of $21 \%$. At the same time, an increase in production capacity was achieved by 21 tonnes per year. For company that is constantly struggling with insufficient capacities, this improvement is a fairly significant step forward.

The case study then illustrated how the SMED can achieve significant annual cost savings through selected industrial engineering tools.

\section{References}

Anand, G. \& Kodali, R. (2009). Selection of lean manufacturing systems using the analytic network process - a case study, Journal of Manufacturing Technology Management, 20(2), 258-289. https://doi.org/10.1108/17410380910929655

Ani, M., \& Shafei, M. (2012). The Effectiveness of the Single Minute Exchange of Die (SMED) Technique for the Productivity Improvement. International Journal of Sciences: Basics and Applied Research, 5(1), 9-13.

Bhamu, J., Kumar, J. V. S. \& Sangwan, K. S. (2012). Productivity and quality improvement through value stream mapping: a case study of Indian automotive industry. International Journal of Productivity and Quality Management, 10(3), 288-306. https://doi.org/10.1504/IJPQM.2012.048751

Blackburn, J. D. (c1991). Time-based competition: the next battleground in American manufacturing. Homewood, Ill.: Business One Irwin. ISBN 15-562-3321-3.

Chase, R. B., Aquilano, N. J., \& Jacobs, F. R. (2001). Operations Management for Competitive Advantage, (9th Edition). New York: McGraw Hill/Irwin. 
Cua, K., Mckone, K. \& Schroeder, R. (2001). Relationships between implementation of TQM, JIT, and TPM and manufacturing performance. Journal of Operations Management, 19(6), 675-694. https://doi.org/10.1016/S0272-6963(01)00066-3

Dave, Y. \& Sohani, N. (2012). Single Minute Exchange of Dies: Literature Review. International Journal of Lean Thinking, 3(2), 28-37.

Ezeiruaku, S. C. (2004). Single Minutes Exchange of Die (SMED) By Solomon C. (C 20082018 ResearchGate $\mathrm{GmbH}$.

Fullerton, R. R. \& Wempe, W. F. (2009). Lean manufacturing, non-financial performance measures, and financial performance. International Journal of Operations, 29(3), 214240. https://doi.org/10.1108/01443570910938970

Garcez, A. C. M. (2013). Implementation of the Single Minute Exchange of Die (SMED) Methodology in Small to Medium-sized Enterprises: A Portuguese Case Study. International Journal of Management, 30(1), 66-87.

Holweg, M. (2006). The Genealogy of Lean Production. Journal of Operations Management, 25, 420-437. https://doi.org/10.1016/j.jom.2006.04.001

Krugman, P. (1994). Competitiveness: A Dangerous Obsession. Foreign Affairs. 1994, 73(2), 28-35. https://doi.org/10.2307/20045917

Liker, J.K. \& Wu, Y.C. (2000). Japanese automakers, US suppliers and supply-chain superiority. Sloan Management Review, 42(1), 81-93.

McIntosh R. I, Culley. S. J, Mileham A. R, \& Owen. G. W. (2000). A critical evaluation of Shingo's 'SMED' (Single Minute Exchange of Die) methodology. International Journal of Production $\quad$ Research, 38(11), 2377-2395. https://doi.org/10.1080/00207540050031823

Melton, T. (2005). The benefits of lean manufacturing: what lean thinking has to offer the process industries. Chemical Engineering Research and Design, 83(A6), 662-673. https://doi.org/10.1205/cherd.04351

Moxham, C. \& Greatbanks, R. (2001). Prerequisites for the implementation of the SMED methodology: A study in a textile processing environment. International Journal of Quality \& Reliability Management, 18(4), 404-414. https://doi.org/10.1108/02656710110386798

Moyano-Fuentes, J. \& Sacristan-Diaz, M. (2012). Learning on lean: a review of thinking and research. International Journal of Operations \& Production Management, 32(5), 551582. https://doi.org/10.1108/01443571211226498

Park, K. S. \& Han, S. W. (2001). TPM-Total Productive Maintenance: Impact on competitiveness and a framework for successful implementation. Human Factors and Ergonomics in Manufacturing \& Service Industries, 11(4), 321-338. https://doi.org/10.1002/hfm.1017

Pellegrini, S., Shetty, D. \& Manzione, L. (2012). Study and Implementation of Single Minute Exchange of Die (SMED) Methodology in a Setup Reduction Kaizen. Proceedings of the 2012 International Conference on Industrial Engineering and Operations Management. 2353-2363.

Sahin, F. (2000). Manufacturing competitiveness: different systems to achieve the same results. Production and Inventory Management Journal, 41(1), 56-65. 
Shah, R. \& Ward, P.T. (2003). Lean manufacturing: context, practice bundles, and performance. Journal of Operations Management, 21(2), 129-149. https://doi.org/10.1016/S0272-6963(02)00108-0

Shingo, S. (1985). A revolution in manufacturing: the SMED system. Cambridge, Ma: Productivity Press Inc.

Sivasankar M., Dhandapani N., Manojkumar S., Karthick N., Raja K. \& Yuvaraj J. (2011). Experimental verification of Single Minute Exchange of Dies (SMED). Recent Research in Science and Technology, 3(3), 92-97.

Stone, K. B. (2012) Four decades of lean: a systematic literature review. International Journal of Lean Six Sigma, 3(2), 112-132. https://doi.org/10.1108/20401461211243702

Trovinger, S. C. \& Bohn, R. E. (2005). Setup Time Reduction for Electronics Assembly: Combining simple (SMED) and IT-based methods. Production and Operations Management Society, 14(2). https://doi.org/10.1111/j.1937-5956.2005.tb00019.x

Ulutas, B. (2011). An application of SMED Methodology. International Journal of Mechanical, Aerospace, Industrial, Mechatronic and Manufacturing Engineering, 5(7), 1194-1197.

Worley, J. M. \& Doolen, T. L. (2006). The role of communication and management support in lean manufacturing implementation. Management Decision, 44(2), 228-245. https://doi.org/10.1108/00251740610650210

Yoo, S. H. \& Seo, Y. W. (2017). Effect of supply chain structure and power dynamics on R\&D and market performances. Journal of Business Economics and Management, 18(3), 487504. https://doi.org/10.3846/16111699.2017.1326979

\section{Contact information}

Ing. Kateřina Gálová

Tomas Bata University in Zlín, Faculty of Management and Economics

nám. T. G. Masaryka 5555, Zlín

+420737681718

kgalova@utb.cz

ORCID: 0000-0002-5639-6281

DOI ID: https://www.doi.org/10.7441/dokbat.2018.10 


\title{
THE ROLE OF THE PENSION SYSTEM IN THE MODERN WORLD
}

\author{
Raman Herasimau
}

\begin{abstract}
On the base of previous researches and papers, this article shows importance of pension system. Were shown three different pension systems from Europe and Asia. Some systems are young and some are old with long history, but all of them unite strong relationship with other spheres of national economy. In this article, we look at historical improvement of different pension system, compare it and also find similarities. For the purpose of the article author uses historical method to show development of countries pension systems, graphical method to better view of current pension systems, analysis, analogy and comparison methods for understanding of the similarities of pension systems, there weaknesses and strengths, why we should use best elements from different systems to create or improve our. Results of the article are that pension system is the great source of investments, the political weapon and the source of social stability of a country, also we answered the question: how important pension system today and why policymakers should take into account best parts of different pension models and don't blindly copy systems, as it was in $80^{\text {th }}$. That's why government should create as autonomic system without "hand control" as it's possible.
\end{abstract}

Key words: Funded system, Kazakhstan, PAYG, pension models, pension system, scope of government, Slovakia, social security, Sweden, JEL Classification: H11, H55, H75, N33, N34, N35.

\section{INTRODUCTION}

Today most of countries faced with the problem of ageing population, and according to UN's report this process will continue in future 50 years UN World population ageing (2015), so decline of population, decline of fertility and growth of old people create a great challenge to future work productivity, unemployment rate, modern and future social security system and pension system as it part.

The obvious question is "How improve this situation?" Many countries tried to change their systems through the copy others, for example in the 80th of 20 century was very popular Chile's model. It is fully funded system without any basic part. But soon, countries went back to their systems or reformed new one because they didn't take into account specific of social and economic situation in every single country. Tendency of implementation should be treated with much more caution than policymakers think. Sudén (2004) says that it is a trend to introduce individual accounts as part of both public and occupational schemes, but it's not a trend it is necessity to have in system individual accounts, first of all it's easier to take into account person's contributions and second it's instrument for stimulating of work productivity.

Presently we can talk about how effectively build three-pillar pension system which component should prevail for this or that country as said Orszag and Stiglitz (1999) "The complexity of optimal pension policy should caution us against believing that a similar set of recommendations would be appropriate in countries ranging from Argentina to Azerbaijan, from China to Costa Rica, from Sierra Leone to Sweden. In response to the question "What should we do about our pension system?" we should be wary of offering a single answer across the globe". That's why in this article author tries to answer the following questions: why 
pension system is important, why the pension provision is state responsibility and analyze 3 model from 3 different countries Sweden, Slovakia and Kazakhstan.

\section{IMPORTANCE OF PENSION SYSTEM}

Many economists from all over the world agree, that pension system is important, e.g Rievajová (2004) says that reforms of pension system have a first place in political programs, because of market can't solve in the right way problems of some live needs or provide person on the retirement period. Fedotov (2007) highlight the importance in the framework of organizational structure. As any system pension has it financial mechanism, and how it works qualitatively depend the whole system. Cremer and Pestieau (2000) look at the importance of pension system from the side of political decision making. As we there are a lot of different opinions about pension system, but all of them highlight importance of it.

For the purpose of this article we should understand what does mean: "system", "scheme", "program", - because in many articles authors confused it. Today exist 3 models of pension system: Solidarity pension system (PAYG), Accumulative pension system (Funded) and mixed pension system (combination of first two systems). Based on Dahl's dictionary system is the order of the arrangement of parts of the whole, the predetermined structure, the course of something, in a sequential, coherent order. Focuse on mentioned definition pension system is a system of sequential and coherent elements (legislative acts, institutions, firms, households etc.) and it parts which work in the common social-economic environment and aimed to financing expenses of pension provision of citizens through pension schemes and programs. Therefore, for best understanding pension system say that scheme - is a set of parts which provide maximal contentment for individual or group of individuals, in turn, program detail scheme e.g. investment plans, investment strategy, funds etc.

Solidarity pension system (PAYG) means that person start to get pension from the moment of his/her retirement age, also it means that current working generation pays to current retirement generation. However, some authors understand PAYG system not as distribution mechanism but as public/ state accumulative fund, which accumulate money and then pay it to pensioners Orszag, Stiglitz (1999). That is why should say that PAYG is only distribution mechanism nothing more. The main advantage of this type is that all people have guarantee pension to the rest of their lives. It creates social stability and decrease worry about future life, at the same time that type of pension system has one great problem which is also today's tendency - growth of population, if population of the country decrease system becomes instability and usually this leads first to increasing of deductions to the system and then to deficit of state pension fund. From the first implementation of solidarity (Beveridge) pension system in 1942 it has undergone changes and include in itself some kind accumulative component - notional. All modern PAYG systems have this component which means that people have non-financial individual accounts Hagen (2016) where contribute their payments, but at the same time real money pays to current retirements. Notional component increase individuals' responsibility for future pension. Notional component is important especially for occupational pensions, because usually it indexed to wage growth and in contrast to funded pension more stable in long-run 
period. Today hardly find pure PAYG system in Europe it is only Republic of Belarus has pure PAYG system 3 and in Asia it is Japan.

Fully funded (pure) pension system also exists in several countries and the most famous is Chili. Such type of system has several advantages: high level of income, commonly accumulated money invested in different instruments shares, companies' bonds, government bonds, securities, commodities what in the end gives good profit; every person responsible for it own future pension life, this is create a strong relationship between today work and future life, increase wish to work, decrease unemployment; attract citizens to investment process; pure funded system less influenced by political cycles in the country, etc.

But at the same time funded system has disadvantages such as high investment risks, which connected with crisis of world economy, and either people can lost all money; poverty for the reason of own irresponsibility or health problems; as we said system less influenced by political cycles, but no one can protect on $100 \%$ from political cycles in other countries, from nationalization for example, or wars, or other social upheaval.

As we see both systems have advantages and disadvantages, society can use one of this system and worry about future problems or use best features from both and worry much more less. Mixed pension system is the most used and less risky system. Official history of mixed pension system began from 1994 when was proclaimed three-pillar doctrine by World Bank M. Leimgruber (2012). Three-pillar doctrine take their roots from Switzerland system of 1960s, but we can find earlier mentions of such kind of system in Sweden where first pension system was discussed in 1907 and accepted in 1913. First system was funded after that it added solidarity component and then during whole period of reforms until the 1998 when pension system took modern look, it changed by ways of financing and strengthening or weakening of PAYG or funded component.

Lindbeck and Person (2003) give several arguments for introducing a mandatory system as necessity component of any system: to prevent free-riders; prevent myopic from ending up in poverty in old age; the market for annuities is rather undeveloped, due, for instance, to adverse selection; PAYG introduces a new type of "asset" a pension claim whose yield is tied to the growth in the country's tax base, and this provides an opportunity for better portfolio diversification; and also it a sort of gift to itself, because generation $t$ fear discontinue finance generation $t-1$ since they would expect generation $t+1$ will do the same for them, another distributional argument that generation $t$ would like to be a part of the best future live of generation $t+1$, because for the last century the quality of life seriously increased, hence, in future we can expect the same trend.

There are different methods for modeling pension system, e.g. Lindbeck and Person (2003) highlight some basic principles of pension reform base on generic overlapping generations. Such model focuses on real economic transactions (consumption and labor supply) and the distribution of income among generations. According to that they proved that system with notional component more financial stable then just PAYG or funded. We should mention that system is financial stable if capital value of expected pension payments more or equal to the capital value of the revenues to the system from contributions (in aggregate). For

\footnotetext{
${ }^{3}$ There are funded component but it so small that cover no more than $1-2 \%$ of population of the country
} 
intergeneration fairness and financial stability, Sinn (2000) suggested increasing the accumulation of physical capital to compensate the fall of human capital accumulation by the reason of low fertility of current generation. It's some kind of payment for decision to have less children. As was said above like any system it has risks. There are can be not only fluctuations of growth rate of the tax base or market rate, but also political risks. Political risks is lower in the country with high decentralization of system and with strong property rights. At the same time decentralization connects with higher administrative costs of decentralize privet funds. That's why for decreasing and diversification political risk better to have mixed system. If we have risks in the system, also we should have opportunity to reduce them. There are three dimensions of distribute pension systems' risks: among generations, within generations and over an individual's life cycle. Issues of intergenerational risk sharing are particularly apparent in the context of PAYG. In such a system of the defined-contribution type, hence with a fixed contribution rate, fluctuations in the real wage rate $\mathrm{w}$ influence the disposable income of both workers and contemporary retirees in the same direction Lindbeck and Person (2003).

While defined benefit systems (regardless of whether they are pay-as-you-go or fully funded) do not contribute directly to risk sharing among generations, they can certainly function as a risk-sharing device within generations. For instance, in the case of a basic pension, fluctuations in earnings do not result in corresponding fluctuations in pensions Storesletten, Telmer, Yaron (1999). The risks sharing properties of the pension system are then similar to those of a progressive income tax. Due to specific institutional arrangements, however, certain elements in defined benefit systems in the real world accentuate rather than mitigate intragenerational income risk. One example is when the pension is tied to earnings during the $\mathrm{x}$ last years of work, rather than to lifetime earnings. Individuals who turn out to have low incomes late in life will then suffer a low income when retired. Another type of intragenerational income risk is associated with family dissolution. Historically, non-actuarial pension systems have included simple rules for allotting incomes among family members after the breakup of a family, in the form of pensions to widows and their children. By contrast, in a (quasi-) actuarial system with individual accounts, the pension is closely tied to the individual income earner. Without special arrangements, income risk due to the dissolution of a family is therefore larger in systems with individual accounts than in many existing pension systems. The family member with the lower market income, usually the woman, would therefore be exposed to a higher risk in a pension system with individual accounts. One remedy might be to give each spouse a property right to the other's pension wealth. This is straightforward in the case of formal marriages, where similar arrangements are already in place for other types of property, but is more difficult to implement in the case of cohabitation Lindbeck and Person (2003).

Pension systems may redistribute not only income but also income risk over the life cycle. In a defined contribution system, there is uncertainty concerning wage rate (w), while the fixed contribution rate $(\tau)$ may be known. There is also uncertainty about the return on contributions, since real interest rate $(R)$ and rate of change in the tax base $(G)$ are not guaranteed in advance. By contrast, in a defined benefit system, there is uncertainty not only about wage rate (w) but also about fixed contribution rate $(\tau)$, since the latter has to be adjusted to achieve budget balance. On the other hand, the pension benefit may be known in advance. Indeed, with a fixed benefit, there is no uncertainty at all concerning the pension, while in a defined benefit system with a fixed replacement rate, there is uncertainty about the pension behind the veil of ignorance solely as a result of uncertainty about wage rate (w). All this means that a pension reform represented by a shift from a defined benefit system to a defined contribution system will 
remove one source of uncertainty from the first period of an individual's life (uncertainty about $\tau$ ), but introduce a new source of uncertainty in the second period of life (uncertainty about $R$ or G). It is difficult to say a priori whether such a shift in the distribution of risk elements over the life cycle is favorable or not. Presumably this depends not only on the assumed utility function, but also on the properties of the stochastic processes underlying the shocks. Lindbeck and Person (2003).

According to the above we can answer the question "Is pension system important" - yes. It is the most important mechanism of stable social and economic situation in the country for the next reasons: payments in pension system directly connected with level of inflation, growth rate of wage, market rate and government expenditures, for all this indicators state could influence, so any problem in one of them reflects on the pension system and at last on social stability. The second reason, as said above that pension system is a some kind of "asset" which can be expressed as risk/return, in this case state should decide how to share, diversify or grade it, between one or several generations, how to improve not only pensioners' level of life but don't hurt future generations.

We took a view on the importance of pension system but we have another question "Should government provide it, or send it into "free swimming" in the sea of financial market?"

\section{IS PENSION PROVISION A STATE RESPONSIBILITY?}

As Suden (2004), Lindbeck and Person (2003) mentioned that today there is a strong trend for individualization of pension system through the individual accounts, different investment programs etc. In 2003 journal The Economist published a picture of state pensions in Europe which called "The crumbling pillars of old age" this picture shows that first and second pillars non-stable and only the third pillar respectively individual is stable, but in a five years we got financial crisis of 2008-2009 years. Because of that only in USA pension funds lost 200 billion dollars only from credit crisis and got great lost from fall of prices on share market. In this case, who should compensated lost for pensioners especially if person would went on retirement in near future? Even for this purpose, countries should have diversified pension system and give guarantees to people to help in the case of crisis.

As we said above there are three systems and many different models, so let us look at the most interesting.

Modigliani and Ceprini (2000) suggested the model for risk solving problem, according to author's opinion this model is the most fair. The main idea that this model is partly funded, actuarially fair, that is mean that marginal return on contributions is equal to market interest rate, and with only one fund with wide investing portfolio (securities, stock-market index, bonds etc.). Inasmuch as there is only one fund the risk of many different funds, with different returns is avoided - at the cost of abolishing portfolio choice according to individual preferences. Intergenerational risk is excluded by the guaranteed real rate of return, for the Modiliani and Ceprini suggestion it is five percent per year. The annuitization risk of retirees (indeed, intercohort risk) is thereby also removed. The rate of return is achieved through a swap between the fund and the Treasury; in exchange for the return derived from the fund's portfolio, the Treasury pays a fixed real return. 
This type of model used by the Republic of Kazakhstan. Unified National Pension Fund (Figure $1)$.

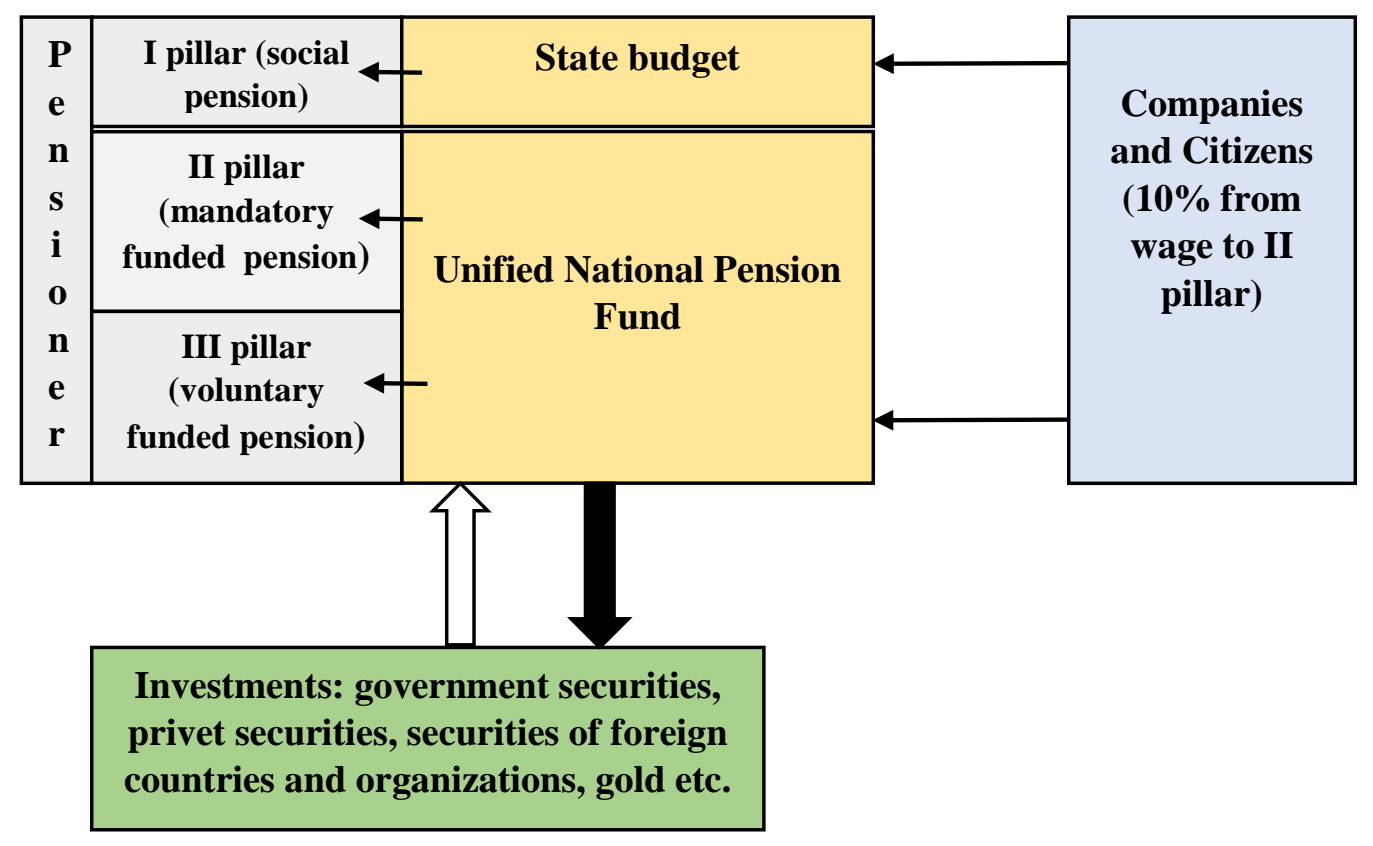

Figure 1. Model of Kazakhstan pension system. Source: Author. Based on [17].

As we see, the role of single fund is performed by the Unified national pension fund, in this model three pillars belong to state. State guarantee security and return of money. State budget pay social pension for every one, and UNPF accumulated part. The second pillar is mandatory and funded, the third pillar is voluntary and funded too, so this model looks like Modiliani and Ceprini's. If we look at the structure of investment we can see that around 50\% invested into government securities, $28 \%$ into domestic commercial companies, and $22 \%$ invested into other actives like foreign countries securities, gold and other Shayakhmetova and Elshibekova (2014). This model except removing mentioned risks also gives to economy cheap and long money for developing, social stability and remove the problem of choosing fund, plus additional taxes to the budget because, citizens should pay income tax from pension.

Another model used by Slovak Republic. This type of model belong to classical three-pillar doctrine with some specific. The first pillar is PAYG with notional accounts, the second pillar is mandatory but person can choose the fund, if he would like to have higher rate of return then he can choose so-called non-guarantee fund, this funds invest into shares, indexes, bonds, commodities and so on, also depositor can lose all money during the financial crisis. In this fund marginal interest rate equal to market interest rate so it's actuarially fair Škrovánková and Simonka (2015). At the same time person can choose guarantee fund, in this case depositor protected by the law from losing money also he has guarantee interest rate level. And finally, the third pillar is voluntary and non-guarantee fund. Person can open additional pension account and choose a big varies of investment programs (Figure 2). 


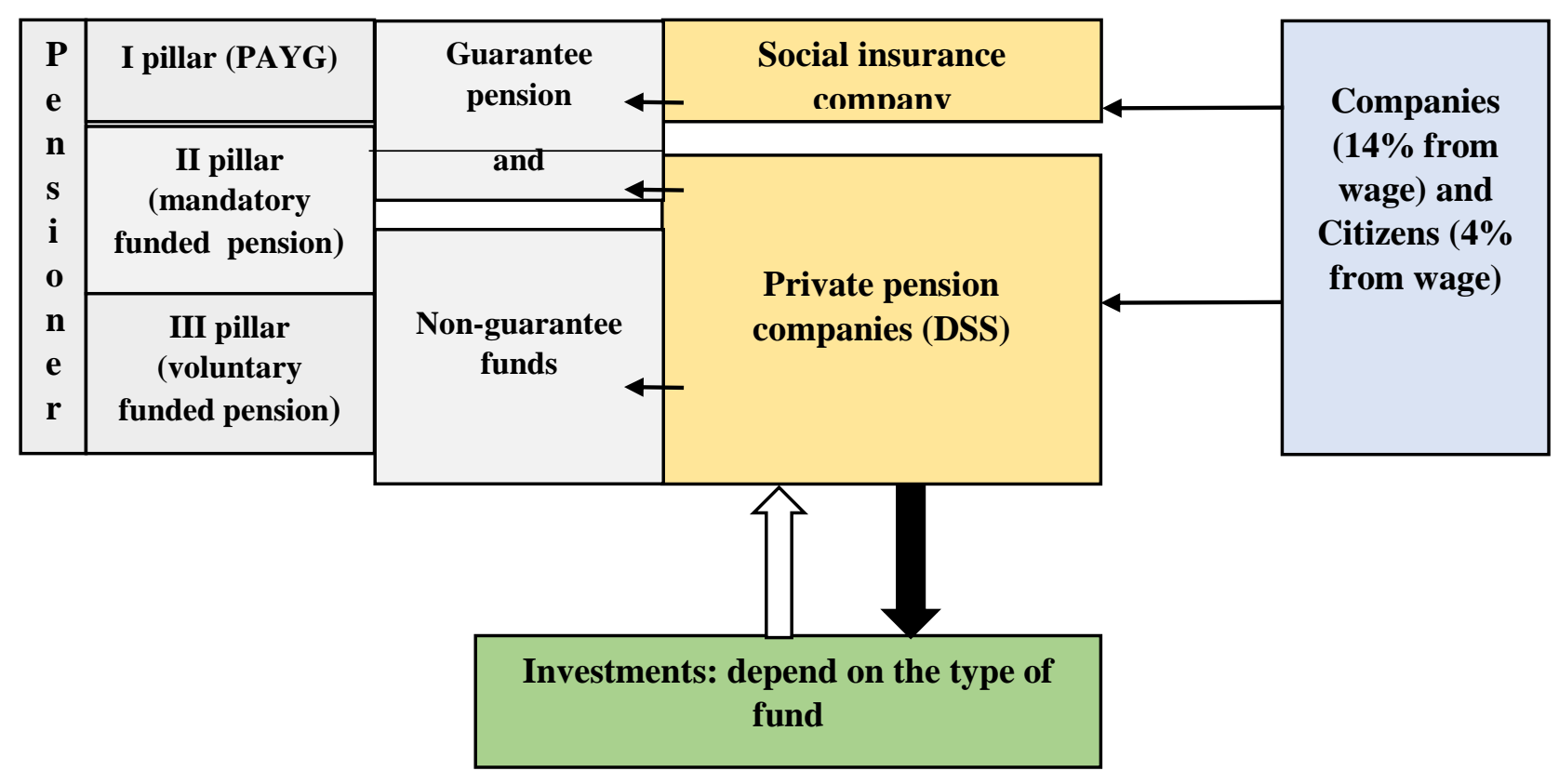

Figure 2. Model of Slovak pension system. Source: Author. Based on $[15,18]$.

This type of model have as intragenerational risks and intergenerational risks, but at the same time much smaller political risk as Kazakhstan's model has.

Both discussed models is quit young, because reforms started in $1990^{\text {th }}$ and new system toughed only one generation, but more interesting the swedish pension system which was formed in 1913 and has been improving until the $1990^{\text {th }}$. The Sweden pension system consist of three „pillars“ in reality it's pillars inside the pillars. In authors oppinion this system could formed only in scandinavic country in the result of long negotiating process between different parties, trade unions and labor unions Kangas, Lundberg and Ploug (2010). The first pillar is the most ineresting it divides on three parts: the minimum guarantee pension, the NDC component and premium pension.

The minimum guarantee pension is a basic protection for everyone and that pension indexed to prices, but in case of Sweden, the role of the it decrease in times of economic growth in contrast to many other countries where basic pension is very small in all periods of economic development. There are some discussions that it disregards income from the occupational pension and low-paid workers becomes disincentive to work around the retirement. Should to add that this part financed from taxes to budget.

Novation of new pension system of Sweden is non-financial defined contribution (NDC) this the main part of pension. This notional component paid by employer and employee and finance current pensioners. The rate of return in the NDC plan is determined by the per capita wage growth. The NDC was designed to bring stability into the pension system. There are several mechanisms for that. The first one links with life expectancy through dividing the person's balance of notional account by an annuity divisor. If life expectancy continues to increase, 
future cohorts will receive less monthly pension, because earned rights will distributed across more years. The second mechanism is automatic stabilizer that abandons indexation when financial stability of the system under threat. It activates when ratio of the system's assets to its liabilities falls below a certain threshold. Because of automatic work the system doesn't need political intervention, which minimizes the risk of political manipulations.

Finally, the third part of the first pillar is premium pension. It is a fully funded mandatory part formed from $2.5 \%$ from earnings on individual accounts. The accumulated money can be invested in five funds or choose default fund suggested by government. The role of administrator performs clearinghouse. The clearinghouse model was chosen to keep administrative costs down by drawing on economies of scale in administration Suden (2004). Main aims of premium pension part are increase overall savings, the policy-makers wanted to allow participants to take account of the higher return in the capital markets as well as to tailor part of their pension to their risk preferences and avoiding instability in other parts of pension system, as an individual benefit's are directly financed by own accumulated contributions. The second pillar is occupational pensions. In the past, these pensions were DB, but now they are DC or mixed. This type of pension financed by employer according to agreements with labor union. Occupational pension linked and depend on the level of wage and typically rises with income. Occupational pension increase if the rate of return in funded part exceeds the rate of return in the NDC. And finally third pillar is private pension. It is savings in commercial pension funds which limited only by contract conditions between person and fund. Thereby, whole pension consist of next parts: I pillar $\approx 55 \%$, II pillar $\approx 30 \%$ and III pillar $\approx 15 \%$ Hagen (2016).

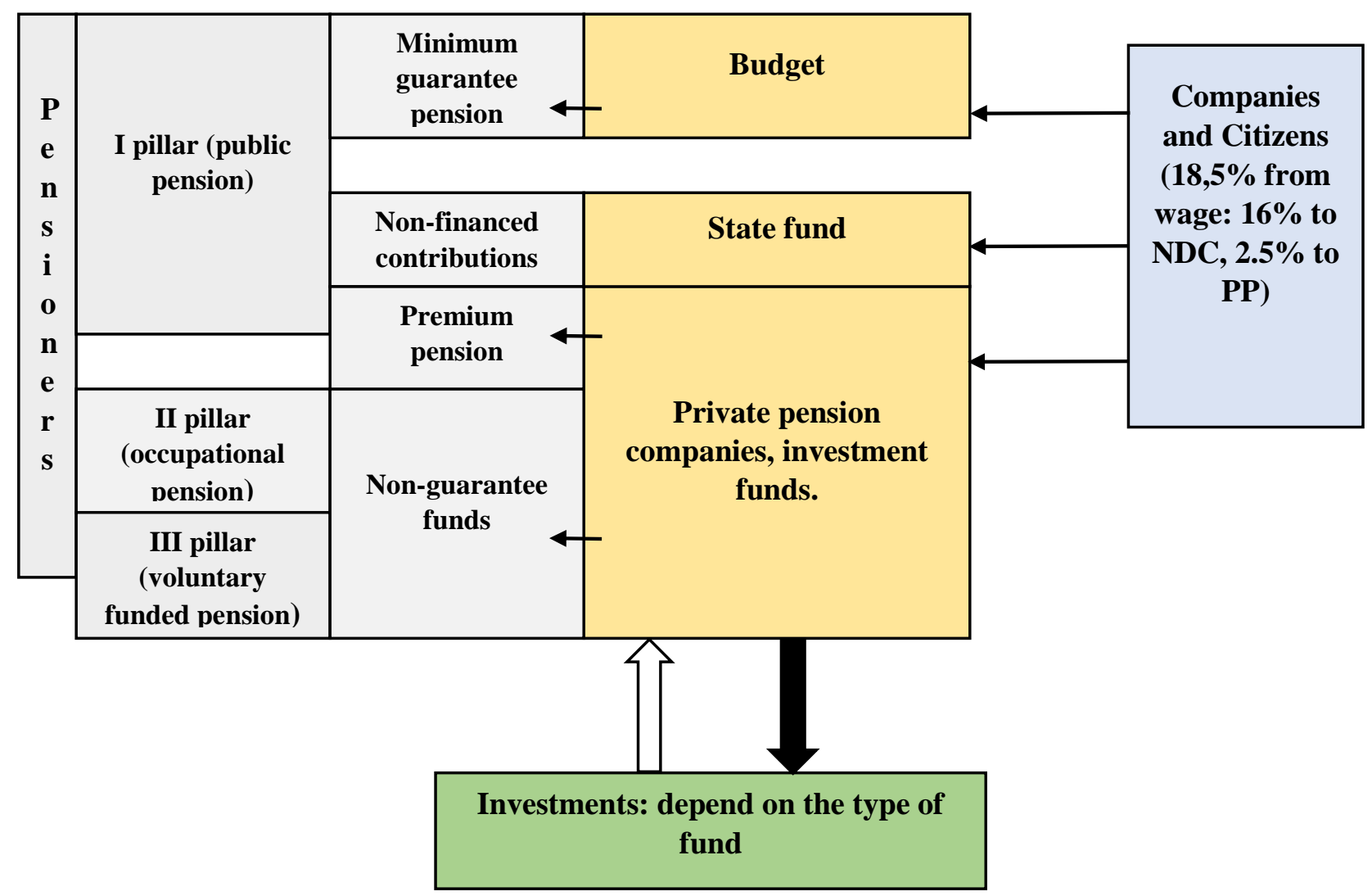

Figure 3. Model of Swedish pension system. Source: Author. Based on [2,4]. 


\section{CONCLUSION}

In the framework of the article we show that pension system is on of the most important component of social politic, it could a political weapon due to the growth of old population, it keeps a lot of risks and in case of mismanagement it could hurt several generations. At the same time pension is a source of great investment resources for economy of the country, it is mechanism of stimulating people to work and economy to growth.

Pension provision is the responsibility of state, as we see state regulate and guarantee pensions through different mechanism: guarantee minimum pensions, guarantee funds, non-financed contributions or to privatization whole system and control all three pillars, in any case more than $50 \%$ of pension fall on state.

If Kazakhstan took onus for pension provision of citizens Slovakia and Sweden do not work in this way.

We should mentioned that Slovak pension system is young and results we can see only in 1015 years, but it will has the same questions about individuals making active investment decisions and heuristic choice. Every pension system should take into account individualism of country if Kazakhstan has big share of state companies in GDP then it preferable to have pension system under the control of state, because state knows better where it could invest, and at the same time can give investment projects to society. If Slovakia attracts international companies than it should be sure that citizens will be protected in the future. Sweden integrate inside their system as strong social defense as profitable additional part. For authors opinion Sweden pension system is unique not only the structure but mostly of the process of reforming and improvement during last century.

As a result policymakers mustn't blindly copy experience of other country, even in a framework of EU where there are common indicators of development region, where exist deeply penetration economics into each other, we still can't fully implement e.g. Swedish model into Slovakia as cann't implement Slovakian model into Kazakhstan. But we should to take best parts of different models and create something new.

\section{Acknowledgements}

For helpful comments and suggestions, I thank professor Erika Pastoraková from Economic university of Bratislava.

\section{Disclosure statement}

No potential conflict of interest was reported by the author.

\section{References}

Cremer H, Pestieau P. (2000). Reforming our pension system: Is it a demographic, financial or political problem? European economic review, 44, 974-983. Amsterdam: Elsevier B.V. https://doi.org/10.1016/S0014-2921(99)00054-9 
Engstrom S., Westerberg A. (2003). Which individuals make active investment decisions in the new Swedish pension system. Journal of Pension Economics and Finance, 2(03). Cambridge: Cambridge University Press.

Fedotov D.Y. (2007). Structure of financial mechanism of Russian pension system. Bulletin of Baikal State University, 1(51), 5-8. Irkutsk: Baikal State University.

Hagen J. (2016) Pension principles in the Swedish pension system. Scandinavian economic history review, 2017, 1-23.

Hedesstrom T.M., Svedsater H. Garling T. (2007). Determinants of the Use of Heuristic Choice Rules in the Swedish Premium Pension Scheme an Internet-Based Survey. Journal of Economic Psychology, 28, 113-126.Amsterdam: Elsevier B.V. https://doi.org/10.1016/j.joep.2006.04.002

Leimgruber M. (2012). The historical roots of a diffusion process The three-pillar doctrine and European pension debates (1972-1994). Global Social Police, 12(1), 24-44. London: SAGE Publications Ltd.

Lindbeck, A., Persson, M. (2003). The gains from pension reform. Journal of Economic Literature, 41(1), 74-112. NY: JSTOR. https://doi.org/10.1257/.41.1.74

Modigliani F., Ceprini M.L. (2002). A Common European Pension System. Capitalization: Privatization or Risk Sharing Through a Common Portfolio? Wirtschaftspolitische Blätter, 49.2002,4, 385-417. Wien: Manz.

Orszag P.R., Stiglitz J.E. (1999). Rethinking Pension Reform: Ten myths about social security system. Working paper.

Rievajova E. 2004. Sociálne zabezpečenie. Bratislava: Ekonóm.

Shayakhmetova K., Elshibekova K. (2015) Modernization of pension system of the Republic of Kazakhstan. Herald of International Institute of Economics and Law, 4(21), 20-26. Kazakhstan: IIEL.

Storesletten, Kjetil, Chris I. Telmer, Amir Yaron. (1999). The Risk-Sharing Implications of Alternative Social Security Arrangements. Carnegie-Rochester Conf Ser Public Policy 50, pp. 213-59. Amsterdam: Elsevier B.V. https://doi.org/10.1016/S0167-2231(99)00028-7

Suden A. (2004). How do individual accounts work in the Swedish pension? Issue in brief, 22, 1-9. Boston: Boston College.

Sinn Hans-Werner. (1997). The Value of Children and Immigrants in a Pay-As-You-Go Pension System: A Proposal for a Partial Transition to a Funded System. NBER Work. Paper 6229. MA: NBER

Škrovánková L., Simonka Z. (2015) Analýza dôchodkového systému v súčasnosti. Economic review, 44, 205-221. Bratislava: EUBA.

UN. (2015). World populating ageing. Report.

Internet resource. Access data [01.03.2017]. https://www.enpf.kz/ru/o-pensionnoysisteme/prosto-o-pensionnoy-sisteme/bazovyy-kurs/index.php?ELEMENT_ID=1907\# 
Internet resource. Access data [01.03.2017]. http://www.socpoist.sk/tabulka-plateniapoistneho-od-1-januara-2017/55433s

\section{Contact information}

Mgr. Raman Herasimau

University of Economics in Bratislava, Faculty of National Economy, Department of Insurance Address: Dolnozemská cesta 1, Bratislava, Slovakia

Telephone number: +421919220932

E-mail: raman.herasimau@euba.sk

ORCID: 0000-0001-7698-5844

DOI ID: https://www.doi.org/10.7441/dokbat.2018.11 


\title{
CURRENT STATE OF SCIENTIFIC KNOWLEDGE IN THE FIELD OF CRM USE IN TOURISM
}

\author{
Monika Hýblová
}

\begin{abstract}
This article focuses on defining and specifying the client in tourism and managing the relationship with the client. Tourism is a specific and expensive service, with its own ways of communicating and accessing the client. In addition to the basic concept, the article also contains an overview of how the Czech legal system defines a client. Furthermore, Customer relationship management and its specifics in the field of tourism are defined in detail. This article provides not only an overview of the customer, but it also shows the summarizes specific rules and communication with the customer. The aim of the thesis is to define and explore the basic concepts of the studied subject and to compare the established foreign experience.
\end{abstract}

Keywords: CRM, tourism, previous research

\section{INTRODUCTION}

Tourism is already a common part of our life. Many of us travel more than once a year not only for holidays, but also for education, sports or entertainment. The development of tourism has also helped the development of transport in recent years. Air transport is no longer just for the richest in the world, so almost anyone can travel around the world. This is the cause of a large number of potential clients, on the other hand, there are also a large number of destinations, cities and tourists who try to get customers at the minimum cost. CRM is one of the possible tools that can be used in tourism. This tool is commonly used in a business environment, its use in this area is relatively new and rare. The goal of CRM is to get a satisfied and loyal customer who will be returning for the services and will not have to invest in high marketing costs.

\section{CLIENT AND CUSTOMER}

\subsection{Origin and meaning of words}

The word "client" originally meant someone "protected by the patricians of Rome". The clients were people who sought material and legal protection provided by the wealthy. As the consequence they became dependent on their protectors, who also benefited from these relationships. Nowadays, the word "client" has wider meaning, no longer is it just a person who has legal protection, but it can also mean a patient, a guest or a business partner. This term can also be used for listeners and viewers at concerts, theatres, radio and TV. However, it inconsidered stylishly inappropriate and insensitive to characterize as clients the people who use a variety of services such as cosmetics, plumbing, hairdressing, dressing, cleaning, etc. In these cases, we should still use the expression - "a customer" (O cizích slovech v českém jazyce).

\subsection{Client from an economic view}

The client in tourism is from the economic point of view on the side of demand. This demand is determined by many factors, notably disposable income, leisure time, price level of services offered, fashion trends, motivation, season, economic and political situation, safety, transport or way of life. These factors represent the components necessary to realize the participation of 
the client in tourism and to full fill the client's expectations. The subject of the offer are tourism objects that are available at a certain place and time to meet the needs of the clients. The offer is influenced by the quality of nature, human resources, legal regulation, transport accessibility and relatively low supply flexibility (Institute for Information System of MENDELU; Palatková, 2013).

\subsection{The specifics of the client in tourism}

The client in tourism is a specific type of a customer, for whom the psychological motive is important. Some people provide tourism services, while others that use these services have their personal feelings affected during their meetings. These feelings will affect the future buying behaviour of the clients. In this field, a single employee can influence whether the customer will use the offered services again. People tend to buy tourism services according to their own ideas. The offered product is intangible, so the seller has to try to induce the appropriate emotions from the client, which will encourage purchase. People providing tourism services have to take care of their clients in a very comprehensive way. A nice holiday can be spoiled for the clients by a bad experience from a nearby restaurant. For this reason, different tourism businesses have to cooperate to provide the clients with comprehensive services at the level the clients expect from them (Institute for Information System of MENDELU; Palatková, 2013).

Tourism is a specific sector based on money coming directly from a customer. Without a client there is no income for the tourism service providers. Perfect customer service is required in every respect, whether in restaurants, hotels, airports, etc. There is a strong link between the client and the company. If a customer is satisfied with a travel agency, airline or hotel network, they will often use this proven company again on the next trip. In addition, pleased clients very often spread word of their good experience, as they share their satisfaction with the service with their families and friends. Moreover, the internet and social networks are nowadays a common place to share the experiences, whether positive or negative. A bad client experience can simply ruin the service providers reputation, which is nowadays increasingly important as there is often a large amount of competition in this field. The modern customer uses all available information and demands certain services in a given quality for the money. Satisfied and faithful customers tend to use the given service again and sharing their positive experience to other people promotes word-of-mouth business. Apart from a good reputation a satisfying and strong customer support is also necessary. By creating a base of long-term customers, the service providers can reduce the cost of finding new clients. Excellent customer service can turn a client into an ambassador for the business. The customers will regularly buy the product or service and moreover they will provide valuable feedback that can help bring new clients and therefore produce increased revenue for the supplier even during an economically downturn (Institute for Information System of MENDELU).

\subsection{Customer definition by the law}

According to the Czech law Act No. 159/1999 Coll., On Certain Terms of Business in the Field of Tourism: "Customer is the person who concludes a travel contract with the travel agency or the person in whose favor this contract was concluded or the person who the trip was transferred to under the conditions laid down by a special legal regulation" (Zákon č. 159/1999 Sb.).

\subsection{Customer protection in the Czech Republic}

The client is also protected by other entities apart from the above-mentioned law. Frequent inspections of travel offices and agencies are carried out in the Czech Republic by the Association of Travel Agencies and the Czech Trade Inspection Authority. Besides, the Association of Travel Agencies also helps its members, for example in the legal conditions. In 
2015, the Czech Trade Inspection Authority carried out a total of 310 inspections, out of which 200 were based on consumer's requests. That means the inspections were carried out only on a small sample of travel offices or agencies as there are about 8,500 of them in the Czech Republic. These controls revealed that $30 \%$ of the inspected entities committed mistakes regardless of the mistakes severity level. According to their statements, they often had only minor inaccuracies (ACK ČR a ČOI přispívají ke zvýšení ochrany klientů cestovních kanceláŕí).

\section{CRM}

CRM is one of the direct marketing tools, which has the advantage of direct targeting, flexibility, its low time consuming, and its biggest disadvantage is the recipient's aversion to unsolicited offers. The development of direct marketing, according to Palatková, together with IT development, is one of the biggest steps to create CRM. The whole conception is based on relational marketing, which is not a new strategy at all - its biggest innovation is the change with client relationship (Adaptic, s.r.o.; Ř́zení vztahu se zákazníky CRM).

The quality or level of customer relationship then determines to what extent a company is able to meet the requirements that the customer awaits. Each of these customers expects another attribute of value, so it is necessary to differentiate customers according to the values they demand. The market is more focused on the synergy between the consumer and the company than in the past. The role of the consumer and the business converges as the consumers are both sources of information and profits; and more and more companies are aware of this (Lehtinen, 2007; Mlejnková, 2011).

Customer relationship management (CRM) comprises of the communication, customer coordination, reconciliation and management processes. Its main goal is to acquire new customers, satisfy their needs and establish long-term relationships with them (Adaptic, s.r.o.).

Customer relationship management and its building is a key aspect to all businesses and organizations that are customer focused. However, the basic principles of CRM are common to all sectors. The main goal is to create loyal and satisfied customers and build a long-term and full-value relationship with them. The whole cycle of acquiring new customers is covered by following list:

- $\quad$ At first, the customer does not know the company and vice versa.

- The customer has heard about the brand, he perceives it, but has not bought anything from the company yet.

- The company addresses a potential customer.

- $\quad$ After the first purchase, he finally becomes a customer.

- The customer purchases repeatedly and becomes loyal, this is the desired goal of a CRM.

- Without appropriate customer care, the relationship between the customer and the company starts to decline.

The customers are a key aspect of existence for each business as they provide income for companies and services. A satisfied customer has no reason to exchange his service provider for another competitor, but it is important to communicate with the customer and take care of him. For companies, the most difficult task is to acquire a new customer and then to retain him. A satisfied customer brings profit to the company and reduces its marketing costs (Customer Service in Tourism Industry; Lehtinen, 2007; What is CRM?). 


\subsection{The pitfalls of CRM}

The whole CRM conception has evolved into a very significant topic since its origin in 1990s. A key factor of the CRM development consists primarily in communication and information technologies. However, there is often a problem with the realization of CRM, because it does not bring significant positive effect in the early years after its implementation. The survey shows that only $28 \%$ of companies are satisfied and have gained a considerable advantage for their investments. The breakthrough occurs roughly two years after implementing the system into a companies processes, when the profit rises significantly and the costs remain relatively low (Řízení vztahu se zákazníky CRM; Žebrák, 2009).

Since its origin, there was a great progress not only in the CRM itself as part of the management process but also in the necessary information technologies. Because of this progress and gained valuable experience the CRM has obtained a considerable support also from the company's governing bodies (Řízení vztahu se zákazníky CRM; What is CRM?).

\subsection{Loyal customer}

"We can broadly define loyalty as the customer's positive attitude and loyalty to his retailer, resulting in repeated buying behavior." (Loajalita - co si pod ní přesně představit?, 2003)

A loyal customer is the goal of successful business. On average, the company costs six times more to get a new customer than to maintain the existing one. In addition, customer loyalty is considered to be ten times, more than one purchase. (Atashfaraz, M., \& Abadi, M. H., 2016)

The probability of selling to an existing customer is approximately 60-70 percent, while the probability of selling to a new customer is only about 5-20 percent. However, the reality remains that most companies still invest more in acquiring new customers than in keeping existing ones. (Pilík, M., Piska, J., \& Sasínková, M., 2011)

Many companies are still unaware that customer loyalty is becoming an economic necessity.

A loyal customer has a shopping behavior defined as a non-commercial purchase. It has a specific availability for what to buy and who to buy from. The word loyalty also emphasizes the condition of a certain duration over time and requires that the purchase act be played at least twice. Loyalty also means that the customer is partially immune to the competition, as it is also emotionally involved. (Pilík, M., Piska, J., \& Sasínková, M., 2011)

Based on the questionnaire survey, the relationship between satisfaction and loyal customer was established. This figure describes the dependency found. (Pilík, M., Piska, J., \& Sasínková, M., 2011)

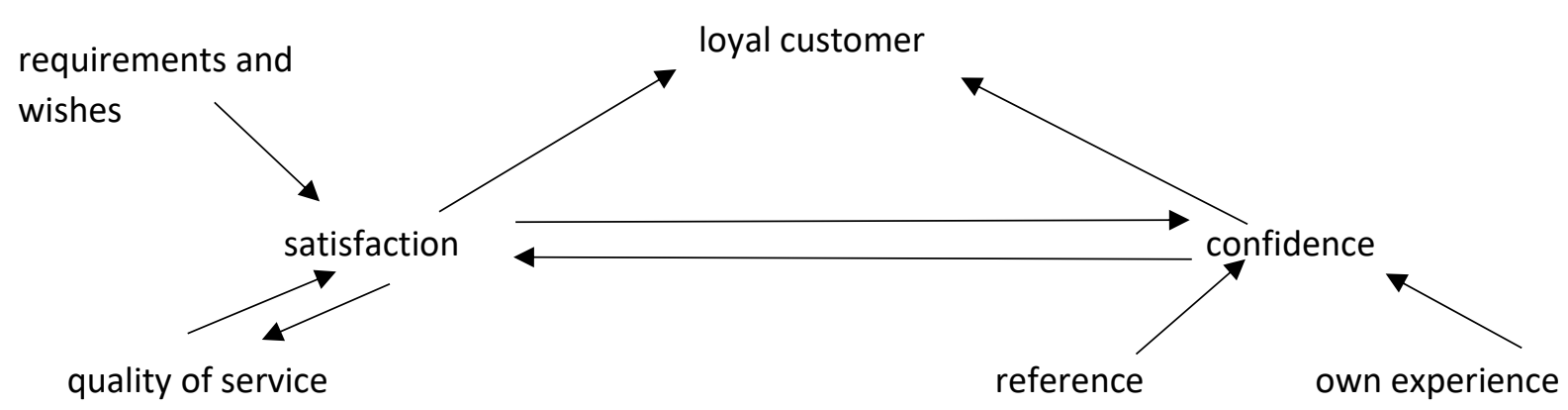

Figure 11 Relationship with loyal customer (Pilík, M., Piska, J., \& Sasínková, M.) 


\section{CRM IN TOURISM}

CRM is a marketing tool suitable for many industries and has also begun to be used in some areas of tourism. This sector is very specific by its different approach to the customer as well as by its comprehensive service. A research has also been conducted in this area and will be described in the following section (Importance of Customer Service in Hospitality \& Tourism).

\subsection{CRM research in tourism area}

Pulevska sees great potential for CRM in tourism. As the biggest problem to CRM usage in tourism, she especially consideres the financial difficulty, where the implementation is relatively costly while the service margins are rather low. Another problem can be found by the cultural organizations that are reluctant to change their way of service. The complexity of the service and its considerable fashionability is also problematic. In addition, according to KPMG's research, it is important to understand the CRM implementation in detail to make it more sensitive to price competitiveness and to prioritize customer retention (Customer Service in Tourism Industry; Pulevska-Ivanovska, 2008).

For these reasons, a large part of tourism organizations are cautious about adopting this conception. Yet, some organizations are willing to accept and expand e-business. They perceive that customers are increasingly using the Internet and their company could become the leader in the e-world (Customer Service in Tourism Industry; Pulevska-Ivanovska, 2008).

The companies in tourism are also discouraged from implementing the CRM because they do not expect, it would have such a powerful influence on the Internet. According to their experience, the customers are often choosing the travel service over the Internet, but then they also prefer individual contact and personally visit a branch. The customer is often overwhelmed by the information that are in many cases irrelevant to him (Customer Service in Tourism Industry; Pulevska-Ivanovska, 2008).

Nevertheless, a group of customers who are familiar with the Internet and know how to use it in their advantage are finally starting to appear. They can better find relevant information or compare service prices. Especially for these customers, both airlines and travel agents create specific offers. E-business is a very important part of modern companies, that fight for every customer, or even for every click on the Internet. These companies are trying to build a loyal and mainly satisfied customer base (Customer Service in Tourism Industry; PulevskaIvanovska, 2008).

In general, we can describe the individual steps of developing this database in the following way. The customer data need to be stored in a way that the special software can then easily process them. The customer's preferences, such as climate, price, or desired season can be easily obtained from the database. There can be promoted various actions such as group discounts or joint offers. This allows the company to offer the best deal for the customer (Customer Service in Tourism Industry; Pulevska-Ivanovska, 2008).

This is not the only benefit of the CRM. With the introduction of this system, it is easier to share printed materials in all languages, check sales agents, generate analytical and statistical reports, check visa applications or count costs (Customer Service in Tourism Industry; Pulevska-Ivanovska, 2008).

\subsection{Macedonian experience}

A very interesting progress in tourism e-marketing has been made by the Republic of Macedonia. For such a small country it was possible to gather all important information on a single web site that provides comprehensive information for tourists. This site has gained 
considerable popularity and high traffic in a relatively short period of time. The Tourist portal of the Republic of Macedonia has gathered all the information not only about hotels or resturants, but also about all cultural events and monuments that you can visit there and thus the web page soon became very popular. This considerable success has been achieved also through the implementation of CRM (Pulevska-Ivanovska, 2008).

\subsection{Thailand research}

One of the CRM tourism researches was focused on the area of Thailand and e-CRM. The survey used a questionnaire survey, with almost 500 respondents from hospitality and tourism. The survey was conducted in Udon Thani, Nongkhai and Loei, where respondents assigned their responses in the five-step Likert scale (Mekkamol, P., Piewdang, S., \& Untachai, S. 2013).

Three statistical hypotheses were tested in this paper. From the methodological point of view, a questionnaire survey was used, and it was attended by bachelor students at Udon Thani Rajabhat University. The questionnaire was tested by the tourism experts to avoid possible misunderstandings. Besides, also the reliability tests were performed and led to a satisfactory result. The study also included Gerbing and Anderson's findings for determining the convergent and discriminatory validity of e-CRM (Mekkamol, P., Piewdang, S., \& Untachai, S. 2013).

Prior to evaluating the questionnaires, erroneous and incomplete ones were excluded from the investigation. The research has shown that customers are aware of the positive relationship between shopping convenience and e-CRM interactivity for community tourism in Upper North-East Thailand. This was confirmed also by a private business research that was conducted earlier. Another hypothesis was to confirm the positive relationship seen by the inhabitants of the given area between the website character and the website contact interactivity dimensions of the modeling e-CRM. This fact was also supported by other research conducted in this field. Even the last confirmed hypothesis is in line with a further research, which has shown that there is a positive relationship between the website contact interactivity and care and service dimensions of the modeling e-CRM (Mekkamol, P., Piewdang, S., \& Untachai, S. 2013).

\subsection{Rural Tourism in Catalonia and CRM}

The rural tourism has recently gained considerable popularity, when many people are living in big cities and do not have a link to the countryside any longer. Moreover, this type of tourism is considered to be an encouragement for rural areas, that often suffer from poor harvest or natural disasters, which make the living in the given area difficult for the people. This activity has helped to diversify the incomes in rural areas and spread the idea of sustainable development. The rural tourism has significantly boomed over the last decade. It is especially popular with families with more children coming from the urban areas. This type of tourism helps to increase employment, to promote and restore traditions and culture, to protect the environment and to develop the local economy (Prat, J. M. 2012).

The marketing in rural tourism is very difficult. The main goal is to make profit but it is also important to preserve the original landscape. Therefore, it is necessary to focus on understanding the customer and his needs (Prat, J. M. 2012).

The survey authors conducted a questionnaire survey that was divided into five main parts in which the five-point Likert scale was used. The questionnaire was divided into the following sections: ICT local development, Education level, CRM positive and negative impacts, Rural tourism local development, Tourist resources, CRM and ICT use. The respondents answered whether they strongly disagree, disagree, have neutral opinion, agree or strongly agree with each statement. The main objective of the research was to get information on the CRM impact 
on rural tourism. For this reason, not only quantitative research has been used, but also a qualitative semi-structured interviews have been carried out (Prat, J. M. 2012).

The spanish rural tourism has grown in importance later than it happened in the rest of Europe. Subsequently, this type of tourism was also supported by the legislation, as it was considerable popular only in the coastal areas because of the sun and beach holidays. The main destination of this new type of tourism happened to be Catalonia. Nowadays, the agrotourism in Catalonia accounts for about $12 \%$ of the rural tourism in the whole Spain (Prat, J. M. 2012).

In the survey, 98 potential interviewees had been approached, of which 76 eventually answered the questions. The data were tested in two waves. The first test examined the reliability of the data and its validity and in the second part the hypotheses were tested and the factor analysis was calculated (Prat, J. M. 2012).

The results show that CRM can be an appropriate support for rural tourism. The advanced use of information technology helps not only with the income growth in this area, but also with the education spread in the field of sustainable tourism. The main requirement for the efficiency improvement is to have a good knowledge of ICT backgrounds. It has also been shown that the costs and revenues from the CRM use have to be carefully determined in order to thoroughly consider its usage appropriation (Prat, J. M. 2012).

\subsection{Summary of research}

Table 9 Comparison of research

\begin{tabular}{|c|c|c|c|c|}
\hline Research & Advantages & Disadvantages & Region & Methods \\
\hline $\begin{array}{l}\text { E-CRM IN THE } \\
\text { TOURISM } \\
\text { SECTOR }\end{array}$ & $\begin{array}{l}\text { The potential of } \\
\text { the Internet } \\
\text { Easy access to } \\
\text { travel } \\
\begin{array}{l}\text { Custom offer } \\
\text { selection }\end{array}\end{array}$ & $\begin{array}{l}\text { High price } \\
\text { Fear of using the } \\
\text { Internet } \\
\text { Habit to shop at a } \\
\text { branch }\end{array}$ & Macedonia & $\begin{array}{l}\text { Description of } \\
\text { CRM } \\
\text { implementation } \\
\text { in Macedonia. } \\
\text { Taking } \\
\text { advantage of a } \\
\text { small country } \\
\text { where it is } \\
\text { possible to merge } \\
\text { information on } \\
\text { all attractions } \\
\text { and tourism } \\
\text { facilities on one } \\
\text { page }\end{array}$ \\
\hline $\begin{array}{l}\text { Modeling e- } \\
\text { CRM for } \\
\text { Community } \\
\text { Tourism } \\
\text { Upper in } \\
\text { Northeastern } \\
\text { Thailand }\end{array}$ & $\begin{array}{l}\text { Customers and } \\
\text { entrepreneurs are } \\
\text { aware of the } \\
\text { benefits of CRM } \\
\text { Interactive offer } \\
\text { option }\end{array}$ & $\begin{array}{l}\text { Difficult CRM } \\
\text { implementation }\end{array}$ & Thailand & $\begin{array}{l}\text { Questionnaire, } \\
\text { evaluation of } \\
\text { tested hypotheses }\end{array}$ \\
\hline
\end{tabular}




\begin{tabular}{|c|c|c|c|c|}
\hline $\begin{array}{l}\text { A Structural } \\
\text { Equation } \\
\text { Modelling for } \\
\text { CRM } \\
\text { Development in } \\
\text { Rural Tourism in } \\
\text { the Catalan } \\
\text { Pyrenees }\end{array}$ & $\begin{array}{l}\text { The introduction } \\
\text { of CRM has } \\
\text { brought revenue } \\
\text { growth } \\
\text { Increasing } \\
\text { communication } \\
\text { efficiency }\end{array}$ & $\begin{array}{lr}\text { An important } \\
\text { knowledge } \\
\text { ICT of } \\
\text { costs r and } \\
\text { revenues from } \\
\text { the CRM use had } \\
\text { to be carefully } \\
\text { determined }\end{array}$ & Catalonia & $\begin{array}{l}\text { Questionnaire } \\
\text { survey }\end{array}$ \\
\hline
\end{tabular}

The table compares research in the area of CRM in tourism. All of these researches see significant potential in CRM, but the funding of deploying this system is a problem. Therefore, it is necessary to plan the costs and revenues well. The same prerequisite is the same experience in different parts of the world. If the financial part is solved, it is a good idea to use the acquired knowledge and implement CRM in tourism and other areas.

\section{CONCLUSION}

The articles mentioned in this paper provide different views of the solved problem and test it in different environments. However, the individual articles state the same opinion about the importance of the CRM in tourism. Everyone consideres the CRM as an interesting and functional tool that is new and still not widely used in tourism. Everybody, however, perceives its high financial requirements, which are demanding for the tourism organizations.

The CRM is a modern way of communication. It is focused on the most important person throughout the market - on the client. Principally, the customer will be pleased after the flawless satisfaction of his needs and with the opportunity to establish a long-lasting and faithful relationship with the provider. The CRM principles are used especially in highly saturated markets where there is a big fight for each client. Gradually increasing market saturation and high competition is coming to more and more markets and the customer is getting himself into the viewfinder of different service providers. Nowadays, these strategies are also used in tourism, which is a very specific sector. The research and practice have shown that CRM can also be suitable for tourism, but it is not widely used yet. Especially the acquisition costs can be problematic for the investors, as it often means a long-term financial commitment. However, the CRM effect is certainly not negligible. The possible solution is in connection of all providers and their services with the goal to create a perfect destination and these providers then can uniformly act for the whole area and not just individually as private subjects. The cost of acquiring new technology would be reduced, but there would also emerge a problem in managing more entities with many different interests.

\section{Acknowledgment}

The author would like to thank the Internal Grant Agency of FaME for providing financial support to carry out this research. Funding was extended through: TBU No.IGA/FaME/2018/002 - Using of Marketing 4.0 principles for customer relationship management in the Czech Republic. 


\section{References}

ACK ČR a ČOI přispívají ke zvýšení ochrany klientů cestovních kanceláŕí. (n.d.). Retrieved November 2, 2017, from http://www.ttg.cz/ack-cr-a-coi-prispivaji-ke-zvyseni-ochranyklientu-cestovnich-kancelari/

Adaptic, s.r.o. - Internetová řešení podle vašich potřeb; www.adaptic.cz. (n.d.). CRM. Retrieved December 3, 2017, from http://www.adaptic.cz/znalosti/slovnicek/crm/

Atashfaraz, M., \& Abadi, M. H. (2016). Impact of E-Service Innovation on Brand Equality and Customer Loyality in Samsung International Corporation. Procedia Economics and Finance, 36, 327-335. doi:10.1016/s2212-5671(16)30044-2

Customer Service in Tourism Industry. (2017, March 24). Retrieved November 28, 2017, from https://www.vivocha.com/customer-service-tourism-industry/

Importance of Customer Service in Hospitality \& Tourism. (n.d.). Retrieved November 20, 2017, from http://smallbusiness.chron.com/importance-customer-service-hospitalitytourism-81068.html

Institute for Information System of MENDELU. (n.d.). Retrieved November 15, 2017, from https://is.mendelu.cz/eknihovna/opory/index.pl?cast=2770

Lehtinen, J. (2007). Aktivní CRM: řízení vztahů se zákazníky. Praha: Grada.

Loajalita - co si pod ní přesně představit? (n.d.). Retrieved from http://www.marketingovenoviny.cz/marketing_1246/

Loštáková, H. (2009). Diferencované řízení vztahů se zákazníky. Praha: Grada.

Mekkamol, P., Piewdang, S., \& Untachai, S. (2013). Modeling e-CRM for Community Tourism in Upper Northeastern Thailand. Procedia - Social and Behavioral Sciences, 88, 108117. doi:10.1016/j.sbspro.2013.08.486

Mlejnková, L. (2011). SPOTŘEBNÍ CHOVÁNÍ V LÁZEŇSKÉM CESTOVNÍM RUCHU ČESKÉ REPUBLIKY. In Acta oeconomica Pragensia: Vědecký sborník Vysoké školy ekonomické v Praze (2011 ed., Vol. 1). Praha

O cizích slovech $\mathrm{v}$ českém jazyce. (n.d.). Retrieved November 21, 2017, from http://www.rozhlas.cz/plzen/jazykovykoutek/_zprava/97242

Palatková, M. (2013). Management cestovních kanceláŕí a agentur: legislativní úprava činnosti cestovních kancelaří a agentur a ochrana spotřebitele: funkční a procesní management v cestovní kanceláŕí a agentuře: sestavení podnikatelského plánu cestovní kanceláře. Praha: Grada Publishing.

Pilík, M., Piska, J., \& Sasínková, M. (n.d.). SPOKOJENOST, DƯVĚRA A ZÁKAZNICKÁ LOAJALITA V PROSTŘEDÍ E-COMMERCE NA B2C TRZÍCH V ČR (Rep.).

Prat, J. M. (2012). A Structural Equation Modelling for CRM Development in Rural Tourism in the Catalan Pyrenees. AlmaTourism, 6. Retrieved from https://www.researchgate.net/publication/307662140_A_Structural_Equation_Modelli ng_for_Crm_Development_in_Rural_Tourism_in_the_Catalan_Pyrenees.

Pulevska-Ivanovska, L. (2008). E-CRM IN THE TOURISM SECTOR. Journal of tourism studies and research in tourism, 5(5), 14-19.

Řízení vztahu se zákazníky CRM (Customer Relationship Management). (2016, July 21). Retrieved November 27, 2017, from https://managementmania.com/cs/customerrelationship-management 
Vallabh, D., Radder, L., \& Venter, D. (2015). Factors preceding CRM readiness in small- and medium-sized tourism enterprises. Acta Commercii, 15(1). doi:10.4102/ac.v15i1.263

What is CRM? (n.d.). Retrieved November 30, 2017, from https://www.salesforce.com/eu/learning-centre/crm/what-is-crm/

Zákon č. 159/1999 Sb., o některých podmínkách podnikání v oblasti cestovního ruchu. (n.d.). Retrieved November 25, 2017, from http://www.mmr.cz/cs/Regionalni-politika-acestovni-ruch/Cestovni-ruch/Pravo-Legislativa/Prehled-platnych-pravnichpredpisu/Archiv/Zakon-c-159-1999-Sb-o-nekterych-podminkach-podn

Žebrák, M. (2009, February 04). Integrace CRM se systémy třetích stran. Retrieved December 2, 2017, from http://businessworld.cz/crm-lidske-zdroje/Integrace-CRM-se-systemytretich-stran-4214

\section{Contact information}

Monika Hýblová

Tomas Bata University in Zlín, Faculty of Management and Economics

nám. T. G. Masaryka 5555,760 01 Zlín, Czech Republic

Telephone number:777 332119

E-mail: mhyblova@utb.cz

ORCID: 0000-0002-7788-6204

DOI ID: https://www.doi.org/10.7441/dokbat.2018.12 


\title{
RELATIONSHIP BETWEEN REPUTATION AND COMPETITIVENESS
}

\author{
Mária Kozáková
}

\begin{abstract}
Concept of corporate reputation has been known for many years. Positive reputation can bring many positive advantages for company and also countries. Positive reputation of country can attract investors, labor force, opportunities for companies and it can increase competitiveness of the country. The paper examine's how positive country reputation can influence competitiveness of the country. To confirm the relationship between reputation and competitiveness we used statistical methods bivariate correlation and Pearson correlation. The test results confirm relationship between country reputation and competitiveness. The dataset includes the Global Competitiveness Index and reputation score of the most reputable countries and it covers top 53 countries all over the world.
\end{abstract}

Keywords: reputation, country reputation, competitiveness, country image.

\section{INTRODUCTION}

When the company decides to make the leap into other markets, there is a one of the most important key factors - the reputation of the country in which that firm is based. The reputation of a company from a country ends up having a decisive influence on the reputation of that country in general. Country's good reputation may aid the carrying of business activity by domestic entities abroad and contribute to the building of their strong position on the market.

With respect to country reputation, many key questions remain unanswered. Concept of country reputation is connected with causality, liability of foreignness versus country of origin, country reputation dimensions, management of country reputation, industry and other moderating effects and developing versus developed market impacts (Newburry, 2012).

\subsection{Concept of competitiveness}

One of the concept, affects a country's reputation is the state of an economy and competitiveness of the country. Competitiveness is considered to be a natural economic phenomenon and the main source of wealth creation. The term competitiveness is used in a bewildering variety of ways, both in the policy community and in academic research. It has been described by various authors as a theoretical, multidimensional and relative concept associated with the market mechanism. Definitions of the competitiveness the concept may refer to different levels of aggregation: supranational, national, regional, local, industrial, sectoral, as well as to individual companies. Popularity of the concept is derived from the fact that the competitiveness is treated as the mean for time-space comparison, i.e. for external validation of an area, and thus as the mean for achieving and sustaining economic growth, contented living standard and well-being of people (Borozan, 2008). Competitiveness is one of the fundamental criteria for evaluating economic performance, and also reflects the success in the broader comparison. (Nevima, 2012).

Competitiveness from a firm's point of view is defined as its economic strength against its rivals in the global marketplace where products, services, people and innovations move freely despite the geographical boundaries. Competitiveness at the firm level are quality, cost (such as labor costs and cost of capital) and the price levels (Arslan \& Tatlidil, 2012).

Nowadays competitiveness is one of the most monitored characteristic of national economies and is increasingly appearing in the evaluation of their prosperity, welfare and living standards. 
The concept of country's competitiveness is described as a country's ability to generate innovation in order to achieve or maintain an advantage compared to other countries in a number of key industries (Huggins, 2005). According to European Commission competitiveness of a nation is the he ability of an economy to provide its population with high and rising standards of living and high rates of employment on a sustainable basis (2001). The most intuitive definition of competitiveness is a country's share of world markets for its products. This makes competitiveness a zero-sum game, because one country's gain comes at the expense of others (Porter et al., 2008).

The key criterion for the distinction of country's competitiveness from company's competitiveness is a place these entities have in the creation of economic value in society. For a country to be more competitive, the development of countries should be improved at the firm level with the help of firms' increasing performance (Arslan \& Tatlidil, 2012). Economic values are created by companies only, and the country can establish an environment that supports or hinders their activities (Nedić, Lepojević, Despotović, Cvetanović, 2015).

The country competitiveness is measured by World Economic Forum and the results are presented through the The Global Competitiveness Report.

\subsection{Concept of reputation}

The concept of reputation has been known for many years in both academic and business world. It has multidisciplinary character and it has been studied by various disciplines.

Reputation is commonly defined as the overall estimation of an organization by all its stakeholders (Fombrun 1996). Consumers use reputation as a means of evaluating products and the characteristics and abilities of a country's firms (Jones et al., 1997). In situations of high uncertainty when quality is unobservable, the positive impact of reputation increases the probability of purchase and decreases consumer uncertainty. Correspondingly, it is not an individual's attitude (image), but the public esteem in which a social entity — in this case a country - is held. Country reputation is the emergent synthesis of multiple individual attitudes about a country as the result of complex communication processes in modern media societies (Thiessen, Ingenhoff 2011).

Reputation is a cumulative judgement created by various groups of stakeholders. According to Swajcza (2017) reputation of a country as an outcome of perception of various groups of stakeholders is influenced by the following factors:

- direct experiences of stakeholders, their personal contacts with representatives of a given country on different levels: international, interorganisational and interpersonal,

- communication activities and initiatives of representatives of the state: parliaments, governments, organisations, businesses, individual persons

- influence of third parties i.e. opinions, reports, ratings etc. developed by various international bodies, stereotypes i.e. widely held believes reinforced by the media and other opinion shaping centres with respect to particular countries and their residents.

Country reputation refers to perceptions of a country, shared by domestic and international publics, on the basis of personal experience and information received. Images of a country are based on differences between 'personal' to 'public' images, depending on the extent to which images of a country are publicly shared or peculiar to the individual (Kleppe et al., 2002). In regards necessity of management, Passow et al. (2005, p.312) explained why a country needs to manage its reputation:

- a country exists and operates within a competitive set; 
- a country is dependent on resources and supportive behavior;

- a country has to follow a financial logic;

- a country has to appeal to an audience;

- to a great extent, the government's function can be compared with that of the general management of a company;

- a country has a vision and a strategic concept; and

- the significance of social responsibility is even greater for a country than it is for a company.

The state of an economy affects a country's reputation. It contributes greatly to improving or worsening the evaluation of that nation in terms of trust, outlook and the possibilities of recovery - should that economy and itself in a difficult situation. In the same way that a country's reputation affects and is affected by its companies, among other factors. According to Newburry (2012), the relationship between country reputation and corporate reputation is one of the most important contemporary issues among reputation and international business scholars. Company reputations influence country reputations based on the logic that consumer experience with foreign products and their companies is a key source of information regarding the home countries of these companies since they often have little direct exposure to the countries themselves (Kang \& Yang, 2010).

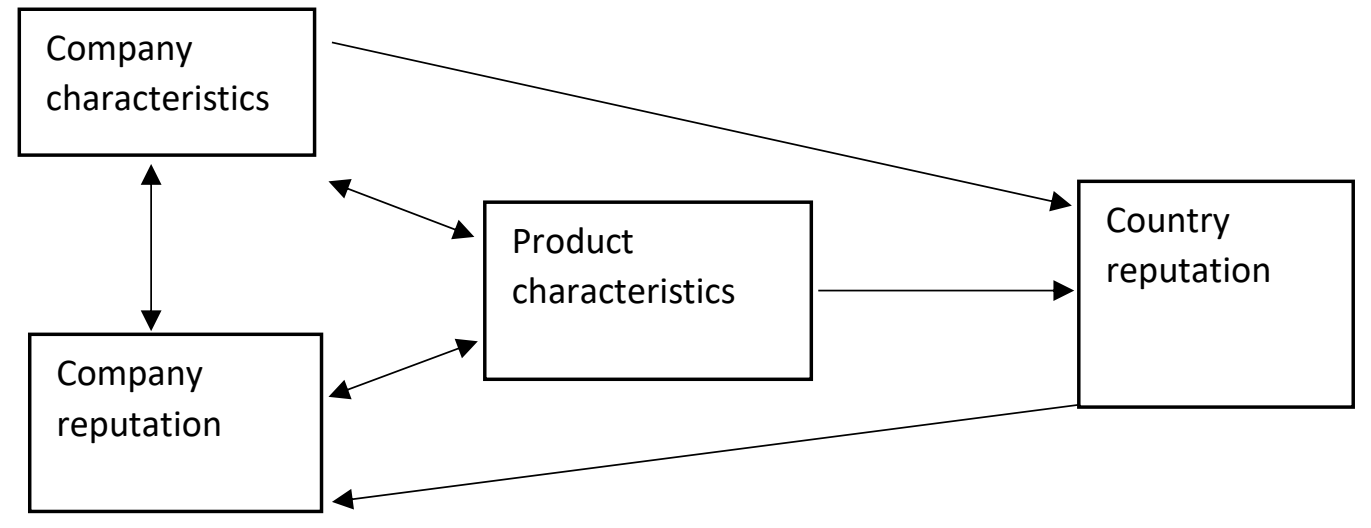

Figure 1 Relationship between country and company reputation. Source: Newsburry (2012)

By combining the two alternative relationships suggested above presents a longitudinal process that may be, in effect, where country characteristics impact company reputations, which in turn feedback on country reputations through their interactions with product quality and as important company characteristic. While company reputations would inherently have a more direct relationship with country reputation dimensions related to the business environment, country characteristics related to the broader country environment could be simultaneously impacting both company characteristics and country reputation (Newburry, 2012).

\section{METHODOLOGY}

The aim of this paper is to analyze relationship between competitiveness and reputation of the countries and if the countries with higher reputation score reach higher Global Competitiveness rankings. The aim is to analyze if the evaluation of the countries from various group stakeholders according to Country RepTrak can influence competitiveness measured by World Economic Forum presented by Global Competitiveness Index. Data was used from the Global 
Competitiveness Report and Country Reptrak of 53 countries. Reputation score is based on stakeholder perceptions. Measurement of reputation is based on levels of trust, esteem, admiration and respect. Country RepTrak ${ }^{\circledR P u l s e}$ is calculated on the basis of 16 attributes within three groups:

- effective government: safe place, ethical country, responsible participant in the global community, progressive social and economic policies, operates efficiently, favourable environment for business, iscepis

- appealing environment: friendly and welcoming, beautiful country, appealing lifestyle, enjoyable country, ichepi

- advanced economy: contributor to global culture, high quality products \& services, welleducated and reliable workforce, well- known brands, values education, technologically

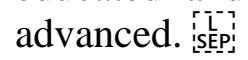

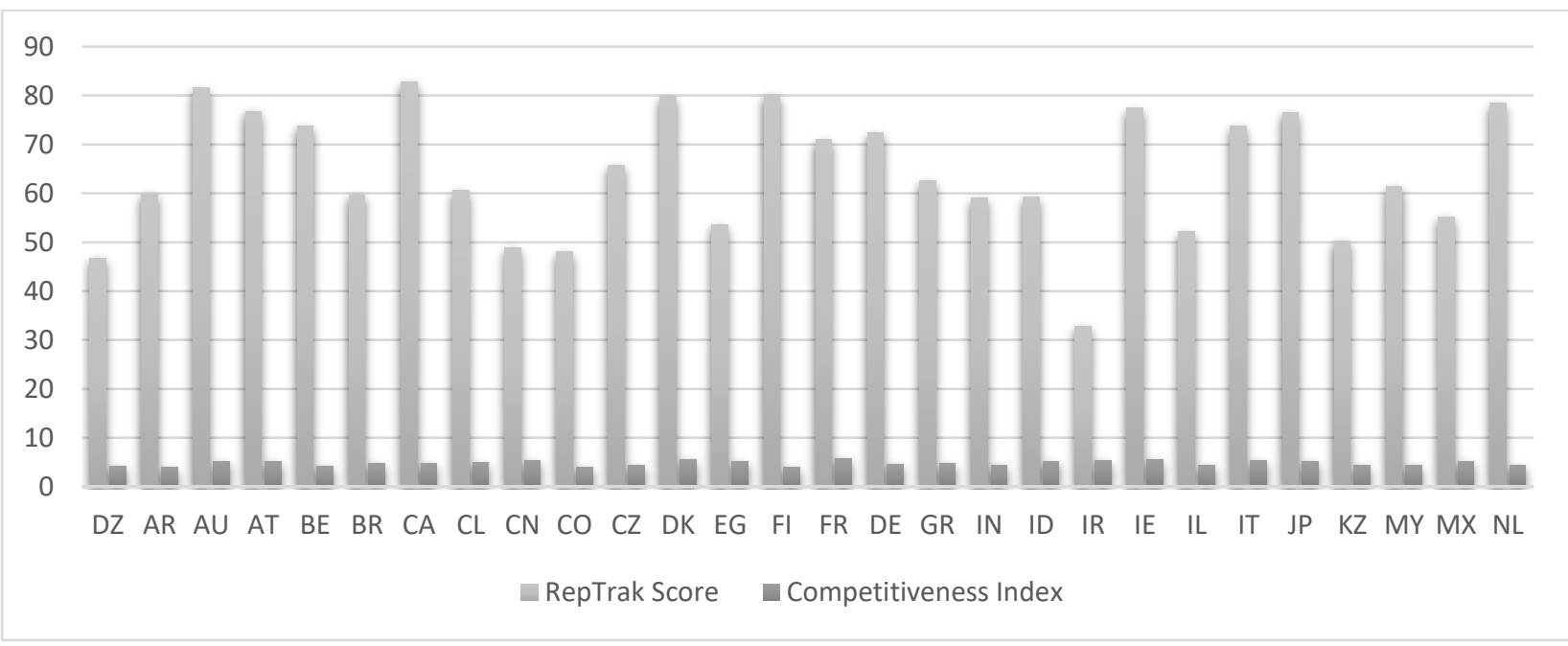

Figure 2 RepTrak Score and Sompetitiveness Index selected countries. Source: own compilation

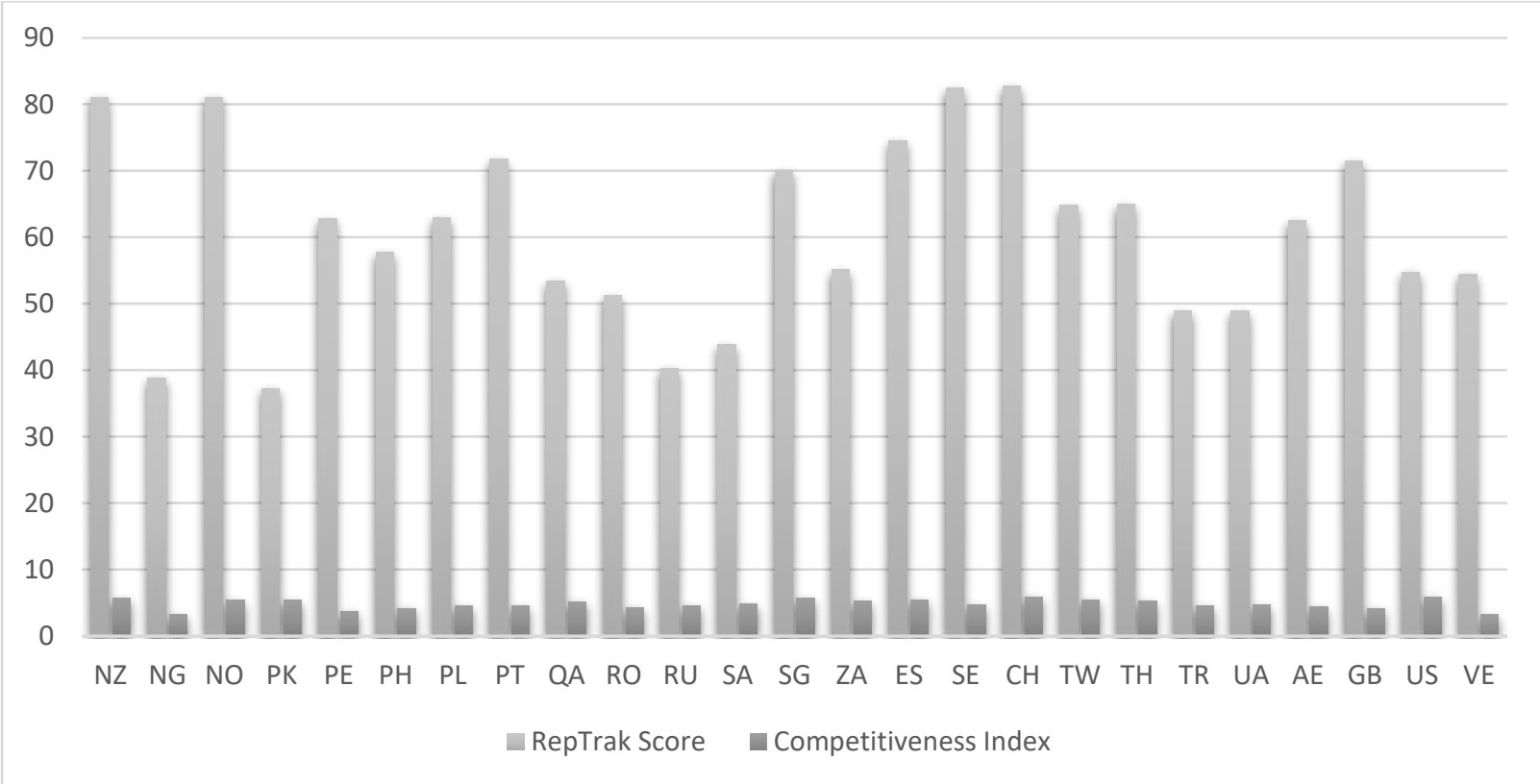

Figure 3 RepTrak Score and Sompetitiveness Index selected countries. Source: own compilation 
Global Competitiveness Report is based on evaluation of 12 indicators divided to the 3 areas: Basic requirements, Efficiency enhancers and Innovation and sophistication factors.

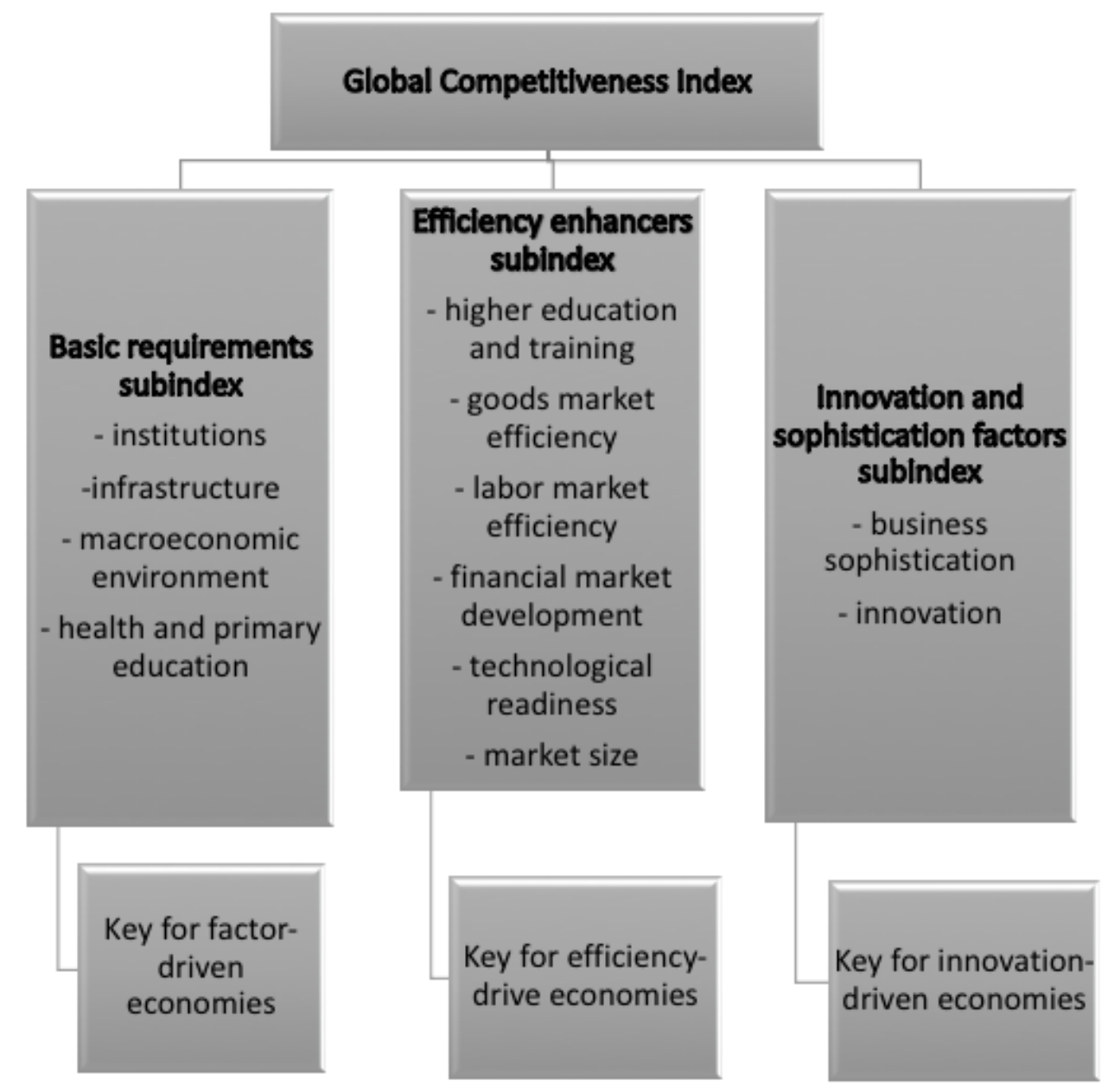

Figure 4 Global Competitiveness Index Source: The Global Competitiveness Report 2017-2018

To confirm this relationship we used statistical method. Firstly, we used descriptive statistics for both variable - reputation and competitiveness. Descriptive statistics include mean (the sum of all values in data set divided by the number of values), standard deviation, minimum, maximum, skewness, kurtosis and variance.

The second step includes correlation analysis. Correlation in statistical terms is a way to assess the degree of relationship or association that is observed between variables.

First, we had to test data distribution through Koglomorov- Smirnov test. The KolmogorovSmirnov test quantifies the differences between the observed and expected distribution by estimating the relative height of the distribution at many places. Kolmogorov-Smirnov test ( $\mathrm{K}-$ $\mathrm{S}$ test or KS test) is a nonparametric test of the equality of continuous, one-dimensional probability distributions.

Depending on the type of data distribution, we used a specific correlation test. The Pearson $r$ is probably the best known and most widely used measure of correlation. The Pearson correlation is designed to describe the degree to which two quantitative variables are linearly related. The value of the Pearson $r$ can vary between zero and 1; values closer to zero represent weaker relationships and values closer to 1 represent stronger relationships. Positive values indicate a direct relationship (e.g., higher values of one variable are associated with higher values of the 
other variable); negative values indicate an inverse relationship (e.g., higher values of one variable are associated with lower values of the other variable).

We will compare 2 variables: reputation and competitiveness score. We assume, that these variables are closely related. It means that, higher values of country reputation are associated with higher values of the competitiveness score. We will set hypotheses:

H1: There is a relationship between variables reputation and competitiveness measured by correlation coefficient.

H0: There is not a relationship between variables reputation and competitiveness measured by correlation coefficient.

\section{RESULTS}

Table 3 Descriptive statistics Source: Own processing

\begin{tabular}{|l|r|r|r|r|r|r|r|r|r|r|r|r|r|}
\hline Variable & $N$ & Mean & $\begin{array}{r}\text { S.E. } \\
\text { Mean }\end{array}$ & $\begin{array}{r}\text { Std } \\
\text { Dev }\end{array}$ & Variance & Kurtosis & $\begin{array}{l}\text { S.E. } \\
\text { Kurt }\end{array}$ & Skewness & $\begin{array}{r}\text { S.E. } \\
\text { Skew }\end{array}$ & Range & Minimum & Maximum & Sum \\
\hline Reputation & 53 & 62,62 & 1,84 & 13,42 & 180,17 &,- 86 &, 64 &,- 18 &, 33 & 50,00 & 32,80 & 82,80 & 3318,60 \\
Competitiveness & 53 & 4,80 &, 09 &, 65 &, 42 &,- 47 &, 64 &,- 34 &, 33 & 2,70 & 3,20 & 5,90 & 254,20 \\
\hline
\end{tabular}

53 countries were analyzed. The mean of reputation score is $\mathrm{M}=62,62$; standard deviation SD $=13,42$. The mean of competitiveness score is $\mathrm{M}=4,80$; standard deviation $\mathrm{SD}=0,65$.
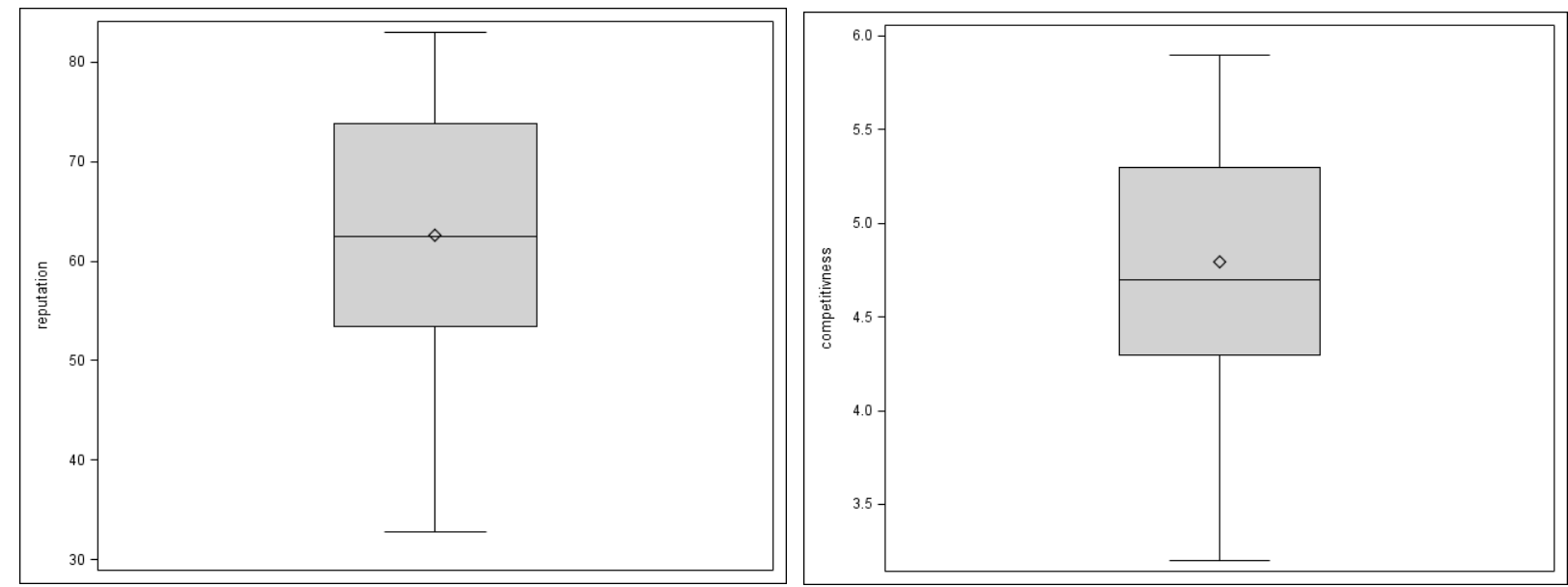

Figure 5 Box plot for variables competitiveness and reputation Source: Own processing

The box plot displayed in Figure 4 represents summary statistics for the analysis variable competitiveness and reputation. The length of the box represents the interquartile range (the distance between the 25th and 75th percentiles). The symbol in the box interior represents the group mean (reputation mean $=62,62$, competitiveness mean $=4,80$ ). The horizontal line in the box interior represents the group median. The vertical lines from the box extend to the group minimum and maximum values.

Skewness is a moment that measures the degree of symmetry of a probability distribution. If skewness is greater than zero, the distribution is skewed to the right, having more observations on the left. Kurtosis measures the thinness of tails or "peakedness" of a probability distribution. 
We had to test data distribution through Koglomorov- Smirnov test. The significance level is $\mathrm{p}$ $=0.36$, which is more than 0.05 and therefore the test is not statistically significant. Therefore, we can say that our data is normally distributed.

Table 4 Koglomorov- Smirnov test Source: Own processing

\begin{tabular}{||ll|rr|}
\hline & & Reputation & Competitiveness \\
\hline \hline N & & 53 & 53 \\
Normal Parameters & Mean & 62,62 & 4,80 \\
& Std. Deviation & 13,42 &, 65 \\
Most Extreme Differences & Absolute &, 09 &, 15 \\
& Positive &, 07 &, 07 \\
& Negative &,- 09 &,- 15 \\
Kolmogorov-Smirnov $Z$ & &, 67 & 1,08 \\
Asymp. Sig. (2-tailed) & &, 756 &, 182 \\
\hline
\end{tabular}

The results of Koglomorov- Smirnov test are displayed also in Figure 5 and Figure 6.

A normal distribution:

- is symmetric

- is fully characterized by the mean and standard deviation

- has mean=median=mode

Normal probability plots compare ordered variable values with the percentiles of the normal distribution. If the data distribution matches the normal distribution, the points on the plot form a linear pattern. Probability plots are preferable for graphical estimation of percentiles. The distribution reference line on the plot is created from the maximum likelihood estimate for the parameter.

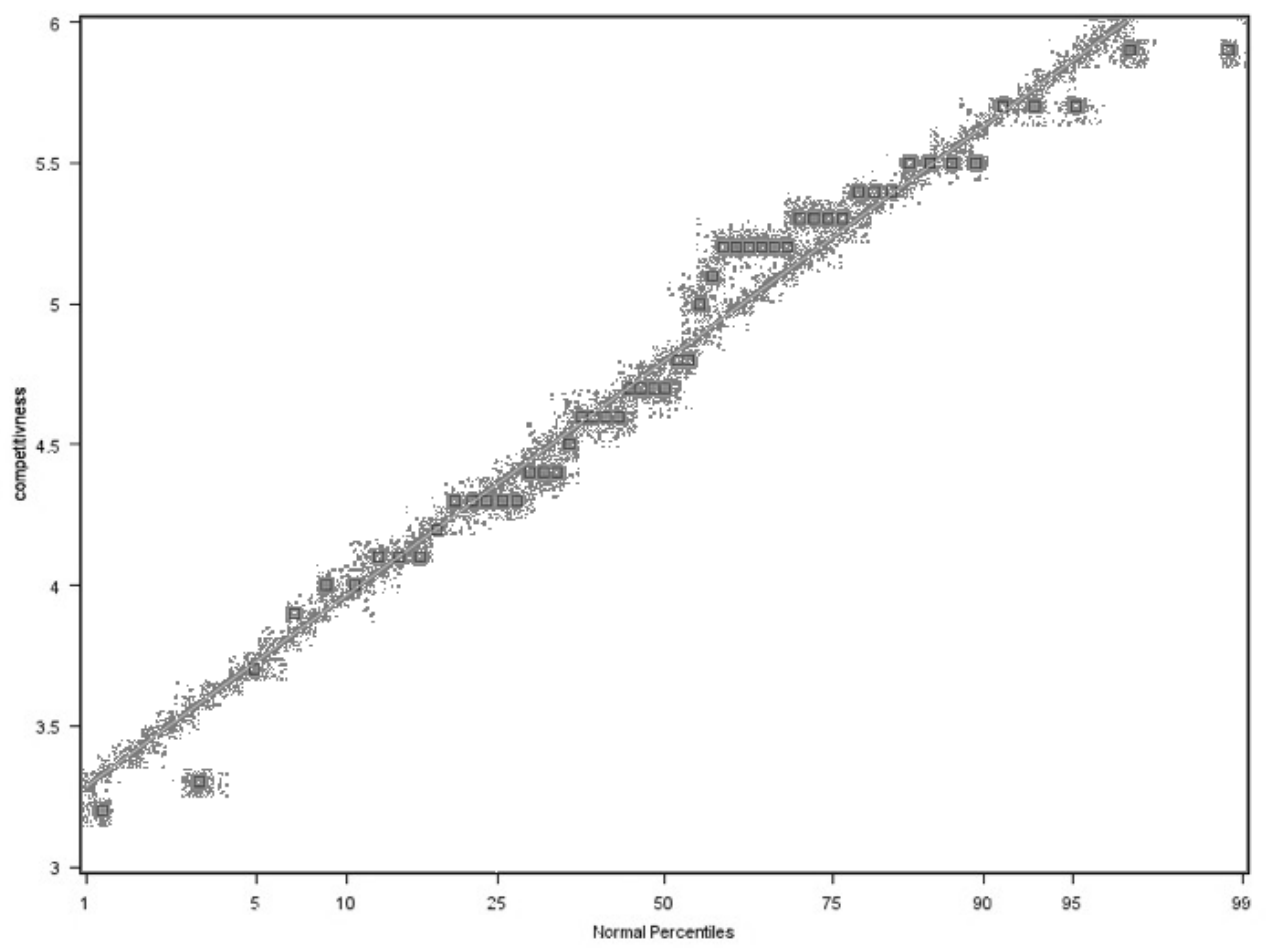

Figure 6 Data distribution - competitiveness Source: Own processing 


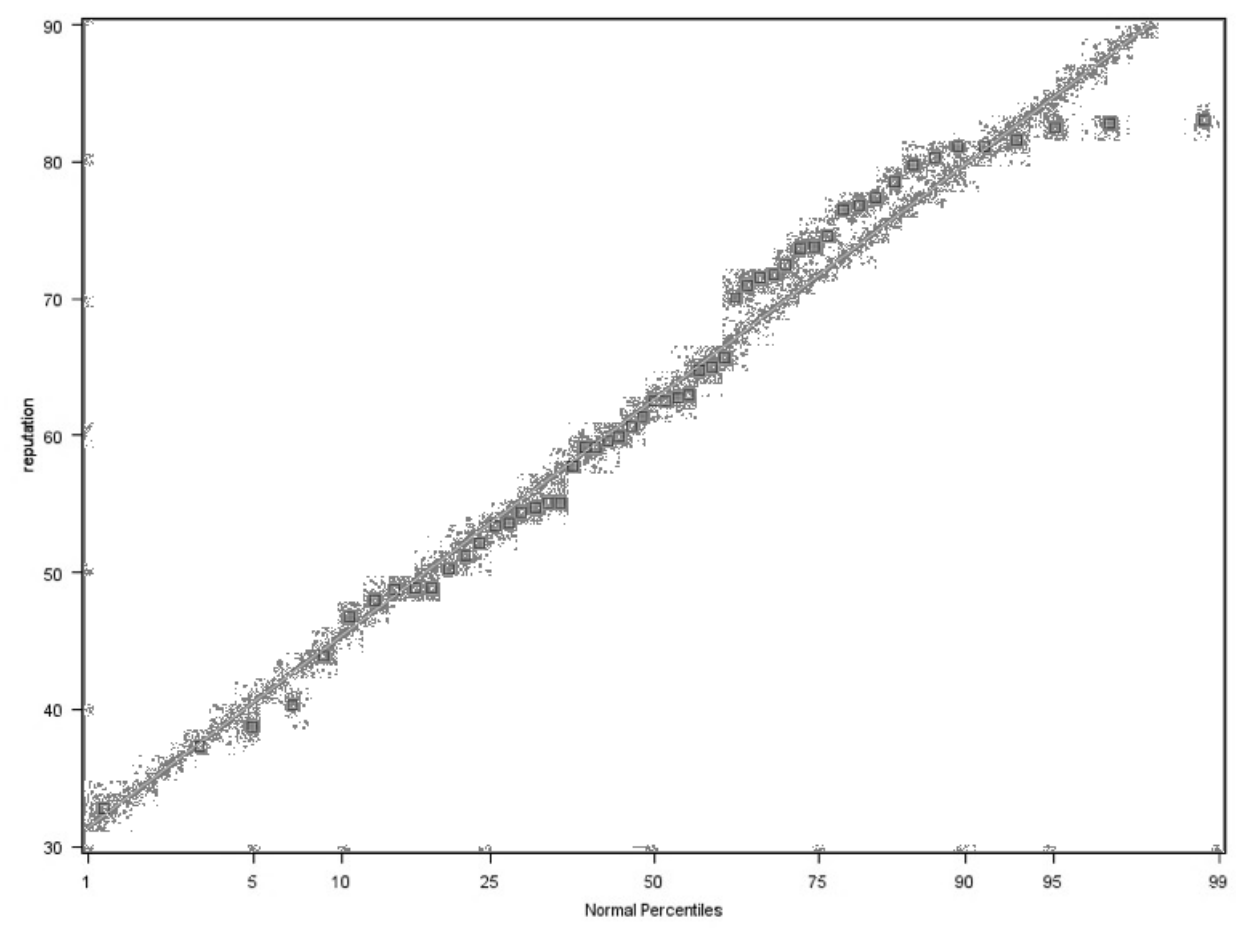

Figure 7 Data distribution - reputation Source: Own processing

Correlation is the way to assess the degree of relationship or association that is observed between variables. In our case, we work with two variables: reputation and competitiveness of country. We focus on obtaining two correlation coefficients, the Pearson $r$ and Spearman rho correlation coefficient.

The Pearson $r$ is statistically significant ( $p<.0001$ is less than our alpha level of $\alpha=.05$ ). We may therefore conclude that reputation correlating with competitiveness $(r=0,67, p<0,0001)$. Between variables is stronger relationship. Probability values assuming the null hypothesis is not true.

Table 5 Pearson Correlation Source: Own processing

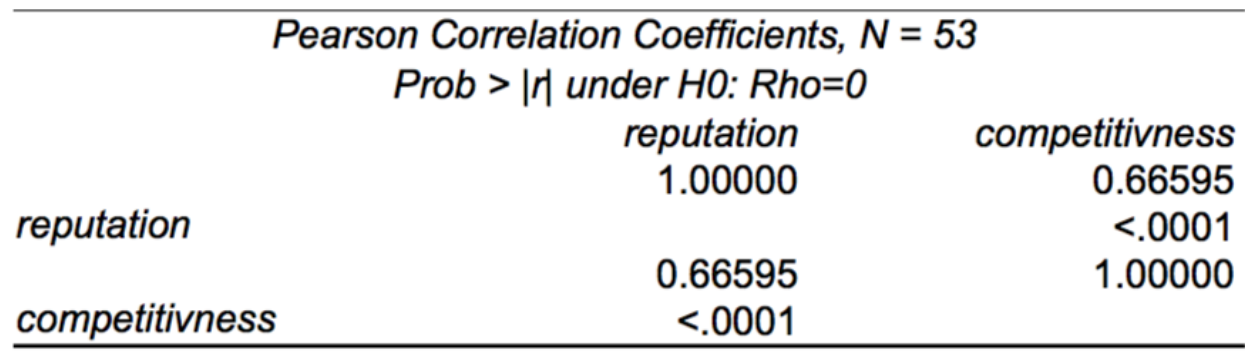

The Spearman rho correlation table appears below the Pearson $r$ table. It is structured in the same manner. Here, the Spearman correlation shown of 0,66652 is a bit lower than the Pearson, but is still statistically significant against an alpha level of $\alpha=.05$.

Table 6 Spearman Correlation Source: Own processing 


\begin{tabular}{lcr}
\hline \multicolumn{3}{c}{ Spearman Correlation Coefficients, $N=53$} \\
& Prob $>|| \mid$ under $\mathrm{HO}:$ Rho $=0$ & \\
& reputation & competitivness \\
& 1.00000 & 0.66652 \\
reputation & & $<.0001$ \\
& 0.66652 & 1.00000 \\
competitivness & $<.0001$ & \\
\hline
\end{tabular}

The results of the correlation test is also presented in Figure 8.

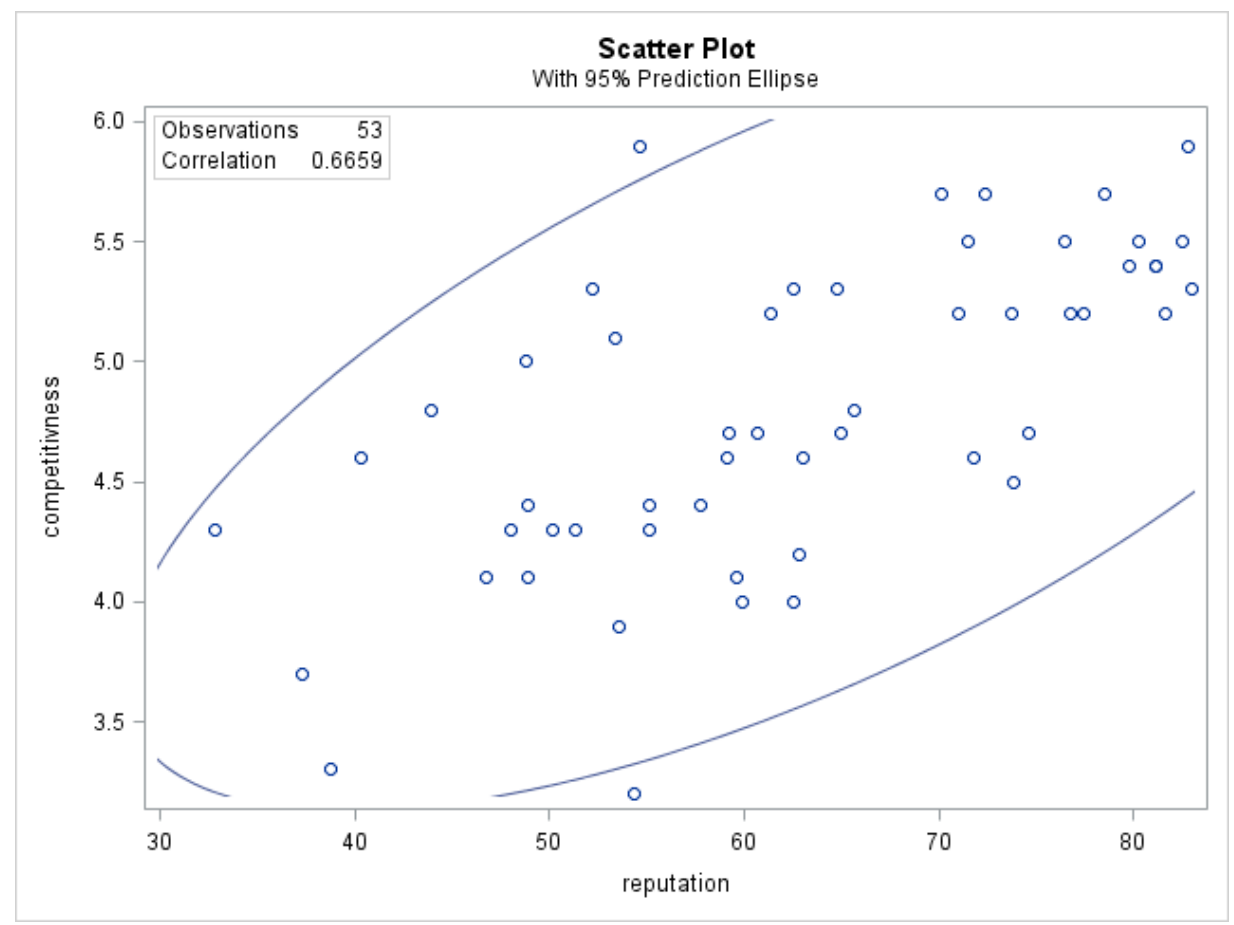

Figure 8 Correlation analysis. Source: Own processing

Based on the results, we can state the following:

1. Reputation and competitiveness have a statistically significant linear relationship $(\mathrm{r}=$ $0.67, \mathrm{p}<.001)$.

2. The direction of the relationship is positive (i.e., competitiveness and reputation are positively correlated), meaning that these variables tend to increase together (i.e., greater competitiveness score is associated with greater reputation).

\section{CONCLUSION}

Reputation plays very important and strategic role. Reputation management is no longer restricted to corporates; but countries are now also concerned with managing their reputation relative to each other for its impact on attracting tourism and foreign investments, increasing exports, improving public diplomacy, attracting knowledge and talent, and also gaining support from various stakeholders. The image of the country of its origin has a substantial meaning for every company which decides about its expansion abroad; its motherland's reputation affects the image and the attitude, as well as, in consequence, the sales of goods and/or brands manufactured therein. 
Our research has two main approaches: a theoretical one focused on researching the area of competitiveness and reputation theory and a practical one, namely identifying how competitiveness is affected by reputation of the country.

We demonstrated the relationships between competitiveness and reputation. We selected 53 countries and analysed their reputation score and competitiveness score. Data was used from the Global Competitiveness Report and Country Reptrak.

First, we had to test data distribution through Koglomorov- Smirnov test. Then we used correlation test - the Pearson $r$ and Spearman rho correlation coefficient to verify relationship between reputation and competitiveness. The results of correlation coefficients confirm, that between variables is strong relationship and reputation and competitiveness have a statistically significant linear relationship.

The country reputation is key factor when a company decides to make the leap into other markets and it is a primary consideration affecting the way public opinion and stakeholders in those countries make their evaluations. Reputation of a product's country of origin plays an important role in consumer choice behaviour and individuals' images of other countries can affect their support of or opposition to those countries.

Acknowledgement

This article is one of the partial outputs of the currently solved research grant APVV no. APVV15-0511 entitled "Research of the issue of Online Reputation Management (ORM) of subjects from automotive industry".

\section{References}

Arslan, N. \& Tatlidil, H. (2012). Defining and Measuring Competitiveness: A Comparative Analysis of Turkey With 11 Potential Rivals. International Journal of Basic \& Applied Sciences IJBAS-IJENS Vol: 12 No: 02, p.31-43.

Borozan, D. (2008). Regional competitiveness: some conceptual issues and policy implications. Interdisciplinary Management Research. Fourth Interdisciplinary Symposium, p.50-64.

European Commission, 2001. European Competitiveness Report 2001. DG for Enterprise and Industry, Brussels.

European Commission (2009). European Competitiveness Report 2008. Brussels.

Huggins, R. (2003). Creating a UK Competitiveness Index: Regional and Local Benchmarking. Regional Studies, 37(1), 89-96. doi:10.1080/0034340022000033420

Jones, C., Hesterly, W. S., \& Borgatti, S. P. (1997). A General Theory Of Network

Governance: Exchange Conditions And Social Mechanisms. Academy of Management Review, 22(4), 911-945. doi:10.5465/amr.1997.9711022109

Kang, M., \& Yang, S. (2010). Comparing Effects of Country Reputation and the Overall Corporate Reputations of a Country on International Consumers' Product Attitudes and Purchase Intentions. Corporate Reputation Review, 13(1), 52-62. doi:10.1057/crr.2010.1

Kleppe, I. A., Iversen, N. M., \& Stensaker, I. G. (2002). Country images in marketing strategies: Conceptual issues and an empirical Asian illustration. Journal of Brand Management, 10(1), 61-74. doi:10.1057/palgrave.bm.2540102 
Nedic, V., Lepojevic, V., Despotovic, D., \& Cvetanovic, D. (2016). Competitiveness of the selected Balkan countries in the period 2006-2015. Marketing, 47(4), 278-292. doi:10.5937/markt1604278n

Nevima, J. (2012). Visegrad Four Countries - Case Study of Econometric Panel Data Model for Regional Competitiveness Evaluation. Journal of Competitiveness, 4(4), 3-15. doi:10.7441/joc.2012.04.01

Newburry, W. (2012). Waving the Flag: The Influence of Country of Origin on Corporate Reputation. Oxford Handbooks Online. doi:10.1093/oxfordhb/9780199596706.013.0012

Passow, T., Fehlmann, R., \& Grahlow, H. (2005). Country Reputation - From Measurement to Management: The Case of Liechtenstein. Corporate Reputation Review, 7(4), 309326. doi:10.1057/palgrave.crr.1540229

Porter M., Ketels C., Delgado M., (2008). The Microeconomic Foundations of Prosperity: Findings from the Business Competitiveness Index. In: WEF, The Global Competitiveness Report 2007-2008 WEF, Geneva. [LỆ]

Szwajca,D. (2017). The importance of reputation of a country in the process of building its competitive advantage on the global market. Scientific Journal WSFiP, Issue 1, p.99114.

The Most Reputable Countries in the World (2017). Country RepTrak®.

Thiessen, A., \& Ingenhoff, D. (2011). Safeguarding reputation through strategic, integrated and situational crisis communication management. Corporate Communications: An International Journal, 16(1), 8-26. doi:10.1108/13563281111100944

World economic forum (2017). The Global Competitiveness Report.

\section{Contact information}

Ing. Mária Kozáková

University of Economics, Faculty of Business Management

Dolnozemská cest 1/b, 85235 Bratislava

+421908036568

maria.kozakova@euba.sk

ORCID: 0000-0003-4950-7585

DOI ID: https://www.doi.org/10.7441/dokbat.2018.13 


\title{
CZECH COMPANIES' ATTITUDES IN TRAINING MANAGEMENT
}

\author{
Ladislav Kudláček, Ravindra Hewa Kuruppuge, Aleš Gregar
}

\begin{abstract}
This paper describes the attitudes of Czech companies towards training. The work wants to respond to the issue of using subsidies in the field of further training. The research plan focuses on the question of whether granted programmes (funded from EU funds) are used efficiently, and whether Czech companies behave equally responsibly to further training, depending on funding from their own or other sources (EU funds). The work evaluates the hypothesis of a link between sources of financial founding for further training in small and medium size enterprises (SMEs) and the quality of the training process. The presented results are part of a comprehensive study involving SMEs. This paper focuses on mapping the behaviour of Czech companies and their management in the context of the attitude of employees towards training. It has used quantitative research on data collection through a questionnaire survey to address management of SMEs responsible for human resource management and training. The paper has presented data and an elementary analysis, which will continue in the next step by deeply analysing the efficiency of financial resources used for further training, and company behaviour in the context of money sources in efficiency of training programmes. At the same time, the management approach is assessed to evaluate employee training and also to understand whether there are written standards in the SMEs concerned to implement the acquired knowledge and skills within the framework of the training: these are described and used in the company's practice. The survey showed that the Czech companies underestimated the expenditure to their training. The results from the research showed that there is not a link between sources of financial funding for further training in SMEs and the emphasis on the implementation of the knowledge / skills acquired in the framework of further training into the processes / practice of the company. On the other hand, there is not a link between sources of financial funding and the emphasis on evaluation (measurement) of training in SMEs, because the data did not show the bigger differences despite higher interest from the companies using subventions for their training. The first results show that there is not statistically supported negative impact on Czech companies' attitude to further training and the evaluation of training programmes. However, if these results will be not confirmed in further research according to revenue and ROI development due to training and there will be find an impact on training according to funding, this should also be reflected in donor grants policy.
\end{abstract}

Keywords: further training, training evaluation, training efficiency, training measurement, quality of the training

\section{INTRODUCTION}

This paper is mapping the attitudes in training management in Czech companies in the category of small and medium size enterprises (SMEs) in the manufacturing industry. It is part of the complex research among Czech companies and their stand on quality of training in the context of financial resources. This part of the research focuses on data collection and their elementary analysis, which will continue with an in-depth analysis of the efficiency of the financial resources used for further training and company behaviour in the context of money sources in efficiency of training programmes. This paper focuses more on mapping the behaviour of the companies and their management in the context of the attitude of their 
employees towards training. The companies and their managers invest in training programmes if they believe that the benefits from the training will have a real effect on the companies. (Curado \& Teixeira 2014: 851). The mapping of the behaviour of management is mainly focused on comparing access to training in companies that fund their further training (from legal training framework) with their own resources, resources from European funds (as a subvention) or a combination of these two. At the same time, the management approach is assessed to evaluate employee training and also to understand whether there are written standards in the SMEs concerned to implement the acquired knowledge and skills within the framework of the training and are described and used in the company's practice. The work evaluates the hypothesis that there is a link between sources of financial founding for further training in SMEs and the quality of training process. In the Czech Republic and even within Europe there is no work that would define and compare the effectiveness of the funds spent on further training according to their origin. That is, there is no study comparing the impact of sources of funding for further training on the financial performance of SMEs. The choice of SME companies is due to the fact that EU funds prefer this target group and also form the backbone of the Czech economy. This research is important for mapping the access of SMEs to further training and the implementation of knowledge and skills into practice / business processes. At the same time, the work questions whether the change in the source of financing for further training influences the access of Czech companies to training programmes with regard to their effectiveness and the implementation of knowledge and skills in companies. It also shows the positive or negative effects of using subsidies on company management behaviour in the case of further training.

\section{THEORETICAL BACKGROUND}

Definition for training, education or development has not unified. There is only example of interpretation of this terms. Training endeavours to impart knowledge, skills and attitudes necessary to perform job-related tasks. It aims to improve job performance in a direct way' (Truelove, 1992: 273) Development activities are not job related but are oriented to both personal and organizational growth. The focus of such activities is on broadening the learner's conceptual and perceptual base in areas not previously explored or experienced by the individual. (Nadler 1994: 7) Education focuses on learning new skills, knowledge, and attitudes that will equip an individual to assume a new job or to do a different task at some predetermined future time. (Nadler 1994: 6).

This work has been interested in training and its evaluation and funding. In the Czech context, the financing of corporate training can be from external sources, such as subsidies from the EU funds - such as Operational Programme Employment (OPE) and from internal sources within the company regular expenditure / costs for training of employees.

There are many surveys in the world about the average or typical training budget. ASTD's (Association for Talent Development) benchmarking study in 1998 estimated that U.S. businesses spend only an average of 1.8 percent of payroll on training. ASTD recommends, at minimum, that an annual commitment should be 3 percent of the salary budget. In Australia, in 1992, it accounted for about 1.5 percent. (Nilson 2002:100-101) There is also the study from Hong Kong which refers to the average training budget in 2006 with 2.1 percent of the total annual base salary. It was a downward trend in allocations to the training budget since 
2003, when the figure was 3.4 percent. Moreover, the budget allocation in professional services sectors was 3.65 percent in 2006 and 3.67 percent in 2003. (Tsui and Lai 2009: 134)

For the evaluation of the real value of training programmes and their impacts, companies must develop and implement standards of training evaluation as a routine tool:

- The process of getting outputs must determine the effectiveness of the training.

- From who, what, when and how information is gained, to efficiently determine of the training. (Noe: 2010)

Robert O. Brinkerhoff (Brinkerhoff: 2006) examines evaluation strategy and methods of training implementation. His paper has given a lesson for organizational training and development. For maximizing the impact of training, the way that companies make use of training is also important, the way it is organized, planned, implemented, and above all, followed up and supported. The value from training comes when capability is transformed into improved job performance. Training that is well learned but never used produces no value for the business. According to Brinkerhoff research, only 15 out of 100 people that receive new training eventually use it in a way to produce valuable performance results. (Brinkerhoff 2006: 303). This could lead to the conclusion that the evaluation of the training by the participants is secondary for the real contribution to the company performance.

Increasing the number from Brinkerhoff's research means, depending on supervisor favour, implementing new skills to practice. Providing feedback to the training department or function is partially useful, but cannot be the sole focus of evaluation, because there is little the training department can do to correct deficiencies in the performance system. The author recommends focusing on increasing the consciousness that learning and work performance are inseparable. (Brinkerhoff 2006a)

Measuring the outputs of training programmes and its outcomes in the form of enterprise knowledge and employee knowledge as well as the whole process of training is an important aspect of human resource management. In the context of enterprise knowledge management, it is very important to have an overview of what added value, how effective and how beneficial the specific training is for the company and its development. There are studies in the UK that evaluate the impact of further training in SMEs and their underestimation of the impact of the development of small businesses in particular. (e.g. compere Storej and Westhead: 1997)

If we understand that training is an investment, it must be held accountable like other investments done by the company, and it must demonstrate that the decisions and actions taken are relevant and profitable. It means that the actual impact made by training to the companies' results need to be discovered. Evaluation is the key tool for this purpose. (Pindea 2010: 674)

According to Mann (Mann 1996: 14), few companies, despite the massive investment in training, are actually determining whether the training produced the desired results. Many training events remain poorly evaluated except for the high esteem with which they may be regarded by training personnel. Many training organizers wring their hands in despair and either choose a method based on their own view, or simply do not bother to evaluate. 
Curado and Teixeira has described four "classical" levels of measuring efficiency / satisfaction of the employees training and has also added a fifth level, which is measuring with ROI. (Curado and Teixeira 2014: 847-849, 851) These four levels also reflect Kirkpatrick's (1960) four criterion levels of reactions, learning, behaviour and results.

- Level 1 - Reactions: It measures participants' satisfaction with the training program.

- Level 2 - Learning: It appraises the difference in knowledge, skills, principles, attitudes and techniques that trainees present after the training programme.

- Level 3 - Behaviour: It assesses changes in on-the-job behaviour and implications in the workplace presented by trainees after the training program.

- Level 4 - Results: It measures changes in business results in terms of performance coming from improvements presented by trainees after the training programme.

According to Curado and Teixera (2014: 847-849) or Noe (2010) some from these four measuring levels use more than 90 percent of companies. In the Czech context, it is relevant to mention the project "Koncept", which wanted to find a system for measuring the quality of further training. The result was the proposal of the system of training institutes evaluation as the holders of the quality. (see Bezděková 2012)

There are no studies that focus on the sources of funding for further training with regard to the impact on the effectiveness of training programmes in the context of the EU subsidy policy. However, there are studies that focus on studies about the effect of convergence policy on employment in supported regions and on their GDP growth (compare Beckera, Eggerb, and Ehrlich: 2010). Mentioned study work did not find any existing verifiable impact between ESF expenditure and increasing employment. On the other hand, there is verifiable impact on the speed of GDP growth especially in the countries, which use ESF after entering EU. (Beckera, Eggerb, and Ehrlich: 2010)

\section{RESEARCH}

The research which has been presented in this paper is built on the hypothesis that there is a link between sources of financial founding for further training of SMEs and the quality of training process. The research which has been presented in this paper is built on the hypothesis that there is a link between sources of financial founding for further training of SMEs and the quality of training process. Respectively, it is a presentation of partial outcomes and verification of hypothesis $\mathrm{H} 1$ which has been defined in the conceptual framework displayed below (see diagram 1). The presented outcomes focus on the part of verification of partial hypothesis $\mathrm{H} 1$ and its sub-hypotheses.

Diagram 1 Conceptual framework

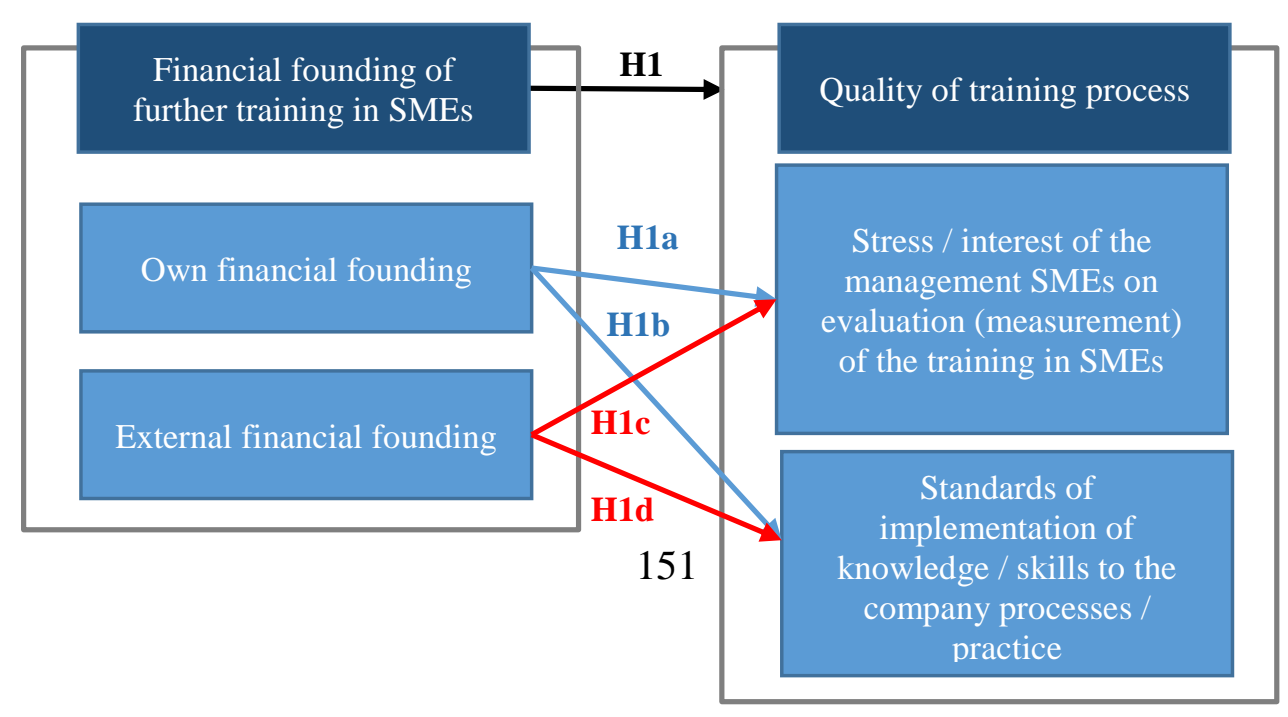


H1 There is a link between sources of financial founding for further training in SMEs and the quality of the training process.

H1a There is a link between sources of financial funding for further training in SMEs (i.e. from own financial founding) and emphasis on evaluation (measurement) of training in SMEs.

$\mathrm{H} 1 \mathrm{~b}$ There is a link between sources of financial funding for further training in SMEs (i.e. financial funding from own sources) and the emphasis on the implementation of the knowledge / skills acquired in the framework of further training into the processes / practice of the company.

H1c There is a link between sources of funding for further training in SMEs (i.e. financial funding from external sources) and the emphasis on evaluation (measurement) of training in SMEs.

H1d There is a link between sources of financial funding for further training in SMEs (i.e. financial funding from external sources) and the emphasis on the implementation of knowledge / skills acquired in the framework of further training into the processes / practice of the company.

\subsection{Methodology}

The research has focused on mapping the attitudes in training management of Czech companies in the category of SMEs from the manufacturing industry. The questioning is the part of the research focusing on evaluating the measurement approach of further training in Czech companies which have been financed from public or from the EU / state subvention.

The survey maps - through the following questions - the companies' attitudes in training management. The first question is dichotomous; the rest are polytemic questions allow the respondent to choose from several variants of predefined answers. Questions 2, 3 and 5 are closed questions with defined variants of answers which helps to unify it for evaluation of absolute and relative frequency of responses. Question 4 uses Likert's scale.

The question Q2, Q4, Q5 helps verify the factual hypothesis. Q1 and Q3 are here for supporting information about SMEs and will be useful for next research about the evaluation of training according to revenue and ROI in further training. Here are the following zero hypotheses and alternative hypotheses defined for factual hypotheses:

H1:

Zero hypothesis H0:

Own and external sources of financing for further training of SMEs have the same impact on the quality of the training process.

Hypothesis HA (alternative):

Own and external sources of financing for further training of SMEs do not have the same impact on the financial quality of the training process.

$\mathrm{H} 1 \mathrm{a}$ and $\mathrm{H} 1 \mathrm{c}$

Own and foreign sources of financing for further training of SMEs have the same impact on emphasis on evaluation (measurement) of training in SMEs.

$\mathrm{H} 1 \mathrm{~b}$ and $\mathrm{H} 1 \mathrm{~d}$ 
Own and foreign sources of financing for further training of SMEs have the same impact on the emphasis on the implementation of knowledge / skills acquired in the framework of further training into the processes / practice of the company.

The questions asked to the management of companies are the following:

Q1) Does your company regularly train your employees beyond the call of law duty? Answers: yes or no

The question is finding out if companies train their employees beyond the legal obligations and are so relevant to research.

Q2) What kind of financial resources do you use for financing your training programmes beyond the call of duty?

Answers:

A. predominantly own sources of financial founding

There is an explanation of the question: The company generally uses its own funding sources more than $60 \%$ of its training budget.

B. predominantly financial founding sources from EU subventions

There is an explanation of the question: The company generally uses some EU subventions more than $60 \%$ of its training budget.

C. combination of own sources of financial founding and EU subventions in the same proportion

There is an explanation of the question: The company generally uses some EU subventions and own funding sources in similar proportion of its training budget.

The question identifies the sources of funding for their training and contracts to compare other responses to determine the behaviour of companies and the attitudes of their management to training. The question is relevant for verifying the $\mathrm{H} 1$ hypothesis and their subtypes.

Q3) How big are your annual expenditures to your training programmes according to salary budget?

Answers:
A. up to $0.5 \%$ of the annual salary budget
B. $0.5 \%-1 \%$ of the annual salary budget
C. from $1 \%-2 \%$ of the annual salary budget
D. more than $2 \%$ of the annual salary budget
E. not able to answer

The question is used to compare the intensity of training. This question is mainly used for further research, where information on secondary sources about the impact of further training on the development of revenue and on the effectiveness of investment in training programmes - ROI evaluation.

Q4) What is your attitude towards the training measurement and evaluation in the whole training process? 
There is an explanation of the question: The management of the company evaluates the training process - it measures its success at least at the level of evaluating the participants' reactions, including the feedback on the possibility of using knowledge and skills in company practice. Based on this evaluation, conclusions are made.

Answers scale:

1 - great importance

2 - importance

3 - average importance

4 - not great importance

5 - not important

The question is used to identify attitudes and approach of company management to evaluation of training programmes. It is linked to the hypothesis verification $\mathrm{H} 1 \mathrm{a}$ and H1c. That is, whether the change in the funding source affects management's emphasis on the evaluation and quality of further training.

Q5) Do you have standards for knowledge and skills implementing from the training? There is an explanation of the question: This means that there is an established practice within the company that defines the rules on how to proceed after completing the training to maximize the use of knowledge and skills when implementing business processes.

Answers:

A. written standards with fully functionality

Explanation: Written standards means that company have and fully use internal regulations for methods which managers have to use after the employees training to maximize the use of knowledge and skills when implementing business processes. These standards are required at all levels of management.

B. only partially written standards with partial functionality

Explanation: Written standards means that company have and use internal regulations for some methods which managers have to use after the employees training to maximize the use of knowledge and skills when implementing business processes. These standards are required only at selected levels of management. Some procedures are implemented but not defined at some management levels.

C. no written standards

Explanation: There is no internal regulations for methods which managers have to use after the employees training to maximize the use of knowledge and skills when implementing business processes.

The question is to determine the companies' approach to the implementation of knowledge and skills in the company, which is related to the quality of the training process. The question is related to the hypothesis verification $\mathrm{H} 1 \mathrm{~b}$ and $\mathrm{H} 1 \mathrm{~d}$. That is, whether the change in the source of funding affects how knowledge and skills are implemented in corporate practice and business processes.

The validity of the questionnaire was evaluated in an expert judgment. The questionnaire's reliability will be evaluated based on the repeated measurement method and will be defined correlation coefficient. The prerequisite for repeating the poll is one year away. This is due to the fact that shorter time could affect the returnability and behaviour of responses. Responders could remember that they answered the questionnaire. 
The survey was held among 6090 companies from the database Albertina, with 337 responding companies. These companies are in the category of SME (from 20 employees till 249 employees). They are from the manufacturing industry according to CZ-NACE (The Branch Classification of Economic Activities) classification code, section $\mathrm{C}$. The return of the questionnaire is 5.53 percent. The survey was not anonymous and all companies that answered are known. The distribution of the questionnaires was conducted by e-mail inquiries aimed at top managers who are responsible for the development of human resources and training.

\subsection{Outcomes and discussion}

The outcomes that were obtained during the queries are summarized in the absolute figures in Table 1. The results, which then show the ratio of percentage responses, are graphically illustrated in the appendix to this paper in the graphs $1,2,3,4,5$.

These results show that $82 \%$ of the SMEs from interviewed companies provide further training to their employees beyond legal training. 18 percent of companies provide only legal training. All these companies invest 62 percent of their own financial funds in training. Other companies use subventions from the EU -7 percent predominantly use financial founding sources from EU subventions and 28 percent combine own sources of financial founding and EU subventions in the same proportion. Around 35 percent of the companies use somehow EU funds for training: it is an important figure, but not dominant. The other question is if these fundings somehow change the behaviour of the management of the SMEs.

Table 10 Answers to the questionnaire. Source: own primary data

\begin{tabular}{|c|c|c|c|c|c|c|}
\hline \multirow{2}{*}{ Q1 } & YES & $\mathrm{NO}$ & & & & \\
\hline & 277 & 60 & $82 \%$ & $18 \%$ & & \\
\hline \multirow[t]{2}{*}{ Q2 } & $\begin{array}{l}\text { A. predominantly } \\
\text { own sources of } \\
\text { financial founding }\end{array}$ & $\begin{array}{l}\text { B. predominantly } \\
\text { financial founding } \\
\text { sources from EU } \\
\text { subventions }\end{array}$ & $\begin{array}{l}\text { C. combination of } \\
\text { own sources of } \\
\text { financial founding } \\
\text { and EU subventions } \\
\text { in the same } \\
\text { proportion }\end{array}$ & no response & \multirow[b]{2}{*}{$62 \%$} & \\
\hline & 209 & 22 & 94 & 12 & & $7 \%$ \\
\hline \multirow[t]{2}{*}{ Q3 } & $\begin{array}{l}\text { A. up to } 0.5 \% \text { of } \\
\text { the annual salary } \\
\text { budget }\end{array}$ & $\begin{array}{l}\text { B. } 0.5 \%-1 \% \text { of } \\
\text { the annual salary } \\
\text { budget }\end{array}$ & $\begin{array}{l}\text { C. from } 1 \%-2 \% \text { of } \\
\text { the annual salary } \\
\text { budget }\end{array}$ & $\begin{array}{l}\text { D. more than } 2 \% \\
\text { of the annual } \\
\text { salary budget }\end{array}$ & $\begin{array}{l}\text { E. not able to } \\
\text { answer }\end{array}$ & \multirow[b]{2}{*}{$44 \%$} \\
\hline & 149 & 67 & 27 & 9 & 85 & \\
\hline \multirow[t]{2}{*}{ Q4 } & 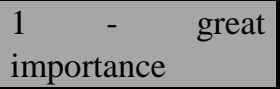 & 2 - importance & $\begin{array}{ll}3 \quad- & \text { average } \\
\text { importance } & \end{array}$ & $\begin{array}{l}4-\text { not great } \\
\text { importance }\end{array}$ & 5 - not important & no response \\
\hline & 70 & 115 & 97 & 38 & 16 & 1 \\
\hline \multirow[t]{2}{*}{ Q5 } & $\begin{array}{lr}\text { A. } & \text { written } \\
\text { standards } & \text { with } \\
\text { fully functionality }\end{array}$ & $\begin{array}{l}\text { B. only partially } \\
\text { written standards } \\
\text { with partial } \\
\text { functionality }\end{array}$ & $\begin{array}{l}\text { C. no written } \\
\text { standards }\end{array}$ & no response & \multirow[b]{2}{*}{$24 \%$} & \multirow[b]{2}{*}{$39 \%$} \\
\hline & 80 & 132 & 123 & 2 & & \\
\hline
\end{tabular}

The results obtained in the third question in the questionnaire show how the selected companies invest into the company training. In contrast to the studies quoted above, the funds are spent 
below the level of the US and other countries listed above. Only 3 percent of companies said they invest in training more than 2 percent of the amount of money spent per annual salary budget. Most Czech companies that responded said they spend up to 0.5 percent of the annual salary budget. This figure is very low, for example, the ASTD recommendation of at least 3 percent of the salary budget or $1.8 \%$ of the average in the US. (cf. Nilson 2002: 100-101 or Tsui and Lai 2009: 134)

An important part of mapping companies' management approach in the category of SMEs were questions 4 and 5, which focused on the area of training evaluation and implementation. The result from question 4 shows that 55 percent of the management interested in the result of evaluation and measurement of training programmes. However, about 16 percent of managers do not give such an interest to the evaluation and implementation. Philips says that some kind of evaluation and measurement should carry out from 100 percent. (Phillips and Phillips 2016) The result from question 5 shows that 24 percent of the companies (SMEs) have written standards for knowledge and skills fully implementing from the training, and 39 percent have partially implemented this kind of standards. Nevertheless, 36 percent of the respondents said that their companies do not have any kind of system of implementation of knowledge and skills to the practical life of their business. It means that the managements of these companies do not care about the practical use of the training. As mentioned above, according to Brinkerhoff research, only 15 percent of people that receive new training use it in a way to produce valuable performance results. (cf. Brinkerhoff: 2006) In this context, the results of the questionnaire show quite good awareness of the company management about the importance of using skills and knowledge from the training in company life.

On the other hand, at a deeper analysis, the results show slight differences if the company use or do not use subventions. However, there was not find any statistical support for hypothesis that there is a link between sources of financial founding for further training in SMEs and the quality of the training process (see values of chi-square for statistical tasting of zero hypothesis). The answers to question 4, according to companies that predominantly use own sources of financial founding (see absolute figures in table 2 and compere with table 3 and 4), 54 percent of the companies give importance to the measurement and evaluation of training programme. However, 19 percent of companies with own funding do not care about measurement and evaluation. See chart 6 in appendix 1. Companies which use predominantly subventions care a bit more about the measurement and evaluation (see chart 8). 14 percent of the companies do not care about it. Moreover, it is interesting that the numbers are more different if the sources are a combination on both. 67 percent of companies give importance to it, and only 2 percent do not care about it. See chart 10. The comparison shows that companies' behaviour according to sources of financial funding is slightly different and the companies see the value of the measuring and evaluating training programmes. However, there was not find any statistical support for the link between sources of funding for further training in SMEs and the emphasis on evaluation (measurement) of training in SMEs. 
Table 2: A. predominantly own sources of financial founding. Source: own primary data

\begin{tabular}{|c|c|c|c|c|c|c|}
\hline \multirow[t]{2}{*}{ Q4 } & $\begin{array}{l}1 \text { - attach great } \\
\text { importance }\end{array}$ & $\begin{array}{lcl}2 & - & \text { attach } \\
\text { importance } & \\
\end{array}$ & $\begin{array}{l}3 \quad-\quad \text { average } \\
\text { importance }\end{array}$ & $\begin{array}{l}4-\text { not great } \\
\text { importance }\end{array}$ & 5 - not important & no response \\
\hline & 43 & 69 & 55 & 30 & 11 & 1 \\
\hline \multirow[t]{2}{*}{ Q5 } & $\begin{array}{lr}\text { A. } & \text { written } \\
\text { standards } & \text { with } \\
\text { fully functionality }\end{array}$ & $\begin{array}{l}\text { B. only partially } \\
\text { written standards } \\
\text { with partial } \\
\text { functionality }\end{array}$ & $\begin{array}{l}\text { C. no written } \\
\text { standards }\end{array}$ & no response & & \\
\hline & 52 & 86 & 69 & 2 & & \\
\hline
\end{tabular}

Table 3: B. predominantly financial founding sources from EU subventions. Source: own primary data

\begin{tabular}{|c|c|c|c|c|c|c|}
\hline \multirow[t]{2}{*}{ Q4 } & $\begin{array}{l}1 \text { - attach great } \\
\text { importance }\end{array}$ & \begin{tabular}{|ll}
2 & - \\
importance & \\
\end{tabular} & $\begin{array}{l}3-\text { average } \\
\text { importance }\end{array}$ & $\begin{array}{l}4-\text { not great } \\
\text { importance }\end{array}$ & 5 - not important & no response \\
\hline & 6 & 5 & 8 & 3 & 0 & 0 \\
\hline \multirow[t]{2}{*}{ Q5 } & $\begin{array}{lr}\text { A. } & \text { written } \\
\text { standards } & \text { with } \\
\text { fully functionality }\end{array}$ & $\begin{array}{l}\text { B. only partially } \\
\text { written standards } \\
\text { with partial } \\
\text { functionality } \\
\end{array}$ & $\begin{array}{l}\text { C. no written } \\
\text { standards }\end{array}$ & no response & & \\
\hline & 4 & 8 & 10 & 0 & & \\
\hline
\end{tabular}

Table 4: C. combination of own sources of financial founding and the EU subvention in the same proportion. Source: own primary data

\begin{tabular}{|c|c|c|c|c|c|c|}
\hline \multirow[t]{2}{*}{ Q4 } & $\begin{array}{lcc}1 \quad- & \text { great } \\
\text { importance } & \\
\end{array}$ & 2 - importance & $\begin{array}{l}3 \quad-\quad \text { average } \\
\text { importance }\end{array}$ & $\begin{array}{l}4-\text { not great } \\
\text { importance }\end{array}$ & 5 - not important & no response \\
\hline & 21 & 40 & 27 & 2 & 0 & 0 \\
\hline \multirow[t]{2}{*}{ Q5 } & $\begin{array}{lr}\text { A. written } \\
\text { standards with } \\
\text { fully functionality }\end{array}$ & $\begin{array}{l}\text { B. only partially } \\
\text { written standards } \\
\text { with partial } \\
\text { functionality }\end{array}$ & $\begin{array}{l}\text { C. no written } \\
\text { standards }\end{array}$ & no response & & \\
\hline & 23 & 36 & 35 & 0 & & \\
\hline
\end{tabular}

Taking into account the behaviour of companies, respectively their running through the implementation of knowledge and skills in their practice, there is a visible difference in the approach depending on the way of financing. See absolute figures in table 2 and compare with table 3 and 4. 66 percent of answers of companies using only own financing funds have some kind of written standards for implementation of skills or knowledge coming from training within the business. However, 33 percent of the answering companies do not have any standards. It is shown in chart 7 . If the companies mainly use subventions, 54 percent of them have some kind of written standards and 45 percent do not consider any kind of regulations (chart 9). If the companies use a combination of financial funds, they have similar results as the first group (own financing) - 66 percent of the answering companies use some type of regulation for implementation skills and knowledge and 39 percent do not have any (see chart 
11). It shows some differences between the sources of financing with the slightly influence on behaviour of the management and their interest is bigger if they use own sources of financial funds. However, there was not find any statistical support for the link between sources of financial funding for further training in SMEs and the emphasis on the implementation of knowledge / skills acquired in the framework of further training into the processes / practice of the company.

For the values for the question Q4 and Q5 how was analysed in table 2,3,4 the chi-square was calculated:

For the question $\mathrm{Q} 4: \mathrm{X}_{0,05}^{2}(6)=0,81$

For the question $\mathrm{Q} 5: \mathrm{X}_{0,05}^{2}(8)=0,01$

This means that we must accept alternative hypotheses for the underlying hypotheses H1a, H1c and $\mathrm{H} 1 \mathrm{~b}, \mathrm{H} 1 \mathrm{~d}$. That is, we dismiss the factual hypothesis and, as a result, the H1 hypothesis is also rejected. The alternative hypothesis is that own and external sources of financing for further training of SMEs do not have the same impact on the financial quality of the training process.

\section{CONCLUSIONS}

This work has mapped out the approach of Czech companies (in the category of SMEs in the manufacturing industry) in the field of training. The presented results are part of a comprehensive research examining Czech companies. It focuses on the impact of financial resources used for training and how this is reflected in its quality. The paper has presented data and their elementary analysis which will continue with the deeper analysis of efficiency of financial resources used for further training and company behaviour in the context of money sources in efficiency of training programmes. Research limits are seen in particular in the field of sample structuring. This is not a random structured selection. The sample is very large, but the final sample is willing to answer the questions. At the same time, there is a problem that, despite the size of the sample, the processing industry is composed of relatively different companies and the need for training. The questions were formulated very simply and briefly to ensure maximum return on the questionnaire. At the same time, this leads to some simplification and limitations in the accuracy of data acquisition or deeper structuring. This has caused a certain limitation / reduction of variables relevant to research. In spite of this, the survey showed some signs or outputs from the implementation of further training in the Czech Republic which point to underestimation of training in Czech SMEs compared to what foreign surveys propose. The survey showed that the Czech companies underestimated the expenditure to their training. The other studies i.e. from the USA, Hong Kong or Australia shows that training expenses are higher. The number of companies which do not invest in further training is 18 percent from firms' sample. On the other hand, 66 percent of the companies using mainly or a combination of own financial funds care about the implementation of the skills and knowledge gained from training. It is bigger a share compared to firms which use predominantly subvention for their training programmes. These first results from the research used the questionnaire showed that there is not a link between sources of financial funding for further training in SMEs and the emphasis on the implementation of the knowledge / skills acquired in the framework of further training into the processes / practice of the company. On the other hand, there is not a link between sources of financial funding and the emphasis on evaluation (measurement) of training 
in SMEs, because the data did not show the bigger differences despite higher interest from the companies using subventions for their training. It is not statistically relevant. The research described above will continue and the data obtained will be further analysed. The data will be compared with secondary data research from public databases in the Czech Republic, where the funds for further training will be compared according to the origin of the source of finances own resources versus subvention) with the development of financial performance of SMEs.

\section{Acknowledgement}

"The authors would like to thank the Internal Grant Agency of FaME for providing financial support to carry out this research. Funding was extended through: TBU No. GA/FaME/2018/006- Evaluation and efficiency of additional training in companies (SME) in the context of financial resources."

\section{References}

Chaplowe, S. G. a Cousins, J. B. (2015). Monitoring and Evaluation Training: A Systematic Approach. Los Angeles, SAGE Publications, Inc.

Curado, C., \& Teixeira, S. M. (2014). Training evaluation levels and ROI: the case of a small logistics company. European Journal of Training and Development, 38(9), 845-870. https://doi.org/10.1108/EJTD-05-2014-0037

Brinkerhoff, R. O. (2006). Increasing impact of training investments: an evaluation strategy for building organizational learning capability. Industrial and Commercial Training, 38(6), 302-307.

Brinkerhoff, R.O. (2006a). Telling Training's Story. Berret Koehler Publishing, San Francisco, CA. https://doi.org/10.1108/00197850610685824

Becker, S. O., Egger, P. H., and Ehrlich, M. V. (2010). Going NUTS: The effect of EU Structural Funds on regional performance. Journal of Public Economics, 94(9-10), 578590. https://doi.org/10.1016/j.jpubeco.2010.06.006

Bezděková, K. (2012). Kvalita dalšího vzdělávání - koncepční část. Retrieved from http://www.nuov.cz/uploads/koncept/k_diskusi/Kvalita_DV_Analyticko_koncepcni_studie.pd f.

Phillips, P. P. and Phillips, J. (2015). Real World Training Evaluation. New York, Association for Talent Development. https://doi.org/10.1108/03090591011070789

Kirkpatrick, D. L. (1960). Techniques for evaluating training programs, Journal of the American Society of Training Directors, 14, 13-32.

Noe, R. (2010). Employee Training and Development. 5th ed., McGraw - Hill International Edition, Singapore.

Pineda, P. (2010). Evaluation of training in organisations: a proposal for an integrated model. Journal of European Industrial Training, 34(7), 673-693.

Phillips, P. P. and Phillips, J. (2016). Handbook of Training Evaluation and Measurement Methods. 4th edition, New York, Routledge. 
Storey, D. J., \& Westhead, P. (1997). Management training in small firms ? a case of market failure? Human Resource Management Journal, 7(2), 61-71. https://doi.org/10.1111/j.17488583.1997.tb00282.x

Mann, S. (1996). What should training evaluations evaluate? Journal of European Industrial Training, 20(9), 14-20. https://doi.org/10.1108/03090599610150264

Kirkpatrick, D. and Kirkpatrick, J. (2005). Transferring Learning to Behavior - Using the Four Levels to Improve Performance. 1st ed., Berrett - Koehler Publishers, San Francisco, CA.

Nadler, L. and Nadler, Z. (1994). Designing Training Programs - the critical events model. 2nd ed., New York, ELVR.

Nilson, C. D. (2002). How to Start a Training Program: Training Is a Strategic Business Tool in Any Organization. American Society for Training \& Development.

Truelove, S. (1992). Handbook of Training and Development. Oxford: Blackwell.

Tsui, A. P. Y., and Lai K. T. (2009). Professional Practices of Human Resource Management in Hong Kong: Linking HRM to Organizational Success. Hong Kong University Press.

\section{Contact information}

Ing. Mgr. Ladislav Kudláček

Tomas Bata University in Zlín, Faculty of Management and Economics

Mostní 5139

76001 Zlín

Phone: +420732424777

Email: kudlacekl@seznam.cz

ORCID: 0000-0001-7375-0388

Ravindra Hewa Kuruppuge

Tomas Bata University in Zlín, Faculty of Management and Economics

Mostní 5139

76001 Zlín

Phone: +420 773173432

Email: kuruppuge@yahoo.com

ORCID: 0000-0002-9456-4071

Doc. PhDr. Ing. Aleš Gregar, CSc.

Tomas Bata University in Zlín, Faculty of Management and Economics

Mostní 5139

76001 Zlín

Phone: +420 606777269

Email: gregar@utb.cz

DOI ID: https://www.doi.org/10.7441/dokbat.2018.14 


\section{Appendix 1}

Chart 1: Answers overview in percentage on question 1. Source: own primary data

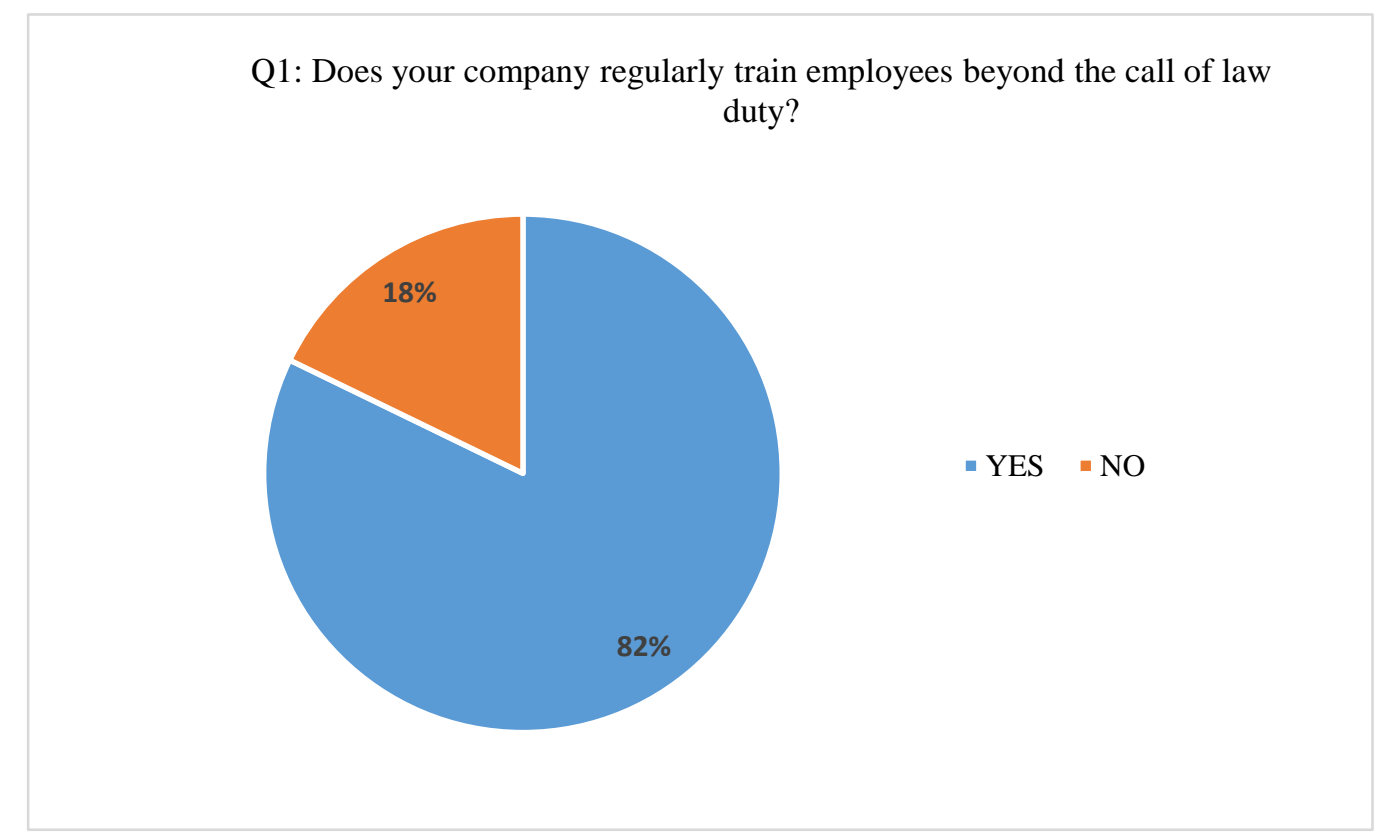

Chart 2: Answers overview in percentage on question 2. Source: own primary data

Q2: What kind of financial resources do you use for financing your training programmes beyond the call of duty?

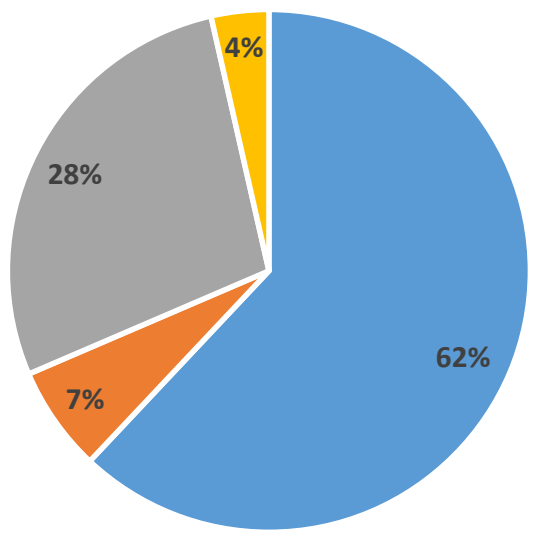

- A. predominantly own sources of financial founding

- B. predominantly financial founding sources from EU subventions

- C. combination of own sources of financial founding and EU subventions in the same proportion

" no response 
Chart 3: Answers overview in percentage on question 3. Source: own primary data

Q3: How big is your annual expenditures to your training programmes according to salary budget?

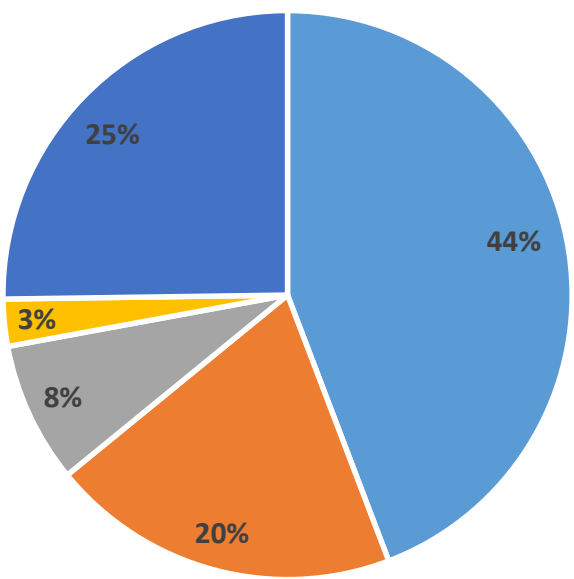

- A. up to $0.5 \%$ of the annual salary budget

- B. $0.5 \%-1 \%$ of the annual salary budget

- C. from $1 \%-2 \%$ of the annual salary budget

- D. more than $2 \%$ of the annual salary budget

- E. not able to answer

Chart 4: Answers overview in percentage on question 4. Source: own primary data

Q4: What is your attitude to the training measurement and evaluation in whole training process?

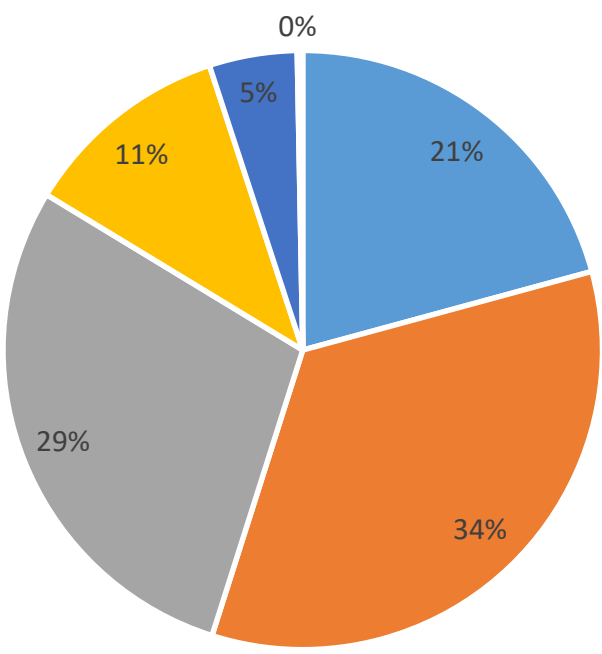

- 1 - great importance

- 2 - importance

- 3 - average importance

$=4$ - not great importance

- 5- not important

- no response 
Chart 5: Answers overview in percentage on question 5. Source: own primary data

Q5: Do you have standards for knowledge and skills implementing from the training?

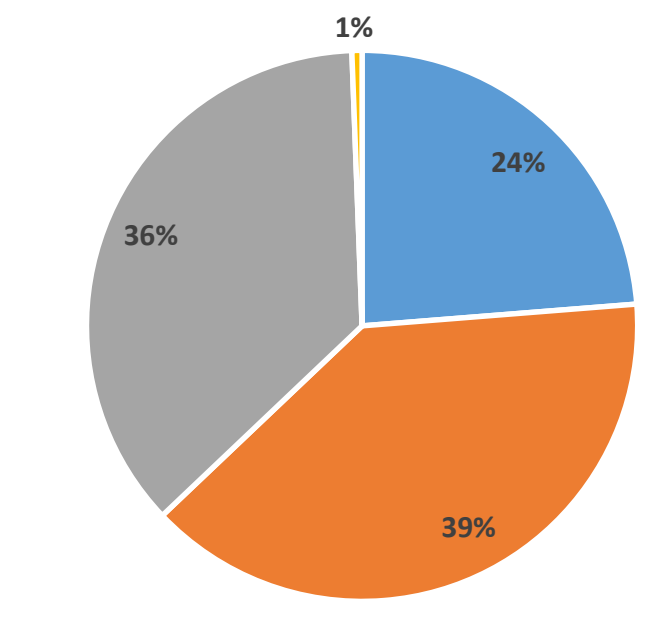

- A. written standards with fully functionality

- B. only partially written standards with partial functionality

- C. no written standards

no response

Chart 6: Answers according to financial funds sources (predominantly own sources of financial founding) on question 4 . Source: own primary data

A. predominantly own financial resources: $\mathrm{Q} 4$

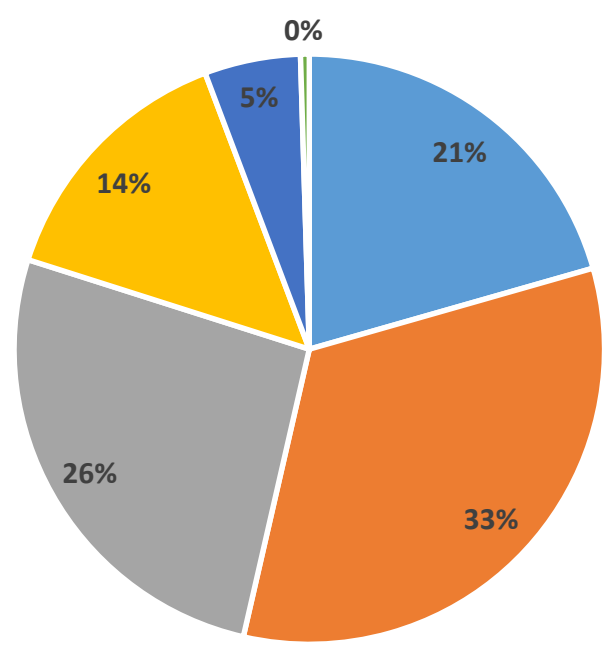

- 1 - attach great importance

- 2 - attach importance

- 3 - average importance

- 4 - not great importance

- 5-not important

- no response 
Chart 7: Answers according to financial funds sources (predominantly own sources of financial founding) on question 5 . Source: own primary data

A. predominantly own financial resources: Q5

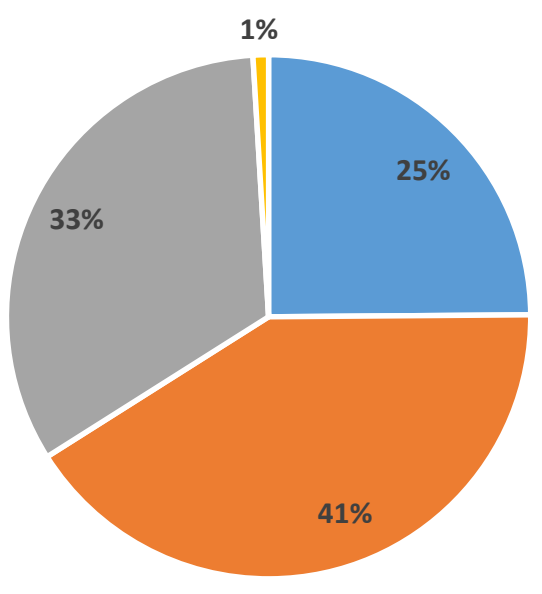

- A. written standards with fully functionality

- B. only partially written standards with partial functionality

- C. no written standards

no response

Chart 8: Answers according to financial funds sources (predominantly own sources of financial founding) on question 4 . Source: own primary data

B. predominantly financial resources from the EU subvention: Q4

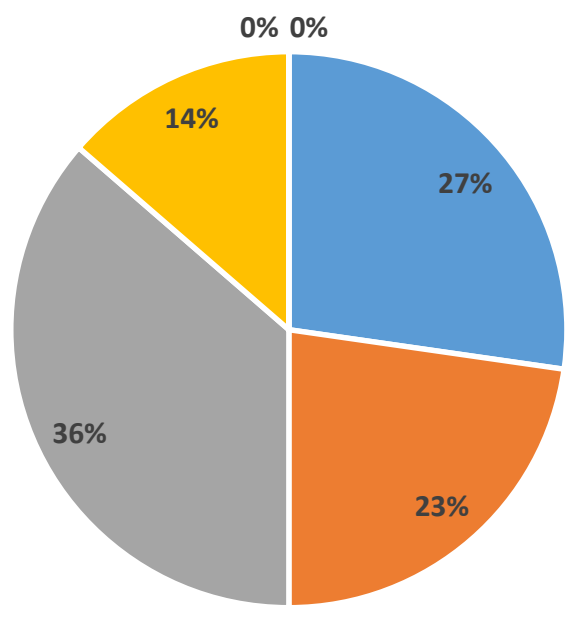

- 1 - attach great importance

- 2 - attach importance

- 3 - average importance

$=4$ - not great importance

-5 - not important

- no response 
Chart 9: Answers according to financial funds sources (predominantly financial founding sources from the EU subvention) on question 5. Source: own primary data

B. predominantly financial resources from the EU subvention: Q5

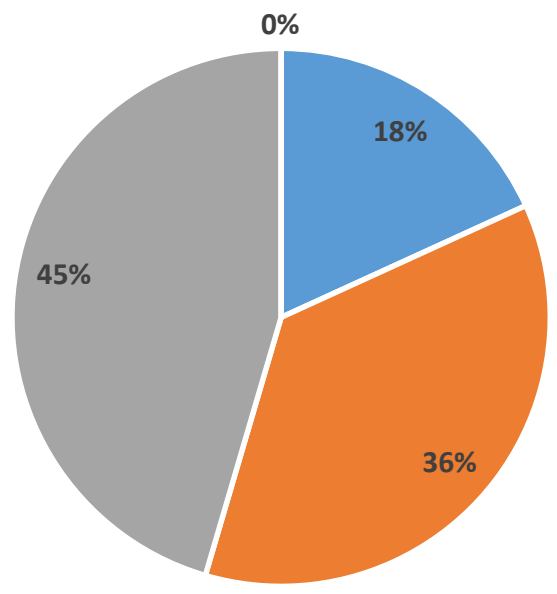

- A. written standards with fully functionality

- B. only partially written standards with partial functionality

๓ C. no written standards

no response

Chart 10: Answers according to financial funds sources (combination of own sources of financial founding and the EU subvention in the same proportion) on question 4. Source: own primary data

C. combination of own financial resources and the EU subvention in the same proportion: $\mathrm{Q} 4$

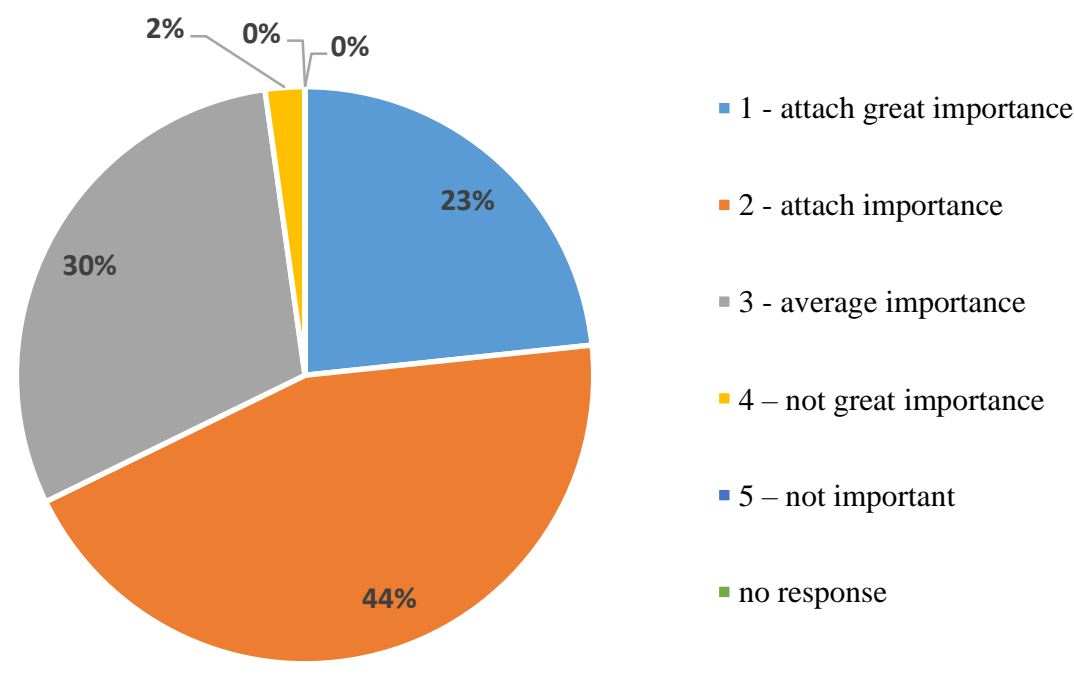


Chart 11: Answers according to financial funds sources (combination of own sources of financial founding and the EU subvention in the same proportion) on question 5. Source: own primary data

C. combination of own financial resources and the EU subvention in the same proportion: Q5

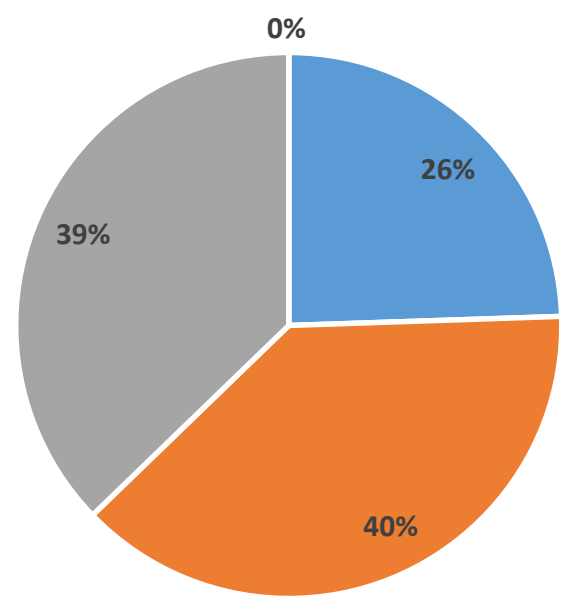

- A. written standards with fully functionality

- B. only partially written standards with partial functionality

- C. no written standards

no response 


\title{
THE EXISTING CORRELATION BETWEEN THE CPI OF OTC DRUGS AND OTHER GOODS AND SERVICES
}

\author{
Eva Loubalová
}

\begin{abstract}
This paper examines the link between the consumer price index (CPI) of over-the-counter (OTC) drugs and other goods and services in the Czech Republic. Private label OTC drugs have been sold on the Czech market since 2013. Taking their brief historic overview into consideration, their advantage is a lower price compared to OTC brand drugs. A lower price should produce a greater benefit over time in the period of an increasing CPI, especially the $\mathrm{CPI}$ of categories with the highest weight. To discover if there is a relation between the OTC drug category and some of the highest weight categories, a linear correlation analysis among $\mathrm{CPI}$ variables was used. Although the results indicate that the CPI of OTC drugs correlates with the CPI of some of the categories with the highest weight, it is not a general rule applicable to all categories. The inverse relation appears in the categories of communication, transport, prescription drugs, food and non-alcoholic beverages and furnishings, household equipment and routine maintenance of the house. According to these results, consumers tend to pay less for the OTC drugs in the periods of time when they pay more for the categories mentioned above. Contrarily, a correlation with miscellaneous goods and services, alcoholic beverages and tobacco, restaurants and hotels, education, clothing and footwear and recreation and culture exists. After linking these results with the weight of individual categories, the results confirmed that the inverse relationship shows up in the category of food and non-alcoholic beverages and transport category and vice versa mainly in the category of alcoholic beverages and tobacco. However, considering the success of the private label products in other categories private label drugs have potential on the Czech market regardless if there is an increase in CPI or not.
\end{abstract}

Keywords: over-the-counter (OTC) drugs, consumer price index (CPI), private label brands, linear correlation, economics, health expenditure

\section{INTRODUCTION}

In this paper the analysis of the Czech Republic's Consumer Price Index within the context of OTC drugs was performed. More specifically the linear correlation between the OTC drugs category and other goods and services was applied. The first stage of the correlation analysis provided results about the existing correlation among the categories within CZ-COICOP. The follow-up analysis then indicated if there is a relation between the resulting correlation coefficients and the weight of particular categories in the consumer basket.

Based on the previous research elaborated in the detail in the theoretical background, many prices of goods and services interact with each other. If one category changes, another category have also tendency to change.

This leads us to hypothesize the following:

H1: There is an inverse linear relationship between the consumer price index (CPI) of OTC drugs and the categories with the highest weight in the COICOP calculation.

The identification of consumer motivators for OTC drug purchases is strongly related to the price level of a given category, other goods and services. Therefore, this paper has a detailed focus on the CPI methodology within the category of health. 


\subsection{Theoretical Background}

The first private label products were introduced in the Czech market in 1994 and since then they have seen a steep rise in consumer interest (Hesková, 2006). Since 2013 onwards, we can also find this increase among over-the-counter (OTC) drugs. In the literature, we can see the OTC abbreviation, which stands for "over the counter". According to Švihovec, J. (2000), in Czech terminology we can see the term medicine, which is not based on the prescription and is therefore freely available. We can include OTC human medicines, traditional herbal preparations, homeopathics, nutritional supplements (vitamins, minerals, probiotics, fatty acids, amino acids), parapharmaceuticals (medical cosmetics, special nutrition), medical devices and biocidal products. It should be noted that the classification of the preparations may vary from country to country depending on the composition and the applicable local legislation.

Dr. Max and Benu pharmacies pertain among the largest vendors of OTC private label drugs on the Czech market. Both brands have shown an increase in sales of their private label products. In case of Dr. Max, sales grew by $230 \%$ in 2014 and accounted for $15 \%$ of the total turnover. In case of Benu, it is a $437 \%$ increase in sales and a $2 \%$ turnover share (Hrdličková, $\&$ Bednař́k, 2014). In their portfolio, Dr. Max pharmacies have over 200 and Benu pharmacies own over 40 private label products (Čechová, 2013). Private brands such as Dr. Max, My Pharmacy, Benu, Nuance, Equilibria, Amilk Bifido can be found in their portfolios. The most common representatives of OTC private label drugs are vitamins, dietary supplements, teas, pregnancy tests and cosmetics. In contrast to prescription drugs, the OTC drug category is specific due to the full decision-making power of the consumer. In addition, OTC drugs are often not covered by health insurance, so patients must pay for them. Contradictory to the above, price influences the decision-making process when buying OTC drugs (Wieringa, 2015). This is confirmed by Zhou et al. (2012), who mentions that price is one of the most important motivators for purchasing private label OTC products. Gönül (1999) indicates that shoppers have price expectations for OTC drugs, which are mainly based on their previous purchases of OTC drugs. The low-price sensitivity connected to the demand for OTC drugs is also confirmed by Akçura et al. (2004). Price is an important indicator of quality, especially if other qualitative indicators are missing. As a result, shoppers tend to choose more expensive OTC drugs. In the minds of consumers, private label products have been the symbol of lower prices redeemed by lower quality goods (Thomassen, Aconis, \& Lincoln, 2009).

The pharmaceutical market is on the rise and with $7.5 \%$ growth rate of OTC drugs plays a crucial role for private brands (Akçura, Gönül, \& Petrova, 2004; Narayanan, \& Manchanda, 2007). The increase is caused by the fact that most patients use food supplements in parallel with the prescription drugs. $86 \%$ of Czech consumers buy food supplements, and $64 \%$ of them believe in their positive health effects (Sadílek, 2016).

Taking the prescription drugs as well as OTC drugs into account, data from SÚKL (2014-2017) suggests that 264.23 million packages of pharmaceuticals were delivered to pharmacies, healthcare establishments and retailers of the drugs in 2014 in the Czech Republic. From financial value point of view, the value of the pharmaceuticals reached 55.45 billion CZK. In 2015 , both delivered packages $(+1.10 \%)$ and financial value $(+9.77 \%)$ increased. On the other hand, 2016 meant a slight decline in both indicators $(-2.37 \%,-3.71 \%)$. However, the growth was resumed in 2017, delivering 262.48 million packages of pharmaceuticals ( $0.64 \%$ increase) worth 67.87 billion CZK (5.56\% increase). The financial value is not calculated based on the price for the final consumer, taking the changing amount of VAT and trade surcharges over the years into consideration.

According to the amount of money spent on health products and services (CSO, 2017), household expenditures for health care amounted to 45 billion CZK in 2015, equivalent to $2.1 \%$ 
of total household expenditures. A $27 \%$ share of healthcare spending falls under OTC drugs. On average, each inhabitant of the Czech Republic spent 1161 CZK on OTC drugs in 2015. The Czech Statistical Office further includes the direct household costs for health care regarding this data. On the other hand, payments that are reimbursed have been excluded (e.g. reimbursement from health insurance companies when paying for urgent health care abroad).

As Gao (2013) mentions, in a real economic system, many prices of goods and services interact with each other. Changes in one tend to drive changes in another. The assumption is that if consumers need to pay more for the goods and services with the highest share in the Czech Classification of Individual Consumption by Purpose (CZ - COICOP) calculation, they tend to pay less for OTC drugs.

Since 2016, the price reference period of December 2013 for the price indices was changed to December 2015. As of January 2017, the have been linked together for all levels of the consumer basket with a base average of 100 since 2015 .

According to the methodological manual of the CPI (2017) issued annually by the Czech Statistical Office, drugs are divided into prescription and OTC drugs within the COICOP at the 4th international classification level. The first group includes drugs that must be prescribed by a physician and are fully or partially reimbursed to patients. The second group contains drugs at full cost. The weight of these groups is based on household account statistics corrected by national accounts data. There are about 50000 different drugs registered in the Czech Republic, which makes the selection of specific price representatives difficult, in relation to their relatively low weight in the consumer basket. Therefore, since 2011, a sub-index of both groups of drugs has been introduced into the consumer basket. The basis for calculating these two subindices is price or a surcharge survey of prescription drugs. This includes the prices of OTC drugs sold by pharmacists in all regional cities. The selection of specific representatives was made on the basis of the data of the State Institute for Drug Control, which keeps a register of drugs offered on the Czech market (as well as the volume of their supplies). According to the list of the most frequently sold drugs, specific types of drugs were selected for a price survey and their weight was determined. In addition, the calculation of the price/surcharge index of the 2500 most distributed medicines in terms of the number of packages and 2500 more medicines in terms of their value is completed each month.

690 price representatives are included in the consumer basket and 18 representatives pertain to the health category. The weight of the whole category is $2.3 \%$ (2014). The list of representatives within the category of OTC drugs (06.112) can be seen in Table 1.

Table 11: A Set of OTC Drug Representatives. Source: CSO, 2017

\begin{tabular}{|c|c|}
\hline 06.112 & OVER-THE-COUNTER (OTC) DRUGS \\
\hline 06.112 .01 & ACYLPYRIN \\
\hline 06.112 .02 & ATARALGIN \\
\hline 06.112 .03 & PARALEN 500 \\
\hline 06.112 .04 & CILKANOL \\
\hline 06.112 .05 & BROMHEXIN \\
\hline 06.112 .06 & CELASKON 250 \\
\hline 06.112 .07 & B KOMPLEX FORTE LÉČIVA \\
\hline
\end{tabular}




\begin{tabular}{|c|c|}
\hline 06.112 .08 & PHARMATON GERIAVIT \\
\hline 06.112 .09 & IBALGIN 400 \\
\hline 06.112 .10 & VITAMÍNOVÉ ŠUMIVÉ TABLETY \\
\hline 06.112 .11 & FAKTU \\
\hline 06.112 .12 & COLDREX HORKÝ NÁPOJ \\
\hline 06.112 .13 & OLYNTH 0.1\% DOSIERSPRAY \\
\hline 06.112 .14 & VALETOL \\
\hline 06.112 .15 & MODAFEN \\
\hline 06.112 .16 & MUCOSOLVAN \\
\hline 06.112 .17 & WOBENZYM DRG 200 \\
\hline 06.112 .19 & OSCILLOCOCCINUM GLO 6X1GMO \\
\hline 06.112 .20 & GS CONDRO FORTE \\
\hline 06.112 .21 & VOLTAREN EMULGEL \\
\hline 06.112 .22 & ACC LONG \\
\hline 06.112 .23 & KORYLAN \\
\hline
\end{tabular}

\section{METHODS}

In order to discover the relation between the CPI of these categories in the Czech Republic, CPI data from the Czech Statistical Office database was used. The existence of a linear correlation among the CPI variables was tested on the data from November 2013 to March 2017.

\subsection{Time and Location Determination}

To test the relation between the CPI of OTC drugs and the other categories, data provided by the Czech Statistical Office (CSO) was used. The data spanned over a period of 41 months (from November 2013 to March 2017) when the Czech National Bank performed foreign exchange interventions as part of their exchange rate commitment (CNB, 2017). The data was collected only from pharmacies in the Czech Republic.

\subsection{Variable Definition}

Thirteen independent variables according to the $\mathrm{CZ}$ - COICOP classification based on the international COICOP were used in this test. The categories are food and non-alcoholic beverages, alcoholic beverages and tobacco, clothing and footwear, housing, water, electricity, gas and other fuels, furnishings, household equipment and routine home maintenance, prescription drugs (a health subcategory), OTC drugs (another health subcategory), transport, communication, recreation and culture and education.

\subsection{Data Processing}

The data was analysed by employing a correlation analysis. A correlation analysis means finding any kind of relation among the categories. If one of them changes, the other one changes 
and vice versa. If there is a correlation between the two processes, it is likely that they depend on one another, but it can not be concluded that one of them has to be the cause and the second one has to be the effect. However, before initiating the correlation analysis, it was necessary to clear the time series of the individual categories from the overall trend. The problem of measuring the relation of the time series lies in the relation of their real values. This is a relation seemingly caused by their trend and seasonal similarity. After this indispensable adjustment, the correlation coefficients of the categories, with a special emphasis on the category of OTC drugs, could be tested. The correlation coefficients, the results of this analysis, are denoted in Table 2.

Table 2: The Value of the Correlation Coefficients of Each Category. Source: Own Calculations

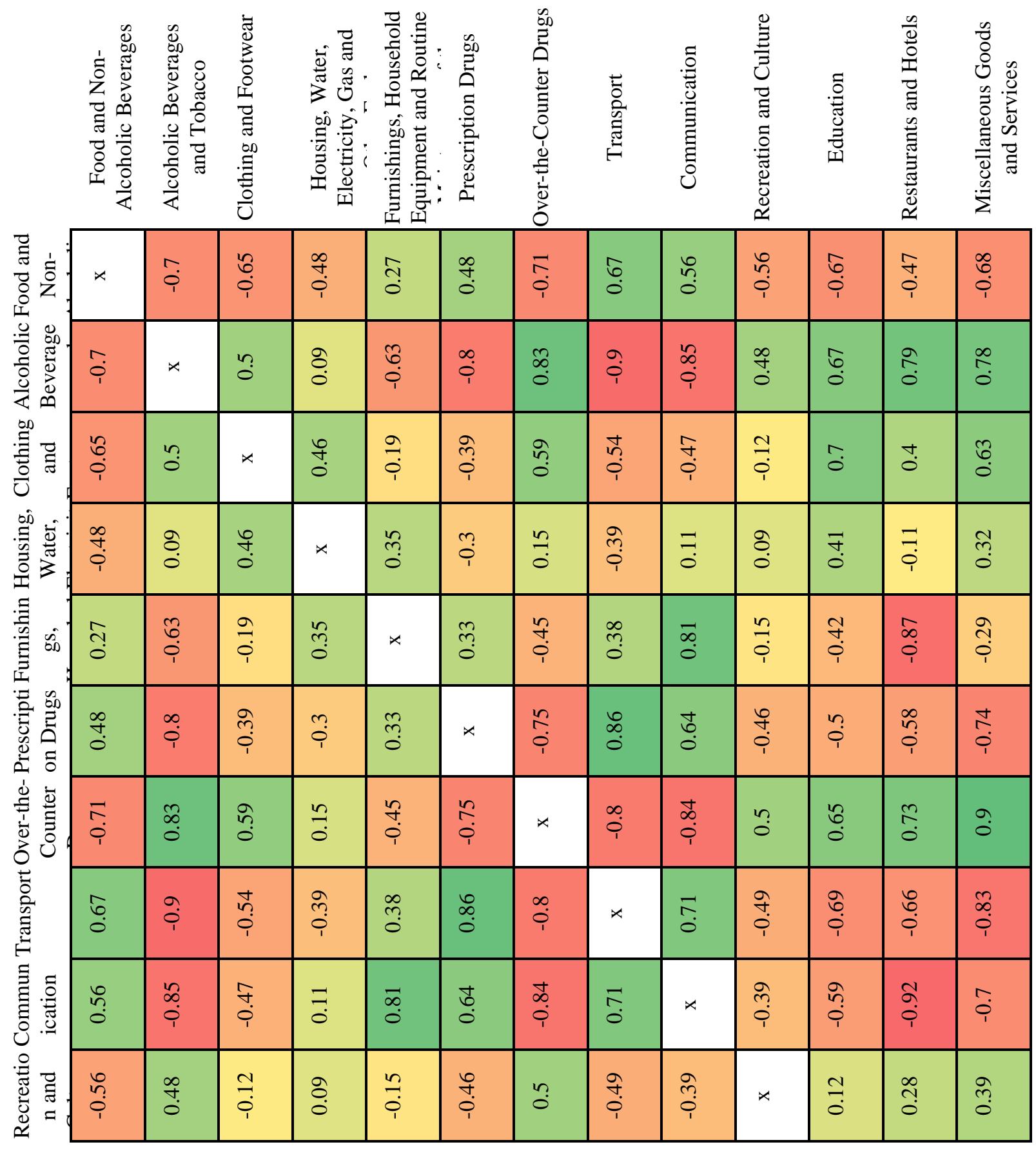




\begin{tabular}{|c|c|c|c|c|c|c|c|c|c|c|c|c|c|}
\hline 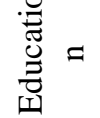 & $\begin{array}{l}\hat{\sigma} \\
0 \\
0\end{array}$ & రి. & $\tilde{o}$ & $\stackrel{\nabla}{\circ}$ & $\begin{array}{l}\text { I } \\
\stackrel{9}{i}\end{array}$ & $\begin{array}{l}n \\
? \\
?\end{array}$ & ?ֶ. & $\begin{array}{l}0 \\
0 \\
0 \\
1\end{array}$ & $\begin{array}{l}\tilde{n} \\
\text { on }\end{array}$ & $\stackrel{\simeq}{\circ}$ & $\star x$ & $\begin{array}{l}8 \\
0\end{array}$ & $\hat{0}$ \\
\hline 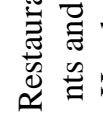 & $\begin{array}{l}\text { f. } \\
\stackrel{0}{0}\end{array}$ & $\stackrel{\overbrace{}}{0}$ & $\stackrel{+}{\circ}$ & $\overrightarrow{\overline{0}}$ & $\begin{array}{c}\infty \\
0 \\
0 \\
0\end{array}$ & $\begin{array}{l}\overbrace{}^{\infty} \\
? \\
?\end{array}$ & $\stackrel{m}{\circ}$ & $\begin{array}{l}0 \\
\stackrel{0}{0} \\
\dot{\varphi}\end{array}$ & ồ & 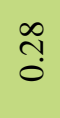 & : & $\star$ & $\tilde{n}$ \\
\hline 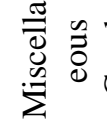 & $\begin{array}{l}\infty \\
\stackrel{0}{0} \\
\stackrel{0}{0}\end{array}$ & $\stackrel{\infty}{\stackrel{\infty}{\circ}}$ & $\stackrel{\overbrace{}}{0}$ & กै? & స़े & $\frac{j}{0}$ & $\hat{o}$ & 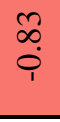 & $\hat{0}$ & ले & $\ddot{\circ}$ & $\hat{n}$ & $\star x$ \\
\hline
\end{tabular}

This study aimed to define and quantify the relation of particular CPI categories. Therefore, the correlation coefficients were used to represent the correlation degree between the CPI of the categories. The correlation coefficient, also known as the Pearson correlation coefficient, is an indicator that measures the degree of correlation between changing trends of variables, with a range of $[-1,1]$. According to Pearson (1895), the higher the absolute value of the correlation coefficient, the greater the degree of correlation between the variables.

\section{RESULTS}

Consumer price index (CPI) measures changes in the prices of goods and services consumed by households. The changes in the prices affect the real purchasing power of consumers. If the CPI of one category increases, it means that consumers are forced to spend more money on the same volume of goods and services, which they may subsequently miss in another category. By increasing the real prices of the categories that have a higher share of the CPI, consumers may tend to reduce the amount of money that was originally intended to be spent on other (dispensable) categories. During this period of time, there may be potential for the purchase of private label OTC drugs.

As it can be seen in Figure 1, both total CPI as well as the OTC drug CPI increased (from November 2013 to March 2017). However, the CPI growth rate of OTC drugs was higher and it even exceeded the total CPI in mid-2015.

Figure 1: The CPI - OTC Drugs (November 2013 - March 2017), year $2015=100$. Source: CSO, 2017 and Own Calculations

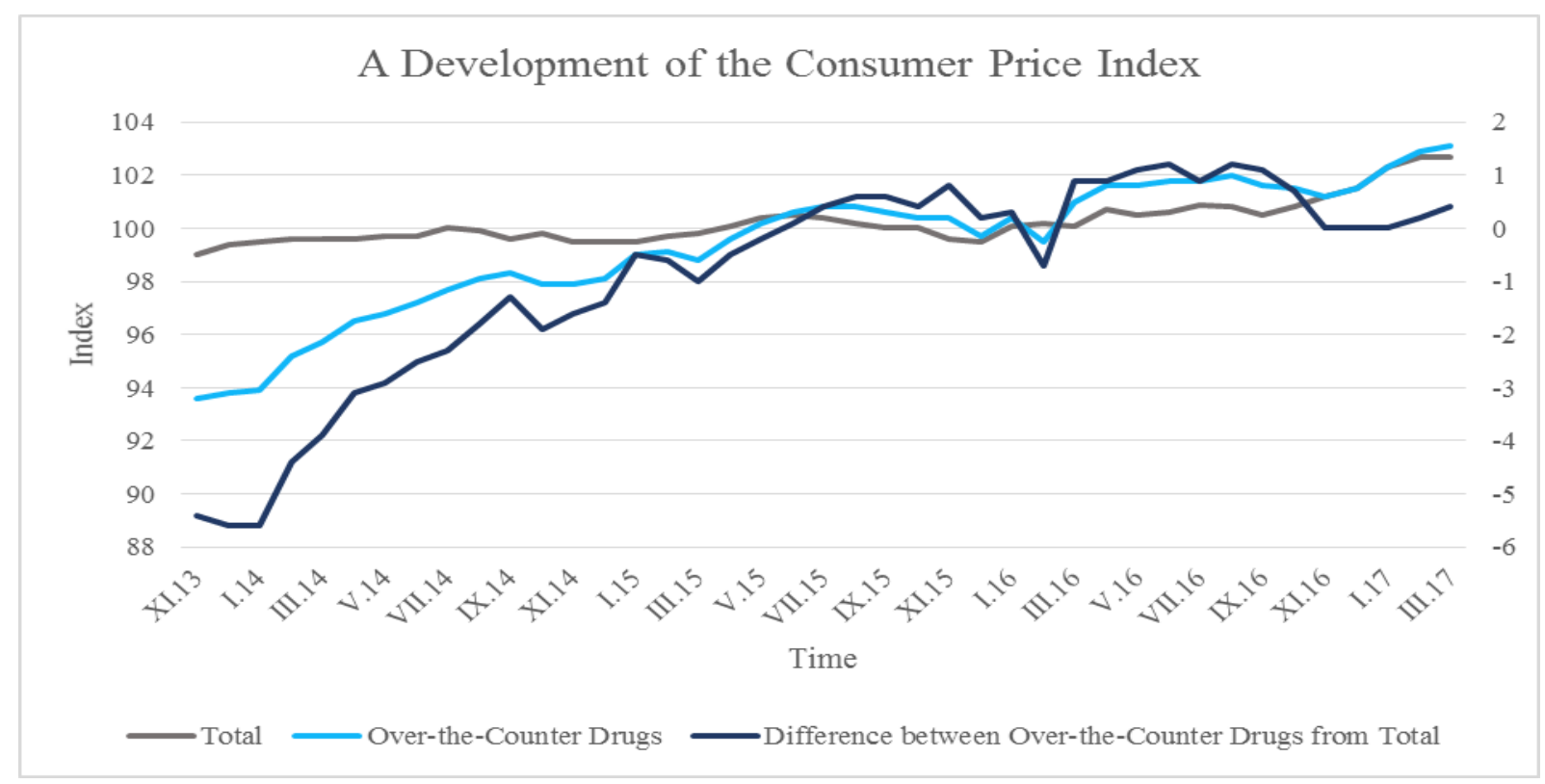


After removing the overall trend from each category, the data was subjected to a correlation test among the individual categories. The results of this statistical analysis are shown in Table 2. In the first column of the table, the individual CPI sections are found. From the health section, there is only prescription drug subcategory. The second column shows the resulting correlation coefficients based on the correlation analysis between the OTC drugs category and the remaining categories. The categories with the highest value of the coefficient (meaning the categories with the highest mutual positive relationship) are highlighted in green. On the other hand, the categories with the lowest value of the coefficient (meaning the categories with the highest inverse relationship) are highlighted in red. In the third column, the weight of the individual categories in the CPI index, based on the household account statistics corrected by national accounts data, are shown. Again, here is the rule that green colour means higher values (the categories with the largest weight in the CPI calculation), in other words the categories the average Czech household spends the most money on and the red colour means the opposite. The results indicate the existing anti-correlation between the CPI of the OTC drugs category and categories of communication, transport, prescription drugs, food and non-alcoholic beverages and furnishings, household equipment and routine home maintenance.

This means that there is an inverse linear relationship between the average price that Czech households spent on OTC drugs and the average price that Czech households spent on the mentioned categories.

Table 2: The Value of the Correlation Coefficients between OTC Drugs and Other Categories and the Weight of the Particular Categories in the CPI Calculation. Source: CSO, 2017 and Own Calculations

$$
\begin{array}{cc}
\text { Correlation } & \text { Category } \\
\text { Coefficient } & \text { Weight }
\end{array}
$$

\begin{tabular}{|c|c|c|}
\hline Food and Non-Alcoholic Beverages & -0.71 & 180.6 \\
\hline Alcoholic Beverages and Tobacco & 0.83 & 93.4 \\
\hline Clothing and Footwear & 0.59 & 39.2 \\
\hline Furnishings, Household Equipment and Routine Maintenance of the House & 0.15 & 251.3 \\
\hline Prescription Drugs & -0.45 & 57.8 \\
\hline Transport & -0.75 & not available \\
\hline Communication & -0.80 & 100.9 \\
\hline Recreation and Culture & -0.84 & 30.7 \\
\hline Education & 0.50 & 89.6 \\
\hline Restaurants and Hotels & 0.65 & 6.2 \\
\hline Miscellaneous Goods and Services & 0.73 & 58.1 \\
\hline
\end{tabular}

When the results of the correlation coefficients in the OTC drug category were compared to the shares of individual categories in total CPI, no rule was found that would support the hypothesis 
of this paper. The hypothesis that there is an inverse linear relationship between the consumer price index (CPI) of OTC drugs and the categories with the highest weight in the COICOP calculation was rejected.

\section{CONCLUSIONS}

The present paper introduces CPI in the Czech Republic from private label drugs point of view. The existing literature highlights the positive trend that private label products are currently experiencing. Their market share is steadily increasing, even in the health category. Private label products are represented in the health category mainly by OTC drugs. Together with rising pharmaceutical industry this area reveals a strong potential for the future development.

While more expensive private label products (compared to national brands) began to appear, private label products with a lower price still dominate on the Czech market including the health category. Therefore, this research addressed the question whether in a situation when consumers are forced to spend more of their budget for the categories that have the highest weight in the consumer basket, it will affect their spending for the category of OTC drugs. If so, it could uncover the potential for OTC private label drugs. In order to achieve the desired results, the $\mathrm{CZ}$ - COICOP data from the Czech Statistical Office was used applying the correlation analysis. The largest share belongs to the category of housing, water, electricity, gas and other fuels, category of food and non-alcoholic beverages, followed by transport category.

In conclusion, to answer the question of whether there is an existing correlation between OTC drugs and other categories of goods or services, this research investigated the mutual influence of the $\mathrm{CZ}$ - COICOP categories. The findings suggest that there is an anti-correlation between OTC drugs and categories of communication, transport, prescription drugs, food and nonalcoholic beverages and furnishings, household equipment and routine maintenance of the house. The anti-correlation indicates that there is an inverse relation between the price that consumers pay for these categories and the price that consumers pay for the category of OTC drugs. On the other hand, there appears to be a correlation with miscellaneous goods and services, alcoholic beverages and tobacco, restaurants and hotels, education, clothing and footwear and recreation and culture.

Nevertheless, the hypothesis that there is an inverse linear relationship between the consumer price index (CPI) of OTC drugs and the categories with the highest weight in the COICOP calculation was finally rejected. Although there is an inverse relation between the correlation coefficient of the OTC drugs category and some of the categories with the highest weights, it is not a general rule applicable to all categories. The inverse relationship is visible in the category of food and non-alcoholic beverages (180.6 category weight) and transport category (100.9 category weight). On the contrary, the strong relation appears mainly in the category of alcoholic beverages and tobacco ( 93.4 category weight).

Therefore, this data examination has not uncovered an obvious rule applying to all categories and clearly predicting the future success of OTC drugs sales when consumers are forced to allocate a significant proportion of their budget to other areas. However, these findings are preliminary and future study shall examine consumer motivators (not only price) for purchasing private label OTC drugs in detail.

\subsection{Limitations and Future Research}

The limitations of this study should be noted. Firstly, the results of this paper only include data from the Czech market. Possible follow-up research could expand on an international level. Secondly, future research could focus on different periods of time, possibly without the Czech 
National Bank foreign exchange interventions. Finally, a deeper look into similar existing research in other countries and markets could also further improve future studies in this field.

\section{Acknowledgment}

The author would like to thank the Internal Grant Agency of FaME for providingfinancial support to carry out this research. Funding was extended through: TBU No.IGA/FaME/2018/002 - Using of Marketing 4.0 principles for customer relationship management in the Czech Republic.

\section{References}

Akçura, M. T., Gönül, F. F., \& Petrova, E. (2004). Consumer Learning and Brand Valuation: An Application on Over-the-Counter Drugs. Marketing Science, 23(1), 156-169. doi:10.1287/mksc. 1030.0028

Bulmer, M. G. (1979). Principles of statistics. New York: Dover publ.

Czech National Bank. (2017, October 23). Účet za devizové intervence nám ekonomika již vystavila. Cnb.cz, Retrieved from https://www.cnb.cz/cs/verejnost/pro_media/clanky_rozhovory/media_2017/cl_17_171 023_tomsik_vlcek_bankovnictvi.html

Czech Statistical Office. (2017). Indexy potřebitelských cen [Brochure]. CSO. December 4, 2017, from https://www.czso.cz/documents/10180/26822363/manual_isc_2017.pdf/ 1a05920c-f2fc-4215-9622-43f2a58664ee?version=1.1

Czech Statistical Office. (2017). Index spotřebiteských cen [data from the questionnaire survey]. Retrieved December 4, 2017. data is not publicly available

Čechová, R. (2013, April 27). Penta uvede na trh vlastní léky a investuje do svých obchodů. MarketingSalesMedia, Retrieved from https://marketingsales.tyden.cz/rubriky/trhy/penta-uvede-na-trh-vlastni-leky-ainvestuje-do-svych-obchodu_268503.html

Gao, X., An, H., \& Zhong, W. (2013). Features of the Correlation Structure of Price Indices. PLoS ONE, 8(4). doi:10.1371/journal.pone.0061091

Gönül, F. F. (1998). Estimating price expectations in the OTC medicine market: An application of dynamic stochastic discrete choice models to scanner panel data. Journal of Econometrics, 89 (1-2), 41-56. doi:10.1016/s0304-4076(98)00054-2

Hesková, M. (2006). Category management. Praha: Profess Consulting.

Hrdličková, L., Bednařík, R. (2014, July 18). Lékárenské sítě učí lidi kupovat "bílý ibuprofen". Ihned.cz, Retrieved from https://archiv.ihned.cz/c1-62526570-lekarenskesite-uci-lidi-kupovat-bily-ibuprofen

Narayanan, S., \& Manchanda, P. (2007). Heterogeneous Learning and the Targeting of Marketing Communication for New Products. SSRN Electronic Journal. doi:10.2139/ssrn.935339

Pearson, K. (1895). Note on Regression and Inheritance in the Case of Two Parents. Proceedings of the Royal Society of London (1854-1905), 58(-1), 240-242. doi:10.1098/rspl.1895.0041 
Sadílek, T (2016). Analysis of Buying Behaviour on the Food Supplement and Over the Counter Drugs Market. Emijournal, 8 (2), 58-65. Retrieved from http://www.emijournal.cz/

State Institut for Drug Control. (2015, February 17). Hodnocení distribuovaných a vydaných léčivých př́pravků za rok 2014. SÚKL. Retrieved from http://www.sukl.cz/hodnocenidodavek-distribuovanych-lecivych-pripravku-za-rok-4

State Institut for Drug Control. (2016, February 12). Hodnocení distribuovaných a vydaných léčivých prŕípravků za rok 2015. SÚKL. Retrieved from http://www.sukl.cz/hodnocenidistribuovanych-a-vydanych-lecivych-pripravku-za

State Institut for Drug Control. (2017, February 15). Hodnocení distribuovaných a vydaných léčivých prŕípravků za rok 2016. SÚKL. Retrieved from http://www.sukl.cz/hodnocenidistribuovanych-a-vydanych-lecivych-pripravku-za-1

State Institut for Drug Control. (2018, April 5). Hodnocení distribuovaných a vydaných léčivých př́ípravků za rok 2017. SÚKL. Retrieved from http://www.sukl.cz/hodnocenidistribuovanych-a-vydanych-lecivych-pripravku-za-2

State Institut for Drug Control. (2016). Související informace. SÚKL. Retrieved April 4, 2018 , from http://www.sukl.cz/souvisejici-informace-2

State Institut for Drug Control. (2016). Informace o distribuci léčiv lékárnám, jiným zdravotnickým zařízením a prodejcům vyhrazených léčiv [Brochure]. SÚKL. Retrieved April 18, 2018, from https://www.czso.cz/csu/czso/vysledky-zdravotnickych-uctu-cr2016

Švihovec, J. (2000). Volně prodejná léčiva: Význam pro samoléčení, propagace, registrace, prodej. Praha: Panax.

Thomassen, L., Aconis, A., \& Lincoln, K. (2009). Retailization: Brand survival in the age of retailer power. London: Kogan Page. Wieringa, J. E., Reber, K. C., \& Leeflang, P. (2015). Improving pharmacy store performance: The merits of over-the-counter drugs. European Journal of Marketing, 49(7/8), 1276-1299. doi:10.1108/ejm-06-20130331

Zhou, Z., Xue, Y., \& Ping, Q. (2012). Private label drugs in China: The consumer perspective. International Journal of Pharmaceutical and Healthcare Marketing, 6(2), 124-139. doi:10.1108/17506121211243059

\section{Contact Information}

Ing. Eva Loubalová

Tomas Bata University in Zlin, Faculty of Management and Economics

Mostni 5139, 76001 Zlin

University: +420 576032120

Eva Loubalova: +420737864879

Eva.loubalova@seznam.cz

ORCID: 0000-0003-3997-338X

DOI ID: https://www.doi.org/10.7441/dokbat.2018.15 


\title{
SOCIAL MEDIA: NEW CHANNEL OF INTERNAL COMMUNICATION FOR EMPLOYEE ENGAGEMENT?
}

\author{
Lien. H.L. Nguyen and Aleš Gregar
}

\begin{abstract}
This paper aims to fill the gap in the literature review of internal communication and employee engagement in the age of social media and then, proposes a conceptual model of using social media channel in internal communication for enhancing employee engagement. Qualitative methodology is adopted by reviewing and analysing research papers related to the following terms: "social media", "internal communication", and "employee engagement". The result of this study is the conceptual model based on three hypotheses, including social media usage on employee engagement directly and indirectly through mediating variable "perceived organizational support". This positive result intends to encourage managers and employers to allowing using social media among employees as an internal communication tool. However, regarding the reliability, it is essential to collect data and do empirical research based on this model.
\end{abstract}

Keywords: Employee engagement, internal communication, social media, conceptual framework

\section{INTRODUCTION}

Employee engagement is always the concern of managers and employers due to its potential consequences, such as enhancing employee loyalty, employee productivity and performance (Sievert \& Scholz, 2017). Therefore, boosting employee engagement is still a hot topic both in theory and practice. According to previous studies, internal communication is one of the main factors in employee engagement improvement in an organizational context (Karanges et al., 2015; Sievert \& Scholz, 2017). Through internal communication, employees develop their relationship with supervisors and, co-workers and become more involved in the organizational culture. Moreover, with good internal communication, employees will know their roles and their responsibilities, which will help them to better reach the objectives of organization and improve their performance.

However, in the era of digitalization where internal communication is influenced by technology, choosing a communication strategy for improving employee engagement is not an easy question for communicators, managers and academics. The world has witnessed how quickly social media has grown in the last two decades since its first introduction to users in 1997 (Ellison, 2008). Along with this exponential growth, companies realized and applied social media in internal communication (Burgess, 2014). Large companies built enterprise software for internal social media and encourage employees to use social media externally as well. Although they generally recognize the benefits of social media, especially for employee engagement, studies in recent years have identified an unpleasant result that many companies, especially small and medium-sized enterprises, fail in using social media internally (Sievert \& Scholz, 2017).

Replying to the call for more studies in facilitating social media internally (Bridger, 2015; Kluemper, Mitra \& Wang, 2016), this study investigates the role of social media in internal communication to improve employee engagement. Additionally, despite the important influences of social media, the author found that there is still a limited number of studies focusing on social media in internal communication and employee engagement. Therefore, this paper will fill the gap with the proposed conceptual framework of social media communication 
for employee engagement improvement and explain how social media, as a new channel of internal communication, can influence employee engagement.

\section{LITERATURE REVIEW}

\subsection{Employee engagement}

Employee engagement has been identified in many different ways, including "the needssatisfying approach, the burnout-antithesis approach, the satisfaction-engagement approach and the multidimensional approach" (Truss et al, 2014).

When employee engagement was firstly introduced, Katz and Kahn (1978) described it as the act of engaging "in occasional innovative and cooperative behaviour beyond the requirements of the role but in the service of organizational objectives". Later, Kahn (1990) further specified the three psychological conditions of an engaged employee: meaningfulness, safety and availability. Based on Kahn's work, many engagement scholars further developed the construct of "employee engagement". For example, a team of academics in Britain (Truss et al., 2006) characterised employee engagement as having three dimensions: emotional, cognitive and physical, which later became fundamental for communication scholars building the relationship between employee engagement and internal communication (Welch, 2011).

Another common definition of employee engagement is by organizational psychologists, Schaufeli and Bakker (2004). For them, employee engagement is "a positive, fulfilling, workrelated state of mind that is characterised by vigour, dedication, and absorption. Rather than a momentary and specific state, engagement refers to a more persistent and pervasive affectivecognitive state that is not focused on any particular object, event, individual, or behaviour". In another way, this concept is about long-term intrinsic motivation, not created by external factors. In particular, vigour, the first state of mind, is specified to be persistent even when suffering work-related difficulties and always to be energetic while working. Next, dedication is described as a state of mind in which an employee is strongly involved in their work and expresses "a sense of significance, enthusiasm, inspiration, pride and challenge". Last but not least, absorption is identified as being focusing completely and happily into work, regardless of obstacles (Schaufeli et al., 2002; Schaufeli \& Baker, 2004). Due to these good characteristics, engaged employees are highly sought after.

Along with these academic views, in practice, employee engagement by Gallup firm is defined as "the right people in the right roles with the right managers drive employee engagement" in their business book (Buckingham \& Coffman, 2005). The Gallup organization also created a 12 question workplace questionnaire for measuring employee engagement in organizations. Buckingham and Coffman (2005) evaluated the person who says yes to all these 12 questions as an engaged employee.

In each view, employee engagement is characterised and measured differently but it has a common point that engaged employee is considered to willingly work harder for performance improvement, think positively about jobs and organizations, and actively discuss with coworkers and supervisors about work-related issues (Bridger, 2015). Those positive attitudes are the causes to performance improvement, employee loyalty and productivity (Moqbel,Nevo and Kock, 2013; Parry and Solidora, 2014; Sievert and Scholz, 20170

\subsection{Social media and internal communication}

In organizational context, internal communication is described as "approaches by a company to communicate their employees" (Cornelissen, 2017). Given this definition, an effective internal 
communication strategy is extremely necessary and it is because employees are motivated and delivered essential information on time, which leads to better performance (Hola \& Pikhart, 2014). Furthermore, knowledge sharing, motivations and teamwork in the organization is also fostered with the good internal communication implementation. However, internal communication is a never-ending challenge due to geographical obstacles and misunderstanding, which needs the action of expert communicators and organizations. In the past, common channels of internal communication were face-to-face, writing and web 1.0 platform. With face-to-face and writing channels, misunderstanding and slow information transfer were the hug troubles in large companies which had many branches in different locations. Then, Web 1.0, including text message and e-mail, pushed internal communication forward and improved the speed of information transfer. However, this is only linear way so that mail goes back and forth only. They also are not supported in the large and interactive networks (McFarland \& Ployhart, 2015). Those encourage employers searching more technology to deliver message smoothly and reduce the noise of communication.

Going with the growth of technology, internal communication now moves further with the help of social media as an electronic channel. One of the commonly accepted definitions by Kaplan and Haenlein (2010) is that social media is " a group of Internet-based applications that build on the ideological and technological foundations of Web 2.0 and that allow the creation and exchange of User Generated Content.' 'Thus, using social media platforms, users can have twoway dialogues and share digital content with other users faster than Web 1.0 platform. Comparing with Web 1.0, social media also allows people share knowledge effectively and foster the collaboration within groups (McFarland \& Ployhart, 2015) because many users can interact with one post at the same time and they even can edit the content of this post. McFarland and Ployhart (2015) summed up some characteristics which differ social media from other channels of internal communication: physicality (barriers of geography and weather are reduced), accessibility (more open access for users), latency (faster sharing speed), interdependence (information is shared in a wider range), synchronicity (either synchronous or asynchronous), permanence (content is permanent on social media), verifiability (easy to verify) and anonymity (users are anonymous). Those are promising features for an effective internal communication channel and as a result, many companies invested in their own software as enterprise social networking or facilitate public social networking sites, such as: Facebook at work and LinkedIn. Some companies which are successful in implementing social media at work are listed as following: IBM, McDonald, Texas Instrument Industry and some other large companies (Arjomandy, 2016).

To sum up, social media is believed strongly to improve the quality of internal communication much more than other channels. Even, it is essential for companies to implement soon because the Generation Y, who were born between 1982 and 2000 and have grown up with internet (King, 2008), is now in the labour force. On other hand, social media has itself so many risks, especially in data control. Additionally, many companies felt in using social media for internal communication (from now, it is referred with "social media communication") effectively and others are looking forward to implementing but do not know where to start. Hence, it is important to conduct more researches on the strategy of facilitating social media in companies.

\subsection{Perceived organizational support}

Perceived organization support is defined as the beliefs of employees that their organization appropriates their contributions and cares about their health and safety (Rhoades and Eisenberger, 2002). This definition is originated from the Organizational Support Theory (Eisenberger, Huntington, Hutchison, \& Sowa, 1986), which explains that employee perceives organization as humanlike characteristics and thus, they will consider treatments from 
organization as indicator for favours or non-favours to them. Employees will perceive the supports from organization through treatments from supervisors, organizational polices, norms and culture (Levinson, 1965). From then, they will feel a sense of connection to organizations. From previous studies, perceived organizational support has been found to be the antecedence of organizational commitment, performance and employee engagement (Rhoades and Eisenberger, 2002; Saks, 2006). The relationship between perceived organizational support and those concepts is explained with the Social Exchange theory (Emerson, 1976), which said that employees receive the support from organization, they will return back their good attitudes and better performance, in particular: employee engagement, performance, loyalty and commitment.

\subsection{Organizational culture and leadership style}

There is the disagreement in defining and measuring the concept organization culture. However, all researchers seem to agree that organizational culture is one of the main factor to commitment and performance (Ogbonna and Harris, 2011). In this study, organizational culture is defined simply as the expectations, norms and values which are shared within organization (Geertz, 1973; Smircich, 19830). Usually, in organization, they would seek potential applicants who share the similar values and norms with them. All of those create the organizational culture with specific characteristics.

Leadership style plays the important roles in management field because its consequences are the performance and employee engagement (Ogbonna and Harris, 2011). Leadership has a long history with different important phases and components. In this study, leadership style is considered simply as the adopted behaviour and style of leaders, based on the approach by Hemphill and Coons (1957).

\section{METHODOLOGY}

This study adopted the qualitative research in which technique for data collection and data analysis is secondary data. Secondary data method is recommended for studies of framework because it is highly reliable, inexpensive and useful for exploration (Tashakkori \& Teddlie, 2010). Those features of this method meet the purposes of this study which are to explore the role of social media and to propose the conceptual framework.

Secondary data for this study are articles and papers related social media, employee engagement and internal communication from Scopus and Web of Science. The reason for those sources are their reliability and the huge range of covered topics (Falagas et al., 2008). Those selected articles in this study have to meet those following requirements:

- Qualitative or quantitative research paper based on primary data or secondary data.

- Consisting of those keywords: social media, employee engagement and internal communication.

These mentions about social media should be published within lately 5 years (2013 2018) so that it can update the new trends in the field. Moreover, the period of time is controlled because this paper focuses only on the latest trend - social media in internal communication.

After all, 20 articles from two main databases: Scopus and Web of Science were reviewed and analysed for exploring the role of social media and building framework. (Table 1) 
Table 12 the overview of analysed articles for conceptual framework. Source: own research

\begin{tabular}{|c|c|c|c|}
\hline No. & Author & Research design & Kinds of social media \\
\hline 1 & Moqbel, Nevo and Kock (2013) & Quantitative & Public social media \\
\hline 2 & Badea (2014) & Quantitative & Public social media \\
\hline 3 & Charoensukmongkol (2014) & Quantitative & Public social media \\
\hline 4 & $\begin{array}{l}\text { Leftheriotis and Giannakos } \\
\text { (2014) }\end{array}$ & Quantitative & Public social media \\
\hline 5 & Parry and Solidoro (2014) & Qualitative & Both types \\
\hline 6 & Sedej and Justinek (2014) & Qualitative & Both types \\
\hline 7 & Ainin and et.al. (2015) & Quantitative & Public social media \\
\hline 8 & $\begin{array}{l}\text { Ali-Hassan, Nevo \& Wade } \\
\text { (2015) }\end{array}$ & Quantitative & Public social media \\
\hline 9 & $\begin{array}{l}\text { Gibbs, MacDonald and MacKay } \\
\text { (2015) }\end{array}$ & Quantitative & Both types \\
\hline 10 & Korzynski (2015) & Quantitative & Both types \\
\hline 11 & Men \& Hung-Baesecke (2015) & Quantitative & Both types \\
\hline 12 & Ngai, Tao and Moon (2015) & Quantitative & Both types \\
\hline 13 & Alqahtani and Abunadi (2016) & Qualitative & Enterprise social media \\
\hline 14 & Charoensukmongkol (2016) & Quantitative & Public social media \\
\hline 15 & $\begin{array}{l}\text { Ter Hoeven, van Zoonen and } \\
\text { Fonner (2016) }\end{array}$ & Quantitative & Public social media \\
\hline 16 & King and Lee (2016) & Qualitative & Both types \\
\hline 17 & Naim and Lenka (2017) & Quantitative & Enterprise social media \\
\hline 18 & Madsen (2017) & Qualitative & Enterprise social media \\
\hline 19 & $\begin{array}{l}\text { van Zoonen, Verhoeven and } \\
\text { Vliegenthart (2017) }\end{array}$ & Quantitative & Public social media \\
\hline 20 & Sievert and Scholz (2017) & Quantitative & Enterprise social media \\
\hline
\end{tabular}

\section{FINDINGS}

After reviewing and analysing articles related to social media, employee engagement and internal communication, some significant findings should be pointed out and discussed further. The positive relationship between employee engagement and social media exists. However, there are some factors influencing this relationship, which companies should pay more attention. At the end of this discussion, a conceptual framework will be proposed for using social media to enhance employee engagement.

Social media communication positively influences employee engagement 
As a typical tool of internal communication, social media connect employees and employers in the organizations together and communication among those now will become more interactive (Arjomandy, 2016). With horizontal communication, employers can use social media to spread vision and objectives as from top to down. On the contrast way, employees can raise their voice to employers with the characteristics of anonymity (Parry \& Solidoro, 2014; Arjomandy, 2016). With the vertical communication, employees now do not only contact with co-workers in the same location, they even can get in touch and update information from the huge range of colleagues in other corners of the world (Sedej \& Justinek, 2014). On the other hand, previous studies proved that determinants of employee engagement are employee voice and dialogue (Parry \& Solidoro, 2014; Bridger, 2015). Thus, with social media channel, internal communication is expected to be more effective and turns into two-way communication, which helps employee easily raise their voice and their concerns to employers. On the other hand, the employers can response to employees more quickly and conduct effective dialogue within organizations. From then, social media communication in internal communication is suggested to have the positive impacts on employee engagement, thanks to advantages of two-way dialogue and anonymity.

Hypothesis 1: Social media communication positively associates with employee engagement.

Besides that, social media allows users to join forum or online group and then they can contact and receive supports without the impacts of geographical barriers. Therefore, when implementing in organization, social media communication enhances the organizational support from supervisors and co-workers to employees. Consequently, those perceived organizational support as job resources in the job demand-resources model increases employee engagement (Truss et al., 2014). Another kind of perceived organizational support from social media communication is the knowledge sharing through Web 2.0 platform (Paroustis \& Saleh, 2009; Ali-Hassan, Nevo \& Wade, 2015). It is easier to share knowledge on blog, forum and websites so that any employees in the same company can access the knowledge source.

Hypothesis 2a: Social media communication positively associates with perceived organizational support.

Hypothesis 2b: Perceived organizational support positively associates with employee engagement.

Factors influencing the relationship between employee engagement and social media communication

Despite the positive association between social media and employee engagement, there are two main factors, including organizational culture and leadership, which should be considered before using social media (Parry \& Solidoro, 2014; Sedej and Justinek, 2014). Social media is more democratic than other internal communication channels because of its anonymity. As asked about social media usage, employees expressed the fear of speaking up things on social media because of its "unsafety" (Parry \& Solidoro, 2014). An opened leadership style and organizational culture is demanded to reduce this fear, which will encourage more employees to speak, engage and improve performance. In another way, leadership and organizational culture are moderating variables in the relationship between employee engagement and social media communication.

Hypothesis 3a: As the safety of organizational culture and openness of leadership style increase, social media communication associates with employee engagement more positively.

Hypothesis 3b: As the safety of organizational culture and openness of leadership style increase, social media communication associates with perceived organizational support more positively. 
Hypothesis 3c: As the safety of organizational culture and openness of leadership style increase, perceived organizational support associates with employee engagement more positively.

\section{Conceptual model}

Discussion about employee engagement and social media results in the following conceptual framework (figure 1), which presents the idea how social media can have positive impacts on employee engagement under the consideration of some variables. Also, this view is interpreted in the employee level.

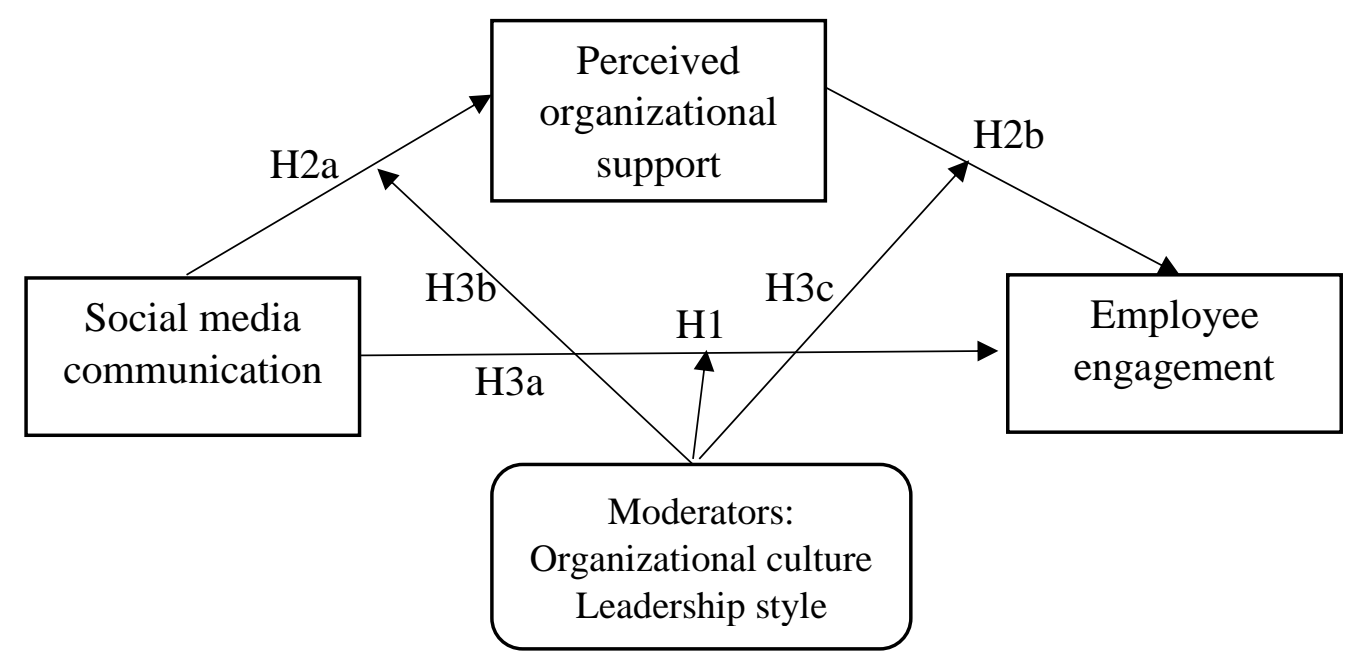

Figure 12 - The conceptual framework between social media communication and employee engagement.

Source: Own research

\section{DISCUSSION AND CONCLUSION}

Overall, the results presented the conceptual model of using social media internally to improve employee engagement. The results are supported by the results from previous studies. Social media should be examined in different aspects, such as: benefits of internal social media usage, individual usage and the frequency of usage. When organizations use social media internally for communication, employees are believed to feel connected to organizations and then improve their engagement. Also, they can use social media freely, they can balance their work-life and as consequences, increase engagement too. Employee engagement should be examined in the whole three aspects: vigour, dedication, and absorption. So, the researchers can have clear results of the impacts by social media communication. Perceived organizational support in this conceptual model should be considered from supervisor supports and co-worker supports in the further researches. The moderating variables: organizational culture and leadership style are considered only as dimensional concept to find the effects on other main relationships in this study.

The findings of this study supported the relationship between social media communication and employee engagement. The relationship is built based on the theory of internal communication and employee engagement. Social media communication positively has impacts on employee engagement in the direct way and through perceived organizational support. This result contributes to the internal communication literature review in the new era of technology but also encourage managers and practitioners to facilitate social media at work. Social media is not only technology if we can facilitate effectively and have a good communication strategy. Nevertheless, managers should have an opened leadership style and organizational culture first before promoting social media usage internally. Also, it is important for employers to be aware 
that employees may only waste time of social media (Khosla, 2016) while defining the social media communication strategy for employee engagement.

On the other hand, two main limitations of this study are that the results are not from empirical data analysis and it may overlook some details in this relationship. These limitations come from the chosen method, secondary data (Tashakkori \& Teddlie, 2010). Hence, it is necessary to conduct further researches with empirical data to generalize the results. Moreover, it is important to consider more variables in this conceptual model, such as: employee satisfaction, employee communication needs, employee performance and so employee-related variables.

\section{Acknowledgement}

The research for this paper was financially supported by the Internal Grant Agency of Faculty of Management and Economics, Tomas Bata University in Zlín, grant No.IGA/FaME/2018/009

\section{References}

Ainin, S., Parveen, F., Moghavvemi, S., Jaafar, N. I., \& Mohd Shuib, N. L. (2015). Factors influencing the use of social media by SMEs and its performance outcomes. Industrial Management \& Data Systems, 115(3), 570-588. https://doi.org/10.1108/IMDS-072014-0205

Ali-Hassan, H., Nevo, D., \& Wade, M. (2015). Linking dimensions of social media use to job performance: The role of social capital. The Journal of Strategic Information Systems, 24(2), 65-89. https://doi.org/10.1016/j.jsis.2015.03.001

Alqahtani, F. H., \& Abunadi, I. (2016). Participating in the Enterprise Web 2.0 Platform: The Influence of Trust. Journal of Organizational and End User Computing (JOEUC), 28(3), 31-48. https://doi.org/10.4018/JOEUC.2016070103

Arjomandy, D. (2016). Social media integration in electronic human resource management: Development of a social eHRM framework. Canadian Journal of Administrative Sciences / Revue Canadienne des Sciences de 1Administration, 33(2), 108-123. https://doi.org/10.1002/cjas.1380

Badea, M. (2014). Social media and organizational communication. Procedia-social and behavioral sciences, 149, 70-75. https://doi.org/10.1016/j.sbspro.2014.08.192

Bridger, E. (2015). Employee engagement. London: Kogan Page.

Buckingham, M., \& Coffman, C. (2005). First, break all the rules: what the world's greatest managers do differently. New York.

Burgess, C. (2014). The Social Employee: How Great Companies Make Social Media Work. McGraw-Hill.

Boyd, D. M., \& Ellison, N. B. (2007). Social Network Sites: Definition, History, and Scholarship. Journal of Computer-Mediated Communication, 13(1), 210-230. /https://doi.org/10.1111/j.1083-6101.2007.00393.x

Charoensukmongkol, P. (2014). Effects of support and job demands on social media use and work outcomes. Computers in Human Behavior, 36, 340-349. https://doi.org/10.1016/j.chb.2014.03.061 
Charoensukmongkol, P. (2016). Mindful Facebooking: the moderating role of mindfulness on the relationship between social media use intensity at work and burnout. Journal of health psychology, 21(9), 1966-1980. https://doi.org/10.1177/1359105315569096

Cornelissen, J. (2017). Corporate communication: a guide to theory and practice. Thousand Oaks, CA: SAGE Publications.

Eisenberger, R., Huntington, R., Hutchison, S., \& Sowa, D. (1986). Perceived organizational support. Journal of Applied Psychology, 71, 500-507. https://doi.org/10.1037/00219010.71.3.500

Emerson, R.M. (1976) Social Exchange Theory. Annual Review of Sociology, 2, 335-362. https://doi.org/10.1146/annurev.so.02.080176.002003

Falagas, M. E., Pitsouni, E. I., Malietzis, G. A., \& Pappas, G. (2008). Comparison of PubMed, Scopus, Web of Science, and Google Scholar: strengths and weaknesses. The FASEB Journal, 22(2), 338-342. https://doi.org/10.1096/fj.07-9492LSF

Khosla, V., Social media affecting workplace productivity: Report. (2016, October 18). Retrieved August 02, 2017, from https://economictimes.indiatimes.com/jobs/socialmedia-affecting-workplace-productivity-report/articleshow/54915706.cms

Geertz, C. 1973. The interpretation of cultures. New York: Basic Books.

Gibbs, G., MacDonald, F., \& MacKay, K., (2015), Social media usage in hotel human resources: recruitment, hiring and communication, International Journal of $\begin{array}{lllll}\text { Contemporary Hospitality } \quad \text { Management, } & 27(2), \quad 170 \quad-\quad 184\end{array}$ https://doi.org/10.1108/IJCHM-05-2013-0194

Hemphill, J.K. and Coons, A.E. (1957) 'Development of the Leader Behaviour Description Questionnaire '. In Stogdill, R.M. and. Coons, A.E. (eds) Leadership Behaviour: Its Description and Measurement. Columbus, OH: The Ohio State University, Bureau of Business Research.

Holá, J., \& Pikhart, M. (2014). The implementation of internal communication system as a way to company efficiency. E M Ekonomie a Management, XVII(2), 161-169. https://doi.org/10.15240/tul/001/2014-2-012

Kahn, W. A. (1990). Psychological Conditions Of Personal Engagement And Disengagement At Work. Academy of Management Journal, 33(4), 692-724.

Kaplan, A. M., \& Haenlein, M. (2010). Users of the world, unite! The challenges and opportunities of Social Media. Business Horizons, 53(1), 59-68. https://doi.org/10.1016/j.bushor.2009.09.003

Karanges, E., Johnston, K., Beatson, A., \& Lings, I. (2015). The influence of internal communication on employee engagement: A pilot study. Public Relations Review, 41(1), 129-131. https://doi.org/10.1016/j.pubrev.2014.12.003

Katz, D., \& Kahn, R. L. (2015). Organizations and the system concept. In Classics of organization theory (8th ed., pp. 347-358). Boston: Cengage Learning.

King, S. (2008) Virtual mobility - Future trend. In G. Ginsberg (Ed.), Melcrum's top 50 internal communication case studies: An anthology of best-selling research to tackle key communication issue. London: Melcrum Publishing Limited.

King, C. \& Lee, H. (2016). Enhancing internal communication to build social capital amongst hospitality employees - the role of social media, International Journal of Contemporary 
Hospitality Management, 28, 2675-2695. https://doi.org/10.1108/IJCHM-06-20150321

Kluemper, D. H., Mitra, A., \& Wang, S. (2016). Social Media use in HRM. Research in Personnel and Human Resources Management, 153-207. https://doi.org/10.1108/S0742-730120160000034011

Korzynski, P. (2015). Online networking and employee engagement: what current leaders do?. Journal of Managerial Psychology, 30(5), 582-596. https://doi.org/10.1108/JMP-102013-0344

Leftheriotis, I. \& Giannakos, M.M. (2014). Using social media for work: Losing your time or improving your work?, Computers in Human Behavior, 31, 134-142.

Levinson, H. (1965). Reciprocation: The relationship between man and organization. Administrative Science Quarterly, 9 (4), 370-390.

Madsen, V.T. , (2017)," The challenges of introducing internal social media - the coordinators' roles and perceptions ", Journal of Communication Management, 21(1), 2 - 16

Men, L.R. \& Hung-Baesecke, C.F., (2015). Engaging employees in China: The impact of communication channels, organizational transparency, and authenticity, Corporate Communications: An International Journal, 20(4), https://doi.org/10.1037/a0039244

Men, L.R. \& Tsai, W.S. (2013), "Beyond liking or following: understanding public engagement on corporate social media in China", Public Relations Review, 39, 13-22. https://doi.org/10.1016/j.pubrev.2012.09.013

Mcfarland, L. A., \& Ployhart, R. E. (2015). Social media: A contextual framework to guide research and practice. Journal of Applied Psychology, 100(6), 1653-1677. https://doi.org/10.1108/ITP-10-2012-0110

Moqbel, M., Nevo, S., \& Kock, N. (2013). Organizational members' use of social networking sites and job performance. Information Technology \& People, 26(3), 240-264. https://doi.org/10.1037/a0039244

Naim, M. F., \& Lenka, U. (2017). The impact of social media and collaboration on Gen Y employees' engagement. International Journal of Development Issues, 16(3), 289-299. https://doi.org/10.1108/IJDI-04-2017-0041

Ngai, E. W., Tao, S. S., \& Moon, K. K. (2015). Social media research: Theories, constructs, and conceptual frameworks. International Journal of Information Management, 35(1), 33-44. https://doi.org/10.1016/j.ijinfomgt.2014.09.004

Ogbonna, E., \& Harris, L. C. (2000). Leadership style, organizational culture and performance: Empirical evidence from UK companies. The International Journal of Human Resource Management, 11(4), 766-788. https://doi.org/10.1080/09585190050075114

Paroutis, S., \& Saleh, A. A. (2009). Determinants of knowledge sharing using Web 2.0 technologies. Journal of Knowledge Management, 13(4), 52-63.

Parry, E., \& Solidoro, A. (2013). Social Media as a Mechanism for Engagement? Social Media in Human Resources Management Advanced Series in Management, 121-141. https://doi.org/10.1108/13673270910971824

Rhoades, L., \& Eisenberger, R. (2002). Perceived organizational support: a review of the literature. Journal of applied psychology, 87(4), 698. https://doi.org/10.1037/00219010.87.4.698 
Tashakkori, A., \& Teddlie, C. (2010). SAGE Handbook of Mixed Methods in Social \& Behavioral Research. London: SAGE. https://doi.org/10.4135/9781506335193

Ter Hoeven, C. L., van Zoonen, W., \& Fonner, K. L. (2016). The practical paradox of technology: The influence of communication technology use on employee burnout and $\begin{array}{llll}\text { engagement. } & \text { Communication }\end{array}$ https://doi.org/10.1080/03637751.2015.1133920

Truss, C. (2014). Employee engagement in theory and practice. London: Routledge, Taylor \& Francis Group.

Saks, Alan M. Antecedents and consequences of employee engagement. Journal of managerial psychology, 2006, 21.7: 600-619. https://doi.org/10.1108/02683940610690169

Schaufeli,W.B., et al. (2002). The measurement of engagement and burnout: A two sample confirmatory factor analytic approach. Journal of Happiness studies, 3(1), 71-92. https://doi.org/10.1023/A:1015630930326

Schaufeli, W. B., \& Bakker, A. B. (2004). Job demands, job resources, and their relationship with burnout and engagement: a multi-sample study. Journal of Organizational Behavior, 25(3), 293-315. https://doi.org/10.1002/job.248

Sedej, T., \& Justinek, G. (2013). Social Media in Internal Communications: A View from Senior Management. Social Media in Human Resources Management Advanced Series in Management, 83-95. https://doi.org/10.1108/S1877-6361(2013)0000012008

Sievert, H., \& Scholz, C. (2017). Engaging employees in (at least partly) disengaged companies. Results of an interview survey within about 500 German corporations on the growing importance of digital engagement via internal social media. Public Relations Review, 43(5), 894-903. https://doi.org/10.1016/j.pubrev.2017.06.001

Smircich, L. (1983). Concepts of culture and organizational analysis. Administrative science quarterly, 28(3), 339-358. https://doi.org/10.2307/2392246

van Zoonen, W., Verhoeven, J. W., \& Vliegenthart, R. (2017). Understanding the consequences of public social media use for work. European Management Journal, 35(5), 595-605. https://doi.org/10.1016/j.emj.2017.07.006

Welch, M. (2011). The evolution of the employee engagement concept: communication implications. Corporate Communications: An International Journal, 16(4), 328-346. https://doi.org/10.1108/13563281111186968

\section{Contact information}

Ing. Lien.H.L.Nguyen

Tomas Bata University in Zlin

Faculty of Management and Economics

Nám. T. G. Masaryka 5555, 76001 Zlín

+420778 821828

Email: lnguyen@utb.cz

ORCID: 0000-0002-7527-6453

DOI ID: https://www.doi.org/10.7441/dokbat.2018.16 


\title{
ASSESSMENT OF EFFICIENCY IN GOVERNMENT SERVICES DELIVERY THROUGH E-PLATFORM IMPLEMENTATION? EVIDENCE FROM KENYA
}

\author{
Patrick Asango Okanga, Ho Thanh Tri, Nguyen Thi Bich Thuy
}

\begin{abstract}
Digital service innovations play an important role in service delivery in our day-to-day lives, particularly in public sector service delivery. socio-economic sectors such as finance, health, education, agriculture and Governments are quickly embracing technology for dissemination of information, enhancement of service delivery and reaching their customers more effectively and efficiently. The aim of e-government is to provide a digital platform for improving communication and information access from government to citizens and vice versa. The Government has identified the potential of ICT in driving the economy and has embarked on several transformative ICT initiatives. This study uses literature review to focuses on Kenya's public sector digital service innovations. It looks into challenges encountered on the digital platform, and the fact that this platform has not realized the objective of maximizing service delivery to the public. A number of factors and situations which has resulted into inefficiency arising from digital divide among other factors has been mentioned along other recommendations.
\end{abstract}

Keywords: Efficiency, Government service, e-Platform, JEL Code: B23, B26

\section{INTRODUCTION}

The application of information and communication technology remains the central focus of reference in modern service delivery and network connections. For any institution to remain relevant and competitive, it must go digital, irrespective whether it is a private or public enterprise. Therefore, the digital service platform must be developed nearly by all institutions to uplift their level and value of service or product delivery. In such circumstance, government sector service delivery network (E-Government) must be made to be active and running.

E-government involves the application of information technology like the area network, internet and even mobile computing to improve and diversify the quality of service delivery to citizens and to the business community (Compeau, Higgins 1995, Lin, Fofanah et al. 2011). This is a platform created by government to digitize the services and establish more effective communication between itself and the general citizens (Lin, Fofanah et al. 2011).

Generally, there is a serious concern from the managers of public services to address the cost of service delivery without necessarily compromising on its quality and efficiency, . It has been observed that the approach to manage public affairs by governments of developing countries has shifted from traditional approach of bureaucracy to citizen driven through information revolution. (Nguluba, 2007) such digital wind is blowing all over global continents.

Views in many sub-Saharan Africa countries is that government digital service innovation in the public sector is a political affair and not a technical challenge, requiring a professional attention Nguluba, (2007) 
Even though digital government services are aimed at being inclusive in terms of service dissemination, there exist a number of inequality in terms of enabler distributions and other hindrances which does not allow efficiency to prevail (Belanger 2012).

Digital divide is conceived as a key factor which degrades efficiency in the working of government, it exists in most of the countries and it reflect on the gap existing between those categories of citizens who can access the ICT and those who cannot due to certain socioeconomic or some other reasons (Cullen 2001).

The paper focuses on the literature review on e-government platform in Kenya. It looks into various innovations which the country has put in place to ultimately open up efficient government public interaction. It finally looks into the possible reasons impeding the digital service delivery and discusses some possible solutions as way forward to improving the digital service delivery.

\subsection{Statement of a problem}

Government of Kenya has constantly struggled to improve on the quality and efficiency of public service delivery to its citizens since the independence from the colonial government in 1963 This situation has called for a number of government initiative reforms in the civil service ranging from periodic training of government workers, setting of a number of government training institutions and intergovernmental exchange programmes. The desire to provide more efficient public service resulted into setting up of an e-government platform in 2004, to further efficiency in service delivery.

However, there are limited number of studies which have been conducted regarding the egovernment performance in Kenya. The studies have revealed insufficient information relating to efficiency level in the service delivery through e-government in Kenya. This study, through literature review, will assess the efficiency measures and innovations which the government has put in place to achieve efficient quality service, and will further recommend the way forward to make the digital government more efficient and effective in it service delivery.

The findings from the study will help in the policy formation regarding ways on how to possibly improve the efficiency in service delivery.

\subsection{Objectives of the study}

The main objective of the study is to assess the efficiency of the e-government platform in the delivery of public services in Kenya.

Specific objectives:

1. To examine the digital innovations used in the e-government platform.

2. To determine factors causing digital divide in Kenya.

3. To establish if the e-government services spreads out equally throughout the rural Kenya.

\section{LITERATURE REVIEW}

Many findings have established that e-government is majorly influenced by the objective to enhance efficiency in accessibility to public information and services, at a manageable cost, and improve efficiency (Adeboye 1995, Njuru 2011). (Kashorda 2009) observed that the Kenyan government has increased access to ICT equipment in all ministries. Even though, Thompson (2009) argue that ICT equipment do not necessarily translate to positive outcome if 
not put into proper and meaningful use. Equally, the two scholars (Adeboye 1995) is of the opinion that electronic government is not a cure to many of the challenges facing developing countries particularly in regard to democratic management, (Adeboye 1995, Njuru 2011).

E-government services continue to be embedded in the environment of today's public administration and therefore remain limited by what these administrations are capable and willing to do. The term "e-government" as used by the OECD E-Government Project, applies to the use of ICT as a tool to achieve better government. Thus, e-government is not about business as usual but should instead focus on the using ICT to transform the structures, operations and most importantly the culture of government public interaction (Ochara 2010).

According to (Harriss 2002), due to poor Internet connectivity, it may take time for Kenyans to achieve universal access full ICT use, since less than $10 \%$ of 38.8 million Kenyans have access to computers. In addition, (Kashorda 2009) argued that while digital Hubs are still in their initial level of development, the country still, has limited pervasive cyber cafes and institutional access to the Internet facilities (Karshoda 2009), observes that more than $80 \%$ of Kenyans live in the rural areas and this intensifies the challenge of Internet connections, even though the use of other ICT gadgets such as smartphones has proliferated as more than $77 \%$ of the Kenyan population own mobile telephones (Bailard 2009, Kashorda 2009).

\subsection{Demand and supply perspectives of e- government}

Generally, reforms in an administration system of government can be analysed or explained from both demand and supply perspectives. The demand-side explanation falls around national challenges of governance. The recognition is that administrative reforms are closely intertwined with political reform, aimed at strengthening the ability and capacity of elected officials to produce results (Ochara 2010). The success of the democratic elected representatives, as being measured by the benefits they are creating for their constituents, who demand top performance and efficiency, proper accountability and public trust, and a renewed focus on delivering better services and results (Ochara 2010). Thus the demand-side explanation has to do with the politicization of the reform agenda which can be driven internally (bureaucracy), and politiciandriven as well as society-driven (Ochara 2010).

Another orientation of the demand-side explanation is the 'political nexus triad' (PNT) in which actors (politicians, bureaucrats, and citizens) negotiate their political interests regarding the function and structure of government (Moon, Ingraham 1998). The dominant interests therefore emerge to shape the structure and function of government. For instance, in the Kenyan situation, after having a highly centralized government since gaining independence from Britain in 1963, the general elections of December, 2007, brought to the fore serious issues of governance, which has culminated into a shift of governance structure to a parliamentary (Ochara 2010) system. This change of governance was 'forced' on the PNT after a break out of civil unrest (citizens' demands as part of the PNT) for close to three months.

The supply-side focus argues that the reform practices including New Public Management (NPM) are being spread by reform-pioneering countries, institutions, or leaders to imitator countries, such as those in emerging economies (Ochara 2010). An increasingly post-NPM claim is the emphasis on the influence of the civil society as a source of demand for improved governance (Polidano, Hulme 2001, Ochara 2010). This may be a sign of two different versions of the supply-side explanation, one which is highly managerial oriented under the banner of NPM, while another is rooted under the 'good governance' notion (Ochara 2010). Given that the good governance paradigm also includes intra governmental reforms, it therefore appears to be a combination of an influence from pioneering countries to implement NPM-related 
reforms as well as that from the civil society in order for government to meet citizen expectations.

\subsection{Kenya E-Government Scenario}

The pioneer of e-Government in Africa predicted that the development of e-Government in most African countries would be the world's major and fastest-growing business in the next period (Yayehyirad Kitaw 2006). The government of Kenya has remained committed in the promotion of this platform of e-Government initiative since 2006. The goals of this initiative include better and more efficient delivery of government information and services to all citizens, increased productivity among public employees, the encouragement of public' participation in government initiatives.

The Kenyan Government approved E-Government strategy in 2004, making the start of egovernment journey. In 2006, National ICT policy was approved under the Ministry of Information and Communications (Wamoto 2015). This was to create order and harmony in Government ICT initiatives which were at the time regularly characterized by lack of coordination with each department following their own ICT program which resulted to wastage through replication of resources. Directorate of e-Government was set to oversee, coordination of implementation programme, formulation and communication of ICT guidelines and enforcement of national and international standards in the working of ICT service platform (Odongo 2012). The government has since initiated several e-government systems with the aim of enhancing efficiency, transparency and democracy within public administration. The Government has identified the potential of ICT in driving the economy and has embarked on several transformative ICT initiatives.

Further data available in the ministry of information and technology annual report (2006) reveals that some of the projects that were implemented during the five-year plan. Key among them is the Integrated Financial Management Information System (IFMIS) and Integrated Personnel and Payroll Database (IPPD) which are fully operational in the ministries. Other applications that have been rolled out include the Local Authorities Integrated Financial Operations Management Systems (LAIFOMS), Education Management Information System (EMIS), Integrated Taxation Management Systems (ITMS) currently known as ITAX after making great improvement in design, online Recruitment and Selection System in the public service commission and the Border Control System in the Ministry of state for Immigration and Registration of persons (Midida, et al. 2013).

To effectively create the e-government interactive platform, a project was launched by MoIT in Kenya, the Huduma Centres as one-stop shops that aims at providing a wide range of services demonstrated how ICT can be leveraged to substantially improve public service delivery (Abdallah, et al. 2015) The private sector in partnership with the Government has also played a critical role in driving some of the projects including the use of mobile payment platforms to collect government revenue such as e-citizen and e-JijiPay. noticeable evidence from is the County (e-JijiPay) is an application designed for citizens of the capital city of Kenya, Nairobi to facilitate easy payment of City County bills and expenses which includes; Parking, Land Rates, Rent Payment, Construction Permits, Single Business Permits, Advertisements and more (Okiro, et al. 2015).

The digital economy holds huge potential for growth, so ICT will be expected to play an increasing role in affording opportunities to the youth of the country to play an active role in the economic sector. 


\subsection{Objectives of E-Government in Kenya}

The current Kenyan e-government strategy, E-Government 2006 Strategy and Programme, includes the same main goals as many OECD countries' e-government strategies:

- Electronic government should make public administration more efficient, transparent and in the long run - less expensive.

- A more efficient central public administration providing better services should allow for the broadening of participatory democracy, an increase in citizens' and business actors' confidence and trust in the state, and greater participation by citizens in political life. Efforts should be made to develop a more transparent and substantial relationship between representatives of public authorities and citizens.

- By providing new public forums and easier access to public services oriented towards the needs of citizens, an environment can be created in which public administrative bodies and communities can share their experiences and influence the realisation of local and national egovernment programmes. The relationship between the state, citizens, and their communities should be reconstructed on new foundations that meet the requirements of citizens and businesses.

- As a service provider, the state will only be able to accomplish its tasks by ensuring the free flow of information. Public administration must initiate and foster the process of consultation and create opportunities for information sharing. In more general terms, Hungary has to catch up with the countries that are currently at the forefront of developing and providing egovernment services.

- The state's increased role in leading the application, use and dissemination of ICT will drive the process of constructing and developing a knowledge-based society and increasing the competitiveness of the economy. The strategy identifies six areas for action:

- Basic infrastructure elements: Establish a network infrastructure such as: a government backbone network connecting all government bodies, an e-authentication system.

\subsection{Theoritical model}

The study applies the Technological Acceptance Model (TAM), to explain the relationship between the introduction of information technology and its adaptation as an approach to explain differences in human behaviours in the IT adoption and use: (Lin, Fofanah et al. 2011, Taylor, Todd 1995).

TAM theory explains that there exist linkages flow in a sequence of beliefs, attitudes, intentions, and behaviours. In order to understand individual system applications, most studies focus on factors affecting the individual's intentions of system acceptance (Lin, Fofanah et al. 2011, Karahanna, Straub et al. 1999). The model of TAM can be demonstrated in the given diagram below. 


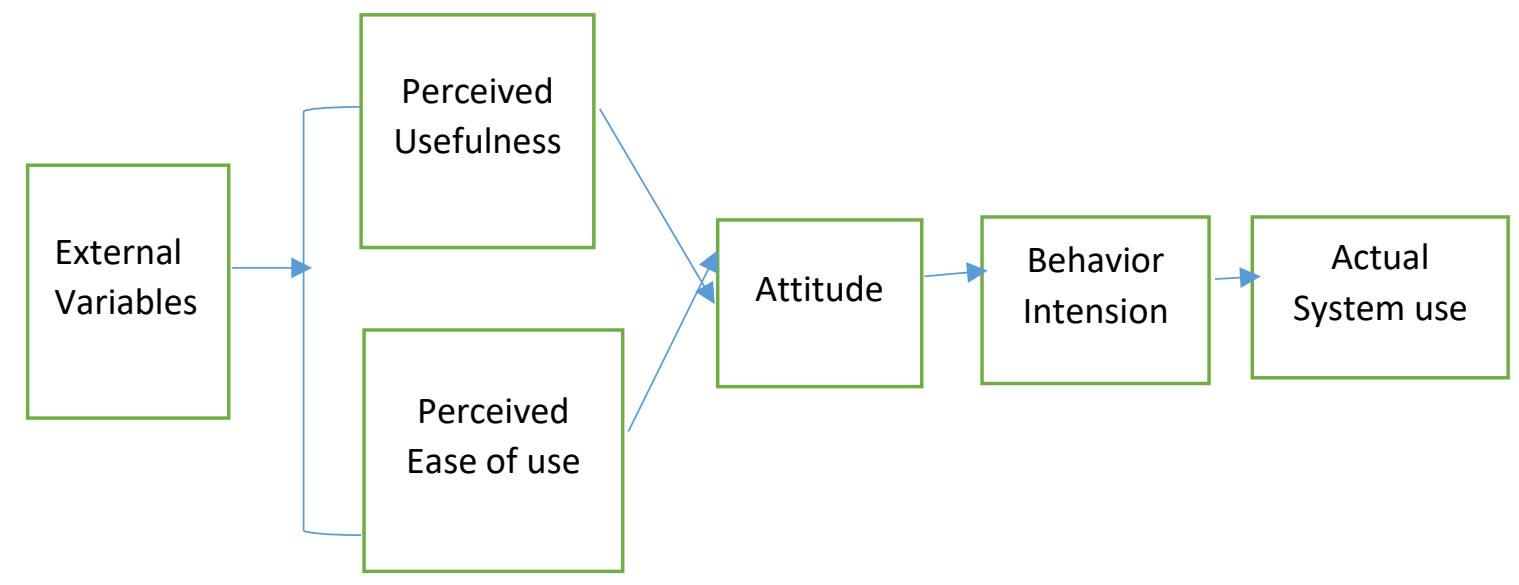

Fig 1: Technology Acceptance Model (TAM)

Sources: (Lin, Fofanah et al. 2011); TAM model in e-government

Prior research suggests that perceived usefulness (PU) and perceived ease of use (PEOU) are two major influential emotional beliefs that determine a user's IT acceptance. (Chin, et al. 1989) defined perceived usefulness as "the degree to which a person believes that using a particular system would enhance his or her job performance" and perceived ease of use as "the degree to which a person believes that using a particular system would be free of effort (Lin, Fofanah et al. 2011, Venkatesh, Davis 2000).

This study mainly focuses on the evaluation of the efficiency through the applicability of TAM in the e-Government setting in Kenya and focuses on how Kenyans behave differently, and exhibit different levels of acceptance, then other e-Government users. Information and communications technologies (ICTs) are playing an increasingly vital role in the daily lives of people in Africa, revolutionizing work and leisure and changing the rules of doing business (Lin, Fofanah et al. 2011, Taylor, Todd 1995). With the emergence of an information technology economy, the country of Kenya could reach higher levels of social, economic, and political development. The e-Government services include information for research, government forms and services, public policy information, employment and business opportunities, voting information, tax filing, license registration, or renewal, payment of fines, and submission of comments to government officials (Larsen, et al. 2002) . However, the successful operation of e-Government does not depend on the technology, but rather on the people (Lin, Fofanah et al. 2011, Akman, Yazici et al. 2005). Thus, this study focuses on the efficiency of e-Government success from the perspective of Kenyan citizens.

\subsection{Drivers facilitating the E-Government in Kenya}

\section{Government initiatives}

The government has enshrined development strategies of the ICT sector in the country's Vision 2030 goals. Campaigns to promote more investments in this sector are underway led by the government and the ICT Board, such as the development of the US\$ 14.5 billion Konza Technology City Government initiatives. The city aims at building a stronger ICT Hub, with an aim of improving internet connectivity to bust the use of ICT in the country. 


\section{Local innovation}

A number of ICT Hubs in Kenya have been established to promote the development and use of ICT technologies through co-working, collaboration and incubation services. The I-Hub, one of the best known hubs brings together technologists, investors, tech companies and hackers in the area creating an ecosystem of creators and users of ICT and mobile technologies Local innovation.

\section{Local private companies}

Mobile operator Safaricom M-pesa has revolutionised m-commerce in the country. The operator in collaboration with Microsoft has also made it possible for software developers on the Microsoft platform to sell their products via the Safaricom payment platform Local private companies.

\section{Foreign multinationals}

Google, IBM, Nokia Siemens, Huawei, Samsung and many other multinational companies operational in Kenya have boosted development and confidence of the sector and doing business in Kenya.

\section{Digital Literacy Programme(DLP)}

The government initiated the program out of the conviction that technology has the power to bring about systemic change in basic and higher education by transforming teaching and learning through integrating technology in the learning environment. The learners are entitled to a luminous green tablet while the teachers receive a blue laptop. In the on-going implementation targeting all public Primary schools in Kenya.

Over 75000 teachers in public Primary Schools have been trained in readiness for the project implementation. With full implementation of the DLP project, the government expects increased national digital literacy levels and revolution of the countries digital economy. (Peixoto, et al. 2016).

\section{Presidential Digital Talent Program (PDTP)}

The project was conceived through the Information, Communication and Technology (ICT) Master plan. The program is aimed at growing ICT through leadership and increase the relevance of ICT in business principles in management and public service delivery. It is also aimed at building ICT technical capacity in government for effective service delivery. The program provides internship to ICT and engineering graduates. The trainees undergo mentorship in private and public institutions for a period of one year. The first 100 trainees graduated in March 2016 and another group of 400 are already on board undergoing training. The program aims at achieving workforce development for effective and efficient services delivery leveraging on ICT (Peixoto, et al. 2016).

\section{Development of Technological Hub (Konza Smart City - Kenya)}

The objectives of the projects are to support entrepreneurs and access to free Wi-Fi in all the 290 constituencies countrywide. It will also enhance awareness and uptake of on-line platforms for employment and business opportunities (Peixoto, et al. 2016).

In line with the technological development in Kenya, Konza City is set to be a world-class Smart City and a prime economic driver for the nation, with a robust mix of businesses, workers, residents, and urban amenities. It purpose is to be the country's heart of innovative solutions for ICTs, business, and health and education. 


\section{EVIDENCE FROM SUCCESSFUL DIGITIZATION OF E- GOVERNMENT IN KENYA}

In many ways, Kenya is ideally suited to digitize its government functions. Consider the following:

Mature Mobile Money Ecosystem: According to the World Bank's Global Findex report, 58 percent of the adult population in Kenya had active mobile money accounts in 2014, the highest rate in the world. The Central Bank of Kenya reported 31 million mobile money subscribers backed by close to 144,000 agents in 2015. Usage extends beyond person-to-person transfers to include airtime purchase, credit, insurance, payments among others, however, many types of handsets used by many people does not accommodate many transactions which take place in the e-government platform (Baller, et al. 2016)

In contrast, payment card usage is generally low in Kenya, especially for online transactions: 95 percent of debit cards are used solely at Automated Teller Machines, while credit card usage is at 4 percent. That's one reason previous efforts to digitize the public transport system by introducing "My1963" and "BebaPay" cards were unsuccessful. Given the low values of public transport costs and poor uptake of card-based products, these services could not adequately compete with cash. But owing to its pervasiveness, mobile money - though largely dominated by the M-PESA service - can avoid similar pitfalls, becoming a critical enabler in the digitization of government service payments in Kenya.

Supporting Infrastructure (Huduma Centres): "Huduma" means "service" in Swahili, and Huduma centres are one-stop shops set up countrywide by the government to complement the e-Citizen portal by providing additional services and those requiring physical presence or special assistance. The 47 Huduma centres are comprised mainly of upgraded post office outlets in each county, with mobile units serving extremely remote areas. However, the centres are not effective because of the frequent power supply disruptions, fluctuating internet connections and operational skills which many people within the country side face from time to time.

On average, 12,000 people are served daily at Huduma Centres, and as of June 2015, payments for services rendered totalling $\$ 50$ million.

Internet Access and Usage: According to the Internet live stats, Kenya's internet penetration rate is 45 percent of the population (21.2 million), after Nigeria, South Africa and Seychelles. Mobile technology and the increase in smartphone ownership have played key roles in improving access. Affordable and accessible Internet enables quicker government service delivery especially for services such as driving license renewal or land rent payments, which can be initiated and completed online (Kimenyi, et al. 2015).

Enabling Legal and Regulatory Environment: The Central Bank of Kenya passed regulation governing the digitization of government services and payment platforms in December 2014. This is in addition to existing local and international laws and policy frameworks aimed at promoting a safe, efficient and transparent digital payment ecosystem (Kimenyi, et al. 2015)

\section{FINDINGS}

It is generally established that a number of initiatives which the government of Kenya has put in place are still at the initial initiative level. A number of institutions are in the process of enforcing the government policies to enable the e-government project to work. 
Mass education and awareness regarding ICT knowledge is still missing. However, government has initiated a number of activities to make the public aware regarding the use and application of ICT networks in the economy.

It is also observed that inequality exist when it comes to the way instruments of e-government has to be distributed for the public use.

\section{CONCLUSION AND RECOMMENDATIONS}

The e-Government initiative will be a shared vision between the National and County Governments and the private sector and the implementation process will involve all stakeholders. The broad objectives of e-Government in all aspects of National and County governments will be to:- (a) Improve collaboration between Government agencies and enhance efficiency and effectiveness of resource utilization; (b) Improve Kenya's competitiveness by providing timely information and delivery of Government services; (c) Reduce transaction costs for the Government, citizens and the private sector through the provision of services electronically; (d) Provide for access to information held by public institutions, provide for information security and protection of personal information; and (e) Ensure automation of Government services and the extension of establishment of "Huduma" centres: one-stop centres for accessing all Government information and services by the citizens; to sub-counties. EGovernment Applications: In order to improve productivity \& ensure all citizens participate effectively in the information society, the government shall consider the following: (a) Automation of Government functions. - by undertaking Business Process re-engineering of government departments in order to identify opportunities for automation (e-Health, transport, e-Agriculture, e-Lands, etc.); (b) ICT Integration into the economy - by promoting the use of ICTs across all public and private sectors (within SMEs) in order to increase productivity and competitiveness of the overall economy; (c) ICT integration in Education - by reviewing and ensuring that the basic \& tertiary education curriculum and teaching methods are geared for the knowledge economy (Digital Literacy Program); (d) Digital Villages- by promoting the creation of information centres/digital villages (e.g. Huduma centres) across all counties.

Acknowledgements

This research was funded by a grant from Tomas Bata University, No. IGA/FaME/2018/019. The authors are grateful to the anonymous referees of the journal for their beneficial suggestions to improve the quality of the article. Usual disclaimers apply.

\section{References}

Adeboye, Titus, et al. Effects of reforms on technological capability in Sub-Saharan Africa: a conceptual framework. ATPS working paper/African Technology Policy Studies Network; no. 1, 1995.

Akman, I., Yazici, A., Mishra, A. and Arifoglu, A., 2005. E-govemment: A Global View and an Empirical Evaluation of Some Attributes of Citizens. Government Information Quarterly, 22(2), pp. 239-257. https://doi.org/10.1016/j.giq.2004.12.001

Bailard, Catie Snow. Mobile phone diffusion and corruption in Africa. Political Communication, 2009, 26.3: 333-353. https://doi.org/10.1080/10584600903053684

Baller, Silja; Dutta, Soumitra; Lanvin, Bruno. Global Information Technology Report 2016. Ouranos, 2016. 
Belanger, C.L., 2012. Individual to Community-level Faunal Responses to Environmental Change from a Marine Fossil Record of Early Miocene Global Warming. PLoS ONE, 7(4), pp. e36211. https://doi.org/10.1371/journal.pone.0036290

Compeau, D.R. and Higgins, C.A., 1995. Computer Self-Efficacy: Development of a Measure and Initial Test. MIS Quarterly, 19(2), pp. 189-211. https://doi.org/10.2307/249688

Chin, Wynne W.; Todd, Peter A. On the use, usefulness, and ease of use of structural equation modeling in MIS research: a note of caution. MIS quarterly, 1995, 237-246.

Cullen, R., 2001. Addressing the Digital Divide. Online Information Review, 25(5), pp. 311320. https://doi.org/10.1108/14684520110410517

Harriss, John. Depoliticizing development: The World Bank and social capital. Anthem Press, 2002.

Karahanna, E., Straub, D.W. and Chervany, N.L., 1999. Information Technology Adoption Across Time: A Cross-Sectional Comparison of Pre-Adoption and Post-Adoption Beliefs. MIS Quarterly, 23(2), pp. 183-213.

Kashorda, Meoli. Electronic/mobile government in Africa: Progress made and challenges ahead. 2009https://doi.org/10.2307/249751.

Kimenyi, Mwangi; Ndung'U, Njuguna. Expanding the financial services frontier: Lessons from mobile phone banking in Kenya. Washington, DC: Brookings Institution), October, 2009.

Kitaw, Yayehyirad. E-government in Africa: Prospects, challenges and practices. International Telecommunication Union, 2006.

Larsen, Elena; Rainie, Harrison. The rise of the e-citizen: How people use government agencies' web sites. Pew internet \& American life project, 2002.

Lin, F., Fofanah, S.S. and Liang, D., 2011. Assessing Citizen Adoption of E-Government Initiatives in Gambia: A Validation of the Technology Acceptance Model in Information Systems Success. Government Information Quarterly, 28(2), pp. 271-279. https://doi.org/10.1016/j.giq.2010.09.004

Madida, P. K.; Gakure, R. W.; Orwa, G. O. Factors hindering adoption of Integrated Human Resource Management Information System for service delivery in civil service: A case of civil service in Nairobi. International Journal of Social Sciences and Entrepreneurship, 2013, 1.7: 610-623.

Moon, M. and Ingraham, P., 1998. Shaping Administrative Reform and Governance: An Examination of the Political Nexus Triads in Three Asian Countries. Governance, 11(1), pp. 77-100. https://doi.org/10.1111/0952-1895.581998058

Njuru, Jane Wangari. Implications of e-government on public policy and challenges of adopting technology: The case of Kenya. Ustawi Journal of Global Affairs and Public Policy, 2011, 1.1.

Ochara, N.M., 2010. Assessing Irreversibility of an E-Government Project in Kenya: Implication for Governance. Government Information Quarterly, 27(1), pp. 89-97. https://doi.org/10.1016/j.giq.2009.04.005

Odongo, A.O., 2012ICT Policy in Africa - a Comparative Study of Ghana and Kenya Drawing on Lessons from Developed Countries, 2012, pp. 192-201. 
Okiro, Kennedy; Aduda, Josiah; Omoro, Nixon. The effect of corporate governance and capital structure on performance of firms listed at the East African community securities exchange. European Scientific Journal, ESJ, 2015, 11.7.

Peixoto, Tiago; Fox, Jonathan. When does ICT-enabled citizen voice lead to government responsiveness?. 2016.

Polidano, C. and Hulme, D., 2001. Towards a Post-new Public Management Agenda. Public Management Review, 3(3), pp. 297-303. https://doi.org/10.1080/14616670110058347

Taylor, S. and Todd, P.A., 1995. Understanding Information Technology Usage: A Test of Competing Models. Information Systems Research, 6(2), pp. 144-176. /https://doi.org/10.1287/isre.6.2.144

Venkatesh, V. and Davis, F.D., 2000. A Theoretical Extension of the Technology Acceptance Model: Four Longitudinal Field Studies. Management Science, 46(2), pp. 186-204. https://doi.org/10.1287/mnsc.46.2.186.11926

Wamoto, Francis Osanya. E-government Implementation in Kenya, an evaluation of Factors hindering or promoting e-government successful implementation. International Journal of Computer Applications Technology and Research, 2015, 4.12: 906915. https://doi.org/10.7753/IJCATR0412.1006

\section{Contact}

\section{Patrick Asango Okanga}

Institution: Tomas Bata University

Full address of institution: T.G. Masaryka 555576001 Zlín, Czech Republic

Mail: okanga@utb.cz

ORCID: 0000-0003-0696-2641

\section{Ho Thanh Tri}

Institution: Tomas Bata University

Address of institution: T.G. Masaryka 555576001 Zlín, Czech Republic

Mail: tho@utb.cz

ORCID: 0000-0002-7614-4217

\section{Nguyen Thi Bich Thuy}

Institution: Industrial University of Ho Chi Minh City

Address of institution: No. 12 Nguyen Van Bao, Ward 4, Go Vap district, Ho Chi Minh City

Mail: nguyenthithuy@iuh.edu.vn

ORCID: 0000-0001-9780-3114

DOI ID: https://www.doi.org/10.7441/dokbat.2018.17 


\title{
APPLICATION OF VALUE STREAM MAPPING IN ORDER TO RECOGNIZE OPPORTUNITIES TO IMPROVE PROCESSES AND INCREASE BUSINESS PROCESS PERFORMANCE: A CASE STUDY FROM MANUFACTURING COMPANY IN THE CZECH REPUBLIC
}

\author{
Pavel Ondra
}

\begin{abstract}
Companies are encouraged to make changes and improve their business processes to achieve performance and competitiveness. For these purposes, industrial engineering methods can be used in business practice. The main aim of this paper is to check and prove the applicability and utility of Value Stream Mapping as a supporting industrial engineering tool for increasing business process performance. The results shows, that Value Stream Mapping is an appropriate tool to support improvement projects in manufacturing companies. Because of its utilization, companies can achieve a higher performance of business processes and thus to increase competitiveness of the company.
\end{abstract}

Keywords: Industrial Engineering Methods, Business Process Improvement, Business Performance, Value Stream Mapping, Value Added Index.

\section{INTRODUCTION}

Continuing competition, customization, shortening product lifecycles or continuous technological innovation have a significant impact on the competitive environment, which is characterized by increased competition resulting from market saturation and growing demands for customer-driven production (Salvendy, 2001). In order for a manufacturing company to be successful, it must produce customer-driven products and at the same time perform business processes efficiently to ensure long-term and sustainable performance. Thus, it gains an economic advantage over competition, i.e. competitiveness (Magretta, 2012). The uncompetitive company means that its market position is unsustainable, its future is at risk and if it does not improve its performance, it will deal with existential problems and will not survive long (Pribeanu \& Toader, 2016).

The competitiveness of the manufacturing company depends on the direction of the company and the balanced management in areas of product, production, supply-chain, and value-added for customers (Hitt, Ireland, \& Hoskisson, 2011). One of the ways to achieve competitiveness is to adopt a competitive low cost strategy. Because of competitive struggle, companies are forced to reduce production costs, improve quality, improve additional services, and shorten delivery times (Corbett, 2011). Significant performance cannot be achieved only by new regulations or motivated employees. It is the result of measures, actions and the use of new tools and business management methods (Magretta, 2012). The tools of Lean and Industrial Engineering (IE) represent instruments, which can influence these areas, performance and competitiveness through processes improvement.

\section{LITERATURE REVIEW}

Parry, Mills and Turner (2010) argue that achieving long-term growth in business performance and competitiveness is part of the Lean business concept, so called Lean. Kislingerova (2008) adds that the prerequisite for long-term sustainable growth and business competitiveness is the innovation of production systems. The goal of Lean is to create the required quantity of products in the highest possible quality with the lowest possible cost in the shortest possible time (Badiru, 
2014; Thurston \& Ulmer, 2016). For this purpose, many companies are increasingly concerned with the use of modern management tools, which create great potential for improving business performance (Wanitwattanakosol \& Sopadang, 2011). According to Wilson (2010), part of this concept is to increase business process performance, reduce costs, shorten delivery times and improve quality, by eliminating waste. Waste can occur in all activities across company. There are three types of activities in companies, that adds value to the final product; do not add value but are necessary, which should be reduced; and do not add value and are unnecessary, which should be eliminated (Womack \& Jones, 2003).

Every activity that costs money, makes the product more expensive, adds no value, and the customer does not want to pay for it, is waste (Bauer, 2012; Chen, Li, \& Shady, 2010). Ohno (1988) identified the original seven common wastes: defects, inventory, motion, over processing, overproduction, transportation and waiting. Liker and Meier (2006) pointed out an additional waste: talent or unused potential. An effective tool for identifying waste has proven to be Value Stream Mapping (Chen et al., 2010).

Value Stream Mapping (VSM) is one of the industrial engineering and Lean tools to mapping and visualizing the entire production process (Womack \& Jones, 2003). VSM illustrates process (material) flow and information flow (Sahoo, Singh, Shankar, \& Tiwari, 2008). The goal is to identify waste and take steps to eliminate it (Seth, Seth, \& Goel, 2008). According to Jones and Womack (2002), VSM is used to both represent the current state of a process and present the future state with better methods and much better performance. The future state map can shows how the company could operate more effectively (Pavnaskar, Gershenson, \& Jambekar, 2003).

With VSM, it is possible to identify different process factors such as Value Added Time, NonValue Added Time, Cycle Time, Production Lead Time, Changeover Time and Process Ratio (Value Added Index) (Venkataraman, Ramnath, Kumar, \& Elanchezhian, 2014). Value Added Index (VA Index) in one of the basic key performance measures of business processes. VA Index is determined as the ratio of the Total Value Added Time to the Production Lead Time (Dlabac, 2014; Venkataraman et al., 2014). According to Dlabac (2014), VA Index is around $1 \%$; in an optimistic case, accounts for $5 \%$ of the total time.

Taylor (2005) stated that VSM is effective tool for summarizing and presenting the key aspects of a business processes. Value stream maps helps managers to understand the operational conditions and recognize opportunities to improve business process performance (Womack \& Jones, 2002). According to Serrano Lasa et al. (2008), VSM is a valuable tool for redesigning the systems. Singh and Singh (2013) stated that VSM is a suitable tool for companies that want to be lean, because it supports implementations of the Lean approach.

Many researchers applied VSM for identification and elimination of waste in various areas of production and services. Some authors have come up with a more classic way of applying VSM in production (Abdulmalek \& Rajgopal, 2007; Chowdary \& George, 2012; Grewal, 2008; Gurumurthy \& Kodali, 2011; Serrano Lasa et al., 2008; B. Singh, Garg, \& Sharma, 2009) and automotive manufacturing (Lacerda, Xambre, \& Alvelos, 2016; H. Singh \& Singh, 2013; Vamsi Krishna Jasti \& Sharma, 2014). Others have focused on less common areas such as product development (Peek \& Chen, 2011; Tyagi, Choudhary, Cai, \& Yang, 2015), architecture (Lima, Rolim, \& Alves, Thais da C L, 2010), construction (Matt, Krause, \& Rauch, 2013), call centre (Piercy \& Rich, 2009), transport (Villareal, Garza, Rosas, \& Garcia, 2012) and maintenance service (Kasava, Yusof, Khademi, \& Saman, 2015). The use of VSM in healthcare also comes to the forefront (Al-Balushi, 2017; Bal, Ceylan, \& Tacoglu, 2017; Dohan, Xenodemetropoulos, \& Tan, 2014; Henrique, Rentes, Godinho Filho, \& Esposto, 2016; Kaale et al., 2005; Sellers, 2014; Tortorella et al., 2017; Vidal-Carreras, Garcia-Sabater, MarinGarcia, \& Garcia-Sabater, 2015). 
Singh and Sharma (2009) implemented VSM in an Indian manufacturing industry and achieved reduction of Lead Time by $92.58 \%$ and WIP by $97.10 \%$. Venkataraman et al. (2014) applied VSM in the automotive manufacturing in India with an increase in the VA Index from $0.60 \%$ to $1.17 \%$. Bhalwankar and Mastud (2014) reduced NVA Time by using VSM from $39.79 \%$ to $31.70 \%$. Lacerda et al. (2016) applied VSM in the automotive industry and achieved reduction of Cycle Time by $64.32 \%$ and inventory level by $25 \%$. Vamsi Krishna Jasti and Sharma (2014) stated that VSM brings out the positive impact on Process Ratio (from $0.93 \%$ to $3.45 \%$ ) and Lead Time (reduction by 73.97\%). According to Singh and Singh (2013), inventory level was reduced by $81.74 \%$, Lead Time by $75.43 \%$ and Cycle Time by $30.59 \%$. Grewal (2008) used VSM in bicycle manufacturing company and reduced Cycle Time by $33.18 \%$ and Lead Time by $81.40 \%$. Tyagi, et al. (2015) reduced waiting time of product development process by $88.97 \%$ and number of steps by $39.58 \%$, while at the same time VA Time was increased by $50 \%$.

\section{METHODOLOGY}

The main aim of this paper is to check and prove the applicability and utility of Value Stream Mapping as a supporting industrial engineering tool for increasing business process performance. For the purposes of the paper, I have decided to obtain the necessary data about companies in the Czech Republic with the help of online questionnaire. The recipients were managers or owners of companies in the Czech Republic. The aim was to reach the largest number of companies from various sectors of the national economy from all regions of the Czech Republic, of various sizes, of different ages. The questionnaire was distributed in two rounds. In the first and second round, potential participants were addressed via email. In the second round, potential participants were also contacted by telephone. After these rounds, 252 companies completed the questionnaires correctly. I consider the size of the research sample as being sufficiently representative. The data group consisted of all the 252 surveyed companies.

After completion of the questionnaire collection, replies were automatically converted to a database in MS Excel (the questionnaire was created through Google Forms). Basic descriptive statistics were processed in this program via Pivot Tables.

After data processing, one company was selected for detailed research and case study. This was a random selection from a predefined set of companies from the manufacturing industry with VA index values lower than $2 \%$. The selected company has previously shown interest in cooperation on research.

After selecting the company, the first step was to create a VSM team. It was necessary to ensure that each member of the team had the required capabilities for VSM. The VSM then proceeded based on the following steps:

1. Selection of a product.

2. Mapping of the current state.

3. Identification of waste in the production activities.

4. Searching for opportunities to improve the production activities.

5. Creating a future state map.

6. Defining a working plan. 


\section{RESEARCH RESULTS}

Data and information were obtained from a sample of 252 surveyed companies from the Mechanical Engineering (20.24\%), Construction (14.68\%), Electrotechnical (11.11\%), Automotive (7.94\%), Wood Processing (7.94\%), Food (5.95\%), Plastics (4.37\%) and Mining industry (3.97\%), other industries and service sectors. The sample of companies surveyed was composed of manufacturing companies $(77.38 \%)$ and service companies $(22.62 \%)$. Serial $(41.03 \%)$, piece $(38.97 \%)$ and mass $(20.00 \%)$ production companies represented the manufacturing companies.

The Figure 1 shows the results of the usage of the Value Stream Mapping in whole companies involved in the research. Respondents from research could choose from three options only one that most closely matches their company.

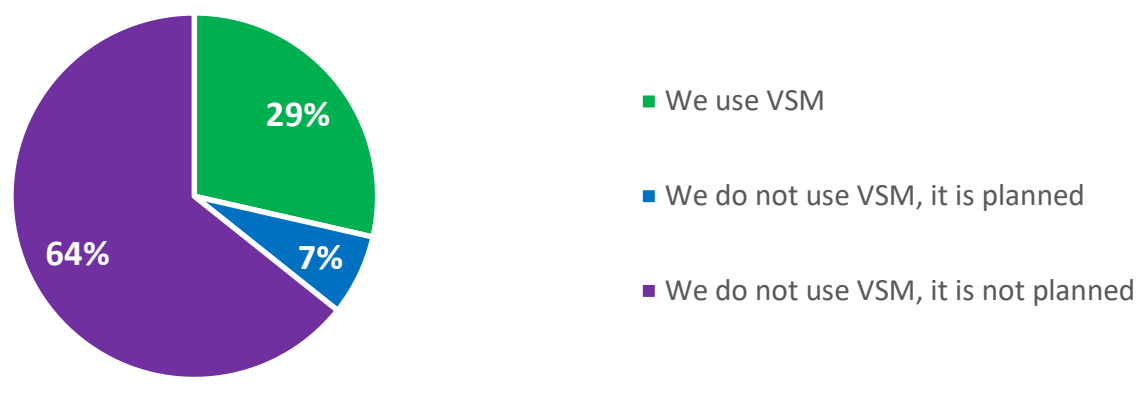

Figure 13 Usage of the Value Stream Mapping tool. Source: own

Respondents who are currently using VSM and are monitoring the VA Index have been asked what the VA Index values on average are doing in their processes. The Figure 2 shows the results of the answers to this question.
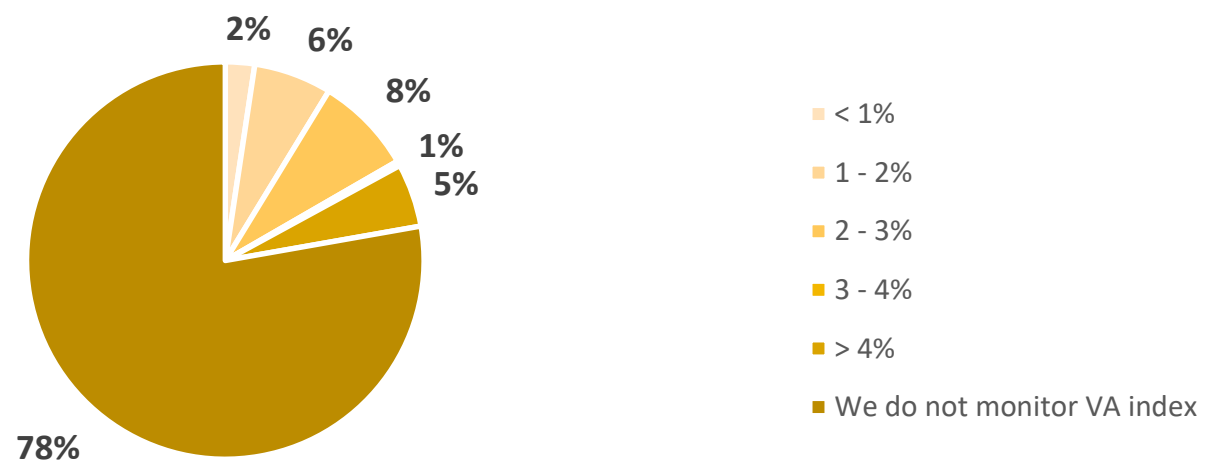

Figure 14 VA Index values. Source: own

By comparing the two figures above, it is clear that $64 \%$ of companies do not use VSM (and they are not even planning to do so). However, the VA Index, which is one of the output data from mapping, is not followed by $78 \%$ of companies. This means that $14 \%$ of companies using VSM do not monitor the value of the VA Index. These companies seem to be primarily monitoring some other indicators, such as Cycle Time or Lead Time. It is also possible that these companies use VSM only to map the overall process, search for bottlenecks, identify waste and uncover opportunities for improvement. 


\section{CASE STUDY}

For the purpose of the case study, a company from the manufacturing industry was chosen. The selected company showed interest in cooperation, but did not want to be named. This company is a manufacturer of optical systems and operates on the global market. In terms of size, more than 500 people are employed here. This company corresponds to a selected group with a VA Index of less than $2 \%$.

The product portfolio of the selected company is very wide. The selected product is one of the most produced products of the selected company. However, this product was non-profit due to conditions in the production process. This was the reason why this product was selected.

The entire production process of the product includes eight operations (OP). First, the material has to be milled, which is done under OP30. The semi-finished product is turned (OP40), mechanically cleaned (OP50) and tumbled in tumbling barrel (OP60). Finally, the semi-finished product is chemically modified and surface-treated (OP70). At the end of the process, the product is varnished (OP100), threads are completed (OP110), and the final product is inspected in the output control (OP130).

All operations throughout the process have been reviewed, measured, and analysed. In addition to the classic control of all operations, more time was spent on thorough control of both CNC operations (OP30 and OP40). The results of individual observations are shown in the following figures.

The Figure 3 shows the times of the milling operation (OP30). Machine milling takes place within two cycles. Both are different depending on the program setting and the cutting conditions. The cycles are separated by one stop for control purposes. During running, the machine is automatically stopped by the program and waiting to perform the check. The operator handles several machines. This may cause the machine to wait for the operator. All activities including machine time, manipulation, cleaning and checking are included in the standard production time of the operation (54 minutes). During this time, all work has to be done, but this is not fulfilled.

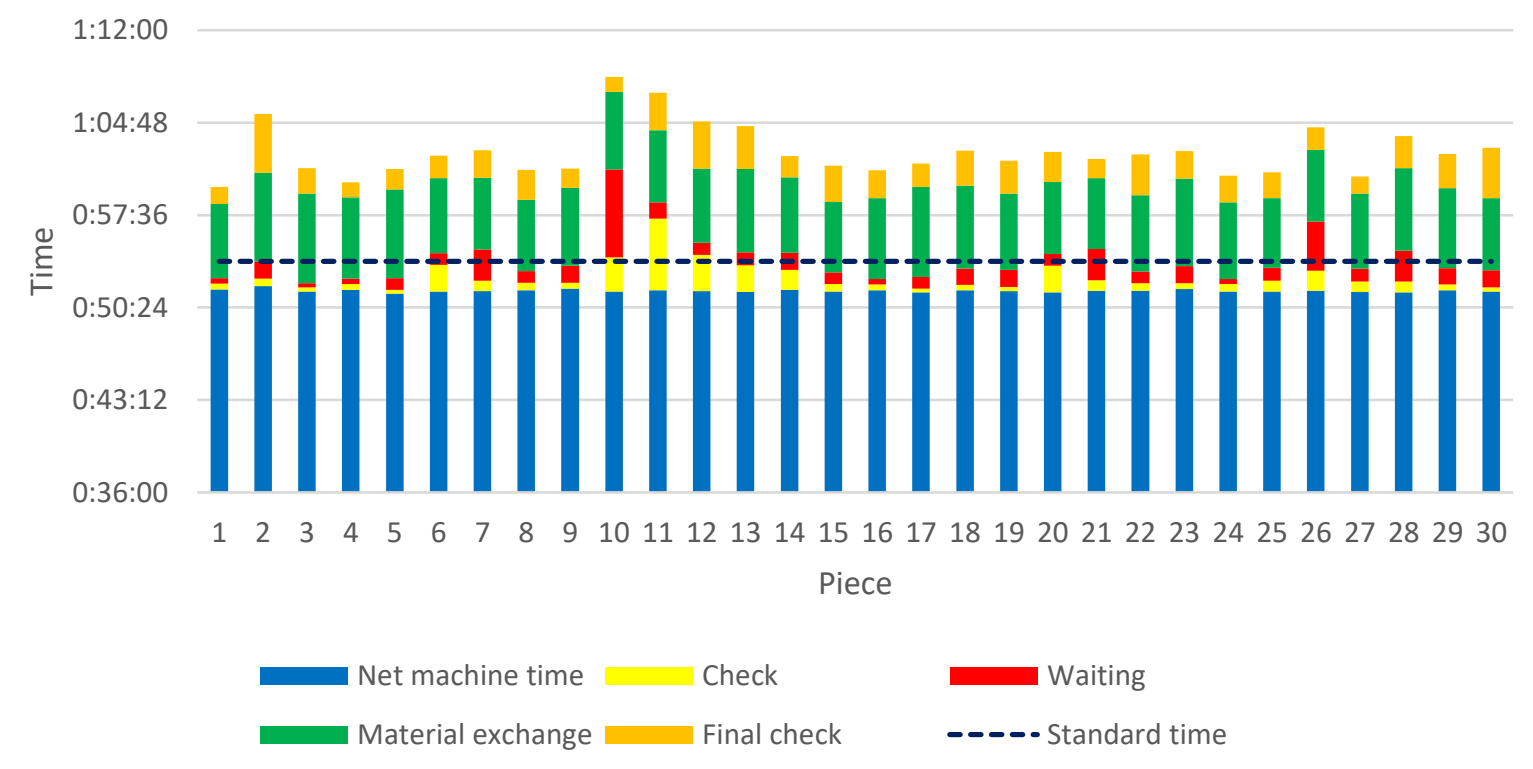

Figure 15 Milling OP30. Source: own

The Figure 4 shows the times of the turning operation (OP40). Unlike the previous operation, turning is done all at once throughout one cycle and there is no stopping during the program. 
The operator handles one cell with two machines. These machines are positioned opposite each other so that the operator has a better view of both machines. All activities including machine time, manipulation, cleaning and checking are included in the standard production time of the operation (11 minutes 30 seconds). During this time, all work has to be done, but this is not fulfilled. There is a question of an appropriate adjustment of the machine's cutting conditions and whether it could not be adjusted to reduce machine time. In this case, machines are not equipped with Andon signalling devices, as is the case with other machines in the shopfloor. The operator must therefore rely on his own capabilities and monitor the machine display.

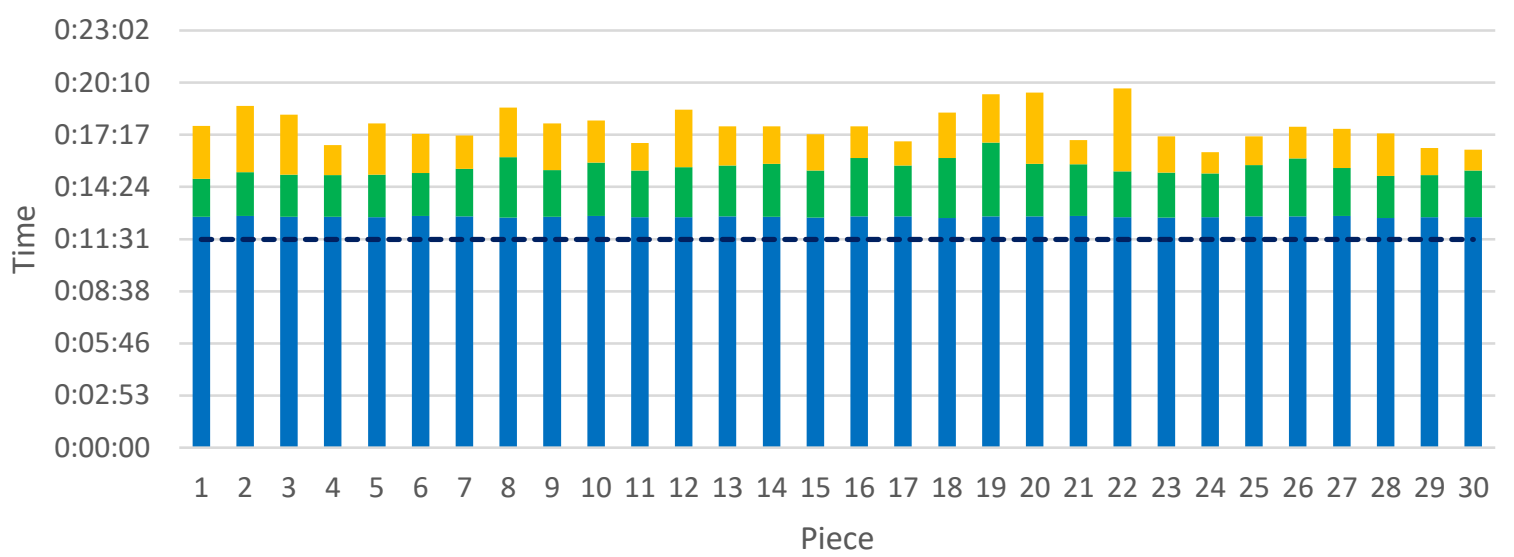

Net machine time Material exchange $\quad$ Final check _-- - - Standard time

Figure 16 Turning OP40. Source: own

For other operations, so many detailed times have not been processed. In the case of milling and turning, there are gradually changes and modifications, so it was necessary to verify the impact of already introduced changes. Even so, a sufficient amount of data and information was generated to create value stream map of this production process. The Figure 5 shows the current state map.

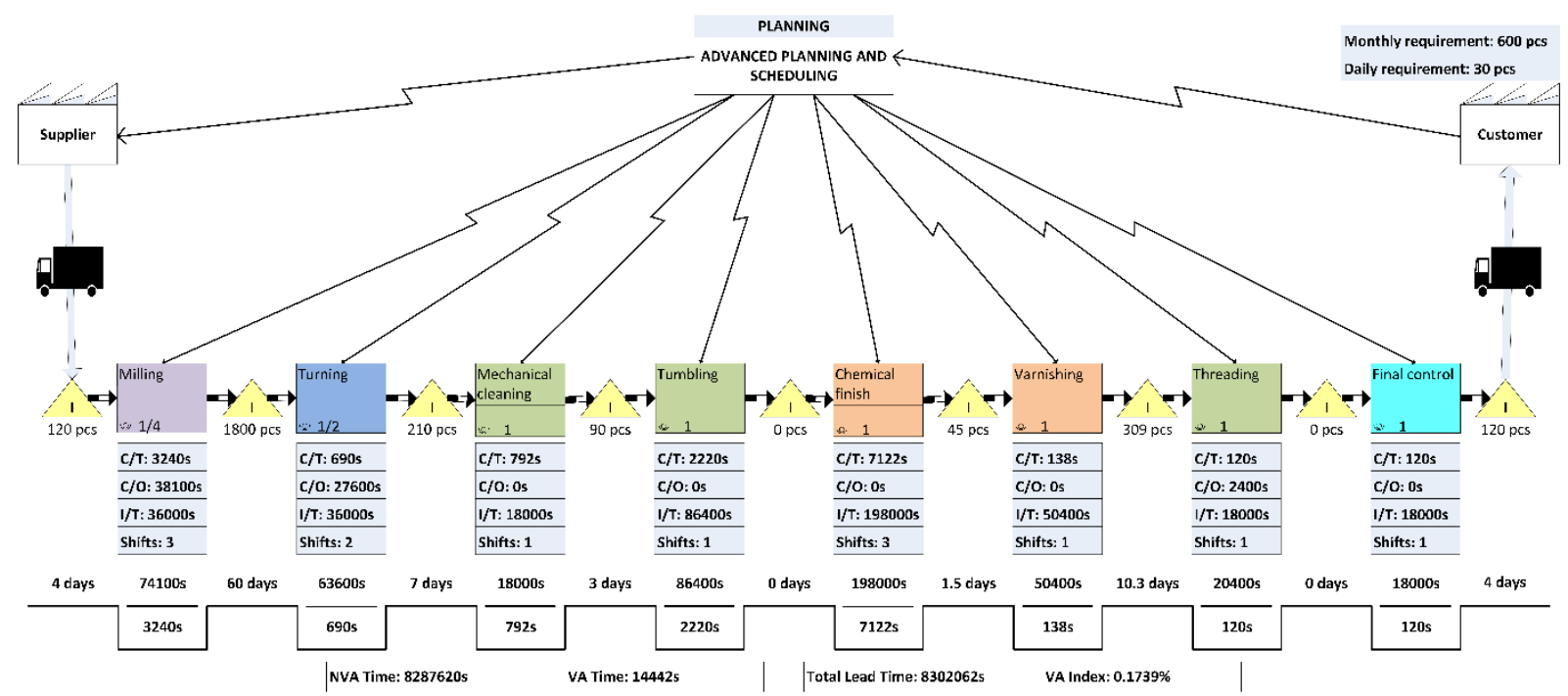

Figure 17 Current state map. Source: own

The current state map represents the state of the process as it has been set up in terms of process times and material flows. At the time of applying VSM, the customer requested 600 quality pieces of selected product per month, which means 30 quality pieces per day to meet the 
customer's requirement. The entire production process is planned based on Advanced Planning and Scheduling (APS) method. Based on the process mapping, some waste, such as unnecessary inventory, unnecessary motion, overproduction, complicated and lengthy transportation, and waiting, was revealed. In addition to the Cycle Times $(\mathrm{C} / \mathrm{T})$ and Changeover Times $(\mathrm{C} / \mathrm{O})$, the map also includes Interoperation Times (I/T) due to technological processes and transport conditions. No value to the final product is added during Interoperation Times, as well as during Changeover Times, so these times are included in total NVA Time of the process. The total NVA Time of the process was found to be approximately 95.92 days. On the other hand, the final product gains a value only for approximately 4.01 hours. As a result, this process shows a VA Index of $0.1739 \%$.

\section{DISCUSSION AND CONCLUSION}

In order to decrease NVA Time and increase VA Index and a competitiveness of the company, several changes will need to be made across the process: editing cutting machining conditions, levelling Interoperation Times, shortening the distance between operations (utilization of available capacity), modification of mechanical technology, new tumbling medium, limitation of Work in Progress (day WIP limit) and SMED application.

One of the major changes is to adjust the Interoperation Times of all operations. These times do not match the current state. Over the years, there have been various changes in the process. These changes should have affected these times. However, there has been no adaptation of these times to the new conditions in the process. In the future state map (Figure 6), the Interoperation Times are set according to conditions in the present and the near future.

It was necessary to modify the Mechanical Cleaning (OP50) technology and use new tools. Several options have been suggested and the time has been reduced from 792 to 700 seconds so far. This value is not yet final, since other alternatives are still being tested. At the same time, it was also necessary to modify the Tumbling (OP60) technology. An alternative operating medium was considered. Because of the use of new operating medium, the same quality was achieved in less time. So far, the Cycle Time has been reduced from 2220 to 2040 seconds, and further adjustments are being considered.

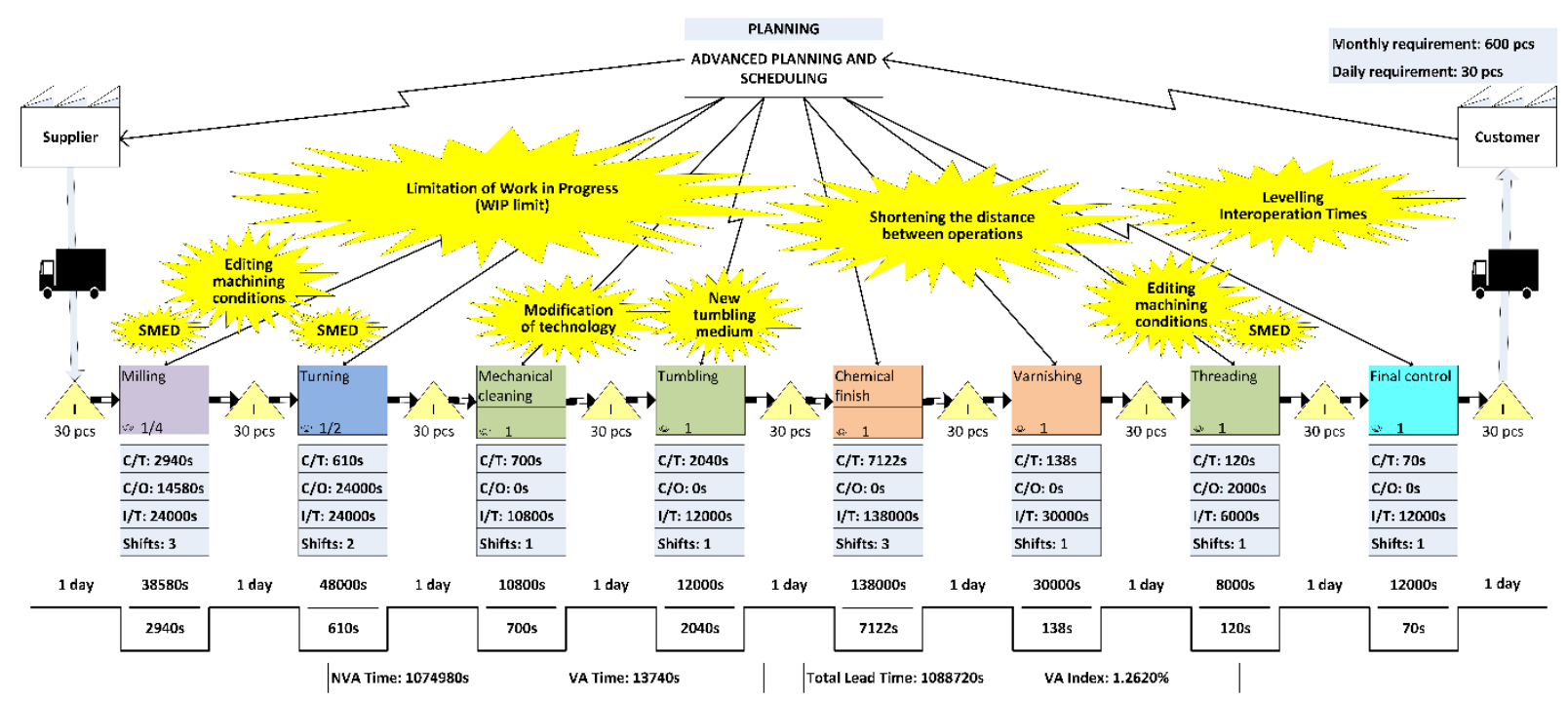

Figure 18 Future state map. Source: own

Several changes have been made, and several will be done, in the case of main machining operations - Milling (OP30) and Turning (OP40). Cutting conditions have been adjusted based 
on computer simulation. In order to achieve the targeted state and acceleration of machining, some new tools have been purchased. This makes it possible to achieve even higher speeds and better quality. At the same time, Standard Times were adapted to the new conditions. In order to reduce Changeover Times, it was decided to implement the Single Minute Exchange of Die (SMED) tool. The implementation project has not yet been completed, but there is enough information. The Changeover Time for Milling (OP30) can be reduced by approximately $60 \%$. In the case of Changeover Time for Turning (OP40), it is assumed that it will be reduced by only $13 \%$.

Because of the changes, the VA Index reaches $1.2620 \%$. On the other hand, VA Time has been reduced. Nevertheless, compared with the reduced NVA Time, the VA Index increased. Reducing VA Time also shortens the Total Lead Time. The customer welcomes this step. However, it is not only about the resulting VA Index. It is also about the overall increase in the performance of the process. The company received a request from its customer to produce a large number of these products for the following period. This impulse is a driving force for even stronger engagement in improving this production process.

As a result, the company has achieved and increased its competitiveness through the application of industrial engineering tools, namely Value Stream Mapping. Companies are very keen to implement these tools and methods to improve business processes. With their use, companies can exist longer and become competitive. For the time being, the company has not taken the lead in reducing price of the production or improving quality, but eliminating waste. As a result, the company can achieve a higher production capacity utilization, which is now very much needed for further development of the company. The company also decided to meet customer requirements faster by shortening production and delivery times. As a result, the company becomes slimmer and more flexible. By modifying and improving processes, it is possible to remove activities that do not add value and to increase the added value of processes and products. As a result, these changes and improvements will have an impact on streamlining the production process, increasing the value of the company and its products, and increasing competitiveness.

\section{Acknowledgment}

Authors are thankful to the Internal Grant Agency of FaME TBU No. IGA/FaME/2017/015 "Impact of selected industrial engineering methods on the overall business performance and process efficiency" for financial support to carry out this research.

\section{References}

Abdulmalek, F. A., \& Rajgopal, J. (2007). Analyzing the benefits of lean manufacturing and value stream mapping via simulation: A process sector case study. International Journal of Production Economics, 107(1), 223-236. doi: 10.1016/j.ijpe.2006.09.009

Al-Balushi, S. (2017, May). The value stream mapping in hospital: The case of emergency department. Paper presented at the 29th International Business Information Management Association Conference, Vienna, Austria. Norristown, PA: International Business Information Management Association.

Badiru, A. B. (2014). Handbook of industrial and systems engineering (2nd ed.). Boca Raton, FL: CRC Press. 
Bal, A., Ceylan, C., \& Tacoglu, C. (2017). Using value stream mapping and discrete event simulation to improve efficiency of emergency departments. International Journal of Healthcare Management, 10(3), 196-206. doi: 10.1080/20479700.2017.1304323

Bauer, M. (2012). Kaizen: Cesta ke stihle a flexibilni firme. Brno, Czech Republic: BizBooks.

Bhalwankar, M., \& Mastud, S. (2014). Applying value stream mapping for improvements in automotive seat manufacturing processes. International Journal of Mechanical Engineering and Robotics Research, 3(4), 164-177. Retrieved from https://goo.gl/SvsQ1f

Chen, J. C., Li, Y., \& Shady, B. D. (2010). From value stream mapping toward a lean/sigma continuous improvement process: An industrial case study. International Journal of Production Research, 48(4), 1069-1086. doi: 10.1080/00207540802484911

Chowdary, B. V., \& George, D. (2012). Improvement of manufacturing operations at a pharmaceutical company. Journal of Manufacturing Technology Management, 23(1), 56-75. doi: 10.1108/17410381211196285

Corbett, L. M. (2011). Lean six sigma: The contribution to business excellence. Lean Six Sigma Journal, 2(2), 118-131. doi: 10.1108/20401461111135019

Dlabac, J. (2014). Stihly materialovy a hodnotovy tok. MM Prumyslove spektrum, 2014(4), 98. Retrieved from https://goo.gl/14Wn3G

Dohan, M. S., Xenodemetropoulos, T., \& Tan, J. (2014). Value stream mapping in lean healthcare: A brief introduction and application. In N. Wickramasinghe (Ed.), Healthcare delivery in the information age (pp. 463-477). New York, NY: Springer. doi: 10.1007/978-1-4614-8036-5_25

Grewal, C. (2008). An initiative to implement lean manufacturing using value stream mapping in a small company. International Journal of Manufacturing Technology and Management, 15(3/4), 404. Retrieved from https://goo.gl/JoP3VF

Gurumurthy, A., \& Kodali, R. (2011). Design of lean manufacturing systems using value stream mapping with simulation. Journal of Manufacturing Technology Management, 22(4), 444-473. doi: 10.1108/17410381111126409

Henrique, D. B., Rentes, A. F., Godinho Filho, M., \& Esposto, K. F. (2016). A new value stream mapping approach for healthcare environments. Production Planning \& Control, 27(1), 24-48. doi: 10.1080/09537287.2015.1051159

Hitt, M. A., Ireland, R. D., \& Hoskisson, R. E. (2011). Strategic management: Concepts: Competitiveness and globalization. Stamford, CT: Cengage Learning.

Kaale, R. L., Vega, D. D., Messner, K., Eitel, D. R., Johnson, D. E., \& McKniff, S. (2005). Time value stream mapping as a tool to measure patient flow through emergency department triage. Annals of Emergency Medicine, 46(3), 108. doi: 10.1016/j.annemergmed.2005.06.398

Kasava, N. K., Yusof, N. M., Khademi, A., \& Saman, M. Z. M. (2015, September). Sustainable domain value stream mapping (SdVSM) framework application in aircraft maintenance: A case study. Paper presented at the 12th Global Conference on Sustainable Manufacturing - Emerging Potentials, Johor Bahru, Malaysia. doi: 10.1016/j.procir.2014.07.075

Kislingerova, E. (2008). Inovace nastroju ekonomiky a managementu organizaci. Prague, Czech Republic: C.H. Beck. 
Lacerda, A. P., Xambre, A. R., \& Alvelos, H. M. (2016). Applying value stream mapping to eliminate waste: A case study of an original equipment manufacturer for the automotive industry. International Journal of Production Research, 54(6), 1708-1720. doi: 10.1080/00207543.2015.1055349

Liker, J. K., \& Meier, D. (2006). The Toyota way fieldbook. New York, NY: McGraw-Hill Education.

Lima, M., Rolim, L., \& Alves, Thais da C L. (2010, July). Value stream mapping of the architectural executive design in a governmental organization. Paper presented at the 18th Annual Conference of the International Group for Lean Construction, Haifa, Israel. Israel: International Group for Lean Construction. Retrieved from https://goo.gl/f3XTB3

Magretta, J. (2012). Understanding Michael Porter: The essential guide to competition and strategy. Boston, Mass: Harvard Business Review Press.

Matt, D. T., Krause, D., \& Rauch, R. (2013, July). Adaptation of the value stream optimization approach to collaborative company networks in the construction industry. Paper presented at the 8th CIRP International Conference on Intelligent Computation in Manufacturing Engineering, Ischia, Italy. doi: 10.1016/j.procir.2013.09.069

Ohno, T. (1988). The Toyota production system: Beyond large-scale production. New York, NY: Productivity Press.

Parry, G., Mills, J., \& Turner, C. (2010). Lean competence: Integration of theories in operations management practice. Supply Chain Management: An International Journal, 15(3), 216226. doi: $10.1108 / 13598541011039974$

Pavnaskar, S. J., Gershenson, J. K., \& Jambekar, A. B. (2003). Classification scheme for lean manufacturing tools. International Journal of Production Research, 41(13), 3075-3090. doi: 10.1080/0020754021000049817

Peek, B., \& Chen, H. (2011, July). Promoting innovations in a lean organization through innovative value stream mapping. Paper presented at the Portland International Center for Management of Engineering and Technology (PICMET): Conference on Technology Management in the Energy-Smart World, Portland, OR, USA. New York, NY: IEEE.

Piercy, N., \& Rich, N. (2009). Lean transformation in the pure service environment: The case of the call service centre. International Journal of Operations \& Production Management, 29(1), 54-76. doi: 10.1108/01443570910925361

Pribeanu, G., \& Toader, C. (2016). The success in business in the context of sustainable development. Agricultural Management, 18(2), 99-102. Retrieved from https://goo.gl/Qaf4ey

Sahoo, A., Singh, N., Shankar, R., \& Tiwari, M. (2008). Lean philosophy: Implementation in a forging company. International Journal of Advanced Manufacturing Technology, 36(5), 451-462. doi: 10.1007/s00170-006-0870-2

Salvendy, G. (2001). Handbook of industrial engineering: Technology and operations management (3rd ed.). New York, NY: Wiley.

Sellers, B. (2014). Value stream mapping in healthcare. In J. A. Larson (Ed.), Management engineering: A guide to best practices for industrial engineering in health care (pp. 225230). Boca Raton, FL: CRC Press. 
Serrano Lasa, I., Ochoa Laburu, C., \& de Castro Vila, R. (2008). An evaluation of the value stream mapping tool. Business Process Management Journal, 14(1), 39-52. doi: $10.1108 / 14637150810849391$

Seth, D., Seth, N., \& Goel, D. (2008). Application of value stream mapping (VSM) for minimization of wastes in the processing side of supply chain of cottonseed oil industry in Indian context. Journal of Manufacturing Technology Management, 19(4), 529-550. doi: $10.1108 / 17410380810869950$

Singh, B., Garg, S. K., \& Sharma, S. K. (2009). Lean can be a survival strategy during recessionary times. International Journal of Productivity and Performance Management, 58(8), 803-808. doi: 10.1108/17410400911000426

Singh, B., \& Sharma, S. K. (2009). Value stream mapping as a versatile tool for lean implementation: An Indian case study of a manufacturing firm. Measuring Business Excellence, 13(3), 58-68. doi: 10.1108/13683040910984338

Singh, H., \& Singh, A. (2013). Application of lean manufacturing using value stream mapping in an auto-parts manufacturing unit. Journal of Advances in Management Research, 10(1), 72-84. doi: 10.1108/09727981311327776

Taylor, D. H. (2005). Value chain analysis: An approach to supply chain improvement in agrifood chains. International Journal of Physical Distribution and Logistics Management, 35(10), 744-761. doi: 10.1108/09600030510634599

Thurston, J., \& Ulmer, J. M. (2016). The principles of lean manufacturing. Franklin Business \& Law Journal, 2016(2), 57-70. Retrieved from https://goo.gl/cT992C

Tortorella, G. L., Fogliatto, F. S., Anzanello, M., Marodin, G. A., Garcia, M., \& Esteves, R. R. (2017). Making the value flow: Application of value stream mapping in a Brazilian public healthcare organisation. Total Quality Management \& Business Excellence, 28(13-14), 1544-1558. doi: 10.1080/14783363.2016.1150778

Tyagi, S., Choudhary, A., Cai, X., \& Yang, K. (2015). Value stream mapping to reduce the lead-time of a product development process. International Journal of Production Economics, 160, 202-212. doi: 10.1016/j.ijpe.2014.11.002

Vamsi Krishna Jasti, N., \& Sharma, A. (2014). Lean manufacturing implementation using value stream mapping as a tool. International Journal of Lean Six Sigma, 5(1), 89-116. doi: 10.1108/IJLSS-04-2012-0002

Venkataraman, K., Ramnath, B. V., Kumar, V. M., \& Elanchezhian, C. (2014, March). Application of value stream mapping for reduction of cycle time in a machining process. Paper presented at the 3rd International Conference on Materials Processing and Characterisation (ICMPC 2014), Hyderabad, India. doi: 10.1016/j.mspro.2014.07.192

Vidal-Carreras, P. I., Garcia-Sabater, J. J., Marin-Garcia, J. A., \& Garcia-Sabater, J. P. (2015, October). Value stream mapping on healthcare. Paper presented at the International Conference on Industrial Engineering and Systems Management, Seville, Spain. New York, NY: IEEE.

Villareal, B., Garza, F., Rosas, I., \& Garcia, D. (2012). An introduction to distribution operational efficiency. International Journal of Industrial Engineering, 19(7), 278-288. Retrieved from https://goo.gl/3756vJ

Wanitwattanakosol, J., \& Sopadang, A. (2011). A framework for implementing lean manufacturing system in small and medium enterprises. Applied Mechanics and Materials, 110-116, 3997-4003. doi: 10.4028/www.scientific.net/AMM.110-116.3997 
Wilson, L. (2010). How to implement lean manufacturing. New York, NY: McGraw-Hill.

Womack, J., \& Jones, D. (2002). Seeing the whole: Mapping the extended value stream. Cambridge, Mass: Lean Enterprise Institute.

Womack, J., \& Jones, D. (2003). Lean thinking: Banish waste and create wealth in your corporation. New York, NY: Free Press.

Contact information

Ing. Pavel Ondra

Tomas Bata University in Zlín

Faculty of Management and Economics

Mostní 5139, 760 01, Zlín

+420604995155

ondra@utb.cz

ORCID: 0000-0002-0145-9134

DOI ID: https://www.doi.org/10.7441/dokbat.2018.18 


\title{
HOW THE HOUSING POLICY CONTRIBUTES TO THE BRAND OF CITY DISTRICT
}

\author{
Petr Štěpánek
}

\begin{abstract}
Brand of city in the form of vision, different symbols and before the all reputation and unmistakable identity is a long process. The results of building a city or region identity determine economic and social sustainability, competitiveness, real estate market or demographic development. Municipal management often resigns from active policy setting of housing. Housing is, however, the key function of the city. Although the tools of strategic planning of cities are not all-powerful, in long-term horizon they can be cleverly using for brand and reputation building and location value growing. The identity of the city (district) influences the quality of life of its inhabitants. Maintaining an attractive community identity depends directly on the smart direction of development and the ability to influence the physical space and urban character in the locality. The reality of public investments management and processes of negotiation with developers often ignores the long-term strategic public interest of the city and only address economic aspects and limits of the master plan. Other qualitative aspects of public investments are excluded usually from considerations, and the way to develop "brand" is seen just in PR campaigns rather than the quality of city development. This article reflects a case study of one of the edge of the capital city of Prague - Kolovraty. The management of the Prague - Kolovraty district prepared a strategic plan in cooperation with the Czech Technical University in Prague. A key paradigm of this strategic plan is the effort to preserve the identity of the city and its goodwill.
\end{abstract}

Keywords: Sustainable housing, affordable housing, social housing, strategic urban planning, spatial planning

\section{INTRUDUCTION: KOLOVRATY - ANOTHER FACE OF THE CAPITAL}

\subsection{Kolovraty - another face of the capital}

Prague-Kolovraty is a city district near Říčany in the south-eastern part of the capital city of Prague on the railway line 221 from Prague to Benešov. There is over three thousand inhabitants. In 1974 Kolovraty was joined to the territory of so-called Great Prague.

At the time of its union with Prague it was clearly a rural character, which limited the quality of life in the place. The intensive development of the region of the suburbanization process in the vicinity of Prague and after 1990 (throughout the whole of Prague) changed the village character of the village into suburban. The village is now preparing a strategic plan that also includes a territorial study.

The Prague-Kolovraty district is properly connected with the Prague-Uhríněves district. The area between the wider center of Prague and Kolovraty (Uhříněves, Horní Měcholupy, Hostivař) has the character of a periphery. Kolovraty is a natural part of the region, whose center is Ŕičany near Prague. However, this town is located in the Central Bohemian Region, whose borders are copied part of the boundary of Kolovrat. It can be said that Ŕíčany near Prague is what we call a good address. 


\subsection{Hrozba ztráty identity}

Many Prague urban areas have lost their easily identifiable identity over the last 25 years, despite their legal subjectivity and subordinate administrative autonomy. Not even the inhabitants of Prague often understand the complicated administrative structure of their city. ${ }^{4}$ The inhabitants often do not know which of the villages is a part of Prague and which municipality is already in the Central Bohemian region. Not for all of these urban districts their identity was historically associated with what we call "good address." The visual identity of such districts of the city has often been reformatted by socialist and post-revolutionary housing estates or easily interchangeable suburban structures (settlement mash). This process does not usually mean a quantifiable deterioration in the quality of life, but is often the result of a social cohesion deficit and a loss of local identity. The inhabitants of Kolovraty perceive very strongly the threat of loss of identity, mainly due to the loss of the architectural character of the village. Most of this feeling concerns the historically significant settlement of Lipany. This is evidenced by the results of the quantitative research, which was attended by 421 respondents in the framework of the participatory preparation of the strategic plan.

The current situation of the real estate market in Prague is characterized by an oversupply of demand over the offer. Strong demand puts pressure on intensive construction on all available landscapes. The disadvantage of incorporating the municipality of Kolovraty into the capital city of Prague is based on necessity to respect the metropolitan master plan. City districts can only comment on the prepared master plan. The current also designed master plan allows for the construction of large residential buildings in the district. The result is a conflict of interest between developers and communities and municipal representations. Part of the land in Kolovraty was bought by developers. They plan their intensive exploitation, it means the construction of large apartment buildings with small-sized flats. In practice, this means a classic housing estate.

The management of the municipality has limited options to prevent construction that can cause irreversible social and demographic changes and a change in the character of the city district. Potential risk is also the decrease in the real estate value and the gradual decrease of its regional reputation.

The well-developed Strategical plan has the potential to help methodically negotiate with the higher administrative authority, opt-out of the metropolitan planning plan and dialogue with developers. Part of this plan is also the assignment of a territorial study that defines the limits of the use of different types of Kolovraty territory. The Strategic Plan solves the need to preserve the identity of the municipality and build its brand through policies that positively determine the public space.

\section{STRATEGIS PLAN}

\subsection{Identity and vision of the municipality}

The strategic plan for Kolovraty formulates the vision of the village. The definition is based on participatory activities (questionnaire survey, stakeholder consultation). The vision of the municipality is based on the fact that for Kolovraty brand (goodwill) it is more natural to share the image with the region around Ríčany (the territory defined by the surroundings of the railway line 221 to Benešov). Neighboring parts of Prague towards its center - originally primarily the industrial and agricultural inner periphery of the Central Bohemian Region - are

\footnotetext{
${ }^{4} 57$ městských částí, 22 správních obvodů, nelogické vazby k historickým katastrálním územím
} 
perceived as less reputablely attractive. Therefore, their environmental, urban or tourist potential can not be used effectively.

The vision of Prague-Kolovraty was defined using the following propositions.

\subsection{Beautiful Kolovraty}

The quality of the public space and the preservation of the residential character of the city is a key objective of the regulation of the construction in the city. Accent is placed on the aesthetic quality of the district, the preservation of the surrounding landscape character, the spatial cohesion and the permeability. These parameters strengthen the identity of the municipality and build a good address mark.

a) Kolovraty - another face of Prague

Kolovraty are presented as part of the region on the border between Prague and the Central Bohemia. They are distant from the industrial and housing estates. It offers the unpretentious quality of a prosperous suburb. Quality of life is determined by the same requirements as in the capital.

b) Kolovraty - a good place to educate your children.

This vision presents Kolovraty as a community providing quality and competitive (in the context of Prague) primary education. The quality of local education determines the reputation of the community and the quality of life. Kolovraty is an educational destination for the adjacent region. Supporting out-of-school activities and junior sport is part of the municipal policy.

c) Kolovraty - an attractive destination for all generations.

Affordable and physically and socially permeable and cohesive Kolovraty are also competitive Kolovraty. The city district is an attractive place for the natives - the holders of the municipal tradition and also for the new inhabitants who have invested in housing on its territory. Kolovraty are preparing for future demographic changes and are generously diverse and for everyone friendly place to live.

Building infrastructure enhances environmental sustainability and quality of life in the city district. Strengthening the identity of the municipality towards the metropolis and the surrounding region is also a tool to increase its competitiveness and social and economic sustainability.

New investments take into account the paradigm of the quality of life of all generations. Kolovraty is a welcoming place for your visitors.

\subsection{Strategic Plan Policies}

The vision of Kolovraty is implemented through more Strategic Plan policies. The key issue is "Beautiful Kolovraty". It includes the following theses, which, among other things, form the content of a territorial study.

a) Kolovraty are an authentic residential location. It combines the original village style with modern city-forming elements (public lighting, sidewalks, smaller apartment buildings, modern architecture, public areas typical of residential neighborhoods, municipal infrastructure). The available building regulation will be consistent with the preservation of the housing character of the village and its unique aesthetic identity.

b) In order to preserve the aesthetic face of the locality and the desirable nature of the village, the quality of public prosperity is crucial. The city district will pay special attention to its quality with the aim of fulfilling the vision of this plan ("Another Face of Prague"), in order to maintain 
the real estate status of all localities, with the aim of preventing the emergence of socially excluded or otherwise negatively determined localities in order to disturb tourism, quality of life, the health of the community. Upon planning, planning and revitalizing public areas, relevant documents related to city planning will be taken into account.

c) The municipality will engage in all legitimate ways to prevent such development projects, which contravene the recommended building regulations and whose character is associated with the risk of a decrease in the quality of life and well-being of any part of Kolovrat, demographic, social or economic and environmental sustainability and resilience.

d) The evaluation criterion for assessing investment plans in the municipality will be so-called comfort and quality of housing in the sense of anchoring this parameters in the relevant legal framework.

e) Currently constructed or repaired transport, environmental and other technical infrastructure must respect the paradigm of the architectural character of the village, the permeability and the quality of life of the inhabitants.

f) The village will systematically endeavour for the revitalization of the places, which aesthetic character of the municipality deteriorates. Locations owned by the municipality will rank among their investment priorities. Other partners will offer synergies or methodological assistance.

g) The process of architectural tender will be apply for major investments in construction in public space.

h) The municipality will support the revitalization of the transformation localities in order to improve the quality of life, the residential character of the village and the support of small and environmentally sensitive businesses.

i) Buildings and locations with the potential to increase the reputation of Kolovraty's competitiveness will be the subject of both internal and external communications.

j) Within the communication activities of the region, exemplary, interesting or typical residential, civil or economic buildings will be identified.

k) Physical and optical (psychological) separation of the backbone transport infrastructure (transport, high-speed rail) will be realized through a suitably chosen green infrastructure.

1) Public spaces will be complemented by urban furniture that respects the character of the village and other aesthetic and useful criteria.

m) The negotiation process with investors will be conducted on the platform both-acceptable planning contracts respecting the requirements for sustainable development and quality of life in the community. 


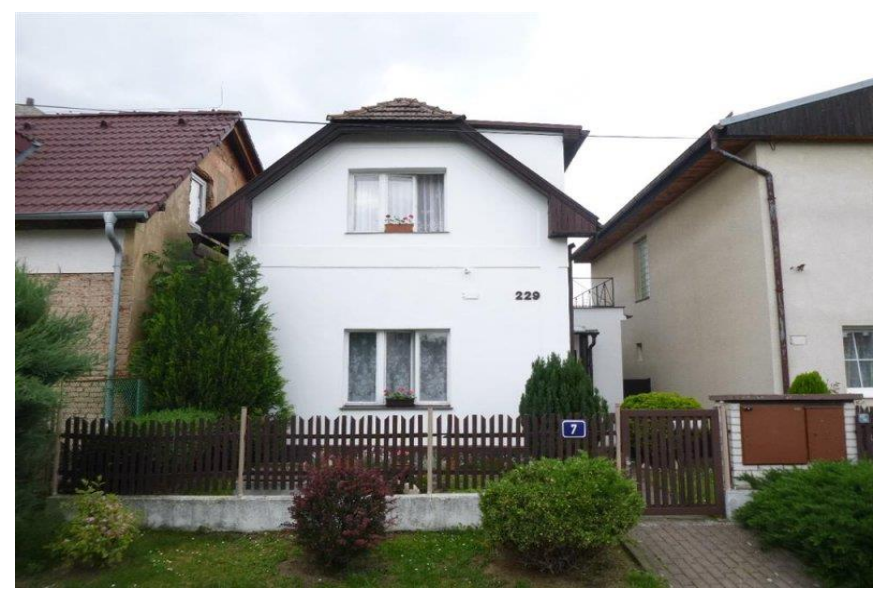

Figure 19 - Typical suburban area in the village, which was formerly a village character. Important is the existence of a sidewalk, front gardens, public lighting. Source: author's archive

\subsection{Kolovraty between regions}

Other policies define the positioning of Kolovrat among other Prague urban districts.

n) The municipality of Kolovraty will support the creation of a micro region on the border between Prague and the Central Bohemian Region (primarily connected to the railway line 221 Prague - Benešov), including mainly Říčany, Mnichovice, Strančice, Světice, Nupaky, Nedvězí u Řiccan, Benice and others.

o) The municipality supports institutional (especially cultural, investment, transport, environmental and tourism) as well as civil and working cooperation between the micro region municipalities, in the same way as with the whole city (capital Prague) institutions.

p) Kolovraty will strengthen the cultural, geographical and social identity of the city of Prague 22. The Prague-Kolovraty City Center does not present itself as a Prague periphery.

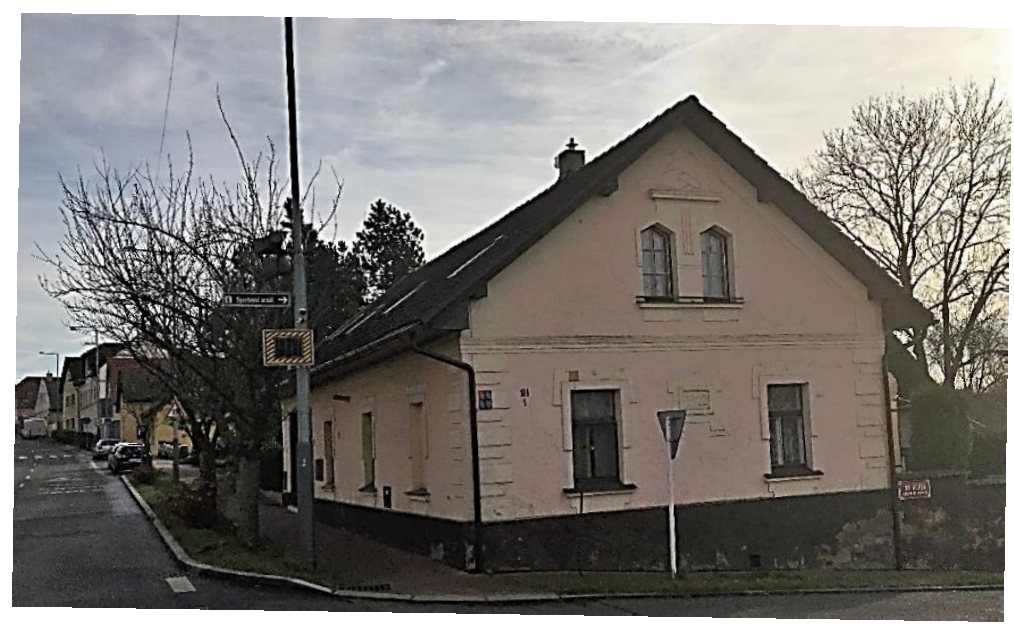

Figure 2 - A proof of the architectural quality of the village from the first quarter of the 20th century. Source: author's archive

r) Colovrats are a unique, easily identifiable and attractive city part of the capital city of Prague, one of the defined and available residential locations for residents, who have their working activities in all Prague and central Bohemian region. 
s) Kolovraty is an interesting and well-known tourist destination especially for one-day excursions of the inhabitants of other Prague city districts and residents and visitors to the neighboring Central Bohemia Region.

t) The cultural and social life in Kolovraty is accessible and well known to other inhabitants of the city. m. Prague and municipalities from the nearby parts of the Central Bohemia Region.

v) The municipality supports activities aimed at the authentic perception of Kolovrat by its own citizens and visitors.

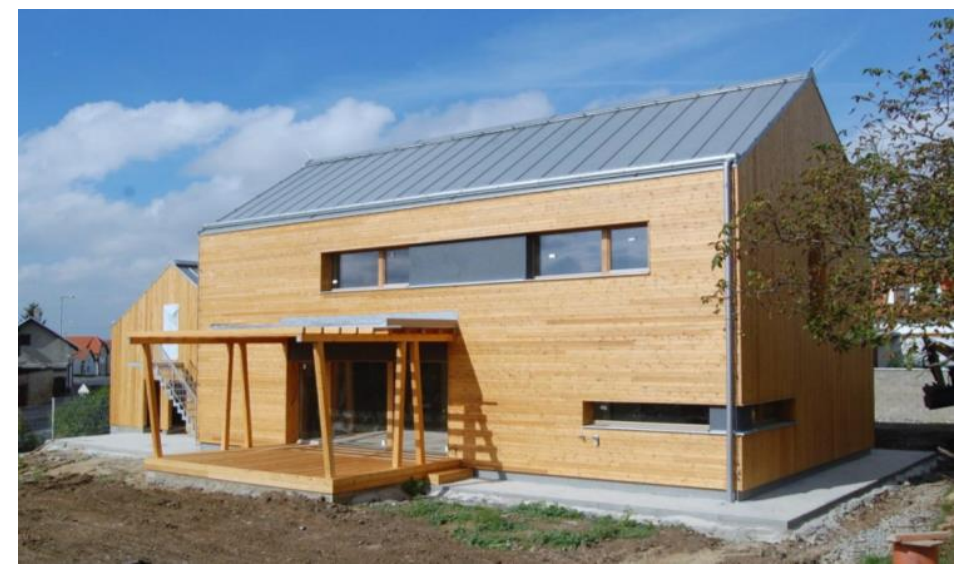

Figure 3 - A new face of the Prague suburbs and one of the pillars of attractive reputation and identity. Source: author's archive

\subsection{Permeability and mobility}

a) The municipality will support the environmentally friendly mobility of its inhabitants, especially the use of public train and bus services. Support will also include cycling infrastructure and eventual support for e-mobility.

b) Public spaces will be user-friendly for users of compensatory aids and tools, children and seniors.

c) The investment activities of the municipality will support the spatial complexity between the part of Lipany and their interconnection with the rest of Kolovraty. This cohesion will be supported by the expansion and improvement of communication and the promotion of a change in the character of the area that separates Lipany from the other parts of Kolovraty.

d) The municipality will endeavor to strengthen the bus connection with other parts of Prague.

e) The municipality wants to make the public infrastructure connected with rail transport connecting Kolovraty with the center of Prague and the Central Bohemian region more attractive.

f) The municipality will support the strengthening of the accessibility of the adjacent Central Bohemian region, especially within the microregion 221 at the border of the city. Prague and Central Bohemia.

g) The municipality will support the provision of partial and supraregional Park \& Ride concepts in order to make local rail transport available and reduce traffic in the city.

h) Public roads affected by traffic will be the subject of priority investments in improving public space.

i) Natural bio-corridors will be preserved in the village. 
j) The Negotiation of the Metropolitan Plan, public investment and building regulation will support a compact building with the aim of eliminating the spatial barriers to the physical and social permeability of the community.

k) Public spaces are built to promote their public or semi-private or semi-private character. The public space must support the functioning of natural local communities, the sense of security and physical permeability. This paradigm is also used to private investment in construction.

1) The municipality will support all available logistic permeability projects between Kolovraty, its parts and the surrounding municipalities of the Central Bohemian Region.

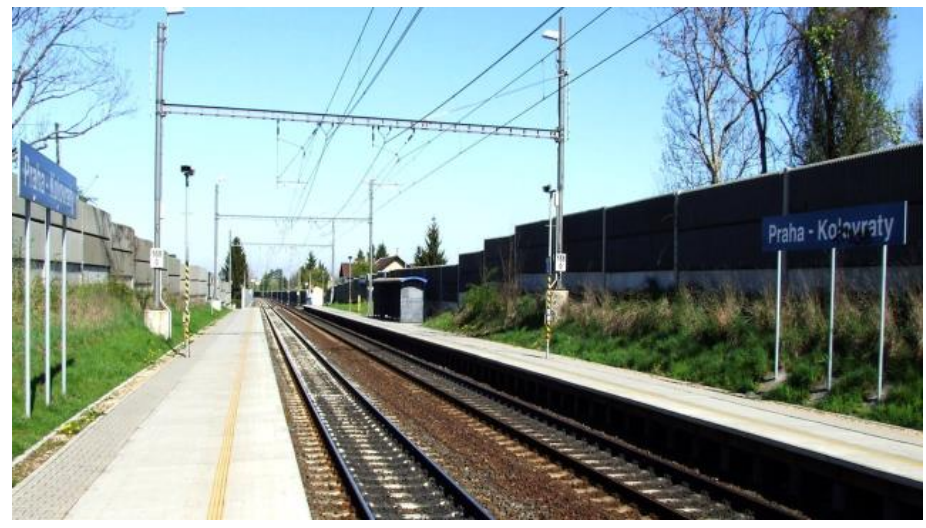

Figure 4 - A railway stop built at the beginning of the 21 st century illustrates the desperate deficit of the public sector's competence for building public space. Source: author's archive

\section{CONCLUSION}

The quality of public space, the architectural character and the physical permeability of the municipality influence its competitiveness and its economic, social and environmental sustainability. Strategic planning is a tool for improving the quality of life of the population. However, it must also work with so-called soft parameters that do not define any legislative framework. The essential parameter is the identity of the municipality. Here, it is often necessary to define the basis of expert analysis and participative research. Key is the reputation as well as the physical / regional positioning of the municipality. Building a clearly formulated identity is critical in the case of peripheral Prague's urban areas. Future demographic, economic, and social developments can move them to the position of a subtle periphery. The strategic plan for Kolovraty is going to prevent it.

\section{Aknoclegment}

The paper presents partial results of the research project (supported by Technology Agency of the CR - Éta programme) „Sustainable and affordable housing in strategic urban planning "processed at Czech Technical University in Prague. The author of the article is also the head of the City of Praha-Kolovraty Strategic Plan project.

\section{References}

ČSÚ. (2017). Ceny bytů v České republice. https://www.czso.cz/csu/czso/ceny_bytu

Gehl J. (2010). Cities for people. Washington: Island Press. 
Lux, M. \& Burdová P., (2000). Výdaje na bydlení, SB a napětí na trhu s bydlením (mez.

komparace a polistop. vývoj v ČR). 1. vyd. Praha: NÚ J. Hlávky, 2000. 114 s. Studie 2/2000.

Lux, M. (2002). Bydlení - věc veřejná: sociální aspekty bydlení v České republice

a zemích Evropské unie. Vyd. 1. Praha: Sociologické nakladatelství, 2002.

Quigley, J. M. (1997). The economics of housing. Vol. 1. Cheltenham: Edward Elgar.

Štěpánek, P. (2017). Models of Social Housing in Strategic Planing. In KOBDAT 2017.

Štěpánek, P.\& Dobrucká, L.: (2017). Dotazníkové šetření v rámci přípravy Strategického plánu MČ Praha-Kolovraty.

Špirková, D.\& Štěpánek,P. (2017). Economic Aspects and Contradictions of Sustainable

Housing. In IBIMA 2017.

\section{Contact information}

Ing. arch. Ing. Petr Štěpánek, Ph.D.

ČVUT Praha

Kolejní 2a, 16000 Praha 6

+420602555040

petr.stepanek@cvut.cz

DOI ID: https://www.doi.org/10.7441/dokbat.2018.19 


\title{
PHENOMENON BITCOIN: MONEY OF FUTURE OR JUNK COMMODITY?
}

\author{
Vojtěch Sadil
}

\begin{abstract}
The paper is aimed at a very accurate topic which is problematic of cryptocurrency Bitcoin. The main aim of this paper is to evaluate the potential of this most important cryptocurrency to serve as full-value money. The matter of the first chapter is introducing the Bitcoin concept including its characters and history. In this phase, we are thinking about Bitcoin as a commodity. The analysis of cryptocurrency Bitcoin within currency relations framework is subject for next chapter. Each commodity, which has a role of money, must fulfil three criteria. This commodity must be convertible, relative stable and liquid. This paper discusses the evaluation of these aspects. Based on the analysis, we can contribute to the question whether bitcoin can be used as full-value money in the future. The paper is not concerned on technical aspects like the algorithm of mining, blockchain technology or account safety.
\end{abstract}

Keywords: Bitcoin, Cryptocurrency, Liquidity, Stability, Convertibility

\section{INTRODUCTION}

Forbes Magazine declared 2013 to be 'The Year of the Bitcoin'. (Christensen, 2013) This cryptocurrency is the phenomenon of today's times. But we can say now, the Year of the Bitcoin is 2017. True madness about Bitcoin has started in June 2017. After half year, Bitcoin price peaked on incredible level 20000 USD/BTC.

Almost everyone has heard about Bitcoin. This cryptocurrency attracts the attention of financial professionals and the general public. Critics say that it's just a speculative bubble. Many sceptics, since the issue of the Bitcoin, put the question "Why use virtual currency instead of traditional currencies? On the other side, Bitcoin supporters see this reality as the beginning of a new era of free money.

Cryptocurrencies are also a great challenge for the academic sphere. There exist almost 2000 cryptocurrencies today. (coimarketcap.com, 2018) It is necessary to understand how Bitcoin works and what is its position in the contemporary monetary system. And above all, it is necessary to answer the question: "What is Bitcoin?" Is it the currency of the future, or is it merely just a Ponzi scheme for the internet age? Obviously, this is the question that everyone with an interest in Bitcoin is curious to find out.

Today, intensive discussion is taking place about cryptocurrency classification. Is Bitcoin currency or investment asset? (Bitcoin.com, 2018) Next type of discussion is about ecology aspects for cryptocurrencies. Process of minning is very demanding on energy power. Cryptocurrencies are still not fully understood, especially from the monetary point of view. Saito (2014) discuss the problematic of financing of illegal activities.

For economic and academic sphere is research about monetary aspects of cryptocurrencies very accurate and relevant. Cryptocurrencies represent new element in international monetary system. These elements create new relations among all elements in this system. Cryptocurrencies are not a matter of small groups of IT experts but it is thing which influences the current world currency arrangement. 


\section{THE PRINCIPLE OF BITCOIN}

Bitcoin can be described as a virtual asset which is absolutely identical across markets where is traded. The market for this asset operates 24 hours daily and 7 days in a week. If the market participant has an access to the internet then data from this market are available immediately. (Pieters, Vivanco, 2017)

Urquhart (2016) describes bitcoin as a cryptocurrency which has received substantial attention given by its innovative features, simplicity, transparency and due to increasing popularity.

Virtual currency Bitcoin is an alternative to traditional coins because it does not depend on a specific bank or state, is not controlled by any state and is protected of inflation. Georgetta et. all (2016) The similar view is possible to find in the book by Stroukal and Skalicky (2015). Authors character Bitcoin as a digital P2P currency (no as commodity). In addition, the authors describe Bitcoin as "good money". The characteristics of good money are divisibility and interchangeability. Authors also state that good money does not need internal value. That is generally true. At the first sight is possible to state that bitcoin is a very hopeful alternative for classic fiat money. The same view as mentioned authors has Graf (2013). Bitcoin is understood as a full-value money. The more caution argument is presented by Heissler et. all (2016). According them Bitcoin can have (but only in case of stable value) the character of good money.

On the other side, Baeck and Elbeck (2015) arguing that Bitcoin should be understood as a speculative commodity rather than a currency. Rate of divisibility and interchangeability is not enough here. The same view has Shostack (2016) who says that Bitcoin has price only within using as a transaction service.

Georgetta et. all (2016) claim, that individuals attracted to new technology and virtual coins followers, believes there are a number of advantages of using them:

1) Protection of Privacy for Bitcoin users

2) Facilitates people's ability to buy of anywhere

3) Secured financial data (blockchain technology)

4) System does not allow seizure

Bitcoin was launched in 2009. The global financial crisis has reached its peak this year. The market price has reached level from 0 USD to 20000 USD per 1 Bitcoin (in December 2017) since launched. At the time of writing this paper (February 2018), the Bitcoin price have been oscillated from 8,000 to 11,000 USD per 1 Bitcoin.

For the purpose of conceptual purity, there will be use concepts "currency" and "money" as synonyms. The currency can be defined according to Holman (2003) as national money unit which is issued by law. Naturally, Bitcoin has never been "issued". However, this fact is not an obstacle to that Bitcoin can serve as an instrument of market exchange.

There are several ways to get Bitcoin. The first way is minning. It is process of creating new Bitcoins with using mathematic algorithms. Common user can buy Bitcoin on cryptocurrency stocks. Very popular way is using Bitcoin ATM. In Czech Republic, there is a relatively wide network of these machines. If investor want to speculate on BTC price development he can use CFD (Contract for Difference) on Cryptocurrencies. Some FOREX brokers provide this service (XTB). It is possibility how to speculate with Bitcoin without its hold. The investor holds only derivate which works as stock swap. 


\section{BITCOIN AS A MEDIUM OF EXCHANGE}

If we want to evaluate the potential of Bitcoin to serve as money of the future we need to study the economic characteristic of Bitcoin and also its position within monetary systems which including the links among Bitcoin, cryptocurrencies.

Cryptocurrencies (respectively crypto-assets) form unique monetary system. This system is in a form other than that we know in the case of conventional currencies. At present, there are approximately 1500 crypto-assets, which are commonly referred to as cryptocurrencies. Bitcoin represents the dominant crypto-asset in this system with a market capitalization of 178 billion USD. (Coinmarketcap.com, 2018) Cryptocurrency system is possible to describe with using an analogy as the aggregate of existing links among individual cryptocurrencies to whole system and whole system to individual cryptocurrencies. This system can be examined (according to Nemecek, 2000) from the point of view within monetary relations.

In the case of Bitcoin, we should start with an analysis of basic fundaments (see figure 1 below). The first one is the Bitcoin price. The price has already been analysed in the previous chapter. The price and volatility of Bitcoin will be discussed in the next chapters. Total market capitalization reached 178.5 trillion dollars in February 2018. A very interesting indicator is the number of daily transactions. At the time of article writing, it takes about $192 \mathrm{~K}$ transactions each day. Here we can observe an interesting fact. While bitcoin and market capitalization has increased since the begin of February, the number of daily transactions has been steadily decreased. This can be explained mainly by the speculation theme.

Bloomberg issued an article where is published the fact about decreasing number of the places where is possible to pay with Bitcoin. This fact also supports the assumption of a growing speculative motive. (Bloomberg, 2017)

The basic questions that arise in the case of cryptocurrency systems are the convertibility, stability and liquidity requirements of individual cryptocurrencies. In the following chapters, we will attempt to analyse how Bitcoin achieves to these important requirements.

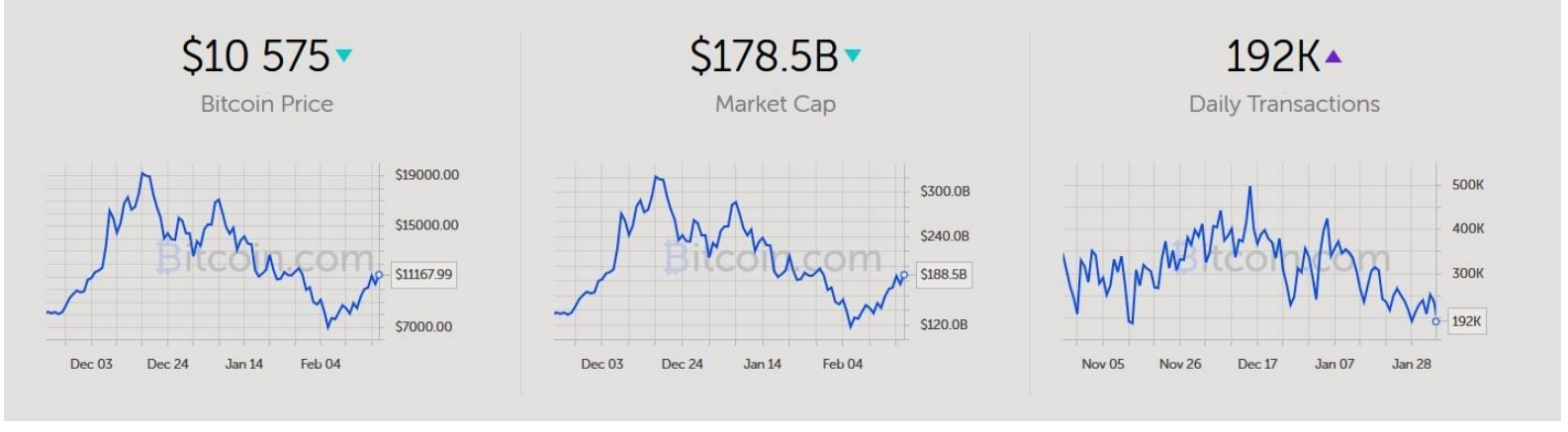

Figure 20 - Basic Bitcoin Fundaments. Source: bitcoin.org (2018)

\subsection{Question of Convertibility}

In the case of Bitcoin, convertibility is understood as a possibility to convert one cryptocurrency into another cryptocurrency. Cryptocurrency which can be converted by anyone, at any time, for any purpose and in any quantity, can be described as well convertible. There exist almost 30 cryptocurrencies which can be converted into Bitcoin directly. The selection included the most important cryptocurrencies, such as Ethereum, Ripple or Monero. The list of other cryptocurrencies is available on the webpage: changelly.com (2018)

It is also possible to make indirectly conversion with using of classical currencies. However, in this case, we cannot speak about true convertibility. This fact is a reason why is classical 
currency existing still essential for the functioning of cryptocurrency market (especially for non-convertible cryptocurrencies).

The exchange ratio for the most important cryptocurrencies is quoting around their market values (see webpage: bestchange.com). We can observe that spreads are relatively narrow. However, exchange rates vary across platforms for cryptocurrencies conversion considerably. For illustration see figure 2 where are showed exchange ratios between Bitcoin and Ethereum.

In the case of Bitcoin, the convertibility is limited by the fact that there are bans on Bitcoin in some countries. Bitcoin has been banned for example in Taiwan, Russia, Bolivia, Colombia and Bangladesh. It can be assumed that the ban on Bitcoin will be gradually expanded. Cryptocurrencies are a threat especially for undemocratic governments with a problematic monetary policy (for example in the case of high-inflation).

\begin{tabular}{|c|c|c|c|c|c|}
\hline & Exchanger & Give & Get $\mathbf{v}$ & Reserve & Reviews \\
\hline i & Bitochek & 1 BTC $\min 0.01$ & $13.08230000 \mathrm{ETH}$ & 8.82 & $0 / 3$ \\
\hline is & AlfaCashier & 1 BTC $\min 0.00445631$ & $13.06745800 \mathrm{ETH}$ & 171.65 & $0 / 75$ \\
\hline i & Cashex & 1 BTC $\min 0.01$ & 13.06636737 ETH & 7.01 & $0 / 2$ \\
\hline is & 24PayBank & 1 BTC $\min 0.003$ & 13.06210000 ETH & 9.01 & $0 / 7$ \\
\hline i & WestChange & 1 BTC $\min 0.05$ & $13.05325100 \mathrm{ETH}$ & 12.52 & $0 / 40$ \\
\hline i & WMGlobus & 1 BTC $\min 0.003$ & $13.05315100 \mathrm{ETH}$ & 13.33 & $0 / 12$ \\
\hline i & IObmen & 1 BTC $\min 0.005$ & $13.05247300 \mathrm{ETH}$ & 42.39 & $0 / 3$ \\
\hline is & BaksMan & 1 BTC $\min 0.005$ & $13.04940000 \mathrm{ETH}$ & 594.70 & $0 / 1$ \\
\hline i & $100 \mathrm{Btc}$ & 1 BTC & 13.04580000 ETH & 7971.87 & $0 / 2$ \\
\hline i & Bankcomat & 1 BTC $\min 0.003$ & 13.02980000 ETH & 41.87 & $0 / 3$ \\
\hline is & Xchange & 1 BTC $\min 0.005$ & 12.91390000 ETH & 37.09 & $0 / 10$ \\
\hline
\end{tabular}

Figure 21 - BTC/ETH exchange rates sample. Source: bestchanges.com (2018)

Another problem that makes Bitcoin's conversion difficult is high exchange rate volatility. This problem will be discussed in chapter stability (3.2.). The volatility of Bitcoin and Ethereum is there compared with the volatility of currency pair EUR/USD. Bitcoin is likened to gold by his supporters, but this comparison is not accurate. The last barrier for Bitcoin convertibility is connected with the impossibility to convert cash. Bitcoin can only exist in virtual space.

Despite the above, Bitcoin can be considered a relatively well convertible cryptocurrency. In the near future, banks will not be so willing to do conversional operations with cryptocurrencies. Cryptocurrencies can be converted only with using specialized web platforms. However, those platforms are without any regulation. In compare with the level of convertibility in the case of conventional currencies those will always be significantly more convertible. The reasons for this assumption are described above.

\subsection{Question of Stability}

In the case of the stability parameter, the following question should be answered: Is it necessary for Bitcoin to be stable? In other words, is it possible to stabilize Bitcoin in any way? However, the notion of stability must be understood in a relative sense. (Nemecek, 2000) A stable currency can be considered as one for which its internal and external stability changes only slowly. The exchange rate of this currency oscillates around the chaotic attractor. (Sadil, 2016)

Bitcoin is unstable in its principle (see Nakamoto, 2008). Its price is influenced by market forces, supply and demand. Demand for Bitcoin is based on two motives, transactional and 
speculative. At present, it is clear that the speculation motive is stronger than the transaction motive. This assumption can be supported by the fact that the volume of payments is decreasing while Bitcoin's price is rising in the month February 2018. This is evident from the figure, which is mentioned in Chapter 3.

As already mentioned, we recognize internal and external stability. Internal stability means stable purchasing power. In the case of Bitcoin, the instability of purchasing power is apparently. In 2010, it was possible to buy two pizzas for 10,000 BTC. At present, those would be worth over $\$ 115,000,000$. (bitcoin.org, 2018)

The Bitcoin Price is showed in figure 3 below. We can also measure parameter of stability with using volatility. The Bitcoin price is currently 20x more volatile than the most traded currency pair EUR / USD. (bitvol.info., 2018) The development of volatility in last year is also showed on figure 3 below. The average value of standard deviation of daily returns is between 5 and 6 percent. Actually volatility (measured by standard deviation of daily returns) of currency pair EUR/USD moves around 0,4\% in March 2018. (authors calculation)

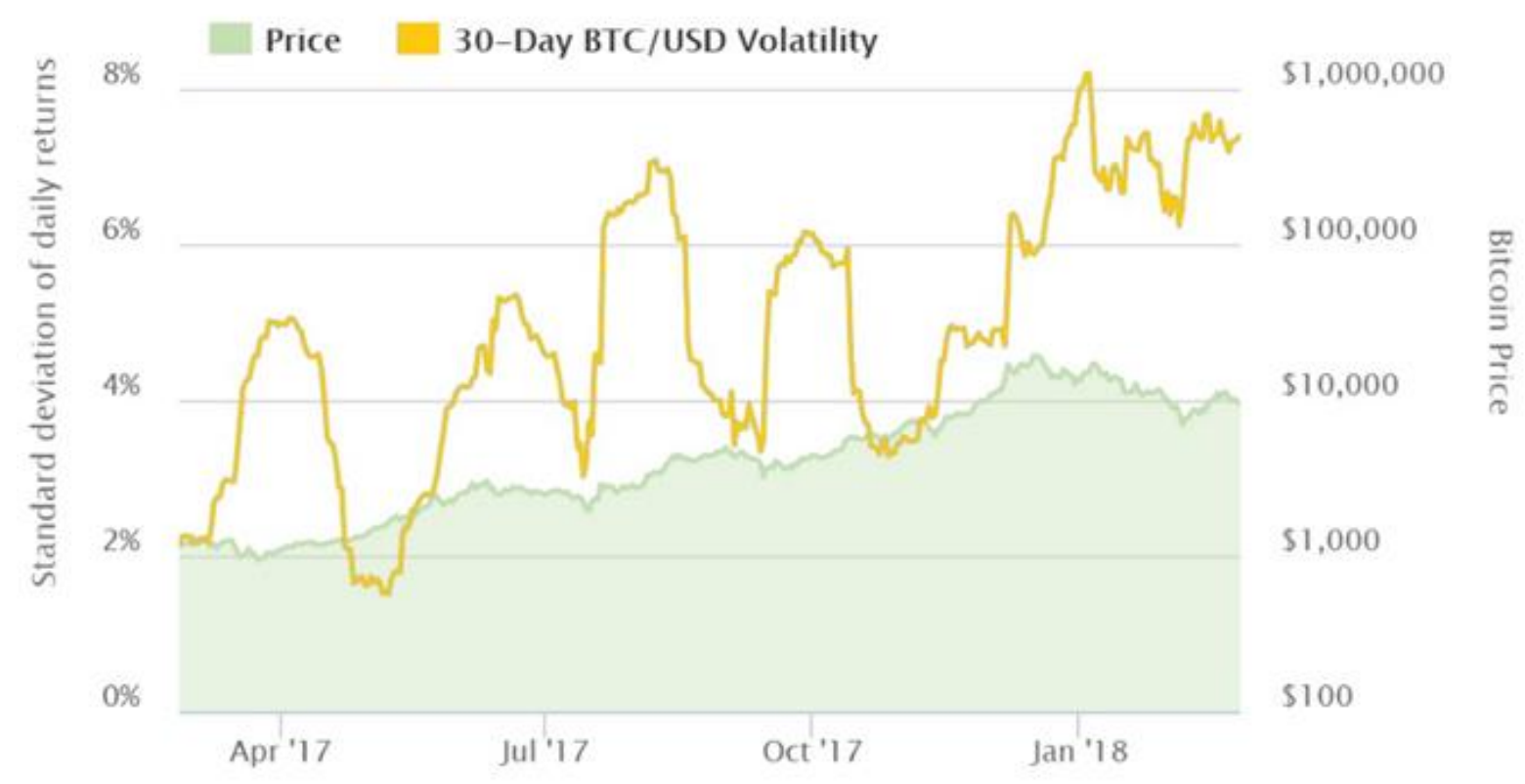

Figure 22 - Bitcoin/USD Volatility index (bitvol.info., 2018)

Let's also consider external stability. This means the stability of Bitcoin courses against other cryptocurrencies. At first, we can observe the exchange rate for cryptocurrency pair Bitcoin/Ethereum. This rate is showed in figure 4 below. We can see, that exchange rate was very instable last year. In the present time, the 1 Bitcoin unit is equal 11,6 Ethereum units (at the end of February 2018). 


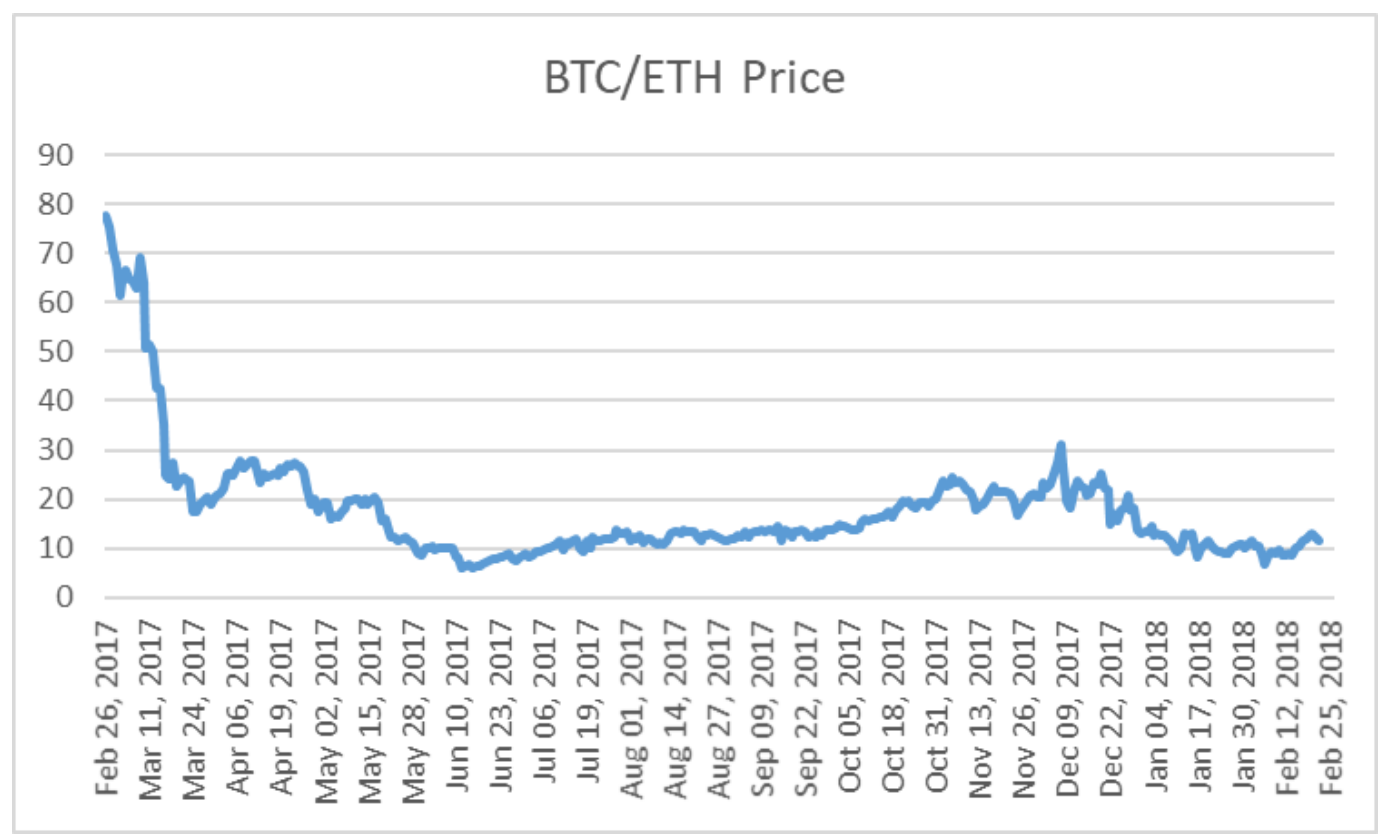

Figure 23 - Bitcoin/Ethereum exchange rate. Source: author's own calculation

And secondly, there is also possible to study correlation between Ethereum and Bitcoin prices. Figure 5 shows the daily returns ratio for the Bitcoin and Ethereum. There is also possible to observe high instability here. Correlation coefficient between Ethereum and Bitcoin daily returns is only 0,18 . This result means weak relation between price of those two cryptocurrencies and visible high volatility for both of them. (author's own calculation)

It is clear from the above that Bitcoin does not fulfil the stability requirement. Bitcoin cannot be pegged to anything. There is also no chance to stabilize its price. Its price is left to purely market influences. So, could it be working in these conditions? The answer is very difficult. Generally, the existence of reflexivity in complex economic systems means that also Bitcoin is vulnerable to making price bubbles. The impossibility of regulation, in this case, is an obstacle.

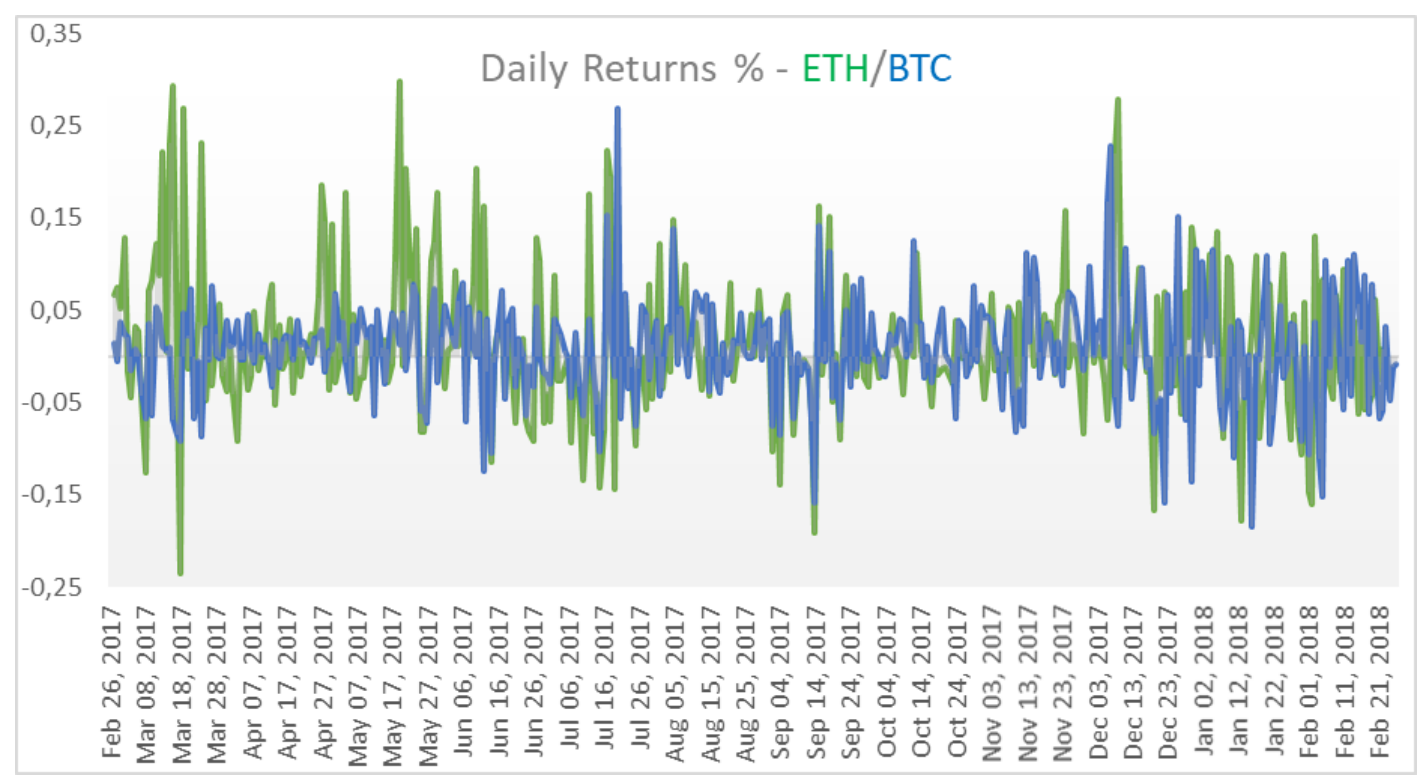

Figure 24 - Standard Deviation of Daily Returns for ETH and BTC. Source: author's own calculation 


\subsection{Question of Liquidity}

In case of liquidity, it is necessary to deal with obligational argument by opponents of Bitcoin. Those claim that with according to final limited amount of Bitcoin there exist risk situation. It is assumed that will be not enough of Bitcoin. So, the asks are simple. Will be enough Bitcoin in the future? And does the deflation design mean an essential problem for Bitcoin's using? The question of liquidity is also related with the significant asymmetry between the holders of Bitcoin which is also mentioned here.

The Bitcoin opponents state legitimate arguments. At first, Bitcoin is constructed to reach infinite deflation. The amount of Bitcoin is limited to 20 million units. Deflation means, according to Mises (2006), the drop in the amount of money which cause a grow of purchase power of money unit. This decrease is not compensated by an equal decline in money demand.

We must recognize price and monetary deflation. In case of Bitcoin, it is not possible to expect price deflation. The amount of Bitcoin in its circulation is strictly limited. With increasing number of Bitcoin users is possible to assume increasing demand for Bitcoin. Because of limited amount, it is possible to assume a gradual appreciation of this cryptocurrency.

Figure 6 shows the plan of Bitcoin mining. We can observe here that almost all Bitcoins have been already mined. Bitcoin is also endurance against inflation. According to asymmetric distribution, the loss of Bitcoins from the most significant accounts can have a significant impact on its value. It can be said that monetary deflation if it will be significant, represents a difficult problem for Bitcoin. It cannot be used in the current banking environment for the mentioned characteristics. It can be used only for $100 \%$ reserve coverage banking system. For example, DeSoto (2006) describes the characteristics of this system. The inability to use Bitcoin in the partial reserve system is a serious barrier for Bitcoin for today's times.

On the other side, Bitcoin's proponents do not see in its fixed amount an obstacle for its functioning. Supporting arguments can be found in the theory of the Austrian School of Economics. Bitcoin defenders often use an analogy with the gold standard. These arguments stem from the work of Rothbard (1990) and Mises (2006). The logic of this argumentation is as follows: Bitcoin, as well as gold, will not be lacking because its value can be constantly divided. According to the Gold Commission report (in Nemecek, 2000), the golden standard of the international monetary system did not suffer from a lack of gold. This is also argued in the case of Bitcoin.

Let us briefly discuss the asymmetric among Bitcoin holders. There is apparently that almost 2 percent of Bitcoin holders hold 96 percent of Bitcoin units (see figure 7). It is theoretically possible that those holders are able to influent Bitcoin value significantly. The market with Bitcoin has oligopoly character. However, the asymmetric distribution may not pose a problem under "relative stability" conditions. Bitcoin has not been able to stabilize. This feature makes Bitcoin a fragile currency. Great changes in the volume of Bitcoins held may have a significant impact on the stability and liquidity of this currency. 


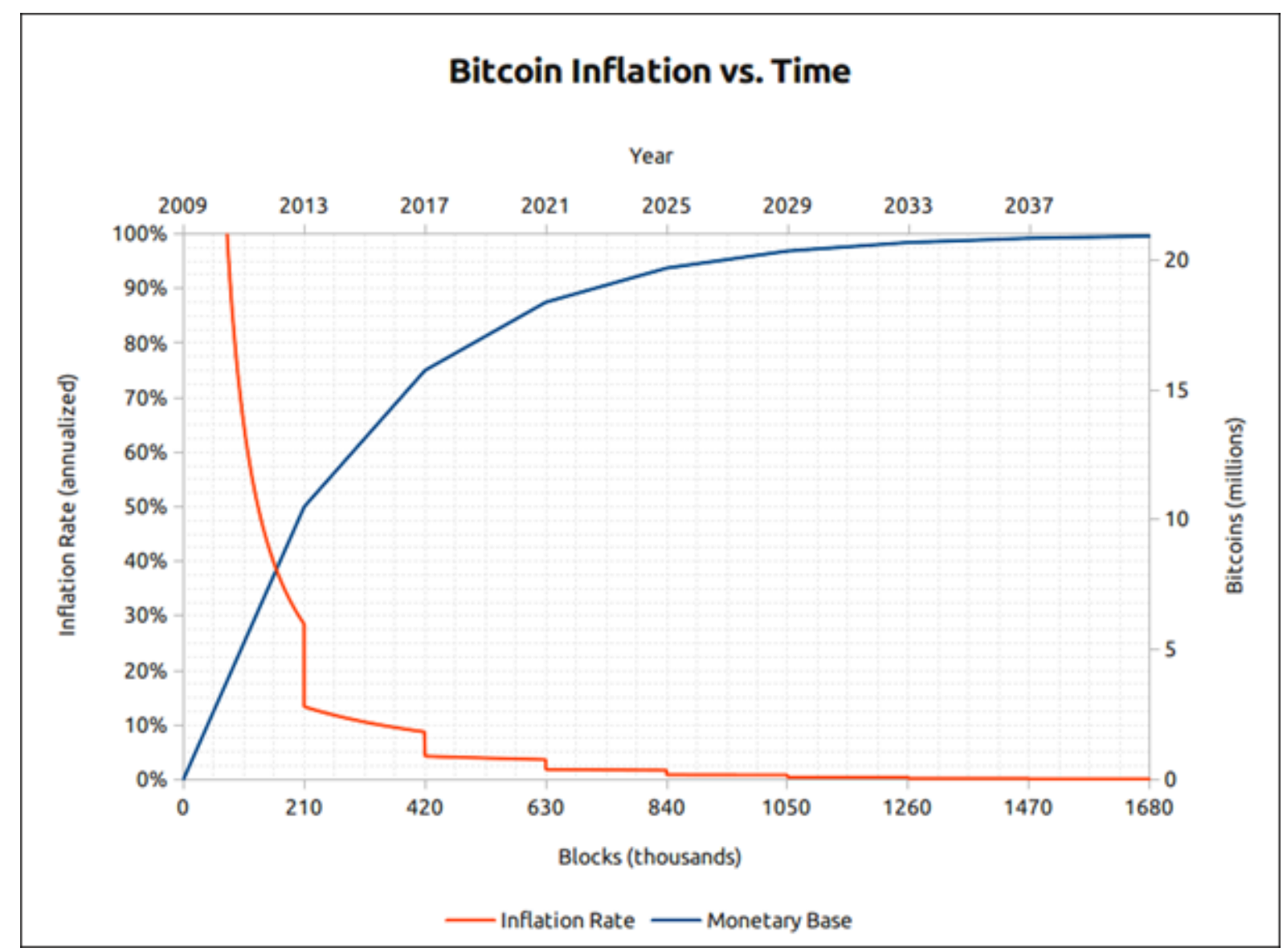

Figure 25 - Bitcoin Inflation vs. Time. Source: bitcoin.org (2018)

\begin{tabular}{llllll} 
Balance & \multicolumn{2}{l}{ Addresses $\%$ Addresses (Total) Coins } & \multicolumn{2}{l}{ SUSD } & \% Coins (Total) \\
\hline $0-0.001$ & 13403330 & $54.66 \%(100 \%)$ & 2,246 BTC & $23,855,921$ USD & $0.01 \%(100 \%)$ \\
\hline $0.001-0.01$ & 4878651 & $19.89 \%(45.34 \%)$ & 20,469 BTC & $217,372,939$ USD & $0.12 \%(99.99 \%)$ \\
\hline $0.01-0.1$ & 3912007 & $15.95 \%(25.45 \%)$ & 125,143 BTC & $1,328,976,626$ USD & $0.74 \%(99.86 \%)$ \\
\hline $0.1-1$ & 1643969 & $6.7 \%(9.5 \%)$ & 527,974 BTC & $5,606,904,417$ USD & $3.14 \%(99.12 \%)$ \\
\hline $1-10$ & 536956 & $2.19 \%(2.79 \%)$ & $1,423,795$ BTC & $15,120,224,193$ USD & $8.47 \%(95.98 \%)$ \\
\hline $10-100$ & 130996 & $0.53 \%(0.6 \%)$ & $4,343,090$ BTC & $46,122,152,325$ USD & $25.83 \%(87.51 \%)$ \\
\hline $100-1,000$ & 15664 & $0.06 \%(0.07 \%)$ & $3,699,365$ BTC & $39,286,004,108$ USD & $22 \%(61.68 \%)$ \\
\hline $1,000-10,000$ & 1527 & $0.01 \%(0.01 \%)$ & $3,356,340$ BTC $35,643,196,975$ USD & $19.96 \%(39.68 \%)$ \\
\hline $10,000-100,000$ & 111 & $0 \%(0 \%)$ & $2,984,769$ BTC $31,697,237,021$ USD & $17.75 \%(19.72 \%)$ \\
\hline $100,000-1,000,000$ & 2 & $0 \%(0 \%)$ & 330,491 BTC & $3,509,699,571$ USD & $1.97 \%(1.97 \%)$
\end{tabular}

Figure 26 - Bitcoin distribution. Source: bitcoin.org (2018)

\section{CONCLUSION}

Cryptocurrencies are phenomenon for today's time. The market of cryptocurrencies is growing by incredible speed. Although there are great gaps in cryptocurrency research for academic and practical purposes. The hidden aim of those article is open discussion about cryptocurrencies, especially about Bitcoin. This cryptocurrency is the most important in today's time. It is evidently that Bitcoin is very accurate topic for wide public and investors.

This article is divided into two basic chapters. In the chapter 2, there was introduced the basic principle of Bitcoin. This part was followed by chapter 3 which deal with basic questions which are important for Bitcoin understanding. The main idea of this paper is to judge whether Bitcoin 
can serve as full-value currency. The questions of convertibility, stability and liquidity have been analysed in this paper. It is evident that Bitcoin is relative well convertible. There also exists the possibility to make direct conversion into other cryptocurrencies. In the case of stability there is evident that Bitcoin is not very unstable. There is no way to stable it. The price and purchase power are very variable. Standard deviation of daily returns was almost $8 \%$ in 2017. For comparation, the same deviation for EUR/USD pair was $0,4 \%$. Correlation between Bitcoin and Ethereum was calculated only 0,18. That means weak relation between Bitcoin and Ethereum price development. This grade of this parameter is not sufficiently achieved. The last parameter was liquidity. The amount of Bitcoin is strictly fixed. There also exist high asymmetry in Bitcoin distribution. Almost 2 percent of Bitcoin holders hold 96 percent of Bitcoin units. Bitcoin inflation is going to zero due to this cryptocurrency construction. There is possible to expect a stable deflation trend.

Finally, there are a number of cryptocurrencies that work better, are less energy to consume, or even slightly inflationary. The market for crypts grows incredibly. Bitcoin, however, remains the first cryptocurrency that represents the beginning of the crypto-money era. However, if we look at it with the optics of Schumpeter's theory of economic cycles, it can be quite pessimistic. Bitcoin, as a significant innovation, can be seen as a monopoly gain. This "profit" is given in the form of its high price, which has given its founder, the "innovator", a reward for risk. As more cryptocurrencies are launched on the market, it can be expected that this monopoly gain will be gradually erased. It can even be assumed that Bitcoin will not survive the 21 st century.

On the other side, the dream about free money is near as never before. Bitcoin will remain the first visionary concept. The era of golden standard money is thing of history. The future is unknown but it is almost certain that cryptocurrencies will have its place in global monetary system. It will be Bitcoin or another cryptocurrency? And how will be significant this position? Those asks will be answered in the future. In the present time, it is necessary to try to understand how cryptocurrencies working. This paper is a humble contribution to this very interesting area.

\section{References}

Baeck, C., and Elbeck M. (2015). Bitcoins as an investment or speculative vehicle? A first look. Applied Economics Letters, vol. 22, n. 30-34. DOI 10.80/13504851.2014.916379.

Bitcoin.com. (2018). Bitcoin News and Technology Source. Retrieved from: https://www.bitcoin.com/

Bitvol.info. (2018). The Bitcoin Volatility Index. Retrieved from: https://bitvol.info/

Bloomberg. (2017). Bitcoin Acceptance Among Retailers Is Low and Getting Lower. Retrieved from: https://www.bloomberg.com/news/articles/2017-07-12/bitcoin-acceptanceamong-retailers-is-low-and-getting-lower.

Changelly.com. (2018). Bitcoin to Ethereum instant exchange, BTC/ETH rates. Retrieved from: https://changelly.com/

Christensen, N. (2013). 2013: Year of the Bitcoin. Forbes online. Retrieved from: http://www.forbes.com/sites/kitconews/2013/12/10/2013-year-of-the-bitcoin/

Coin Market Cap. (2018). Cryptocurrency market cap rankings, charts, and more. Retrieved from: https://coinmarketcap.com/

De Soto, J. H. (2006). Money, Bank Credit and Economic Cycles. Auburn: Ludwig von Mises Institute. 
Georgetta, S., et all. (2016). Virtual Currency Bitcoin - Challenges and Controversies. Annals of the Constantin Brancusi University of Tartu Jiu, Economy Series, 3/2016. Retrieved from: http://www.utgjiu.ro/revista/ec/pdf/2016-03/46.pdf DOI 10.1109/SP.2015.14. 104.

Graf, K. (2013). On the Origins of Bitcoin. Nakamoto Institute. Retrieved from: http://nakamotoinstitute.org/static/docs/origins-of-bitcoin.pdf

Heissler, H., et all. (2014). Ekonomie Bitcoinu, Analýza a modelování Bitcoinu v rozvinutém stádiu. Praha: Vysoká škola finanční a správní, o.p.s.

Holman, R., et. all. (2003). Ekonomický slovník. Praha: C.H.Beck.

Mises, L. V. (2006). Lidské jednání. Praha: Liberální Institut.

Nakamoto, S. (2008). Bitcoin: A Peer-to-Peer Electronic Cash System. Retrieved from: https://bitcoin.org/bitcoin.pdf

Němeček, E. (2000). Mezinárodní měnový systém. Praha: Karolinum.

Pieters, G., and Vivanco S. (2017). Financial regulations and price inconsistencies across Bitcoin markets. Information Economics and Policy, vol. 39, n. 1-14. DOI: $10.2139 / 2576452$.

Rothbard, M. N. (1990). What Has Government Done to Our Money? Retrieved from: https://mises.org/library/what-has-government-done-our-money

Sadil, V. (2016). Využití teorie chaosu a Ellittových vln na finančním trhu. Retrieved from: https://theses.cz/id/84xv6f

Saito, Tetsuya. (2014) Bitcoin: A Search-Theoretic Approach. International Journal of Innovation in the Digital Economy, 6(2), pp. 52-71. Retrieved from: https://ssrn.com/abstract=2405013 DOI: $10.4236 /$ tel.2012.23052. 33.

Shostak, F. (2016). Myth of electronic money. Retrieved from: http://www.libertarium.ru/94532

Stroukal, D., and Skalický, J. (2016). Bitcoin: Peníze budoucnosti. Praha: Ludwig von Mises Institute

Urquhart, A. (2016). The inefficiency of Bitcoin. Economics Letters, vol. 148, n. 80-82. DOI: 10.1016/j.econlet.2016.09.019.

\section{Contact information}

Ing. et Ing. Vojtěch Sadil

Tomas Bata University in Zlín, Faculty of Management and Economics

The Department of Finance and Accounting

Mostní 5139, 76001 Zlín, Czech Republic

Email: Vo.Sadil@seznam.cz, Sadil@fame.utb.cz

ORCID: 0000-0003-4905-8871

DOI ID: https://www.doi.org/10.7441/dokbat.2018.20 


\title{
THE ROLE OF MANAGERS IN THE CONTEXT WITH THE IMPLEMENTATION OF LEAN SIX SIGMA IN SMALL AND MEDIUM- SIZED ENTERPRISES
}

\author{
Roland Stankalla and Felicita Chromjakova
}

\begin{abstract}
The aim of the paper is to examine the influence of managers during the implementation of Lean Six Sigma in small and medium-sized enterprises. A systematic literature review consisted of published journal papers from academic databases is conducted. The active participation during the Lean Six Sigma implementation process and in Lean Six Sigma trainings as well as the motivation of the employees are the most important responsibilities of the management for the successful LSS implementation in small and medium-sized enterprises. The greatest strength of the management in small and medium-sized enterprises would be the easy support due to fewer hierarchical layers while the greatest weakness is the low Lean Six Sigma awareness and knowledge. The training, resource and financial limitations in small and medium-sized enterprises are the largest hurdles for the management to implement LSS successfully.
\end{abstract}

Keywords: Lean Six Sigma; small and medium-sized enterprises; Managers; Leadership.

\section{INTRODUCTION}

Since a decade the pressure started rising throughout small and medium-sized enterprises (SMEs) to use established quality management techniques like Six Sigma (SS) or Lean Six Sigma (LSS) as well as other approaches. The growing importance of supply chain management issues in a global market environment make large firms heavily dependent on SMEs for the provision of high quality products or services at low costs. This fact leave no choice for SMEs to consider the introduction of a business strategy like SS or LSS (Antony et. al. 2005).

The current literature shows that there are very few research papers about SS or LSS in smaller organizations which indicate that these initiatives in the SME sector have not been studied very critically so far. Many key questions remain unanswered as the LSS discourse in the SME literature is emergent in nature (Antony et al. 2008; Kumar and Antony, 2008, 2009). However, various authors argue that LSS can be implemented successfully in any organizations, irrespective of the size of the company. There is nothing inherent in SS or LSS that makes it more suitable in larger companies (Kumar and Antony, 2009). Until now, LSS has been extensively implemented in the larger industrial units successfully and not in SMEs due to resource and financial limitations (Deshmukh and Chavan, 2012) although SMEs are considered according to Antony et al. (2005) as the lifeblood of a modern economy.

Top management commitment and a strong leadership are the key characteristics for the successful implementation of quality initiatives in enterprises (Tennant, 2001; Kumar and Antony, 2009). Nevertheless, management skills and styles in SMEs and larger enterprises differentiate with each other (Wolf et. al. 2009). Due to this reason this paper examine the management role in the context with the implementation of LSS in SMEs.

In order to achieve the proposed objective the research is organized into seven chapters. In chapter 2, the research questions and methodology will be presented, followed by theoretical fundamentals about terms like management, LSS and SMEs (chapter 3). Chapter 4 provides an overview about the requirements and responsibilities of the SME management while chapter 5 discusses the SME management strengths and weaknesses. In Chapter 6 are the challenges for 
the SME management derived and finally, the paper ends with a summary and conclusion in chapter 7 about the key findings of the research.

\section{RESEARCH AND METHODOLOGY}

The study was prepared to answer the following research questions:

RQ1: What are the requirements and responsibilities of the SME Management in the context with the implementation of LSS in SMEs?

RQ2: What are the strengths and weaknesses of the SME Management in the context with the implementation of LSS in SMEs?

RQ3: What are the challenges for the SME Management in the context with the implementation of LSS in SMEs?

To answer these research questions a systematic literature review consisted of published journal papers from academic databases will be conducted. The "journal" search for research literature was undertaken through four well-known academic databases: Emerald, Elsevier, ProQuest and Taylor \& Francis. Search strings were used as follows: [(lean six sigma) or (six sigma) AND (management) AND (sme)].

\section{THEORETICAL BACKGROUND}

\subsection{Management}

The current literature consists of many papers where differences between the terms management and leadership are debated. It is very often thought that management and leadership have the same meaning, however this is not the case. Management creates rules and constancy while leadership creates change and moving (Kotter, 2008). Leadership is rather defined as a process which involved the leaders personality and behaviours. It can be considered as commitment, enthusiasm, beliefs and values needed to motivate employees to apply their talents to help implementing companies plans (Pamfilie et al. 2012). Managers rather ensure that the processes and organization function well and smoothly (Kotter, 2008). Kotter (2008) defined for both terms 3 core processes. For the term "management" these are planning and budgeting, organizing and filling vacancies as well as controlling and problem solving whereas for the term "leadership" these are showing and directing, aligning employees accordingly as well as motivation and inspiration. Nevertheless, the paper continue with the term "management" in the following chapters because for the scope of this article a differentiation of these two terms is not needed.

\subsection{Lean Six Sigma}

SS is a disciplined and data driven business improvement methodology that was developed to enhance the quality of processes with the objective to establish an almost zero-defect quality strategy and thus to increase customer satisfaction and to improve financial results. Bill Smith from Motorola/USA developed SS in 1987. Based on the ideas of statistical process control, Motorola defined "six sigma" as 3,4 defects per million opportunities in a given production process. Sigma $(\sigma)$ is used to represent the variation (standard deviation) of a process mean. "Six" means that the distance between the mean and the critical tolerance limits shall be 6 standard deviations constantly. It is initially applied in the manufacturing sector but has now 
spanned over service, financial, healthcare and public sectors (Arnheiter and Maleyeff, 2005; Pyzdek, 2003). SS is also being widely recognized as an effective leadership development tool. After 1995, SS was enhanced by GE as a business strategy used to improve business profitability (Coronado and Antony, 2002). In 2003, LSS was established as part of the evolution of SS. It is the combination of Lean Management and SS which are the most popular business strategies for enabling continuous improvement and improved bottom-line results (Albliwi et al. 2015). It achieves these by merging tools and principles to overcome the weaknesses and bring out the advantages of both programs. Lean focuses on removing all types of waste from the process (the efficiency issue) while SS concentrates on controlling the process statistically and removing variation from the process (the effectiveness issue). The phrase "Lean Six Sigma" is therefore used to describe the integration of these both approaches as a comprehensive management system (Arnheiter and Maleyeff, 2005).

\subsection{Small and medium-sized enterprises}

From 1990s onward, with the globalization of the world market, a continuous trend toward downsizing large firms and outsourcing businesses to smaller firms seems to be the latest trend (Antony et al. 2005; Kumar and Antony, 2008). SMEs hold up to 99.8\% of the total number of enterprises, representing $66.5 \%$ of total employees and contribute $57.6 \%$ of the total value added to the EU. Moreover, more than $50 \%$ of the employees from manufacturing companies in the countries of the European Union are working in SME manufacturing companies (Gagliardi et al. 2013). For this reasons, SMEs moved into the focus of the scientific work of many authors. Table I presents a detailed definition of SMEs, which was proposed by the European Commission (2005), adopted by the European Union Member States and entered into force in 2005.

Table 1 Definition of SMEs. Source: European Commission (2005)

\begin{tabular}{|c|c|c|c|c|c|}
\hline Enterprise size & Employees & \multirow{5}{*}{ AND } & Annual turnover & \multirow{5}{*}{ OR } & Annual balance sheet total \\
\hline Large & $>250$ & & $>€ 50$ million & & $>€ 43$ million \\
\hline Medium-sized & $<250$ & & $<€ 50$ million & & $<€ 43$ million \\
\hline Small & $<50$ & & $<€ 10$ million & & $<€ 10$ million \\
\hline Micro & $<10$ & & $<€ 2$ million & & $<€ 2$ million \\
\hline
\end{tabular}

\section{REQUIREMENTS AND RESPONSIBILITIES OF THE SME MANAGEMENT}

According to the results from different empirical studies management involvement and commitment is the most important critical success factor irrespective from the organization size (Kumar and Antony, 2008; Antony et al. 2008; Antony and Desai, 2009; Brun, 2010). Taking now into consideration the many differences in SMEs, it must be understood that LSS requires the same leadership and commitment with the same responsibilities as in larger companies (Burton, 2004). A high management participation in the LSS implementation process and training as well as the employee motivation to LSS are the most important responsibilities discussed in the literature and therefore detailed in the next subchapters (Raghunath and Jayathirtha, 2013; Arnhneiter and Maleyeff, 2005).

\subsection{Active management participation in the Lean Six Sigma process}

Cultural changes assume to be a difficult and realizable long-term process and also present a high degree of anxiety, on which the leader should focused his attention in order to make changes within the organization and to implement a new organizational culture (Pamfilie et al. 2012). An obsessive, compulsive and visibly management commitment and support is 
absolutely required to drive LSS deep into a company's culture. According to many authors experiences can be said that if the management actively gets involved, support and drive the initiative, it will definitely work. And if one important person is actively against SS, then this attitude must be changed immediately (Pande et al. 2000; Coronado and Antony, 2002; Tennant, 2001; Kumar and Antony, 2009). Similar results found Leyendecker et al. (2011) in their study that if SS is accepted by the management, the program is overall more active and more projects achieve the targets regarding time, costs and quality.

The level of the target achievement should be controlled by the management via key performance indicators (KPIs). Until now, not many enterprises have implemented such KPIsystem, however in these companies who have it, the achievement of the project targets is $15 \%$ higher than in enterprises which have no KPI-system (Leyendecker et al. 2011).

Raghunath and Jayathirtha (2013) state that a poor leadership and lack of management commitment can actually lead to the result that SS is viewed as just a passing management fad which only adds to cost without significant financial gains. Others argue that if the team members feel a lack of confidence in their leaders, they will start the project with many doubts and they will not give all their efforts in order to complete the project with good results (Pamfilie et al. 2012; Leyendecker et al. 2011). LSS shall be therefore driven hierarchically from the senior management team and deployed effectively throughout an organisation like a top-down strategy which is the best approach for successful LSS implementation. Additionally, it is recommended to link any quality improvement initiative directly with the management strategy, culture and change into a sound corporate strategy plan (Tennant, 2001; Antony, 2004). Pande et al. (2000) for instance suggest to link LSS into the mission and vision of their organization.

\subsection{Active management participation in Lean Six Sigma trainings}

If leaders may choose to implement the LSS methodology because they just heard about its success in other organizations, the project will fail in most cases when this is the only argument in driving the implementation. First of all, leaders as well as the top management has to be familiar with the methodology, tools, techniques, processes and should also have knowledge how to create an organization that works together for proper implementation of LSS. Therefore, training is a very serious critical success factors (Pyzdek, 2003; Pande et al. 2000). Pande et al. (2000) recommend managers to understand the concept, benefits and implementation steps by participating in an overview training of LSS.

To produce the expected results with LSS, organizational roles on higher management level are clearly defined in the LSS approach. On top of that is the Sponsor who is responsible for the overall initiative and develop a deployment strategy with a time plan. Sponsors shall participate on a basic awareness and understanding training for approximately a half day so they can fund projects appropriately and understand what will be delivered. Champions, who are also on executive level, usually receive training on technical aspects as well as on how to lead an initiative. They are responsible to identify the right projects, ensure the availability of resources for training and projects as well as being involved in project tollgate reviews. They request the quality managers to form a team from respective departments where there is a problem. If the business leaders and their team cannot invest two days of their own time in learning more about SS and their role, then they are not ready to start such initiative (Pande et al. 2000; Pyzdek, 2003).

\subsection{Active employees motivation to Lean Six Sigma}

As described in subchapter 4.1 LSS shall be de deployed effectively throughout an organisation like a top-down strategy which is also related to the training approach. Training shall start at 
the top of the organization and then be cascaded through the organizational hierarchy to transfer the knowledge into the organization effectively for a company-wide commitment regarding the introduction of new quality initiatives (Raghunath and Jayathirtha, 2013). The number and range of tools and techniques available in the LSS tool kit is vast and it is critical that staff are aware of them and trained well enough in their use as well as being able to follow the DMAIC methodology. For this reason, it is very important that the management provide regular training opportunities to their employees and formulating newer training methods which promote their commitment (Deshmukh and Lakhe, 2009). According to Leyendecker et al. (2011) the share of successful projects increase from $70 \%$ to over $80 \%$ by a higher quality of the own training programs. Beside the classifications on higher management level (Sponsor, Champion) exist the following four main classifications for employees who are trained in the LSS approach: Master Black Belt, Black Belt, Green Belt and Yellow Belt (Chakraborty and Tan, 2007). Additionally, the management should give their employees commitment of support and communicate how important their participation will be towards the success of the program and the business before a training program for employees start (Raghunath and Jayathirtha, 2013).

Training for employees is only one important key requirement for their motivation. Hoerl et al. (2004) conclude that LSS offers statisticians and quality professionals a unique opportunity to play a leadership role in their organizations. For this reason, it is essential to attract the best people with good leadership to be involved in the company's first wave SS Black Belt training (Pyzdek, 2003; Leyendecker et al. 2011). Enterprises, that consider for the selection of Black Belts and Green Belts various criteria, achieve better results. They manage twice as many projects and the portion of successful projects is on average $15 \%$ higher than in enterprises that have no structured personnel selection procedures (Leyendecker et al. 2011). The selection of top talents would give a clear message to the organization that the management is committed and serious about LSS which will also motivate other employees to get involved in the journey (Pyzdek, 2003).

Furthermore, the involvement of all employees in the implementation phase is also an essential success factor for the successful introduction of LSS (Deshmukh and Lakhe, 2009). As in subchapter 3.1 already described leadership is crystallizing a direction for employees. It is the source of beliefs and values that has the ability to motivate people in order to achieve the organization objectives. Through their involvement by the management, employees are encouraged to contribute to change. If the implementation of LSS has resulted in improved processes within the organization and the employees are informed of the benefits brought, whether they were directly involved in the implementation flow or not, this will give a state of positive spirit and confidence in their workplace and within the organizations. By applying this approach, the employees will follow the model of their leaders and will focus their work (Pamfilie et al. 2012). Biolos (2002) report that Subir Chowdhury, executive vice president of the American Supplier Institute and author of Design for Six Sigma, has found that many SS efforts fail because the leadership fails to ensure that everybody "gets it".

Moreover, the introduction of a reward and recognition system would be a very effective motivational tool to increase the performance of LSS employees. This can be in terms of gifts, promotions or celebrating parties (Arnheiter and Maleyeff, 2005). As example is here Antony et al. (2006) study to mention where resistance from employees occurred in regards to the implementation of the LSS framework. The employees thought that LSS could endanger their job opportunities. This attitude was corrected by the top management, convincing the 
employees that their jobs would not be in danger and that they would be rewarded for better performance what boosted confidence in the employees and therefore they were ready to embrace the proposed LSS framework in their processes.

\section{STRENGTHS AND WEAKNESSES OF THE SME MANAGEMENT}

Beside the requirements and responsibilities of the SME management there are specific strengths of the SME management which make it easier on the one hand but also specific weaknesses which make it more difficult on the other hand to carry out the needed tasks in the context with the successful implementation of LSS in SMEs.

Starting with the benefits can be said that smaller companies are more agile because of a smaller number of sites, management members and direct stakeholders as well as a strong owner influence. These aspects make it much easier then to buy-in management support and commitment as opposed to large organizations. Furthermore, the fewer layers in the management hierarchy ensure a better top management physical presence and involvement, a faster decision making process and more effective, open and faster communication channels (Antony et al. 2005; Rowlands, 2004). Additionally, Freiesleben (2006) mentioned in his article the better control of policy implementation because of the smaller management in SMEs.

As weaknesses of the SME management Wessel and Burcher (2004) report the little awareness of LSS which also lead to the fact that training needs are not recognized. Many SMEs in Germany for instance even do not know about SS or do not believe their organization is suitable for its implementation (Wessel and Burcher, 2004). Deshmukh and Lakhe (2010) found in their study that the majority of SMEs located in central India are aware of SS but most of them have never used it. Additionally, various authors found in their studies also a lack of intellectual capacity of the management in regards to statistics compared to large organizations. In many cases the management even become frightened when statistical tools are required and discussed (Wessel and Burcher, 2004, Deleryd et al. 1999).

According to Jie et al. (2014) lacking management skills and knowledge of LSS is one of the main causes that bring such projects to fail. The lower the knowledge about LSS benefits, the more difficult convincing the top management what was discovered as the most arduous task during the case study of Kumar et. al. (2006) undertaken by implementing a LSS framework into an Indian SME. The management was not ready to compromise on production to improve the quality. For the top management investing in quality meant to increase the cost of production. Examples of other companies about their significant production cost reduction as well as enhanced bottom-line results by using LSS principles have been shown to convince them. Also in Jie et. al. (2014) case study analysis in the label printing production the management was not able in the beginning to identify the benefits of LSS due to little awareness. They preferred focusing on production rather than spending time and money to improve the quality aspect of it and were additionally worried that these cultural changes in the production would bring negative impact towards the production. Therefore LSS was implemented in stages, where changes are not too drastic in order to visualize the improvement made in a practical way to the management. 


\section{CHALLENGES FOR THE SME MANAGEMENT}

A such weakness like the low LSS awareness and knowledge of the management result to a low level cultural readiness and make it therefore difficult to implement a quality culture like LSS in SMEs. The management of SMEs must therefore face the challenge to especially motivate itself by participating in regular trainings to get more aware about this methodology. Wessel and Burcher (2004) recommend an one-day awareness training for the management and their employees of SMEs to facilitate the cultural implementation element and consequently to promote willingness to change organizational structures.

Beside this weakness of the SME management there are also general weaknesses of SMEs which could bring special challenges for the SME management to implement LSS. For instance are inadequate resources with insufficient knowledge a reason for non-implementation of LSS in SMEs. Statistical tools like process control theory or experimental design concepts are relatively low applied in SMEs because their employees do not have experiences and are therefore unmotivated to use it. So far, statistical concepts are mainly used in the domain of the larger industries in which resources are available to train the workforce to apply these concepts. Unfortunately, only a limited talent pool exist in smaller companies (Isenberg, 2000). Small companies do not have the slack to free up top talented people to engage in training as they are crucial to the day-to-day operations within the company. SMEs have less spare resources than larger enterprises and usually every employee has beside its key role several other (Isenberg, 2000; Wessel and Burcher, 2004). The lack of resources in form of time and manpower, limitations in financial resources and the non-recognition of training by the management really hinder small companies to provide training and thus to implement LSS (Wessel and Burcher, 2004; Antony et. al. 2005). And these enterprises which recognize the need for training also often do not have a clear vision of what is required (Rowlands, 2004; Antony et. al. 2005; Deshmukh and Chavan, 2012). Due to this facts can be concluded that the training component is much harder in smaller companies. The management of SMEs must motivate their employees to participate in regular trainings and communicate how important it is to understand statistics for LSS. In future, a deeper understanding of statistical concepts is really required in SMEs to improve their manufacturing processes (Wessel and Burcher, 2004, Deleryd et al. 1999).

\section{SUMMARY AND CONCLUSION}

The objective of this paper is the investigation of the management role in the context with the implementation of LSS in SMEs based on the current literature. Core results of this paper are summarized in table 2 which provides an overview about the SME management requirements and responsibilities, strengths and weaknesses as well as challenges. It is a good overview for managers of SMEs to see the expectations in itself as well as the potential hurdles which could arise during the implementation of LSS.

Management commitment is the most important critical success factor for the implementation of LSS. The most essential requirements and responsibilities of the management are the active participation during the LSS implementation stages and in LSS trainings to receive a better understanding of this methodology as well as the motivation of their employees to achieve a company-wide commitment for the LSS program. The smaller management with fewer layers in the hierarchy make it easier for SMEs to buy-in management support which is to be considered as the greatest strength for SMEs. On the other hand are the low LSS awareness and methodology understanding of the SME management the major weakness which make it difficult to implement LSS. Furthermore must be mentioned the training, resource and financial 
limitations in SMEs as further challenge for the management to implement LSS. To avoid these problems the management must deepen its focus there. In future, a detailed concept with guidelines must be developed how to avoid these weaknesses to ensure an easier implementation of LSS in SMEs. This can only be achieved by undertaking more and more practical studies, empirical studies and expert interviews in different regions of the world.

Table 2 Summary of the SME Management role for the implementation of Lean Six Sigma

\section{Requirements and Responsibilities}

1. Obsessive and compulsive commitment

2. Visible supportive as well as active participation and involvement

3. To communicate the need and importance of LSS to the employees (especially statistics)

4. To develop a LSS deployment strategy plan

5. To develop a LSS implementation time plan (3-5 years)

6. To link LSS with the management/business strategy

7. To link LSS into the mission, vision and values of the company

8. To ensure an effective hierarchically top-down strategy (e.g. training, communication, commitment, implementation etc.)

9. To understand the LSS techniques, methodology, tools and processes

10. To participate in a LSS overview training

11. To participate in project reviews and monitor the level of target achievement by KPIs

12. To identify the right projects

13. To ensure budget and resource availability for projects and training

14. To provide regular training opportunities to their employees and formulating newer training methods

15. To attract the best people for training with good leadership by a structured personnel selection procedures

16. To involve and motivate all employees in the implementation phase

17. To inform employees about successful LSS results

18. To indtroduce a reward and recognition systém

19. To incorporate LSS into their leadership development process

\begin{tabular}{|c|c|}
\hline Strengths & Weaknesses \\
\hline $\begin{array}{l}\text { More agile management, easier to buy-in } \\
\text { management support/ commitment as well as } \\
\text { better control of policy implementation due to } \\
\text { smaller number of sites, stronger owner } \\
\text { influence and a smaller management } \\
\text { - Faster decision making process and more } \\
\text { effective communication channels due to fewer } \\
\text { layers in the management hierarchy }\end{array}$ & $\begin{array}{l}\text { - Little LSS awareness and knowledge } \\
\text { - Lack of intellectual capacity (statistical tools) } \\
\text { by the management } \\
\text { - Non-recognition of LSS training needs by the } \\
\text { management }\end{array}$ \\
\hline
\end{tabular}

- Difficult to train and motivate employees due to limited talent pool, little personnal spare resources, financial limitations and non-recognition of the training needs by the management

- Difficult to implement LSS due to lacking LSS skills, low LSS awareness and low methodology understanding by the management

\subsection{Acknowledgments}

"The authors are thankful to the Internal Grant Agency of Tomas Bata University in Zlín, No. IGA/FaME/2018/005 for financial support to carry out this research.” 


\section{Abbreviations}

Six Sigma $\quad$ SS

Lean Six Sigma $\quad$ LSS

Small and medium-sized enterprise SME

\section{References}

Albliwi, S. A., Antony, J. and Lim, S. A. H. (2015) 'A systematic review of Lean Six Sigma for the manufacturing industry', Business Process Management Journal, Vol. 21, No. 3, pp. 665- 691. https://doi.org/10.1108/BPMJ-03-2014-0019

Antony, J. (2004) 'Six Sigma in the UK service organizations: results from a pilot survey', Managerial Auditing Journal, Vol. 19, No. 8, pp. 1006-1013. https://doi.org/10.1108/02686900410557908

Antony, J., Antony, F.J., Kumar, M. and Cho, B.R. (2006) 'Six Sigma in service organizations: benefits, challenges and difficulties, common myths, empirical observations and success factors', International Journal of Quality \& Reliability Management, Vol. 24, No. 3, pp. 294-311. https://doi.org/10.1108/02656710710730889

Antony, J., Kumar, M. and Labib, A. (2008) 'Gearing Six Sigma into UK Manufacturing SMEs: Results from a Pilot Study', The Journal of the Operational Research Society, Vol. 59, No. 4, pp. 482-493. https://doi.org/10.1057/palgrave.jors.2602437

Antony, J., Kumar, M. and Madu, C.N. (2005) 'Six Sigma in small and medium sized UK manufacturing enterprises', International Journal of Quality \& Reliability Management, Vol. 22, No. 8, pp. 860-74. https://doi.org/10.1108/02656710510617265

Arnheiter, E. D. and Maleyeff, J. (2005) 'The integration of lean management and Six Sigma', The TQM Magazine, Vol. 17, No. 1, pp. 5-18. https://doi.org/10.1108/09544780510573020

August 18, 2017 from https://www.isixsigma.com/implementation/basics/six-sigma-smalland-medium-sized-businesses/

Biolos, J. (2002) 'Six Sigma Meets the Service Economy', Harvard Management Update, Vol. 7, No. 11, pp. 1-3.

Burton T.: "Six Sigma for small and medium sized businesses", 2004. Retrieved on

Chakraborty, A. and Tan, K. C. (2007) 'The current state of six sigma application in services', Managing Service Quality, Vol. 17, No.2, pp. 194-208. https://doi.org/10.1108/09604520710735191

Coronado, R. B. and Antony, J. (2002) 'Critical success factors for the successful implementation of Six Sigma projects in organizations', The TQM Magazine, Vol. 14 No. 2, pp. 92-99. https://doi.org/10.1108/09544780210416702

Dedhia, N. S. (2005) 'Six Sigma basics', Total Quality Management and Business Excellence, Vol. 16, No. 5, pp. 567-74. https://doi.org/10.1080/14783360500077468

Deshmukh S.V. and Lakhe R.R. (2009) 'Development and validation of an instrument for Six Sigma implementation in small and medium sized enterprises', IEEE Second International Conference on Emerging Trends in Engineering and Technology 
(ICETET-09), Nagpur, India, December 16-18, pp. 790-7. https://doi.org/10.1109/ICETET.2009.79

Deshmukh, S. V. and Chavan, A. (2012) 'Six Sigma and SMEs: a critical review of literature', International Journal of Lean Six Sigma, Vol. 3, No. 2, pp. 157-167. https://doi.org/10.1108/20401461211243720,

Deshmukh, S. V. and Lakhe R. R. (2010) 'Six Sigma awareness in Central Indian SMEs', International Journal of Productivity and Quality Management, Vol. 5, No. 2, pp. 200212. https://doi.org/10.1504/IJPQM.2010.030742

El-Homsi, A. and Slutsky, J. L. (2009) Corporate sigma: optimizing the health of your company with systems thinking. CRC Press. https://doi.org/10.1201/b10310

European Commission (2005) 'The new SME definition: user guide and model declaration', Luxembourg: European Commission.

Freiesleben, J. (2006) 'Communicating Six Sigma's benefits to top management', Measuring. Business Excellence, Vol. 10, No. 2, pp. 19-27. https://doi.org/10.1108/13683040610668675

Gagliardi-Main, D., Muller, P., Glossop, E., Caliandro, C., Fritsch, M., Brtkova, G., and Ramlogan, R. (2013) `ANNUAL REPORT ON EUROPEAN SMEs 2012/2013: A recovery on the Horizon?', SME Performance Review.

Hoerl, R.W., Rodebaugh, W. and Snee, R. D. (2004) 'Six Sigma and statistical leadership', Quality Congress, Annual Quality Congress Proceedings, Vol. 58, pp. 385-9.

Isenberg, D. (2000) 'Implementing six sigma in small and medium-sized corporation', IQPC Conference: Best Practice in Six Sigma, San Francisco, CA.

Jie, J. C. R., Kamaruddin, S. and Azid, I. A. (2014) 'Implementing the Lean six sigma framework in a small medium enterprise (SME) - a case study in a printing company, International conference on industrial engineering and operations management Bali, January, pp. 7-9.

Kotter, J. P. (2008) Force for change: How leadership differs from management. Simon and Schuster.

Kubiak, T. M. (2011) 'Six Sigma in the 21st century', Six Sigma Forum Magazine, Vol. 11, No. 1, ASQ.

Kumar M. and Antony J. (2008) 'Comparing the quality management practices in UK SMEs', Industrial Management and Data Systems, Vol. 108, No. 9, pp. 1153-1166. https://doi.org/10.1108/02635570810914865

Kumar, M. and Antony, J. (2009) 'Investigating the quality management practices in Six Sigma against Non-Six Sigma UK manufacturing SMEs: key findings from multiple case studies', Journal of Engineering Manufacture, IMECH E Part B, Vol. 223, No. 7, pp. 925-934. https://doi.org/10.1243/09544054JEM1288

Kumar, M., Antony, J., Singh, R. K., Tiwari, M. K., and Perry, D. (2006) 'Implementing the Lean Sigma framework in an Indian SME: a case study', Production Planning and Control, Vol. 17, No. 4, pp. 407-423. https://doi.org/10.1080/09537280500483350

Leyendecker, B., Schindewolf, S., Hutwelker, R. and Weigel, H. (2011) 'Erfolgsfaktoren für die Etablierung von Six Sigma: Bei guter Führung wertvoll', QZ Qualität und Zuverlässigkeit, Vol. 7, pp. 29-33. 
Pamfilie, R., Petcu, A. J. and Draghici, M. (2012) 'The importance of leadership in driving a strategic Lean Six Sigma management', Procedia-Social and Behavioral Sciences, Vol. 58, pp. 187-196. https://doi.org/10.1016/j.sbspro.2012.09.992

Pande, P., Neuman, R. and Cavanagh, R. (2000) The Six Sigma Way McGraw-Hill. New York, NY.

Pyzdek T. (2003) The Six Sigma handbook. A complete Guide for Green Belts, Black Belts, and Managers at All Levels, New York, USA: McGraw-Hill.

Raghunath, A. and Jayathirtha, R. V. (2013): Lean Six Sigma approach for auto component manufacturing SMEs', Proceedings of International Simulation Conference of India, IITM Research Park, Indian Institute of Technology Madras,

Rockart, J. F. (1978) 'Chief executives define their own data needs', Harvard Business Review, Vol 57, No. 2, pp. 238-241.

Rowlands, H. (2004) 'Implementation issues of Six Sigma in an SME', First International Conference on Six Sigma, Vol. 16.

Snee, R. D. and Hoerl, R. W. (2003) Leading Six Sigma: a step-by-step guide based on experience with GE and other Six Sigma companies. Ft Press.

Tennant, G. (2001) 'Six Sigma: SPC and TQM in Manufacturing and Services'. Ashgate, Aldershot.

Wessel, G. and Burcher, P. (2004) 'Six Sigma for small and medium-sized enterprises', The TQM Magazine, Vol. 16, No. 4, pp. 264-72. https://doi.org/10.1108/09544780410541918

Wolf, H. P. V. J. and Zipse, T. (2009) Erfolg im Mittelstand. Gabler Verlag/GWV Fachverlage Wiesbaden (GWV). https://doi.org/10.1007/978-3-8349-8512-5

\section{Contact information}

Roland Stankalla, M.Sc., M.Sc

Prof. Dr.-Ing. Felicita Chromjakova

Department of Industrial Engineering and Information Systems

Faculty of Management and Economics

Tomas Bata University in Zlin, Mostni 5139, 76001 Zlin

Email: roland.stankalla@yahoo.com

ORCID: 0000-0002-7225-8487

ORCID: 0000-0002-5084-1153

DOI ID: https://www.doi.org/10.7441/dokbat.2018.21 


\title{
WHY IT IS IMPORTANT TO USE SOCIAL MEDIA IN INTERNATIONAL MARKETING STRATEGIES
}

\author{
Mariana Tesařová
}

\begin{abstract}
Nowadays, social media are undoubtedly becoming vital part of international marketing strategy. The 21 st century is characterized by huge boom of social media and has delivered both challenges and opportunities in this international, boundaryless world. The main purpose of the study is to identify and furtherly describe main perspectives that comes into play when using social media for international marketing strategies. Used methods are represented by content analysis of existing literature, whereas main perspectives are identified. Synchronously, over fifty articles focusing on social media were observed. Article also serves as a starting point for authors' dissertation. As a result, author identifies four key perspectives that play important role in usage of social media: international advertising, role of culture, role of technology and traditional vs. social media perspective. These perspectives are furtherly discussed and possible areas for future development, together with its limitations are identified. All these perspectives show the importance of social media topic and why it should not be overlooked. Practical implications might be seen mainly by managers who deal with social media. Managers might get inspired by these perspectives, use its opportunities and be aware of its limitations in order to create successful international online marketing campaigns. Moreover, since this topic is really broad and there is often the requirement to high degree of cumulation in research area, limitations are captured mainly by the fact that there is also more time needed to develop useful theories that can be furtherly presented in literature.
\end{abstract}

Keywords: international marketing, international advertising, internet, marketing strategy, social media

\section{INTRODUCTION}

Social media represents vital part of todays' international marketing strategies. However, to date, there is no unified framework, nor linked perspectives that should be used when dealing with social media. Nevertheless, nowadays it is quite clear social media have become important part of advertising agenda and they possess strong potential for several companies to use them cross-nationally. Furthermore, there is still lack of clear theoretical perspectives in this field, from which clear research hypotheses may be formulated and tested by an empirical study. Since theoretical development in a research area often requires high degree of cumulation, development of useful theories need more time in order for them to be articulated in the literature (Okazaki \& Taylor, 2013). Furthermore, existing articles usually focus only on one specific perspective and how it influence international marketing strategies through social media. Therefore, this paper focuses on finding more perspectives through extensive content analysis, in order to identify interconnections in specific perspectives and how these could be combined and used to boost international marketing strategies. The originality of the paper is captured mainly in the identification of four main perspectives that are repeatedly mentioned in articles but never with certain connections or with the focus on its opportunities and limitations, all in one. Paper follows other studies in this field by trying to find main perspectives that influence international marketing strategies through usage of social media, and furtherly, identifying opportunities and weaknesses of each perspective. 


\section{MAKING SENSE OF THE IMPACT OF SOCIAL MEDIA ON INTERNATIONAL MARKETING STRATEGIES}

Social media represent significant part of international marketing strategy nowadays. Marketing managers and experts have to face chances and threats regarding social media highly connected with interconnected global environment. With huge boom of internet, social media are part of people everyday life. Therefore, it is logical that companies, in attempt to reach out and address potential customers worldwide, use social media as a part of their international marketing strategy. For the purpose of this paper, international marketing strategy is perceived in connection with companies' endeavor to broader their reach in order to enter foreign countries through social media as a powerful marketing tool. It may include posts and tweets on social media. Likewise, firms elevate their mobile capabilities in foreign markets, including knowledge and reputation, via content in online social networks that is typically user-generated (Paniagua, Korzynski \& Mas-Tur, 2017). Through digital technology, marketers were able to facilitate passive bystanders on-board and make them an active hunters, supported by Internetbased campaigns (Hanna, Rohm \& Crittenden, 2011).

Kaplan and Haenlein (2010) define social media as a collection of Internet-based applications that permit to create and exchange user-generated content (Abrahams, 2012). In the same wein, Kietzmann et al. (2011) describes social media as mobile and web technologies via which individuals and communities are able to share, cocreate, discuss, and even modify user-generated content (Maltby, 2012; Kietzmann et al., 2011; Okazaki \& Taylor, 2013). Several networks can be covered under this definition, including communities of practice using forums and blogs in order to discuss common interests or professional practices. It is possible to find these communities tightly connected within larger social networks, for example circles within Google+ (Maltby, 2012). Another examples are social networking sites such as Facebook, Twitter representing microblogging services, content communities like YouTube, and collaborative projects like Wikipedia (Abrahams, 2012).

As shown above, many social media networks exist. For the purpose of this paper, the focus is put on YouTube, Facebook and Twitter as representants of social media used for the purposes of marketing and business strategies creation. YouTube, Facebook and Twitter were chosen due to the fact that these social media were used the most and were the most repetitive ones in examined fifty articles. It is possible to frame a firm's activities towards social medias as resources that enhance headquarter knowledge capabilities tight to marketing, financial services or foreign location planning. While doing business internationally, social media can provide significant help (Paniagua, Korzynski \& Mas-Tur, 2017).

Social media represent significant part in daily life of Internet users (Knoll, 2016). As an increasing popular and promising advertising venue, social media are more and more used in marketing activities of companies. Synchronously, marketing research shows that exposure to promotional content via members of one's social network are tightly connected with increased intention to purchase, in comparison to Internet ad exposure alone. Suitable example can be Facebook notifications referring that a friend has "liked" a specific page of specific product (Abrahams, 2012). Firms have responded to this fast and promising development of social media through allocation of greater proportions of their media budgets to social media. In other words, they pay more attention to online social media in their advetising campaigns (Okazaki \& Taylor, 2013; Saxena \& Khanna, 2013). Social media also seem to create its own environment in which advertising, as part of marketing strategy, takes place. More and more scholars focusing on marketing start to pay more attention to social media and dedicate their works to advertising in social media. However, only small 
number of papers adressing this topic exist (Okazaki \& Taylor, 2013). Therefore, existing reviews focusing on online advertising (Cho \& Khang, 2006; Ha, 2008; Kim \& McMillan, 2008) are not able to provide an in-depth analysis of advertising in social media. On the other side, few exceptions exist, naming two exceptions that are the reviews conducted by Li \& Zhan (2011) and Khang, Ki \& Ye (2012), which consider new ways of advertising made possible through social media (Knoll, 2016).

Generally, studies define social media as a convenient tool in order to elevate firms' capabilities, mainly those that have straight associating with international business, such as headquarter services. Social media surface as a key factor that helps to understand concepts related to headquarter services, e.g. business performance (Enders et al., 2008; Paniagua \& Sapena, 2014), customer relationship management (Trainor et al., 2014), human resources (Korzynski, 2013), marketing (DesAutels, 2011; Leeflang et al., 2014; Weinberg \& Pehlivan, 2011), brand management (Sabate et al., 2014), finance (Kaplan \& Haenlein, 2010), and sports business (Korzynski \& Paniagua, 2016). Firms start to understand significant strategic role of social media and its effect on international marketing results. Nevertheless, their implications for international business persist largely unknown (Paniagua, Korzynski \& Mas-Tur, 2017).

Potential customers need to become aware of the product or service before they are offered and subsequently sold on the international market. Traditional marketing techniques are very expensive, especially if they want to address multiple countries at once. On the contrary, social networks enable companies to communicate their reports to mass audiences at a fraction of the cost. Segmentation of audiences is also easier with the use of social media. While traditional media, such as newspapers or TV stations, are mostly focused on topics at national level, social networks also allow other transnational criteria such as interest only on specific topics, interests, and websites that customers are members of. As a result, all campaigns can become more effective by targeting customers who can really be interesting for their business. Paco Viudes, CEO of Gentyo.com and a digital marketing expert, believes that the ability to segment and hit potential customers, focusing on their interests, increases product awareness with very low costs, which is also a major benefit of using social media. The size of the company is therefore not important if the company develops a good strategy and can reach potential customers with content related to their product. Social media not only enhances B2C communication but also $\mathrm{C} 2 \mathrm{C}$ communication between customers, which can increase awareness faster and reach the wider public. Another important reason for the use of social media in international marketing strategies is their usefulness for valuable market research. Every communication on social media is a valuable source of information for brands that perfectly match the preferences and expectations of their potential customers (Nicolas, 2017). The role of social media in the international marketing strategies varies depending on the specific case of each firm. For instance, a company like IKEA have used social media to enter a specific market while the Dollar Shave Club used social media to bring its own company and services to the entire online community, saving a great deal of money compared to conventional marketing tools. Kiosked \& Moodyo have built platforms based on existing social networks and used the global media intervention to quickly gain access to international markets (European Commission, 2017).

Happy Legs' international marketing strategy also uses Facebook's advertising tools, allowing for excellent international segmentation, as well as publishing content that helps companies focus on a particular segment. They also support the "Buy" button that directs users to the online store and their sites on electronic markets such as Amazon United Kingdom. During the survey phase, and thus often before the product is available in a given country, they have also managed to get people and potential customers to show interest in this product. Society improves understanding of public sensitivity and creates expectations. Another great 
example is Mariscal \& Sarroca, who has created a Beetailer online store on Facebook, along with an international community manager in Spanish and English. Real business opportunities come through the social network. Munich Sport is another success story. This Barcelona-based sneakers company and factory in Spain sells more than 850,000 pairs of shoes per year. In recent years, the company has built an enviable position in the fashion industry, both domestically and internationally, with sales in both Europe and Asia. The company owns more than 300 outlets throughout Spain. The company uses social networks, primarily Twitter, with 17,000 followers, using innovative techniques such as crowdsourcing to attract thousands of designers for their sneakers, all in-brand, putting the work team in direct contact with the consumer involved in the project. This approach also supports different forms of engagement and encourages discussion among the target public (Nicolas, 2017).

\section{METHODS}

A content analysis of scientific articles was used to create this paper. Keywords as international marketing, social media, marketing strategy, internet and such have been used. In the end, author managed to observe over fifty articles from academic databases based on chosen keywords. The number of articles is limited due to the lack of existing empirical overview regarding this topic. It was quite complicated to find relevant articles that could be used for further identification of main perspectives influencing international marketing strategies with the usage of social media.

Content analysis of over fifty articles had been used, whereas four key perspectives were identified. When finding reasons to choose specific perspectives, questions such as "What is the important factor that comes into play when dealing with international marketing strategies with the use of social media"? The answer was quite clear: advertising, culture, technology and relationship between social and traditional media. Even between these perspectives can be find linkages and interconnections. Furthermore, these perspectives were also chosen because some of them include obsolete data that need further examination, while others were chosen for their controversial nature in terms of sometimes contradictory opinions of the authors observing certain perspective. As a result, this paper will be used as a base for author's dissertation focusing on "Business and marketing strategies of SMEs in terms of internationalization".

\section{WHY IT IS IMPORTANT TO USE SOCIAL MEDIA IN INTERNATIONAL MARKETING STRATEGIES: MAIN PERSPECTIVES}

\subsection{The role of international advertising}

To date, in the field of international advertisting, social media have not received enough attention, which consequently resulted in a very limited number of cross-cultural and cross-national studies. This frailty is caused by several reasons. First of all, researchers might perceive the field of research regarding internationalization of social media as premature considering the very recent evolution of social media as an important advertising tool. Only quite recently Facebook and Youtube have started to be used in advertising, and only in last couple of years a substantial number of studies focusing on social media and its connections with advertising have begun to appear in the context of only one single country, focusing on single country studies (Okazaki \& Taylor, 2013). 


\subsection{The role of culture}

Similarly, adoption of international marketing strategies is also tightly connected with question of culture. For several years researchers claimed that cultural convergence leads to consumers that become more alike in many aspects (Okazaki \& Taylor, 2013). Mazaheri, Richard \& Laroche (2010) also focused on the role of cultural values while invetigated online consumer behavior. They developer a model focused on online consumer behavior that was based on Zajonc's (1980) Stimulus-Organism-Response Framework. Model included emotions, such as pleasure, dominance or excitement, as well as site atmospherics (informativeness, effectiveness, and entertainment). Then, model was compared between Canadian and Chinese respondents pursuant Hofstede's (1991) model of cultural values. As a result, the model was supported and number of non-invariant paths between groups were identified (Laroche, 2011).

Another related issue when discussing the role of culture is the degree to which cultural factors manage to influence consumer responsiveness regarding social media advertising and promotion. This issue is again tightly connected to cultural dimensions including individualism vs collectivism, monochronic vs polychronic time orientation, communal vs agentic tendencies in friendships. These dimensions, again, need to be examined in order to find out to which extent and how they influence consumer response to social media advertising internationally, within various cultures (Okazaki \& Taylor, 2013).

\subsection{The role of technology}

Technology is considered to be a driving force when it comes down to economic development. Technology consequently has accelerated changes in marketing behavior. Furthermore, methods of collecting information have been created thanks to technology. Since technology has revolutionized the way companies and individuals communicate, it should thus be take into consideration as a vital instrument regarding any marketing stragegy (Doole \& Lowe, 2012). Hasan (2011) claims that increase of Internet users caused decline in the usage of traditional media including television, radio, newspapers and magazines. Synchronously, internet is responsible for openess of new possibilites in the Marketplace and represents increasingly important platform for international business transactions and marketing operations (Liang, Lin \& Chen, 2004). In the same vein, Kaplan and Haenlein (2010) state that digitalization represents a vital part of the daily routine, while at the same time developing and changing the way in which businesses and consumers interact with each other. Furthermore, utilization of social media have become a significant role for any business in order to express their presence (Gilmore et al., 2007). Synchronously, such utilization have encouraged new marketing tools that can be used not only in huge companies but also in smaller organizations, due to its usability and affordability (Sigala, 2002; Laurenius \& Wikstrom, 2016).

\subsection{Social vs. traditional media point of view}

Another view that should not be omitted when discussing relevance of social media in business and marketing strategies of companies operating internationally are possible synergies between social media and traditional media. More attention should be paid to this topic as more and more traditionally transported advertising campaigns (e.g., billboards, television, or magazine ads) make direct reference to Facebook sites or YouTube channels through display of a link or a quick response (QR) code (Sago 2011). Okazaki and Hirose (2012) claim that social media users have been a key driver of this growth and they act as early adopters. In case that consumer is interested in an advertisement, he or she usually just type the link or scan the code with their smartphone to get direct access to the site (Knoll, 2016). 


\section{RESULTS}

As international marketing strategies are really broad, main perspectives were adopted while examining current research in order to identify opportunities and limitations of social media usage for marketing purposes of firms, these are captured in Table 1.

Table 13 Opportunities and challenges regarding different perspectives on international marketing strategies. Source: own, based on the content analysis of articles used in the paper

\begin{tabular}{|c|c|c|c|c|}
\hline View & $\begin{array}{l}\text { International } \\
\text { advertising }\end{array}$ & $\begin{array}{l}\text { The role of } \\
\text { culture }\end{array}$ & $\begin{array}{l}\text { The role of } \\
\text { technology }\end{array}$ & $\begin{array}{l}\text { Traditional vs. } \\
\text { social media }\end{array}$ \\
\hline Authors & $\begin{array}{l}\text { Okazaki } \quad \& \\
\text { Taylor, 2013; De } \\
\text { Vries, Gensler \& } \\
\text { Leeflang, 2012; } \\
\text { Kumar \& } \\
\text { Mirchandani, } \\
\text { 2012; Hennig- } \\
\text { Thurau, Wiertz \& } \\
\text { Feldhaus, 2015; } \\
\text { Nelson-Field, } \\
\text { Riebe \& Sharp, } \\
\text { 2012; Swani et } \\
\text { al., 2017; Knoll, } \\
\text { 2016; Pashkevich } \\
\text { et al., 2013; } \\
\text { Villiard \& } \\
\text { Moreno, 2012; } \\
\text { Smit, Reijmersdal } \\
\text { \& Neijens, 2009; } \\
\text { Ha, 2008 }\end{array}$ & 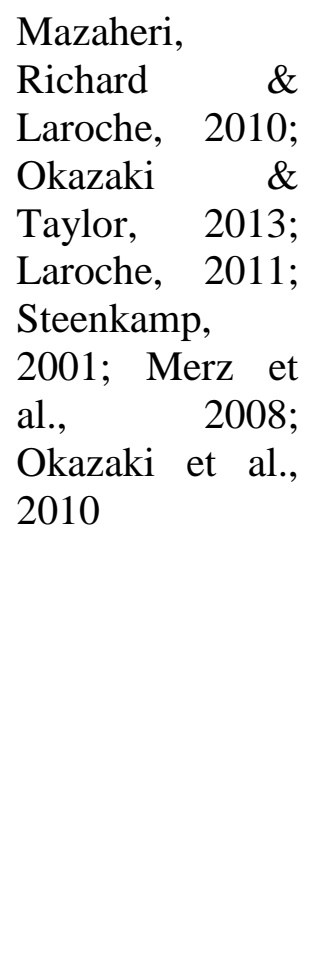 & $\begin{array}{l}\text { Doole \& Lowe, } \\
\text { 2012; Hasan, } \\
\text { 2011; Liang, } \\
\text { Lin \& Chen, } \\
\text { 2004; Gilmore } \\
\text { et al., 2007; } \\
\text { Kaplan \& } \\
\text { Haenlein, } \\
\text { 2010; Sigala, } \\
\text { 2002; } \\
\text { Laurenius \& } \\
\text { Wikstrom, } \\
\text { 2016; Berthon } \\
\text { et. al., 2012 }\end{array}$ & $\begin{array}{l}\text { Hasan, 2011; } \\
\text { Nicolas, 2017; } \\
\text { Ha, 2008; Sago, } \\
\text { 2011; Okazaki } \\
\text { \& Hirose, 2012; } \\
\text { Knoll, 2016; } \\
\text { Hanna, Rohm \& } \\
\text { Crittenden, } \\
2011\end{array}$ \\
\hline Opportunities & $\begin{array}{l}\text { 1) development of } \\
\text { useful theories } \\
\text { 2) integral part of } \\
\text { international } \\
\text { marketing } \\
\text { strategy, } \\
\text { 3) influence of } \\
\text { brand outcomes } \\
\text { 4) influence } \\
\text { decisions } \\
\text { regarding } \\
\text { purchases }\end{array}$ & $\begin{array}{l}\text { 1) cultural } \\
\text { convergence } \\
\text { 2) global } \\
\text { consumer } \\
\text { culture } \\
\text { 3) supports } \\
\text { standardized } \\
\text { international } \\
\text { marketing } \\
\text { strategy } \\
\text { 4) role of } \\
\text { emotions }\end{array}$ & $\begin{array}{l}\text { 1) driving force } \\
\text { in economic } \\
\text { development } \\
\text { 2) openess of } \\
\text { new } \\
\text { possibilities in } \\
\text { the } \\
\text { marketplace } \\
\text { 3) platform for } \\
\text { international } \\
\text { marketing } \\
\text { operations }\end{array}$ & $\begin{array}{l}\text { 1) shift of } \\
\text { Internet from a } \\
\text { platform for } \\
\text { information to a } \\
\text { platform for } \\
\text { influence } \\
\text { 2) consideration } \\
\text { of both } \\
\text { traditional and } \\
\text { social media as } \\
\text { a part of an } \\
\text { ecosystem } \\
\text { 3) more } \\
\text { effective } \\
\text { marketing } \\
\text { campaigns }\end{array}$ \\
\hline
\end{tabular}




\begin{tabular}{|c|c|c|c|c|}
\hline & & & & $\begin{array}{l}\text { through usage } \\
\text { of social media }\end{array}$ \\
\hline Limitations & $\begin{array}{l}\text { 1) limited number } \\
\text { of cross-cultural } \\
\text { studies } \\
\text { 2) side effects of } \\
\text { advertising } \\
\text { 3) gap in general } \\
\text { empirical } \\
\text { overview } \\
\text { 4) industry's view } \\
\text { is missing }\end{array}$ & $\begin{array}{l}\text { 1) cultural } \\
\text { dimensions } \\
\text { affecting } \\
\text { consumer } \\
\text { responsiveness } \\
\text { 2) role of } \\
\text { emotions }\end{array}$ & $\begin{array}{l}\text { 1) employees } \\
\text { restricted to } \\
\text { use social } \\
\text { media while at } \\
\text { work } \\
\text { 2) "digital } \\
\text { divide" - lack } \\
\text { of basic } \\
\text { technological } \\
\text { tools }\end{array}$ & $\begin{array}{l}\text { 1) number of } \\
\text { obsolete studies } \\
\text { 2) embedement } \\
\text { of social media } \\
\text { as a separate } \\
\text { elements of a } \\
\text { marketing plan } \\
\text { 3) } \\
\text { expensiveness } \\
\text { of traditional } \\
\text { marketing }\end{array}$ \\
\hline
\end{tabular}

\subsection{The role of international advertising}

First perspective aims at international advertising that is tightly connected to international marketing strategy. Undoubtedly, researchers agree on the fact that social media is becoming an integral part of international marketing and consequently international business strategy and has transformed the way that businesses interact with their customers. In other words, correct international advertising as a part of marketing strategy enables marketers to influence brand outcomes and decisions regarding purchases by fan promotion and popularization of brand content (De Vries, Gensler \& Leeflang, 2012; Kumar \& Mirchandani, 2012; Hennig-Thurau, Wiertz \& Feldhaus, 2015; Nelson-Field, Riebe \& Sharp, 2012; Swani et al., 2017). Further research is needed in order to examine specific steps leading to the adoption of social media in order to popularize brand content. However, understanding the importance of the topic and making relevance through several articles that have been already published, it is a very promissing start (Knoll, 2016).

\subsection{Possible synergies between traditional and social media}

While some studies focusing at synergies between offline and online advertising already exist, many of them are obsolete and work with information that accessing online content that come across in offline media is very complicated process (Ha, 2008; Knoll, 2016). That is the reason why another perspective is focused on traditional vs. social media. As social media platforms have started to revolutionize the state of marketing, advertising, and promotions, social media naturally transformed the Internet from a platform for information, to a platform for influence. Nowadays, companies of all sizes operating in different industries now see social media marketing as a mandatory element of their marketing strategy. To support the importance social media, Nicolas (2017) claims that traditional marketing techniques are very expensive, mainly in case when they try to focus on more than just one country at the same time. In contrast, social media offer firms possibility to communicate their reports to huge audiences only for a small part of the cost. Furthermore, social media also allow companies to focus on specific topics and interests, and not only on topics at national level as with traditional media (Nicolas, 2017). Therefore, it is no longer enough to only embed a social media as separate elements of a marketing plan. 


\subsection{The role of culture}

Another perspective used in this paper is related to culture, as international strategy is held in not only one country and culture factors that might occur are more than usual. Number of studies show that cultural convergence might lead to the fact that consumers become more alike in several aspects. This represents great opportunity for social media to capitalize on networking capability in order to bring people together and build the strong brand with larger audiences than it was possible ever before. Such phenomenon is obvious mainly in emerging global cultures while putting emphasis on modernity, technology, freedom, and individual choice (Steenkamp, 2001). People and groups of people who belong to a global consumer culture are more likely to associate similar meanings with particular places, people, and things (Merz et al., 2008). In the same vein, Okazaki et al. (2010) claims that such a global consumer culture is characterized by shared feelings towards sets of symbols. In other words, marketers should focus on strategy that supports standardized marketing and advertising strategy (Okazaki \& Taylor, 2013).

Furthermore, the degree to which cultural factors affect consumer responsiveness to social media advertising and promotion as part of international marketing strategy represents one of the main issues that deserve more attention. Several cultural dimensions, including indvidualism vs collectivism, monochronic vs polychronic time orientation and such, need to be furtherly examined in order to find out how they affect consumer response when it comes down to social media advertising in various cultures. Moreover, it is beneficial and crucial to focus on the brand building potential through social media across cultures in comparison to traditional media. This area is also connected to possible synergies between social and traditional media discussed above (Okazaki \& Taylor, 2013).

\section{$5.4 \quad$ The role of technology}

Last perspective considered in paper is focused on the role of technology while using social media for international marketing purposes. In order to successfully implement social media plans, technology is a must. Paradoxically, several organizations nowadays still face the situation where they tend to engage stakeholders by means of social media, while synchronously restrict their own employees from using social networking tools while at work. Large number of reported instances indicates that employees are not authorized the social media networks they are told to use (Berthon et al., 2012).

Furhermore, large number of organizations still suffer with what is called the „digital divide“, representing a situation where many parts of the population - developer countries included - do not possess access to basic technological tools, including desktops and access to the Internet. Consequently, such population do not logically have access to more sophisticated social media tools either (Berthon et al., 2012).

\section{DISCUSSION}

There is an existing gap in general empirical overview of possibilities for firms and organizations to advertise in social media. Side effects or unintended effects of advertising in social media have been neglected. Although Pashkevich \& colleagues (2013) address existing study focused on negative impacts of advertising on website satisfaction of users, together with Villiard \& Moreno (2012) conducting the study that addresses the issue that targeted advertising might enforce unhealthy nutrition because vulnerable groups might be targeted intentionally or unintentionally. There need to be brought more evidence in future how side effects of advertising in social media might occur, taking into account the different sectors in which firms can operate (Knoll, 2016). Moreover, the industry's view on social media 
advertising is definitely an area that needs to be furtherly investigated and deserves extensive research. Even though there are several articles powered by practitioners that discuss users views and attitudes regarding social media advertising, the industry's perspective is still missing. Systematic and empirically collected overview addressing this issue is missing. In most cases, studies in other advertising areas show that the industry's view is very distant from homogenous one, whereas advertisers, marketing managers, media salespeople, and website owners might largely differ in their opinions (Smit, Reijmersdal \& Neijens, 2009). Additionally, it might be interesting to see to which extent the practitioners' perspective matches the industry view (Ha, 2008; Knoll, 2016).

Synchronously, it is important to keep in mind customers' point of view. From the perspective of the customer, there may also be a problem in accepting international social media campaigns. Censorship by national governments can also prevent certain groups of customers from using specific types of social media. The biggest trigger in the process of increasing customer interest in social media is above all their increasing willingness to be informed, to discuss offers of companies with friends, or to even directly participate in and influence the product created by the company (European Commission, 2017). Consumers no longer want to be just passive recipients in the marketing process. They want to be involved in the process of creating the product itself, and being active throughout the marketing process (Hanna, Rohm \& Crittenden, 2011). Furthermore, Berthon et al. (2012) indicates that the usage of most prominent social media (such as Facebook or Youtube) is strongly dependent on technology and culture. In other words, the infrastructure that enables social media, and the shared values that comes from culture and cultural heritage. One big paradox is captured in todays' firm environment where they try to engage and approach stakeholders through social media, however, at the same time, companies own employees are truly restricted from the usage of social networking tools in working hours. This paradox should be eliminated in order for employees to be authorized to use the social media networks they are told to use (Berthon et al., 2012). Firms also need to consider both social and traditional media to be part of an ecosystem whereas all elements work together to reach a common objective, and it does not really matter whether the objective is to launch and promote a new product or service; to communicate a new company initiative; or to just further engage customers in a rich, meaningful, and interactive dialogue (Hanna, Rohm \& Crittenden, 2011).

\section{CONCLUSION}

This paper discusses main perspectives observed through literature review analysis focused on how social media can be used in international marketing strategies of companies. Paper also serves as a basis for authors' dissertation. Nowadays, there are many authors that focus on the problematics of usage of social media within international marketing strategies, while adopting different frameworks and perspectives. As this topic is really broad and authors' perspectives are often in conflict, it is still quite complicated to identify one unified way how usage of social media can boost international marketing strategies. The environment of social media where firms operate has initiated several changes, including the ways in which firms act, hire staff, and mainly plan marketing and business strategies worldwide. Consequently, casual evidence suggests that social media represent significant tool in making international strategies (Paniagua, Korzynski \& Mas-Tur, 2017). However, there are still some limitations that need further examination in order to bring sufficient results that will be able to accurately describe the impact of social media on marketing strategies in international environment, especially scope of the paper and the lack of empirical evidence. Moreover, there is often the requirement on high degree of cumulation in a research area. As a result, more time is needed in order to develop sufficient theories that can be articulated in the literature (Okazaki \& Taylor, 2013). 
Nevertheless, most authors and their existing scientific papers agree that social networks are important and should receive appropriate attention. Therefore, when designing their international marketing strategies, firms should take into account factors and perspectives identified and discussed above: advertising, culture, role of technology or possible synergies between traditional and social media. The author has found out that each perspective used in the paper deals with certain limitations that must be taken into account, while at the same time brings several opportunities. Thus, managers dealing with social media might get inspired by these perspectives and be aware of its limitations, and if used correctly in the company, they can create successful international online marketing campaigns. As a result, four main perspectives were developed, whereas these perspectives have been analysed more in detail, defining opportunities and limitations regarding international marketing strategies with focus on social media. Although social media are experiencing boom nowadays and more and more authors focus on this issue in their articles, it is still possible to find many gaps that should be filled in order to create a sufficient framework for firms when creating international marketing strategies, with the help of social media.

Acknowledgment

This is part of research project: Use of the holistic concept in company management, Mariana Tesařová, FP-J-18-4915.

\section{References}

Abrahams, S. W. (2012). Milk and Social Media: Online Communities and the International Code of Marketing of Breast-milk Substitutes. Journal of Human Lactation, 28(3), 400406. /https://doi.org/10.1177/0890334412447080

Berthon, P. R., Pitt, L. F., Plangger, K., \& Shapiro, D. (2012). Marketing meets Web 2.0, social media, and creative consumers: Implications for international marketing strategy. Business Horizons, 55, 261-271. https://doi.org/10.1016/j.bushor.2012.01.007

Cleveland, M., \& Laroche, M. (2007). Acculturation to the global consumer culture: scale development and research paradigm. J Bus Res, 60(3), 249-259. https://doi.org/10.1016/j.jbusres.2006.11.006

De Vries, L., Gensler, S., \& Leeflang, P. S. H. (2012). What factors influence buying center brand sensitivity? Industrial Marketing Management, 41, 508-520. https://doi.org/10.1016/j.indmarman.2011.06.008

DesAutels, P. (2011). UGIS: Understanding the nature of user-generated information systems. Business Horizons, 54(3), 185-192. https://doi.org/10.1016/j.bushor.2010.12.003

Doole, I., \& Lowe, R. (2012). International marketing strategy: analysis, development and implementations (6th ed.). United Kingdom: Cengage Learning EMEA.

Enders, A., Hungenberg, H., Denker, H. P., \& Mauch, S. (2008). The long tail of social networking: Revenue models of social networking sites. European Management Journal, 26(3), 199-211. https://doi.org/10.1016/j.emj.2008.02.002

European Commission. (2017). Case study summary: Social media for internationalization. Retrieved February 20, 2018, from http://ec.europa.eu/growth/content/social-mediainternationalization_sv

Gilmore, A., Callagher, D., \& Henry, S. (2007). E-marketing and SMEs: operational lessons for the future. European Business Review, 19(3), 234-247. https://doi.org/10.1108/09555340710746482 
Ha, L. (2008). Online advertising research in advertising journals: A review. Journal of Current

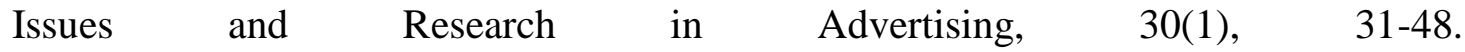
https://doi.org/10.1080/10641734.2008.10505236

Hanna, R., Rohm, A., \& Crittenden, V. L. (2011). We're all connected: The power of the social media ecosystem. Business Horizons, 54(3), 265-273. https://doi.org/10.1016/j.bushor.2011.01.007

Hasan, J. (2011). Analysis of E-marketing Strategies. Studia Commercialia Bratislavensia, 4(14), 201-208. oi.org/10.2478/v10151-011-0006-Z

Hennig-Thurau, T., Wiertz, C., \& Feldhaus, F. (2015). Does Twitter matter? The impact of microblogging word of mouth on consumers' adoption of new movies. Journal of the Academy of Marketing Science, 43(3), 375-394. https://doi.org/10.1007/s11747-0140388-3

Hofstede, G. (1991). Cultures and organizations: software of the mind. New York: McGraveHill.

Cho, C.-H., \& Khang, H. (2006). The state of Internet-related research in communications, marketing, and advertising: 1994 - 2003. Journal of Advertising, 35(3), 143-63. https://doi.org/10.2753/JOA0091-3367350309

Kaplan, A. M. \& Haenlein, M. (2010). Users of the world, unite! The challenges and opportunities of social media. Business Horizons, 53(1), 59-68. https://doi.org/10.1016/j.bushor.2009.09.003

Khang, H., Ki, E.-J., \& Ye., L. (2012). Social media research in advertising, communication, marketing, and public relations, 1997 - 2010. Journalism, and Mass Communication Quarterly, 89(2), 279-298. https://doi.org/10.1177/1077699012439853

Kim, J., \& McMillan, S. J. (2008). Evaluation of Internet advertising research: A bibliometric analysis of citations from key sources. Journal of Advertising, 37(1), 99-112. https://doi.org/10.2753/JOA0091-3367370108

Knoll, J. (2016). Advertising in social media: a review of empirical evidence. International $\begin{array}{llll}\text { Journal of } & \text { Advertising, 266-300. }\end{array}$ https://doi.org/10.1080/02650487.2015.1021898

Korzynski, p. (2013). Online social networks and leadership: Implications of a new online working environment for leadership. International Journal of Manpower, 34(8), 975994. https://doi.org/10.1108/IJM-07-2013-0173

Korzynski, P., \& Paniagua, J. (2016). Score a tween and post a goal: Social media recipes for $\begin{array}{lllll}\text { sports } & \text { stars. } & \text { Business } & \text { Horizons, } & \text { 59(2), }\end{array}$ https://doi.org/10.1016/j.bushor.2015.11.002

Kumar, V., \& Mirchandani, R. (2012). Increasing the ROI of social media marketing. MIT Sloan Management Review, 54, 54-61.

Laroche, M. (2011). Globalization, culture, and marketing strategy: Introduction to the special issue. Journal of Business Research, 64, 931-933. https://doi.org/10.1016/j.jbusres.2010.11.014

Laurenius, A., \& Wikstrom, N. (2016). Social Media in the Business Environment. Halmstad University. 
Leeflang, P. S., Verhoef, P. C., Dahlstrom, P., \& Freundt, T. (2014). Challenges and solutions for marketing in a digital era. European Management Journal, 32(1), 1-12. https://doi.org/10.1016/j.emj.2013.12.001

Li, J., \& Zhan, L. (2011). Online Persuasion: How the Written Word Drives WOM. Journal of Advertising Research, 51(1), 239-257. https://doi.org/10.2501/JAR-51-1-239-257

Liang, T. P., Lin, C. Y., \& Chen, C. N. (2004). Effects of electronic commerce models and industrial characteristics on firm performance. Industrial Management \& Data Systems, 104(7), 538-545. https://doi.org/10.1108/02635570410550205

Maltby, T. (2012). Using Social Media to Accelerate the Internationalization of Startups from Inception. Technology Innovation Management Review. October 2012: 22-26. Kietzmann, J. H., Hermkens, K., McCarthy, I. P., \& Silvestre, B. S. (2011). Social media? Get serious! Understanding the functional building blocks of social media. Business Horizons, 54, 241-251.

Mazaheri, E., Richard, M., \& Laroche, M. (2012). Investigating the Moderating Impact of Hedonism on Online Consumer Behavior. Journal of Global Academy of Marketing Science, 20(2), 123-134. https://doi.org/10.1080/12297119.2010.9730185

Merz, M. A., He, Y., \& Alden, D. L. (2008). A categorization approach to analyzing the global consumer culture debate. International Marketing Review, 25(2), 166-82. https://doi.org/10.1108/02651330810866263

Nelson-Field, K., Riebe, E., \& Sharp, B. (2012). What's not to „like?“. Journal of Advertising Research, 52, 262-269. https://doi.org/10.2501/JAR-52-2-262-269

Nicolas, I. R. (2017). Internationalization through social networks. E-Business Issue Summary.

Okazaki, H., Li, H. \& Hirose, M. (2012). Benchmarking the use of QR code in mobile promotion. Three studies in Japan. Journal of Advertising Research, 52(1), 102-117. https://doi.org/10.2501/JAR-52-1-102-117

Okazaki, S., \& Taylor, C. (2013). Social media and international advertising: Theoretical challenges and future directions. International Marketing Review, 30(1), 5671. https://doi.org/10.1108/02651331311298573

Okazaki, S., Mueller, B., \& Taylor, C. R. (2010). Global consumer culture positioning: testing perceptions of soft-sell and hard-sell advertising appeals between US and Japanese consumers. Journal of International Marketing, 18(2), 20-34. https://doi.org/10.1509/jimk.18.2.20

Paniagua, J., Korzynski, P., \& Mas-Tur, A. (2017). Crossing borders with social media: Online social networks and FDI. European Management Journal, 35, 314-326. https://doi.org/10.1016/j.emj.2016.09.002

Pashkevich, M., Dorai-Raj, S., Kellar, M. \& Zigmond, D. (2013). Empowering online advertisements by empowering viewers with the right to choose. Journal of Advertising Research, 52(4), 451-457. https://doi.org/10.2501/JAR-52-4-451-457

Sabate, F., Berbegal-Mirabent, J., Canabate, A., \& Lebherz, P. R. (2014). Factors influencing popularity of branded content in Facebook fan pages. European Management Journal, 32(6), 1001-1011. https://doi.org/10.1016/j.emj.2014.05.001

Sago, B. (2011). The usage level and effectiveness of quick response (QR) codes for integrated marketing communication purposes among college students. International Journal of Integrated Marketing Communications, 3(2), 7-17. 
Saxena, A., \& Khanna, U. (2013). Advertising on social network sites: A structural equation modelling approach. The Journal of Business Perspective, 17(1), 17-25. https://doi.org/10.1177/0972262912469560

Sigala, M. (2002). Modelling E-Marketing Strategies: Internet Presence and Exploitation of Greek Hotels. Journal of Travel \& Tourism Marketing, 11(2-3), 83-103. /https://doi.org/10.1300/J073v11n02_05

Smit, E., Reijmersdal, E., \& Neijens, P. (2009). Today's practice of brand placement and the industry behind it. International Journal of Advertising, 28(5), 761-782. https://doi.org/10.2501/S0265048709200898

Steenkamp, J. B. E. M. (2001). The role of national culture in international marketing research. $\begin{array}{llll}\text { International } \quad \text { Marketing } & \text { 30-44. }\end{array}$ https://doi.org/10.1108/02651330110381970

Swani, K., Milne, G. R., Brown, B. P., Assaf, A. G., \& Donthu, N. (2017). What messages to post? Evaluating the popularity of social media communications in business versus consumer markets. Industrial Marketing Management, 62, 77-87. https://doi.org/10.1016/j.indmarman.2016.07.006

Trainor, K. J., Andzulis, J., Rapp, A., \& Agnihotri, R. (2014). Social media technology usage and customer relationship performance: A capabilities-based examination of social CRM. Journal of Business Research, 6(67), 1229-1236. https://doi.org/10.1016/j.jbusres.2013.05.002

Villiard, H., \& Moreno, M. A. (2012). Fitness on Facebook: Advertisements generated in response to profile content. Cyberpsychology, Behavior, and Social Networking ,15(10), 564-568. https://doi.org/10.1089/cyber.2011.0642

Weinberg, B. D., \& Pehlivan, E. (2011). Social spending: Managing the social media mix. Business Horizons, 54(3), 275-282. https://doi.org/10.1016/j.bushor.2011.01.008

Zajonc, R. B. (1980). Feeling and thinking: preferences need no inferences. Am Psychol, 35(2), 151-175. https://doi.org/10.1037/0003-066X.35.2.151

\section{Contact information}

Ing. et Ing. Mariana Tesařová, MSc

Brno University of Technology, Faculty of Business and Management, Department of Management

Kolejní 2906/4

61200 Brno-Královo Pole

The Czech Republic

Telephone number: 00420606890411

E-mail: mariana.tesarova@vut.cz

ORCID: 0000-0002-1515-0357

DOI ID: https://www.doi.org/10.7441/dokbat.2018.22 


\title{
MODEL 5P FOR ECONOMIC ZONES IN VIETNAM
}

\author{
Tran Ngoc Son
}

\begin{abstract}
The Economic Zone (EZ) is an economic term formed in the late 1970s of the twentieth century, originating in China under Deng Xiaoping. The first economic zone of the country is called SEZ (Special Economic Zone) - Shenzhen China. The essence of EZ is a distortion of the Industrial Park (Industrial Park), which was first established in 1896 in England. However, in terms of organization, the functional areas within the EZ are more diverse than the IZs; In particular, the policies of the state have a higher priority, the scale of the territory is often larger. In Vietnam, EZ is a name in Vietnam. In other countries, the term is also known by other names such as the Free EZ, Free Trade Zone, Non-tariff Zone, Tax Free Zone, Export Processing Zone, SEZ Open, Economic Zone . To organize and manage EZs in Vietnam, this article will be addressed in Model 5P to provide an overview of this type of economic zone.
\end{abstract}

Keywords: Economic Zone, Special Economic Zone, Open Economic Zone, Free Economic Zone, 5P model.

\section{INTRODUCTION}

At present, in the world in countries like China, India, South Korea, Philippines, Singapore, Malaysia, Thailand, UAE, Taiwan, Vietnam, ... have built EZ models, although there are different names, but the nature of these types are geared towards free EZ. For example, in China there are 5 SEZ (Shenzhen, Shantou, Zhuhai, Xiamen, Hainan). In addition, there are 2,063 Economic Development Zone, which is a kind of free EZ of the local to attract foreign investment in technology. The free-market mode is not limited to a single economic space, but a large administrative unit that is open to the public. Currently, the world's most open city Hong Kong in China is a symbol of the open city has been built more than 100 years, many cities around the world are heading for this model. The United Arab Emirates, the secondlargest city opened in the world, was successfully built in just over 15 years. These two cities have brought a new dimension of free economics.

EZ "we need to study the basic theories and practices of the organization and management of Industrial Zones (IZ) and another form of industrial parks and export processing zone that is (EPZ) for K Sun or EPZ is a component of the EZ.

South Korea, China, India, Russia, Singapore and other developing countries like Ukraine, Kazakhstan, Iran, Jordan, North Korea, the Philippines, Malaysia, Vietnam, other territories such as Hong Kong, Taiwan, ... also in industrialized countries, the model is less organized.

However, in developing countries is accelerating the EZ as a mission to develop the country, though now in the country and even a country with which China has developed soon EZ the world is the Reform Commission and National Development of China said the next administration will probably limit the increase and expansion of the EZ since late 2007.

The argument concerning the organization and management of the industrial park has many studies T U centuries with famous theorists in the world such as the review of industrial zone of A. Weber, Theory of the agricultural belt of G. Thunen, the central theory of W. Christaller, growth pole theory of Perroux Francoi, bell-shaped model developed by Alonso, Theory of 
Jean Fourastier three areas, ... Since the theory that the world has many forms of research on industrial organization in the territory of different schools, among them the major contributors of the Soviet AT Khorutsov previously brought a successful great scientific and industrial organizations territory. However, research on organizational models for type management in Vietnam is not mentioned that at present only be made through the establishment decision, and the Regulation on organization and operation of the EZ which the Government has approved, such as economic zones, open economic zone, the border gate economic zone. D o vậy, nghiên cứu về cơ sở lý luận và sự tồn tại của KKT để tổ chức và quản lý là một việc rất cần thiết hiện nay khi mà các quốc gia đang thí điểm về mô hình kinh tế này. Do this, research on basic theory and the existence of the EZ to the organization and management is very necessary today when the pilot countries of this economic model.

Vietnam has great potential of the sea, territorial waters 3 times larger than its land area (which also means that if management is sea we will have a Vietnamese New South almost 3 times now and still be able to see) has 112 estuaries, bays, islands 4000, nearly half of the provinces/cities $(28 / 64)$ is the sea.

Vietnam is just not dare to stand before the sea and the sea: the new marine economy contributing about $18.6 \%$ (oil and gas accounting for $8.6 \%$, mining and processing of marine products $4 \%$, sea transport and $1 \%$ tourism; industrial production, construction and other related services for about 5\%). Average $1 \mathrm{~km} 2$ coast in the developed countries gained 100 thousand dollars, but in our country get 20 thousand dollars.

Research issues of this economic model is really necessary organizational issues and manage it.

However, this is still new to the field need to be studied systematically from the EZ model in the world for the construction and development in Vietnam. For the reasons above, thesis "organizational model, management of economic zones in Vietnam" should be studied and additional theoretical and a practical model of this economy.

\section{MATHERIALS AND METHODS}

By the method collected from the secondary data of EZ and goverment in Vietnam for analysis and evaluation through the years of EZ.

Use the data collection method and use the questionnaire to find the relationships of the five variables: Position, Policies, Project, Potential, People.

\section{RESULTS}

\section{1 $\quad$ EZ and 5P model for EZ}

From a practical study, it has been found that: In terms of the creation of free EZ forms in a developing country that transforms the economy from a centrally planned to a market economy, most type. Although the name is different, the degree of liberalization is open to foreign exchange, the SEZs of China have common characteristics of having special economic policies and special targets in a defined area. The study by Guang Wen Meng (2003) combined the SEZs of China with different names into a general concept of free EZs, in which free Chinese EZs 
are classified as free EZs. Composite, EZ-Free, EZ-Free, Cross-border Free-Trade and EZ, with various forms and names such as SEZ, Economic and Technological Development Zone (TEDZ), integrated development zones (CDZs), new high-tech zones (NHIPs), border trade zones (FFIZs), growth trunnions (GTZs), EPZs, Hong Kong administrative district, Macau. The free EZ in China is considered by many to be successful. Many new forms of free EZs have played a major role in the rapid development of China's economy over the past 30 years, prompting China's reforms to deepen and gradually form the economy. modern market.

In Vietnam, until 2018, there are 16 coastal EZs and 28 EZ border gates. (This study only mentions the coastal economic zone of Vietnam.) Based on individual studies on the organization and management of 16 coastal EZ in Vietnam and the experiences of other countries in the world, it is clear that to successfully build EZs in Vietnam, Five factors: Position, policies in accordance with international practices and policies, with national projects or projects located in the EZ (Project), have the potential to promote the potential of the place (Potenial), human-human resources to meet the organization and operation (People). According to the method of modeling objects with keywords in English, the first letter of each word starts with the letter P, I have given the model 5 variables starting with the letter P, Figure 5P (there is a P-shaped coincidence in Philip Kotler's marketing theory with the 4P model). The contents of the 5P model are as follows:

\section{Position}

Recent Chinese and Vietnamese experiences suggest that the formation of EZs is often based on natural factors such as coastal locations, which are usually associated with deep water bays or at the border gate (EZ border). to welcome trade opportunities with your country. From there, formed two types of EZ: EZ coastal and EZ trade gate. Both of these EZs draw on external resources as a goal and motivation. EZs are often far from large cities to obtain a sufficiently large land fund for the formation of an industrial-urban complex and attractive for low rents. On the other hand, it is necessary to select the most advantageous locations, first of all having international ports and convenient transportation with international maritime routes; near the arterial roads, near the EZ, science, culture, social development. The minimum area of an EZ must be greater than 10,000 ha in order to be able to accommodate all types of functional areas inside. The internal distribution of the existing heavy duty units includes: Essentially, these areas must achieve proportions relative to the total charge of an EZ to develop in harmony; In which: general industrial zone accounts for 50\%; Export processing zones: 15-16\%; commercial areas: 10-12\%; Infrastructure: 10-12\%; Public service: 8-10\%.

\section{Policies}

Policies formulation should ensure that factors such as the domestic environment are favorable (the political, social and economic situation of the country must be stable, the trend of market economy development, international integration must be mainstream, exchange relations between EZ freedom and domestic economy must be open ...); (must have friendly relations with all countries, especially the great powers, economic blocs, international organizations). At the same time, a system of administrative and economic institutions should be built in line with international norms that are universal for free EZs in general, including a zero protection barrier, an import / export tariff zero, abolish all tariff barriers; Visa exemption for all tourists, business and trade; allows long-term residence for business managers, technicians ... attractive taxes; Allows business freedom in all areas except for certain sectors that prohibit ... the implementation of administrative autonomy; To ensure the independence of the three powers: the legislature, the executive and the judiciary, the central government is unified in the management of security, defense and foreign affairs. varies according to the free EZ in different countries. But it can be seen that the greater the freedom, the greater the attractiveness. The development of operating regulations for EZ in accordance with international practice, while exploiting the comparative advantages of the national economy. This regulation should be 
consistent, easy to understand and easy to implement on the basis of ensuring the principle of "one door, on the spot", management of EZ access should be strict, however, avoid the cumbersome procedures And security should be ensured for EZ with feasible and effective measures.

\section{Project}

The construction of key projects or projects should take one of the basic factors as a nucleus, as a driving force for development, such as land border, deep-sea bays, or a key project, EZ is not just a clear boundary, it has its own policy and role as a driving force for regional development, but needs to be complemented by a number of factors such as the EZ formed in the area. The most favorable point for attracting external resources in relation to the internal market, having a land bank wide and not close to the crowded residential area, is organized to facilitate the management and merit. Key to motivation for development. For example, in EZ Dung Quat, Nghi Son and Nam Phu Yen, the national key oil refinery project was established; At Van Phong EZ formed a deep-sea port; EZ Chan May-Lang Co, Van Don to form high-end ecological tourism area, ...

\section{Potential}

This is an element that promotes local potential and influences the development of the surrounding area. However, in Vietnam, when building EZs, this factor is often less noticeable, so EZ, which often has the same spatial structure of the same functional areas, has not been able to promote the potential in situ about nature, resources. The EZs are separate, yet EZs really do have the power to influence other EZs to evolve.

\section{People}

This is a very important element. This factor requires the selection of a human resource from the experts to the managers of modern thinking, the heart of the country. Human resources are abundant in quantity and trained appropriately. The management of EZs needs to be neat and light, with highly qualified staff who are knowledgeable in economics, law, foreign languages and organizational capacity, have a strong political background and expertise. gold. The stage of formation of EZ specialties in China can be drawn 3 points to note: to arrange the structure of the profession is reasonable; Mechanisms must be flexible to adapt to the market; The level of management and qualifications of workers must be adapted to the requirements of the special area.

Figure 27 - The Model describes the factors for organizing and managing EZ by Venn diagram as follows: (5P Model)

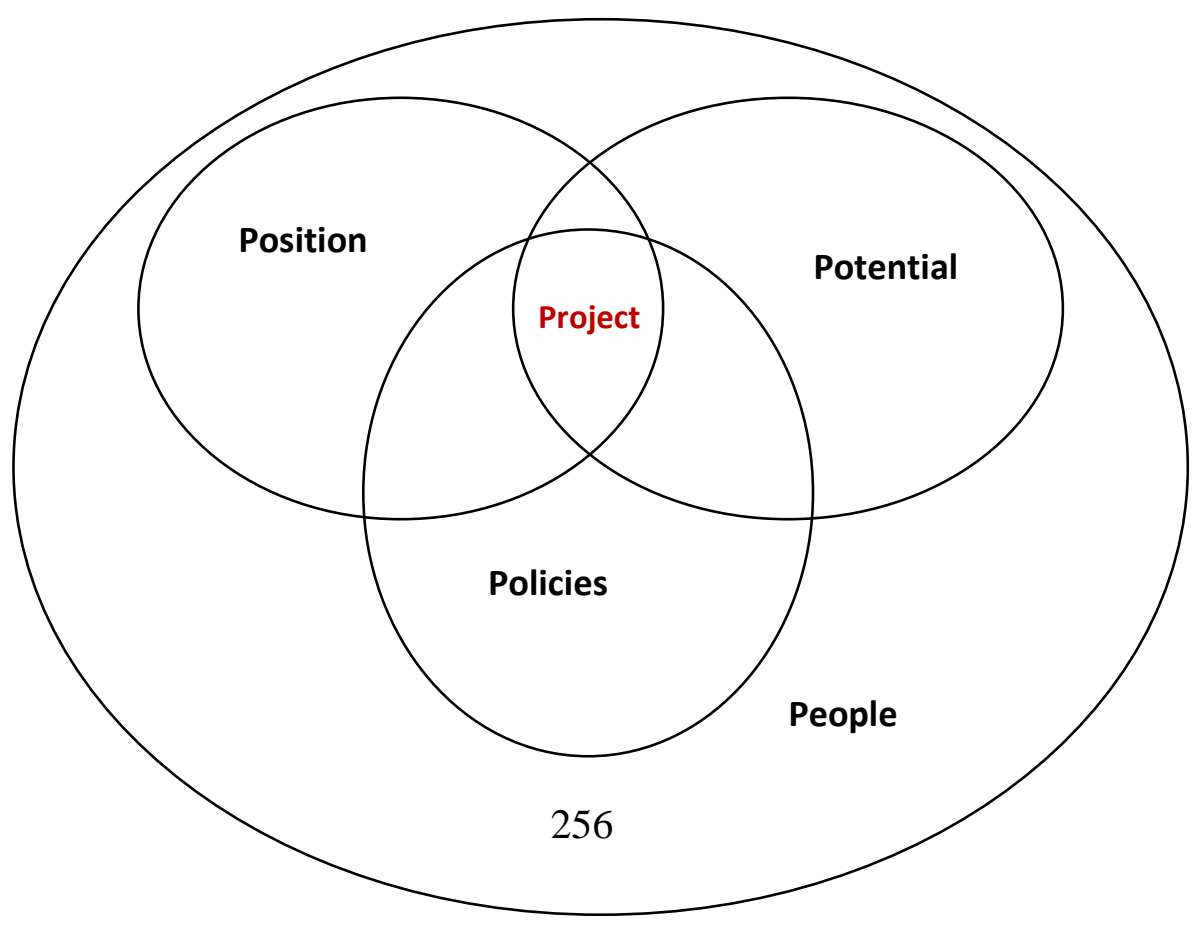




\subsection{P Model for EZ in Vietnam - some suggestions.}

From the practical point of view, through the 5P model for EZ in Vietnam, we propose some ideas as follows:

Firstly, for EZ types, in Vietnam, there should be such types as EZ gate and EZ coastal as the last time was held. (Vietnam currently has 3,260 km of coastline with 28 out of 64 coastal provinces and cities and $30 \%$ of coastal population. At the same time, through research on open cities, special economic zones, economic development zones, etc., there should be only open economic zones in Vietnam.

Considering the outstanding advantages of geo-economic, in Vietnam should transfer EZ Nam An Thoi-Phu Quoc and Van Don Quang Ninh province into two special economic zones. These are areas with deep water ports, international airports being built. On October 1, 2008, the United States Millennium Migration (MIGS) has presented to Quang Ninh PPC leaders the first EZ Van Don planning scheme with the vision of becoming a free EZ. Best. In addition, the Government proposed that one of these two island districts become centrally-run administrative units to have separate policies for attracting key national investment. Moreover, in the EZ development plan of Vietnam by the Government until 2020 with a vision to 2030, it has also been determined that in the North, EZ Van Don in Quang Ninh province will be firstly "open" Facing the sea, developing towards economic integration with Northeast Asia, in the cooperation of two corridors and one belt economic in the Gulf of Tonkin. In the south, EZ Phu Quoc, Kien Giang Province became an "open gate" to the sea and ASEAN economic integration.

Considering the nature of the Regulations promulgated by the Government for the Chu Lai open EZ, there is no big difference for the remaining EZs. On the other hand, EZ open Chu Lai also does not show the superiority of geo-economic and investment attraction policy. Thus, this EZ is just a normal sea EZ without the need for an "open" tag to avoid misunderstanding when compared to other EZ openings in the world. Investors, especially foreign investors, for EZ are open in Vietnam while the government does not have separate regulations for this type.

Secondly, in terms of mechanisms and policies applicable to EZ types. Recently, in order to create the development of EZs, the Government has issued many guiding documents, especially Decree No. 29/2008 / ND-CP dated March 14, 2008 of the Government. economic zones and industrial parks and Decision No. 1353/QD-TTg approving the Scheme on "Planning on development of Vietnam's coastal economic zones up to 2020" Based on the analysis and reference: The successes and failures of many countries and the actual organization and operation of EZs in Viet Nam over the last 15 years have shown that to better organize and manage EZs in Viet Nam, the Government should Early approval of the master plan for industrial development; In particular, there are plans to develop EZs in the whole country and at the same time assign the Ministry of Planning and Investment to coordinate with the concerned branches and localities in elaborating the detailed planning of EZ networks in each region. the provincial. The network of EZs must be within the framework of the planning strategy and socio-economic development programs of the whole country, each region and in the overall solution of territorial structure and city construction. open economy of the country. In building EZ, special attention should be paid to meeting the natural, geographic, socioeconomic conditions; In particular, there is a problem of EZ infrastructure. This is a key factor. The state needs to have a specific program in place to call for infrastructure investments in EZs and need immediate plans to build infrastructure outside the EZ; In that, we need to stratify the time of each stage to form the EZ. On the other hand, the industry structure of each EZ needs to be adapted to meet the new world market requirements, avoiding the "lucrative" industries in the EZ. Financial management in EZ should be studied carefully, simple, easy to implement and in line with international practice. There is no need for a large financial incentive for businesses operating in the EZ, but it should not set a lot of revenue that undermines the EZ. 
For EZ coastal and EZ border gates, the government should have common regulations and policies for these types. For special economic zones, there should be separate policies.

Third, The roadmap for each type of EZ. In general, the roadmap for developing EZs in the world is almost always necessary. China's experience shows that for Hong Kong, the world's most open city, it takes more than 100 years, the Shenzhen Special Economic Zone takes 30 years. The free EZ in Korea takes 50 years. Singapore took nearly 40 years. The roadmap to open the city was only 15 years old. This is also the EZ model opened by the EZ Vietnam is heading to.

For Vietnam, there are currently two types of EZ; that is EZ gate and EZ coastal area. These two forms are in line with current socio-economic development situation in Vietnam. The proposal of two SEZ in Vietnam is very necessary, as this is a new breakthrough of Vietnam in the strategy of marine economic development. At present, Vietnam has no conditions to build its own open city can still build new city in the heart of the open SEZ. At the same time, it is necessary to consolidate and develop existing EZs, without setting a roadmap that every province has EZ as the last time. According to us, the EZ planning of Vietnam to 2020 with the number of $16 \mathrm{EZ}$ is very suitable policy for the current socio-economic development of Vietnam, Especially, should form 2 SEZ to From there it is possible to build the city open in the heart of SEZ like Shenzhen or Dubai.

In fact, in Vietnam, industrial zones and export processing zones have been established and developed up to now for almost 25 years but it is only the first step, not enough to create an appearance for an industrial country. Therefore, the fastest roadmap for EZ in Vietnam at least 20-30 years from 2018 onwards can confirm its initial success. Therefore, the government should boldly apply the concession (this is the form of state franchise for public administration and for foreign individuals to carry out certain business activities in their territory such as mining useful constructions, construction and operation of enterprises, ... State-assigned concession to private or foreign private companies, governed by the laws of that country) to build SEZs and Streets open in the heart of the SEZ.

Fourth, on EZ management decentralization. It is necessary to develop a system of organization and management of EZs, including management boards nationwide from central to local levels (where EZ is available). In the above countries, the superiors of the EZ management boards are well defined: the agencies directly under the Government or the departments or sub-departments under the Ministry. In Vietnam now, the EZ is under the provincial People's Committee and the direction of the Ministry. This has created many levels of management, in our opinion, the higher authorities of the EZs should be assigned to the Ministry of Planning and Investment for direct management is most appropriate, because the formation and development of the EZ It is not only related to domestic and foreign investment but also to the process of economic restructuring and economic development policy. in the long future of the country. On the other hand, policies and measures are needed to build and operate the infrastructure outside the EZ fence, ensuring consistency and enabling each EZ to communicate with the external environment. as it exerts its influence. At the same time, research needs to be done to separate three types of activities, as many have already done and are doing: infrastructure construction and business under state-approved planning and developed by the infrastructure company. present; services for production, import and export and activities organized by specialized companies; Collection of fees and maintenance of public utilities made by specialized organizations of local governments.

In addition to the EZs that have been established and are in operation, it is important to evaluate the potential of each EZ, both in terms of infrastructure and the ability to attract investments into the EZ. Reorganizing investment mobilization to promote effectiveness, improve quality and unified management of this important activity for EZ. The choice of partner plays a decisive role in the success of an EZ. Therefore, adequate effort must be devoted to the investigation 
and selection of partners in the EZ. On the other hand, there must be budget or financial resources for the propaganda, promotion, organization of seminars, introduction widely at home and abroad; Particular attention should be paid to the training of qualified personnel in charge of investment mobilization. It is possible to combine and consolidate and develop EZ simultaneously with the opening of centralized IZ. In IZ, it is possible to have an export processing zone to create favorable conditions for investors depending on the needs of production-business development and to participate in export processing zones or IZ if the products are mainly for export. it will invest in export processing zones, if mainly domestic consumption will invest in IZ and subject to the provisions of the Law on Foreign Investment.

\section{CONCLUSION}

Firstly, the form of FEZs to facilitate large corporations converging and operating in the context of globalization will not only disappear, but continue to have great appeal and create making great breakthroughs in both economic scale and territorial space layout. Therefore, we suggest that, in the thinking of marine economic development, along with the construction of coastal economic zones, it is possible to study and select some construction sites as economic zones themselves. by the coast, to create a breakthrough large enough, opening a period of economic development of the sea with the goal of "becoming a strong country on the sea, enriched by the sea."

Secondly, economic zones in general and FEZs in particular focus on exploiting the strengths, especially in terms of geographic location (coastal areas, convenient transportation ...). , on socio-economic conditions (near or within a city, good human resources, good markets, etc.). Recommendation, the construction of coastal economic zones in Vietnam should also study more specific areas of strength to guide the development of each zone into a number of specialized areas, avoid the situation of This economic zone has no significant difference.

Thirdly, successful FEZs share the following points: modern institutions, international law, diverse development resources and high levels of concentration, It is the convergence of the world's leading companies. The proposal to select one of the above-said coastal economic zones shall apply the experiences of the free economic zones of the above-mentioned countries and build into Vietnam's free economic zone in the 2011-2015 period. 2020.

Fourthly, in order to build and develop coastal economic zones, especially in accepting the idea of building some coastal economic zones, it is very practical to create brand names for them useful. Recommend, continue propaganda and organize the contribution to build the brand of Vietnam Sea in general, the brand of each marine economic zone in particular.

In a nutshell, in most countries, there is an increasing tendency to remove tariff barriers, barriers to economic protection $t$ o create an open area, an open city and an open country. door. In that trend, the existence of EZ in developing countries such as Vietnam is needed and the 5P model is a way of looking at building an EZ in Vietnam.

\section{References}

Economic Zones World E-Services Guides at <http://www.dubaitrade.ae/knowledgecentre/learning/248-economic-zones-wold-user-guides23>.

Bui Tat Thang (2016), The Coastal Economic Zones in the Progress of VN become a greater country in sea and sea shorts. Development Strategy Institute, Ministry of Planning and Investment.

Special economic zones of China (SEZs) at <https://en.wikipedia.org/wiki/Special_economic_zones_of_China> 
P. Pakdeenurit, N. Suthikarnnarunai Member, IAENG and W. Which is the world's first SEZ? Rattanawong Special Economic Zone: Facts, Roles, and Opportunities of Investment at $<$ https://timesofindia.indiatimes.com/Which-is-the-worlds-firstSEZ/articleshow/2393897.cms>

VN Prime Minister: Decision No. 1353 / QD-TTg dated 23rd September 2008 approving the Scheme on development planning of Vietnam's coastal economic zones up to 2020.

VN Prime Minister: Official Letter No. 1231 / TTg-KTTH dated August 17, 2012 on the scheme on reviewing and formulating criteria for selecting a number of coastal economic zones to concentrate investment in the period of 2013-2015.

VN Ministry of Planning and Investment: Summary of the 20-year review conference on construction and development of industrial zones, export processing zones and economic zones in Vietnam, February 17, 2012.

VN Ministry of Planning and Investment - People's Committee of Quang Nam province: Proceedings: Mechanisms and policies for development of coastal economic zones of Vietnam, Quang Nam, 2014.

Dang Tien: Development of coastal economic zones, lack of planning and vision, Electronic Labor Newspaper, No. 85: Laodong.com.vn, updated on 16-4-2014. Department of Management of Economic Zones, Ministry of Planning and Investment: Assessment Report on Development of Coastal Economic Zones in Vietnam, Hanoi, 2014.

\section{Contact information}

Tran Ngoc Son

ORCID: 0000-0003-2754-6647

DOI ID: https://www.doi.org/10.7441/dokbat.2018.23 


\title{
TOURIST ATTITUDE ON LUXURY HOTELS
}

\author{
Nga $\mathrm{Vo}$
}

\begin{abstract}
The study is all about customers experience on the upscale hotels. The hotel industry is complex with particular reasons and opens up new frontiers in research on customer satisfaction. Respectively, customer service is the hotel industry's backbone that is used to be actual concept of industry itself. No matter the hotel businesses are big or not, a strong service-based philosophy is extremely importance to achieve business success level. The receipt of success in fostering high service quality of luxury hotel is to exhibit to customer that the hotel is serving the best facility they could offer by the best employee performance achievement through the most breathtaking views ever. For most people, hotel or hospitality service means entertaining guests with courtesy and warm, e.g the front desk is the hub of any guest transactions in a hotel to generate customers' problem-free at the beginning and end of cycle of services; housekeeping service is a vital and integral part of guest experience and satisfaction to being good infection prevention, healthy hygiene and cleanliness for guests, staff and visitors; security staffs maintain, safety and protective feeling for any individuals in a hotel, etc. The impact of these functions should not be under-estimated, but well collaboration and intercommunication to treat in-house guests such a family to absorb the feeling of home-away-from home. Therefore, the hotel' service quality especially in room division service is critical in shaping guest' pleasant memories of their stay. Different types of visitor segment regard to customer life cycle have various types of factors in a growth stage, and they unify to performance factors when the products and services mature. The diversity of guest market segments and booking channels have been charged by dynamic price strategy of hotel revenue management to maximize average room rate and occupancy percentage. The main objective of this study is to draw a theoretical framing of elements towards customer satisfaction and brand loyalty on the luxury hotel sector including guest online reviews, rate strategy and hotel website toward customer engagement behaviors through the process of perceived service quality. By integrating multiple marketing effort on brand attitude and customer focused, the multiple levels of customer satisfaction is related to perceptions of guests in order to be very affected in tourist arrivals and competitive performance of contemporary hotel industry. Specially, the conceptual model provides knowledge and recommendation to owners, managers, marketers, and practitioners to be more effective and efficient hotel and tourism management.
\end{abstract}

Keywords: Brand, Customer cognition, Customer engagement behaviors, Customer satisfaction, Luxury hotel, Service quality.

\section{INTRODUCTION}

The impact of tourist arrivals plays the vital role on the hotel and tourism industry. The only way to survive in the endless competitive market is to make customers happy. There is crucial to understand what makes customers feel satisfied through perception of service quality from their cognition of what and how to make them from willing to recommend and repurchase the service especially on the luxury hotels. Therefore, customer satisfaction should be taken as the most effective outcome measure to the hotels' competitiveness performances in overall. And the marketing effort is directed to customer attitude and hence it is imperative that retailing strategy initiatives result in higher customer satisfaction levels. Leadership style and marketing practices do score the vital of customer satisfaction for a business success (McColl-Kennedy \& Schneider, 2000; Reichheld \& Sasser, 1990). 
As many studies has mentioned about customer satisfaction particularly in hotel services. Hung (2003) stated that providing excellent service quality and achieving customer satisfaction is the most important and challenging issue facing the contemporary service industry. The hotel industry is a large and high diversification that includes wide range of property style, usages and quality (Go 1995). Attsllah (2015) observed in Egypt that tourists had clear general notion regarding the services provided by the tourism establishments. In fact, the consumer perceptions of service quality in three hotel categories in Hong Kong found that when people pay more, they expect to get better quality services (Choi, T. Y., Chu, R. K., 1999). Whereas, service industry has been increasing stop less competition. Heung, V. C. S. \& Wong, M.Y. (1997) studied hotel service in Hong Kong mentioned that in order to be successful in customer satisfaction, the management must know what their customers expect and then provide services to meet or go beyond their expectations.

A study in Malaysia found that customer awareness on hotel website impacts on consumer perceived service quality and repurchase intention toward revisit hotel website in the future (Abdullah et all, 2016). Furthermore, in Australia efficient website hotel and e-service enhance customer's willingness to book rooms and recommend the website o others (Weber, N. et all, 2005). And Bilgihan, A., Bujisic, M. (2014) confirmed that web design features such as hedonic and utilitarian, help improve customer's trust and loyalty. There is essential to understand consumer behavior in the progress of e-commerce in hospitality and tourism service, especially, it is usually claimed that online travel portals likely felt behind when attempt to create positive online environment for dynamic consumers' intention.

Besides, the management response to online reviews plays a crucial channel to communicate to customers toward the frequency, speed and length of response to enhance customer engagement on social media (Li et all, 2017). The online tourist comments allow either them to be willing to share opinions, exchange experiences or significantly affect a firm' value. And Fuentes, E., M. (2017) quoted that "despite the differences in criteria in implementing the hotel star-rate classification system throughout the world, a relationship does exist with user satisfaction, based on the scores awarded by former customers both on TripAdvisor and on Booking". Consequently, the recent emergence of online review services has opened up a new frontier in conducting research on customer satisfaction in the hospitality industry (Radojevic, 2017). So, the power of online platforms counts on the hotelier' ability to expand the word of mouth (WOM) and e-WOM effect and social effect among travelers in various tourist destination worldwide.

Wei et all (2013) stated that customers enjoy positive Customer Engagement Behaviors (CEBs) evaluation more than negative CEBs. Therefore, the recent emergence of online review services has opened up a new frontier in conducting research on customer satisfaction in the hospitality industry (Radojevic, 2017). The reviews and comments via hotel' website, social channels (e.g., Facebook, Twitter,..) and trustworthy sites (e.g., Trip advisors, Agoda.com, Expedia.com,..named OTA (Online Travel Agents) likely effect on reputation and business performance of luxury hotel chains.

The hotel competition worldwide is significant correlation with revenue management (RM) toward dynamic rate strategy (Guizzardi, A., Porns, F. Ranieri, E.,2017). But the various room rate application in the hotel might effect on the CEBs for repurchasing hotel service quality negatively (Algeciras et all, 2017). There is essential for hotel management to be aware of rate strategy to decrease price unfairness toward customer satisfaction.

In addition, the term 'brand loyalty' in tourism and hospitality has been studied by numerous researchers. Aaker (1991) defined brand loyalty is such "the attachment that a consumer has to 
a brand". In 1992, Grover and Srinivasan observed that brand loyal customers will favorably sometime response to brand more than non-loyal or switching customers. So, what does 'brand loyal customer' mean? The brand loyal customers who are content to pay more to perceive service/product of that brand offers (Reicbbeld, 1996). At the matter of fact, branding is such a marketing strategy varies widely used to foster the performance of business (Liu et al, 2012). Hence, high brand loyalty can favorably help brand attitude as well. Liu et all (2017) asserted that brand loyalty is reflected by customer engagement behaviors, and the reaction is to repurchase behavior product/service under the strong sensible conditions. Eventually, guests who are repeating and prioritizing to stay at particular luxury hotels regarding their decision making oriented brand loyalty (Odin, Odin, \& Valette-Florence, 2001). The higher numbers of brand loyalty, the higher brand performance and sale revenue of the business and in contrast. There is essential to hotel industry to effectively customize brand experience to satisfy customers, and enhance the loyalty toward the hotel brand.

To an aspect of empirical evidences and knowledge from previous research, the study wants to draw the theoretical outcomes regard tourist attitude based on customer satisfaction and brand loyalty on the luxury hotel sector including guest online reviews, rate strategy and hotel website toward customer engagement behaviors through the process of perceived service quality. In addition, this study wants to pursue knowledge and recommendation to managers, marketers, practitioners, and owners to improve service quality in both direct contact service delivery and e-service to customers; and efficient and effective managerial tactics and marketing activities to support for the hotel performance in overall.

\section{THEORETICAL BACKGROUND}

Viet Nam is breathtaking places which have been recognized by World Heritage Site such Halong Bay (where Kong film has been shot in 2017), Son Doong cave, Phong Nha caves,.. International visitors come to Viet Nam in April, 2017 estimated 1,071,650 arrivals, increasing $6.5 \%$ over March and up 34\% over the same period last year and total international arrivals in 4 months reached 4,284,130 arrivals, increasing 30.3\% over the same period last year (VNAT 2017a). Accordingly, over a decade, the International tourism operators in Vietnam transform from 428 in 2005 to 1519 in 2015, significantly increasing 1091 tourism establishments including state-owned, limited, joint stock, private, joint-venture (VNAT, 2016a). At the subsequent contribution, total tourism receipts jump from VND30tri. in 2005 to VND337tri. in 2015, modestly increasing 15\% growth rate over last year (VNAT, 2016a). Following the boom of tourism industry, despite 05 categories of hotel star rating (1-5star rating, 5-star hotel is highest ranking star (set up by VNAT), the accommodation industry in Viet Nam has suddenly risen from 3,267 hotels in 2000 to 18,800 hotels with 355,000 rooms in 2015 (VNAT 2016b), and the significant influence by changes in currency rates of USD VND for international tourists who absolutely use US dollar to purchase service and products coming in Vietnam.

Consequently, the number of four and five star hotels in Ho Chi Minh city (the highest population in nation) dramatic shifts to 41 hotels ( 4 star -20 hotels, and 5 star -20 hotels, 1 tourist apartment) over 306 hotels (215 4-star hotels and 915 -star hotels) in VN (VNAT, 2016b). As consequences, the more numbers of accommodation venues are built in certain area by International hotel groups (e.g. IHG (Intercontinental Hotel Group), J.W Marriot corporation, Hilton corporation, etc.), State companies (Vin group, Saigon tourist, Ben Thanh tourist) and private companies (Muong Thanh hospitality group, Alagon group, Cititel group, etc) the more competitors in the market to beat among each other to catch prospective customers and retain current guests as many as possible. The channels of reservation on upscale hotels particularly in Vietnam take up from percentage of sales via travel agent and tour operators 
(37.3\%), via direct booking with hotel (24.1\%) is second popular one, the rest booking channels are via online sale and other channels (VNAT, 2016a). There is other contemporary booking channel has become popular by its advantages such as Airbnb service. However, this new way of taking accommodation in a new place is less likely to be strong competitor to standard service of luxury hotel in relation to budget guests, limited service, and risk awareness when sharing a stay with unprofessional host. In order to motivate repeated guests as a kind of stimulating brand consumer loyal, there are various loyalty programs in Vietnam are being delivered by luxury hotel chains such as Marriot Rewards, Starwood hotels and resorts has SPG (Starwood Preferred Guest) program, Rewards Clubs of Intercontinental hotel groups (IHG), Park Hyatt, Best Western, Saigon Tourist Company (Caravelle, New world Saigon, Pullman, Majestic, Rex,..), Muong Thanh hospitality group, and Vin group which propose customers to earn from two to three Star point for every eligible US dollar spent, discounts $15 \%$ to $20 \%$ for additional services (restaurant and bar, spa, .. ), allow them for early check-in and late check-out until $4 \mathrm{pm}$, upgrade guest' room upon check-in whenever available, provide welcome fruit every stay, propose free night stay at participating hotels for every five to fifty stays, provide free Wi-Fi in room and menu of pillows with 07 choices to pamper guests' quality of sleep, mobile checkin is incredibly popular among Marriott Rewards, and Hyatt. The highly attention to personalized service and special care of hoteliers and marketing managers will properly enhance the customer' experiences and brand awareness when selecting a hotel. However, the negative comments and events effect on hotels may influence brand attitude on purchase intention despite the high brand performance. This causes marketing initiatives will be more difficult and costly to promote guest loyalty in such hotels. According to Asian Development Outlook (2007) the world market's trend has changed remarkably from agriculture to service industry. In order to uphold service quality, any enterprise fields including hotel markets are struggling day by day for every stay of individual consumers (even in a tourist group visits hotel for pleasure purposes). Therefore, diversified facility and vibrant service have been facilitated to support customer's needs and wants such as customers just dial number zero connecting operator named Star Service (being used at Starwood corporation, one of sub-brand of JW Marriot corporation), Instant Service (being used at IHG corporation) this only unique hot line in the luxury hotel would probably overcome all of their requests (Juwaheer T.D. 2003).

How the customer perceives the quality of service is stated customer satisfaction? Before taking service provided by staffs of enterprises, customer has several ways to measure or compare with what he/she expects to be served at the beginning of stage. On hotel industry especially the level of customer satisfaction, the higher star rating, the more desirable service quality demanding from customer. If the service delivery meets or exceeds customer expectation, he/she would be content to be there or even come back in the future (Choi 2001). In the other side, customer does experience unqualified service performance, he/she would never return. And there would be negative consequences suffer from that unexpected situation.

In recent decade, competition grows steadily and staffs are not being staffs' roles in physical tasks anymore, they seemly turn to a type of amenity as a personalized server for customers. As Wipoosattaya (2001) mentioned that personal service is the top most important list of travelers when deciding an accommodation. In addition, all employees' behaviors, either negative or positive, are highly correlated to the customers' overall satisfaction (Kattara, H. S., Weheba, D., El-said, O. A.,2008). And the most common critical incidents in a diverse group of Hongkong hotel involved in front-desk employees' responses to guest requests (Ching, E., Tse, Y, Ho, s. C., 2009). Besides, "Service satisfaction as a mediator" said by Lara, P. Z., Acosta, M. A., Baez, R. M. in Spain in 2015, the authors highlighted the role of guest' citizenship helps hotel to function and the role of management likely involves in employee satisfaction to embrace hotel performance in overall. This trend combined with sophisticated customers and various media 
focus, employee achievement has made significant relationship of service quality and customer satisfaction.

On the other hand, hotel businesses sometimes depend on good reviews or word-of-mouth from satisfied consumers on social media to increase sale volume from potential customers who take those comments as strong recommendations into concentrations to choose hotel before choosing particular establishment to stay. The beauty of this natural marketing tool is uncostly. The use of social internet platform like Trip-advisor, Facebook, Instagram, and Twitter and so on involve peer-to-peer communication channel to one and raise healthy engagement between clients and hotelier. The minus of social media is considerable when displeasure ideas about the service quality of the hotel were expressed leading unhealthy influence reputation. Based on those needs, online hotel reviews play crucial technology readiness for hoteliers to study the degree of customer satisfaction and enable them to control the service delivery. Radojevic et all (2017) studied factors effecting customer satisfaction behinds the rating on Trip advisors found that hotel performance towards customer satisfaction evaluation has significant interaction with visitors' characteristics including nationality, highly characteristic destination. Sometimes, customers prefer positive CEBs' evaluation more than negative CEBs (Wei et all, 2013).

Till now reasons based arguments and scientific statistical reports have not been shown and published much regard Vietnamese hotel and tourism industry' facts and figures in the measurement of customer satisfaction when tourists perceived hotel service in Vietnam and led to repurchase service in the future, but reviews and comments via hotel' website and fanpage, social channels (e.g, Facebook, Twitter,..) mainly in luxury hotels and hotel chains (e.g, IHG (Intercontinental Hotel Group), J.W Marriot corporation, Hilton corporation, etc.) and trustworthy OTA sites (e.g, Trip advisors, Amadeus.com, Agoda.com, Expedia.com,..- such Online Travel Agents market segment).

The hotel competition worldwide is significant correlation with RM towards dynamic rate strategy (Guizzardi, A., Porns, F. Ranieri, E.,2017). In light of the progress of online reservation systems, room rate dynamic needs a relevant management role regard online daily BAR (Best Available Rate) display despite seasonal effect, locations, customer purposes to attract tourist and maximize room yield. Some studies found that, limited service hotels offer higher rates among room categories (Becerra et al, 2013), in contrast, luxury hotels display smaller seasonal rate variations (Espinet et all, 2012). Mauri and Minazzi (2013) researched on the 349 young adults named generation $\mathrm{Y}$ through online survey to study the affection of WOM in the hospitality industry and analyses a new operational problem for lodging managers.

Arguably, Algeciras et all (2017) noticed that the application of RM principles is essential to maximize room revenue for hotel establishment, unless it may negatively impact consumer intention for loyalty. And Ferguson (2014) measured pricing strategy in turbulent economies in order to decrease price unfairness. Chua et all (2015) likely mentioned price sensitivity of the cruise vacationer's experience to evaluate the impacts of cruise service quality and price on them, but hotel service industry. Whereas, setting room rates on the Internet or through third party can be precarious to the reputation of any hotel establishments when customers who had purchased the rooms began to compare room rates on online discussion board or accidentally spoke with other in-house guests at the particular hotel. There is vital to set fair room rates on the Internet and other pricing mechanism to increase market power and consumer intention regard positive dynamic rate strategy in the hospitality and tourism service industry.

Ball (1995) explained consistent monetary policy in US. that explains changes in inflation over time- adverse supply shocks trigger increases in inflation. Collies International reported the room rate occupancy percentage and ARR (Average Room Rate) in Ho Chi Minh in Dec 2015 
within the same 5-star rating hotels, the occupancy rate consumes from $64 \%$ to $100 \%$, and ARR significantly differs from USD151 to USD451/room/night. Particularly, the market performance of 4-star hotels follows the growth of 5-star hotels in both of occupancy rates and ARR (Average Room Rate), reaching 87\% and USD127/room/night respectively (Colliers International, 2016)

Moreover, the fig. 1 modifies the channels of reservations in luxury hotels in 2015 vs 2016 in Viet Nam. The percentage of sales via travel agent and tour operators in 2016 is expected to remain the most popular booking channel at $37.3 \%$, decreases at $2.7 \%$ compared to 2015 . The percentage of sales via direct booking with hotel is second popular one, and slightly increase at only $0.5 \%$. The percentage of sales via online sale and other channels follows at $20.7 \%$ and $17.7 \%$ in 2016 , takes a decreasing $1.2 \%$ and increasing $3.6 \%$ compared to last year respectively. OTA is taking up as popular booking channel for variant market segments as well (Grant Thornton, 2017)

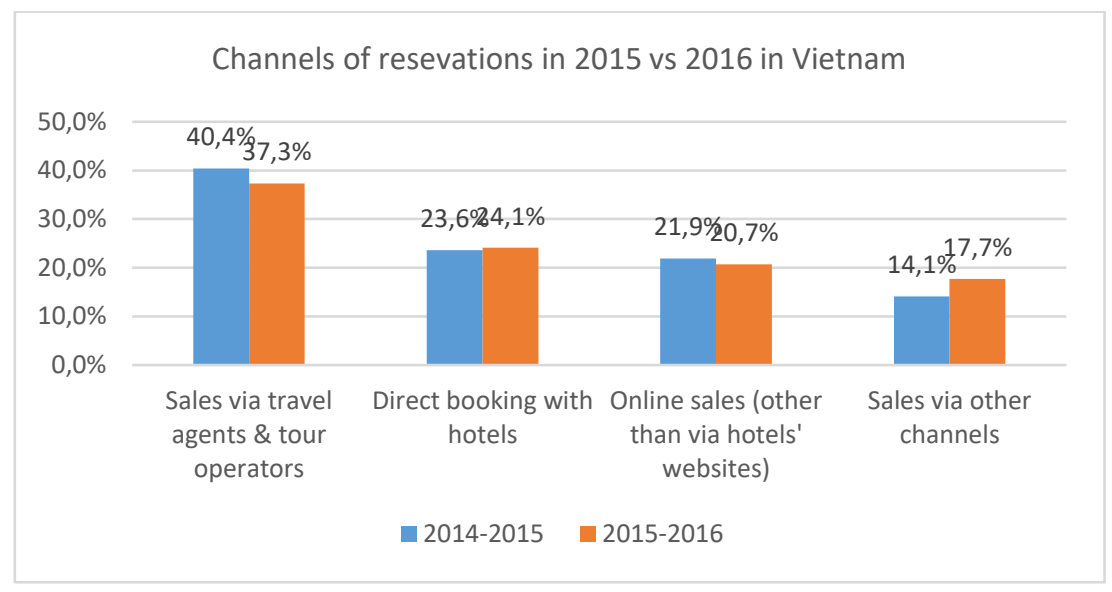

Figure 28 - Channels of reservations in 2015 vs 2016 in Viet Nam (developed by Researcher)

Technology becomes popular alternative to lower costs and improves customer experiences. A part of this, smart technology continues to involve globally, for example, hoteliers drive the volume of direct bookings as a marketing and booking engines tool via mobile services. Furthermore, the use of social internet platforms like Trip-advisor, Facebook, Instagram, and Twitter and so on involve peer-to-peer communication channel to one and raise healthy engagement between clients and hotelier. The minus of social media is considerable when displeasure ideas about the service quality of the hotel were expressed leading unhealthy influence reputation. Based on this needs, online hotel reviews play crucial technology readiness for hoteliers to study the degree of customer satisfaction and enable them to control the service delivery. Fong, Wai, \& Law (2017) found that locus of control (LOC) dimensions predict intention to reuse mobile apps to make hotel bookings help facilitate the relationship between control by powerful others and intention.

Shamim, Cang, \& Yu (2017) identified the indirect impact of supervisory orientation on knowledge management as a mediation of front line hotel employees' goal orientation. 'The locus of responsibility for personnel management no longer resides with (or is "relegated to") specialist managers' has been mentioned by Sisson (1990). And Purcell et all (2003) put the compulsory and priority of commitment and capability of lines management with HR policies are the must to run and manage organization smoothly. Kohli et al.(1998) mentioned that supervisors can effect employee learning and performance though orientation.

With a modest increasing number of tourists to Viet Nam yearly, the management of Viet Nam National Administration of Tourism set up tourism strategy development plan by 2020, and had 
established the VTOS (Viet Nam Tourism Occupational Skills Standards) to upgrade standard and improve quality of Viet Nam' tourism human resource for ASEAN integration. This massive plan benefits for tourism and hospitality sector, improve the relevance and effectiveness of the VTOS. VTOS inherits knowledge; practical suggestions for policy making; education and training; and huge asset support from EuroCham (12.1 million Europe fund of EuropeAid, from 2010-2016); experts in Viet Nam tourism field; investors; tourism businesses; domestic and international airlines and media agencies. Then it expands its value in tourism and hotel service sector throughout 13 series of occupational skills standards in dual languages (Vietnamese - English) with video clip attached to friendly facilitate and modify for hoteliers and tourist service providers, to meet the increasing demand of the sustainable tourism development. Learning at workplace can no longer stand at afterthought, but a main part of any hotel' development strategies. The continuous updating of skills and qualifications is such a norm for lifelong learning. However, any form of training or learning, is useless if managers ignore the continuous practical application of the knowledge in the workplace, no matter how well designed or conducted. And the managers should analyze the needs, employees' skill deficiencies then decide what and how to train could be appropriated. According to customer satisfaction in luxury hotels, Lai and Hitchcock (2017) found that the different types of visitor segment (new, repeat, and frequently traveler) regard to customer life cycle have various types of factors in a growth stage, and they unify to performance factors when the products and services mature.

The accommodation service in Vietnam is improving in both numbers of hotel, room capacity provided for various market segments and quality of standard in relation to reach the high demand of upscale international travelers. Luxury hotels and resorts have been built across the coastline $3400 \mathrm{~km}$ long to serve for high-class tourists. Whist budget tourists have been accommodated by low and medium lodging venues throughout the country. The competition is never end in this service sector, as consequences travelers and tourists benefit from this battle with cheaper prices which expect to pay at least 5 dollars for budget and 150 dollars for luxury option (Vietnamnet, 2017). In addition, food and beverages service are main components attached in accommodation service towards nutrition, food security, and good health. As long as Vietnam' cuisine is one of motivation of travelers to visit the country due to its famous with diversity, fresh, and tasty ingredients. Service sector contributes about $45 \%$ in developing country (VNN). Brooks et all (2008) investigated Asia's recent experience in international capital allocation through flows of foreign direct investment towards human capital, productivity, endogenous growth, and institutional behavior. The results supported the argument that all these factors played a role in Asia's recent growth, to different degrees in different countries, with complex relationships to investment incentives.

Tabaku, E. , Cerri, S. (2016) measured the assessment of the quality of the service offered by the hotels in the Albanian coast and also an assessment of the effect of service quality on the satisfaction of hotel customers. The authors found that the significant importance of the perceptions of the tourists about the service quality and the significant impact of the perceived service quality on customer satisfaction for hotel guests. At the matter of fact, Gilbert, D. Horsnell, S. (1998) argued that guest satisfaction measurement became familiar practice in United Kingdom, but with care less adequate assess especially in poor hotel achievement.

Thus, many researchers have studied the impact of staff attitude on the consequences of perceived service quality to create the degree of customer satisfaction, but the prospective hotel employees who are current hotel and tourism major students. These young adults, namely generation Z (born from year 1995), are enthusiasm, experienced tourism and hotel service through either full time jobs, part time jobs, or internship, or even being actual guests in luxury hotels, especially they have fundamental knowledge and high expectation regarding perceived 
hotel service quality. Their cognition of guest online reviews, hotel website, and room rate strategy that might effect on their satisfaction though receiving service quality seemly has not been explored by researchers yet. Therefore, there is crucial for the author to study in which ways customer cognition regarding room rate strategy, guest online reviews, and hotel websites may influence hotel' service quality via customer engagement behaviors and how these intentions, in turn, influence customer satisfaction and brand loyalty on luxury hotels.

\section{RESEARCH OBJECTIVES \& THEORITICAL REVIEW}

The key objective of this research is to develop a comprehensive model in customer cognition of perceived service quality and customer engagement behaviors to repurchase service on luxury hotels. The other five sub-objectives of the study remain as below.

1. To examine the impacts of guest online reviews on the customer satisfaction towards perceived service quality on luxury hotels

2. To examine the impacts of hotel room rate strategies on the customer satisfaction towards perceived service quality on luxury hotel

3. To examine the impacts of luxury hotel websites on the customer satisfaction towards perceived service quality

4. To examine insights of service quality context on the what and why of the influence of service quality on customer satisfaction and brand awareness.

5. To suggest practical managerial recommendations towards possibly gaining enhanced customer bonding value for luxury hotels in Vietnam.

The main argument concerns for this literature review is "how customer cognition regarding room rate strategy, guest online reviews, and hotel website influenced service quality to customer engagement behaviors and how these intentions, in turn, influenced customer satisfaction and brand loyalty?". In this regard, customer cognition of room rate strategy, guest online reviews, and hotel website towards perceived service quality has a role to play in shaping the continuation purchase service in luxury hotels. The customer cognition of guest online reviews, hotel website, and room rate strategy, towards perceived service quality, why they are important in case of business performance?

Customer cognition of guest online reviews. Why guest online reviews are important?

Customer cognition of guest online reviews has been defined by various scholars differently. Mauri, A. G., Minazzi, R. (2013) studied online survey by 349 young adults, confirmed online travel reviews are important information which effect on customer decision-making process and purchasing intentions. In addition, the influence of comments generated on Facebook in the users' decision-making process (Ladhari, R., Michaud, M., 2015). Fuentes, E., M. (2017) examined 14,000 hotels in 100 cities around the world taken from Booking and TripAdvisor website to find out the significant relationship of customer satisfaction towards rating scores awarded by former customers despite the different criteria in implementing the hotel star-rating. Radojevic et all (2017) analyzed Correlations Between the Rating Scores regarding guest online reviews from 13,410 hotels located in 80 major global urban tourism destinations in order to conclude that characteristics of hotel and individual visitors most powerfully influence customer satisfaction.

However, when Wei et all (2013) observed the impact of positive reviews vs. negative reviews by 101 online surveys towards service quality, the authors found that customers prefer positive than negative evaluations despite the different targets and motivations of customer engagement behaviors in perceived service quality. Mauri, A. G., Minazzi, R. (2013) said that the guest online review has a positive correlation with hotel purchasing intention and customer expectations, but has a negative impact on purchasing intentions towards the presence of hotel 
managers' responses. Li et all (2017) based on content of 108,410 reviews from 212 hotels to find out vital role of the management response as an ongoing communication process to engage travelers and increase brand awareness on online social community presence.

Geethe, M., Singha, P., Sinha. S. (2017) based on online reviews from 20 hotels in Goa found that the consistency between customer ratings and actual customer feelings across hotels belonging to the two categories of premium and budget. Although clients may seek travel and hotel information with relatives, and friends, guest reviews on social media still is reliable channel for references. For both current and prospects customers, especially young generations who tend to spend time a lot online, surfing referent information on the internet is fast and easy, convenience, free of charge, numerous information, and available prices. It is argued that customers who plan for travel should look for guest online reviews including rating score before making purchasing decision for accommodation and other services. It is far more meaningful now to travelers to read through positive and negative former comments rather than in terms of management response to uphold the interaction and brand awareness via social network. Therefore, either the negative comments of guest online reviews or improper engagement of management responses also weaken the customer intention to visit in the particular hotels.

Customer cognition of hotel websites. Why hotel websites are important?

Mostly, studies on hotel websites have considered as another interesting fact of the consumer behavior in relation to his or her sources of information and intention for the trip.

According to Abdullah et all (2016), customer perception on the interactivity of hotel website affect customer perceived value and to what extend to revisit the hotel website afterwards. Weber et all (2005) said that when customers are happy with the websites and e-service, they are likely to book via and to recommend the website. Previous studies have mentioned about the importance of information via the internet, and hotel website is also a part of this crucial channel which is particularly operated and managed by hotel management. Of course, the viewers are less likely able to see the negative comments from former users on hotel website but positive comments to suggest prospects customers to stay at this hotel no matter how.

Therefore, users tend to be aware of the reliability of the information displayed on the hotel website. Bilgihan, A., Bujisic, M. (2014) used Structural Equation Modeling by 5000 online questionnaire service survey to examine the vital role of hedonic and utilitarian features which can sway customers' trust towards the online vendor and trust is an important antecedent of eloyalty. As continuous steps, after picking the referent hotel brand via social media or online travel agency, word of mouth, then the prospect customers probably will search for referent hotel website to either generate larger ideas, images, information, reputation of the hotel or last user "comments in order to foster the purchasing intention later.

As previous studies, on the one hand the needed things online users ask for hotel website is in order of incentive information, proper interface, friendly usage, and interactivity, especially trustable sources information. Ferguson, J. L. (2015) observed that the purchase decisions of consumers is influenced by how much information from Internet sources and social media that they know. On the other hand, prospect customers turn to 'real customer' in someday and they properly will engage the service quality of the hotel itself and hotel website is to ensure the promise of service delivery by hotel staff then if not, customer just raise their voices and might receive immediate hotelier's responses.

Customer cognition of hotel room rate strategy. Why hotel room rate strategy is important?

The one of criteria for selecting hotels have been displayed with dynamic room rate by the hotel rate strategy. A hotel has different room category based on room size, furnishing, amenities, et...The particular room rate is set by hotel management based on particular room type and value added service, and users may be charged in different amount of money and benefits within dynamic market segment. Depending on various market segment and room category; supply and demand of users, the hotel management in particular named Revenue Management or Yield 
Management offer booking tools at lower room rates to increase sale in low demand and higher room rates in high demand of the market to maximize revenues spread over the various type of booking channels (i.e. direct to hotel via face to face, telephone, hotel website; tour agent; online travel agent; and tour operators, etc.).

Why this room rate strategy exists in this hotel industry? Due to the fixed inventory of perishable number of rooms sold daily in the hotel, these rooms cannot be stored if unsold at the end of the day. If there are unsold rooms, there are lost forever for those rooms and services as a packages. Therefore, various rates/prices have been set by Revenue Management/Hotel management to sell rooms/service/products either in advance to forecast the numbers of room reservation or depends on transaction time and delivery date. Guizzardi, A., Porns, F. Ranieri, E. (2017) studied that price levels are explained by a variety of structural determinants. In the meantime, to customers, price sensitivity regarding to perceived value which in turn, affected satisfaction and loyalty (Chua, B. et all, 2015).

However, according to Algeciras, A. R., Ballestero, B. T. (2017) the effects that implementing Revenue Management have caused in the studied hotels, if there are inappropriate Revenue Management principles used in the venues, then might negatively affect in consumer intention for loyalty. Monroe \& Xia (2006) studied that the more consumers who perceive a price as unfair experience, the more negative attitudes toward the provider engage in self-protection intention. Therefore, in some venues, the hoteliers can offer offline fares to potential guests in relation to last-minute prices to improve customer relationship (Guizzardi, A., Porns, F. Ranieri, E., 2017).

Eventually offering potential customers different room rates on particular room category helps hotel maximize room revenue on a daily, monthly, and annual. The performance of hotel in Revenue Management aspect in relation to room rate strategy directly affect numbers of room sell and at which rates have been set to charge customers in different market segment. The tasks of overseeing revenue management, distributing hotel strategy, and managing day to day operations and so on have to understand the hotel services and products, the market the hotel in, and have a unique knowledge of economics.

Customer engagement behaviors (CEBs). Why understanding of CEBs is important?

For most people, tourism and hotel service markets mean entertaining guests with courtesy, warm, and experiences. The receipt of success in fostering high service quality of luxury hotel is to exhibit to customer that the hotel is serving the best facility they could offer by the best employee performance achievement through the most breathtaking views ever. As different types of visitor segment (new, repeat, and frequently traveler) regard to customer life cycle have various types of factors in a growth stage, and they unify to performance factors when the products and services mature. Therefore, understanding the consumer behaviors is vital role for any establishments, and especially tourism and hotel industries are struggling to study and fulfill what customers want and demand based on dynamic expectations of their different behaviors.

In the concept of marketing, getting to know consumer engagement behaviors is study how their buying decision making go and how marketers exploit the knowledge to attract, maintain, and eventually they willing to buy, repurchase, be loyal to the brand and suggest others to try the products/services. Focusing on corporate performance in today's interactive and dynamic business environments highlights the vital role of Customer Engagement Behaviors (CEBs). It refers to the types of connections customers make with other customers, firms, and brands (Smith and Wallace, 2010) and as a key concept that influences customer experience, values (Brodie et al., 2011; Mollen and Wilson, 2010). The marketing researchers and practitioners have to keep in mind the insights of customers' engagement behaviors to manage relationships, retention, and their loyalty (Hollebeek, 2011), lack of CEBs can cause inaccurate valuation of customers (Kumar et al., 2010), affect marketing metrics, and influence firm values (e.g., Lehmann, 2004). "CEBs include, but are not limited to, a variety of customers' behavioral 
expressions that have influences on firms, such as word-of-mouth (WOM) activity, referrals and recommendations, voluntary assistance with other customers, web postings and blogging, participation in brand communities, engagement in product development, and other behavioral manifestations that are likely to influence the firm and its brands" (van Doorn et al., 2010). On the aspect of hotel services and operations, in order to increase sale revenue and repeated guests, the hotel managements including restaurant services study customer behaviors by asking customer feedbacks about the service in overall while staying at the venues either via commend cards available in rooms, on the table or at the front desk, or directly face-to-face, or sending the customer satisfaction survey to customers' inbox. In tourism and travel services, customer behaviors are got to know through observation, talk in person, phone call, and customer evaluation sheet will be delivered to guests at the end of the tour by tour leaders to obtain their judgment and expectation for next trips, and so on.

The attempt to value customer' evaluation of tourism and hotel management resolve the unexpected situations and pamper customers' feeling if they got unhappy for certain cases during perceived service with the establishments. In addition, many studies said that consumer engagement behaviors are effected by factors of personal, culture, and social. The factors characteristics are influenced by relationships such as family, neighbors, friends, siblings and family of procreation which includes spouse and children, etc. i.e. if the customers grew up and used to see family prefer nice, medium to high-priced products/services particularly in hotel and tourism services, the customers properly will practice like that and in contrast. Specially, personal factor is mainly influenced by the age and stage in the life cycle, occupational and economic conditions, personality and self-development, and lifestyle and values. According to guests' point of view, roles and status, needs and demands, the hotel management takes into account the habits and traditions that influence the customers' choices better than to create or change their innate behaviors to foster the overall hotel performance.

Previous studies and literature background of customer cognition of guest online reviews, luxury hotel websites, and room rate strategy in luxury hotels provides the knowledge of how they affect customer satisfaction in relation to customer perceived service quality. In the meantime, they show how tourist attitude regarding on customer satisfaction regarding customer perceived service quality leads customer engagement behaviors, in turn, to repurchase and to be brand loyalty to referent hotel services. The below conceptual model indicates the relationship among predictor, mediate and outcome variables reflecting the literature findings (Fig.2)

Is there a relationship between customer perceived service quality and customer satisfaction? 


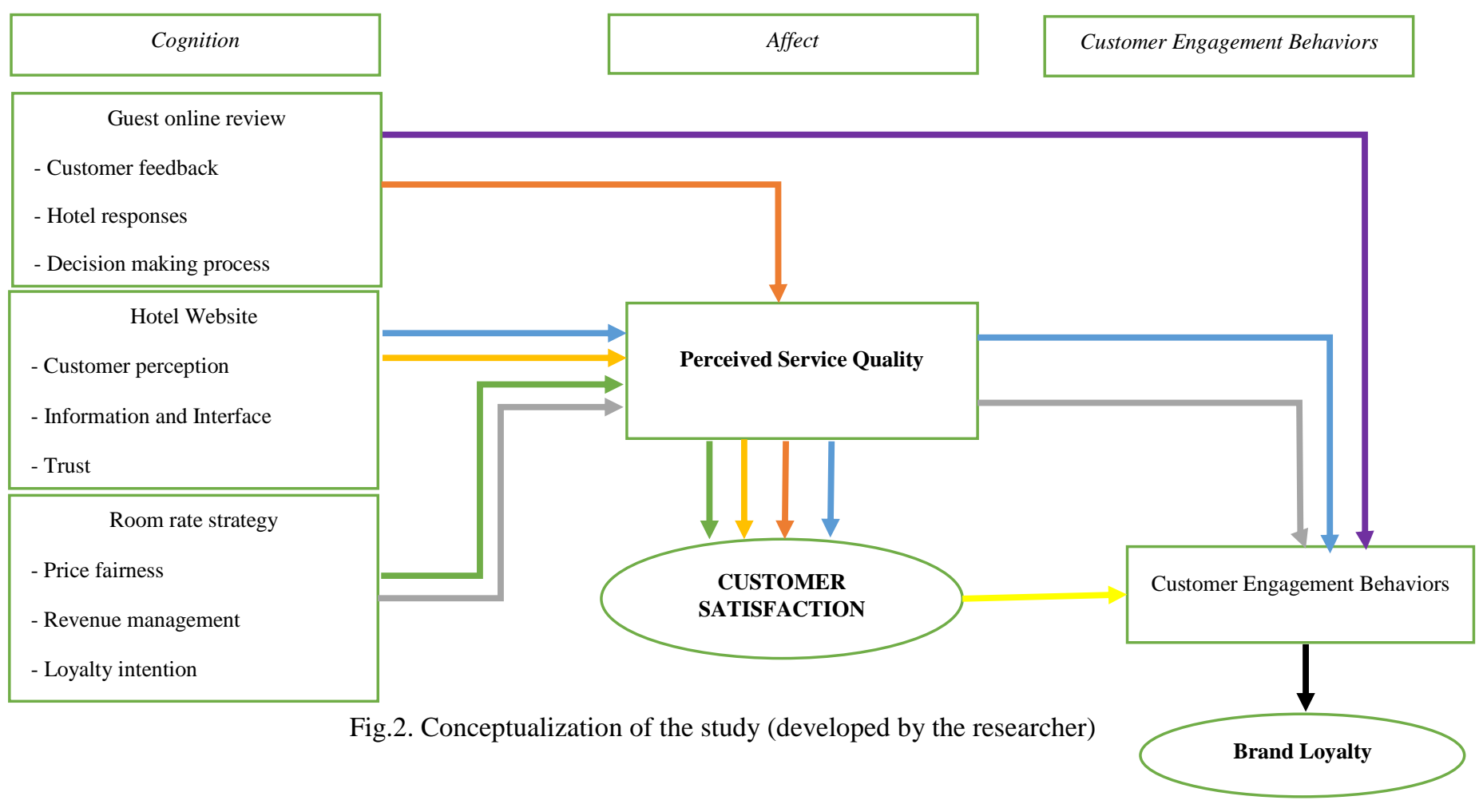

The study considers an emerging market on a luxury hotel setting in Vietnam. The theoretical background provides practical guidelines for managers and marketers in the luxury hotel industry to balance their resources and efforts in hotel revenue management and marketing activities to improve business effectiveness. The customer satisfaction on actual trial has supported customer engagement behaviors towards the hotel performances in achieving service quality. The theoretical of the study suggests the customer cognition of online reviews, room rate strategy and hotel website is empirically influenced level of customer satisfaction regarding perceived service quality in luxury hotels. Moreover, another interesting finding is from those three different customer perceptions affect towards levels of CEBs when receiving service at the hotels, and the study wants to pursue knowledge and recommendation to managers, practitioners, and owners to improve service quality in both direct contact service delivery and e-service to customers, and efficient and effective managerial tactics to support for the hotel performance in overall.

\section{References}

Aaker, D. A. (1991). Managing brand equity. New York: The Free Press

Abdullah, D. Jarayaman, K., Kamal, S. (2016). A Conceptual Model of Interactive Hotel Website: The Role of Perceived Website Interactivity and Customer Perceived Value Toward Website Revisit Intention. Procedia Economics and Finance 37 (2016) 170 175.

Algeciras, A. R., Ballestero, B. T. (2017). An empirical analysis of the effectiveness of hotel Revenue Management in five-star hotels in Barcelona, Spain. Journal of Hospitality and Tourism Management 32 (2017) 24-34. (2017). DOI: 10.1016/j.jhtm.2017.04.004. 
Anonymous (2017). Colliers. Vietnam quarterly knowledge report Q.1 2017. Retrieved June 09, 2017, from http://www.colliers.com/-/media/files/apac/vietnam/pdf/vietnamquarterly-knowledge-report-q1-2017-en.pdf

Anonymous (2017). Grant Thornton. Executive Summary Hotel Survey 2017. Vietnam Hotel Upscale Lodging Industry. Retrieved Aug 08, 2017, from http://www.grantthornton.com.vn/globalassets/1.-memberfirms/vietnam/media/executive-summary-hotel-survey---eng.pdf.

Anonymous (2017). Vietnamnet. Over 345 million in FDI poured into property. Retrieved June, 01st, 2017, from http://english.vietnamnet.vn/fms/business/173737/over--345-millionin-fdi-poured-into-property-sector.html.

Attsllah, F. A. (2015). Evaluation of perceived service quality provided by tourism establishments in Egypt. Tourism and Hospitality Research. Vol 15, Issue 3, pp. 149 160.

Ball, L. (1995). Time-consistent policy and persistent changes in inflation. Journal of Monetary Economics. Volume 36, Issue 2, November 1995, Pages 329-350. DOI: 10.1016/03043932(95)01218-4

Bilgihan, A., Bujisic, M. (2014). The effect of website features in online relationship marketing: A case of online hotel booking. Electronic Commerce Research and Applications xxx (2014) $\mathrm{xxx}-\mathrm{xxx}$.

Brooks, H. D., Holst, R. D., Zhai, H. (2008). Behavioral and empirical perspectives on FDI: International capital allocation across Asia. Journal of Asian Economics 19 (2008) 4052. doi:10.1016/j.asieco.2007.10.004

Brooks, H. D., Holst, R. D., Zhai, H. (2008). Behavioral and empirical perspectives on FDI: International capital allocation across Asia. Journal of Asian Economics 19 (2008) 4052. DOI:10.1016/j.asieco.2007.10.004

Ching, E., Tse, Y, HO, s. C. (2009). Service Quality in the Hotel Industry - When Cultural Contexts Matter. Cornell Hospitality Quarterly, vol. 50, 4: pp. 460-474.

Choi, T. Y., \& Chu, R. (2001). " Determinants of hotel guests' satisfaction and repeat patronage in the Hong Kong hotel industry." International Journal of Hospitality Management 20: 277-297.

Choi, T. Y., Chu, R. K (1999). Consumer perceptions of the quality of services in three hotel categories in Hong Kong. Journal of Vacation Marketing, vol. 5, 2: pp. 176-189.

Chua, B. et all (2015). Impacts of cruise service quality and price on vacationers' cruise experience: Moderating role of price sensitivity. International Journal of Hospitality Management 44 (2015) 131-145. DOI: 10.1016/j.ijhm.2014.10.012.

Cross, R.G., 1997. Revenue Management: Hard-core Tactics for Market Domination. Broadway Books, New York.

Espinet et all, 2012. Hotel characteristics and seasonality in prices: an analysis using Spanish tour operators' brochures. Tour. Econ., 18 (4) (2012), pp. 749-767.

Ferguson, J. L. (2015). Implementing price increases in turbulent economies: Pricing approaches for reducing perceptions of price unfairness. Journal of Business Research 67 (2014) 2732-2737. DOI: 10.1016/j.jbusres.2013.03.023. 
Fuentes, E., M. (2017). Are guests of the same opinion as the hotel star-rate classification system? Journal of Hospitality and Tourism Management 29 (2016) 126e134. DOI: 10.1016/j.jhtm.2016.06.006.

Geethe, M., Singha, P., Sinha. S. (2017). Relationship between customer sentiment and online customer ratings for hotels - An empirical analysis. Tourism Management 61 (2017) 4354. DOI: 10.1016/j.tourman.2016.12.022.

Gilbert, D. Horsnell, S. (1998). Customer Satisfaction Measurement Practice in United Kingdom Hotels. Journal of Hospitality \& Tourism Research, vol. 22, 4: pp. 450-464.

Go, P. (1995). Globalization strategy in the hotel industry. London ; New York, Routledge Hung, Y. H., Huang, M.L. and Chen, K.S. (2003). " "Service quality evaluation by service quality performance matrix"." Total Quality Management and Business Excellence, 14(No. 1): 79-89.

Guizzardi, A., Porns, F. Ranieri, E. (2017). Advance booking and hotel price variability online: Any opportunity for business customers? International Journal of Hospitality Management 64 (2017) 85-93. DOI: 10.1016/j.ijhm.2017.05.002.

Heung, V. C. S. \& Wong, M.Y. (1997). Hotel service quality in Hong Kong: A study of tourists' expectations. Journal of Vacation Marketing. Vol 3, Issue 3, pp. 264 - 271.

Kattara, H. S., Weheba, D., El-said, O. A. (2008). The Impact of Employee Behavior on Customers' Service Quality Perceptions and Overall Satisfaction. Tourism and Hospitality Research, vol. 8, 4: pp. 309-323.

Kohli et al.(1998). Learning and Performance Orientation of Salespeople: The Role of Supervisors. Journal of Marketing Research, Vol. 35, No. 2 (May, 1998), pp. 263-274. American Marketing Association.

Ladhari, R., Michaud, M. (2015). eWOM effects on hotel booking intentions, attitudes, trust, and website perceptions. International Journal of Hospitality Management 46 (2015) 36-45. DOI: 10.1016/j.ijhm.2015.01.010.

Lai, I., K., Hitchcock, M. (2017). Sources of satisfaction with luxury hotels for new, repeat, and frequent travelers: A PLS impact-asymmetry analysis. Tourism Management 60 (2017) 107-129. doi: 10.1016/j.tourman.2016.11.011

Li, C. Y, Cui, G., Peng, L. (2017), The signaling effect of management response in engaging customers: A study of the hotel industry. Tourism Management 62 (2017) 42-53. DOI: 10.1016/j.tourman.2017.03.009.

Li, L. et all (2017). An empirical study on the influence of economy hotel website quality on online booking intentions. International Journal of Hospitality Management 63 (2017) 1-10. Doi: 10.1016/j.ijhm.2017.01.001

Liu, M., Chu, R., Wong, I. A., Angel Zúñiga, M., Meng, Y., \& Pang, C. (2012). Exploring the relationship among affective loyalty, perceived benefits, attitude, and intention to use co-branded products. Asia Pacific Journal of Marketing and Logistics, 24(4), 561-58.

Liu, S., Law, R., Rong, J., Li, G., Hall, J. 2013. Analyzing changes in hotel customers' expectations by trip mode. International Journal of Hospitality Management, 34, 359371.

McColl-Kennedy, J., \& Schneider, U. (2000). Measuring customer satisfaction: why, what and how. Total Quality Management, 11 (7), 1-14. 
Mauri, A. G., Minazzi, R. (2013). Web reviews influence on expectations and purchasing intentions of hotel potential customers. International Journal of Hospitality Management 34 (2013) 99-107. DOI: 10.1016/j.ijhm.2013.02.012.

Maxwell, S., 2002. Rule-based price fairness and its effect on willingness to purchase. Journal of Economic Psychology 23 (2), 191-212.

Odin, Y., Odin, N., \& Valette-Florence, P. (2001). Conceptual and operational aspects of brand loyalty: An empirical investigation. Journal of Business Research, 53(2), 75-84.

Purcell, J., Kinnie, N., Hutchinson, S., Rayton, B. and Swart, J. (2003) Understanding the People and Performance Link: Unlocking the Black Box. London, CIPD.

Radojecic, T., Stanisic, N., Stanic, N., (2017). Inside the Rating Scores: A Multilevel Analysis of the Factors Influencing Customer Satisfaction in the Hotel Industry. Cornell Hospitality Quarterly, 1-32. doi:10.1177/1938965516686114.

Reicbbeld, F. F. (1996). The loyalty effect. Boston: Harvard Business School Press. Liu et all (2017). Applying consumer-based brand equity in luxury hotel branding. Journal of Business Research. Doi: 10.1016/j.jbusres.2017.06.014.

Shamim, S., Cang, S., Yu, H. (2017). Supervisory orientation, employee goal orientation, and knowledge management among front line hotel employees. International Journal of Hospitality Management 62 (2017) 21-32. doi: 10.1016/j.ijhm.2016.11.013

Sisson, K. (1990), Introducing The Human Resource Management Journal. Human Resource Management Journal, 1: 1-11. doi:10.1111/j.1748-8583.1990.tb00213.x

Tabaku, E., Cerri, S. (2016) An Assessment of Service Quality And Customer Satisfaction In The Hotel Sector. Tourism \& Hospitality Industry 2016, Congress Proceedings, pp. 480489.

W Viechtbauer, L Smits, D Kotz, L Budé, M Spigt, J Serroyen, R Crutzen : A simple formula for the calculation of sample size in pilot studies . J Clin Epidemiol (In Press, 2015).

Weber et all (2005). An Investigation of Satisfaction and Loyalty in the Virtual Hospitality Environment. Information and Communication Technologies in Tourism 2005 pp 452462. DOI: 10.1007/3-211-27283-6_41.

Wei, W., Miao, L., Huang, Z. (2013). Customer engagement behaviors and hotel responses. International Journal of Hospitality Management 33 (2013) 316-330. DOI: 10.1016/j.ijhm.2012.10.002.

\section{Contact information}

Vo Thi Nga (Ms.)

+420774335051

Ngavongoc789@gmail.com

Tomas Bata University, Faculty of Management and Economics

Mostni 5139, 76001 Zlin, Czech Republic

ORCID: 0000-0001-9004-8208

DOI ID: https://www.doi.org/10.7441/dokbat.2018.24 


\title{
INVESTMENT-RELATED ISSUES IN VIETNAM: A CASE STUDY OF THE AUTOMOTIVE AND ELECTRONIC INDUSTRIES
}

\author{
Vu Hoang Duong and Do Le Nhu Quynh
}

\begin{abstract}
This paper points out some remaining problems of investment in Vietnam. Firstly, it is hard to identify the leading industry due to the huge amount and overlapped legal documents for the long time in Vietnam. Secondly, after conducting the in-depth interview for three specific cases of foreign firms in Vietnam, the paper finds that the capability of Vietnamese firms is weak. Consequently, Vietnamese firms are unable to compete and/or cooperate with foreign counterparts.
\end{abstract}

Keywords: Automobile industry, Electronic industry, Vietnam, Investment.

\section{INTRODUCTION}

Investment is one the most important factors that could effectively boost economic growth. Total investment capital in Vietnam has accounted for a significant proportion of Gross Domestic Product (GDP). However, this ratio has decreased since 2011. Regarding the investment structure, the proportions of the foreign direct investment (FDI) sector, as well as the state and non-state sectors, remained relatively unchanged between 2008 and 2013. The largest proportion was the state sector, followed by the non-state sector and then FDI (Vu, 2012). Nevertheless, the bigger proportion does not always relate to better efficiency. Investment in the state sector was insufficient, with a high score on the incremental capitaloutput ratio (ICOR) index of 8.7 (in 2013), while the non-state sector is the most effective, with the lowest ICOR score of 4.9 (2013). However, the economy as a whole underwent an improvement in investment efficiency, with increasingly smaller ICORs. In the period 20082010, the average ICOR score of Vietnam was 6.7, but in the period 2011-2013, it went down to 5.53. (Tran, Pham \& Vu, 2014). Even so, the ICOR index is unable to entirely reflect the current state of the Vietnamese economy. Instead, it is necessary to look at the disaggregate numbers at the industrial level to better understand the reality.

It is argued that the domestic sector should be the developing engine of economic growth. In other words, if an economy grows by over-relying on foreign investment, it could become easily stuck in the middle-low income trap. Therefore, this study attempts to examine the current state of the domestic sector in relationship with the FDI sector to figure out the basis of economic growth of Vietnam. It seeks to determine whether the industrial development of Vietnam is stable or not by analyzing investment-related issues at the industrial level. The study focuses on two essential industries of Vietnam: automotive and electronics.

\section{THEORETICAL FRAMEWORK}

Investment is a vital factor for the economic development at both firm level and national level. At national level, it could be categorized into domestic investment and foreign investment. Domestic investment could be a good source for public infrastructures, utilities and economic activities. In fact, the neo-classic growth model and endogenous growth model are the popular school that appreciate the importance of domestic investment in boosting the economic growth (Mankiw, Romer \& Weill, 1992, Lucas, 1998 and Barro \& Sala-i-Martin, 1999). For example, 
the the A-K endogenous growth model, the government expenditure is defined as the domestic investment that contributes significantly to economic development (Barro, 1990). Similarly, the importance of foreign direct investment is well documented in many studies. It is an important source for developing countries in the world. Therefore, there are substantial papers find the positive relationship between FDI and economic growth of host nations (Nair-Reichert \& Weinnhold, 2001, Vu, Gangnes \& Noy, 2008, Duasa, 2007 and Singh \& Liew, 2013). At firm level, it could be investment in physical capital, human capital or technology infrastructure. One of the most well-known theory related to investment at firm level is business cycle theory. Investment is considered the essential part which could affect consumption, employment and other factors. Investment is endogenous element and it directly influence on the performance of firm (Haavelmo. 1960).

This paper examines the investment-related issues at firm-level. It is believed that both investment of domestic firms and foreign firms are the catalyst for development, however, one of them could crowd out the other (Aiken \& Harrison, 1999 and Hu \& Yun, 2016). Therefore, the paper seeks to recognize the phenomenon in Vietnam.

In fact, one problem with investment in Vietnam concerns the stage of selecting prioritized industries. The government has spent many years identifying which ones should be the leading industries. However, the documents on leading industries are overlapped and still unclear, and therefore it is difficult to identify which ones are top priorities. Hence, the paper firstly reviews all strategies and master plans on selecting leading industries over time before analyzing the automotive and electronics industries. The two industries were chosen because they are two identified leading industries that were increasingly important in Vietnam between 2001 and 2013. The framework of the paper is in the Figure 1 as follow:

\section{METHODOLOGY}

The study exploits the secondary data analysis and in-depth interview method.

Instead of analyzing all industries, the study chooses the automotive and electronics industries based on their importance and contribution to the development of the manufacturing sector. More specifically, investment structure and efficiency are examined. The data of the two industries are collected and processed from annual enterprise surveys from 2001 to 2013. They are from the official database of the General Statistics Office of Vietnam, which includes most firms in Vietnam. Note that the automotive and electronics industries are the 3-digit industries. However, due to the constraint of data availability, the study only exploits 2-digit industry data. Hence, the automotive industry is analyzed via data of the manufacture of motor vehicles, trailers and semi-trailers (of which the largest proportion is the automobile). Similarly, the electronics industry is analyzed via data from the manufacture of computer, electronic and optical products.

Finally, the study also includes in-depth interviews with two FDI firms in the automotive industry (Honda and Toyo Denso) and one firm in the electronics industry (Samsung) to identify the cooperation between FDI firms and the domestic sector. These in-depth interviews were conducted in Bac Ninh province in 2013. The interviewees are the top managers and the Director of these companies and the discussion is based on the prepared questionnaires to collect all necessary information. 


\section{ANALYSIS AND DISCUSSION}

\subsection{Strategies and master plans on selecting the prioritized industries}

An economy needs some leading industries but in Vietnam, there are a huge amount of sectors have been named as leading ones such as mechanics, technology communication, textiles or energy etc. In other words, the selection of leading industries in Vietnam is quite unclear. Consequently, investment incentives are scattered and inefficient.

In fact, the selection of leading industries has been mentioned from 1995, however, after 30 years it has not been clarified yet. In 2007, the Prime Minister issued Decision No 55/2007/QDTTg on standardizing prioritized industries or sectors to invest. The Decision indicated 07 prioritized industries and 03 leading industries. However, until 2014, these industries are unable to take a leading role for the economy. Note that, Vietnam is targeting the goal that Vietnam will become an industrialized country by 2020 , but until 2014 , it is unlikely to answer the question what the leading industries of Vietnam is. Therefore, Vietnam restarts the process by re-selecting the leading industries in 2014.

In 2014, the Government approves the Strategy on the industry development of Vietnam to 2025 , vision to 2030 that amends the previous strategy and points out 03 groups of prioritized industries and 12 prioritized sectors (Table 1). Note that, in this Strategy, the term "leading industries" is no longer appeared. At the same time, the Prime Minister also issues the Decision 880/QD-TTg on the Master plan of the industry development of Vietnam to 2020, vision to 2030 that shows 10 prioritized industries including (1) mechanical-metallurgical industry; (2) chemical industry; (3) The electronics, information technology; (4) The textile, leather \& footwear; (5) processing of forestry, fisheries, food and beverages; (6) Manufacturing of construction materials; (7) mining and mineral processing; (8) The power; (9) The coal industry; (10) oil and gas. It also mentions to the orientation to develop the supporting industry for mechanical-metallurgical industry; the electronics, information technology and textile, leather \& footwear. The selection of prioritized industries of the new Strategy and the Master plan bases on the agreement between Japanese consultants and Vietnam state agencies could be a good choice for industry development. However, it takes too much time for Vietnam to identify prioritized industries. Consequently, after 30 years, foundation of Vietnam industry is quite poor.

Table 14 Prioritized industries in Strategy on industry development of Vietnam to 2025, vision 2035

\begin{tabular}{|c|c|c|c|c|}
\hline Group & & Period to 2025 & & $2025-2035$ \\
\hline $\begin{array}{l}\text { Processing and Manufacturing } \\
\text { industries }\end{array}$ & $\begin{array}{l}\text { (1) } \\
(2) \\
(3) \\
(4) \\
(5) \\
(6) \\
(7) \\
(8)\end{array}$ & $\begin{array}{l}\text { machinery and equipment } \\
\text { for agriculture } \\
\text { automobile and } \\
\text { mechanical parts } \\
\text { fabrication steel } \\
\text { basic chemicals } \\
\text { plastics production - } \\
\text { technical rubber } \\
\text { petrochemicals } \\
\text { agricultural products, } \\
\text { seafood and wood } \\
\text { processing } \\
\text { materials and sub- } \\
\text { materials serving the }\end{array}$ & $\begin{array}{l}\text { (1) } \\
\text { (2) } \\
\text { (3) }\end{array}$ & $\begin{array}{l}\text { shipbuilding, nonferrous } \\
\text { metals and new materials } \\
\text { pharmaceutical sector } \\
\text { fashion clothing, luxury } \\
\text { shoes }\end{array}$ \\
\hline
\end{tabular}




\begin{tabular}{|l|l|l|}
\hline & \multicolumn{1}{|c|}{$\begin{array}{l}\text { domestic production and } \\
\text { exports }\end{array}$} & \\
\hline $\begin{array}{l}\text { The electronics, information } \\
\text { technology industries }\end{array}$ & $\begin{array}{l}\text { (9) Phones } \\
\text { (10) Computer equipments } \\
(11) \text { Accessories }\end{array}$ & $\begin{array}{l}\text { (4) software development, } \\
\text { digital content, IT } \\
\text { services and medical } \\
\text { electronics }\end{array}$ \\
\hline $\begin{array}{l}\text { New energy and renewable } \\
\text { energy industries }\end{array}$ & (12) wind, solar, biomass & $\begin{array}{l}\text { (5) energy for peaceful } \\
\text { purposes }\end{array}$ \\
\hline
\end{tabular}

Source: The Decision 879/QĐ-TTg

Experience from the past show that nothing can make sure that the new Strategy and Master plan will not be replaced in the future. However, assume that the new Strategy and the Master plan on the industry development in 2014 are appropriate and concrete. Then, let us analyze the current state of investment of two important industries: automobile and electronic in order to realize the weak developing foundation of them.

\subsection{Intra-industry problems}

Automobile and electronic industries are two of 12 prioritized industries in the next development period. Simultaneously, they are on the list of products that will be entitled to investment incentives (the Investment Law 2014 (article 16)). The ultimate objective of these policy incentives is to create a sound automobile and electronic industry for Vietnam. However, these industries need a large number of initial capital and high level of technology that is unable to provide by the Vietnamese firms. Therefore, the appearance of multinational corporations (MNCs) is necessary. It coupled with many policy incentives to attract foreign investor into these industries leads to the fact that there are variety of MNCs operating in automobile and electronic industry such as Sam Sung, Intel, LG, Nokia or Ford, Toyota, Honda.

However, is an achievement in attracting FDI the same with benefits for domestic firms?

In 2014, automobile and electronic industries contribute significantly to Vietnam economic growth. More specifically, products of phone, automobile and television increases $67 \%, 29 \%$ and $18 \%$ respectively.

Table 15: Phone, TV and automobile in 2014

\begin{tabular}{|l|l|l|l|l|l|l|}
\hline & Unit & $\begin{array}{l}\text { Accumulated } \\
11 \text { months } \\
/ 2013\end{array}$ & $\begin{array}{l}\text { Estimated } \\
12^{\text {th }} / 2013\end{array}$ & $\begin{array}{l}\text { Accumulated } \\
12 \text { months } \\
/ 2014\end{array}$ & $\begin{array}{l}12^{\text {th }} / 2014 \\
\text { compared to } \\
12^{\text {th }} / 2013(\%)\end{array}$ & $\begin{array}{l}\text { Compare } \\
2014 \text { to 2013 } \\
(\%)\end{array}$ \\
\hline Phone & Million & 156,1 & 19,7 & 175,8 & 285,0 & 167.5 \\
\hline Television & Thousand & 3188.5 & 444.4 & 3632.9 & 154.4 & 118 \\
\hline Automobile & Thousand & 114.8 & 13.5 & 128.3 & 131 & 129 \\
\hline
\end{tabular}

Source: General Statistics Office (2014)

The first impression from these numbers is that these industries could be an engine for the industrial development in the future. In the period 2001-2013, these industries positively contribute to the economic growth. Value added of electronic industry rises from VND 4,300 billion in 2001 to VND 19,000 billion in 2013. Similarly, value added of automobile industry rises from VND 2,700 billion in 2001 to VND 41,000 billion. Regarding to gross output, the electronic industry reaches the number of VND 770 trillion revenue and this number of automobile industry is VND 145 trillion in 2013. However, they are only the surface numbers that could blur intra-industry problems. Hence, it is necessary to look further into each industry. 


\section{Automobile industry.}

As above-mentioned, the numbers of value added and gross output of automobile industry show the positive features. However, if looking at investment structure within industry, we could realize some risks.

Firstly, investment capital into automobile industry has increased significantly from 2001 to 2013 (45 times bigger). Similarly, numbers of gross output and value added also have risen gradually over years (Figure 2)

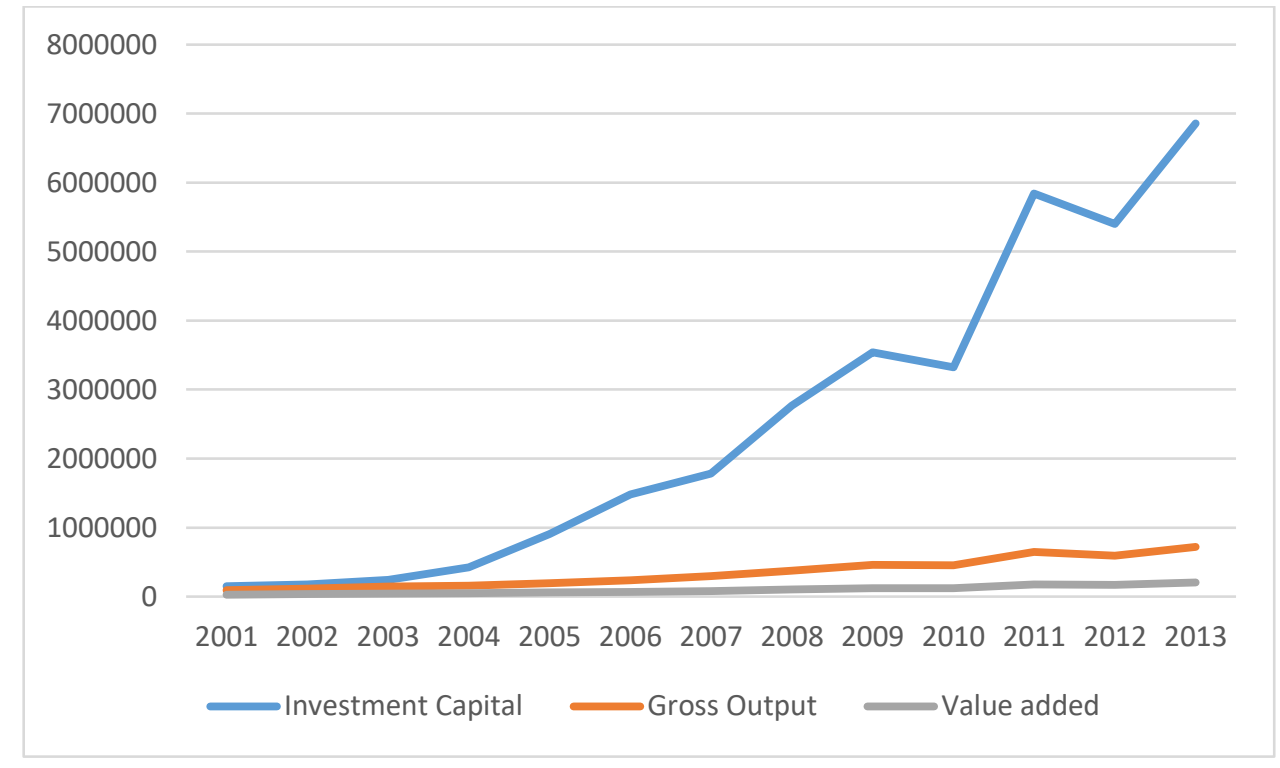

Figure 2: Investment capital, gross output and value added of automobile industry

Source: Annual enterprises survey from 2001 to 2013

From the Figure 2, we could see that, an increase in capital flow into automobile industry is much higher than an increase in gross output and value added. From 2001 to 2013, total investment in this industry rank $17^{\text {th }}$ over 99 industries in Vietnam, accounting for $2 \%$ of total investment in Vietnam. Respectively, value added of automobile industry also creates an impressive rise. Between 2001 and 2012, average rank of automobile industry in terms of value added only stand at $27^{\text {th }}$ place. However, in 2013, value added reach USD 4,100 million and it is ranked at $20^{\text {th }}$ place over 99 industries.

What is the motivation of this positive situation? First, let consider investment structure. FDI sector accounts for a large proportion in total investment into automobile industry (Figure 2). From 2011 to 2013, proportion of FDI is more than 76\%. The domination of FDI also implies the poor performance of the domestic sector, especially is the state sector. Although in the period of 2010-2013, the absolute number of state investment increase significantly (from VND 4500 million in 2010 to more than VND 165000 million in 2013), the proportion does not change much. In addition, cumulative capital of FDI in the period 2001-2013 accounts for 99\% total cumulative capital in automobile industry. 


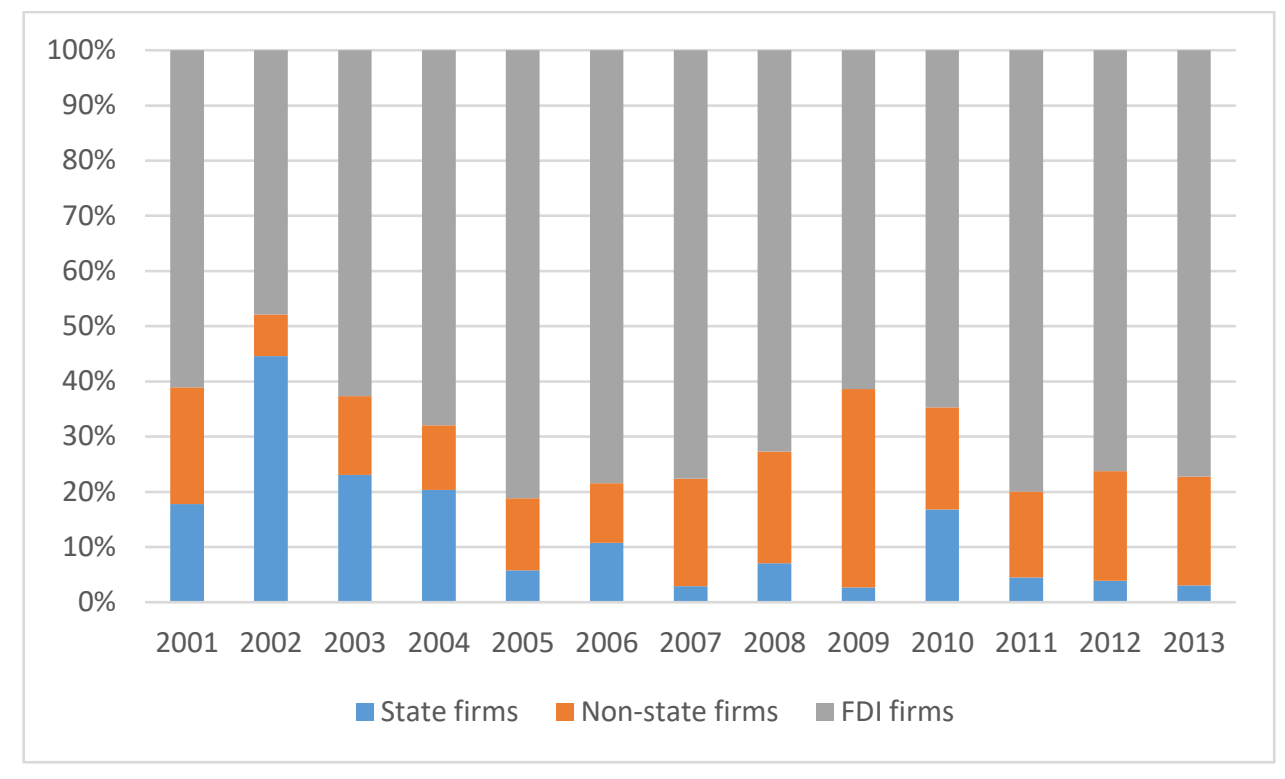

Figure 3: Investment structure in automobile industry

Source: Annual enterprises survey from 2001 to 2013

Additionally, the FDI sector also dominates in creating value added for this industry. Figure 3 shows contribution of economic sectors in creating value added in automobile industry. From 2001 to 2009, domestic contributions tend to increase and reaches the peak in 2009 with the proportion of more than $40 \%$. However, by 2010, the contribution of domestic sector starts decreasing while contribution of FDI sector is larger and larger. Remarkably, between 2001 and 2013, proportion of non-state sector increases gradually which is opposed to a decrease in proportion of state sector.

Generally, FDI sector absolutely dominates the automobile industry in terms of investment capital, gross output and value added. In addition, is it a positive sign for the development of the industry? In the short term, the automobile industry could develop with the contributions of foreign sector, but in the long term, if domestic sector cannot improve their capability, the industry could become over-dependent on FDI. Theoretically, attracting FDI (especially MNCs) can bring direct benefits and spillover effects to domestic firms. Consequently, foreign capital not only facilitate the industry development but also indirectly enhances the domestic capability via competing or cooperating with foreigners. However, current state of automobile industry seems to be far from this expectation.

It is the fact that domestic firms are unable to compete with FDI firms. Illustratively, the number of FDI firms is bigger than this of domestic firm. In 2013, number of FDI is 182 compared to 178 of non-state firms and 14 of state firms. Remarkably, number of FDI firms with initial capital of more than VND 200 billion is only 67 while this of non-state and state firms is 24 and 8 respectively. It is argued that the bigger number of big-sized FDI firms is understandable because it is the way to create spillover effects to domestic firms. However, the number of smaller firms of FDI with initial capital of VND 10 million to VND 20 million is still higher than this of domestic ones. Domestic firms only outweigh FDI firms in terms of number of very small firms with initial capital of less than VND 10 million. Regardless to the fact that capability of domestic firms is too weak to compete with FDI firms, assume that the capability of FDI and domestic firms are fair, the domination in number of FDI firms must be the viable proof for the 
disadvantage of domestics firm in competition. However, making conclusion from the difference in number of firms could be not precise. Therefore, the study continues to analyze the case study of two FDI automobile firms to figure out current state of cooperation among FDI and domestic firms and whether the latter were benefited from the former or not.

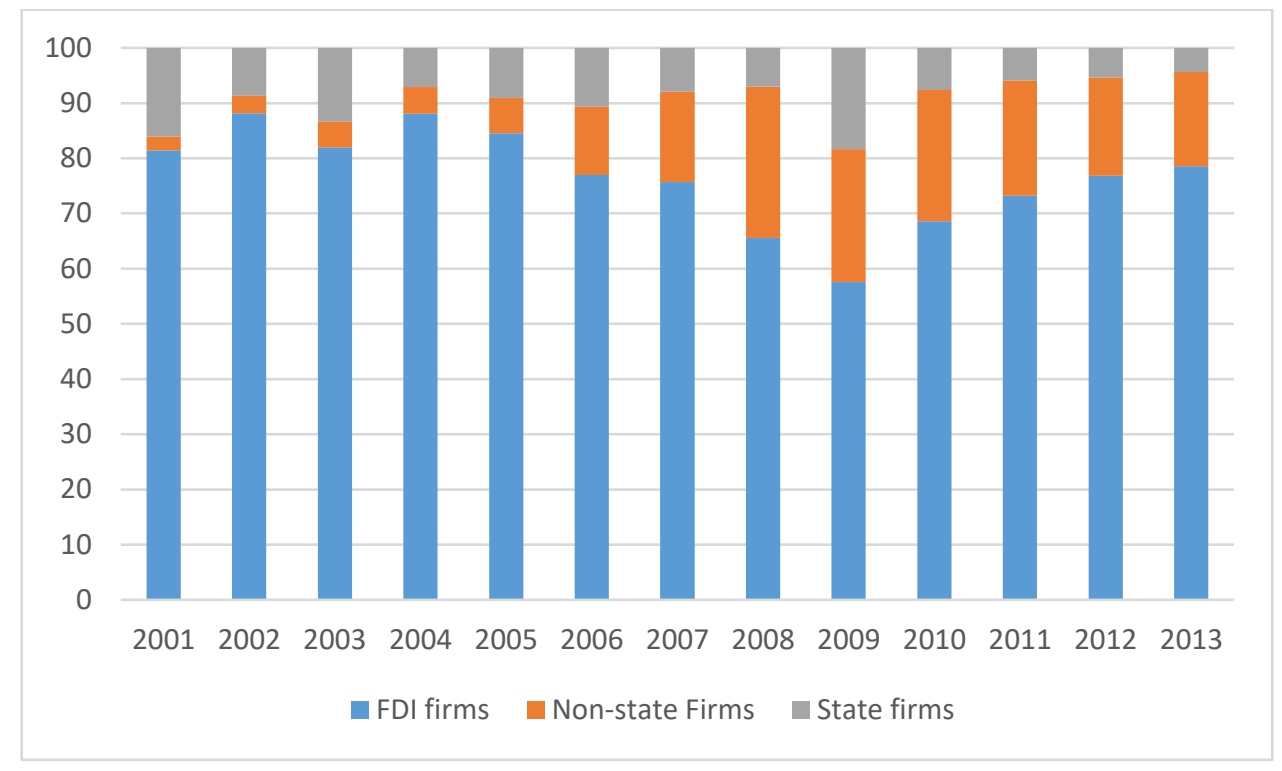

Figure 4: Contributions of economic sectors in creating value added for automobile industry

Source: Annual enterprises survey from 2001 to 2013

\section{Honda Vietnam}

Honda is certified to invest in the automobile industry in Vietnam in 2005. However, until 2013, the localization rate of Honda is very low, only $10 \%$ (based on revenue) ${ }^{5}$. Although the rate is low, it is not even "Vietnamization". Honda reveals that they have bought $100 \%$ of components from Japanese manufacturers located in Vietnam. Moreover, these components were not produced in Vietnam. Instead, these Japanese manufacturers imported spare parts outside and only assembled them into components in Vietnam. It reveals that the domestic firms are unable to take part in the production chain of Honda, hence managerial and technological diffusion is unlikely to happen. There are two reasons given by Honda for this situation. Firstly, Honda is a big corporation and already has their own first-tier and second-tier-component producers. Therefore, Honda tends to make use of the existing network to reduce costs. Moreover, clients of Honda are also the big corporations who requires some specific manufacturers must produce the specific components. However, this process happens at any countries where Honda investing in. Hence, the second reason is more important. Honda reveals that the Vietnamese producers are unable to meet the requirements on time delivery and quality of products. In addition, Honda also shows that market size of Vietnam is not big enough for Honda to expand their operation. Consequently, domestic firms cannot participate in the production chain of Honda and unable to learn officially anything from Honda.

Some might argue that because Honda is a big brand and it is impossible for Vietnamese firms to be their first tier due to poor capability and technology level. Thus, the study shows the case of Toyo Denso - the first tier of Honda to examine the potential cooperation with the domestic

${ }^{5}$ Information is taken from the in-depth interview 
firms. Toyo Denso is established in 2001 at Vietnam and Honda is their biggest partner over the world. From 2001 to 2013, the localization rate of Denso is $40 \%$ in which Denso have bought $18 \%$ of components from Japan, $17 \%$ from Thailand, $30 \%$ from China, $5 \%$ from Indonesia and $40 \%$ from Vietnam ${ }^{6}$. Nevertheless, once again, localization rate is not "Vietnamization rate" when the number of $40 \%$ from Vietnam is totally foreigners located in Vietnam. Unlike Honda, Denso states that they want to find Vietnamese producers to minimize their costs but no Vietnamese firms could meet their requirements on quality of products. Denso also reveals that they are ready to support Vietnamese firms in terms of financial fund and technology as long as Vietnamese firms can meet their minimum requirements. However, so far, there are no firms could satisfy Denso.

From the two cases, we can see that Vietnamese firms are unable to take part in production chain of a big brand name (Honda) or the first tier of Honda (Toyo Denso). Therefore, technology diffusion or labor skills transferring is limited.

Generally, the development of automobile industry depends too much on FDI sector. Domestic sector is totally dominated in terms of investment capital or gross output. Moreover, the domestic firms are unlikely to benefit from FDI firms because of weak capability. Hence, it seems that the development of automobile industry in Vietnam is quite unstable.

\section{Electronic industry}

The contributions of electronic industry to the economic growth are even greater than the contributions of the automobile industry. Total investment capital into electronic industry has increased significantly from VND 810 billion in 2001 to 37000 billion in 2013 (based year is 2001). In addition, gross output and value added of electronic industry also go up impressively. Particularly, gross output rises from VND 178 billion in 2001 to almost VND 4 billion in 2013. Value added increases from VND 92 billion in 2001 to VND 720 billion in 2013 (Figure 5).

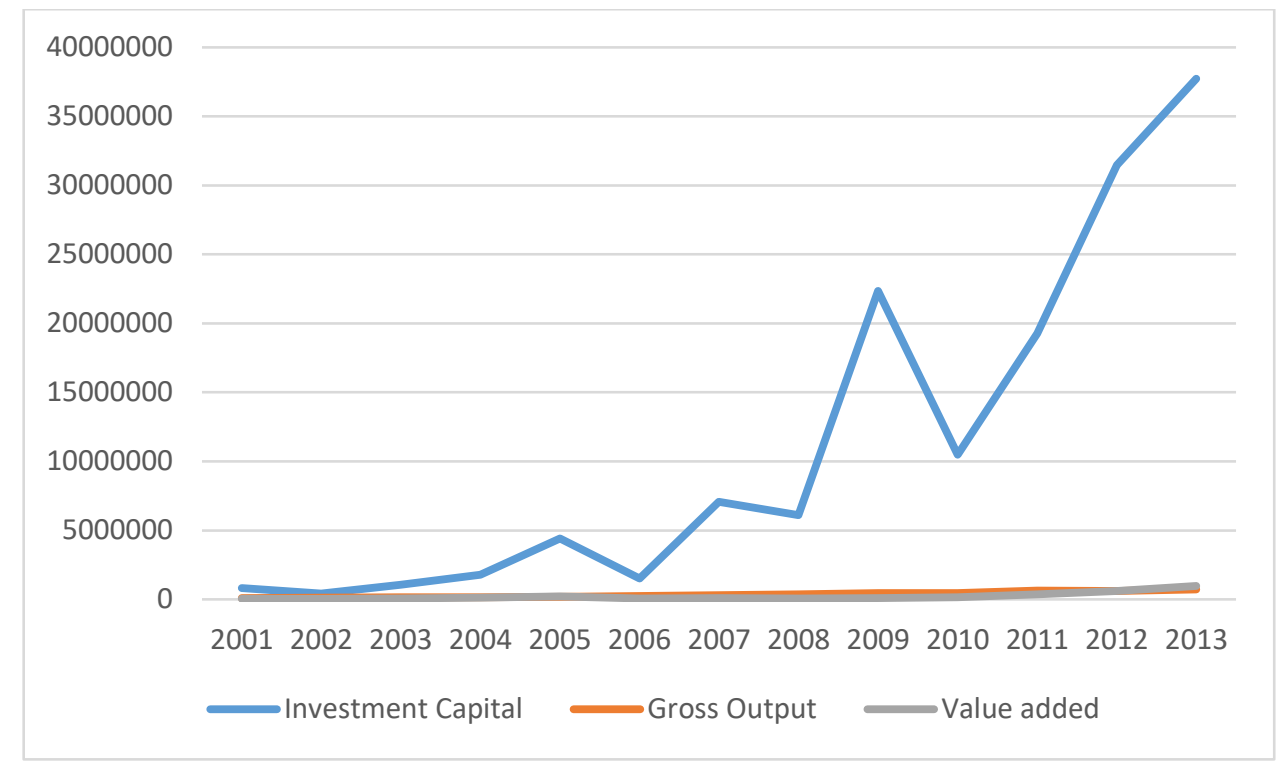

Figure 5: Investment capital, gross output and value added of electronic industry

Source: Annual Enterprises Survey from 2001 to 2013

\footnotetext{
${ }^{6}$ Information is taken from the in-depth interview
} 
In the period 2001-2013, total investment capital flow into the electronic industry ranks the $10^{\text {th }}$ over 99 industries. Remarkably, value added of this industry show the great contribution from 2010 to 2013 . By 2010, the contribution in terms of value added only stands at the $33^{\text {rd }}$ position, but it climbs to the $11^{\text {th }}$ and the $3^{\text {rd }}$ position in 2011 and 2013 respectively. It is a great development of the automobile industry in such a short period.

Similar to the automobile industry, however, the engine of electronic industry development is FDI sector. Even the impact of FDI sector in this industry is bigger than the impact of FDI sector in the automobile industry.

Regarding to investment structure, FDI sector always accounts for more than $90 \%$ of total investment capital into electronic industry from 2001 to 2013 (Figure 5). More specifically, the appearance of Samsung Vietnam recently pushes the domination of FDI sector over domestic ones. By 2013, investment capital of FDI sector account for $98 \%$ of total investment capital. In addition, Samsung Vietnam continues to expand their operation in Vietnam, coupled with the fact that there have been many other big companies in Vietnam such as LG, Nokia etc, it will be true to argue that the domination of FDI sector in electronic industry will be continue in the future.

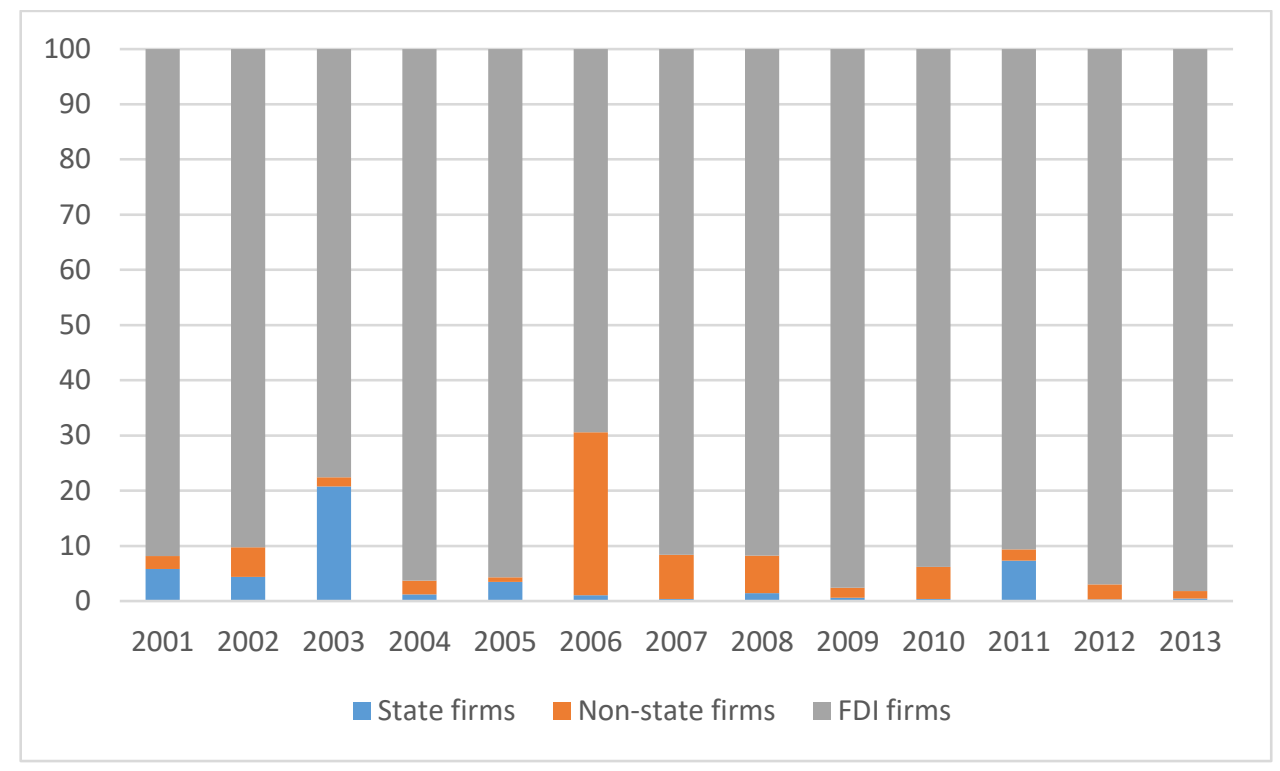

Figure 5: Investment structure in electronic industry

Source: Annual Enterprises Survey from 2001 to 2013

Regarding to value added creation, the FDI sector is also the dynamic force of the industry. We can see from the figure 9 that, FDI sector always creates more than $86 \%$ of value added in electronic industry. Particularly, from 2006 to 2013, the proportion of FDI sector is increasingly larger and reaches the level of $98 \%$ in 2013 (Figure 6). 


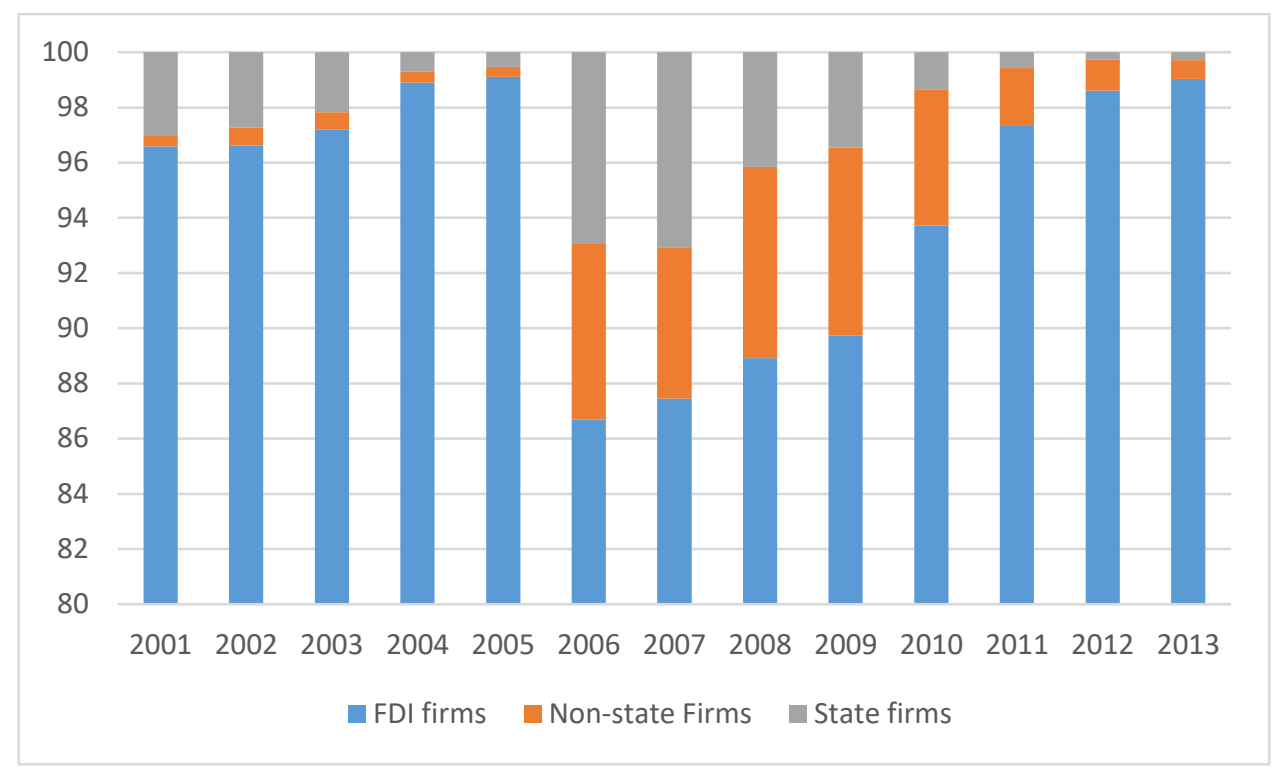

Figure 6: Contribution of economic sectors in creating value added for electronic industry

Source: Annual Enterprises Survey from 2001 to 2013

Additionally, the number of job created of FDI sector is also bigger than this of the domestic firms. In 2013, number of worker in FDI sector is 310 million while this of domestic sector is only 14 million people. More importantly, labor productivity of FDI sector is also higher than domestic ones. From 2001 to 2013, there are some specific periods when labour productivity of state firms is higher than FDI. However, from 2010 on, value added per head of FDI firms starts growing rapidly (Figure 7).

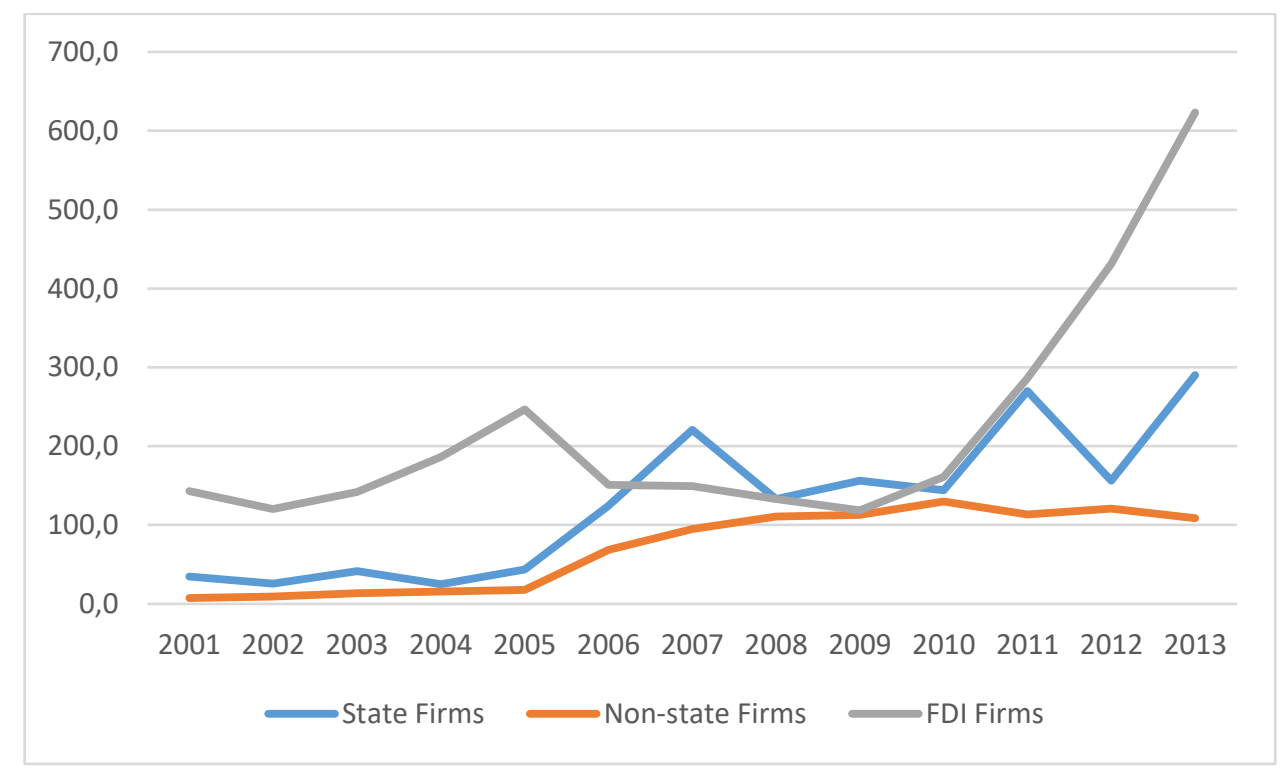

Figure 7: Average value added per head in electronic industry

Source: Annual Enterprises Survey from 2001 to 2013

In general, the electronic industry witnesses the remarkable development in Vietnam recently, however, the engine of this development is FDI sector with great contribution in raising capital, creating gross output as well as value added. FDI performance could be a good addition for industrial development. Additionally, it is expected that FDI appearance must create positive 
effects on domestic firms with technology and managerial diffusion. Consequently, domestic firms could improve their capability via operation of FDI sector. However, how is the current state in the electronic industry? Let us take a case of Samsung into consideration.

Samsung is authorized to operate in Vietnam from March, 2008 at Bac Ninh. In 2012, Samsung exports USD 12.6 billion which accounts for $11 \%$ of total exports. In 2014, Samsung continues to export, and the number of exports reaches a level of more than USD 28 billion. Moreover, Samsung will expand its operation in Vietnam by building other facilities at Thai Nguyen province focusing on smart phones and accessories. Total investment capital at Thai Nguyen province is more than USD 2 billion. Therefore, in 2014 and 2015, estimated revenue from exporting of Samsung will be more than USD 8 billion and USD 12 billion respectively ${ }^{7}$

Samsung has performed well with the impressive statistic numbers. However, how Vietnamese firms could participate in production chain of Samsung? In fact, the case of Samsung is similar to other big corporations located in Vietnam. Most Samsung's component providers are FDI firms locating in Vietnam. More specifically, among 52 component providers of Samsung, there are only 4 Vietnamese firms. Moreover, these Vietnamese firms only provide the low valueadded inputs for Samsung. Samsung indicates that the weakness of Vietnam is the poor supporting industry, hence domestic firms are unable to join in production chain of Samsung and unlikely to be the first tier producers. Even when attempting to be second or third tier producers, Vietnamese firms must compete with a large number of FDI firms locating in Vietnam with higher level of technology and human capital (Figure 8)

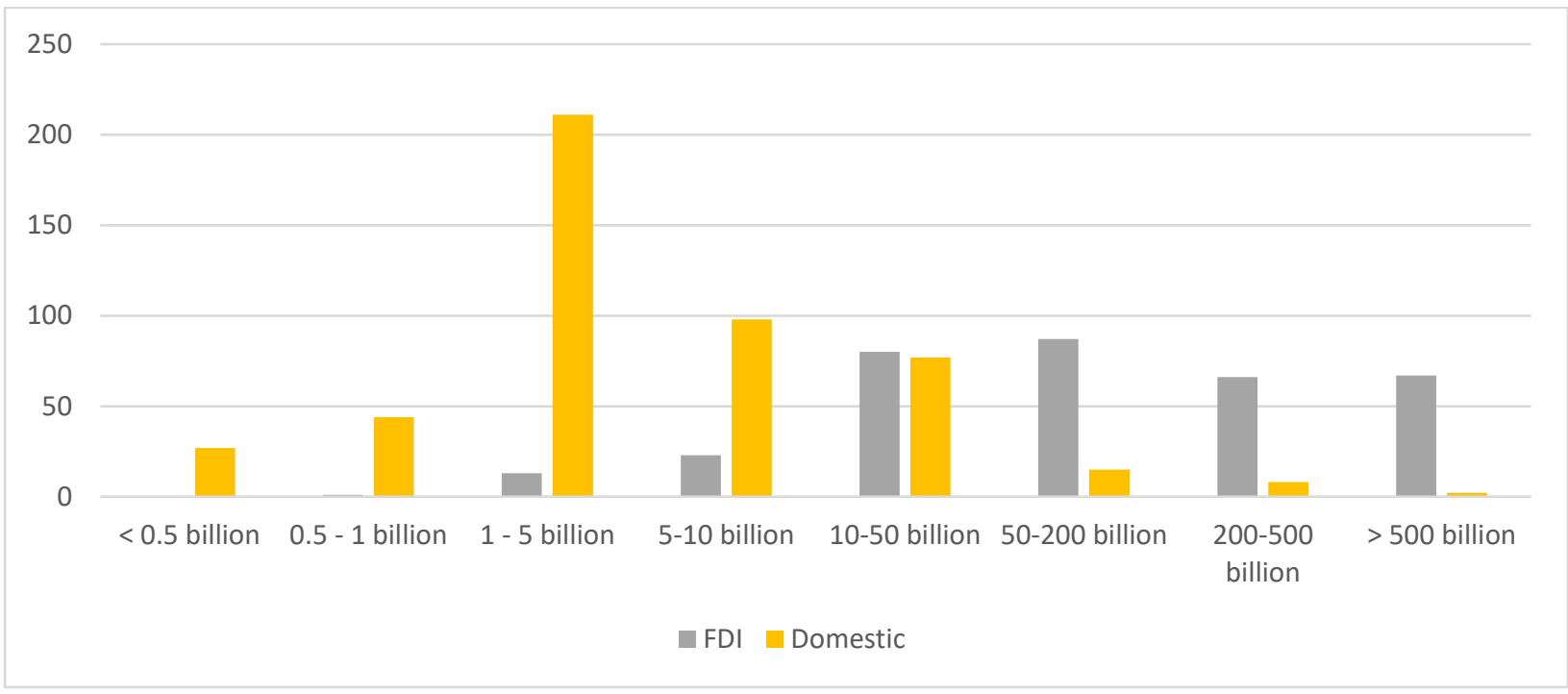

Figure 8: Number of firms in electronic industry (2013)

Source: Annual Enterprises Survey from 2001 to 2013

In general, automobile and electronic industries are two among prioritized industries in Vietnam. Nevertheless, the development engine of the two industries are FDI sector, not domestic one. This study ignores the negative effects of FDI on domestic firms and only looks at the potential impacts of FDI via spillover effects within- industry. However, even when ignoring negative impact of FDI, we only see small benefit for domestic firms in the two industries. FDI firms totally dominate and domestic firms are unable to benefit from

${ }^{7}$ Data are collected from the in-depth interview. 
cooperating with FDI firms because the former cannot take part in production chain of the latter. The most important reason is that the supporting industry of Vietnam is poor and domestic firms cannot meet the requirements of the big corporation such as Samsung or Honda. Consequently, the development of these industries might be an achievement of FDI sector only.

\section{CONCLUSION}

Investment-related problem of Vietnam starts from the stage of selecting prioritized industries. It takes too much time to choose the leading ones. In fact, it is not clear to answer the question that what will be the leading industries of Vietnam in the future.

Then, the problem also occurs within prioritized industries. The study chooses automobile and electronic industry to analyze. The result is that: within these industries, FDI sector totally dominates with a large proportion of investment capital and value added. Domestic firms are not only dominated by FDI but also unable to take part in the production chain of big corporations locating in Vietnam. Consequently, the domestic firms are unlikely to compete and cooperate with FDI. Hence, positive effect of FDI from competition and cooperation is limited. The reason is that the technology gap among FDI and domestic firms is quite big, and the domestic ones cannot fulfill the demand of the foreign partners. Another reason is the difference in human capital among FDI and domestic firms. Therefore, it is time-consuming and costly to learn and adopt new technology and managerial skills (in case they could be diffused). Thirdly, the supporting industry of Vietnam is weak, and it leads to a huge gap unable to fill in the short term among FDI and domestic firms. For all reasons, it is the fact that the engine for development of Vietnam industry is FDI sector, not domestic one. In the short term, it could not be a serious problem, but in the long term, if domestic sector cannot play the leading role, Vietnam economy could be easily stuck into the low-value production trap.

\section{Acknowledgement}

The authors are thankful to the Internal Grant Agency of FaME TBU No. IGA/FaME/2018/019FDI absorptive capacity and the factor determining FDI flows in developing countries of Asia and Africa for financial support to carry out this research.

\section{References}

Barro R.J. (1990) Government Spending in a simple model of endogenous growth, Journal of Political Economy, vol. 98, pp-S103-25

Barro, R. J.\& X. Sala-i-Martin (1999) Economic Growth. Cambridge, MA: The MIT Press

Duasa, J. (2007). Malaysian foreign direct investment and growth: Does stability matter. Journal of Economic Cooperation, 28, 83-98

Haavelmo, T., (1960). A study in the theory of investment. University of Chicago Press, Chicago

Hồ. L.N., (2014). Định huớng phát triển công nghiệp hỗ trợ ngành điện tư Việt Nam. Viện Chiến lược Chính sách Công nghiệp. [ Orientation to develop supporting industry of electronic industry of Vietnam] Hội thảo "Thúc đẩy cung cấp nội địa trong công nghiệp điện tử tại Việt Nam" [Conference: Facilitating domestic producing in electronic industry of Vietnam], Hanoi 3/7/2014 
Hu. C.G., \& Yun. K.H., (2016). How the Rising Domestic Firms crowd out Foreign Firms in an Emergin Market?. In The 2016 Strategic Management Society Special Conference. http://hdl.handle.net/1783.1/85174

Lucas Jr., R. E. (1988) On the Mechanics of Economic Development. Journal of Monetary Economics 22, 3-42. https://doi.org/10.1016/0304-3932(88)90168-7

Mankiw, G. N., D. Romer, \& D. Weil (1992) A Contribution to the Empirics of Economic Growth. Quarterly Journal of Economics. 107:2, 407-437 https://doi.org/10.2307/2118477

Mohamed, M. R., Singh, K. S. J., \& Liew, C. Y. (2013). Impact of foreign direct investment and domestic investment on economic growth of Malaysia. Malaysian Journal of Economic Studies, 50, 21-35.

Nair-Reichert, U., \& Weinhold, D. (2001). Causality tests for cross-country panels: A new look at FDI and economic growth in developing countries. Oxford Bulletin of Economics and Statistics, 63, 153-171. https://doi.org/10.1111/1468-0084.00214

Ngo, N.T.H. (2013) Technology adaption in rent seeking economies: the case of Vietnam. PhD thesis. SOAS, University of London

Phạm, S.A., \& Vu, H.D. (2014), Core information required from case studies to build up analysis of rent management strategies in Vietnam: Case Study of Automobile Industry.

The Decision 55/2007/ QD-TTg dated 23/ 04/2007 on standardizing prioritized industries or sectors to invest (2007)

The Decision 879/QD-TTg dated 09/06/2014 on Strategy on industry development of Vietnam to 2025 , vision 2035 (2014)

The Decision 880/QD-TTg dated 09/06/2014 on the Master plan of the industry development of Vietnam to 2020, vision to 2030 (2014)

Tran D.T., Pham S.A., \& Vu (2014). Kinh te Vietnam: nhung van de cua khu vuc doanh nghiep [ Vietnamese economy: some issues of enterprises]. Khoa hoc xa hoi Publishing. Hanoi.

Vu, T. B., Gangnes, B., \& Noy, I. (2008). Is foreign direct investment good for growth? Evidence from sectoral analysis of China and Vietnam. Journal of the Asia Pacific Economy, 13, 542-562. https://doi.org/10.1080/13547860802364976

Vu. H.D., (2012) Foreign Direct Investment and Economic growth: the case of Vietnam. Master thesis. Leeds University Business School.

\section{Contact information:}

Name: Vu Hoang Duong

Tomas Bata University in Zlin, Faculty of Management and Economics

E-mail: hoangduongvu87@gmail.com

ORCID: 0000-0002-2651-2923

Name: Do Le Nhu Quynh

Tomas Bata University in Zlin, Faculty of Management and Economics

E-mail: nhuquynh.dole@gmail.com

ORCID: 0000-0002-0860-1172

DOI ID: https://www.doi.org/10.7441/dokbat.2018.25 


\title{
LINKEDIN AND ITS IMPACT ON MARKETING STRATEGY IN BUSINESS
}

\author{
Nikola Vykydalová
}

\begin{abstract}
In a fast growing society and globalisation is enormous competition between small and medium businesses all over the world. The role of social media for all of them is huge and getting bigger every day. Social media plays very big part of life not just for human beings but also companies and their marketing. This article contains couple important information and research, which is part of article, is made in the period of end 2017 and beginning of 2018. (December 2017 February 2018). Especially structured interview method were used to acknowledge opinion of companies owners and employees about impact of social media activities, business environment along with a questionnaire to examine social media as "daily bread" for many companies. Data of study were gathered by using few questionnaires with of course different type of questions. A descriptive analysis just showed that usage of social media is important for image of company, relationship with customers or even brand. Recommendations are easy to put forward visible social media and use it more visible for business and entrepreneurs as well. Objectives and goals of the selected research are to show small companies and entrepreneurs how to react on social media. What to do for making profit of social media and how to understand, interact and handle LinkedIn as is platform for hiring people for business.
\end{abstract}

Keywords: Social media impact, Business, small business, marketing, media, LinkedIn, digitization.

\section{INTRODUCTION}

Nowadays, world is globalized the geographical and theoretical distance holds less of an importance of the politics, trade and other parts of life.

Business and all companies nowadays inevitably face tremendous challenges, like very big competitive rivalry among existing firms, the unpredictable changes in consumption trends and more sophisticated customer demands. (Porter, 2008)

The social networking sites are very popular. Social media meant as common online servers meant as multi - ranging online social interactions are used by people for many purposes such as writing blogs, virtual video portals, sharing information or even reviews or experiences. It is modern world, which is getting more important every now and then.

Businesses finally started to realize that they should benefit from social media and use them for their profit. They already interact and reach customers and contributing to customer's experience (Leeflang et al., 2014; Leung et al., 2015; Tuten and Solomon, 2015)

It is known that traditional communication platforms such as radio, newspaper or TV is taken as a old version of communication, people are looking for innovative and cost effective channels which provide customers with high interactivity and individualization (Leeflang et al., 2014). That is mean that social media comprises a number of benefits for the firms brands such as knowledge, engaging customer more, feeling for them, be friendly with customers and act like they are really close to you.

It is not a secret that many organizations are spending too much money in designing their marketing strategy by using social media applications. According to eMarketer issued by 2014 
it was obvious that more than 138 billion of dollars were expected to invest in the marketing in United States. It actually looks like very effective role of social media from organization perspective. It was studied over 15 articles and prior literature about social media and found out effective role of social media for not humans but also companies. (e.g. Hoffman and Fodor, 2010; Kim et al., 2015; Okazaki and Taylor, 2013; Rathore et al., 2016) they found out that firms value can be accelerated by a firm`s marketing effort conducted through social media and their specific platforms.

In comparison with traditional communication channel such as television, radio or even book or newspaper social media are more innovative, progressive and provide customers with individualization. (Leeflang, et, al., 2014)

Using social media have many benefits for the company`s brand such. It can be as expanding the customers knowledge, engaging the new ones, interacting efficiently with other customers etc.

Such as important information to distinguish is the term of social media and social networking. According to biggest source nowadays Wikipedia (2016) is social networking services could be identified as " an electronic service, application, platform, or site used by individuals who have a common interest, beliefs, attitudes, cultures, or even activities. The other hand says something little different about communication, Wikipedia (2016) the concept of social media as such they enable individual to broadcast as well as to approach more people and more influence on them.

\section{THEORETICAL FRAMEWORK}

Digitalization is a "new economy" but also technological progress. In macro economy it is very useful term today. It can be talked about driving force that has been determining the direction of marketing in the last twenty years.

The monumental expansion of the Internet is defined by the term "Internet age" as the current age. The economy of the whole world is shaping new technologies, globalization as well as ecological activities.

The digital era according to Kotler (2007) is formulated into four fundamental forces, namely digitization and connectivity (improvement of quality and interconnection) and new forms of resources (internet retailing called e- retailers ") and customization (comes from the word" custom "which in English means individualizing the offer for each customer)

According to Kotler (2007), digitization mainly concerns data transferring. These are smart phones, various digital TVs, computers, laptops or cameras. The most common form of current distribution is the dissemination of information, the sharing of attractions, music and film. The rapidly changing digital world improves the protection of printed documents by connecting them with a so-called plug-in when it is transferred to an electrical form - official documents, press (media), books and magazines.

Thanks to the digital world, channels are distributed and transformed. With this trend, customers are moving to the online environment and online sales are migrating and distribution channels. This trend is more or less interfering with business.

According to Nirmalayi (2008), online distribution of books, games, software and other huge potential has an online distribution, and this is also shown daily in today's world. At present, the most important thing is to replace the robot employee who will work for workers or clerks, according to the Econom magazine.

However, it is important to note the fact that many companies or retailers and entrepreneurs 
view this trend as a rather temporary issue with many pitfalls. For example, many bookstores and publishers see a chance to revitalize the online store in online sales. However, they add that direct sales to the end customer are far more specific and without further retail margin.

Digitization represents a certain mental change. Companies will have to identify with it, because if it does not, they will come to the end customers and thus to the potential business. According to Hospodarske noviny and Mr. Palisek, the aim of the companies should be to increase the competitiveness of the Czech industry.

Digitization is not an objective, but rather a way to maintain its own competitiveness. According to Hospodarske noviny, "Companies will have to tell if their system works and if their current system allows them to quickly innovate and respond to customer demand."

A key feature of the present era is the digitization of both the product, the production process and the operation of the product. All of this brings together a complete digital image of a product or service that is very important to the end customer, it affects him positively and wants to buy it.

Every company should think about their future in a rapidly changing market environment and whether their existing business models are still working, whether their customers are satisfied and when they need to be upgraded again. Whether their models meet customer needs. Whether their flexibility, the speed of supply to the market, or whether they are in danger of replacing them with another product, correspond to them. Companies must respond to demand.

A digital revolution can completely change the potential of companies and established market rules. According to (IMD) the International Institute for Management Development in the next 5 years will lose market position up to 40 percent of companies that still dominate their industries. Research has analyzed 12 industries among 941 top executives from Australia, Brazil, Canada, China, France, Germany, India, Italy, Japan, Mexico, Russia, the United Kingdom and the United States.

\section{Micro - Psychology}

According to few different research which were studied were found that most influenced advices are coming from friends and relatives in people`s decisions. (Crotts 1999, Perdue 1993) Advices from people who you like is always trustable, honest and more credible than any other information from marketing advertisings. Nowadays times have changed and people react on changes. They started to trust in buying behavior also "strangers means bloggers. Many people in this world use social media to help people and show their experiences from world as well like travel blogs, restaurant reviews, political opinions, city tours, beauty and fashion tips etc. As an example TripAdvisor currently reached peek of 50 million reviews attracting over 50 million unique users/ monthly (Depeches 2010)

Another services which needs to be mention is Uber or Airbnb. Both of those Internet platforms are unique and specific. One is using car and another is accommodation. Both of them need to have a positive feedback on their pages to get more customers and clients. This business is based on the satisfaction of being helpful to other consumers. Pierce, Kostova, and Dirks (2003) said that it is a desire by the consumer to control through such communications, which can lead to different types of feeling.

Firms, companies and corporations should care about social media more and create firm`s strategic benefit based on customer feedback. Positive and negative comments are feedback external. They can also find their benefits in social media especially if they ad a commenting feature to their own firms webpages. After this act they can manage right away content and comments. Whether we talk about producers, they can produce dividends by unique platforms or chain level. That brand is helpful and increasing their visibility through search engine 
marketing.

\section{Macro - Psychology}

(Wasserman and Faust, 1994) understand social network as community of individuals. Those individuals use mathematical models to study own structure, development and evolution as well. Those elements works together they links and connect with each other, interact and together they form a complex graph structure.Mathematical calculation including following segments: Betweenness: the extent of a node lying between other nodes, Centrality: how connected is a node to the network,Closeness: how one node is near all other nodes in the network,Density: all the ties in a network in proportion to all possible ties,Structural hole: the node, which connects other nodes. Those nodes are disconnected without the first node.Elements mentioned above determine importance position of each individual. The measurement can be used for study of social media or for improving network structure. Social media content is materialization and solidification of the chatter, comments or reviews. The recent emergence of multi dimensional network is crucial in studying. (Contractor 2009)

\section{LinkedIn}

It's a main platform for searching a job. Known all around the world. Selected literature suggests that "who you know" plays very important role in finding a job but (Granovetter, 2005) deeply disagree with this statement. He is convinced that social media are great for hiring people around the world. It contains quality information, improving trust and you also see another people in this world in the same field online. According to CareerBuilder. Com in 2009 every job position which can be mentioned received more than $75 \mathrm{CVs}$ in average. Social media can in hiring employees, managers and deeply connect with each other. The social network called LinkedIn has a conduit for hiring people and recruit candidates for different types of jobs. In Zlin LinkedIn have around 10 thousand active users. Most of those users are between age of 25 and 35. According to Statistic office from 20016, they made their profile for communication, get professional insights and catch some career opportunities.

Fortune magazine (Hempel 2010) brought information that connecting through LinkedIn is more useful than exchanging business cards. According to statistics in Alexa.com (November 2013) LinkedIn is consumed by $4.9 \%$ of daily Internet users, each of them are spending approximately 14.6 minutes/day on average. LinkedIn posted a results from 2015 that real user base in job portal is more than 150 million people spanning 200 countries. People are looking for a job, companies are responding and recruiting potential employees by useful advertising.

3.1 Potential usage of LinkedIn

Internet platform LinkedIn has several ways of usage. Here are few of them.

1. Being contacted by an employer

2. Searching for jobs which are posted and advertised

3. Contacting people who you know in network for leads

4. Contacting recruitment companies (people who hire for job)

Social network seems to be very important and great to have a profile there, anyhow it is not very clear how many people get a actual real job.

There are many unknown questions but in this topic we would like to seek few main questions.

\section{RESEARCH METHODS}

The main focus of the current study is on the literature concerned with the implementation of the social media into business and marketing area of selected companies. Therefore, other studies, which have considered the role of social media over different areas such as education, 
social, politics and management, have been excluded. Also another question, which were asked, is how much selected companies use social network and especially LinkedIn for their profits and need. The research is specialized for small and medium companies around Zlin Town.

As we know, companies' brand for small and medium businesses is one of the most important. Whatever it is talked about doctors, real estates agents, investors or politicians, your customers. Many companies realize that social media are important for their future potential customers. Profiles are poor with pictures; they have irrelevant content or even unattractive descriptions of experience and skills. The table below shows how much serves LinkedIn is used according to Statista.

Table no.1 Generally LinkedIn User Growth till 2016

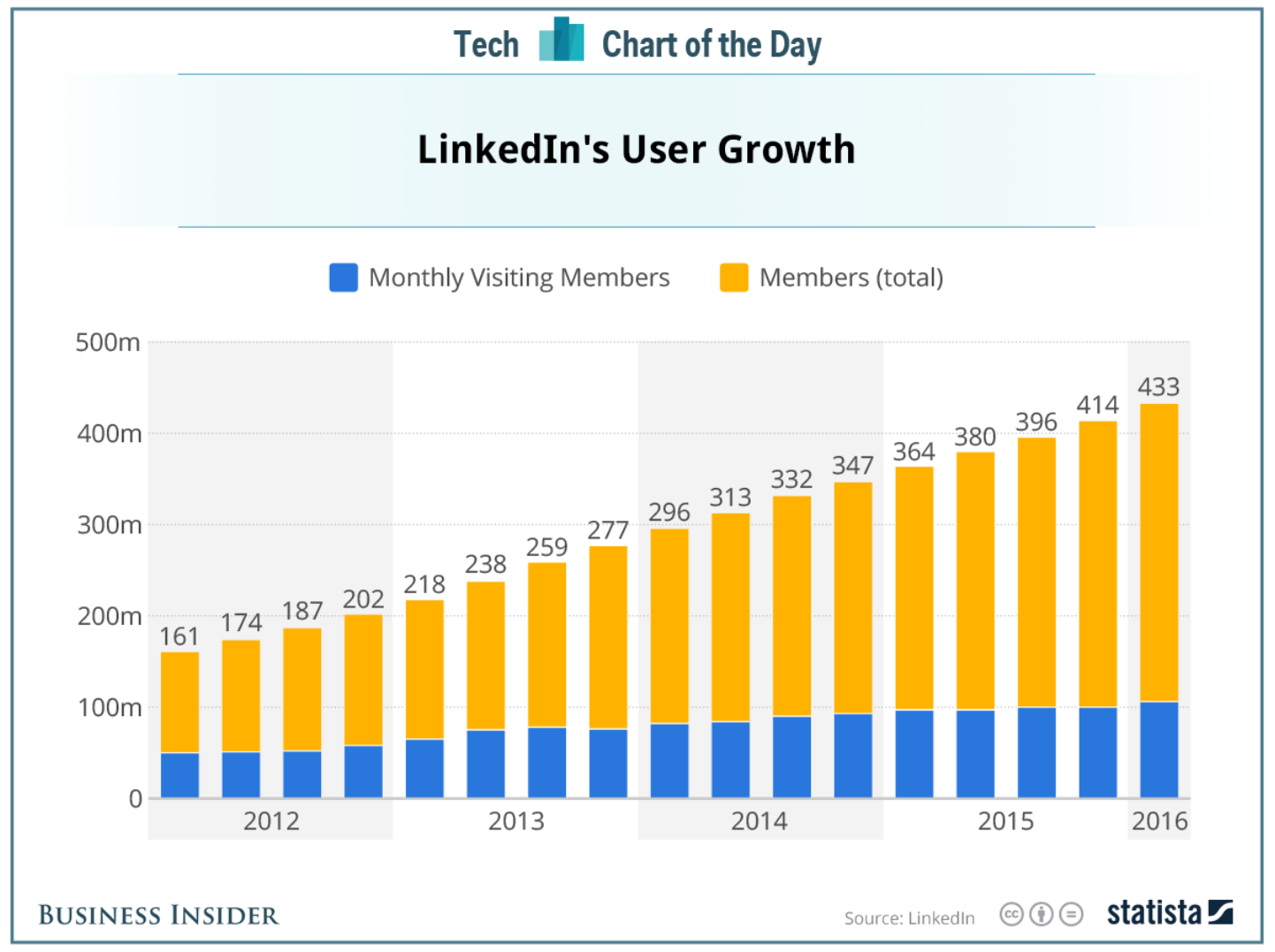

(SOURCE, STATISTA, 2018)

According to latest news in web server Statista, even owners of small businesses already know that using social media is important for their future in business all around the world. According to graph it is visible that the importance of LinkedIn is still growing and company is having more members.

It is known that social media LinkedIn which is specialized for their professional profile. It is also an excellent centre for marketing communications.

It is also the largest professional social network site in the world; it was designed for professional networking, job seeking, hiring people and recruitment.

Table no. 2 aims survey to LinkedIn profiles of 50 data managers from various companies in Zlin city. Question was whether they use profile and how which type of reasons. The search was conducted as the end of 2017 and beginning of 2018 in filtered specific location. All the information were conducted and adapted by Todd's PA coding scheme. Other features were used and categorized by Kim JY and LEE CK, 2016 method. 


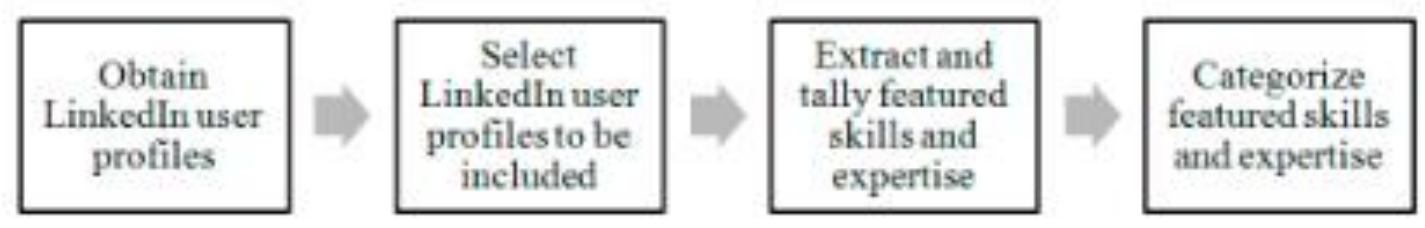

\section{OBJECTIVES AND RESEARCH QUESTIONST}

\subsection{Objectives}

The study sought to fulfill the following objectives:

1. To identify whether small and medium businesses use social media for some purposes

2. To determine how much is used LinkedIn as part of marketing is selected companies.

\subsection{Research questions}

The study was guided by the following research question:

1. What is the reason why small and medium businesses around Zlin City use social media in their micro economy?

2. Do they use server LinkedIn often to hire people or are they still following traditional way?

\section{METHODOLOGY}

\subsection{Data collection}

This study was made by quantitative approach. Data was collected in the end of last year 2017, it was made by using questionnaires in 5 small and medium businesses around specific area Zlin City, questions were aimed at seeking their views and reasons of using social media in companies. Questionnaires distributed and collected using social networking site LinkedIn that is used especially as professional profiles for companies. The author assessed the target group of companies such as Slevici, Svoboda \& Brezik bakery, Dary Kraje. Kafo, Kafe na kole. Duration of gathering data was 3 months.

Managers and the lead specialists of the five small businesses were interviewed. Survey participants understood social media very well and said they use them and paying attention for new trends of digitalization. All of those companies are new with innovative people inside of business.

\subsection{Data analysis}

Data were obtained from respondents by computer and analyzed by using descriptive statistics namely, percentage and frequency.

\section{FINDINGS AND DISCUSSION}

In this section is discussed the findings of the three months study based on small businesses and using LinkedIn server as a way of hiring people, also whether people trust in social media in 
companies. The research based on selected questions. They are as follows.

6.1 Reasons why to use Social Media in business, here in table no.1

Table 2: Reasons for usage of social media at work

\begin{tabular}{|l|l|l|l|}
\hline Numbers & Reasons & N & Mean \\
\hline 1. & Finding new customers & 5 & 3.2 \\
2. & Talking with loyal customers & 5 & 4.2 \\
3. & $\begin{array}{l}\text { Building relationship with all } \\
\text { customers } \\
4 .\end{array}$ & 5 & 4.5 \\
5. & Talking with colleagues & 5 & 3.1 \\
6. & Talking with family and friends & 5 & 2.1 \\
7. & Kill the boredom at work & 5 & 2.0 \\
8. & To create new network & 5 & 4.0 \\
9. & To strengthen networking & 5 & 3.5 \\
10. & Others & 5 & 2.4 \\
\hline
\end{tabular}

The table no. 2 above describes the reasons why selected people in Zlin region use social media. The questionnaire asked using social media especially at work. There were given 10 reasons as it is seen above. The most used reason in questionnaire as we can see is "building relationship with all customers", another most frequent answer was "Talking with loyal customer" and for example less favored reason to use social media at work was watching news and other reasons.

\subsection{2. How much do companies use LinkedIn especially for hiring people}

Table 3: Usage of LinkedIn in companies

\begin{tabular}{|l|l|l|}
\hline Time & Companies & Percentage \\
\hline 3 months & 5 & $40 \%$ \\
\hline
\end{tabular}

Table no. 3 is very easy and quick to read. The fact is that the question, which was given to 5 companies, was very simple. Most of the answers in questionnaire answered that they look at LinkedIn but don't hire people from there. They also check their profiles. But just $40 \%$ of asked said that they hire people from LinkedIn or contact them.

\subsection{3. Discussion}

Marketing principles are established with visibility and urge message to be in real business by using social media. Small businesses and companies are making a big effort to survive in 
today's world. The companies are balancing in the finance site of company and governmental as well it it hard for small entrepreneurs to stay motivated in the jungle of huge businesses. The study and findings are similar as Nylander and Rudstrom that says that social media are good to find new clients and contacts for potential new business. It is 21. Century everything is new and everything you can buy online. Other than a mere percentage usage for fun, the two most important usage of social media is to get visible and have a more clients, stay number one on business and compete with others. That is why companies need to have perfect portfolio and build up the networking.

Internet server LinkedIn is very known all around the world. People using it not even get to know other people but also hiring new employees. This trend is still not that huge as in the world. In Zlin people still using different style of communication. According to this research people rather go and get some people from school or from advertisements. They don't check LinkedIn very often, it can be said that people in Zlin are still very conservative than younger generation.

The world is getting more innovative and Czech people are trying to follow some news as well. As asked people from questionnaire said young generation so called " millenials" are heading and following new trends. But it will take few more years to use LinkedIn more often than it is used.

According to few different research and studies Kuhn and Skuterud 2004 says that internet searchers and platforms for searching jobs with low cost job might value of a job seeker. It might be assumed as Internet applications for every kind of job posting, whereas the print media offer more to application and results in few applications to higher number of job interviews. It can help in interviews vs. applications like it was few years ago when we needed to apply for positions by mailing a resume and cover letter.

\section{CONCLUSION}

This specific study has provided an overview of how much people from Zlin city, Czech republic uses social media and especially LinkedIn, which is media specialized especially for business, companies and profiles oriented to hire people. The study concludes that selected small businesses around town and entrepreneurs trust the social media and see potential in in digitization and social media and their background. Overall, it can be concluded that social media is still not widely and wisely used and trusted in small businesses in Czech republic. It is proved that small and medium businesses still not using social media properly and that is why they are not making too much effort on LinkedIn profiles. This very little research were collecting initial data by using a sample form a representative city Zlin in the Czech republic.

There is several recommendations to make social media in business and companies more visible and hiring people from LinkedIn more often than how it is now.

1. Guidelines in using social media for small businesses. This will help entrepreneurs in trusting and have some proper use of social media and their business purposes.

2. Every company can have their people more searching online and finding new potential colleagues. 


\section{Acknowledgement}

The article`s author Ing. Nikola Vykydalova is thankful and blessed for Internal Grant Agency of FaME UTB, IGA project 2018/015 called Consumer behaviour changes and entrepreneurship for market development through digitization which is cooperate with Miss Quyen Phu Thi Phan, Fortesa Haziri and Sayanti Shaw.

\section{References}

Aral, Sinan, Lev Muchnik, and Arun Sundararajan. 2009. "Distinguishing Influence-based Contagion from Homophily-driven Diffusion in Dynamic Networks." Proceedings of the National Academy of Sciences 106 (51) (December): 21544-21549. https://doi.org/10.1073/pnas.0908800106

Asmah Haji Omar. The Malay Peoples of Malaysia and Their Languages. Kuala Lumpur: Dewan Bahasa dan Pustaka, Kementerian Pelajaran Malaysia; 1983.

Blau, David M., and Philip K. Robins. 1990. "Job Search Outcomes for the Employed and Unemployed." The Journal of Political Economy 98 (3) (June): 637-655. https://doi.org/10.1086/261698

Bloemen, Hans G. 2005. "Job Search, Search Intensity, and Labor Market Transitions an Empirical Analysis." The Journal of Human Resources 40 (1) (January 1): 231-269.

Bortnick, Steven, and Michelle Ports. 1992. "Job Search Methods and Results: Tracking the Unemployed, 1991." Monthly Labor Review 115 (12): 29.

Boyd, D.M., Ellison, N.B. Social Network Sites: Definition, History, and Scholarship. Journal of Computer-Mediated Communication 2007; 13(1), 210-213. https://doi.org/10.1111/j.1083-6101.2007.00393.x

Coleman, James, Elihu Katz, and Herbert Menzel. 1957. "The Diffusion of an Innovation Among Physicians.” Sociometry 20 (4) (December): 253-270.

Dépêches. 2010. "TripAdvisor Becomes the First Travel Brand to Break the 40 Million

Dutton, W. H. \& Shepherd, A. Trust in the Internet as an experience technology, Information, $\begin{array}{lllll}\text { Communication } \quad \& \quad \text { Society, } & \text { 2006; } & \text { 4:4, }\end{array}$ https://doi.org/10.1080/13691180600858606

Emerson, RM. 1976. "Social exchange theory." Annual review of sociology:335-362. https://doi.org/10.1146/annurev.so.02.080176.002003

Evans, D. Social Media Marketing. An Hour A Day. USA: Wiley Publishing Inc.; 2008.

Hampton, K., Goulet, L.S., Rainie, L., Purcell, K. Connected to their use of social networking sites and other technologies. Pew Internet Project 2011; June 16.

Jones, K., Lori, N.K., Leonard, K., Riemenschneider , C.K. Trust Influencers on the Web. Journal of Organizational Computing and Electronic Commerce 2009;19:3, 196-213. https://doi.org/10.1080/10919390903041899

Kaplan, A.M. \& Haenlein. Users of the world, unite! The challenges and opportunities of Social $\begin{array}{llll}\text { Media. Husiness } & \text { Horizons }\end{array}$ https://doi.org/10.1016/j.bushor.2009.09.003 
Kim JY, Lee CK. An empirical analysis of requirements for data scientists using online job postings. International Journal of Software Engineering and Its Applications, 2016;10:161-72 https://doi.org/10.14257/ijseia.2016.10.4.15

Kotler, P. Marketing management. 10. rozšiřr. vyd. Praha : Grada, 2001. 719 s. ISBN 80-2470016-6.

Lee CK. Analysis of skill requirements for systems analysts in Fortune 500 organizations. $J$ Comput Inform Syst 2005;45:84-92. 2005.

Leeflang, PSH, Verhoef, PC, Dahlström, P \& Freundt, T 2014, 'Challenges and solutions for marketing in a digital era' European Management Journal, vol 32, no. 1, pp. 1-12. https://doi.org/10.1016/j.emj.2013.12.001

Nylander, S., Rudstrom, A. Questions, inspiration, feedback and contributions: How entrepreneurs network online. Proceedings of the 5th International Conference on $\begin{array}{llll}\text { Communities } \quad \text { and } & \text { Technologies }\end{array}$ https://doi.org/10.1145/2103354.2103372

O'Reilly, Tim, Web 2.0 Compact Definition: Trying Again. Publikováno dne: 10.12. 2016, dostupné na: http://radar.oreilly.com/2006/12/web-20-compact-definition- tryi.html

Organisation for Economic Co-operation and Development OECD. Participative web and usercreated content: Web 2.0, wikis and social networking. Paris: Organization for Economic Co-operation and Development; 2007.

Parker, C. 301 Ways To Use Social Media To Boost Your Marketing. New York: McGraw Hill; 2011.

Teo, K. S. The Acquisition of Malay as a Second Language. 2001. Retrieved August 20, 2012 from http://sealang.net/sala/archives/pdf4/teo2001acquisition.pdf

Thackeray, R., Neiger, B. L., Hanson, B.L.,MCKenzie. Enhancing Promotional Strategies Within Social Marketing Programs: Use of Web 2.0 Social Media. Health Promot Pract. 2008; 9:338. https://doi.org/10.1177/1524839908325335

Tomek, G. - Vávrová, V. Výrobek a jeho úspěch na trhu. 1. vyd. Praha : Grada, 2001. 352 s. ISBN 80-247-0053-0.bUnique Monthly Visitors Barrier." Pp.

Wikipedia (2016b). Social media. Wikipedia: The Free Encyclopaedia. (Available online: http://en.wikipedia.org/wiki/Social_media. Accessed on 28 February 2016).Williams, J., and Chinn, S. (2010). Meeting relationship- marketing goals through social media: A conceptual model for sport marketers. International Journal of Sport Communication, 3(4), 422-437.

Wilson, R. E., Gosling, S. D., \& Graham, L. T. (2012). A review of Facebook research in the social sciences. Perspectives on Psychological Science, 7(3), 203-220. https://doi.org/10.1177/1745691612442904

Wu, C. W. (2016). The performance impact of social media in the chain store industry. Journal of Business Research. 69(11), 5310-5316. https://doi.org/10.1016/j.jbusres.2016.04.130

Wu, J.J., Tsang, A. S. Factors affecting members' trust belief and behaviour intention in virtual communities. Behaviour \& Information Technology 2008; 27:2, 115-125. 
https://doi.org/10.1080/01449290600961910

Zide, J., Elman, B., \& Shahani-Denning, C. LinkedIn and recruitment: How profiles differ across occupations. Employee Relations, 36(5), 583-604. 2014. https://doi.org/10.1108/ER-07-2013-0086

\section{Contact information}

Ing. Nikola Vykydalová

Tomas Bata University, Economy and Management faculty

Kvítková 4193, Zlín

Telephone number: +420777 865726

E-mail: nikola.vykydalova@icloud.com

ORCID:0000-0001-5283-7513

DOI ID: https://www.doi.org/10.7441/dokbat.2018.26 
Name of publication: DOKBAT 2018 - 14th International Bata Conference for Ph.D. Students and Young Researchers

Edited by: Ing. et Ing. Monika Hýblová

Publisher: Tomas Bata University in Zlín

Issue: 1st edition

Year of publication: 2018

The conference proceedings have not undergone language correction.

ISBN: 978-80-7454-730-0

DOI ID: 7441/dokbat.2018

\section{Expert guarantor:}

Ing. Jana Matošková, Ph.D.

\section{Manager and coordinator:}

Ing. Marek Koňařík

\section{Members of the organizing team:}

Ing. Ottó Bartók

Ing. et Ing. Katka Gálová

Ing. et Ing. Monika Hýblová

Ing. Pavel Ondra 